\title{
Geochemical, Isotopic, and Mineralogical Characterization of the Frobisher Suite Mafic- Ultramafic Sills, Southern Baffin Island, Nunavut, with Implications for Metallogenic Potential
}

by

Dustin Andrew Liikane, B.Sc.H.

A thesis submitted to the Faculty of Graduate Studies and Research in partial fulfillment of the requirements for the degree of Master of Science

Ottawa-Carleton Geoscience Centre and Department of Earth Sciences

Carleton University

Ottawa, Ontario

(c) 2017

Dustin Andrew Liikane 


\section{Dedication}

In loving memory of my brother, Matthew Rein Liikane, who supported me throughout the duration of this thesis project, both in this world, and from the next.

April 2, 1993 - March 22, 2015

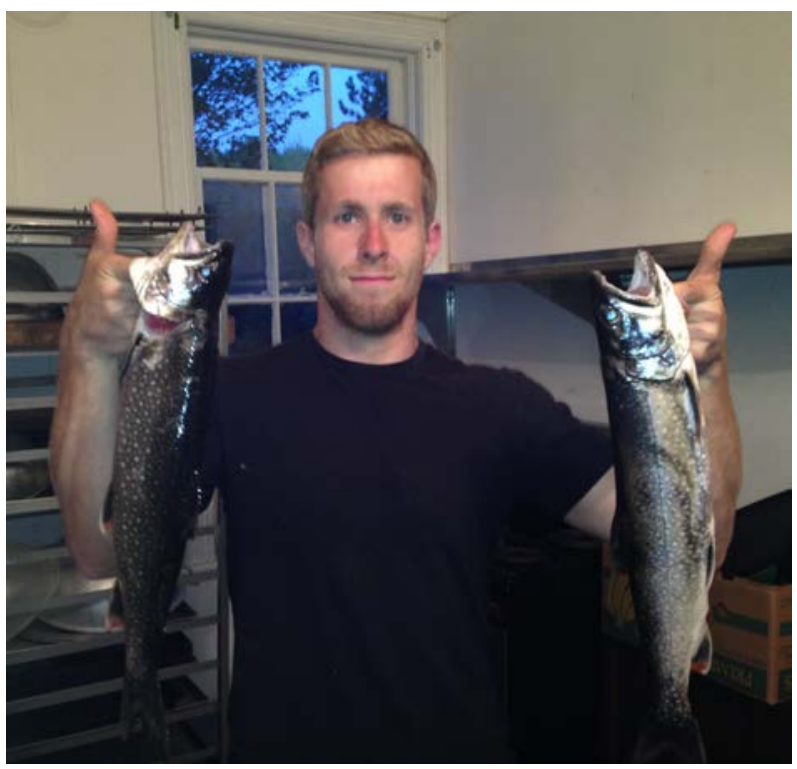




\section{Frontispiece}

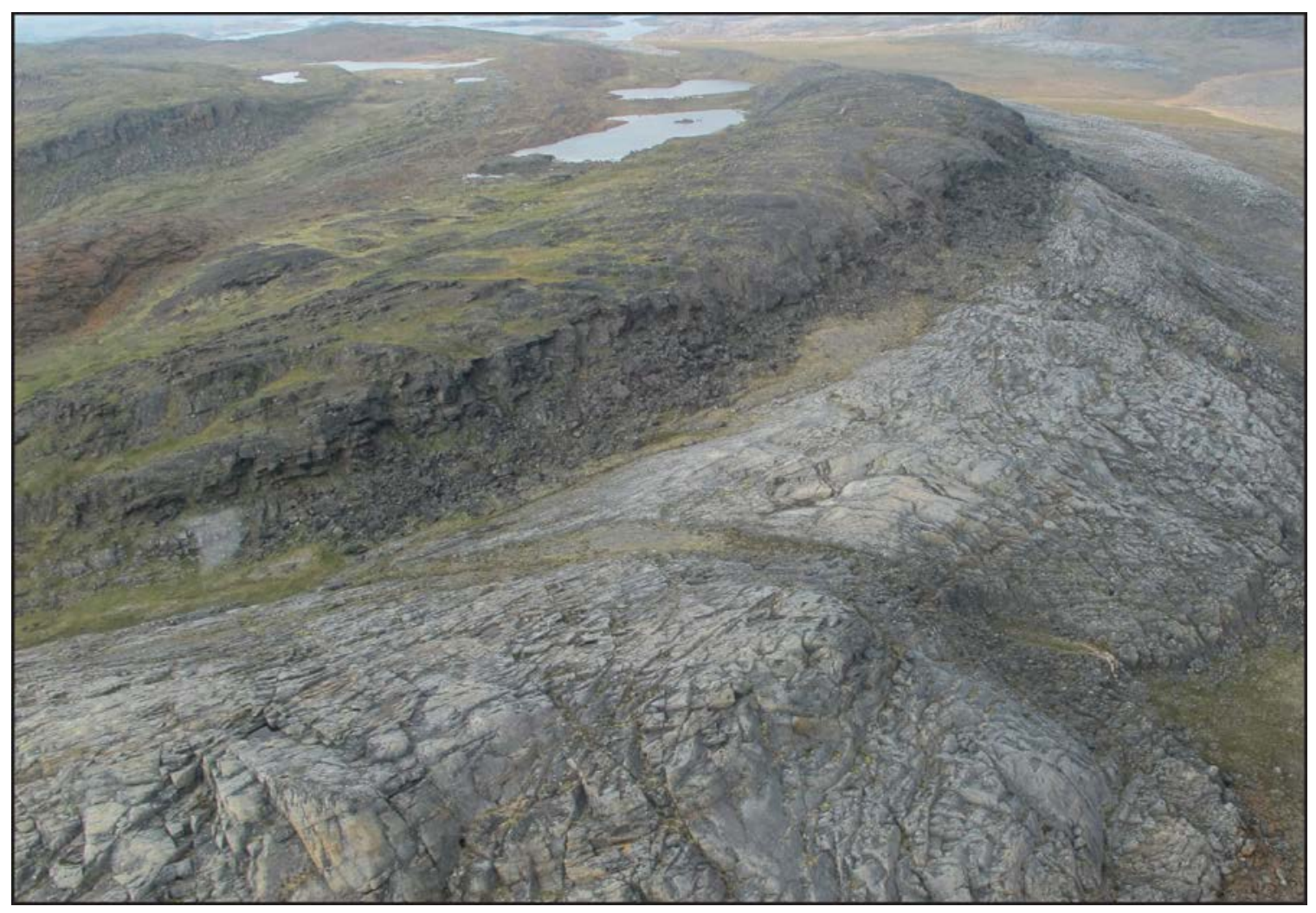

Layered Mafic-Ultramafic sill, Markham Bay

An aerial photograph of one of the more majestic-looking layered maficultramafic sills, located in Markham Bay, Meta Incognita Peninsula, southern Baffin Island, Nunavut. The sill is overturned, such that the mafic unit forms the structural base of the intrusion, and the thin ultramafic component is situated on top. The sill is hosted in metasedimentary quartzite (white weathering - bottom) and psammite (rusty-brown weathering - top) units of the Lake Harbour Group. 


\section{Abstract}

The Frobisher Suite is a newly recognized magmatic province comprised of mafic-ultramafic sills in southern Baffin Island, Nunavut. The sills are emplaced into the metasedimentary strata of the middle Paleoproterozoic Lake Harbour Group, and vary in thickness from several meters to hundreds of meters. Based on major and trace element chemistry, the Frobisher Suite can be divided into eight geochemical groups. The major geochemical groups indicate melting occurred to differing degrees within a mantle plume head, at various depths below the Meta Incognita microcontinent at ca. 1900 Ma. A number of sills formed via injections of multiple, distinct magma types, some of which were influenced by subcontinent lithospheric mantle. Disseminated sulphides are present in the sills, and in some cases, the adjacent host psammite. At this stage, the Frobisher Suite may be considered to be part of its own Large Igneous Province (LIP), termed the "Frobisher LIP." 


\section{Acknowledgements}

First off, I would like to graciously thank my thesis supervisors Dr. Richard Ernst (Carleton University), Dr. Marc St-Onge (Geological Survey of Canada), and Dr. Bruce Kjarsgaard (Geological Survey of Canada) for all of their guidance, support, patience and encouragement throughout the duration of this M.Sc. project.

Thank you to all the enthusiastic field assistants and fellow mappers, most of whom assisted with sample collection: Timothy Chadwick, Dr. Owen Weller, Dr. Brenden Dyck, Dr. Diane Skipton, Terry Milton, Sean Noble-Nowdluk, Tyler Rowe, Angela Ford, Harry Ireyak, Alia Bigio, and Randy Hinanik. Thank you to Jerry Nuttall and Gerard Hartery from Universal Helicopters for their safe and professional air-support in the field. Thanks to the camp cook, Debra Guilfoyle, for providing high quality and diverse meals, daily, which kept me fuelled for the two summers of fieldwork. Thanks to the Polar Continental Shelf Program for providing logistical support.

A special thanks to Holly Steenkamp (CNGO) and David Mate (CNGO) for overseeing the process for obtaining thin sections and bulk-rock geochemical data. Thanks to Celine Gilbert for data-management in the field, as well as later correspondence with regard to Inuit place names, used to name the Killapait and Chidliak sills. Thanks to Micheal Burns (GSC) for carefully preparing samples (e.g. trimming, slabbing) and thin section blocks prior to shipment. Thanks to Vancouver Petrographic for providing quality thin sections and to ALS Chemex for obtaining precise and accurate geochemical data from the samples. Thank 
you to microprobe technician Peter Jones for his time and expertise in obtaining mineral geochemistry and back-scatter electron images.

A big thanks to Nicole Rayner (GSC) for assistance in attempting to date the Frobisher suite. While not every attempt panned out, due to lack of igneous zircons, the minimum crystallization age of $1900 \mathrm{Ma}$ obtained from magmatic zircons in the Killapait sill was key in the regional comparison and modelling sections of the thesis. Also, thank you to the other geochronology staff for their contributions to the $\mathrm{U}-\mathrm{Pb}$ dating process of the Frobisher suite, specifically, Julie Peressini, Dr. Bill Davis, Tom Pestaj, Pat Hunt, and Carole Lafontaine.

I greatly appreciate the thorough and insightful reviews of the Summary of Activities paper [i.e. Liikane et al. (2015)] by Drs. Thomas Skulski (GSC) and Tony Peterson (GSC), and thanks to Tammy Sifer for assistance formatting the text and figures for publication.

A special thanks to Angela Ford for her GIS expertise and assistance with geological map preparation. Thanks to Douglas Oneschuk for plotting maps and conference posters.

Thank you to Dr. Natasha Wodicka for taking the time to sit down with me and discuss the evolution of the syn-magmatic sedimentary basin adjacent to the Meta Incognita microcontinent, and thanks to Dr. Fred Gaidies for discussing the metamorphism of mafic to ultramafic rocks. Thank you to PhD candidates Nico Kastek and Chris Rogers for discussions on geochemistry. 
A special thanks to the Geological Survey of Canada (GSC), Canada Nunavut Geoscience Office (CNGO), Carleton University, Ernst Geosciences, and the LIPs-Supercontinent Reconstruction Project for funding this project.

Thank you to defence committee members Dr. Richard Ernst, Dr. James Mungall, Dr. Sarah Dare, and Dr. lan Honsberger for their participation in the defence process, and for insightful comments and suggestions.

Lastly, I would like to thank friends and family for their support throughout the duration of my master's degree program. And thank you to my girlfriend, Pamela Iraheta-Muñiz, for her unwavering support and encouragement during the writing process of the thesis. 


\section{Method of Presentation}

The body of the thesis is presented in four chapters (Chapters $3 \& 5-7$ ), with each focusing on separate aspects of the Frobisher suite mafic, ultramafic, and mafic-ultramafic sills of southern Baffin Island, Nunavut. They are prefaced by an introduction (Chapter 1) and background (Chapter 2), and followed by a discussion, conclusions and future recommendations (Chapter 8). Between Chapters 3 and 5 there is also an overview of the methods used in the completion of this thesis (Chapter 4).

Chapter 1 - A brief introduction to the study area, and the purpose and objectives of the study.

Chapter 2 - A detailed background of: (1) Large Igneous Provinces (LIPs), describing all of their components and models of formation; (2) Layered intrusions, including their geometry, distribution and mechanisms of formation; (3) Mafic-ultramafic intrusion-hosted mineral deposits, mainly focused on Ni-Cu-PGE mineralization; and (4) Metamorphism of rocks mafic to ultramafic in composition.

Chapter 3 - Introduces the Meta Incognita microcontinent and the Paleoproterozoic Trans-Hudson orogen. The regional geology of the QuébecBaffin Island segment of the orogen is first presented, followed by its tectonic architecture, deformation and metamorphic events, and finally, the Frobisher suite sills and their Lake Harbour Group host rocks. 
Chapter 4 - Overview of the methods used in completing the thesis, including sample collection and processing, and analytical methods.

Chapter $\mathbf{5}$ - Detailed petrography of the Frobisher suite sills, where mineral assemblages and textures are described.

Chapter 6 - Mineral chemistry of the Frobisher suite sills.

Chapter 7 - Detailed geochemical study of the Frobisher suite sills, where eight geochemical groups are recognized and described individually, with some comparison between groups.

Chapter 8 - Discussion of the general characteristics and petrogenesis of each geochemical group, the petrogenesis and models for the formation of the two mafic-ultramafic sills sampled in detail, the candidacy for the Frobisher suite being considered a LIP, evidence for mantle plume-involvement versus passive rift magmatism, post-emplacement modification, regional implications, a model of formation for the Frobisher suite, and its metallogenic potential. This is followed by the summary of the main conclusions of the study, and future considerations.

Appendices: Appendix A contains sample coordinates, Appendix B contains field and petrographic data (Chapter 5), Appendix $C$ contains bulk-rock geochemical data (Chapter 7), Appendix D contains mineral geochemical data (Chapter 6), and Appendix E contains Sm-Nd isotopic data (Chapter 7). 


\section{Table of Contents}

Frontispiece ........................................................................................................

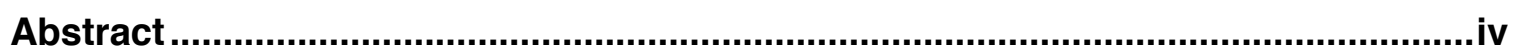

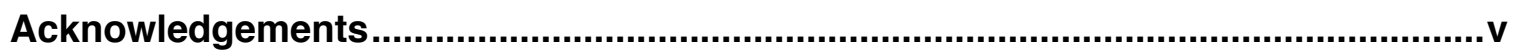

Method of Presentation...........................................................................................viii

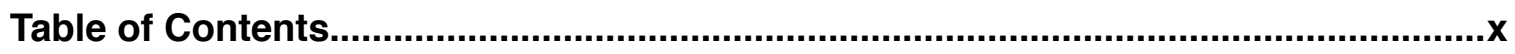

List of Appendices................................................................................................

List of Tables................................................................................................................

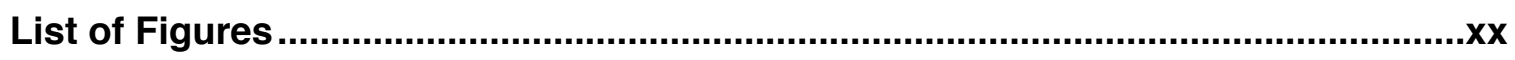

Chapter 1 - Introduction .....................................................................................

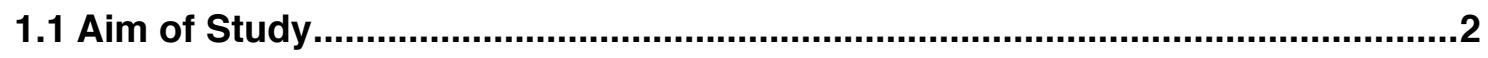

Chapter 2 - Background .........................................................................................4

2.1 Large Igneous Provinces and their Plumbing Systems....................................5

2.1.1 Sub-lithospheric mantle source distribution and depth .............................6

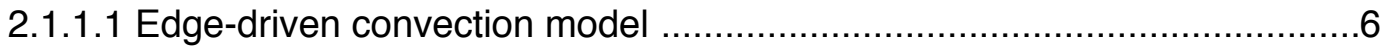

2.1.1.2 Lithospheric delamination model .............................................

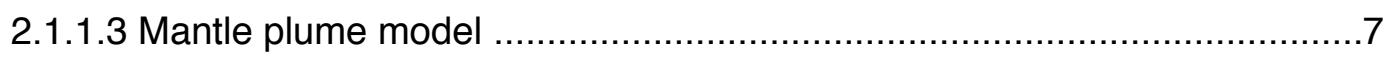

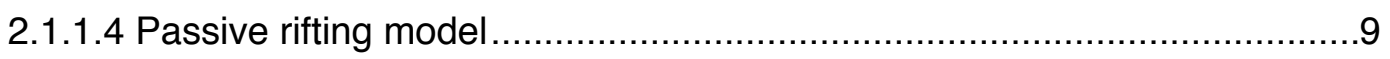

2.1.2 Lithospheric entry points ................................................................10

2.1.3 Intra-lithospheric distribution ...........................................................10

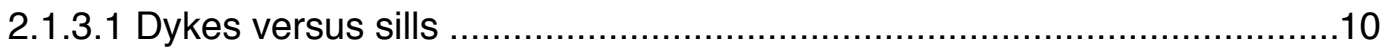

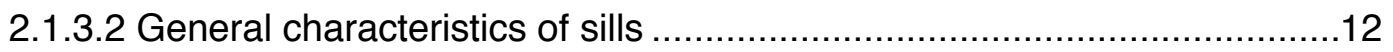

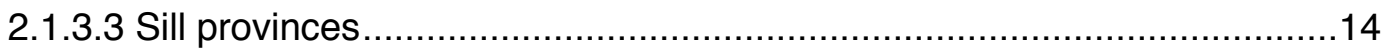

2.1.4 Surface magmatism .................................................................................... 15

2.2 Layered Intrusions.........................................................................................16

2.2.1 Geometry of layered intrusions ......................................................17

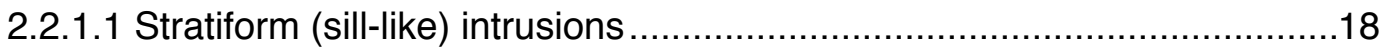

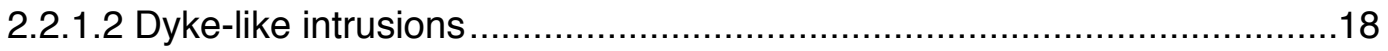




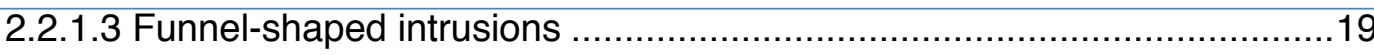

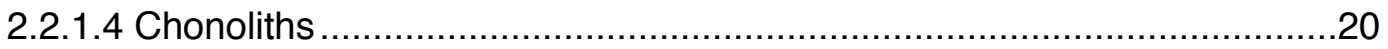

2.2.2 Distribution of layered intrusions in LIPs .................................................21

2.2.3 Mechanisms of layer formation in layered intrusions .............................21

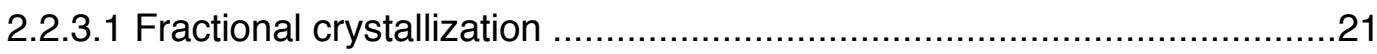

2.2.3.2 Composite sills versus vertically-stacked sills ................................23

2.3 Mafic-Ultramafic Intrusion-Hosted Mineral Deposits .....................................27

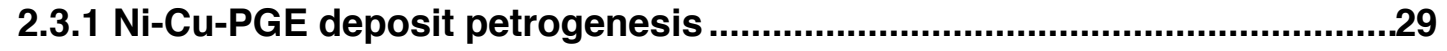

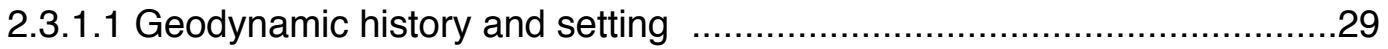

2.3.1.2 Sources and compositions of ore-forming magmas ...........................29

2.3.1.3 Sources of sulphur and transport of sulphide liquid............................30

2.3.1.4 Mineralized intrusion formation ................................................

2.4 Metamorphism of Mafic and Ultramafic Rocks..............................................32

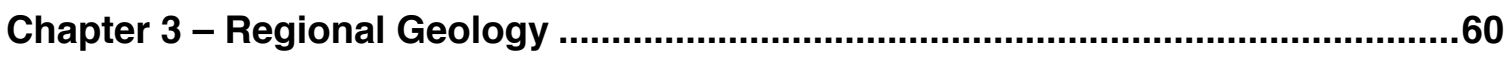

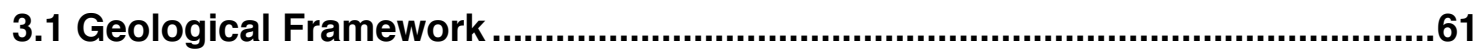

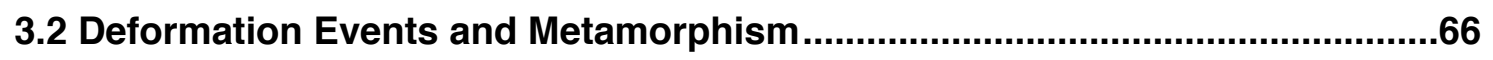

3.3 Lake Harbour Group...........................................................................................70

3.4 Frobisher Suite Mafic, Ultramafic and Mafic-Ultramafic Sills...........................74

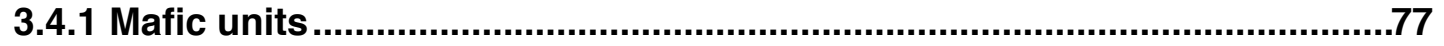

3.4.2 Ultramafic units ....................................................................................

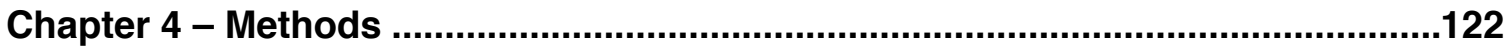

4.1 Fieldwork and Sample Collection .................................................................123

4.1.1 Regional Sampling .........................................................................124

4.1.2 Detailed Sampling ...........................................................................124

4.2 Sample Selection and Preparation.........................................................125

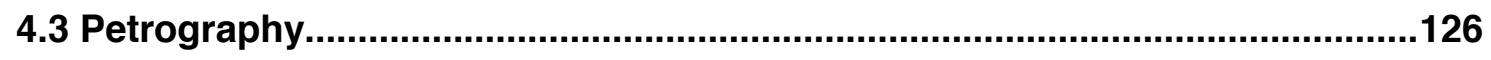

4.4 Photography and Microphotography .......................................................127

4.5 Analytical Methods ...................................................................................128 
4.5.1 Whole Rock Geochemistry .............................................................128

4.5.2 Mineral Geochemistry .....................................................................133

4.5.3 Isotope Geochemistry ............................................................................135

4.6 Potential Error in Geochemical Analyses .................................................139

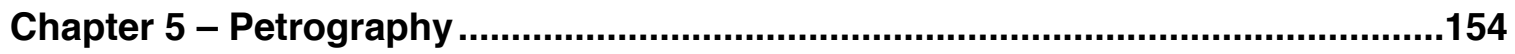

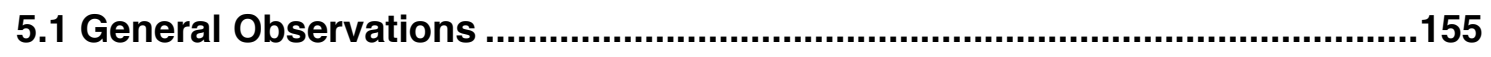

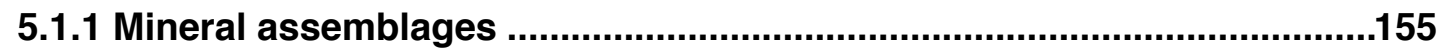

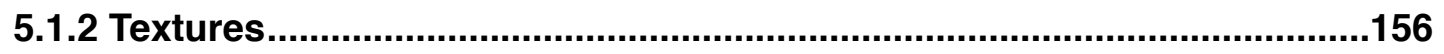

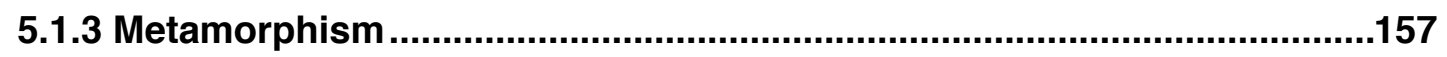

5.2 Mineralogical Characteristics of Geochemical Groups ................................158

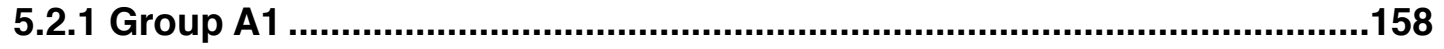

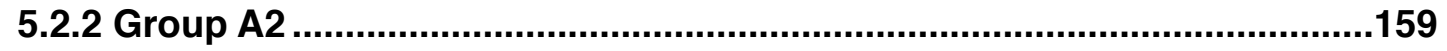

5.2.3 Group B ........................................................................................159

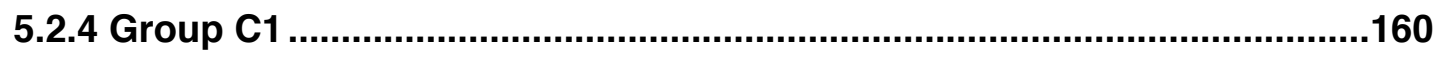

5.2.5 Group C2 .................................................................................................161

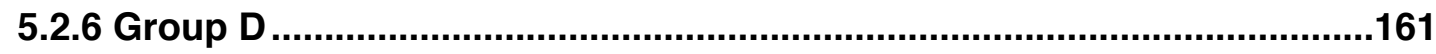

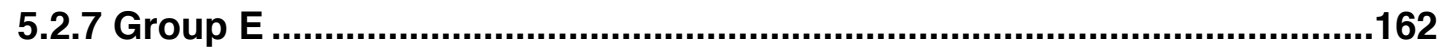

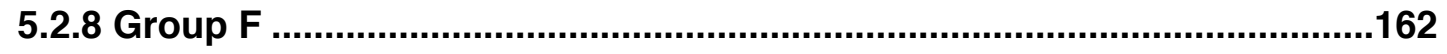

5.3 Silicate Mineralogy ....................................................................................163

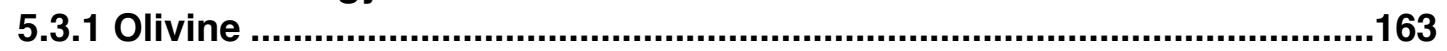

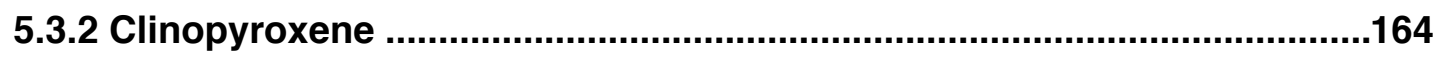

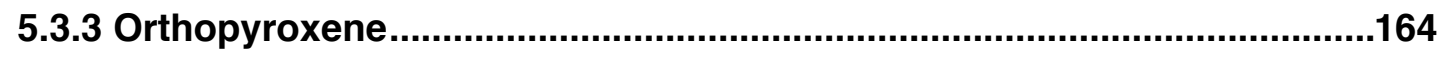

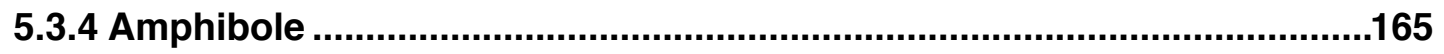

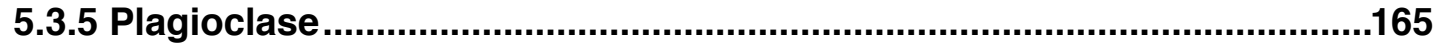

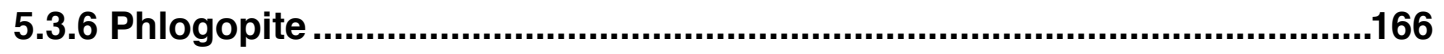

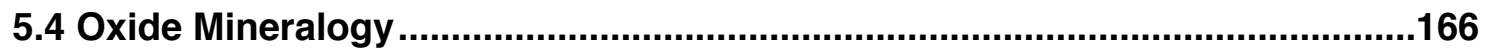


5.4.1 Spinel ..............................................................................................166

5.4.2 Magnetite and ilmenite......................................................................166

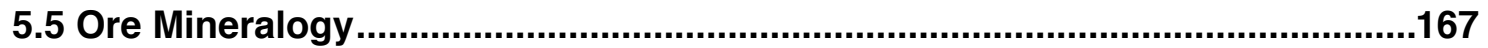

5.5.1 Pyrrhotite .................................................................................................167

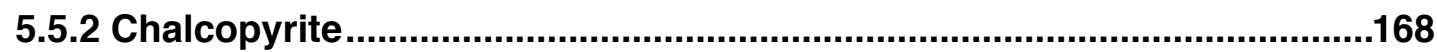

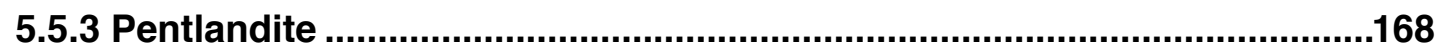

5.5.4 Pyrite .......................................................................................................168

5.6 Mineralogy of Detailed Sample Transects Across Two Mafic-Ultramafic Sills ... 168

5.6.1 Chidliak mafic-ultramafic sill.................................................................168

5.6.2 Killapait mafic-ultramafic sill.................................................................169

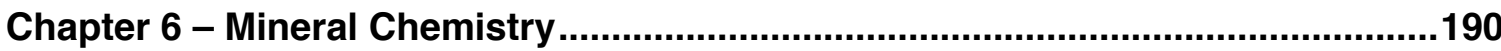

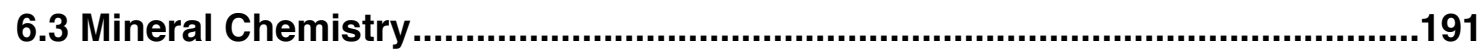

6.3.1 Silicate Mineral Chemistry.....................................................................191

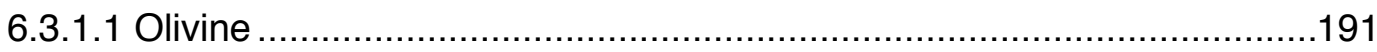

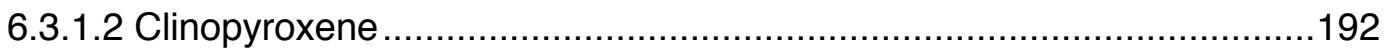

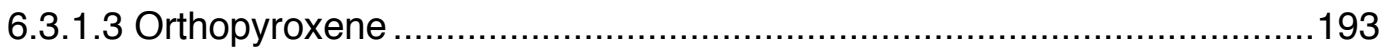

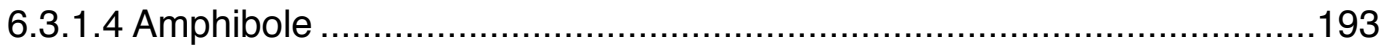

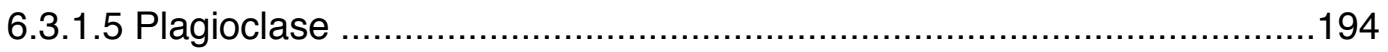

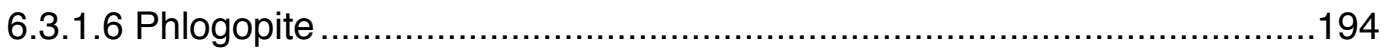

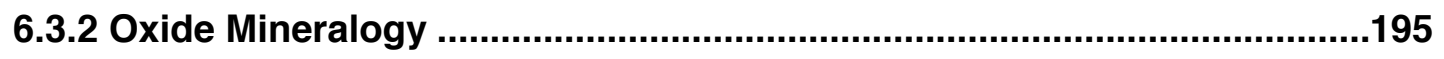

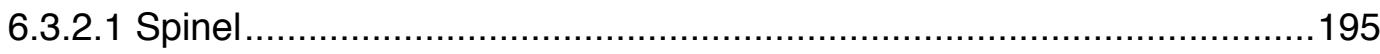

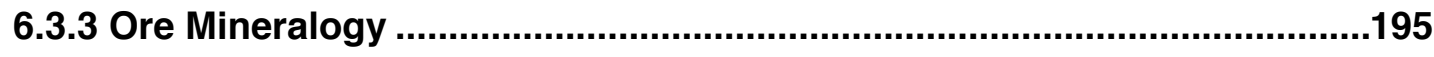

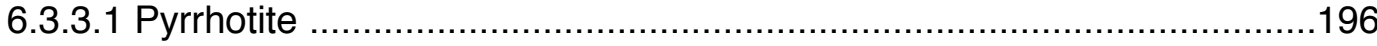

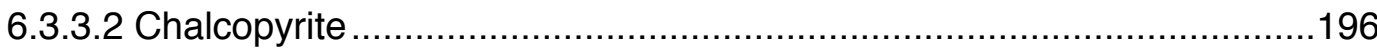

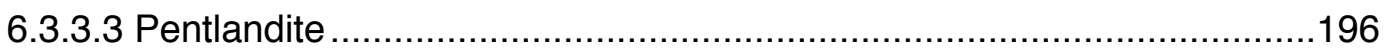


6.3.3.4 Pyrite. .196

6.3.4 Mineralogy of Detailed Sample Transects Across Two Mafic-Ultramafic

Sills. .197

6.3.4.1 Chidliak mafic-ultramafic sill 197

6.3.4.2 Killapait mafic-ultramafic sill.......................................................197

Chapter 7 - Geochemistry ........................................................................220

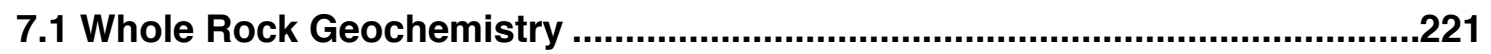

7.1.1 Element mobility................................................................................222

7.1.2 Classification through chondrite-normalized rare-earth element plots .223

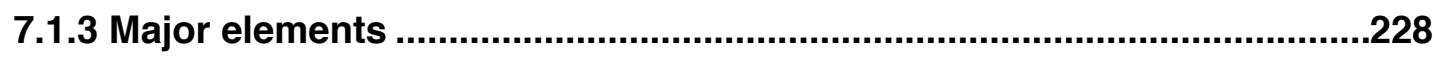

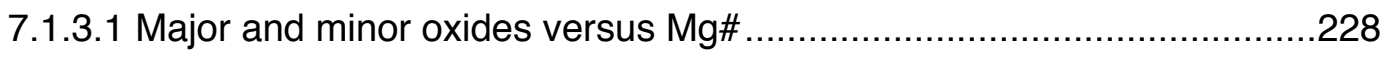

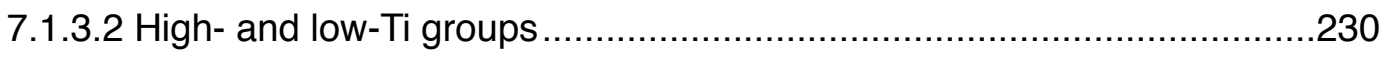

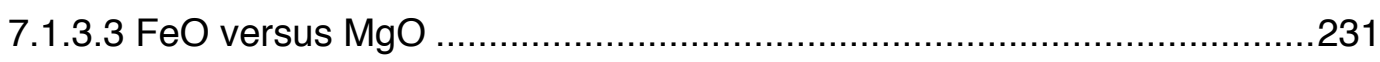

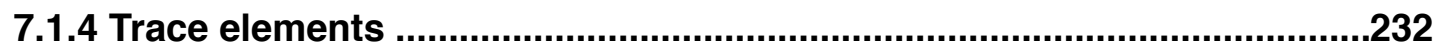

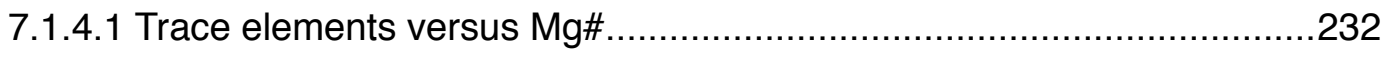

7.1.4.2 Primitive mantle-normalized spider diagrams ...............................234

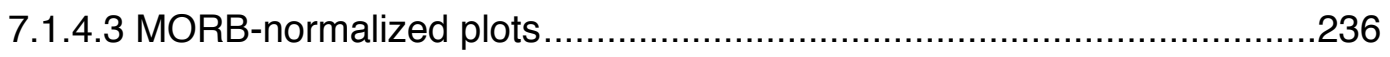

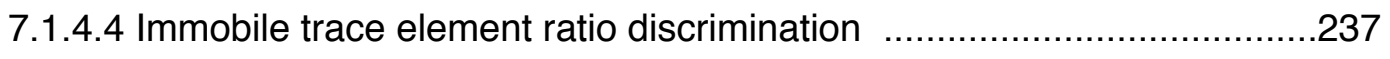

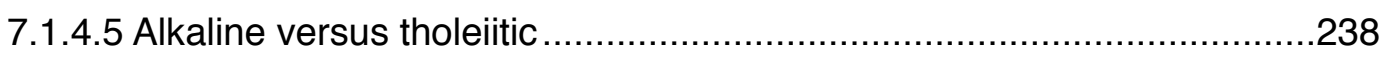

7.2 Sm-Nd Isotopes Geochemistry ................................................................240

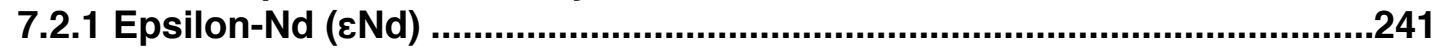

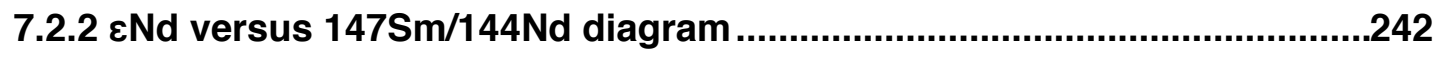

7.3 Geochemistry of Detailed Sample Transects Across Two Mafic-Ultramafic Sills 243

7.4 Interpretation.....................................................................................................244

7.4.1 Single injection versus multiple injection origin of layered sills............244 


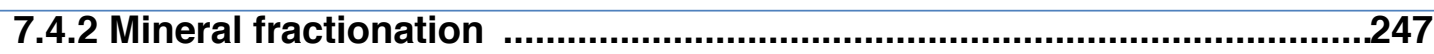

7.4.2.1 Olivine and pyroxene fractionation ..........................................248

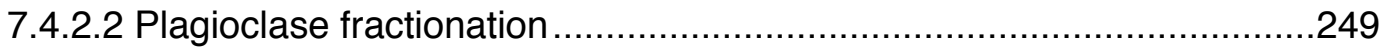

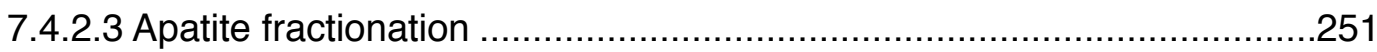

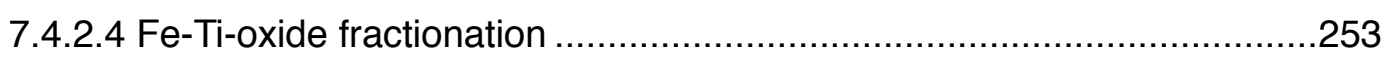

7.4.3 Contamination .................................................................................254

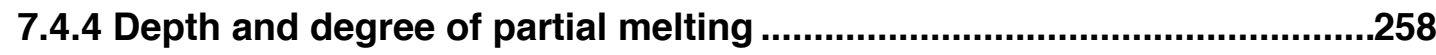

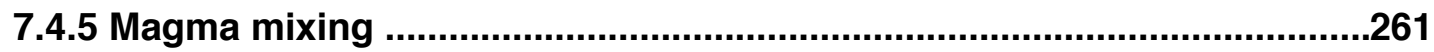

7.4.5.1 Group A1-like Group A2 samples .............................................261

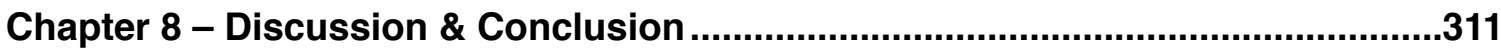

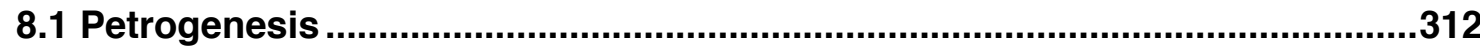

8.1.1 Petrogenesis of major geochemical groups ........................................312

8.1.1.1 High-Ti magma type (Group D) .............................................312

8.1.1.2 Low-Ti magma types (Groups A1 \& A2) ......................................315

8.1.2 Petrogenesis of minor geochemical groups ......................................317

8.1.2.1 Groups B, C1, and C2 magma types .............................................

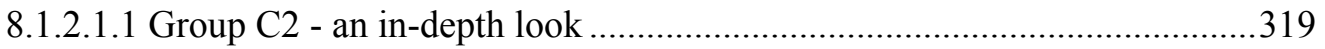

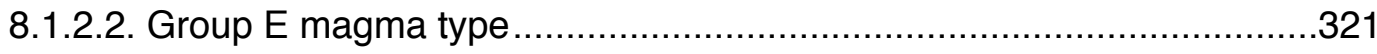

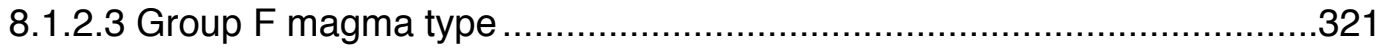

8.1.3 Potential parental magma compositions ...............................................323

8.1.4 Petrogenesis of the Killapait sill ............................................................323

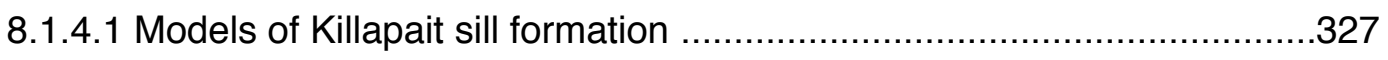

8.1.5 Petrogenesis of the Chidliak sill .......................................................330

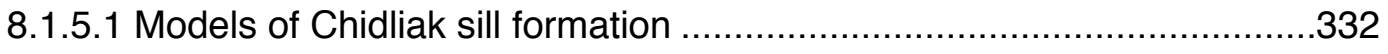

8.1.6 Candidacy for a Large Igneous Province (LIP).....................................335 


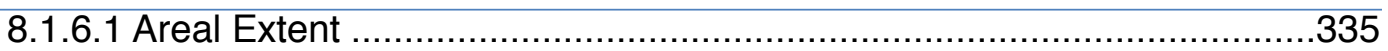

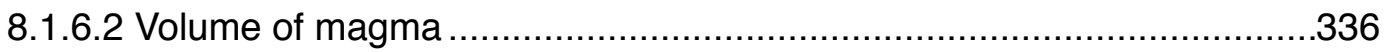

8.1.6.3 Duration and pulsed nature of magmatism .....................................336

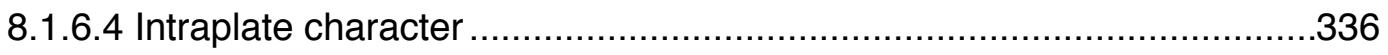

8.1.6.5 Provinciality within Frobisher suite .............................................337

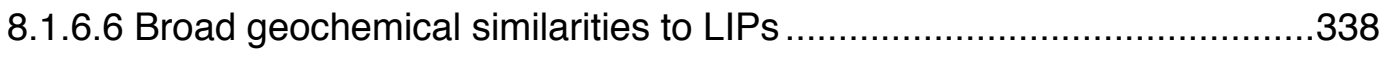

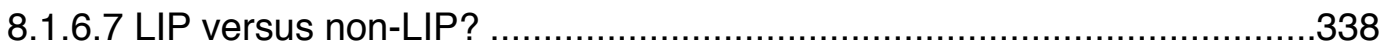

8.1.7 Evidence for mantle plume-involvement .................................................339

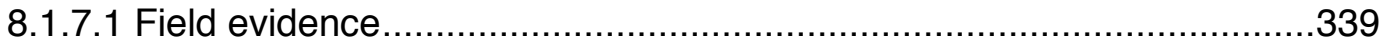

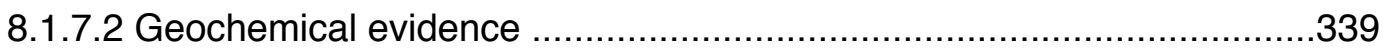

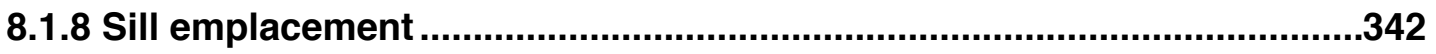

8.1.9 Post-emplacement modification .............................................................345

8.1.10 Metamorphic Character of sills ...........................................................346

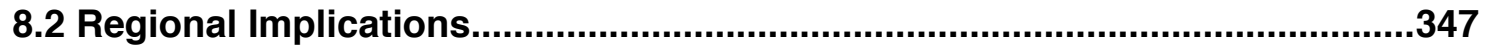

8.2.1 Regional comparison with other LIP and non-LIP events ......................347

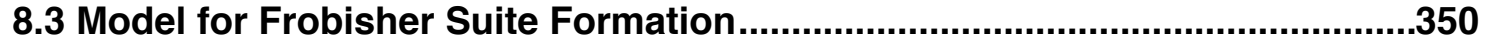

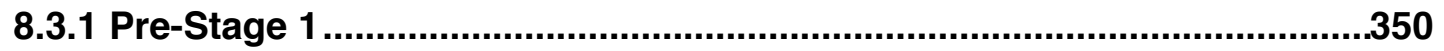

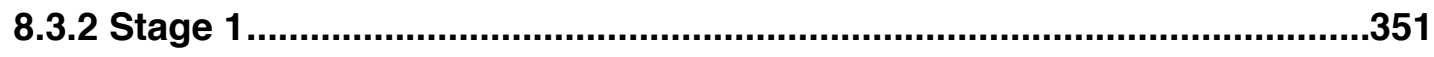

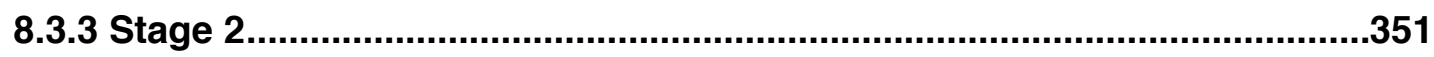

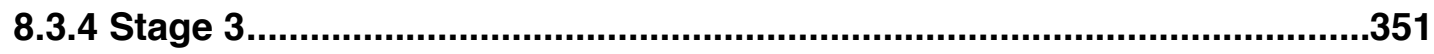

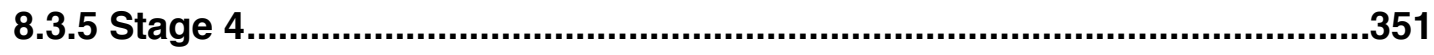

8.4 Mineral Deposit Potential of Frobisher Suite ...................................................352

8.4.1 Field and petrographic observations ................................................353

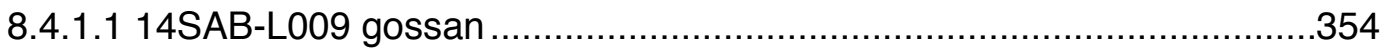

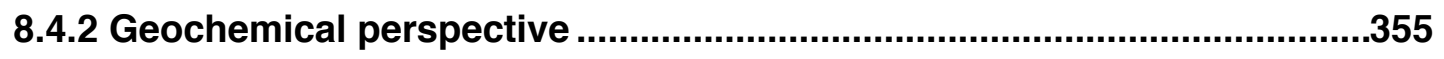


8.4.2.1 Chalcophile element geochemistry ............................................356

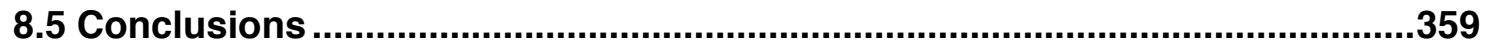




\section{List of Appendices}

Appendix A Sample Coordinates .....................................................................407

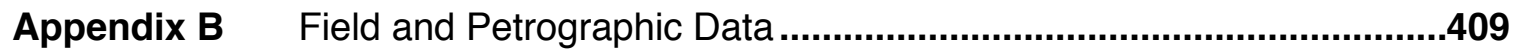

Appendix C Bulk-Rock Geochemical Data........................................................412

Appendix D Mineral Geochemical Data ................................................................417

Appendix E Sm-Nd Isotopic Data....................................................................436 


\section{List of Tables}

Table 4.1 List of Analytes, their lower detection limits and units...................151

Table 4.2 Elements, X-ray lines and standards for EMP.........................153

Table 5.1 Comparison of mineral contents.......................................189

Table 6.1 Ranges in Fo-and Ni-content in olivine..............................216

Table 6.2 Ranges in Di- and Cr-content in clinopyroxene.......................217

Table 6.3 Ranges in En- and Cr-content in orthopyroxene.......................218

Table 6.4 Ranges in An-content in plagioclase.................................219

Table 7.1 Number of occurrences of geochemical groups .......................309

Table 7.2 Relationship in occurrences between geochemical groups..............310

Table 8.1 Details of LIPs which occurred between 1845 - 1945 Ma................404

Table 8.2 Comparison of Frobisher Suite chemistry with other major LIPs......405 


\section{List of Figures}

Figure 2.1 Karoo-LIP sill distribution in sedimentary basin ................................55

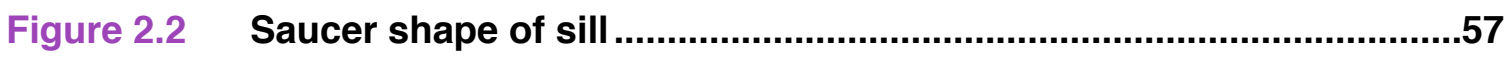

Figure 2.3 Plume emplacement beneath Archean craton ...................................58

Figure 3.1 Summary geology map of North America and Greenland...................94

Figure 3.2 Simplified geological map of Canadian Shield and west Greenland.96

Figure 3.3 Geological terrane map of Quebec-Baffin segment of THO................98

Figure 3.4 Tectonic summary diagram for Quebec-Baffin segment of THO .....100

Figure 3.5 Dome-and-basin patterns in bedrock geology of Meta Incognita

Peninsula ................................................................................................................102

Figure 3.6 Lake Harbour Group units and 14SAB-L009 gossan .......................104

Figure 3.7 Photographs of layered mafic-ultramafic sill and Chidliak sill ........106

Figure 3.8 Bedrock map of Meta Incognita Peninsula .....................................108

Figure 3.9 Bedrock map of northern Hall Peninsula .........................................111

Figure 3.10 Concordant intrusive contact..........................................................114

Figure 3.11 Sill morphology ..........................................................................116

Figure 3.12 Zircon photographs and concordia diagrams ...................................118

Figure 3.13 Gabbro, peridotite and pyroxenite sill components ........................120

Figure 4.1 Major oxide data from bulk-geochemistry standards ........................145

Figure 4.2 Trace element data from bulk-geochemistry standards ....................147

Figure 4.3 Base metal data from bulk-geochemistry standards ........................149

Figure 5.1 IUGS-based classification diagrams .............................................171

Figure 5.2 Textures in hand sample and thin section .........................................173

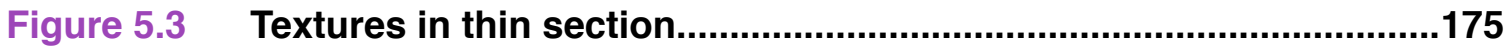

Figure 5.4 Reaction textures and exsolution laminae .......................................177

Figure 5.5 Ore mineral photomicrographs .......................................................179

Figure 5.6 Mineralogical changes through the Chidliak sill ................................181

Figure 5.7 Mineralogical and textural changes through the Chidliak sill..........183

Figure 5.8 Mineralogical changes through the Killapait sill ...............................185

Figure 5.9 Mineralogical and textural changes through the Killapait sill..........187

Figure 6.1 Ni content in olivine compared to Fo content ................................201

Figure 6.2 MnO content in olivine compared to Fo content .............................202

Figure 6.3 Clinopyroxene classification ........................................................203 
Figure 6.4 Orthopyroxene classification .......................................................205

Figure 6.5 Amphibole classification ...............................................................207

Figure 6.6 Plagioclase classification ..............................................................209

Figure 6.7 Phlogopite classification ................................................................211

Figure 6.8 Spinel classification ....................................................................213

Figure 6.9 Spinel composition ..................................................................215

Figure 7.1 Geochemical group legend ..........................................................274

Figure 7.2 Assessment of element mobility.....................................................275

Figure 7.3 Normalized trace-element spiderdiagrams ......................................277

Figure 7.4 LREE and HREE slope comparison ................................................281

Figure 7.5 Major oxide variation with Mg\# ....................................................282

Figure 7.6 High- and low-Ti groups.............................................................283

Figure $7.7 \quad$ FeO versus MgO ..........................................................................284

Figure 7.8 Trace-element variation with Mg\# ...............................................285

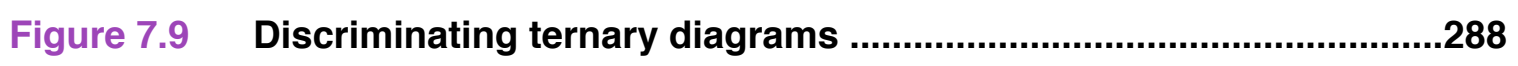

Figure 7.10 Alkaline versus tholeiitic...............................................................290

Figure 7.11 $\varepsilon N d$ versus $147 \mathrm{Sm} / 144 \mathrm{Nd}$; L057B02 contamination ............................291

Figure 7.12 Distinguishing contamination from source enrichment...................293

Figure 7.13 Geochemical variation through the Killapait sill ..............................294

Figure 7.14 Geochemical variation through the Chidliak sill ............................296

Figure 7.15 Chondrite-normalized REE pattern comparison within sills ............298

Figure 7.16 Europium anomalies .....................................................................300

Figure 7.17 Recognizing contamination and changes in melting depth.............301

Figure 7.18 Further distinguishing contamination from source enrichment......302

Figure 7.19 Recognizing crustal contamination .................................................303

Figure 7.20 Group C2 compared to upper crustal units .....................................304

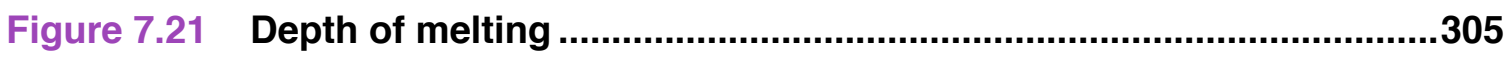

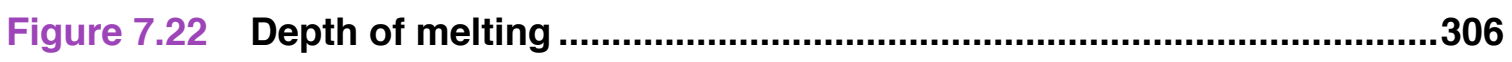

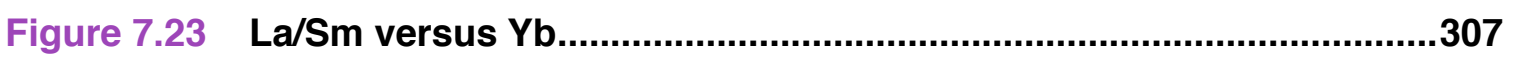

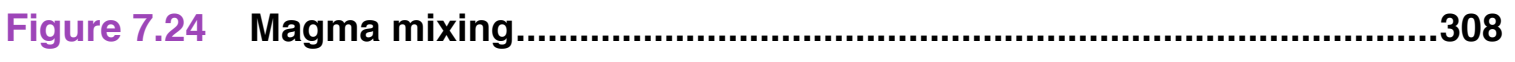

Figure 8.1 Comparison between Groups A2 \& B, and C1 \& D..........................376

Figure 8.2 Xenoliths and plagioclase megacrysts in Killapait sill .....................378

Figure 8.3 Pods of Fe oxide within Killapait sill ...............................................380 
Figure 8.4 Model \#1 of formation for Killapait sill ..............................................381

Figure 8.5 Model \#2 of formation for Killapait sill .............................................383

Figure 8.6 Metapyroxenitic xenolith in metaperidotite within Chidliak sill .......385

Figure 8.7 Model \#1 of formation for Chidliak sill ..........................................386

Figure 8.8 Model \#2 of formation for Chidliak sill .............................................388

Figure 8.9 Distribution of LIPs of similar age ..................................................390

Figure 8.10 Comparison of Frobisher Suite with Circum-Superior LIP...............392

Figure 8.11 Relative position of lithotectonic elements at ca. $1900 \mathrm{Ma}$.............394

Figure 8.12 Cross-section from Superior craton through to Meta Incognita

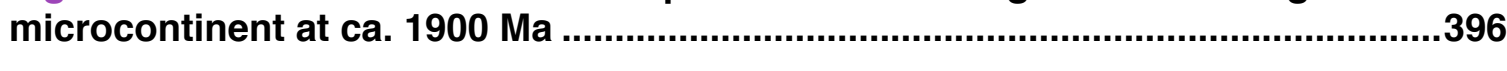

Figure 8.13 Model of formation of Frobisher Suite ...........................................398

Figure 8.14 Mineralized hand samples from 14SAB-L009 .................................400

Figure 8.15 Chalcophile element variation.........................................................402

Figure 8.16 $\mathrm{Log}(\mathrm{Cu} / \mathrm{Pd})$ versus $\mathrm{Mg \#} \mathrm{diagram} \mathrm{.....................................................403}$ 
Chapter 1 - Introduction 


\subsection{Aim of Study}

Prior to the initiation of this study, very few mafic to ultramafic sills within southern Baffin Island had been documented and sampled, and no systematic attempt had been made to understand this potentially economically-interesting group of rocks. The aim of this study was to characterize the widespread, yet understudied, suite of mafic, ultramafic, and layered mafic-ultramafic sills distributed throughout southern Baffin Island, which I have informally named the "Frobisher suite," based on their geographic proximity to Frobisher Bay. This research involved the integration of two summers of fieldwork on Baffin Island, during which regional mapping was conducted, with quantitative petrographic, geochemical, and metallogenic characterization of the mafic to ultramafic units. In addition, unpublished $\mathrm{U}-\mathrm{Pb}$ geochronology was integrated to constrain the timing of this magmatism and propose a time-accurate model.

The results of this thesis suggest that the Frobisher suite represents a geochemically-diverse, plume-generated large igneous province (LIP), which may correlate with already established LIPs elsewhere around the globe. The Frobisher suite is compared to the Circum-Superior LIP, which is proximal to Baffin Island and host to a number of mafic-ultramafic bodies containing significant nickel-copper-PGE mineralization (Ni-Cu-PGE; e.g., Cape Smith Belt). With the recognition that this suite may represent a plume-generated LIP, the conclusions of this thesis may be taken a step further by others, to improve the understanding of the distribution and interaction of tectonic plates during the 
middle Paleoproterozoic (ca. 1.9 billion years ago), and thus, improve existing tectonic and tectono-magmatic models for the eastern Canadian Arctic.

Given the context of the study, a comprehensive background is warranted. In the background (Chapter 2), four important topics of relevance to the thesis are covered: (1) Large igneous provinces (LIPs); (2) Layered intrusions; (3) Mafic-ultramafic intrusion-related mineralization; and (4) Metamorphism of mafic and ultramafic rocks. This is followed by an overview of the regional geology of southern Baffin Island, including its tectonic setting, in Chapter 3. 
Chapter 2 - Background 
A substantial amount of this background was compiled from Cawthorn (2012), Zientek, (2012), Ernst (2014), Barnes et al. (2015), Maier et al. (2015), and Bucher and Grapes (2011).

\subsection{Large Igneous Provinces and their Plumbing Systems}

It has been recognized that throughout the Earth's history, magmatic events characterized by the rapid emplacement of mafic, ultramafic, and less often, silicic magma within intraplate or incipient plate margin settings have occurred. The magmatic events are termed "Large Igneous Provinces (LIPs)" (Coffin and Eldholm, 1992), and have most recently been defined as "mainly mafic (+ultramafic) magmatic province[s] with areal extent[s] $>0.1 \mathrm{Mkm}^{2}$ and igneous volume[s] $>0.1 \mathrm{Mkm}^{3}$, that [have] intraplate characteristics, and [are] emplaced in a short duration pulse, or in some cases multiple pulses (less than 1-5 Ma), with a maximum duration of < c. $50 \mathrm{Ma"} \mathrm{(Ernst,} \mathrm{2014).}$

LIPs may comprise continental (and ocean basin) flood basalts, volcanic rifted margins, oceanic plateaus, and feeder systems (in deeply eroded Archean to Proterozoic terrains), with the latter including sill provinces, layered intrusions and regional dyke swarms (Ernst et al., 2008). The plumbing system for LIPs can be described in terms of the different levels of magma transport from mantle source to paleo-surface, which includes the sub-lithospheric mantle source distribution and depth, lithospheric entry points, intra-lithospheric distribution, and surface magmatism (Ernst et al., 2008). 


\subsubsection{Sub-lithospheric mantle source distribution and depth}

The anomalously high magma fluxes required to form LIPs can be produced through all, or a combination of, three mantle processes: 1) increasing the temperature of the source (e.g. mantle plume);2) decreasing the pressure acting on the source material (decompression melting); and 3) increased fertility and volatile content of the source to generate high degrees of melt (e.g. subduction zones; Saunders, 2005). The first two processes, in combination, are key for voluminous melt generation, which is implicit in the plume model (Saunders, 2005). Impacts from extraterrestrial bodies can also have the ability to produce the vast amounts of melt required to form a LIP (Saunders, 2005), but this is exceptionally rare (e.g. Sudbury impact structure, Canada) and requires considering the impact melt sheets of crust as part of the LIP (J.Mungall, pers. comm., 2017). Other models for LIP generation include edge-driven convection, lithospheric delamination, plume + lithospheric delamination, passive rifting, and asthenospheric convection.

\subsubsection{Edge-driven convection model}

King and Anderson (1995) recognized that many continental flood basalts lie close to Archean cratonic margins, and proposed an edge driven convection (EDC) model for LIP formation. It involves the craton thermally insulating the underlying asthenosphere, raising its temperature. The hot asthenosphere then slides out from under the thick craton, towards areas of thinner lithosphere. The 
mantle then decompresses and melts as it continues to ascend, producing large volumes of magma. King and Anderson (1998) argue that this 'edge-driven convection' model also involves a secondary convection cell active along the cratonic margin, which leads to greater magma production.

\subsubsection{Lithospheric delamination model}

Elkins-Tanton (2005) proposed an alternative model ('delamination model') whereby the lithospheric mantle becomes more dense than adjacent lithospheric mantle through processes including conversion to eclogitic phase assemblages, melt injection, or by thickening and cooling of a lithospheric root (e.g. ElkinsTanton (2005); Lustrino, 2005). As the lithosphere detaches and sinks into the mantle, asthenospheric material flows into the ensuing space and melts extensively (adiabatically). Substantial uplift also occurs as the lithosphere rebounds. Additionally, hydrous magmas may be produced by fluid-induced melting as the delaminated lithospheric material dehydrates, releasing fluids as it progressively heats and descends into the mantle (Elkins-Tanton, 2005). However, it is debatable whether normal-temperature asthenosphere is capable of producing the required volumes of magma and high Mg-melts (Saunders, 2005).

\subsubsection{Mantle plume model}

In the plume model (Morgan, 1971; Campbell and Griffiths, 1989; Richards et al., 1989; Campbell, 2001; Campbell, 2005; Campbell, 2007), hot, 
deep mantle material buoyantly rises, convectively, in a plume and melts at a shallow depth (White, 2010). Many plumes are believed to be rooted at the coremantle boundary (a thermal boundary), however, they need not be rooted there, as they are also believed to spawn at different levels within the lower mantle. The large voluminous heads (or small heads) ascend to shallow depths, extensively melt, and trigger voluminous basaltic eruptions. The initiation of plume upwelling may be caused by cold mantle downwellings, or perhaps, disturbances at the boundary due to plunging oceanic slabs (White, 2010). In other cases, plumes may have very small heads, or are completely headless, which is believed to be responsible for small oceanic plateau formation (e.g. the Azores). The idea of differing shapes and sizes of mantle plumes is supported by the modelling of thermochemical plumes (Farnetani \& Samuel, 2005). In addition to individual plumes, superplumes originating from the deep mantle, and plumes originating from the upper mantle-lower mantle transition zone are also recognized. An alternative origin of plumes was proposed by Davies \& Bunge (2006), who showed that plumes may arise from cold mantle downwellings plunging into hotter mantle regions, initiating upwelling plumes on the fringes of hot regions.

The melting products of plume material are significantly higher in temperature $\left(200-300^{\circ} \mathrm{C}\right.$, typically) compared to mid-ocean ridge basalt (MORB), which are derived from melting of upper mantle material. This is supported by observed negative seismic velocity anomalies beneath 30 hotspots (Montelli et al., 2004), which implies significantly hotter mantle exists in these regions (White, 
2010). The anomalies extend into the deep mantle, and in some cases, down to the core-mantle boundary (Burke \& Torsvik, 2004).

Plumes are generally heterogeneous, containing both incompatibleelement-enriched and depleted components. However, the depleted plume material is chemically distinct from typical mid-ocean ridge basalt (MORB) source, in most cases (Chadwick et al., 2005). Some hypotheses proposed for the origin of the geochemical signature of plumes include the recycling of ocean crust (Hofmann \& White, 1982) and the recycling of sub-continental lithospheric mantle (McKenzie \& O'Nions, 1983).

Plumes are not completely stationary, moving relative to one another, but far less than lithospheric plates do (White, 2010). Mantle plumes may have the ability to affect plate motion and initiate continental breakup, but do not drive plate motion (White, 2010).

\subsubsection{Passive rifting model}

Numerous flood basalt provinces were linked to decompression melting at the onset of crustal extension by White and McKenzie (1989). However, these models required a thermal anomaly $\sim 50-200^{\circ} \mathrm{C}$ greater than that of ambient mantle. A later paper by van Wijk et al., (2001) considered the high beta-factor (i.e. high crustal stretching) rifting influence on a narrow zone $(175 \mathrm{~km})$, and concluded that sufficient volumes of magma could be produced even at normal upper mantle temperatures $\left(1333^{\circ} \mathrm{C}\right)$, consistent with magma production produced along rifted margins of the North Atlantic Igneous Province (NAIP). This 
model suggests volcanic rifted margins do not always require a plume, however, the evidence for an initial pulse of pre-rifting LIP magmatism is not addressed (Ernst, 2014).

\subsubsection{Lithospheric entry points}

There are a variety of ways in which melts from the underlying asthenospheric mantle can initially enter the lithosphere. The magmas can reach shallow levels via active or failed rifts (e.g. triple-junctions rifts) or other translithospheric fracture zones (e.g. Begg et al., 2009, 2010). In some cases, sublithospheric channeling of magma to "thin spots" within the lithosphere or at the edge of cratons may occur (e.g. Oyarzun et al., 1997; Ebinger and Sleep, 1998; Duggen et al., 2009; Ernst, 2014).

\subsubsection{Intra-lithospheric distribution}

\subsubsection{Dykes versus sills}

The fundamental architecture of the magma transport network arises from dyke and sill propagation and linkage as local crustal structure directs magma transport (Kavanagh, et al., 2006; Menand, 2008; Bunger and Cruden, 2011; Magee et al. 2016). Magma ascends via the upward propagation of dykes, where buoyancy of the magma and overpressure at the tips of the dykes are large enough to drive upward crack propagation (Lister and Kerr, 1991). Dyke swarms also have the ability to transport magma laterally for distances $>2000 \mathrm{~km}$ and may feed distal volcanic or sill provinces (e.g. 2215 Ma Nipissing-Ungava event, 
Canada). Dykes may reorient to form sills, and in a similar manner dykes may emerge from sills, controlled by the changing regional stress field. Within sills, magma may also be transported great distances, laterally (e.g. potentially up to 4100 km within mafic sill complexes; Cartwright and Hansen, 2006; Leat, 2008). The orientation of these sheets of magma is also influenced and controlled by propagating sills and dykes interacting with pre-existing mechanical anisotropies, such as foliations, lithological contacts and fractures (Barnes et al., 2015). The majority of sills have been emplaced in sedimentary basins (Figure 2.1), but seismic images have identified sills hosted by crystalline basement (Mandler and Clowes, 1997; Welford and Clowes, 2004). Both dykes and sills can vary in composition from mafic to ultramafic (e.g. Scourie dykes, Scotland: Hughes et al., 2014; Montagnais sills, Labrador Trough, Canada: Rohon, et al., 1993); however, most regional dyke swarms are found to be mafic.

Traditionally, a sill can be defined as "a tabular igneous intrusion that parallels the planar structure of the surrounding rock" (Bates and Jackson, 1980). This type of tabular intrusion is in contrast to a dyke, which is traditionally defined as "a tabular igneous intrusion that cuts across the bedding or foliation of the country rock" (Bates and Jackson, 1980). However, more recent definitions by Ernst and Buchan (2004) do not define sills and dikes based on their relationship to foliation or bedding, but based on their orientation at the time of emplacement (cf. Hall, 1996). As stated by Ernst and Buchan (2004), a dyke may be defined as "a tabular igneous body that was sub-vertical at the time of emplacement," and in a similar manner, a sill could be defined as an originally sub-horizontal tabular 
body. A major determinant in whether the magma is injected as a sill or a dyke is the regional stress pattern (Ernst, 2014). This is because the sheet intrusions will align normal to the direction of minimum compression (Gretener, 1969; Ernst, 2014). An alternative explanation attributes sill formation to variations in a "compensation surface," where magma pressure equaled lithostatic pressure (Bradley, 1965; Meyboom and Wallace, 1978).

Prior to crustal infiltration, mafic-ultramafic magmas often pond at the base of the crust, where isobaric fractionation of primary picritic magmas can occur. Eventually the ponded magma will completely solidify, forming a dense crustal "underplate" (Cox 1980, 1993; Ernst, 2014). This underplate may be recognized as high-velocity lower crust (HVLC) at the base of the crust, and is often associated with LIPs and volcanic rifted margins. Examples of LIPs with a seismically-recognized underplate component include the Keweenawan (Canada) and Emeishan (China) LIPs. Furthermore, significant volumes of silicic melts may be generated by the melting of fusible crustal rocks at the base of the crust (Ernst, 2014).

Given that the intrusions of the Frobisher suite are all sill-like intrusions, the remainder of the background is focused primarily on the characteristics of sills, and consequently, dyke are only discussed where appropriate or necessary.

\subsubsection{General characteristics of sills}

Individual thicknesses of sills may vary from only a few millimeters to hundreds of meters, and sills may extend up to hundreds of kilometers along 
strike (Cawthorn, 2012; Ernst, 2014). Thicker sills may form differentiated intrusions, however, many appear to be the result of repeated injections of magma, where subsequent intrusions are injected before the previous intrusions crystallized significantly (Cawthorn, 2012). The thickest sill is the Windamurra Complex (Australia), which is estimated to be $\sim 13 \mathrm{~km}$ thick (Mathison and Ahmat, 1996).

A study of the Karoo sills (South Africa; Figure 2.1) thickness was conducted in order to typify sill thickness. Of the 160 sills intersected in cores drilled through the Karoo Supergroup, 52 were $<10 \mathrm{~m}$ thick and as the thickness of the sills increased, the frequency significantly decreased, with only 3 sills exceeding $140 \mathrm{~m}$ thick (Cawthorn, 2012). However, it is suggested that the thicker sills may be composite (Galerne et al., 2008; 2011). For example, one 189 m-thick sill recently drilled in the middle of the Karoo appears to have been inflated an additional $102 \mathrm{~m}$ by two thinner sills, both with quenched margins (Slement, 2010). Without proper field exposure, it might have been wrongly identified as a single $290 \mathrm{~m}$ thick sill (Cawthorn, 2012).

In recent decades, advances in the understanding of sill-province geometry has been drawn from modern seismic imaging, experimental modelling, magnetic fabric studies, and detailed mapping (Chevallier and Woodford, 1999; Davies et al., 2002; Smallwood and Maresh, 2002; Thomson and Hutton, 2004; Planke et al., 2005; Hansen and Cartwright, 2006; Thomson and Schofield et al., 2008; Polteau et al., 2008a; Galland et al., 2009; Miles and Cartwright, 2010; Schofield et al., 2010). Through integrated detailed mapping 
and three-dimensional seismic images, the morphology of sills in sedimentary basins has been shown as generally saucer-shaped, characterized by a circular or elliptical shape in plan view with an inner flat dish surrounded by an inward arcuate rim and outer sill (Figure 2.2). Where pre-existing anisotropies exist (e.g., foliations and fractures), complex stair-stepping geometries can develop. Additionally, individual sills appear to be comprised of a series of lobes (analogous to those observed in lava flows) which branch out from a central source or feeder. Their formation has been linked to a shallow depth of emplacement (low confining pressure) into poorly consolidated sediments (Schofield, 2012).

A positive correlation (correlation factor of 4-5) has been observed between the diameter of the inner sill, and the emplacement depth (e.g. MaltheSørenssen et al., 2004; Polteau et al., 2008b; Galland et al., 2009). This relationship supports the observation of greater lateral extents of sills emplaced deep in the crust, particularly in the basement. A correlation also exists between the emplacement of saucer-shaped sills and local domal uplift of the overlying crust (Polteau et al., 2008b; Galland et al., 2009). With regard to channelized flow, thin sill bodies emplaced in cold country rocks will tend to "freeze" in situ due to rapid cooling and crystallization rates (Barnes et al., 2015). As a result, magma will tend to be focused in thicker sections of the intrusion where complete solidification has not been attained (Barnes et al., 2015).

\subsubsection{Sill provinces}


Sills that cluster in a restricted geographic region are often related and may comprise part of a sill province. This typically occurs when LIP-scale volumes of mafic ( \pm ultramafic) magma are injected into thick sedimentary basins, where it is common for extensive arrays of stacked saucer-shaped and/or tabular sills to be linked by dykes (Hansen and Cartwright, 2006; Polteau et al., 2008; Galland et al., 2009). This geometry of sills has been widely developed within the Siberian LIP (e.g., Yakubchuk and Nikishin, 2004) and Karoo Basin (Figure 2.1; e.g., Galerne, 2011; Svensen et al., 2012). The mechanics of shallow intrusions control these geometries, as well as the interaction between the transport network and Earth's surface and space creation through roof lifting (Galland et al., 2009; Bunger and Cruden, 2011). Sill provinces range in size from tens of square kilometers, where they are associated with local volcanic centres, to thousands of square kilometers (e.g. Karoo sills of southern Africa). Despite the large amounts of magma involved, saucer-shaped sills are empirically highly unfavorable for the formation of major mineral deposits.

\subsubsection{Surface magmatism}

In many cases, LIP plumbing systems are expressed on surface in the form of continental flood basalts or as point sources (e.g., shield volcanoes), which appear to be coeval with intrusion emplacement in specific provinces (e.g., Karoo; Cawthorn, 2012). Flood basalts are typically fed from fissures, and lavas can flow over surface distances exceeding $300 \mathrm{~km}$. The longest distance estimated for a single lava flow is nearly $1000 \mathrm{~km}$, in the Deccan LIP, where flows 
typically vary in thickness between 255 and 550 m (India; Self et al. 2008). Furthermore, a considerable portion of the LIP's plumbing system may not connect to the surface (i.e., may not supply magma for extrusion on surface).

\subsection{Layered Intrusions}

There is an important type of igneous intrusion that is distinguished from all other mafic to ultramafic intrusions by the presence of layering, and these are termed layered intrusions. These intrusions mimic sedimentary layering, containing layers ranging from millimeters to hundreds of meters in thickness, and are commonly associated with LIP events (Wilson, 1989). They likely form from a variety of different processes and can take on a variety of shapes, including lopoliths, sills, and dikes. They provide direct samples of crystallization products from the magmas in high-level magma chambers (Wilson, 1989). Layered intrusions were emplaced during both the Precambrian and Phanerozoic (Bogatikov et al., 2000), with many significant ones preserved in the latter. This type of intrusion also commonly hosts magmatic ore deposits (e.g.Ni-Cu-PGE,Ti$\mathrm{V}, \mathrm{P})$.

For the purpose of this paper, a layer may be defined as a sheet-like cumulate unit, distinctive in its textural and compositional features (Irvine, 1981). Layers may be described in terms of their texture, composition, thickness, form or internal structure (Irvine, 1981). Laminae refer to thin layers less than $3 \mathrm{~cm}$ in thickness, that are considered individual distinctive units (Irvine, 1981). Igneous laminations, in contrast, are grain-size scale features that are much more subtle 
and exist pervasively throughout the cumulate fabric (Irvine, 1981).

Layered intrusions may contain a number of different types of layering, including rhythmic, phase, and modally graded layering, which describe the mode of repetition (Irvine, 1981). Rhythmic layering (also termed cyclic layering) is characterized by "the conspicuous, systematic recurrence of distinctive layers or sequences of layers of the same kind" (Irvine, 1981); for example, the rhythmically layered sequence: dunite, olivine websterite, dunite, olivine websterite, etc. Phase layering may be defined by the appearance and disappearance of a certain mineral (Irvine, 1981), for example, the phase layering sequence: harzburgite, chromite harzburgite, chromite wehrlite. Lastly, modally graded layering is used for layers that are systematically graded stratigraphically, with different mineralogies or modal contents (Irvine, 1981), for example, gabbro, leucogabbro with higher plagioclase modal content, and anorthosite. Another common type of layering is cryptic layering, which describes the variation in cumulus-mineral composition (Irvine, 1981); for example, a dunite with olivine $\mathrm{Mg \# \sim 70}$ is stratigraphically higher than a dunite with olivine $\mathrm{Mg \# \sim 80}$ and stratigraphically lower than a dunite with olivine Mg\# 60.

\subsubsection{Geometry of layered intrusions}

The geometry of mafic to ultramafic intrusions is controlled by a number of factors, including: the structure of the crust (homogeneous or stratified, and the distribution of fracture and zones of weakness), far-field stresses governed by tectonic setting; near-field stresses in conjunction with buoyancy forces occurring 
at propagating tips of magma-filled cracks; existence of pre-existing structures; thermo-mechanical erosion influence on conduit geometry; and the interplay between the combined rates of flow, crystallization, and country rock melting and assimilation (Barnes et al., 2015). Roof uplift and floor depression can account, in part, for space creation in some mineralized mafic-ultramafic intrusions, however, the margins of chonolith intrusions in Norils'k-Talnakh (Russia) truncate layering in host sediments, indicating the intrusions created their own space (Barnes et al., 2015). This appears to be a crucial feature of intrusions hosting ore (Barnes et al., 2015). In addition to the typical tabular morphology of sills, layered intrusions can take on a variety of forms, including chonoliths and dykes.

\subsubsection{Stratiform (sill-like) intrusions}

Stratiform, sill-like, intrusions are laterally continuous over great distances. Examples of these include the Bushveld Complex of South Africa (e.g. Mungall et al., 2016), and the Giles Complex of central Australia (e.g. Maier et al., 2015). The latter has been interpreted to originally represent a single, laterally extensive stratiform intrusion that was tectonically dismembered into numerous distinct bodies (Maier et al., 2015), including approximately twenty major layered intrusions and several generations of sills and dykes, which are compositionally diverse (Ballhaus \& Glikson, 1995).

\subsubsection{Dyke-like intrusions}

Dyke-like layered intrusions (also termed "funnel dykes"; e.g. Hall, 1996) 
are unusually-thick, vertical sheet-like bodies that exceed the thickness of typical regional diabase dykes. In cross-section, these intrusions exhibit a Y-shaped profile, narrowing with increasing depth to a feeder dyke or "keel" (e.g. Podmore and Wilson, 1987). In some cases, these dyke-like intrusions are associated with regional dyke swarms (e.g. the Muskox intrusion, which is part of the Mackenzie dyke swarm/LIP; Baragar et al., 1996). Dyke-like layered intrusions include (as per summary in Ernst and Buchan 1997a) the 2575 Ma Great Dyke of Zimbabwe of South Africa (550-km-long and up to 11 km wide; Podmore and Wilson, 1987; Wilson, 1996), the Jimberlana dyke of western Australia (up to $2.5 \mathrm{~km}$ wide; part of 2410 Ma Widgiemooltha LIP; McClay and Campbell, 1976), the Muskox intrusion (up to $0.5 \mathrm{~km}$ wide; part of the 1270 Ma Mackenzie LIP; Irvine, 1980; Francis, 1994), and the ca. 1160 Ma giant Tugtutoq dykes of southern Greenland (0.5 to $0.8 \mathrm{~km}$ wide; Upton and Thomas, 1980; Upton et al., 1996). The Great Dyke of Zimbabwe narrows from $\sim 11 \mathrm{~km}$ to under $1 \mathrm{~km}$ over a distance of less than $3 \mathrm{~km}$ below the surface. In a similar manner, the Muskox layered intrusion narrows from $>11 \mathrm{~km}$ to a feeder dyke of $\sim 500 \mathrm{~m}$ in thickness.

\subsubsection{Funnel-shaped intrusions}

Funnel-shaped differentiated intrusions are a class of layered intrusion that are approximately equant in shape in plan view, and funnel-, cone- or bowlshaped in cross-section (Petraske et al., 1978; Loney and Himmelberg, 1983; Hall, 1996). Depending on the specific geometry, the terms plug, stock, lopolith, or laccolith may also apply (e.g. Corry, 1988; Bunger and Cruden, 2011). 
Examples of this style of intrusion include the Rum and Skye intrusions of the British Tertiary Province of the North Atlantic Igneous Province (NAIP; e.g. Emeleus and Gyopari, 1992), the Kiglapait intrusion of the Nain Plutonic suite of eastern Canada (e.g. Morse, 1979), and the Skaergaard intrusion of the east Greenland portion of the NAIP (e.g. Wager and Brown, 1968; McBirney, 1996). They have been inferred to be fed by pipe-like feeders located beneath the deepest part of the funnels (Loney and Himmelberg, 1983; Hall, 1996), or simply represent localized areas of upflow along a dyke (Ernst and Buchan, 1997b). Funnel-shaped intrusions are sometimes associated with LIP events (e.g. Skaergaard intrusion), while others are associated with subduction settings (Alaskan-type intrusions; e.g. Loney and Himmelberg, 1983; Eyuboglu et al., 2011). Funnel-shaped intrusions may also represent the roots of volcanic systems (Ernst, 2014).

\subsubsection{Chonoliths}

Chonoliths are elongate, tube-like intrusions. Examples include the NeboBabel intrusion in the Musgrave Province of western Australia (Seat et al., 2007), Nkomati/Uitkomst of South Africa (Maier et al., 2004) and the Limoeiro Complex in Brazil (Mota-e-Silva et al., 2013). Some mineralized intrusions in the Norils'kTalnakh camp are also chonoliths (Czamanske et al., 1995; Sluzhenikin et al., 2014), however, they are considerably wider than they are thick, and are therefore ribbon-shaped. The tube-like host chambers of Eagle (Midcontinent rift, USA), Kalatongke (Xinjiang, China), and Haungshandong (Central Asian 
Orogenic Belt; Lightfoot and Evans-Lamswood, 2015) have dyke-like keels, which have led to the suggestion that these intrusions may have resulted from the lateral flow in flared dykes, or they may represent forms of blade-shaped dykes (Barnes et al., 2015).

\subsubsection{Distribution of layered intrusions in LIPs}

It is common for layered intrusions, as well as associated continental flood basalts, to be divided based on their incompatible-element contents, into high- $\mathrm{Ti}$ and low-Ti magma types (Cox et al., 1967; Marsh et al., 2001; Jourdan et al., 2007a; Bryan and Ernst, 2008). Within certain LIPs, there is a marked provinciality in the distribution of the two magma types (e.g. Paraná-Entendeka, Karoo, and Emeishan).

\subsubsection{Mechanisms of layer formation in layered intrusions}

Given that layering is prevalent in sills across the Frobisher suite sills, descriptions of mechanisms of layer formation is justified.

\subsubsection{Fractional crystallization}

The traditional explanation for the formation of layered igneous intrusions is through the process of fractional crystallization. Gravitational settling is believed to be the physical process involved, in which minerals crystallize and then sink or float to either the base or roof of a cooling magma body (Wager and Brown, 1967). This process results in successive batches of crystals accumulating and being preserved as layers (Wager and Brown, 1967). Cumulate is a term that 
was created to describe layers formed exclusively via the crystal settling process (Wager and Brown, 1967). The crystals that are interpreted to have settled out a melt are termed 'cumulus minerals,' and the crystals derived from cooling of the melt surrounding these crystals were termed 'intercumulus crystals' (Wager and Brown, 1967).

However, in the presence of convection, the gravitational settling process is deemed inadequate, as crystals would stay in suspension (Sparks et al., 1984). This reasoning has brought forward an alternative process to layer formation in igneous intrusions termed "convective fractionation." This process takes place at margins of an intrusion and involves magma adjacent to growing crystals convecting away as it progressively develops a different density compared to the parental magma, during crystallization (Sparks et al., 1984).

There is also a possibility that crystallizing magmas in layered intrusions behave as double diffusive convection systems. In such case, the magma would be stacked as a series of thick convecting layers, separated by thin, static "diffusive" boundary layers (Kruger and Smart, 1987). The intrusions would then crystallize from the base upwards, where chemical changes due to fractional crystallization of the lowermost convecting layer would diffuse across the thin "diffusive" boundary layers that separate the thick, stacked convection layers of magma (Kruger and Smart, 1987). This process arises because of the interaction between two fluid components that have different rates of diffusion (Radko, 2013).

An injection of a slurry of crystals may also sort itself by size, density or 
shape, leading to the development of well-formed layers (Marsh, 2013). In this case, the layering present in sills could reflect crystal slurry injection over rhythmic crystallization (Marsh, 2013). Candidates for intrusions derived through this form of emplacement would be those where the sandwich horizon is clearly located above the centre of the intrusion (Marsh, 2013).

Certain rock-types, particularly those of mafic composition, often contain layering (Wager and Brown, 1967). However, numerous massive mafic intrusions have been documented as well (Wager and Brown, 1967). The massive mafic intrusions often have limited thickness (i.e. less than $300 \mathrm{~m}$ thick sills), and as a result, likely cooled relatively quickly; reflected by the presence of ophitic and sub-ophitic textures (Wager and Brown, 1967). Coarser-grained mafic units are more likely to experience significant crystal settling and develop layering (Wager and Brown, 1967). Also note that a narrow intrusion may achieve a gabbroic texture if it is emplaced in a hot environment (Wager and Brown, 1967), allowing for a slower than normal rate of cooling.

Amongst these sheets, there must be an absence of chilled margins and cross-cutting relationships, and in most cases, signs of cryptic variation are present (Wager and Brown, 1967). Cryptic variation is simply a systematic change in the nature and composition of the mineral phases within an intrusion and relates to the stratigraphic height in the layering (Wager and Brown, 1967).

\subsubsection{Composite sills versus vertically-stacked sills}


A more recently recognized mechanism for the formation of "cumulate layers" in layered intrusions is the injection of multiple batches of magma either into a previously emplaced, partially crystallized sill (e.g. Mungall et al., 2016), or underplating previously emplaced, mostly or fully crystallized, sills (e.g. Menand, 2008).

Composite sills may develop when one or more sills are injected inside one another (e.g., Bushveld Complex; Cawthorn, 2012; Mungall et al., 2016). Within these composite sills, internal chilled selvages may or may not be present, depending on the degree to which the initial sill(s) cooled and crystallization prior to subsequent sill emplacement (Cawthorn, 2012). If multiple injections of magma occur over a short time interval, relative to the time it takes a sill of a certain thickness to cool, this magma will inflate the magma chamber and a proper layered intrusion will form (Cawthorn, 2012).

Within a sill $50 \mathrm{~m}$ in thickness, it would only take $\sim 10$ years for its temperature to decrease from $1200^{\circ} \mathrm{C}$ (liquidus temperature) to $1100^{\circ} \mathrm{C}$, at which point the sill would be $\sim 50 \%$ crystallized (based on modeling from Wright et al., 1976; similar results were obtained by Zavala et al., 2011). At these temperatures, chilled margins are expected to occur between a second magma injection and the resident magma, and mixing between the two magmas is unlikely to occur (resulting in composite sill formation, rather than a layered intrusion). Furthermore, modelling by Tegner et al. (1993) suggests a temperature difference as little as $50^{\circ} \mathrm{C}$ is enough to cause sufficient chilling to isolate the first and second magma injections. Additionally, $50 \%$ crystallization is 
considered to be the "rheological lock-up point" (e.g. Johnson and Glazner, 2011), and beyond this point, subsequent injections into the cooling intrusion will retain their physical identity (Patwardham and Marsh, 2011). Therefore, for a newly injected magma to inflate the the center of an intrusion, the temperature of the resident magma had to have been greater $1100^{\circ} \mathrm{C}$ at the time of the second injection.

The time period required for a sill to completely cool is proportional to the intrusion's thickness to the power two (squared), so if the intrusion increases in thickness twofold, it will take four times as long to cool (Cawthorn, 2012). Therefore, if multiple injections occur, continually, before the intrusion becomes $\sim 50 \%$ crystallized $\left(<1100^{\circ} \mathrm{C}\right)$, the chamber inflation process becomes selfsustaining and a single magma chamber will continue to increase in size and thickness indefinitely (e.g., Mount Ayliff intrusion of the Karoo; Marsh et al., 2003; Cawthorn and Kruger, 2004; Cawthorn, 2012).

Alternatively, numerous discrete, vertically-stacked sills may be emplaced within a sedimentary package (e.g. Karoo dolerites; Cawthorn, 2012). If sills are emplaced adjacent to one another, internal chilled margins are expected to form between each sill, if the earlier sill was already solid (Menand, 2008). In the Karoo, the majority of sills occur as discrete entities, however, composite sills with internal chilled salvages are occasionally documented (Galerne et al., 2008).

A key determinant as to whether a vertically-stacked sill complex or a layered intrusion forms is the time interval during which intrusion occurs, and their respective thicknesses (Cawthorn, 2012). Assuming a liquidus of $1200^{\circ} \mathrm{C}$ 
(typical for basaltic magma), sills are virtually solid at $950^{\circ} \overline{\mathrm{C}}$, given relatively cool host rocks, and heat-loss through conduction: a $1 \mathrm{~m}$ sill will be solid in less than a day, a $10 \mathrm{~m}$ thick sill will cool in $\sim 1$ year, and a $200 \mathrm{~m}$ sill will take $\sim 260$ years. However, if a significant volume of crystal-free magma persisted in the core of a thicker sill, it is possible that convection could occur, resulting in more rapid cooling of the sill. However, relatively thin sills are not likely to convect (Marsh, 1989; 2007). With regard to the physical aspects of multiple sill injection, Menand (2008) demonstrated that subsequent injections are more likely to underplate, rather than overplate the previous intrusion. Additionally, if the initial intrusion has not completely cooled and a subsequent injection of magma truncates its lower chilled margin, it would likely be trapped in the liquid core of the initial sill (Cawthorn, 2012).

Definitively distinguishing between a single evolving magma chamber and a sheeted sill complex has generally not been possible due to a lack of extensive, high-precision geochronological data (Mungall et al., 2016). However, modern high-precision U-Pb geochronology, on chemically abraded single magmatic zircon grains, can radically improve overall age accuracy and provide sub-million-year age resolution. For example, Mungall et al. (2016) has demonstrated, through high-precision geochronology, that individual chromite layers of the Rustenburg Layered Suite (of the Bushveld Igneous Complex), presumed to have been formed via crystal settling within a vast magma chamber, formed instead as discrete sill-like intrusions that were emplaced beneath older layers, forming a stack of individual sill-like intrusions. 


\subsection{Mafic-Ultramafic Intrusion-Hosted Mineral Deposits}

Within the geologic record, layered mafic, ultramafic, and mafic-ultramafic intrusions are relatively uncommon (Zientek, 2012). However, these intrusions are host to magmatic sulphide ore deposits, which occasionally contain economic concentrations of copper $(\mathrm{Cu})$, nickel $(\mathrm{Ni})$, chromium $(\mathrm{Cr})$ and platinum-groupelements (PGE; Schulz, 2010), and as a result, are exploited for their base and precious metals. Layered intrusion-hosted mineral deposits contain the world's only economic concentrations of PGE (Zientek, 2012). These metals are of major importance to our economy and everyday living, where copper is used for electrical wiring and plumbing, nickel to make nickel steels and other highlyutilized alloys, and PGEs for their catalytic properties.

There are two major types of magmatic sulphide deposits that occur within layered mafic, ultramafic, and mafic-ultramafic intrusions:

1. Cu- and Ni-rich deposits: These deposits are primarily valued for their $\mathrm{Cu}$ and Ni contents, and are characteristically sulphide-rich (10-90\% sulphide; Schulz, 2010).

2. PGE-rich deposits: These deposits are primarily valued for their PGE contents (namely platinum $(\mathrm{Pt})$, Palladium $(\mathrm{Pd})$, and Rhodium $(\mathrm{Rh})$, and are characteristically sulphide-poor (0.5-5\% sulphide; Schulz, 2010). The deposits can be subdivided into two types on the basis of their style of mineralization:

a. PGE-reef mineralization (e.g. Bushveld): "PGE reefs" comprise stratabound PGE-enriched lode mineralization (Zientek, 2012), and are 
sulphide-poor (<5\% sulphide; Schulz, 2010). The reef-type mineralization is laterally continuous along strike for the length of the intrusion, which is often tens to hundreds of kilometers (Zientek, 2012). However, the mineralized interval is thin, varying from centimeter to meter-scale in thickness, compared to the hundred to thousand-meter stratigraphic thickness in a given intrusion (Zientek, 2012). The term "reef" is used to refer to the rock layer that is mineralized and has a distinctive texture (Naldrett, 2004), or to the PGE-enriched sulphide mineralization that occurs within a rock layer (Zientek, 2012). The primary commodities extracted from these PGE-reef deposits are platinum, palladium, and rhodium, with ruthenium, iridium, osmium, copper, nickel and gold as byproducts (Zientek, 2012).

b. PGE-enriched (contact-type) sulphide mineralization: This type of mineralization occurs near the contacts or margins of layered maficultramafic intrusions (Iljina and Lee, 2005), and is characterized by zones of disseminated to massive concentrations of iron-copper-nickel-PGE enriched sulphide, tens to hundreds of meters in thickness (Zientek, 2012). The igneous host rocks often contain modes and textures that irregularly vary on the centimeter to meter scale. Mineralization is concentrated within both the igneous intrusion and its surrounding country rocks, and tends to preferentially localize along the contacts with sulfur-, iron-, or $\mathrm{CO}_{2}$-bearing units within the host country rock (Zientek, 2012). The deposits are polymetallic, containing variable proportions of primary 
commodities $\mathrm{Ni}, \mathrm{Cu}$, and $\mathrm{PGE}$, with gold recovered as a by-product (Zientek, 2012).

\subsubsection{Ni-Cu-PGE deposit petrogenesis}

\subsubsection{Geodynamic history and setting}

There is a consensus that several major camps (e.g. Duluth Complex deposits of the Midcontinent Rift; Ripley, 2014) are associated with rifted environments where large volumes of mostly mantle-plume-derived mafic or ultramafic magmas were injected into sedimentary basins. Furthermore, a spatial association of Ni-Cu-PGE sulphide deposits, large and small, with ancient Archean cratonic margins, whether the margins are rifted or not, is recognized (Begg et al., 2010). This is believed to be a consequence of the deflection of ascending plume heads towards zones of thinner lithosphere (i.e. cratonic margins; Sleep et al., 2002; Sobolev et al., 2011). Plume deflection (Figure 2.3) may account for linear belts of plume magmatism and ore deposits which must have been derived from a "bullseye" point-source thermal anomaly ascending from the deep mantle (e.g. Circum-Superior LIP; Barnes et al., 2015).

\subsubsection{Sources and compositions of ore-forming magmas}

The metals contained within magmatic mineral deposits ultimately originate from the mantle source from which the transporting magma is derived, which is usually sub-lithospheric and mantle-plume-derived (i.e. deep mantle; Barnes et al., 2015). Mineralized provinces tend to be associated with hotter, high-MgO 
magmas, rather than typical ambient mantle melting products (i.e. MORB; Barnes et al., 2015). Essential to the formation of these deposits is voluminous, high-temperature melts from sub-lithospheric source, making mantle plumes the most likely source for these deposits (Barnes et al., 2015). Consequently, deposits within any province are often associated with the highest degree partial melts, the most adcumulate rocks (i.e. those with highest ratio/proportion of cumulus mineral to intercumulus trapped liquid), and least fractionated magmas within conduit systems (Barnes et al., 2015).

\subsubsection{Sources of sulphur and transport of sulphide liquid}

In nearly all Ni-Cu-PGE deposits, the $S$ isotopic evidence strongly supports the role of assimilated crustal sulphur in the formation of the deposits (Ripley and Li, 2003, 2013; Keays and Lightfoot, 2010). This is particularly important in komatiite-hosted deposits and others associated with high-T magmas, because the $S$ content of their deep mantle sources is far below the sulphide content at sulphide liquid saturation (SCSS; Barnes et al., 2015). Furthermore, due to the negative correlation of SCSS with pressure, the magma becomes more undersaturated as it ascends (Mavrogenes and O'Neil, 1999). The best indicator of prospectivity is the presence of proximal S-rich sediments (Barnes et al., 2015). However, current models for many significant deposits involve initial segregation of immiscible liquid occurring deep within the lower crust, far below the level where the actual deposit forms, followed by subsequent entrainment, upward transport, and mechanical deposition (Barnes et al., 2015). 
Examples of deposits for which this model has been applied include Voisey's Bay , Canada (Lightfoot et al., 2012; Saumur et al., 2013), Norils'k-Talnakh, Russia (Arndt et al., 2003; Li et al., 2009), Eagle, U.S.A. (Ding et al., 2012b), and Jinchuan, China (Tang, 1991; Song et al., 2012). This model is largely driven by the fact that these deposits host a vast excess of sulphide and chalcophile elements that could not have possibly been dissolved in the volume of magma that is their host (Naldrett, 1992; Lightfoot and Keays, 2005; Song et al., 2012).

\subsubsection{Mineralized intrusion formation}

There are two distinctly different mechanisms proposed for the deposition of cumulus sulphide liquid: 1) in-situ nucleation and growth of sulphide droplets from a silicate melt; and 2) a form of mechanical deposition of transported droplets (Barnes et al., 2015). The former process occurs in-situ and involves the segregation of an immiscible sulphide liquid from a silicate magma (Barnes et al., 2015). The segregation occurs in response to changes in temperature and composition of a host magma that causes the $S$ content to exceed sulphide liquid saturation (see review in Barnes et al., 2015). The precipitated sulphide droplets will either co-precipitate with sub-liquidus silicates resulting in disseminated ores, or the droplets will be transported further along in the plumbing system (Barnes et al., 2015). In the latter case, the mechanical segregation of sulphide liquid is driven by density contrast, and may be enhanced by coalescence of the droplets, mechanical riffling, rapid deposition - favouring changes in the flow regime, or 
kinetic sieving in density currents (charges with silicate crystals and sulphide liquid; Barnes et al., 2015).

An essential characteristic of many mineralized intrusions is the discordant relationship of the igneous contact with host country rocks (Barnes et al., 2015). This indicates that space was created via assimilation (physical erosion), rather than roof-lifting, as is the case for saucer-shaped sills (Barnes et al., 2015). If an intrusion is small, a chilled margin will form, preventing heat transfer to wallrocks. If the intrusion is much larger, and of high-flux, the initial chilled margin will re-melt and hot magma will come into contact with wall rocks, leading to assimilation (Huppert and Sparks, 1988).

\subsection{Metamorphism of Mafic and Ultramafic Rocks}

Given that the geology of southern Baffin Island comprises rock units that have been subjected to amphibolite- to granulite-facies metamorphism, an overview of the metamorphism of medium to high grade mafic to ultramafic rocks is warranted. This section is based largely on Bucher \& Grapes (2011).

Mafic units metamorphosed to amphibolite and granulite facies conditions will display the characteristic assemblages of plagioclase + hornblende +/clinopyroxene (or garnet +/- biotite), and plagioclase + clinopyroxene + garnet (or orthopyroxene), respectively. Plagioclase composition ranges from oligoclase $\left(\sim 500^{\circ} \mathrm{C}\right.$; lower amphibolite $)$, to andesine $\left(\sim 600^{\circ} \mathrm{C}\right.$; middle amphibolite), to labradorite $\left(\sim 650^{\circ} \mathrm{C}\right.$; upper amphibolite), however, the anorthite content of the metamorphic plagioclase is influenced also by the bulk composition of the rock. 
The appearance of clinopyroxene or garnet marks the beginning of upper amphibolite facies $\left(\sim 650^{\circ} \mathrm{C}\right)$.

The transition from hydrous amphibolite to anhydrous granulite occurs over a $200^{\circ} \mathrm{C}$ interval $\left(650-850^{\circ} \mathrm{C}\right)$. The appearance of orthopyroxene in clinopyroxene-bearing, quartz-free rocks is clear evidence that granulite facies conditions were attained, even if hornblende is still present. Mafic granulites typically contain either the assemblage plagioclase + clinopyroxene + garnet (at high-pressure), or plagioclase + clinopyroxene + orthopyroxene (at lowpressure). As calcic hornblende breaks down, the dehydration reactions add Diand An- components to clinopyroxene and plagioclase, respectively. This results in abundant labradorite within granulite mafic rocks. High-grade brown hornblende is very stable and can persist to temperatures $>950^{\circ} \mathrm{C}$ in metabasic rocks. As a result many mafic granulites still contain hornblende. Hercynitic spinel is a common accessory in mafic granulites, diagnostic of low-P granulite conditions (<400 MPa).

Ultramafic units metamorphosed to amphibolite and granulite facies, will contain the diagnostic assemblages enstatite + forsterite + hornblende + spinel, and enstatite + forsterite + diopside + spinel, respectively. At lower temperatures $\left(<700^{\circ} \mathrm{C}\right)$, ultramafic rocks contain chlorite as the aluminous phase. At high temperatures $\left(>700^{\circ} \mathrm{C}\right)$, ultramafic rocks also contain one of three different aluminous mineral phases: anorthite at low pressure, spinel at medium to high pressure, and garnet at ultra high pressure (> 1 GPa; eclogite facies). If subjected to retrograde conditions, the aluminous phase may back react to form 
chlorite, and clinopyroxene will form amphibole. 


\section{References}

Arndt, N.T., Czamanske, G.K., Walker, R.J., Chauvel, C., Fedorenko, V.A. (2003). Geochemistry and origin of the intrusive hosts of the Noril'sk-Talnakh CuNi-PGE sulfide deposits. Economic Geology Bulletin, Society of Economic Geologists 98, 495-515.

Ballhaus, C. and Glikson, A.Y. (1995). The petrology of layered mafic- ultramafic intrusions in the Giles Complex, western Musgrave block, central Australia: AGSO Journal, v. 16, p. 69-89.

Baragar, W.R.A., Ernst, R.E., Hulbert, L. \& Peterson, T. (1996). Longitudinal petrochemical variation in the Mackenzie dyke swarm, northwestern Canadian Shield. Journal of Petrology, 37: 317-359.

Barnes, S.J., Cruden, S., Arndt, N., Saumur, B. (2015). The mineral system approach applied to magmatic Ni-Cu-PGE sulphide deposits, Ore Geology Review 71, 673-702.

Barnes, S-J., Lightfoot, P.C. (2005). Formation of magmatic nickel sulfide deposits and processes affecting their copper and platinum group element contents. Economic Geology 100th Anniversary Volume, pp. 179-214.

Bates, R.L. and Jackson, J.A. (ed.). (1980). Glossary of Geology. American Geological Institute, Falls Church, Virginia.

Begg G.C., Griffin W.L., Natapov L.M., O’Reilly S.Y., Grand S.P., O’Neill C.J., Hronsky J.M.A., Poudjom Djomani Y., Swain, C.J., Deen T. \& Bowden P. (2009). The lithospheric architecture of Africa: Seismic tomography, mantle petrology and tectonic evolution, Geosphere, 5, 23-50. (2009). The 
lithospheric architecture of Africa: seismic tomography, mantle petrology, and tectonic evolution. Geosphere, 5: 23-50.

Begg, G.C., Hronsky, J.A.M., Arndt, N.T., Griffin, W.L., O'Reilly, S.Y., \& Hayward, N. (2010). Lithospheric, Cratonic, and Geodynamic Setting of Ni-Cu-PGE Sulfide Deposits, Economic Geology, 105, 1057-1070.

Bogatikov, O.A., Kovalenko V.I., Sharkov, E.V., \& Yarmolyuk, V.V. (2000). Magmatism and Geodynamics. Terrestrial Magmatism Throughout the Earth's History. Gordon and Breach Science Publication, 511.

Bradley, J. (1965). Intrusion of major dolerite sills. Transactions of the Royal Society of New Zealand, 3 (4): 27-55.

Bryan, S., \& Ernst, R.E. (2008). Revised definition of Large Igneous Provinces (LIPs). Earth-Science Reviews, 86: 175-202.

Bunger, A.P., Cruden, A.R. (2011). Modeling the growth of laccoliths and large mafic sills; role of magma body forces. Journal of Geophysical Research, 116.

Burke K, \& Torsvik TH. (2004). Derivation of Large Igneous Provinces of the past 200 million years from long-term heterogeneities in the deep mantle. Earth Planetary Science Letter, 227:531-38.

Campbell, I.H. (2001). Identification of ancient mantle plumes. In R.E. Ernst, K.L. Buchan (eds.), Mantle Plumes: Their Identification through Time. Boulder, CO: Geological Society of America, Special Paper 352, pp. 5-21.

Campbell, I.H. (2005). Large igneous provinces and the mantle plume hypothesis. Elements, 1: 265-269. 
Campbell, I.H. (2007). Testing the plume theory. Chemical Geology, 241: 153176.

Campbell, I.H., Griffiths, R.W., Hill, R.I. (1989). Melting in an Archaean mantle plume: heads it's basalts, tails it's komatiites. Nature 339, 697-699.

Cartwright, J. and Hansen, D.M. (2006). Magma transport through the crust via interconnected sill complexes: Geology, v. 34, p. 929-932, doi:10.1130/ G22758A.1.

Cawthorn, R.G. (2012). Multiple sills or a layered intrusion? Time to decide. South African Journal of Geology, 115: 283-290.

Cawthorn, R.G. \& Kruger F.J. (2004). Petrology and Ni-Cu-PGE potential of the Insizwa lobe, Mount Ayliff Intrusion, South Africa. Canadian Mineralogist, 42, 303-324.

Chadwick, J., Perfit, M., Ridley, I., Jonasson, I., Kamenov, G., Chadwick, W., Embley, R., le Roux, P., and Smith, M. (2005). Magmatic effects of the Cobb hot spot on the Juan de Fuca Ridge. Journal of Geophysical Research, 110:B03101, doi:10.1029/2003JB002767

Chevallier, L. and Woodford, A. (1999). Morpho-tectonics and mechanism of emplacement of the dolerite rings and sills of the western Karoo, South Africa. Transactions of the Geological Society of South Africa, 102, 43-54

Coffin, M.F., Eldholm, O. (1992). Volcanism and continental break-up: a global compilation of large igneous provinces. Geological Society, London, Special Publications 68, 17-30.

Corry, C.E., (1988). Laccolith: Mechanics of emplacement and growth, Spec. 
Pap., Geological Society of America, 220.

Cox, K.G., Macdonal, R., Hornung, G. (1967). Geochemical and petrographic provinces in Karoo basalts of southern Africa. American Mineralogist, 52, $1451-1474$.

Cox, K.G. (1980). A model for flood basalt vulcanism. Journal of Petrology, 21: 629-650.

Cox, K.G. (1993). Continental Magmatic Underplating. Philosophical Transactions of the Royal Society, A 1993342 155-166; DOI: 10.1098/ rsta.1993.0011.

Czamanske, G.K., Zen'ko, K.E., Fedorenko, V., Calk, L.C., Budahn, J.R., Bullock, J.H.J., Fries, T.L., King, B.S., Siems, D.F. (1995). Petrographic and geochemical characterization of ore-bearing intrusions of the Noril'sk Type, Siberia; with discussion of their origin. Resource Geology Special Issue 18, 1-48.

Davies, J.H., Bunge, H-P. (2006). Are splash plumes the origin of minor hotspots? Geology 34:349-52.

Davies, R., Bell, B.R., Cartwright, J.A., and Shoulders, S. (2002), Threedimensional seismic imaging of Paleogene dike-fed submarine volcanoes from the Northeast Atlantic margin, Geology, 30, 223-226.

Ding, X., Ripley, E.M., Shirey, S.B., Li, C. (2012). Os, Nd, O and S isotope constraints on country rock contamination in the conduit-related Eagle $\mathrm{Cu}-\mathrm{Ni}-(\mathrm{PGE})$ deposit, Midcontinent Rift System, upper Michigan. Geochimica et Cosmochimica Acta, 89, 10-30. 
Duggen, S., Hoernle, K.A., Hauff, F., et al. (2009). Flow of Canary mantle plume material through a subcontinental lithospheric corridor beneath Africa to the Mediterranean. Geology, 37: 283-286.

Ebinger, C.J., and Sleep, N.H. (1998). Cenozoic magmatism throughout East Africa resulting from impact of a single plume. Nature, 395: 788-791.

Elkins-Tanton, L.T. (2005). Continental magmatism caused by lithospheric delamination. In: Foulger GR, Natland JH, Presnall DC, Anderson DL (eds) Plates, Plumes and Paradigms. Geological Society of America Special Paper 388, pp 449-462.

Emeleus, C.H. and Gyopari, M.C. (1992), British Tertiary Volcanic Province, Geological Conservation Review Series, No. 4, Chapman and Hall, London, 259 pages, illustrations, A4 hardback, ISBN 0412479807.

Ernst, R.E. (2014). Large Igneous Provinces: Cambridge, UK, Cambridge University Press, 653 p.

Ernst, R.E. and Buchan, K.L. (1997a). Giant Radiating Dyke Swarms: Their use in identifying pre-Mesozoic large igneous provinces and mantle plumes, In Mahoney, J. \& Coffin, M. (eds.) Large lgneous Provinces: Continental, Oceanic, and Planetary Volcanism, AGU Geophysical Monograph Series Volume 100, pp. 297-333.

Ernst, R.E. and Buchan, K.L. (1997b). Layered mafic intrusions: a model for their feeder systems and relationship with giant dyke swarms and mantle plume centres: South African Journal of Geology, v. 100, p. 319-334 
Ernst, R.E. and Buchan, K.L. (2004). Igneous rock associations in Canada 3. Large Igneous Provinces (LIPs) in Canada and adjacent regions: 3 Ga to present: Geoscience Canada, v. 31, p. 103-126.

Ernst, R.E., Buchan, K.L., Bleeker, W. (2008). The Plumbing System of Large Igneous Provinces (LIPs), Paper presented at the 33rd International Geological Congress (33IGC), Oslo, Norway, 6-14 August, 2008.

Eyuboglu, Y., Santosh, M., Bektas, O., Chung, S.-L. (2011). Late Triassic subduction-related ultramafic-mafic magmatism in the Amasya region (eastern Pontides, N. Turkey): implications for the ophiolite conundrum in Eastern Mediterranean. Journal of Asian Earth Sciences, 42: 234-257.

Farnetani, C.G., and Samuel, H. (2005). Beyond the thermal plume paradigm. Geophysical Research Letters, 32: L07311.

Francis, D. (1994). Chemical interaction between picritic magmas and upper crust along the margins of the Muskox intrusion, Northwest Territories. Geological Survey of Canada Paper, 92-12, 94pp.

Galerne, C.Y., Galland, O., Neumann, E.-R. and Planke, S., (2011). 3-D relationships between sills and their feeders: evidence from the Golden Valley Sill Complex (Karoo basin) and experimental modelling. Journal of Volcanology and Geothermal Research, 202, 189-199.

Galerne, C., Neumann, E.-R. and Planke, S. (2008). Emplacement mechanisms of sill complexes: information from the geochemical architecture of the Golden Valley sill complex. Journal of Volcanology and Geothermal Research, 177, 425-440. 
Galland, O., Planke, S., Neumann, E.-R., and Malthe-Sørenssen, A. (2009). Experimental modelling of shallow magma emplacement: application to saucer-shaped intrusions. Earth and Planetary Science Letters, 277: 373383.

Gretener, P.E. (1969). On the mechanics of the intrusion of sills. Journal of Earth , 6(6):1415-1419. doi: 10.1139/e69-143.

Griffiths, R.W., Campbell, I.H. (1990). Stiring and structure in mantle starting plumes. Earth Planetary Science Letters, 99, 66-78.

Hall, A. (1996). Igneous Petrology, 2nd edition. Harlow: Longman Science \& Technology.

Hansen, D.M. and Cartwright, J. (2006). Saucer-shaped sill with lobate morphology revealed by 3D seismic data: Implications for resolving a shallow level sill emplacement mechanism. Journal of the Geological Society, London. 163, 509-523.

Hofmann, A.W. and White, W.M. (1982). Mantle plumes from ancient oceanic crust. Earth Planetary Science Letters, 57:421-36

Hughes, H.S.R., MacDonald, I., Goodenough, K.M., Ciborowski, T.J., Kerr, A.C., Davies, J.H.F.L. and Shelby D. (2014). Enriched lithospheric mantle keel below the Scottish margin of the North Atlantic Craton: evidence from the Palaeoproterozoic Scourie Dyke Swarm and mantle xenoliths. Precambrian Research, vol 250, p.97-126.

Huppert, H.E., and Sparks, R.S.J. (1988). The generation of granitic magmas by intrusion of basalt into continental crust. Journal of Petrology, 29, 599- 
624.

Iljina, M.J., and Lee, C.A. (2005). Chapter 4: PGE deposits in the marginal series of layered intrusions, in Mungall, J.E., ed., 2005, Exploration for platinumgroup element deposits: Ottawa, Mineralogical Association of Canada Short Course Series Volume 35, p. 75-96.

Irvine T.N. (1980). Magmatic infiltration metasomatism, double-diffusive fractional crystallization, and adcumulus growth in the Muskox intrusion and other layered intrusions. In: R.B. Hargreaves (Ed.) Physics of magmatic processes. Princeton University Press. Pp. 325-383.

Irvine, T.N. (1981). Terminology for Layered Intrusion. Geophysical Laboratory, Carnegie Institution of Washington, Washington, D.C. 20008.

Johnson, B.R. and Glazner, A.F. (2011). Formation of K-feldspar megacrysts in granodioritic plutons by thermal recycling and late-stage textural coarsening. Contributions to Mineralogy and Petrology, 159, 599-619.

Jourdan, F., Bertrand, H., Sharer, U., Blitchert-Toft, J., Féraud, G., and Kampunzu, A.B. (2007). Major-trace element and $\mathrm{Sr}-\mathrm{Nd}-\mathrm{Hf}-\mathrm{Pb}$ isotope compositions of the Karoo large igneous province in BotswanaZimbabwe. Journal of Petrology, 48: 1043-1077.

Kavanagh, J.L., Menand, T., Sparks, R.S.J. (2006). An experimental investigation of sill formation and propagation in layered elastic media. Earth Planetary Science Letters, 245, 799-813. http://dx.doi.org/10.1016/j.epsl. 2006.03.025.

Keays, R.R., Lightfoot, P.C. (2010). Crustal sulfur is required to form magmatic 
$\mathrm{Ni}-\mathrm{Cu}$ sulfide deposits; evidence from chalcophile element signatures of Siberian and Deccan Trap basalts. Mineralium Deposita, 45, 241.

King S.D. and Anderson D.L. (1995). An alternative mechanism of flood basalt formation. Earth and Planetary Science Letters 136: 269-279

King S.D. and Anderson D.L. (1998). Edge-driven convection. Earth and Planetary Science Letters 160: 289-296.

Kruger, F. J. and Smart, R. (1987). Diffusion of trace elements during bottom crystallisation of double-diffusive convection systems: The magnetite layers of the Bushveld Complex. Journal of Volcanology, Geothermal Research, 34, 133-42.

Leat, P.T. (2008). On the long-distance transport of Ferrar magmas, in Thomson, K., and Petford, N., eds., Structure and emplacement of high-level magmatic systems: Geological Society of London Special Publication 302, p. 45-61, doi:10.1144/SP302.4.

Li, C., Ripley, E.M., Naldrett, A.J. (2009). A new genetic model for the giant NiCU-PGE sulfide deposits associated with the Siberian flood basalts. Economic Geology Bulletin, Society of Economic Geologists, 104, 291301.

Lightfoot, P.C., and Keays, R.R. (2005). Siderophile and Chalcophile Metal Variations in Flood Basalts from the Siberian Trap, Noril'sk Region: implications for the Origin of the Ni-Cu-PGE Sulfide Ores. Economic Geology, 100, 439-462.

Lightfoot, P.C., Keays, R.R., Evans-Lamswood, D.,Wheeler, R. (2012). S- 
saturation history of Nain plutonic suite mafic intrusions; origin of the Voisey's Bay Ni-Cu-Co sulfide deposit, Labrador, Canada. Mineralium Deposita, 47, 23-50.

Liikane, D.A., St-Onge, M.R., Kjarsgaard, B.A., Rayner, N.M., Ernst, R.E. and Kastek, N. (2015). Frobisher suite mafic, ultramafic and layered maficultramafic sills, southern Baffin Island, Nunavut; in Summary of Activities 2015, Canada-Nunavut Geoscience Office, p. 21-32.

Lister, J.R., and Kerr, R.C. (1991). Fluid-mechanical models of crack propagation and their application to magma transport in dykes. Journal of Geophysical Research, 96-B6, 10049-10077. http://dx.doi.org/10.1029/91JB00600.

Loney, R.A., and Himmelberg, G.R. (1983). Structure and petrology of the La Perouse gabbro intrusion, Fairweather Range, southeastern Alaska. Journal of Petrology, 24: 377-423.

Lustrino, M. (2005). How the delamination and detachment of lower crust can influence basaltic magmatism. Earth-Science Reviews, 72: 21-38.

Magee, C., Muirhead, J.D., Karvelas, A., Holford, S.P., Jackson, C.A.L., Bastow, I.D., Schofield, N., Stevenson, C.T.E., McLean, C., McCarthy, W., and Shtukert, O. (2016). Lateral magma flow in mafic sill complexes: Geosphere, v. 12, no. 3, p. 1-33, doi:10.1130/GES01256.1.

Maier, W., Rasmussen, B., Fletcher, I., Godel, B., Barnes, S.J., Fisher, L., and Yang, S. (2015). Petrogenesis of the $\sim 2.77$ Ga Monts de Cristal complex, Gabon: Evidence for direct precipitation of Pt-arsenides from basaltic magma. Journal of Petrology, 56, 1285-1308. 
Malthe-Sørensen, A., Planke, S., Svensen, H., and Jamtveit, B. (2004), Formation of saucer shaped sills, in Physical Geology of High Level Magmatic Systems, Geol. Soc. London, Spec. Publ., vol. 234, edited by C. Breitkreuz and N. Petford, pp. 215-227, Geological Society, London.

Mandler, H.A.F. and Clowes, R. M. (1997). Evidence for extensive tabular intrusions in the Precambrian shield of western Canada: A 160-km-long sequence of bright reflections. Geology, 25: 271-274.

Marsh, B.D., (1989). On convection style and vigour in sheet-like magma chambers. Journal of Petrology, 30, 479-530.

Marsh, B.D., (2007). Magmatism, magma and magma chambers. In: A.B. Watts (Editor), Treatise on Geophysics, Elsevier, Amsterdam, The Netherlands, 276-333.

Marsh, B.D., (2013). On some fundamentals of igneous petrology, Contributions to Mineralogy and Petrology, 166: 665-690

Marsh, J.S., Allen, P. and Fenner, N. (2003). The geochemical structure of the Insizwa lobe of the Mount Ayliff Complex with implications for the emplacement and evolution of the complex and its Ni-sulphide potential. South African Journal of Geology, 106, 409-428.

Marsh, J.S., Ewart, A., Milner, S.C., Duncan, A.R., \& Miller, R. McG. (2001). The Etendeka igneous province: magma types and their stratigraphic distribution with implications for the evolution of the Paraná-Etendeka flood basalt province. Bulletin of Volcanology, 62: 464-486.

Mathison, C.J. and Ahmet, A.L. (1996). The Windamurra Complex, Western 
Australia. In: R.G. Cawthorn (Editor), Layered Intrusions, Elsevier, The Netherlands, 485-510.

Mavrogenes, J.A., O'Neill, H.S.C. (1999). The relative effects of pressure, temperature and oxygen fugacity on the solubility of sulfide in mafic magmas. Geochimica et Cosmochimica Acta, 63, 1173-1180.

McBirney, A.R. (1996). The Skaergaard Intrusion. In R.G. Cawthorn (ed.), Layered Intrusions. Amsterdam: Elsevier, pp. 147-180

McClay, K.R. \& Campbell, I.H. (1976). The structure and shape of the Jimberlana Intrusion, Western Australia, as indicated by an investigation of the Bronzite Complex. Geological Magazine, 113: 129-139

McKenzie, D.P. \& O'Nions, R.K. (1983). Mantle reservoirs and ocean island basalts. Nature 301:229-31.

Menand, T., 2008. The mechanics and dynamics of sills in layered elastic rocks and their implications for the growth of laccoliths and other igneous complexes. Earth Planet.ary Science Letters, 267, 93-99. http://dx.doi.org/ 10.1016/j.epsl.2007.11.043

Meyer, R., Nicoll, G.R., Hertogen, J., Troll, V.R., Ellam, R.M. and Emeleus, C.H. (2009). Trace element and isotope constraints on crustal anatexis by upwelling mantle melts in the North Atlantic igneous province: an example from the Isle of Rum, NW Scotland. Geological Magazine, 146: 382-399.

Meyboom, A.F. and Wallace, R.C. (1978). Occurrence and origin of ring-shaped dolerite outcrops in the eastern Cape Province and western Transkei. Transactions of the Geological Society of South Africa, 81, 95-99. 
Miles, A., and Cartwright, J. (2010). Hybrid flow sills: a new mode of igneous sheet intrusion. Geology, 38: 343-346.

Montelli, R., Nolet, G., Dahlen, F.A., Masters, G., Engdahl, R., Hung, S-H. (2004). Finite-frequency tomography reveals a variety of plumes in the mantle. Science 303:338-43.

Morgan, W.J. (1971). Convection plumes in the lower mantle. Nature, 230: 4243.

Morse, S.A. (1979) Kiglapait geochemistry II: Petrography. Journal of Petrology 20:591-624.

Mungall, J.E. (2016). U-Pb geochronology documents out-of-sequence emplacement of ultramafic layers in the Bushveld Igneous Complex of South Africa. Nature Communication 7:13385 doi:10.1038/ncomms13385.

Naldrett, A.J. (1992). A model for the Ni-Cu-PGE ores of the Noril'sk region and its application to other areas of flood basalt. Economic Geology, 87, 19451962.

Naldrett, A.J. (1999). World Class Ni-Cu-PGE Deposits: Key Factors in their Genesis: in Mineralium Deposita, 34, 227-240.

Naldrett, A.J. (2004). Magmatic sulfide deposits-Geology, geochemistry, and exploration: Berlin, Springer-Verlag, $727 \mathrm{p}$.

Natural Resources Canada (2016). GEM: Geo-mapping for Energy and Minerals, Government of Canada, accessed January 2017, < https:// www.nrcan.gc.ca/earth-sciences/resources/federal-programs/ geomapping-energy-minerals/18215> 
Neuendorf, K.K.E., Mehl, J.P. Jr., and Jackson, J.A. (2005). Glossary of Geology. American Geological Institute, Alexandria.

Oyarzun, R., Doblas, M., López-Ruiz, J., and Cebra, J.M. (1997). Opening of the central Atlantic and asymmetric mantle upwelling phenomena: implications for long-lived magmatism in western North Africa and Europe. Geology, 25: 727-730.

Patwardharn, K. and Marsh, B.D. (2011). Dynamics of the development of the Isle au Haut gabbro-diorite layered complex: quantitative implications for mafic-silicic magma interactions. Journal of Petrology, 52, 2365-2395.

Petraske, A.K., Hodge, D.S., and Shaw, R. (1978). Mechanics of emplacement of basic intrusions. Tectonophysics, 46: 41-63.

Planke, S., Rassmussen, T., Rey, S. and Myklebust, R. (2005), Seismic characteristics and distribution of volcanic intrusions and hydrothermal vent complexes in the Vøring and Møre basins, in Petroleum Geology: North-West Europe and Global Perspectives-Proceedings of the $6^{\text {th }}$ Petroleum Geology Conference, edited by A. G. Doré and B. A. Vining, pp. 833-844, Geological Society, London.

Podmore, F. and Wilson, A.H. (1987). A reappraisal of the structure and emplacement of the Great Dyke, Zimbabwe. Geological Association Canada Special Paper 33, pp. 317-330.

Polteau, S., Ferré, E.C., Planke, S., Neumann, E.-R. and Chevallier, L. (2008a). How are saucer-shaped sills emplaced? Constraints from the Golden Valley Sill, South Africa. Journal of Geophysical Research, 113: B12104. 
Polteau, S., Mazzini, A., Galland, O., Planke, S. and Malthe-Sorenssen, A. (2008b). Saucer-shaped intrusions: occurrences, emplacement and implications. Earth and Planetary Science Letters, 266: 195-204

Radko, T. (2013). Double Diffusive Convection. Cambridge University Press, Cambridge, UK.

Richards, M.A., Duncan, R.A., \& Courtillot, V.E. (1989). Flood basalts and hotspot tracks - plume heads and tails. Science, 246: 103-107.

Ripley, E.M., 2014. Ni-Cu-PGE mineralization in the Partridge River, South Kawishiwi, and Eagle Intrusions; a review of contrasting styles of sulfiderich occurrences in the Midcontinent Rift System. Economic Geology Bulletin, Society of Economic Geology, 109, 309-324. http://dx.doi.org/ 10.2113/econgeo.109.2.309

Ripley, E.M., Li, C.S. (2003). Sulfur isotope exchange and metal enrichment in the formation of magmatic $\mathrm{Cu}-\mathrm{Ni}-(\mathrm{PGE})$ deposits. Economic Geology Bulletin, Society of Economic Geology, 98, 635-641.

Ripley, E.M., Li, C.S. (2013). Sulfide saturation in mafic magmas; is external sulfur required for magmatic $\mathrm{Ni}-\mathrm{Cu}-(\mathrm{PGE})$ ore genesis? Economic Geology Bulletin, Society of Economic Geology, 108, 45-58. http:// dx.doi.org/10.2113/econgeo.108.1.45.

Rohon, M.-L., Vialette, Y., Clark, T., Roger, G., Ohnenstetter, and Vidal, P.H. (1993). Aphebian mafic-ultramafic magmatism in the Labrador Trough (New Quebec): its age and the nature of its mantle source; Canadian Journal of Earth Sciences, v. 30, p. 1582-1593. 
Saumur, B.M., Cruden, A.R., Boutelier, D., Evans-Lamswood, D.M. (2013). Structure and dynamics of magmatic $\mathrm{Ni}-\mathrm{Cu}$ sulphide deposits: theory, analogue modelling and insights from Voisey's Bay (Labrador, Canada). 13th biennial SGA meeting. SGA, Uppsala, Sweden, pp. 1054-1057.

Saunders, A.D. (2005). Large igneous provinces: origin and environmental consequences. Elements, 1: 259-263.

Schofield, N., Stevenson, C., \& Reston, T. (2010). Magma fingers and host rock fluidization in the emplacement of sills. Geology, 38: 63-66.

Schulz, K.J., Chandler, V.W., Nicholson, S.W., Piatak, Nadine, Seall, II, R.R., Woodruff, L.G., and Zientek, M.L. (2010). Mamatic sulfide-rich nickelcopper deposits related to picrite and (or) tholeiitic basalt dike-sill complexes-A preliminary deposit model: U.S. Geological Survey OpenFile Report 2010-1179, 25 p. (available at http://pubs.usgs.gov/of/ 2010/1179/).

Sleep, N.H. (1996). Lateral flow of hot plume material ponded at sublithospheric depths: Journal of Geophysical Research, v. 101, p. 28,065-28,083.

Slement, C. (2010). The extent of fractionation and mineral accumulation in a $190 \mathrm{~m}$ thick Karoo sill, near the Gariep Dam. Unpublished Honours project. University of the Witwatersrand, South Africa, 41p.

Sluzhenikin, S.F., Krivolutskaya, N.A., Rad'ko, V.,Malitch, K.N., Distler, V.V., Fedorenko, V.A. (2014). Ultramafic-Mafic Intrusions, Volcanic Rocks and PGE-Cu-Ni Sulfide Deposits of the Noril'sk Province, Polar Siberia, Field Trip Guidebook. Institute of Geology of Ore Deposits, Petrography, 
Mineralogy and Geochemistry, Yekaterinburg, Russia.

Smallwood, J. R., and J. Maresh (2002). The properties, morphology and distribution of igneous sills: Modeling, borehole data and 3D seismic from the Faroe-Shetland area, in The North Atlantic Igneous Province: Stratigraphy, Tectonic, Volcanic and Magmatic Processes, Geological Society of London Special Publication, vol. 197, edited by D. Jolley and B. R. Bell, pp. 271-306, Geological Society, London.

Sobolev, S.V., Sobolev, A.V., Kuzmin, D.R., Krivolutskaya, N.A., Petrunin, A.G., Arndt, N.T., Radko, V.A. \& Vasiliev, Y.R. (2011). Linking mantle plumes, large igneous provinces and environmental catastrophes. Nature, 477: 312-316.

Song, X.Y., Danyushevsky, L.V., Keays, R.R., Chen, L.-M.,Wang, Y.-S. (2012). Structural, lithological, and geochemical constraints on the dynamic magma plumbing system of the Jinchuan $\mathrm{Ni}-\mathrm{Cu}$ sulfide deposit, NW China. Mineral. Deposita 47, 277-297.

Sparks, R.S.J., Huppert, H.E., \& Turner, J.S. (1984). The fluid dynamics of evolving magma chambers. Philosophical Transactions of the Royal Society of London. A310, 511-34.

St-Onge, M.R., Rayner, N.M., Liikane, D. and Chadwick, T. (2015a): Mafic, ultramafic and layered mafic-ultramafic sills, Meta Incognita Peninsula, southern Baffin Island, Nunavut; in Summary of Activities 2014, CanadaNunavut Geoscience Office, p. 11-16.

Svensen, H., Corfu, F., Polteau, S., Hammer, Ø., and Planke, S. (2012). Rapid 
magma emplacement in the Karoo Large Igneous Province: Earth and Planetary Science Letters, v. 325-326, p. 1-9, doi:10.1016/j.epsl.2012.01.015.

Tang, Z. (1991). The metallogenetic model of the Jinchuan platinum-bearing copper-nickel sulphide deposit. International Symposium on Sulfide Deposits, Academic Papers on Special Subjects, Jinchang, Gansu, China, pp. 17-43.

Tegner, C., Wilson, J.R. and Brooks, C.K. (1993). Intraplutonic quench zones in the Kap Edvard Holm layered gabbro complex, East Greenland. Journal of Petrology, 34, 681-710.

Thomson, K., and D. Hutton (2004). Geometry and growth of sill complexes: Insights using 3D seismic from the North Rockall, Bulletin of Volcanology, 66, 364-375.

Thomson, K. and Schofield, N. (2008). Lithological and structural controls on the emplacement and morphology of sills in sedimentary basins. In: Thomson, K. and Petford, N. (eds) Structure and emplacement of high-level magmatic systems. Geological Society, London, Special Publications, 302, 31-44.

Upton, B.G.J., Parsons, I., Emeleus, C.H., \& Hodson, M.E. (1996). Layered alkaline igneous rocks of the Gardar Province, South Greenland. In R.G. Cawthorn (ed.), Layered Intrusions. Amsterdam: Elsevier, pp. 331-363

Upton, B.G.J. \& Thomas, J.E. (1980). The Tugtutôq Younger Giant Dyke Complex, South Greenland: fractional crystallisation of transitional olivine 
basalt magma. Journal of Petrology, 21: 167-198.

van Wijk, J.W., Huismans, R.S., Ter Voorde, M., and Cloetingh, S.A.P.L., (2001). Melt generation at volcanic continental margins: no need for a mantle plume? Geophysical Research Letters, 28: 3995-3998.

Wager, L.R. and Brown, G.M. (1967). Layered igneous rocks. xv + 588 p., 278 figs., and 13 pls. (half-tone and coloured). Oliver and Boyd, Ltd., Edinburgh.

Welford, J.K. and Clowes, R.M. (2004). Deep 3-D seismic reflection imaging of Precambrian sills in southwestern Alberta, Canada, Tectonophysics, 388, 161-172.

Weller, O.M., Dyck, B.J., St-Onge, M.R., Rayner, N.M. and Tschirhart, V. (2015). Completing the bedrock mapping of southern Baffin Island, Nunavut: plutonic suites and regional stratigraphy; in Summary of Activities 2015, Canada-Nunavut Geoscience Office, p. 33-48.

White, R.S. \& McKenzie, D. (1989). Magmatism at rift zones - the generation of volcanic continental margins and flood basalts. Journal of Geophysical Research: Solid Earth and Planets, 94: 7685-7729.

White, W.M. (2010). Oceanic island basalts and mantle plumes: the geochemical perspective. Annual Review of Earth and Planetary Sciences, 38: 133160.

Wilson, A.H. (1996). The Great Dyke of Zimbabwe. In R.G. Cawthorn (ed.), Layered Intrusions. Amsterdam: Elsevier, pp. 365-402.

Wilson, M. (1989). Igneous Petrogenesis: A Global Tectonic Approach. Unwin 
Hyman, London. http://dx.doi.org/10.1007/978-1-4020-6788-4

Wright, T.L., Peck, D.L. and Shaw, H.R. (1976). Kilauea lava lakes: natural laboratories for study of cooling, crystallization and differentiation of basaltic magma. In: G.H. Sutton, M.H. Manghani, R. Moberly and E.U. McAfee (Editors), The Geophysics of the Pacific Ocean basin and its margin, Geophysical Monograph Series, American Geophysical Union, D.C., $19,375-390$.

Yakubchuk, A., and Nikishin, A. (2004). Noril'sk-Talnakh Cu-Ni-PGE deposits: a review of the classic model. Mineralium Deposita v39, p 125-142

Zavala K., Leitch A.M. and Fischer G.W. (2011). Silicic segregations of the Ferrar dolerite sills. Journal of Petrology, 52, 1927-1964.

Zientek, M.L. (2012). Magmatic ore deposits in layered intrusions-Descriptive model for reef-type PGE and contact-type Cu-Ni-PGE deposits: U.S. Geological Survey Open-File Report 2012-1010, 48 p. 
Figure 2.1: Karoo large igneous province (LIP) of South Africa. (a) Regional map showing the distribution of the saucer-shaped sills within the Karoo sedimentary basin (yellow units), as well as the associated Drakensberg Group lavas. Modified from Ernst (2014). Originally modified from Svensen et al. (2012). 


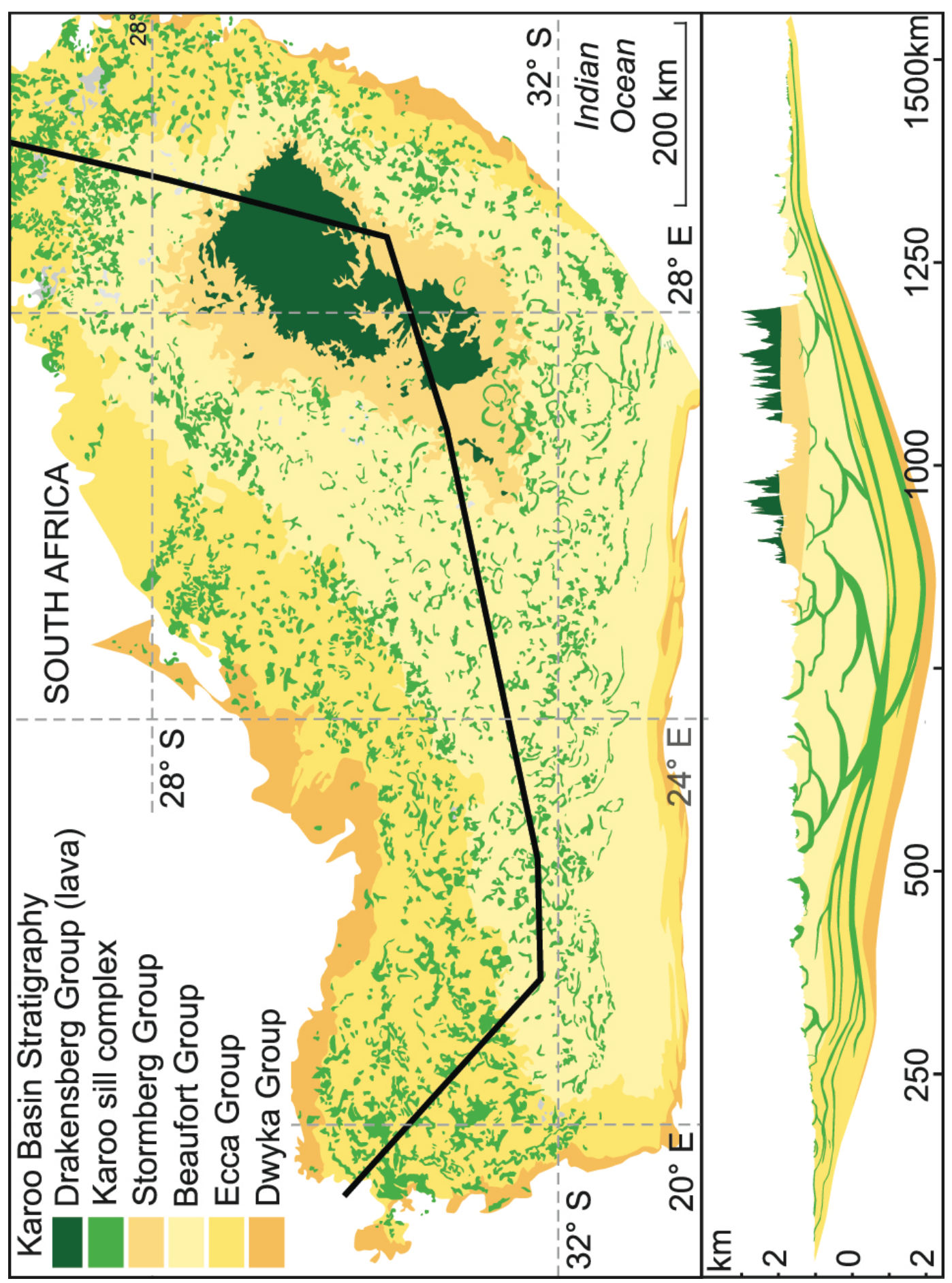




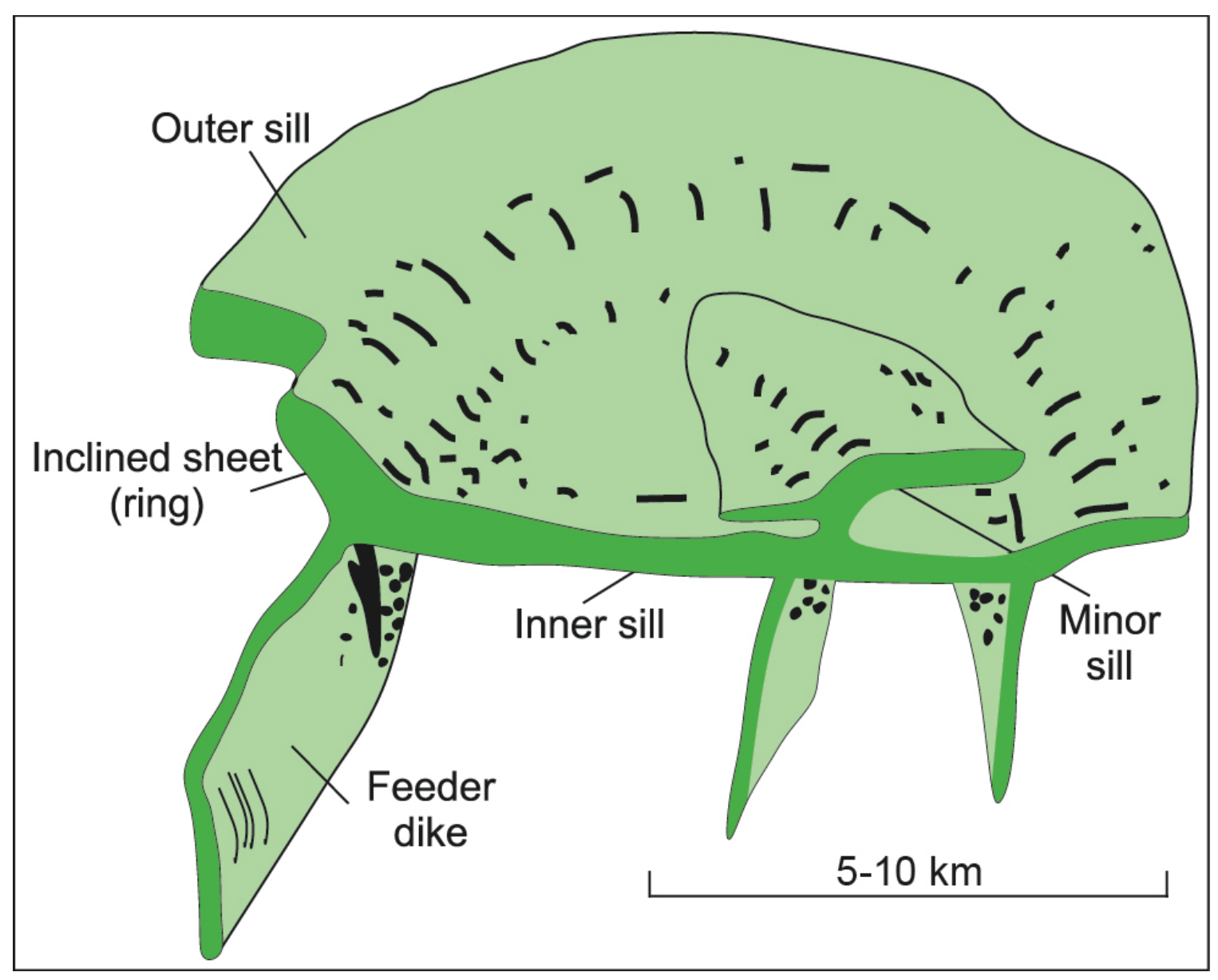

Figure 2.2: Saucer-shaped geometry of mafic sills, typical of sills emplaced in sedimentary basins. Modified from Ernst (2014). Originally from Chevallier and Woodford (1999). 
Figure 2.3: a) Ascending mantle plume beneath an Archean craton, within a few hundred kilometres of the original cratonic boundary. The plume head is mixture of high-temperature tail and entrained ambient upper mantle (Campbell et al., 1989; Griffiths and Campbell, 1990). b) Plume head impinges on base of lithosphere and flattens. c) Plume head and tail are channeled to thinner lithosphere at craton margin, continental rifting is generated at original suture, and high-Mg, low-Ti melts are produced. It is beneath the cratonic margin where maximum melt production occurs, and this is controlled by flow of the plume along the sloping base of cratonic lithosphere (Begg et al., 2010), and predominant flux of komatiite plume-tail melting is focused at cratonic margin. d) Both favourable and unfavourable environments for mineralisation are developed above the melting zone, as high flux "magma freeways" have potential for assimilation of crustal S, transport and deposition of magmatic sulphide ores. Modified Figure 1 from Barnes et al. (2015). 


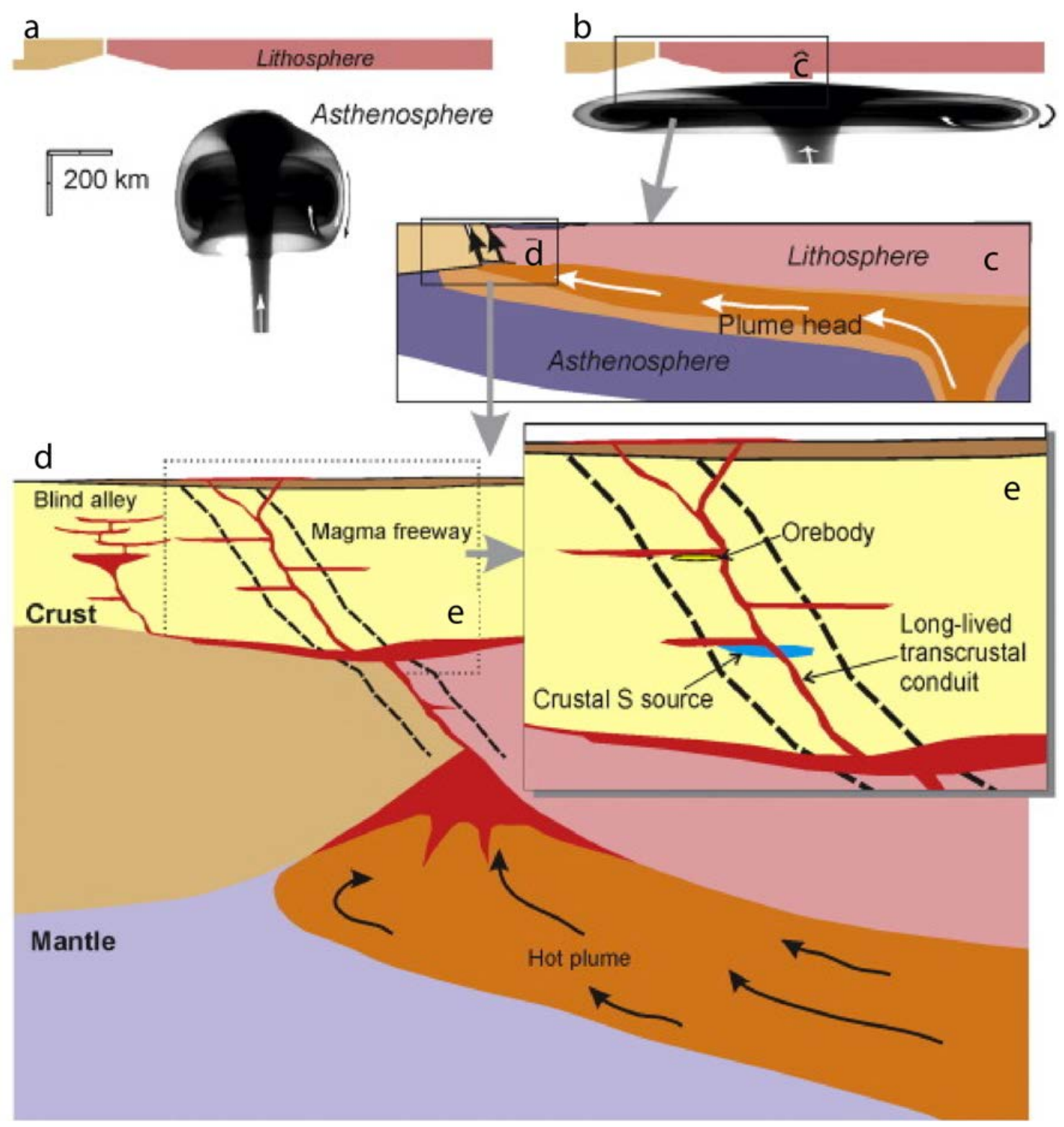


Chapter 3 - Regional Geology 


\subsection{Geological Framework}

The bedrock geology of southern Baffin Island comprises polydeformed and metamorphosed plutonic and supracrustal rocks that form part of the northeastern (Québec-Baffin) segment of the Trans-Hudson orogen (THO); a broad, arcuate, Himalayan-scale collisional orogenic belt that extends from south-central to north-eastern North America (Figure 3.1) (Hoffman, 1988; Lewry and Collerson, 1990; St-Onge et al., 2007; Sanborn-Barrie et al., 2008). The THO formed during the final collisonal phase of Nuna supercontinent growth and records the suturing of the lower Superior and upper Churchill plates between 1.86 and $1.80 \mathrm{Ga}$, concomitantly with closure of the Manikewan Ocean (Weller et al., 2015). During the ca. 120 m.y. of plate convergence, the orogenic system experienced several accretionary events, involving several Archean crustal blocks and younger terranes (Corrigan et al., 2009; St-Onge et al., 2009). The area affected by the THO in the eastern Arctic is outlined on the simplified geological map of Figure 3.2.

Regional bedrock mapping has led to the subdivision of southern Baffin Island into four orogen-scale tectonically stacked domains (Figure 3.3), all separated by major deformation zones (Baffin, Soper River, and Bergeron sutures; St-Onge et al., 2002, 2015f). During the middle Paleoproterozoic, these tectonostratigraphic domains either accumulated on, or were accreted to the northern margin of the lower-plate Archean Superior craton (St-Onge et al., 2000b, and references therein). Collectively, the divergent and convergent margin tectonic activity occurred over a period greater than 200 million years. 
From lowest to highest structural level, these domains include the Superior craton and margin, Narsajuaq terrane, Meta Incognita microcontinent, and Rae craton and margin.

The lower-plate Superior craton and margin (level 1; Figure 3.3) comprises Archean basement orthogneiss of the Superior craton, and the Povungnituk and Chukotat groups, middle Paleoproterozoic cover sequences that stratigraphically overlie, or are thrust imbricated above the Archean basement (St-Onge et al., 1996; St-Onge et al., 2000b). The basement gneiss includes variably deformed granodioritic to syenogranitic plutonic bodies, emplaced in dominantly mafic tonalite-quartz diorite gneiss (St-Onge et al., 2001). Collectively, these have been interpreted to be the remnants of the plutonic root of several Archean-age magmatic arcs, with magmatism evolving temporally from calcic to more potassic (Lucas and St-Onge, 1991). Zircons from the tonalitic orthogneiss and granitoid plutons have been dated (U-Pb), yielding ages between $3220^{+32 /-23} \mathrm{Ma}$ and $2737^{ \pm 2} \mathrm{Ma}$ (Parrish, 1989, personal communication to M. St-Onge; St-Onge et al., 1992; Scott and St-Onge, 1995; Wodicka and Scott, 1997). The overlying Povungnituk Group comprises parautochthonous fluvial clastic rocks, carbonatitic volcanoclastic rocks, and a package of LREE-enriched continental tholeiitic flood basalts and rhyolites, which formed during the initial Paleoproterozoic rifting of the Superior Province (StOnge et al., 2001) and are part of the Minto large igneous province (LIP) (Buchan et al., 1998; Hamilton et al. 2016; Kastek et al. 2016). The Chukotat Group comprises komatiitic to LREE-depleted tholeiitic basalts, which were extruded 
along the northern Superior plate margin (St-Onge et al., 2001) and which are part of the plume-derived Circum-Superior LIP (e.g. Ernst, 2014; Minifie et al. 2013; Ciborowski et al. 2017). Rhyolite flows and mafic to ultramafic intrusions were dated to constrain the timing of the initial continental rifting events, yielding ages between $2038^{+4 /-2} \mathrm{Ma}$ and $1959^{+3.1 /-2.7} \mathrm{Ma}$, and $1887^{+37 /-11} \mathrm{Ma}$ and $1870^{ \pm 4}$ Ma for the renewed rifting (Parrish, 1989; Machado et al., 1993; St-Onge et al., 1992; Wodicka et al., 2002a; R.R. Parish, unpublished data). Parautochthonous sedimentary and volcanic sequences are mostly preserved in the Cape Smith (thrust) Belt (Lucas, 1989a,b), where they are separated from allochthonous crustal elements of the Narsajuaq terrane by the Bergeron suture (St-Onge et al., 2001).

The Narsajuaq terrane (level 2; Figure 3.3) comprises: (1) an arc (Parent Group and Narsajuaq arc) of dominantly monzogranitic to granodioritic plutonic units, interpreted to be either a deformed magmatic arc terrane (Scott, 1997; StOnge et al., 2009) or Narsajuaq-age intrusions (Corrigan et al. 2009); (2) the Watts group, a sequence of both mid-oceanic ridge and oceanic island basalts (Scott et al., 1992); and (3) the Spartan group, an undated fore-arc clastic apron (St-Onge et al., 1992). The magmatic arc includes two petrologically and temporally distinct suites: an older intra-oceanic suite and a younger Andeanstyle margin suite (Dunphy and Ludden, 1998). Calc-alkaline diorite-tonalite gneiss, basaltic andesite and rhyolite dominate the older suite, whereas crosscutting monzodiorite to granite plutons comprise the younger suite (St-Onge et al., 1992). U-Pb ages from the intraoceanic suite range from $1863^{ \pm 2} \mathrm{Ma}$ and 
1845² Ma (Machado et al., 1993; R.R. Parish, unpublished data), and age from the Andean-style margin suite range between $1842^{+5 /-3} \mathrm{Ma}$ and $1820^{+4 /-3} \mathrm{Ma}$ (Parrish, 1989, unpublished data; Machado et al., 1993; Scott, 1997; Scott and Wodicka, 1998). A zircon recovered from a mafic cumulate layer in the Watts Group ophiolite yielded a U-Pb age $1998^{ \pm 2} \mathrm{Ma}$ (Parrish, 1989). A number of kilometer-scale plutons, quartz diorite to monzogranite in composition, intrude into the Watts and Parent groups (Dunphy, 1994) and yield ages that temporally overlap the Narsajuaq arc proper. In addition, they share geochemical similarities, suggesting a lithotectonic correlation (Dunphy and Ludden, 1998). Thus, the intrusion of the Narsajuaq-like plutons into the Watts and Parent groups effectively stitched the allochthonous units of level 2 together (St-Onge et al., 1992). The allochthonous crustal elements of the Narsajuaq terrane are separated from the structurally overlying Archean and Paleoproterozoic rocks of the Meta Incognita microcontinent by the Soper River suture; the second south verging crustal suture found within southern Baffin Island (St-Onge et al., 2001).

The Meta Incognita microcontinent (level 3; Figure 3.3), the main focus of this study, comprises an Archean to Paleoproterozoic basement orthogneiss (Ramsay River orthogneiss; Scott and Wodicka, 1998) with its middle Paleoproterozoic (ca. 2100-1800 Ma) cover sequence (platformal-type continental margin) comprising psammite, semipelite, pelite, quartzite, marble and amphibolite strata (Lake Harbour Group; Jackson and Taylor, 1972; St-Onge et al., 2000), a suggested overlying foreland basin succession (originally broken out from the Lake Harbour Group and referred to as the Blandford Bay 
assemblage; Scott et al., 1997), and a suite of monzogranitic plutons (Cumberland Batholith; Jackson et al., 1990) that pervasively intrude all three of the aforementioned units (St-Onge et al., 2001, 2007). Additionally, there is a ca. 1900 Ma suite of sills, informally named the "Frobisher suite," that extensively intrude the Lake Harbour Group metasedimentary rocks (Liikane et al., 2015). The age of the Ramsay river orthogneiss has been constrained between $3019 \pm 5$ Ma and 2784 \pm 9 Ma (Scott, 1998,1999), with a late-intruding monzogranite yielding an age of 1950+6/-4 Ma (Scott and Wodicka, 1998). Detrital zircons and crosscutting intrusions have been used to bracket the deposition age of both the shelf succession and foreland basin sequences of the Lake Harbour Group to between $1934 \pm 2$ and ca. 1880 Ma (Figure 2.4; Scott, 1997, unpublished data; Scott et al., 1997, 2002). The Cumberland Batholith plutonic units range in age between 1865+4/-2 Ma and $1848^{+/-2}$ Ma (Jackson et al., 1990; Wodicka and Scott, 1997; Scott and Wodicka, 1998; Scott, 1999).

In central Baffin Island, the upper-plate Rae craton and margin (level 4; Figure 3.3) comprise Archean basement orthogneiss, overlain by middle Paleoproterozoic cover sequence of metasedimentary and metavolcanic units (Piling group; Wodicka et al., 2014), that exhibit stratigraphical similarities to the Hoare Bay Group on Cumberland Peninsula. The upper-plate Rae craton is comprised of felsic orthogneiss, metamorphosed supracrustal rocks, and younger felsic plutonic rocks ranging in age from $2868^{+13 /-12} \mathrm{Ma}$ and $2702^{ \pm 3} \mathrm{Ma}$ (Jackson 2000; Wodicka et al., 2002b; Bethune and Scammel, 2003; D.J. Scott, unpublished data; N. Wodicka, unpublished data). Overlying its southern margin, 
the Paleoproterozoic Piling Group comprises rift, shelf margin and foredeep strata, which have ages constrained to between ca. $2159 \pm 16 \mathrm{Ma}$ and $1897+7 /-4 \mathrm{Ma}$ (Wodicka et al., 2002b; N. Wodicka, unpublished data, 2014). In addition to the Cumberland batholith, both basement and cover units are intruded by a felsic plutonic suite (the Qikiqtarjuaq suite) of middle Paleoproterozoic age (ca. 1.89 $\mathrm{Ga)}$; distinctly older than the 1.865-1.845 Ga Cumberland batholith (Rayner et al., 2012).

St-Onge (2009) has interpreted the Cumberland batholith to represent a period of Andean-style magmatism. Alternatively, Whalen et al. (2010) have interpreted the batholilth to be the result of post-accretionary delamination of the lithosphere and subsequent mantle upwelling. All structural levels are crosscut by Franklin dykes that were emplaced during the plume-driven ca. 720 Ma Franklin LIP event, which was associated with the Rodinia supercontinent break-up (Fahrig, 1987; Heaman et al., 1992; Jowitt and Ernst, 2013; Ernst and Bleeker, 2010; Ernst et al., 2016). The 3rd and 4th levels are also unconformably overlain by limestone strata of Ordovician age (Blackadar, 1967).

\subsection{Deformation Events and Metamorphism}

Several tectonothermal magmatic events of Paleoproterozoic age have been recognized in southern Baffin Island, through integrated tectonostratigraphic, structural and petrological studies (Figure 3.4; St-Onge et al., 
2007). This includes at least five regional episodes of compression $\left(D_{0}-D_{4}\right)$ and two thermal events ( $M_{1}-M_{2}$; St-Onge et al., 2015f).

The imbrication of basement and cover units resulted in map-scale $D_{0}$ tectonic contacts. The imbrication post-dates Lake Harbour Group deposition and Frobisher suite emplacement, and pre-dates Cumberland batholith emplacement (St-Onge et al., 1999b). Thrust imbrication best explains the field repetition of distinct tectonostratigraphic units, and is interpreted to result from accretion of the Meta Incognita microcontinent to the southern margin of the Rae craton and closure of the Baffin suture (BaS; St-Onge et al., 2007).

As convergence continued, the Narsajuaq arc was accreted to the Meta Incognita microcontinent (St-Onge et al., 2007). This $D_{1 a}$ event led to the closure of the Soper River suture (SRS) at the structural base of the Meta Incognita microcontinent, which occurred between $1845^{ \pm 2}$ Ma (Dunphy and Ludden, 1998) and $1842^{+5 / 3} \mathrm{Ma}$ (Scott, 1997). These ages were obtained from the youngest unit of the Narsajuaq's intraoceanic phase and the oldest plutonic unit of the Narsajuaq's Andean-margin phase, respectively (Dunphy and Ludden, 1998; Scott, 1997). Associated with the $D_{1 a}$ deformation event is a period of prograde granulite-facies metamorphism $\left(\mathrm{M}_{1 \mathrm{a}}\right)$ that is recorded in the Frobisher suite sills and host Lake Harbour Group metasedimentary rocks (Skipton et al., 2016a,b). The $S_{1 a}$ foliation formed during progressive metamorphism is generally shallowlydipping $\left(<45^{\circ}\right)$ and parallel to supracrustal lithological contacts, and is interpreted to represent an enhancement of the primary bedding ( $\mathrm{S}_{\circ}$; St-Onge et al., 2007; Skipton et al., 2016a,b). The result was near-complete to complete 
recrystallization of primary assemblages, resulting in psammitic and pelitic units containing a subset of the granulite-facies assemblage garnet-cordieritesillimanite-biotite-plagioclase-K-feldspar-quartz-melt, and mafic units containing a subset of the granulite-facies assemblage garnet-orthopyroxene-clinopyroxenehornblende-biotite-plagioclase (St-Onge et al., 2007; Skipton et al., 2016a,b). Within the Frobisher suite, $S_{1 a}$ is locally defined by varying proportions of ferromagnesian minerals and plagioclase.

Following the granulite-facies metamorphic event, there was a high-T thermal perturbation event $\left(\mathrm{M}_{1 \mathrm{~b}}\right)$ at ca. 1833-1829 $\mathrm{Ma}$, related to the emplacement of felsic dykes and plugs (St-Onge et al., 2007). This event was recognized through the $\mathrm{U}-\mathrm{Pb}$ dating of zircon and monazite from siliciclastic and gneiss samples (Scott \& Gauthier, 1996; Wodicka \& Scott, 1997; Scott \& Wodicka, 1998; St-Onge et al., 2007). However, it is not clear whether this is a distinct thermal pulse or a protracted $M_{1}$ metamorphic event.

The final accretion event $\left(D_{2}\right)$ marks the collision of the northern Churchill plate (i.e. Rae craton and accreted microcontinent, arc and ophiolitic units) with the Superior craton (St-Onge et al., 2007). This accretion event involved: (1) the closure of the Manikewan ocean, forming the Bergeron suture (BaS) and the resulting foreland thrust and fold belt within the Superior lower plate (Lucas, 1989; St-Onge et al., 2001); (2) the imbrication of tectonostratigraphic units in southern Baffin Island and further crustal shortening across the Soper River suture; (3) modification of pre-existing fabrics by $\mathrm{D}_{2}-\mathrm{M}_{2}$ tectonothermal events. The terminal collision is bracketed between $1820^{+4 /-3}$ Ma (Scott \& Wodicka, 1998) 
and $1795^{ \pm 2} \mathrm{Ma}$ (Wodicka \& Scott, 1997); the ages of the youngest-dated plutonic rock in the suture's hanging wall and the age of a post-collisional syenogranite dyke cutting the Bergeron suture, respectively (St-Onge et al., 2007). The principal modifications of pre-existing fabrics resulting from $D_{2}$ deformation in southern Baffin Island, within the Bergeron suture's hanging wall, include a more finely layered $S_{2}$ foliation developed in metasedimentary units, and transposition of compositional layering within metaplutonic units (St-Onge et al., 2007). Associated with the $D_{2}$ deformation event was an $M_{2}$ retrograde amphibolitefacies metamorphism on southern Baffin Island, and prograde greenschist- to amphibolite-facies metamorphism within the cratonic margin of the lower-plate Superior craton margin (St-Onge et al., 2000b). This event is recorded in areas of $\mathrm{D}_{2}$ deformation of psammitic and pelitic units of the Lake Harbour Group, as manifested by an $S_{2}$ fabric featuring the growth of biotite-sillimanite \pm garnet \pm cordierite at the expense of the previously described $S_{1 a}$ assemblages. The $M_{2}$ retrograde metamorphism occurred at ca. $1820^{ \pm 1}$ to $1813^{ \pm 2}$ Ma (Wodicka \& Scott, 1997; Scott et al., 2002; St-Onge et al., 2007; Skipton et al., 2016a,b).

A set of regional north- to northwest-trending $D_{3}$ folds reorient preexisting $D_{1}$ and $D_{2}$ structures and fabrics (St-Onge et al., 2015f). These folds range from metre- to map-scale and consistently display west- to southwest-verging asymmetry. The $\mathrm{D}_{3}$ folding involves all tectonostratigraphic units and can clearly be identified in the field and on air photos. In northern Quebec, the $D_{3}$ folding is constrained to ca. 1.76 Ga within structural levels 1 and 2 (Lucas and St-Onge, 1992). The orogen-parallel folds are proposed to have formed from continued 
horizontal compression during post-collisional intra-continental shortening in the northeastern segment of the Trans-Hudson orogen (Lucas and Byrne, 1992).

Fold interference patterns exist as a result of $D_{4}$ upright folding deforming all other structural elements, with fold axis trending east-northeast (St-Onge et al., 2015f). $D_{4}$ generated dome-and-basin map patterns are best preserved in the southern and eastern portions of Meta Incognita Peninsula (Figure 3.5; St-Onge et al., 2015f). The structural relief generated by $D_{3}$ and $D_{4}$ folding allow for the crustal architecture of southern Baffin Island, and its bounding tectonic elements, to be studied. While $D_{1}$ and $D_{2}$ folds do contribute to map patterns, they contribute to a much lower degree.

In summary, five deformation events $\left(D_{0}, D_{1}, D_{2}, D_{3}, D_{4}\right)$ occurred during the sequential north to south closure of three crustal sutures (Baffin suture, Soper River suture, and Bergeron suture, respectively). $D_{1}$ is associated with a regional granulite-facies metamorphic event $\mathrm{M}_{1 \mathrm{a}}$, which is associated with the development of a dominant $S_{1 a}$ compositional foliation. A subsequent regional retrograde amphibolite-facies metamorphic event $\left(M_{2}\right)$ is associated with the development of a penetrative schistose fabric $\left(\mathrm{S}_{2}\right)$. Two later localized thermal events $\left(M_{1 b}\right.$ and post- $\left.D_{2}\right)$ occurred as a result of crustal magmatism, with the latter recorded in Frobisher suite titanite grains (St-Onge et al., 2007). Finally, regional $D_{3}$ and $D_{4}$ folding events generated interference patterns within the units of southern Baffin Island that are exposed on the present-day erosional surface.

\subsection{Lake Harbour Group}


The middle Paleoproterozoic Lake Harbour Group (LHG) of southern Baffin Island comprises psammite, semipelite, pelite, quartzite, marble and amphibolite strata (Figure 3.6a-c), which have been interpreted to represent a platform-type continental margin that formed along the microcontinent after ca. $2010 \mathrm{Ma}$, followed by foredeep sedimentation between $1915 \pm 8 \mathrm{Ma}$ and ca. 1880 Ma (Blackadar, 1967; Jackson and Taylor, 1972; Scott, 1997; Wodicka et al., 2008). Basin closure and the deposition of foredeep sediments along margins appear to be related to the ca. 1.9 Ga Snowbird collisional orogen (Wodicka et al., 2008). The type locality for this succession is situated north of the community of Kimmirut (Figure 3.8; St-Onge et al., 1996, 1998; Scott et al., 1997). These rocks are interpreted to have been deposited between 2.01 and $1.90 \mathrm{Ga}$ (Wodicka, 2010), and deformed at 1845 -1842 Ma (Dunphy and Ludden, 1998; Scott, 1997).

Metasedimentary rocks of the Lake Harbour Group were deformed during the Trans-Hudson orogen, and are now preserved in an obliquely exposed continental collisional zone. Relative to an undeformed, un-metamorphosed, "reference" microcontinent (i.e. at ca. $1900 \mathrm{Ma}$ ), the LHG sequence preserved on Meta Incognita Peninsula represents the more "proximal" facies (i.e. most inlanddeposited sediments) and would have formed on the furthest from the margin of the microcontinent. The LHG sequence preserved on northern Hall Peninsula represents the more "distal" facies (i.e. deeper water, off-shelf strata, moreseaward sequence, closest to the edge of the microcontinent). 
On Meta Incognita Peninsula (Figure 3.8), the Lake Harbour Group exists as two lithologically and geographically distinct sequences (St-Onge et al., 2014). The first sequence is found throughout Meta Incognita Peninsula to the west of York Sound (Figure 3.8) and comprises variable amounts of garnetiferous psammite, quartzite, and minor pelite and semipelite that are structurally overlain by laterally continuous and boudinaged bands of marble and calc-silicate strata ('Kimmirut sequence' of Scott et al., 1997). The second sequence is comprised of garnetiferous psammite interlayered with pelite/semipelite, and volumetrically dominates the far eastern part of the peninsula, including exposures on eastern islands and bluffs, and also around Markham Bay (Figure 3.8; 'Markham Bay sequence' of Scott et al., 1997). Additionally, the latter areas are largely devoid of marble/calc-silicate layers.

On Hall Peninsula, the siliciclastic units bear a strong resemblance to the metasedimentary units of the Lake Harbour Group found throughout Meta Incognita Peninsula. Quartzite occurs as strongly recrystallized, well-layered, rusty weathering panels, up to hundreds of meters in thickness, and is overlain by interbedded psammite, semipelite and/or pelite. Layers within the quartzite vary compositionally from orthoquartzite to feldspathic quartzite; migmatitic psammite and semipelite contain biotite \pm garnet and biotite \pm garnet \pm sillimanite assemblages, respectively (Weller, et al., 2015). Horizons of pelite occur with the assemblage biotite-garnet-sillimanite-K-feldspar-melt. Siliciclastic units often contain gossanous horizons (Figure 3.6d), in which graphite, pyrite, and chalcopyrite are found (Weller, et al., 2015). Marble and calcsilicate units occur 
as panels up to $100 \mathrm{~m}$ thick, and occur structurally above (faulted) the aforementioned siliciclastic units. The carbonate units are compositionally layered, due to varying proportions of medium to coarse-grained calcite, humite, forsterite, apatite, diopside, magnetite, phlogopite, scapolite, spodumene, titanite, and tremolite (Weller, et al., 2015).

Two additional stratigraphic sequences of metasedimentary rocks (the Lona Bay and Schooner Harbour sequences) have been recognized to the west of Meta Incognita peninsula on Foxe Peninsula, where they structurally overlie the Lake Harbour Group (Sanborn-Barrie et al., 2008). The Lona Bay sequence is a succession of relatively homogeneous arenaceous metasedimentary rocks centred around Lona Bay (Figure 3.4). The sequence typically has $10-30 \mathrm{~cm}$ thick beds, highlighted by cross-stratification, variations in grain size, and the heterogeneous distribution of porphyroblasts. The overlying Schooner Harbour sequence is a heterogenous volcanic-bearing supracrustal belt of dominantly alkaline basaltic composition, extending for $100 \mathrm{~km}$ along southern Foxe peninsula, from Schooner Harbour eastward to the West Foxe Islands (Figure 3.4; Wodicka et al., 2008). The lower part of the succession contains at its base fine-grained, metapelitic, sulphidic slate and schist with garnet, staurolite or andalusite porphyroblasts, and gradually becomes more psammitic up-section (Sanborn-Barrie et al., 2008). Also in the lower sequence are orthoquartzite units $1 \mathrm{~m}$ thick are found alternating with small exposures of amphibolite, and discontinuous horizons of $<1 \mathrm{~m}$ thick polymictic metaconglomerate are also present, locally. In the upper part of the Schooner Harbour sequence, volcanic 
units are dominantly alkali basaltic to andesitic in composition, and contain some variolitic and lapilli-tuff units. In the vicinity of Schooner Harbour, extrusive ultramafic units are present in what appears to be komatiitic lapillistone (Sanborn-Barrie et al., 2008). Recent geochronology has constrained the age of the Schooner Harbour sequence to ca. 2099 Ma (Wodicka et al., 2010), suggesting that it is older than the Lake Harbour Group. The Schooner Harbour sequence has been interpreted to potentially represent initial rifting within the Meta Incognita microcontinent (Wodicka et al., 2008).

\subsection{Frobisher Suite Mafic, Ultramafic and Mafic-Ultramafic Sills}

The siliciclastic and carbonate strata of the Lake Harbour Group, and the orthoquartzite and semipelite of the lower Schooner Harbour sequence are intruded extensively by the mafic to ultramafic suite of sills herein referred to as the Frobisher suite (Liikane et al., 2015). The Frobisher suite (informally named after the suite's geographic proximity to Frobisher Bay; Figure 3.4) is a suite of mafic, ultramafic, and mafic-ultramafic sills (Figure 3.7a) found throughout most of the Meta Incognita microcontinent terrane of southern Baffin Island, Nunavut (Liikane et al., 2015). Their distribution throughout Meta Incognita Peninsula and south-central Baffin Island can be seen in Figures 3.8 and 3.9, respectively. However, it should be noted that given the reconnaissance-scale of mapping, it is likely that the majority of sills have yet to be mapped. The sills generally comprise concordant to slightly discordant sheets of variably altered coarse-grained metaperidotite, medium- to coarse-grained metaperidotite-metagabbro, and 
medium-grained metagabbro emplaced into the siliciclastic strata of the Lake Harbour Group (Liikane et al., 2015), and lower Schooner Harbour sequence (Sanborn-Barrie et al., 2008). Their interpreted primary magmatic lithology (e.g. pyroxenite) is derived primarily from CIPW norms, estimated based on major element geochemistry. The layered mafic-ultramafic sills vary lithologically from metapyroxenite at the base, overlain by metaperidotite, and capped by metagabbro to metaleucogabbro (Figure 3.7b; Liikane et al., 2015). If the layering is a result of gravity-induced magmatic differentiation from a single pulse of magma, the ultramafic to mafic progression provides a way-up indicator (see section 2.2.3 for discussion on the mechanisms of layer formation in layered intrusions). All layering within the sills is parallel to the intrusive contacts (Figure 3.10), consistent with their emplacement as strata-bound intrusions. Evidence of partial melting (granophyric intrusive contacts; St-Onge et al., 2015a) or of enclaves of host strata are absent (Liikane et al., 2015). Numerous intrusions contain disseminated sulphide mineralization (see Chapter 5 for more details), and deep orange gossans occur in the host strata immediately adjacent to some of the sills (Liikane et al., 2015).

In map view, the sills typically appear elongate to ellipsoid or annular in shape (Figure 3.11). The apparent tightness of the acutely folded sills varies from gentle to tight, and the bluntness varies from rounded (in parallel folds) to angular (in similar folds). Apparent thicknesses of sills typically vary between 5 and $20 \mathrm{~m}$ - although a few exceed $100 \mathrm{~m}$ in thickness - and in most cases extend several kilometres along strike (Liikane et al., 2015). 
The current erosional surface of southern Baffin Island exposes the Frobisher suite sills in such a way that it may give the impression of a map pattern characterized by primary saucer-shaped intrusions (Figure 1.1). However, consideration of host/intrusion field relationships suggests that in fact the geometry of the sills is best interpreted as a product of the complex regional deformation history in this part of southern Baffin Island. Specifically, St-Onge et al., (2015f) have documented that the $D_{3}$ and $D_{4}$ regional folding events are responsible for generating the pervasive fold interference patterns within the metasedimentary units of the Lake Harbour Group. The genetic deformational link between sill and host rock is suggested by (a) sill outcrop patterns that mimic the outcrop patterns of the enveloping host rocks, and (b) the concordant nature of intrusive contacts and compositional layering within both sill and adjacent host metasedimentary strata. This suggests that the emplacement of the sills predate these folding events.

The Frobisher suite sills must be younger than the Lake Harbour group (ca. $2.01-1.90 \mathrm{Ga}$ ), and older than the 1845-1842 Ma $\mathrm{M}_{1 \mathrm{a}}$ deformation event. More recent geochronological data arrived at a minimum crystallization age of ca. 1900 Ma for the Frobisher suite on southern Baffin Island (Liikane et al., 2015).

To determine the age of the Frobisher suite sills, a sample (14SAB-L017A; location shown in Figure 3.8 as "Killapait sill") collected from the leucogabbroic portion of the Killapait sill (discussed in 4.1.2) of south-central Meta Incognita Peninsula was submitted for U-Pb geochronology, with the sensitive highresolution ion microprobe (SHRIMP) and with isotope dilution-thermal ionization 
mass spectrometry (ID-TIMS), at the Geological Survey of Canada (Liikane et al., 2015). From this sample, abundant, high-quality, clear, colourless zircon grains were recovered (Liikane et al., 2015). The zircon grains are morphologically diverse: anhedral (Figure 3.12a), prismatic (Figure 3.12b) or rounded (not shown), and simply zoned (Figure 3.12c, d) with no apparent core/overgrowths (Liikane et al., 2015). Twenty-five analyses were obtained via SHRIMP, of which 22 zircon grains encompassing the full morphological range yielded ages ranging from 2004 to $1833 \mathrm{Ma}$ (Figure 3.12e), with a weighted mean ${ }^{207} \mathrm{~Pb} / 206 \mathrm{~Pb}$ age of $1922 \pm 12 \mathrm{Ma}(2 \boldsymbol{\sigma}, \mathrm{n}=25, \mathrm{MSWD}=1.9$; Liikane et al., 2015). Four single-grain IDTIMS fractions were analyzed, yielding slightly discordant ${ }^{207} \mathrm{~Pb} / 206 \mathrm{~Pb}$ ages between 1876.9 and1896.6 Ma (Figure 3.12e, inset; Liikane et al., 2015). The results from TIMS indicate some cryptic complexity in the zircon microstructure or U-Pb systematics that only becomes apparent in high spatial resolution analyses (Liikane et al., 2015). All grains also have Th/U ratios greater than 1, which is a common attribute of zircon recovered from mafic lithologies (Wang, et al., 2011). The concentric oscillatory zoning is consistent with magmatic crystallization (Corfu, 2003) and the high Th/U signature suggests an igneous origin for the zircon (Heaman et al., 1990). Based on the collective data, these preliminary results suggest a minimum crystallization age of ca. 1900 Ma (Liikane et al., 2015).

\subsubsection{Mafic units}


The majority of mafic units within the mafic and mafic-ultramafic sills exhibit faint, to well-defined, centimetre- to metre-scale rhythmic layering (Figure 3.13a) defined by variations in the modal abundance of plagioclase, amphibole, clinopyroxene and orthopyroxene (Figure 3.13b; Liikane et al., 2015). In contrast, some of the sills lack any visible layering. These units are interpreted to represent metamorphosed gabbroic to noritic lithologies.

\subsubsection{Ultramafic units}

The ultramafic units with ultramafic and mafic-ultramafic intrusions comprise layered clinopyroxene-orthopyroxene-olivine metaperidotite (Figure 3.13c-d) and clinopyroxene-orthopyroxene metapyroxenite (Figure 3.13e-f; Liikane et al., 2015). As with the metagabbro intrusions, some of the ultramafic intrusions are homogeneous and lack any visible layering.

Petrographic observations of the sills are described in Chapter 5, mineral and bulk-rock geochemical characteristics are explored in Chapters 6 \& 7 , respectively, and their petrogenesis is addressed in Chapter 8. 


\section{References}

Blackadar, R.G. (1967). Geological reconnaissance, southern Baffin Island, District of Mackenzie. Geological Survey of Canada, Paper 66-47, p. 32.

Bethune, K. M. and Scammel, R. J. (2003). Geology, geochronology, and geochemistry of Archean rocks in the Eqe Bay area, north-central Baffin Island, Canada: constraints on the depositional and tectonic history of the Mary River Group of northeastern Rae Province. Canadian Journal of Earth Sciences 40, 1137-1167.

Blackadar, R.G. (1967). Geological reconnaissance, southern Baffin Island, District of Mackenzie. Geological Survey of Canada, Paper 66-47, p. 32. Buchan, K.L., Mortensen, J.K., Card, K.D., and Percival, J.A. (1998). Paleomagnetism and $\mathrm{U}-\mathrm{Pb}$ geochronology of diabase dyke swarms of Minto Block, Superior Province, Quebec, Canada. Canadian Journal of Earth Sciences, 35: 1054-1069.

Ciborowski, T.J.R., Minifie, M.J. Kerr, A.C., Ernst, R.E., Baragar, B., Millar, I.L. (2017). A mantle plume origin for the Palaeoproterozoic Circum-Superior Large Igneous Province. Precambrian Research, v. 294, p. 189-213.

Corrigan, D., Pehrsson, S.,Wodicka, N. and de Kemp, E. (2009). The Palaeoproterozoic Trans Hudson Orogen: a prototype of modern accretionary processes; in Ancient Orogens and Modern Analogues, J.B. Murphy, J.D. Keppie and A.J. Hynes (ed.), The Geological Society, London, Special Publications, v. 327, p. 457-479. doi:10.1144/SP327.19. 
Dunphy, J.M. (1994). Evolution des roches plutoniques du domaine nord de la Fosse de l'Ungava. Ministe 're de l'Energie et des Ressources du Que'bec manuscript brut, MB 94-58: $48 \mathrm{p}$.

Dunphy, J.M., Ludden, J.N. (1998). Petrological and geochemical characteristics of a Paleoproterozoic magmatic arc (Narsajuaq terrane, Ungava Orogen, Canada) and comparisons to Superior Province granitoids. Precambrian Res. 91, 109-142.

Ernst, R.E. (2014). Large Igneous Provinces. Cambridge University Press, 653 p. Ernst, R.E. and Bleeker, W. (2010). Large igneous provinces (LIPs), giant dyke swarms, and mantle plumes: significance for breakup events within Canada and adjacent regions from $2.5 \mathrm{Ga}$ to the Present. Canadian Journal of Earth Sciences, 47: 695-739.

Ernst, R.E., Hamilton, M.A., Söderlund, U., Hanes, J.A., Gladkochub, D.P., Okrugin, A.V., Kolotilina, T., Mekhonoshin, A.S., Bleeker, W., LeCheminant, A.N., Buchan, K.L., Chamberlain, K.R., Didenko, A.N., (2016a). Long-lived connection between southern Siberia and northern Laurentia in the Proterozoic. Nature Geoscience, 9:464-469.

Fahrig, W.F. (1987). The tectonic setting of continental mafic dyke swarms: failed arm and early passive margin. In Halls, H.C. \& Fahrig, W.F. (eds.), Mafic Dyke Swarms. St John's, NL: Geological Association of Canada, Special Publication 34, pp. 331-348.

Hamilton, M.A., Goutier, J., Buchan, K.L. (2016). Minto Large Igneous Province: a 2.00 Ga mafic magmatic event in the eastern Superior craton based on 
U-Pb baddeleyite geochronology and paleomagnetism, IDC 7 conference, Beijing China, August 2016.

Heaman, L.M., LeCheminant, A.N. and Rainbird, R.H. (1992). Nature and timing of Franklin igneous events, Canada: implications for a Late Proterozoic mantle plume and the breakup of Laurentia; Earth and Planetary Science Letters, v. 109, p. 117-131.

Hoffman, P.F. (1988): United Plates of America, the birth of a craton: Early Proterozoic assembly and growth of Laurentia; Annual Reviews of Earth and Planetary Sciences, v. 16, p. 543-603.

Jackson, G. D. (2000). Geology of the Clyde-Cockburn Land Map Area, NorthCentral Baffin Island, Nunavut. Geological Survey of Canada Memoir 440, $303 \mathrm{pp}$.

Jackson, G.D., Hunt, P.A., Loveridge, W.D., Parrish, R.R. (1990). Reconnaissance geochronology of Baffin Island, N.W.T. Geological Survey of Canada Paper 89-2, 123-148.

Jackson, G.D., Taylor, F.C. (1972). Correlation of major Aphebian rock units in the northeastern Canadian Shield. Canadian Journal of Earth Sciences 9, 1650-1669.

Jowitt, S.M., Ernst, R.E. (2013). Geochemical Assessment of the Metallogenic Potential of Proterozoic LIPs of Canada: Lithos, v. 174, p. 291-307.

Kastek, N., Ernst, R.E., Baragar, W.R.A., Söderlund, U., Kamo, S.L., Bleeker, W., Sylvester, P. (2016). U-Pb Geochronology and geochemistry of the Povungnituk Group of the Cape Smith belt: a part of a craton-scale circa 
2.0 Ga large igneous province (LIP), northern Superior craton. GAC-MAC annual meeting 2016 June 2, Whitehorse, Yukon.

Lewry, J.F. and Collerson, K.D. (1990). The Trans-Hudson Orogen; extent, subdivisions, and problems; in The Early Proterozoic Trans-Hudson Orogen of North America, J.F. Lewry and M.R. Stauffer (ed.), Geological Association of Canada, Special Paper 37, p. 1-14.

Liikane, D.A., St-Onge, M.R., Kjarsgaard, B.A., Rayner, N.M., Ernst, R.E. and Kastek, N. (2015). Frobisher suite mafic, ultramafic and layered maficultramafic sills, southern Baffin Island, Nunavut; in Summary of Activities 2015, Canada-Nunavut Geoscience Office, p. 21-32.

Lucas, S.B. (1989a). Structural evolution of the Cape Smith Thrust Belt and the role of out-of-sequence faulting in the thickening of mountain belts. Tectonics 8, 655-676.

Lucas, S.B. (1989b). Geometrical, rheological and mechanical evolution of continental thrust belts: examples from the Cape Smith Belt, northern Quebec, Canada. PhD thesis, Brown University, Providence, Rhode Island, $253 \mathrm{p}$.

Lucas, S.B. and Byrne, T. (1992). Footwall involvement during arc-continent collision, Ungava orogen, northern Canada; Journal of the Geological Society of London, v. 149, p. 237-248.

Lucas, S.B. and St-Onge, M.R. (1991). Evolution of Archean and early Proterozoic magmatic arcs in northeastern Ungava Peninsula, Quebec. Geological of Survey Canada Paper 91-1C, 109-119. 
Minifie, M. J., Kerr, A. C., Ernst, R. E., Hastie, A. R., Ciborowski, T. J. C., Desharnais, G. \& Milliar, I. L. (2013). The northern and southern sections of the western ca. 1880Ma Circum- Superior Large Igneous Province, North America: The Pickle Crow dyke connection? Lithos 174, 217-235.

Parrish, R.R. (1989). U-Pb geochronology of the Cape Smith Belt and Sugluk block. Geoscience Canada 16, 126-130.

Rayner, N.M., Sanborn-Barrie, M.,Young, M.D. and Whalen, J.B. (2012). U-Pb ages of Archean basement and Paleoproterozoic plutonic rocks, southern Cumberland Peninsula, eastern Baffin Island, Nunavut; Geological Survey of Canada, Current Research 2012-8, 24 p.

Sanborn-Barrie, M., St-Onge, M.R., Young, M.D., and James, D.T. (2008). Bedrock geology of south-western Baffin Island, Nunavut: explanding the tectonostratigraphic framework with relevance to mineral resources; Geological Survey of Canada, Current Research 2008-6, 16p.

Scott, D.J. (1997). Geology, U-Pb, and Pb-Pb geochronology of the Lake Harbour area, southern Baffin Island: implications for the Paleoproterozoic tectonic evolution of northeastern Laurentia. Canadian Journal of Earth Sciences 34, 140-155.

Scott, D.J. (1998). U-Pb ages of Archean crust in the southeast arm of the Rae Province, southeastern Ungava Bay, Quebec. Geological Survey of Canada Paper 1998-F, 41-45.

Scott, D. J. \& Gauthier, G. (1996). Comparison of TIMS (U-Pb) and laser ablation microprobe ICP-MS $(\mathrm{Pb})$ techniques for age determination of detrital 
zircons from Paleoproterozoic metasedimentary rocks from northeastern Laurentia, Canada, with tectonic implications. Chemical Geology 131, 127-142.

Scott, D.J., Stern, R.A., St-Onge, M.R. and McMullen, S.M. (2002). U-Pb geochronology of detrital zircons in metasedimentary rocks from southern Baffin Island: implications for the Paleoproterozoic tectonic evolution of Northeastern Laurentia; Canadian Journal of Earth Sciences, v. 39, p. $611-623$.

Scott, D.J. and Wodicka, N. (1998). A second report on the U-Pb geochronology of southern Baffin Island, Northwest territories. Geological Survey of Canada Paper 1998-F, 47-57.

Scott, D.J., Helmstaedt, H., Bickle, M.J. (1992). Purtuniq ophiolite, Cape Smith Belt, northern Quebec, Canada: a reconstructed section of Early Proterozoic oceanic crust. Geology 20, 173-176

Scott, D.J. (1997). Geology, U-Pb, and $\mathrm{Pb}-\mathrm{Pb}$ geochronology of the Lake Harbour area, southern Baffin Island: implications for the Paleoproterozoic tectonic evolution of northeastern Laurentia. Canadian Journal of Earth Science, 34, 140-155.

Scott, D.J. and St-Onge, M.R. (1995). Constraints on Pb closure temperature in titanite based on rocks from the Ungava orogen, Canada: implications for U-Pb geochronology and P-T-t path determinations. Geology 23, 11231126. 
Scott, D.J., St-Onge, M.R.,Wodicka, N. and Hanmer, S. (1997). Geology of the Markham Bay Crooks Inlet area, southern Baffin Island, Northwest Territories; in Geological Survey of Canada, Current Research 1997-C, p. 157-166.

Skipton, D.R., Schneider, D.A., McFarlane, C.R.M., St-Onge, M.R., and Jackson, S. (2016a). Multi-stage zircon and monazite growth revealed by depthprofiling and in situ U-Pb geochronology: resolving the Paleoproterozoic tectonics of the Trans-Hudson Orogen on southeastern Baffin Island, Canada" Submitted to Precambrian Research, 285, 272-298. https:// doi.org/10.1016/j.precamres.2016.09.002

Skipton, D.R., St-Onge, M.R., Schneider, D.A., and McFarlane, C.R.M. (2016b). Tectonothermal evolution of the middle crust in the Trans-Hudson Orogen, Baffin Island, Canada: evidence from petrology and monazite geochronology of sillimanite-bearing migmatites, Journal of Petrology, 57 (8): 1437-1462. DOI: https://doi.org/10.1093/petrology/egw046

St-Onge, M.R., Hanmer, S. and Scott, D.J. (1996). Geology of the Meta Incognita Peninsula, south Baffin Island: tectonostratigraphic units and regional correlations; in Geological Survey of Canada, Current Research 1996-C, p. 63-72.

St-Onge, M.R., Lucas, S.B., Parrish, R.R. (1992). Terrane accretion in the internal zone of the Ungava orogen, northern Quebec. Part 1: tectonostratigraphic assemblages and their tectonic implications. Canadian Journal of Earth Sciences, 29, 746-764. 
St-Onge, M.R., Scott, D.J. and Lucas, S.B. (2000). Early partitioning of Quebec:

Microcontinent formation in the Paleoproterozoic; Geology, v. 28, p. 323326.

St-Onge, M.R., Scott, D.J. and Wodicka, N. (1999a). Geology,Frobisher Bay, Nunavut; Geological Survey of Canada,Map 1979A, 1:100 000 scale, doi: $10.4095 / 210833$

St-Onge, M.R., Scott, D.J. and Wodicka, N. (1999b). Geology, Hid-den Bay, Nunavut; Geological Survey of Canada, 1980A,1:100 000 scale, doi: $10.4095 / 210835$

St-Onge, M.R., Scott, D.J. and Wodicka, N. (1999c). Geology, Mc-Kellar Bay, Nunavut; Geological Survey of Canada, Map1981A, 1:100 000 scale, doi: $10.4095 / 210836$

St-Onge, M.R., Scott, D.J. and Wodicka, N. (1999d). Geology, Wright Inlet, Nunavut; Geological Survey of Canada, Map1982A, 1:100 000 scale, doi: $10.4095 / 210840$

St-Onge, M.R., Scott, D.J. and Wodicka, N. (1999e). Geology, Blandford Bay, Nunavut; Geological Survey of Canada,Map 1983A, 1:100 000 scale, doi: $10.4095 / 210837$

St-Onge, M.R., Scott, D.J. and Wodicka, N. (1999f). Geology, Crooks Inlet, Nunavut; Geological Survey of Canada, Map1984A, 1:100 000 scale, doi: $10.4095 / 210838$ 
St-Onge, M.R., Scott, D.J. and Wodicka, N. (1999g). Geology, White Strait, Nunavut; Geological Survey of Canada, Map1985A, 1:100 000 scale, doi: $10.4095 / 210839$

St-Onge, M. R., Scott, D. J. and Wodicka, N. (1999h). Geological maps and descriptive notes and legend, parts of Meta Incognita Peninsula, Nunavut. Geological Survey of Canada Maps 1979A to 1985A, scale 1:100 000.

St-Onge, M.R., Scott, D.J., and Wodicka, N. (2001). Terrane boundaries within Trans-Hudson Orogen (Quebec - Baffin segment), Canada: changing structural and metamorphic character from foreland to hinterland; Precambrian Research, v. 107, p. 75-91.

St-Onge, M.R., Scott, D.J. and Wodicka, N. (2002). Review of crustal architecture and evolution in the Ungava Peninsula- Baffin Island area: connection to the Lithoprobe ECSOOT transect; Canadian Journal of Earth Sciences, v. 39, p. 589-610, doi:10.1139/E02-022.

St-Onge, M.R., Scott, D.J., Wodicka, N. and Lucas, S.B. (1998). Geology of the McKellar Bay Wight Inlet-Frobisher Bay area, southern Baffin Island, Northwest Territories; in Geological Survey of Canada, Current Research 1998-C, p. 43-53.

St-Onge, M.R., Rayner, N.M., Liikane, D. and Chadwick, T. (2015a). Mafic, ultramafic and layered mafic-ultramafic sills, Meta Incognita Peninsula, southern Baffin Island, Nunavut; in Summary of Activities 2014, CanadaNunavut Geoscience Office, p. 11-16. 
St-Onge, M.R., Rayner, N.M., Steenkamp, H.M., and Gilbert, C. (2015b).

Geology, Grinnell Glacier, Baffin Island, Nunavut; Geological Survey of Canada, Canadian Geoscience Map 217E (preliminary); Canada-Nunavut Geoscience Office, Open File Map 2015-04E, scale 1:100 000. doi: $10.4095 / 296111$.

St-Onge, M.R., Rayner, N.M., Steenkamp, H.M., and Gilbert, C. (2015c). Geology, Pritzler Harbour, Baffin Island, Nunavut; Geological Survey of Canada, Canadian Geoscience Map 216E (preliminary); Canada-Nunavut Geoscience Office, Open File Map 2015-03E, scale 1:100 000. doi: $10.4095 / 296109$.

St-Onge, M.R., Rayner, N.M., Steenkamp, H.M., and Gilbert, C. (2015d). Geology, Terra Nivea, Baffin Island, Nunavut; Geological Survey of Canada, Canadian Geoscience Map 215E (preliminary); Canada-Nunavut Geoscience Office, Open File Map 2015-02E, scale 1:100 000. doi: $10.4095 / 296104$

St-Onge, M.R., Rayner, N.M., Steenkamp, H.M., and Gilbert, C. (2015e). Geology, Pritzler Harbour, Baffin Island, Nunavut; Geological Survey of Canada, Canadian Geoscience Map 216E (preliminary); Canada-Nunavut Geoscience Office, Open File Map 2015-03E, scale 1:100 000. doi: $10.4095 / 296109$.

St-Onge, M.R., Rayner, N.M., Steenkamp, H.M. and Skipton, D.R. (2015f). Bedrock mapping of eastern Meta Incognita Peninsula, southern Baffin 
Island, Nunavut; in Summary of Activities 2014, Canada-Nunavut Geoscience Office, p. 105-118.

St-Onge, M.R., Wodicka, N. and ljewliw, O. (2007). Polymetamorphic evolution of the Trans Hudson Orogen, Baffin Island, Canada: Integration of petrological, structural and geochronological data; Journal of Petrology, v. 48, p. $271-302$. doi:10.1093/petrology/eg1060.

St-Onge, M.R., Van Gool, J.A.M., Garde, A.A. and Scott, D.J. (2009). Correlation of Archaean and Palaeoproterozoic units between northeastern Canada and western Greenland: constraining the pre-collisional upper plate accretionary history of the Trans-Hudson orogen; in Earth Accretionary Systems in Space and Time, P.A. Cawood and A. Kroner, The Geological Society, London, Special Publications, v. 318, p. 193-235. doi:10.1144/ SP318.7.

St-Onge, M.R., Weller, O.M., Dyck, B.J., Rayner, N.M., Chadwick T., and Liikane, D. (2016a). Geology, Sylvia Grinnell Lake (north), Baffin Island, Nunavut. Geological Survey of Canada, Canadian Geoscience Map 253; CanadaNunavut Geoscience Office, Open File Map OFM2016-10, scale 1:100 000,1 sheet.

St-Onge, M.R., Weller, O.M., Dyck, B.J., Rayner, N.M., Chadwick T., and Liikane, D. (2016b). Geology, Sylvia Grinnell Lake (south), Baffin Island, Nunavut. Geological Survey of Canada, Canadian Geoscience Map 254; CanadaNunavut Geoscience Office, Open File Map OFM2016-11, scale 1:100 000,1 sheet. 
St-Onge, M.R., Weller, O.M., Dyck, B.J., Rayner, N.M., Chadwick T., and Liikane, D. (2016c). Geology, Amittok Lake (north), Baffin Island, Nunavut. Geological Survey of Canada, Canadian Geoscience Map 255; CanadaNunavut Geoscience Office, Open File Map OFM2016-12, scale 1:100 000, 1 sheet.

St-Onge, M.R., Weller, O.M., Dyck, B.J., Rayner, N.M., Chadwick T., and Liikane, D. (2016d). Geology, Amittok Lake (south), Baffin Island, Nunavut. Geological Survey of Canada, Canadian Geoscience Map 256; CanadaNunavut Geoscience Office, Open File Map OFM2016-13, scale 1:100 000,1 sheet.

St-Onge, M.R., Weller, O.M., Dyck, B.J., Rayner, N.M., Chadwick T., and Liikane, D. (2016e). Geology, Clearwater Fiord (north), Baffin Island, Nunavut. Geological Survey of Canada, Canadian Geoscience Map 257; CanadaNunavut Geoscience Office, Open File Map OFM2016-14, scale 1:100 000,1 sheet.

St-Onge, M.R., Weller, O.M., Dyck, B.J., Rayner, N.M., Chadwick T., and Liikane, D. (2016f). Geology, Clearwater Fiord (south), Baffin Island, Nunavut. Geological Survey of Canada, Canadian Geoscience Map 258; CanadaNunavut Geoscience Office, Open File Map OFM2016-15, scale 1:100 000, 1 sheet.

St-Onge, M.R., Weller, O.M., Dyck, B.J., Rayner, N.M., Chadwick T., and Liikane, D. (2016g). Geology, McKeand River (north), Baffin Island, Nunavut. Geological Survey of Canada, Canadian Geoscience Map 259; Canada- 
Nunavut Geoscience Office, Open File Map OFM2016-16, scale 1:100 000,1 sheet.

St-Onge, M.R., Weller, O.M., Dyck, B.J., Rayner, N.M., Chadwick T., and Liikane, D. (2016h). Geology, McKeand River (south), Baffin Island, Nunavut. Geological Survey of Canada, Canadian Geoscience Map 260; CanadaNunavut Geoscience Office, Open File Map OFM2016-17, scale 1:100 000,1 sheet.

St-Onge, M.R., Weller, O.M., Dyck, B.J., Rayner, N.M., Chadwick T., and Liikane, D. (2016i). Geology, Irvine Inlet (north), Baffin Island, Nunavut. Geological Survey of Canada, Canadian Geoscience Map 261; Canada-Nunavut Geoscience Office, Open File Map OFM2016-18 scale 1:100 000, 1 sheet.

St-Onge, M.R., Weller, O.M., Dyck, B.J., Rayner, N.M., Chadwick T., and Liikane, D. (2016j). Geology, Irvine Inlet (south), Baffin Island, Nunavut. Geological Survey of Canada, Canadian Geoscience Map 262; Canada-Nunavut Geoscience Office, Open File Map OFM2016-19, scale 1:100 000, 1 sheet.

Weller, O.M., Dyck, B.J., St-Onge, M.R., Rayner, N.M. and Tschirhart, V. (2015g). Completing the bedrock mapping of southern Baffin Island, Nunavut: plutonic suites and regional stratigraphy; in Summary of Activities 2015, Canada-Nunavut Geoscience Office, p. 33-48.

Whalen, J.B., Wodicka, N., Taylor, B.E. and Jackson, G.D. (2010). Cumberland batholith, Trans- Hudson Orogen, Canada: petrogenesis and implications 
for Paleoproterozoic crustal and orogenic processes; Lithos, v. 117, p. 99118, doi: 10.1016/j.lithos.2010.02.008.

Wodicka, N., Madore, L., Larbi, Y. \& Vicker, P. (2002a). Geochronologie U-Pb de filons-couches mafiques de la Ceinture de Cape Smith et de la Fosse du Labrador. Seminaire d'information sur la recherche geologique, Programme et resumes 2002. Ministere des Ressources naturelles, Quebec DV 2002-10, 48.

Wodicka, N., Scott, D.J. (1997). A preliminary report on the U-Pb geochronology of the Meta Incognita Peninsula, southern Baffin Island, Northwest Territories. Geological Survey of Canada Paper 1997-C, 167-178.

Wodicka, N., St-Onge, M.R., Corrigan, D., Scott, D.J. and Whalen, J.B. (2014). Did a proto-ocean basin form along the southeastern Rae cratonic margin? Evidence from U-Pb geochronology, geochemistry (Sm-Nd and whole-rock), and stratigraphy of the Paleoproterozoic Piling Group, northern Canada; GSA Bulletin, v. 126, p. 1625-1653. doi:10.1130/ B31028.1

Wodicka, N., St-Onge, M. R., Scott, D. J. and Corrigan, D. (2002b). Preliminary report on the U-Pb geochronology of the northern margin of the TransHudson Orogen, central Baffin Island, Nunavut. Geological Survey of Canada Paper 2002-F7, , 12 pp.

Wodicka, N., St-Onge, M. R., Whalen, J. B. (2008). Characteristics of two opposing continental margin successions in northeast Laurentia; Geochimica et Cosmochimica Acta, v. 72, p. A1030 
Wodicka, N., Whalen, J. B., St-Onge, M. R., and Corrigan, D. (2010). Meta Incognita microcontinent revisited: insights from $\mathrm{U}-\mathrm{Pb}$ geochronology and $\mathrm{Nd}$ isotopes. In Geological Association of Canada-Mineralogical Association of Canada, Abstract (Vol. 35). 
Figure 3.1: Summary geological map of North America and Greenland (collectively termed Laurentia), and the western Baltic Shield, modified from Hoffman (1988). This map outlines the extent of the Trans-Hudson orogen and the location of bounding Archean cratons and crustal blocks. The collisional lower plate of Trans-Hudson orogen comprises the Archean Superior craton and its marginal Paleoproterozoic supracrustal cover. The collisional upper plate (the Churchill domain) includes the Rae craton, Slave craton, Wyoming craton, Hearne block, and North Atlantic (Nain) craton, together with their associated Palaeoproterozoic supracrustal sequences. M, Manitoba promontory; Q, Québec promontory. Meta Incognita Peninsula (2014) and south-central Baffin (2015) field areas are outlined in teal. 


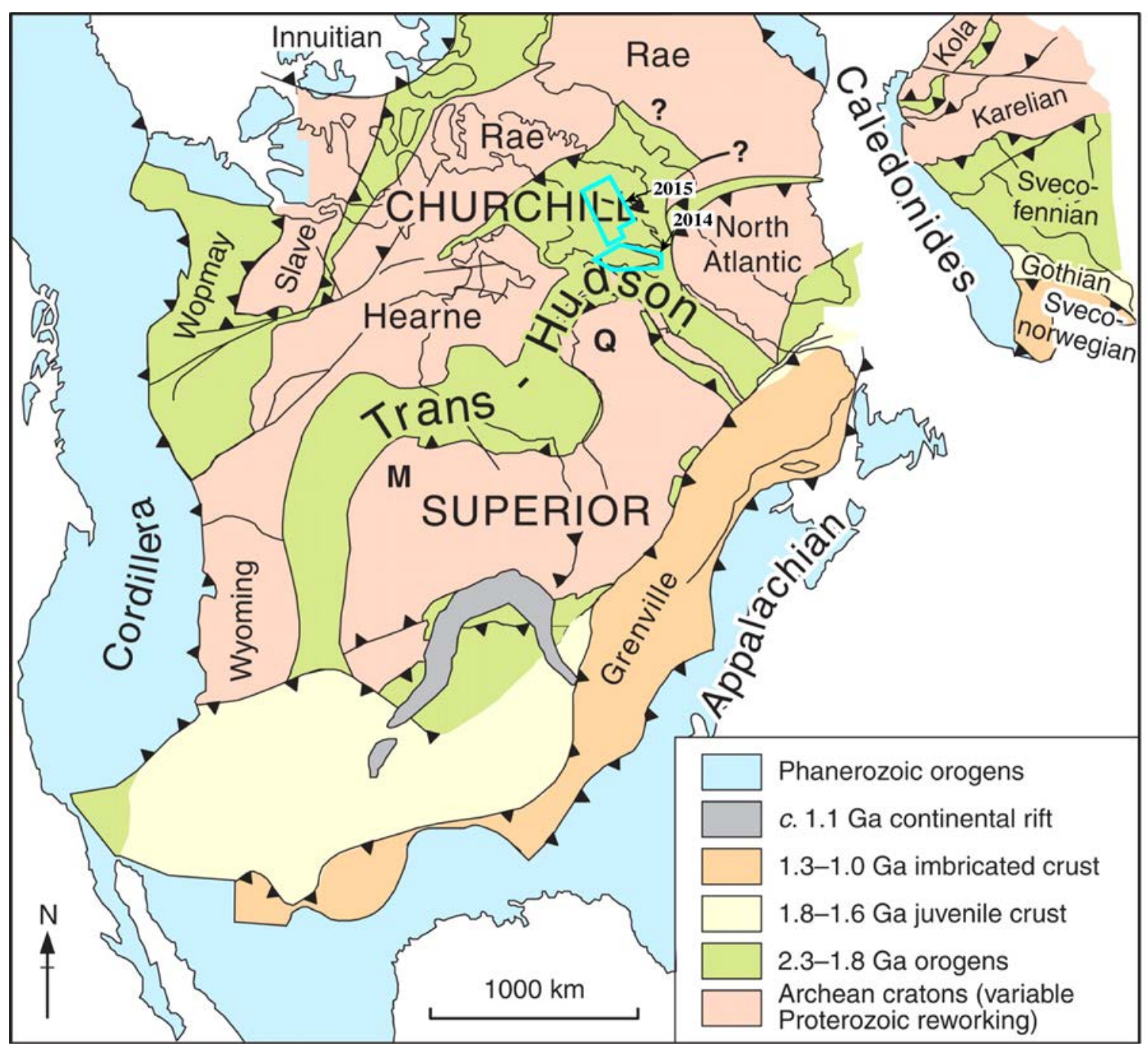


Figure 3.2: Simplified geological map of the Canadian Shield and west Greenland, with the pale colours southwest of thick hashed line outlining the extension of the western Precambrian domains beneath Phanerozoic cover. The minimum extent of the area affected by a Trans-Hudson orogen age tectonothermal overprint $(1.86-1.80 \mathrm{Ga})$ is delineated by the thick red hashed line. The limit of the Reindeer Zone is defined by the thick stippled blue line. Terrane names and major faults: $\mathrm{BH}$, Buffalo Head terrane; BK, Black Hills; C, Chinchaga belt; CZ, Core Zone; FS, Fort Simpson terrane; FFB, Foxe Fold Belt; GB, Great Bear; GSL, Great Slave Lake shear zone; H, Hottah terrane; KS, Ksituan belt; L, Lacombe belt; N, Nahanni belt; NO, New Quebec; NV, Nova terrane; RB, Rimbey Belt; STZ, Snowbird Tectonic Zone; T, Thorsby basin; TA, Tasiuyak domain; W, Wabamun belt. Meta Incognita Peninsula (2014) and southcentral Baffin (2015) field areas are outlined in teal. Modified from Corrigan et al. (2009). 


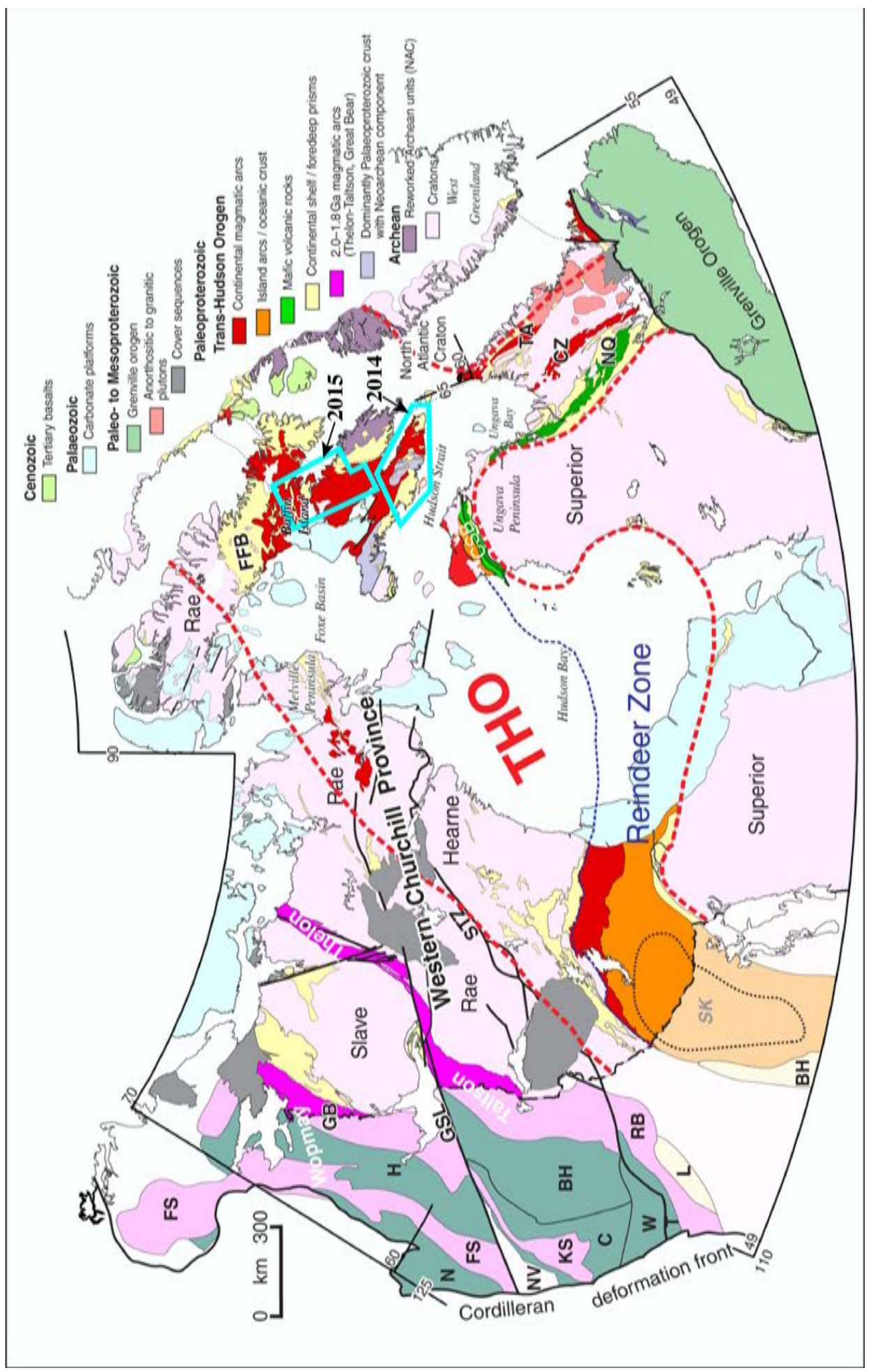


Figure 3.3: Geologic terrane map of the Québec-Baffin segment of the TransHudson Orogen (modified from St-Onge et al., 2007), showing the four tectonically stacked domains of southern Baffin Island and northern Québec and the suture zones that separate the domains. Meta Incognita Peninsula (2014) and south-central Baffin (2015) field areas are outlined in teal. 

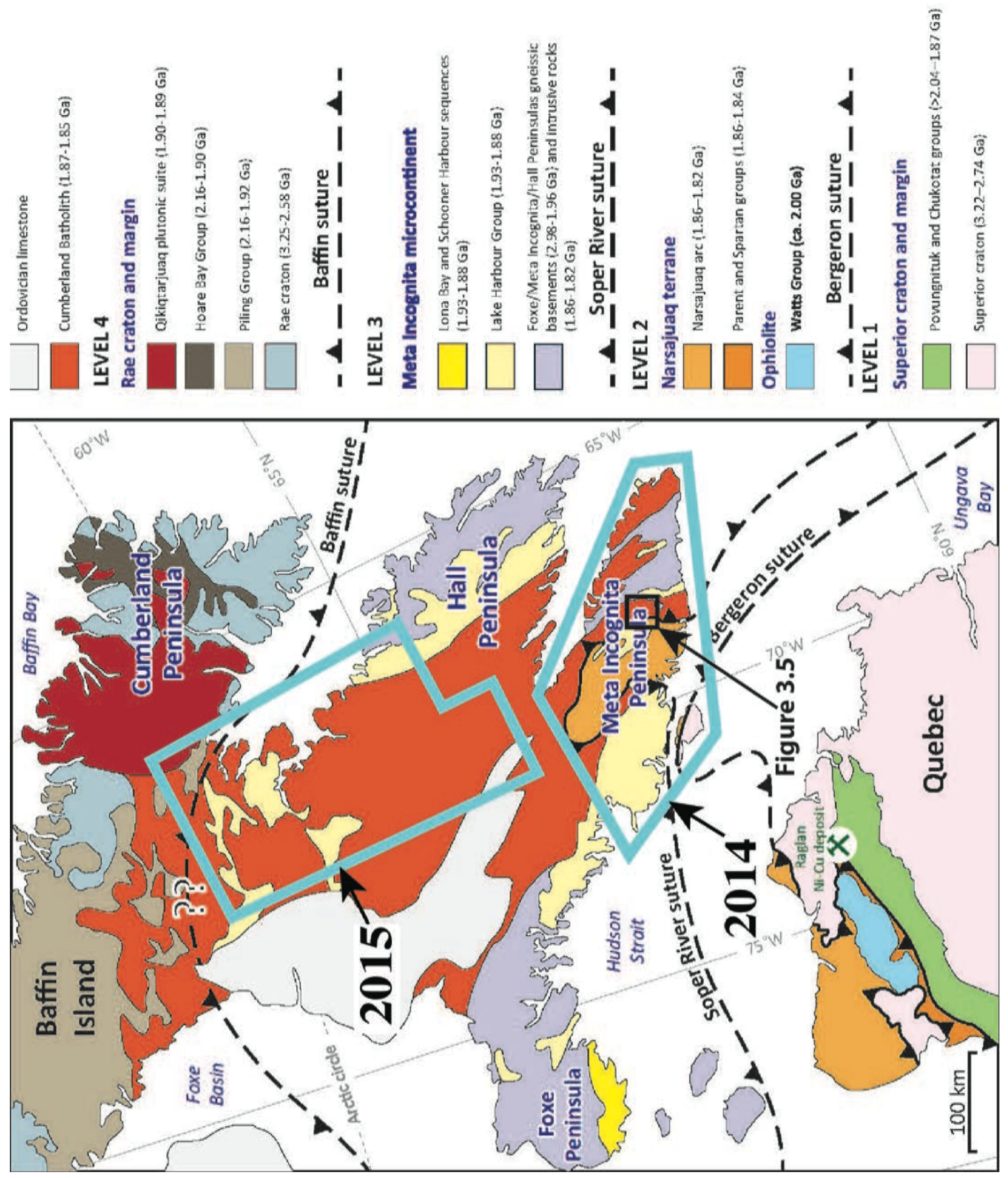
Figure 3.4: Tectonic summary diagram for the Québec-Baffin segment of the Trans-Hudson Orogen (from St-Onge et al., 2007), documenting time intervals for emplacement and accumulation of major plutonic and tectonostratigraphic units on southern Baffin Island and surrounding area. Shaded rectangles indicate Archean or Paleoproterozoic basement units, and the unfilled rectangles indicate Paleoproterozoic supracrustal units and magmatic suites. The horizontal shaded bars $\left(D_{0}-D_{2}\right)$ correspond to crustal sutures, identifying their age and extent, while $\mathrm{M}_{1 \mathrm{a}}-\mathrm{M}_{2}$ represent regional metamorphic events that occurred on southern Baffin Island. Abbreviations: BaS, Baffin suture; BeS, Bergeron suture; SRS, Soper River suture; $\mathrm{M}_{1 \mathrm{a}}$, prograde granulite facies metamorphism; $\mathrm{M}_{1 \mathrm{~b}}$, high-T contact metamorphism; $\mathrm{M}_{2}$, retrograde amphibolite metamorphism. 


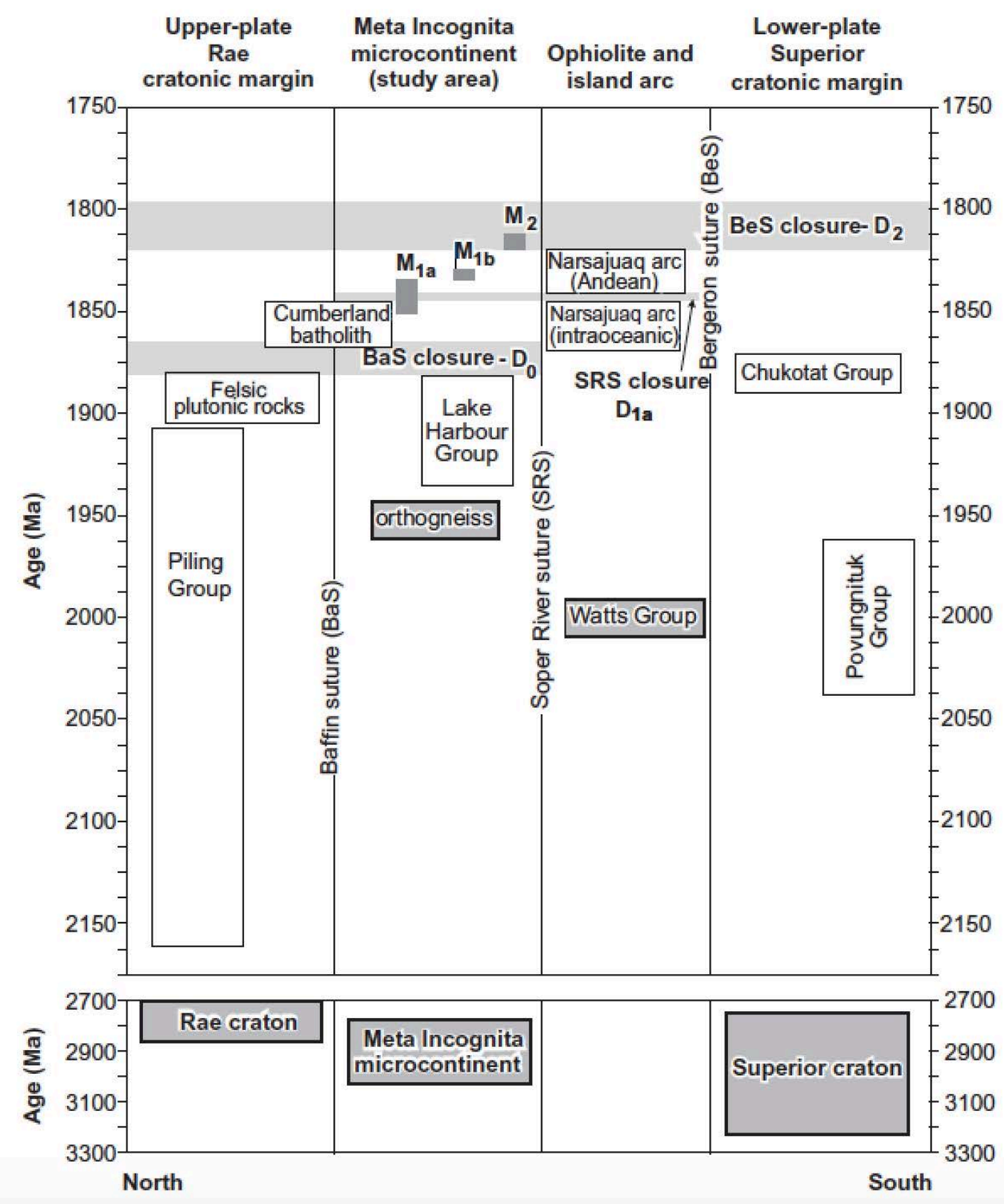


Figure 3.5: Basic bedrock map showing dome-and-basin map patterns, which represent interference patterns formed during the $D_{4}$ upright folding that deformed all other structural elements; these fold axes generally trend eastnortheast (St-Onge et al., 2015f). The $\mathrm{D}_{4}$ generated dome-and-basin map patterns are best preserved in the southern and eastern portions of Meta Incognita Peninsula, Baffin Island, Nunavut. Map area is located in central Meta Incognita Peninsula, adjacent to the east side of the Narsajuaq arc terrane boundary. Coordinates at image centre are: Lat: $62^{\circ} 39^{\prime} 6.23^{\prime \prime} \mathrm{N}$; Long:68 6'30.80”W (coordinates obtained through Google Earth). 

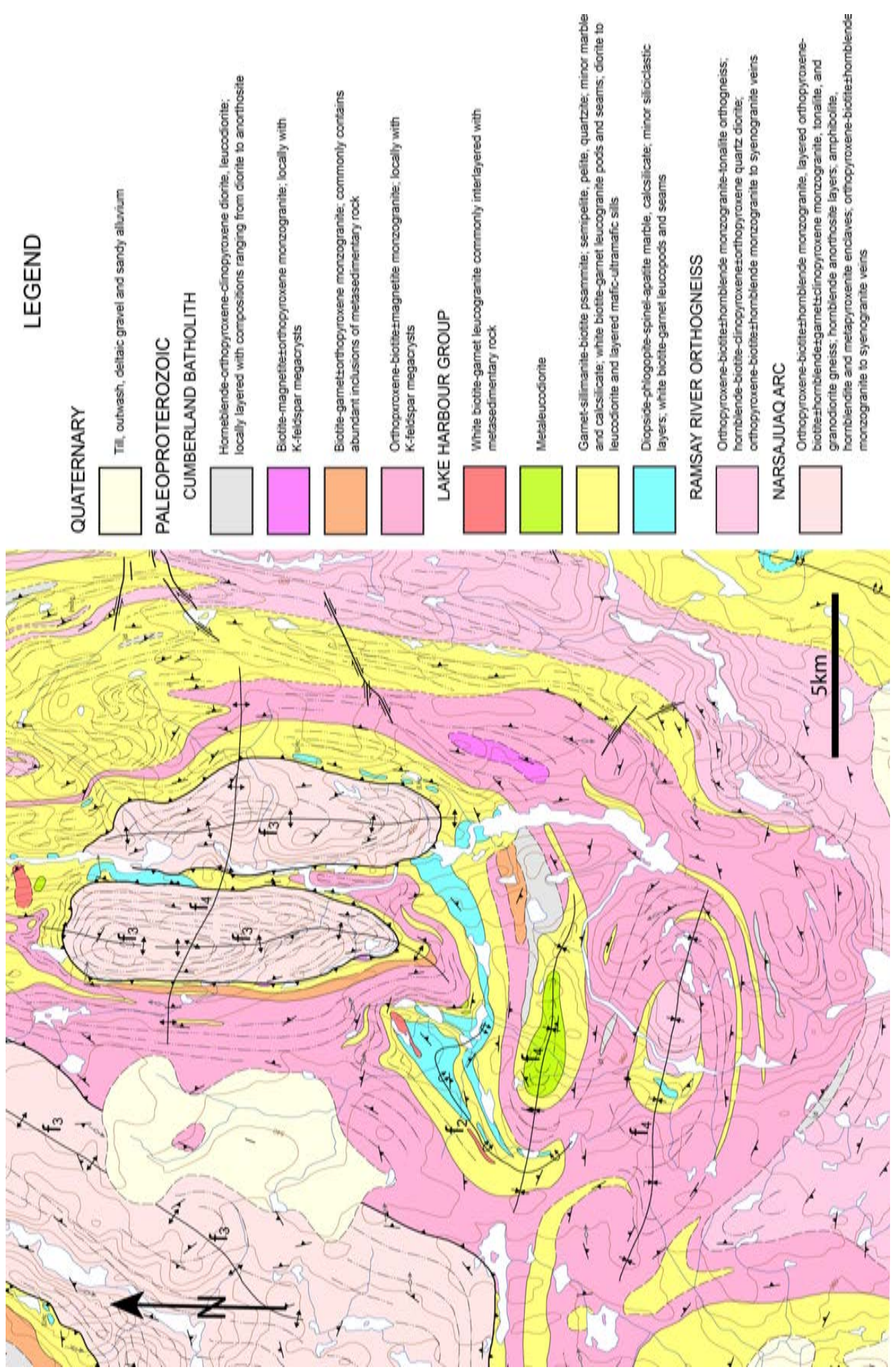
Figure 3.6a-d: a) Gossan in Lake Harbour Group psammite adjacent to a layered mafic-ultramafic sill, Meta Incognita Peninsula, Baffin Island, Nunavut; hammer is $35 \mathrm{~cm}$ long; b) Diopside-phlogopite-spinel-apatite-quartz calcareous grit, Lake Harbour Group, Meta Incognita Peninsula, Baffin Island, Nunavut; c) Shallowlydipping, well-layered, garnet-bearing orthoquartzite, Lake Harbour Group, Meta Incognita Peninsula, Baffin Island, Nunavut; geologist for scale is $2 \mathrm{~m}$ tall; d) Garnet-sillimanite-biotite-melt psammite, Lake Harbour Group, Meta Incognita Peninsula, Baffin Island, Nunavut. From St-Onge et al. (2015a,f). 


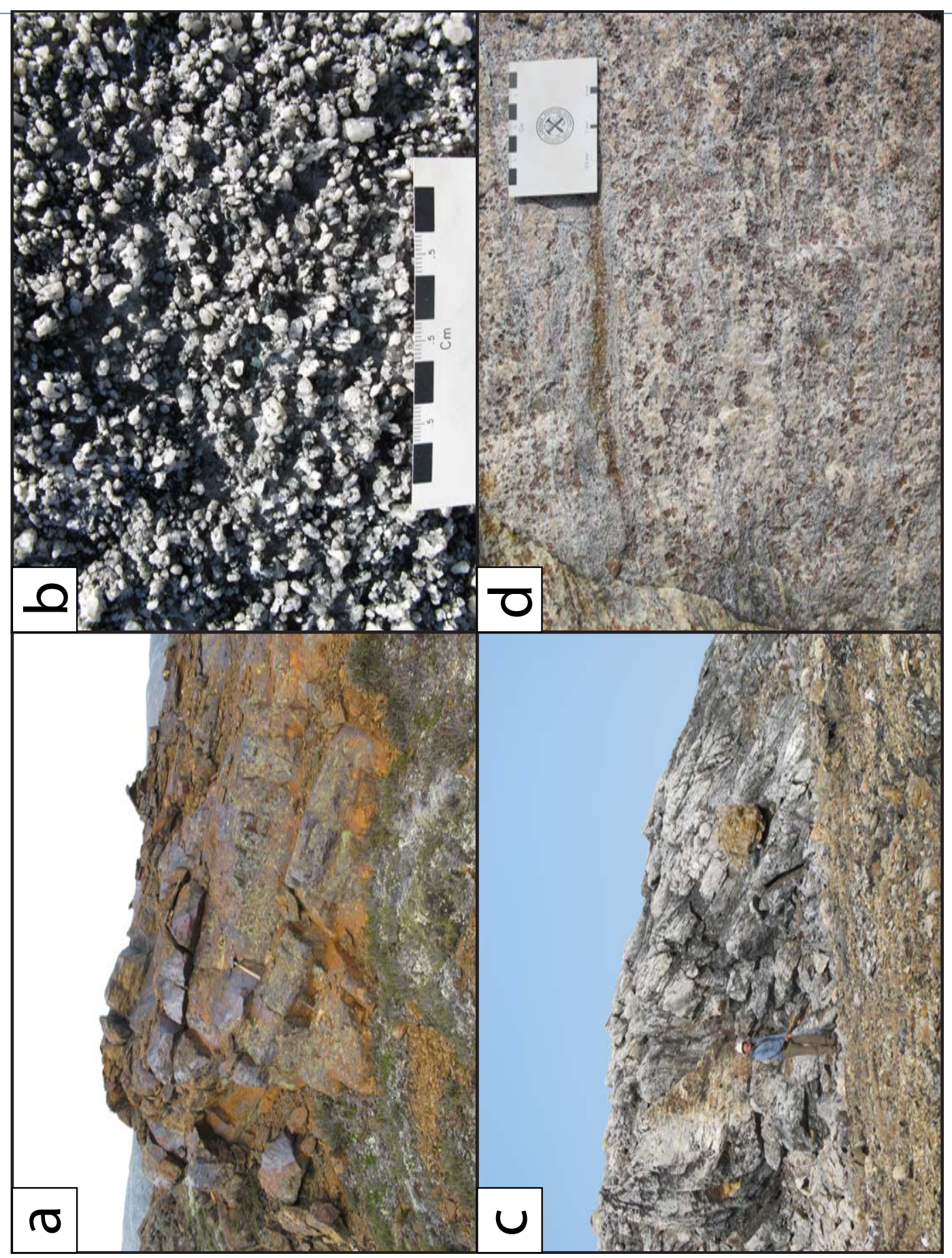


Figure 3.7a-b: a) Mafic-ultramafic sill (dark; from St-Onge et al., 2015a) emplaced in Lake Harbour Group quartzite (white) and psammite (rusty brown) and subsequently folded, Meta Incognita Peninsula, Baffin Island, Nunavut. Width of field of view is $\sim 800 \mathrm{~m}$. b) The Chidliak sill (15SAB-L075A-15SABL081A), Hall Peninsula, Baffin Island (from Liikane et al., 2015). Detailed sampling was conducted across this structurally overturned layered maficultramafic sill in order to determine the petrogenesis of the Frobisher magmatic suite from a regional perspective. The sill comprises a basal metapyroxenite, overlain by metaperidotite, overlain by metagabbro and capped by metaleucograbbro. Width of field of view is $\sim 500 \mathrm{~m}$. 


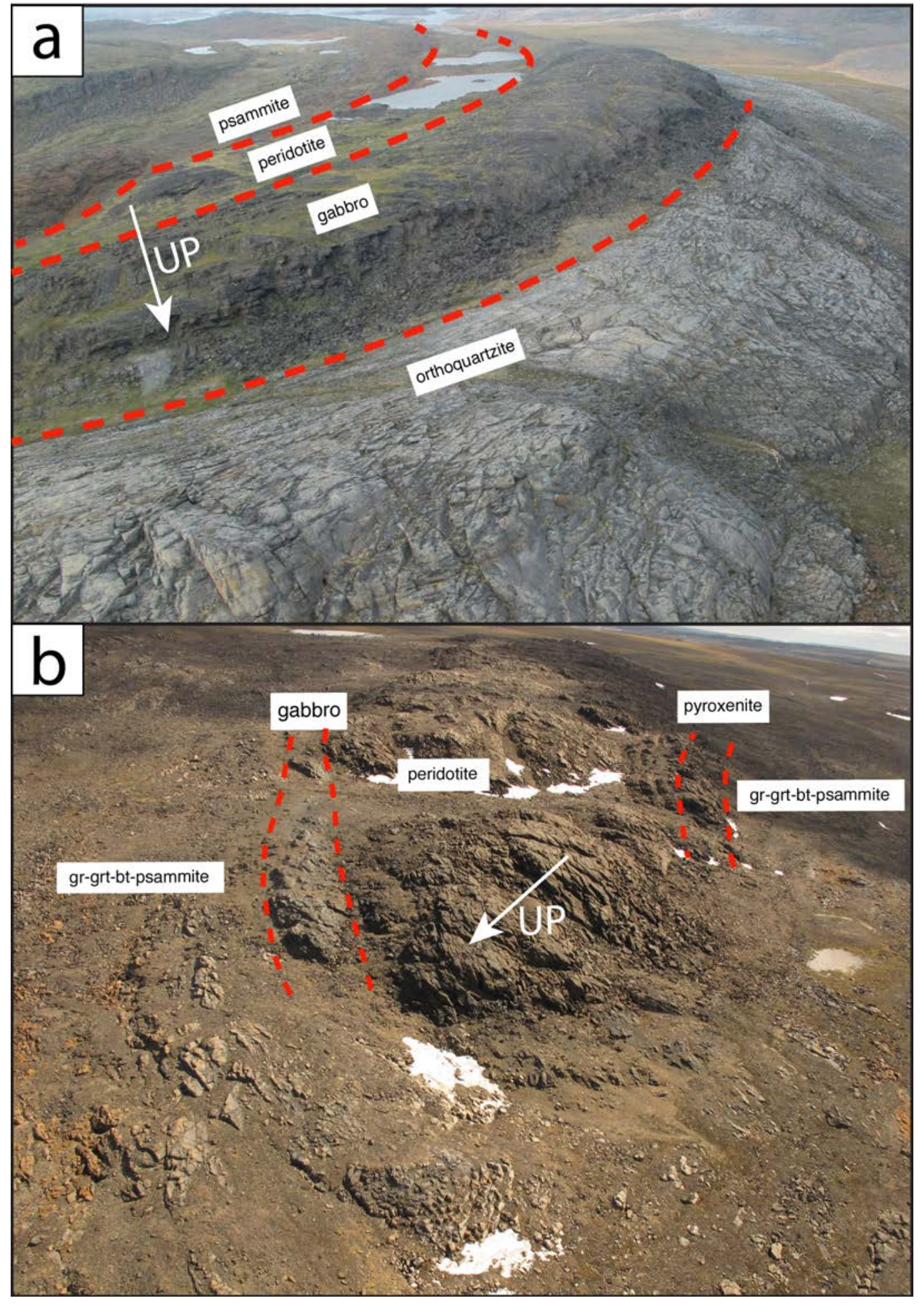


Figure 3.8: Bedrock geology map of Meta Incognita Peninsula, Baffin Island (with legend on following page), showing locations of the mafic, ultramafic and layered mafic-ultramafic sills. Intrusions sampled for geochemical and/or geochronological analysis are shown by their respective group's symbol, described in Chapter 7, geochemistry. Maps modified from St-Onge et al. (1999ah; 2015b-e). 


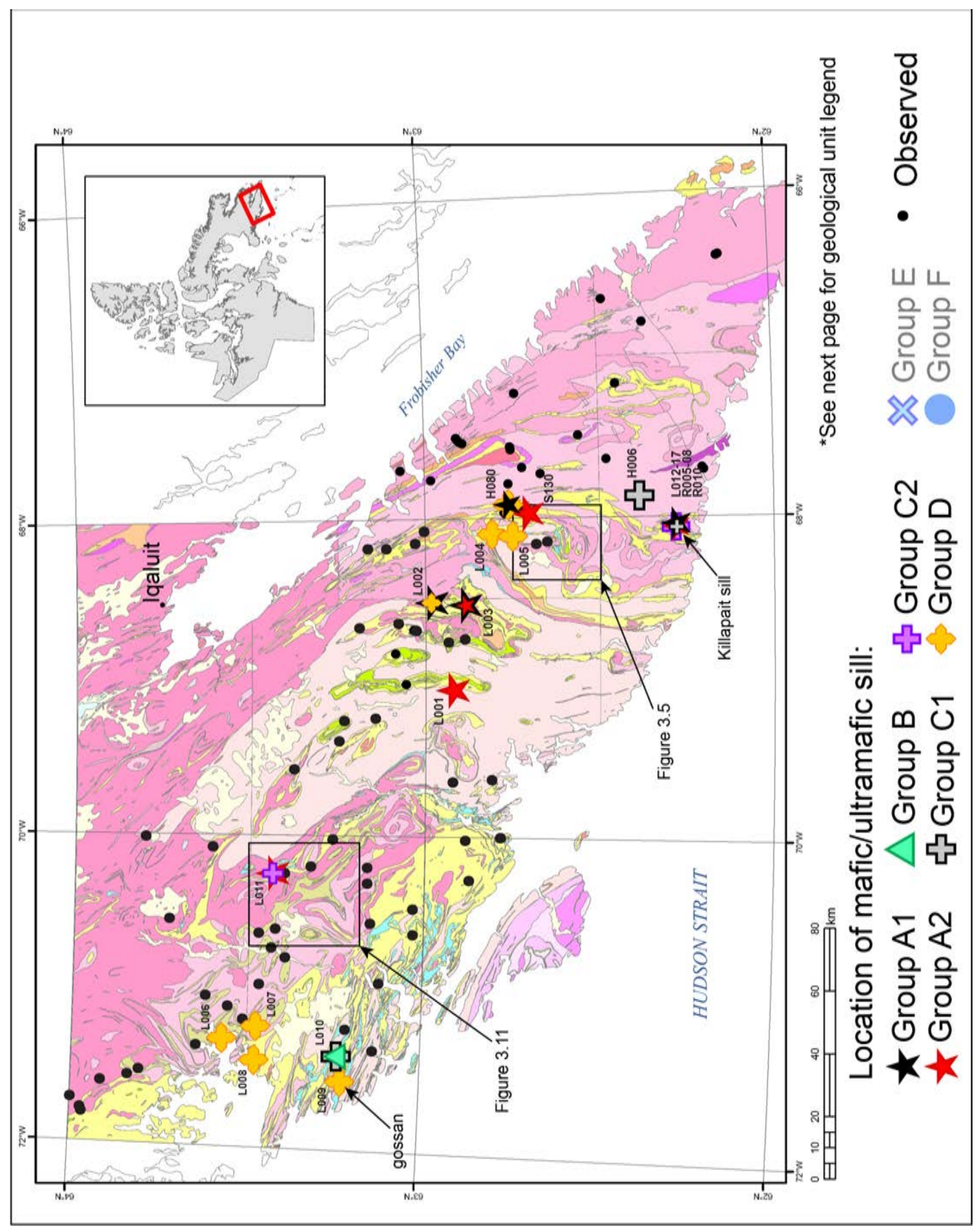




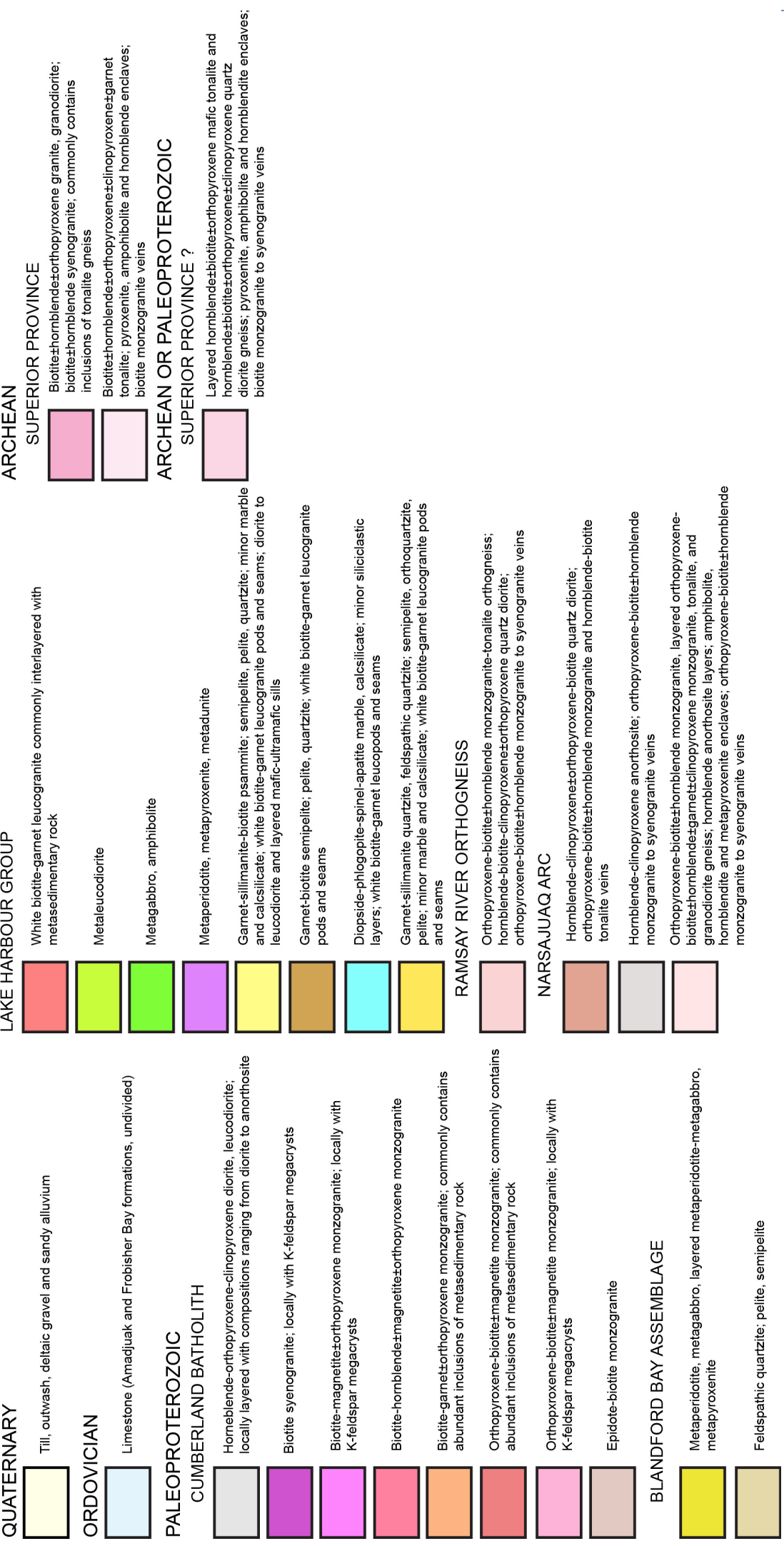


Figure 3.9: Bedrock geology map of northern Hall Peninsula, southern Baffin Island, showing locations of the mafic, ultramafic and layered mafic-ultramafic sills sampled. Intrusions sampled for geochemical and/or geochronological analysis are shown by their respective group's symbol, described in Chapter 7, geochemistry. Maps from Blackadar (1967) and St-Onge et al (2016a-j). Faded legend labels indicate that those specific geochemical groups were not recognized in that map area. 


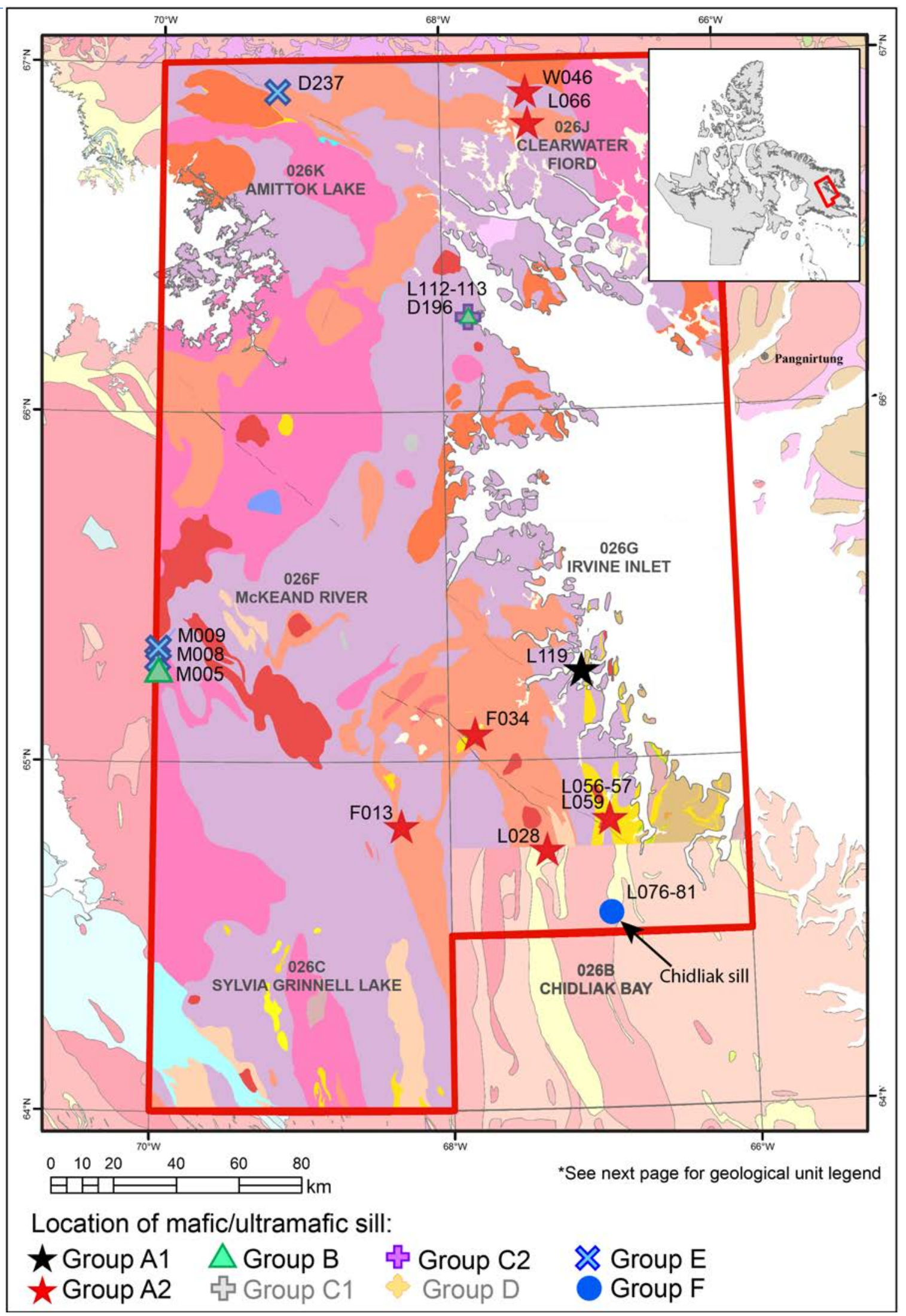




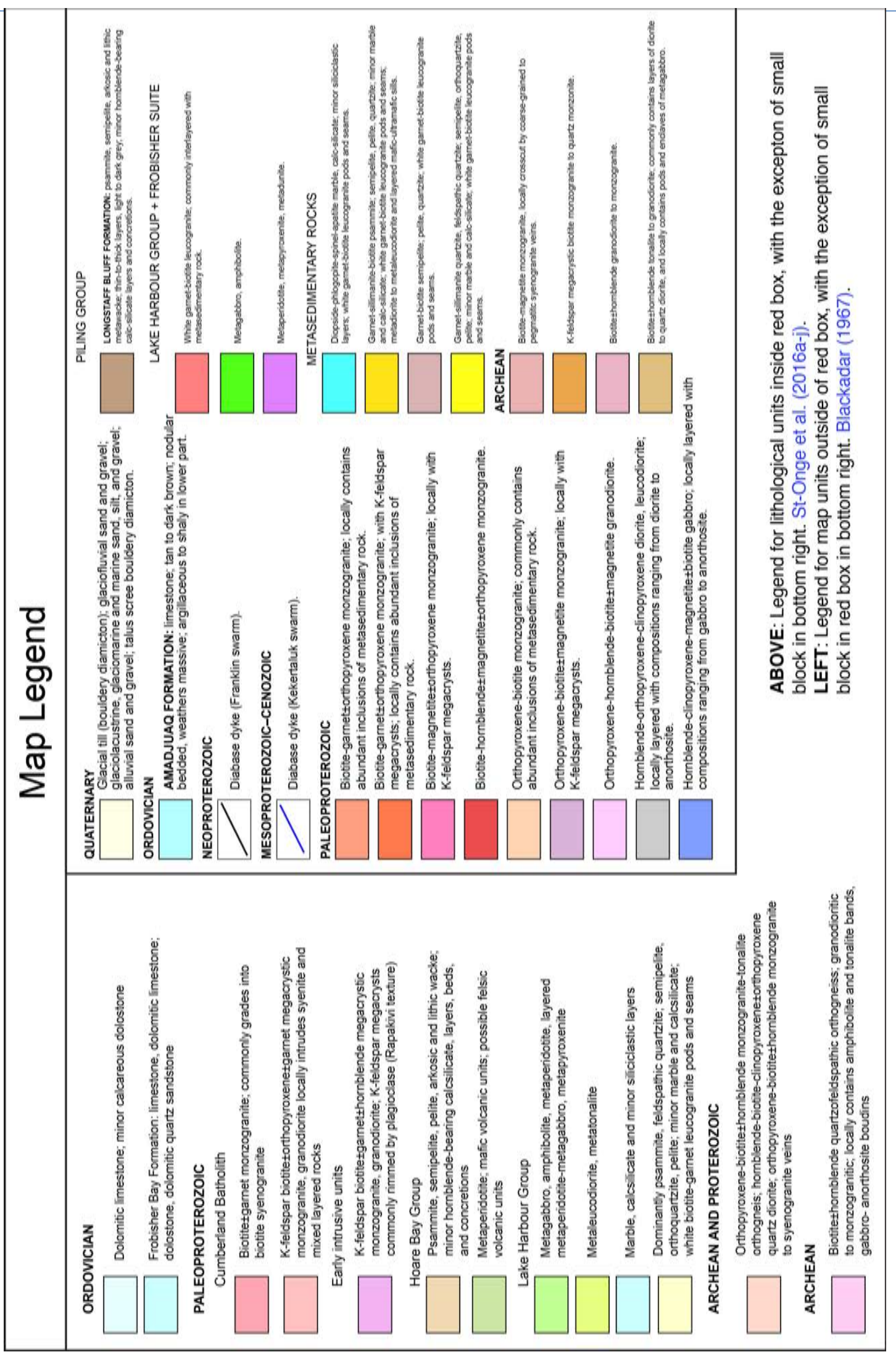


Figure 3.10: Concordant intrusive contact between ultramafic sill (14SAB-L003) and orthoquartzite host rock, Meta Incognita Peninsula, Baffin Island, Nunavut; hammer is $75 \mathrm{~cm}$ in length. 


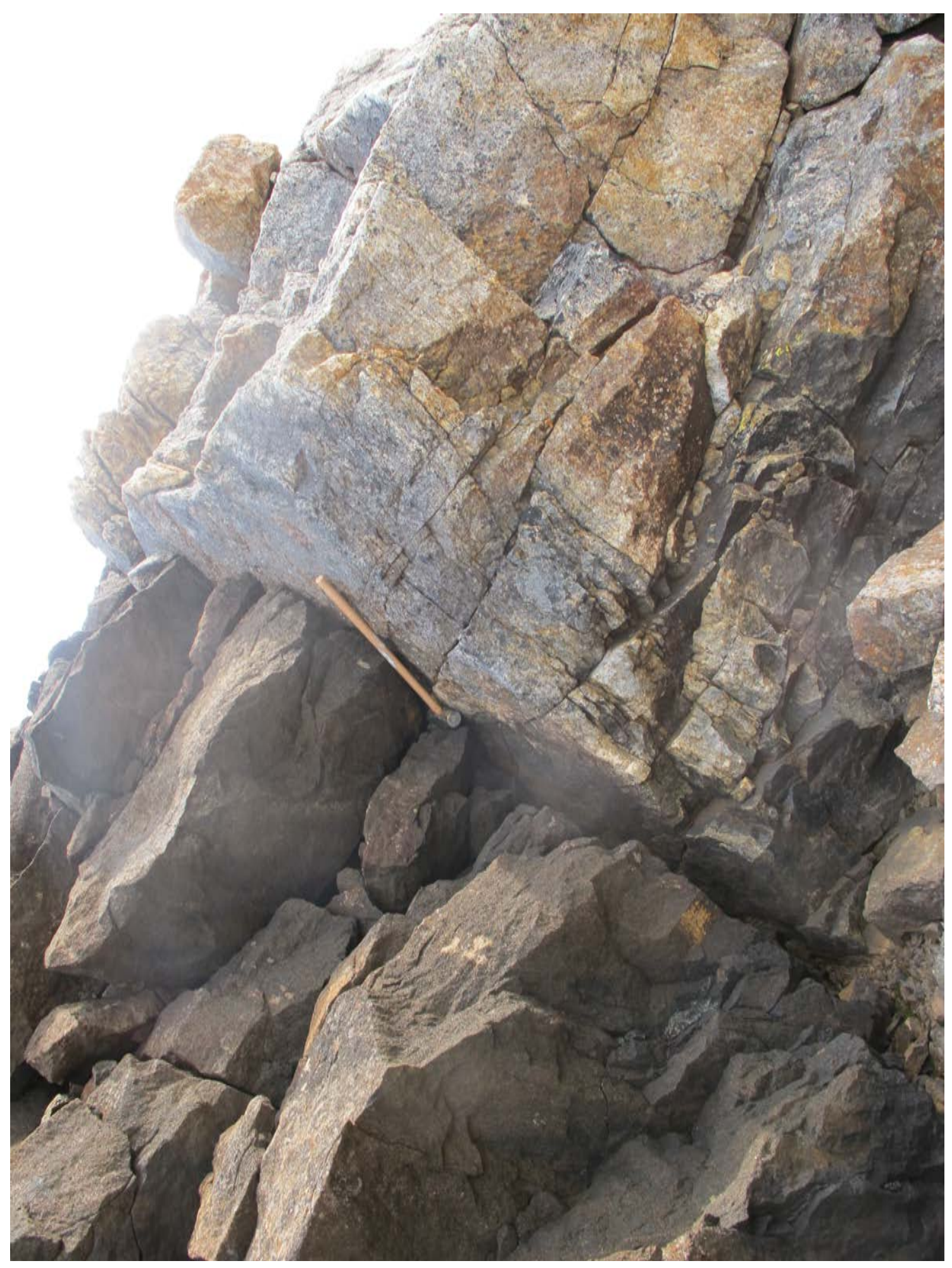


Figure 3.11: Basic bedrock map illustrating the morphology of sills from Meta Incognita Peninsula, Baffin Island, Nunavut; appearing elongate to ellipsoid or annular in shape. This is a result of the $D_{3}$ and $D_{4}$ folding that is responsible for generating interference patterns within the metasedimentary units of the Lake Harbour Group (St-Onge et al., 2015f). Coordinates at image centre are: Lat: $63^{\circ} 20^{\prime} 38.88^{\prime \prime} \mathrm{N}$; Long: $70^{\circ} 21^{\prime} 42.24$ 'W (coordinates obtained through Google Earth). 


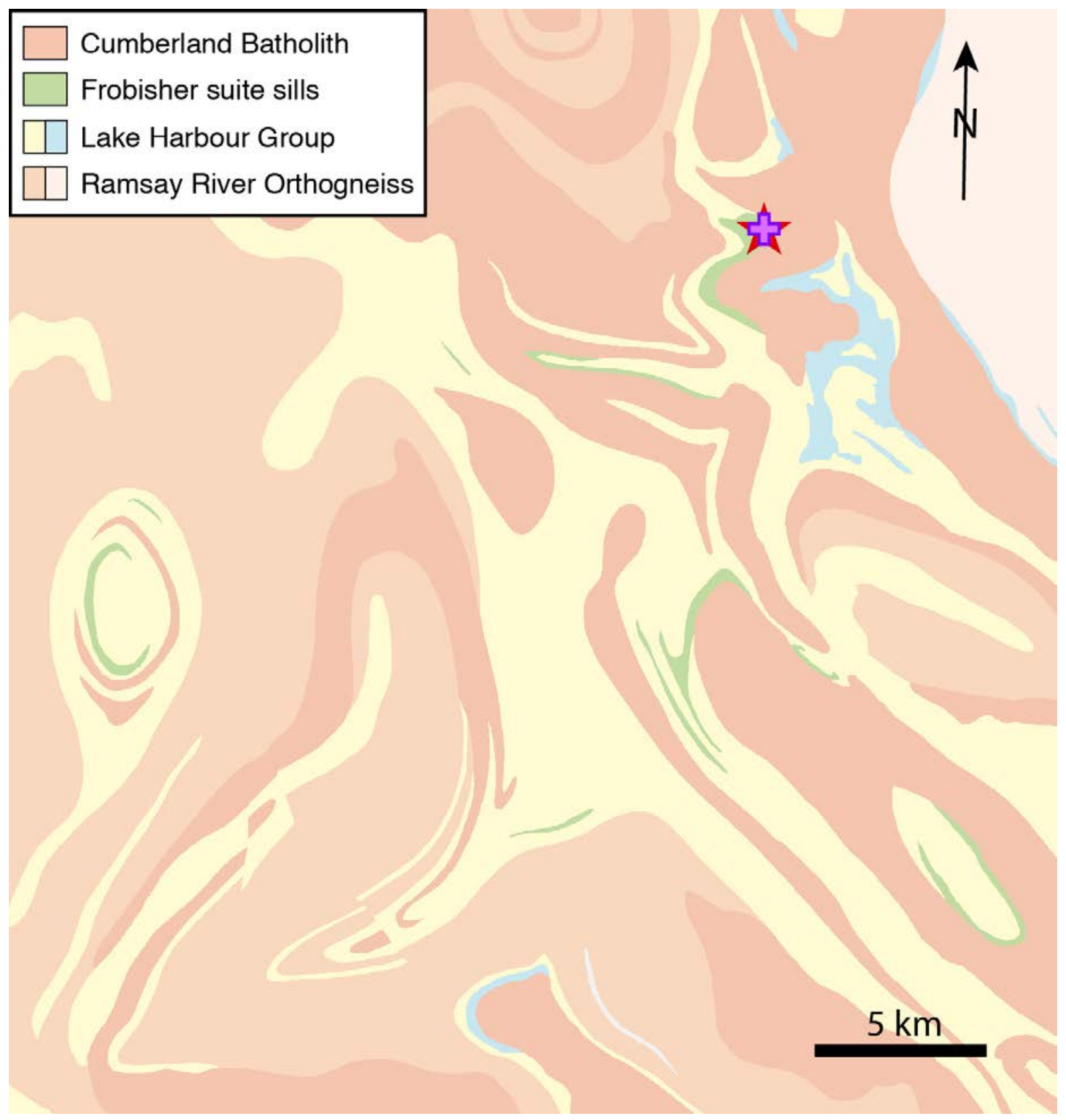


Figure 3.12a-e: Geochronology diagrams for a leucogabbroic sample (14SABL017A) collected from a mafic-ultramafic sill on Meta Incognita Peninsula, Baffin Island, Nunavut: a) transmitted light photomicrograph of anhedral zircon grains from 14SAB-L017A; b) transmitted light photomicrograph of prismatic zircon grains from 14SABL017A; c), d) cathodoluminescence images of zircon grains prior to SHRIMP analysis. White scale bar is $100 \mu \mathrm{m}$; e) Concordia diagram of U$\mathrm{Pb}$ sensitive high-resolution ion microprobe (SHRIMP) results from 14SABL017A. Ellipses are plotted at the $2 \sigma$ confidence level, colour was selected to match the coding of the traceelement signature of the sample, white dashed box delineates the outline of the isotope dilution-thermal ionization mass spectrometry (ID-TIMS) concordia diagram. Inset: Concordia diagram of IDTIMS results from 14SAB-L017A. Ellipses are plotted at the $2 \sigma$ confidence level. After Liikane et al., 2015. 

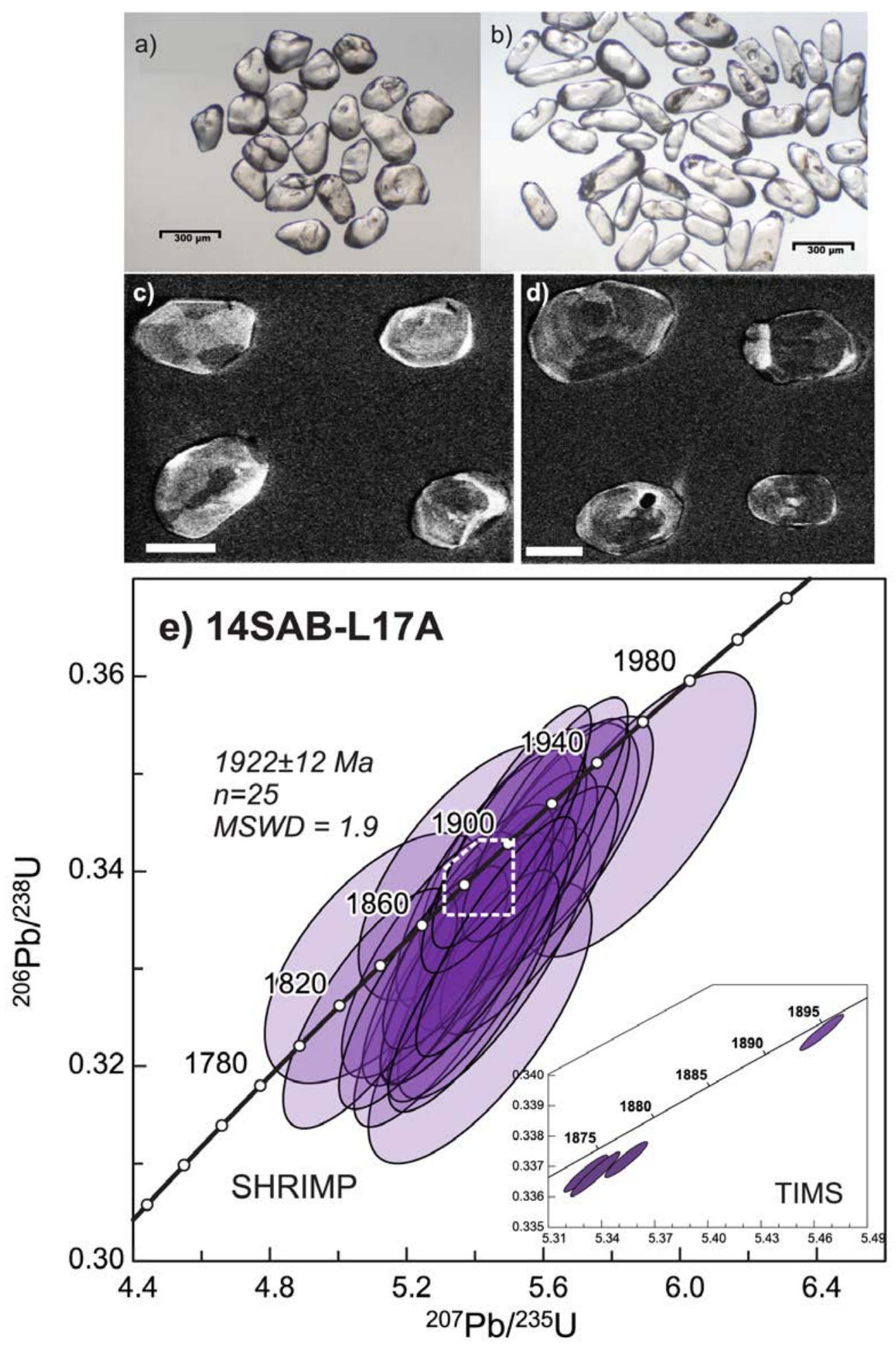
Figure 3.13a-f: a-b) Layered metagabbro (15SAB-L080A), Hall Peninsula, Baffin Island (from Liikane et al., 2015). Rhythmic layering is a result of differences in the modal abundances in plagioclase, clinopyroxene and hornblende; hammer is $75 \mathrm{~cm}$ and $35 \mathrm{~cm}$ in length on the left and right, respectively. c-d) Layered metaperidotite (15SAB-L077A), Hall Peninsula, Baffin Island (from Liikane et al., 2015). Rhythmic layering is a result of differences in the modal abundances of clinopyroxene, orthopyroxene and olivine; hammer is $35 \mathrm{~cm}$ in length. e-f) Basal metapyroxenite (15SAB-L076A), Hall Peninsula, Baffin Island (from Liikane et al., 2015); hammer is $75 \mathrm{~cm}$ in length. 


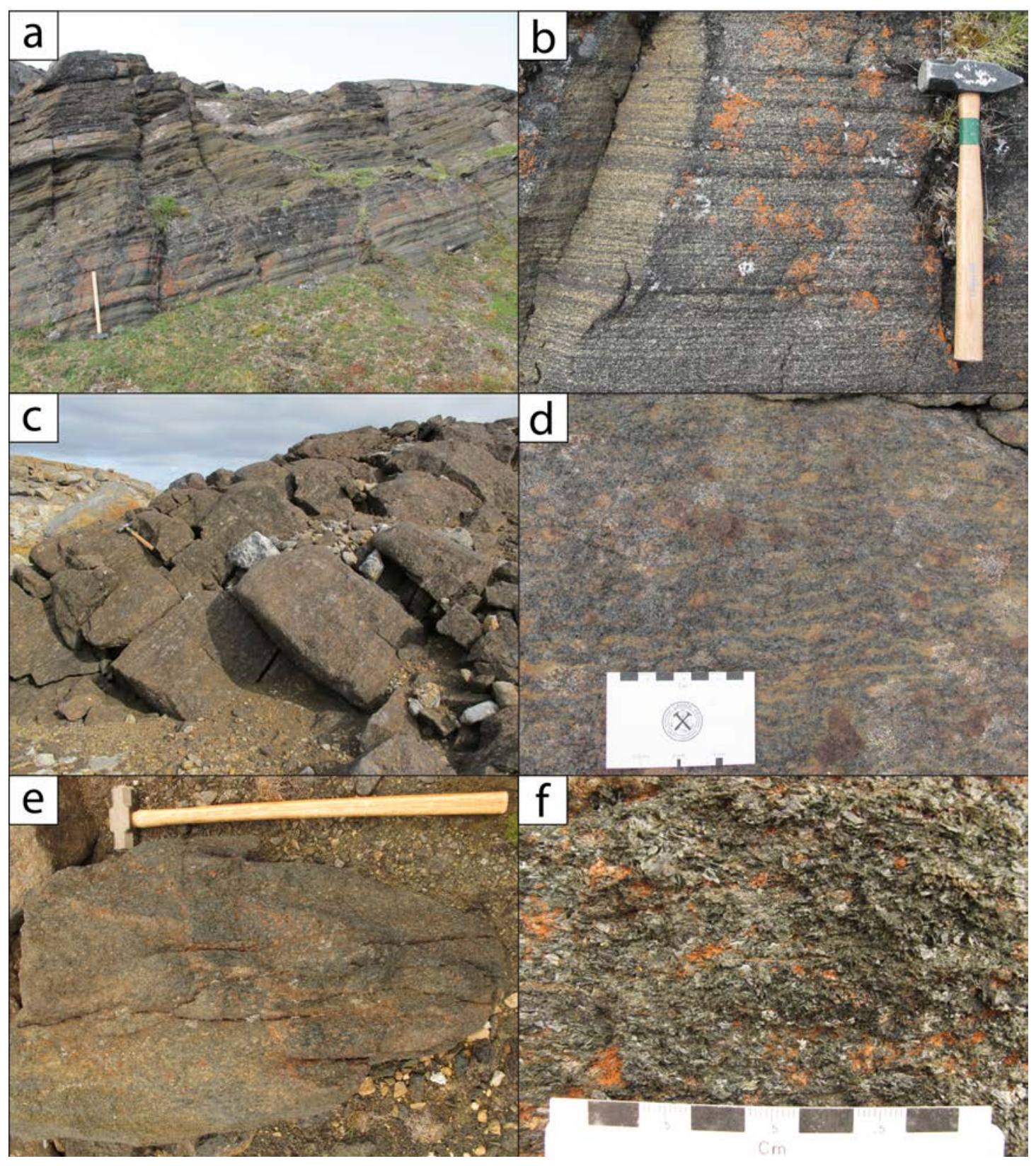


Chapter 4 - Methods 


\subsection{Fieldwork and Sample Collection}

This M.Sc. thesis was one of the activities undertaken as part of the Geomapping for Energy and Minerals (GEM) program, led by Natural Resources Canada (NRCan) in conjunction with the Nunavut Geoscience Office (CNGO), in an effort to complete the regional bedrock mapping for southern Baffin Island, Nunavut (Weller, et al., 2015). The primary objective of GEM is to "unlock the mineral and energy potential of the north" (Natural Resources Canada, 2016), and our contribution to this goal is the compilation and publication of thirteen new geological maps of southern Baffin Island, along with their lithostratigraphic units, boundaries and structures. The synthesis provided by the new geological maps and related research, including this study, has contributed to an increased understanding and better constrained tectonic history of Baffin Island.

Fieldwork was carried out over two consecutive field seasons during the summers of 2014 and 2015. The mapping and sample collection of Meta Incognita Peninsula took place between July 15th and August 15th, 2014, covering all or parts of NTS maps 025G, I, J, K, N, \& O (Liikane et al., 2015; StOnge et al., 2015). The mapping and sample collection on the western Hall Peninsula took place between June 21st and August 18th, 2015, covering all or parts of NTS maps 026B, C, F, G, J, \& K (Liikane et al., 2015; St-Onge et al., 2015). Collectively, the bedrock mapping expeditions involved participants from Nunavut Arctic College, Aboriginal Affairs and Northern Development Canada, the University of Ottawa, Carleton University (myself) and Oxford University. 


\subsubsection{Regional Sampling}

Samples of the Frobisher suite sills were collected throughout the two summers of fieldwork, via $10-15 \mathrm{~km}$ foot traverses and targeted sill-sampling excursions via helicopter. Over one hundred sills were documented over an area of $\sim 130,000 \mathrm{~km}^{2}$ (Figures $3.8 \& 3.9$ ), and 80 fist-size, or larger, representative samples collected. Almost all of the samples used in this study were collected in situ, and taken from outcrops exposing the freshest and least altered rock. In a few situations samples were collected from broken rock, due to poor or insufficient outcrop exposure. In such cases, field constraints (size and angularity of blocks, monolithological population) always indicated little transport. In the field, samples were individually wrapped in fabric bags, placed together in steel pails, and transported via cargo plane back to the Geological Survey of Canada (GSC) in Ottawa, Canada.

\subsubsection{Detailed Sampling}

Detailed sampling was conducted across two of the thicker maficultramafic sills. The first is a 470 m-thick, tightly folded sill located near Kimmirut on the southern coast of central Meta Incognita Peninsula (Liikane et al., 2015), and is herein referred to as the Killapait sill (informally named after the nearby traditional Inuit place name; Figure 3.8). The second is a $230 \mathrm{~m}$-thick, folded, boudinaged, and overturned sill from northern Hall Peninsula (referred to as the "northern" sill in Steenkamp et al., 2014 and Liikane et al., 2015), and is herein informally named the Chidliak sill (based on its proximity to Chidliak Bay). 


\subsection{Sample Selection and Preparation}

Mafic and ultramafic samples that were collected during the two field seasons were sorted and those from mafic to ultramafic units, hosted in Lake Harbour Group metasedimentary rocks, were selected for this study (total of 80 samples). The collection includes samples from 31 sills across southern Baffin Island; 15 sills from Meta Incognita Peninsula (Figure 3.8), and 16 sills from western Hall Peninsula (Figure 3.9). Every sample processed in a rock preparation lab (both at Carleton University and the GSC), where a fist-sized portion was removed using a circular saw with a segmented diamond-encrusted (in soft metal) steel saw blade. The fist-sized sample was trimmed of weathered surfaces, ensuring scuff marks left from the blade were kept to a minimum. From each remaining representative sample, two slabs and a thin section puck were produced. The slabs were cut to a $\sim 1 \mathrm{~cm}$ thickness using the circular saw. One slab was kept for the sample archive and the other was used to produce the thin section puck. The thin section pucks were cut using a trim saw to the approximate dimensions $27 \mathrm{~mm} \times 46 \mathrm{~mm}$.

The fist-sized trimmed samples were inserted into labelled plastic sample bags, neatly packed into steel pails, and sent away to ALS Chemex for wholerock geochemical analysis. Sample bags were labelled twice and an additional label was placed in each bag as a precaution. The thin section pucks were marked with an " $X$ " on one side, indicating the "bad" side or the side not to be made into a thin section. Thin section pucks were then placed into separate small 
labelled envelopes, packed in a cardboard box (in alphanumerical order), and sent to Vancouver Petrographics to be made into polished thin sections.

Rock samples submitted to ALS Minerals' Laboratory in Val D'or, Quebec, for sample preparation were first subjected to fine crushing to $70 \%$ passing 2 $\mathrm{mm}$, using steel jaw crushers. This finely crushed material was then divided up using a riffle splitter, producing representative sub-samples. Each single representative sub-sample (up to $250 \mathrm{~g}$ ) was then pulverized to $85 \%$ passing 75 $\mu \mathrm{m}$, using a "ring and puck" style grinding mill, either composed of low-chrome steel (PUL-31; used for samples collected in 2015) or ceramic (PUL-41; used for samples collected in 2014). For quality control, one out of every 50 samples crushed or pulverized was selected at random for routine pulp QC tests (CRUQC; PUL-QC). For these routine pulps tests, $85 \%$ of the pulp must pass through a $75 \mu \mathrm{m}$ screen, as per pulverization specifications. Following sample preparation, the pulps were sent out to ALS Minerals' Vancouver laboratory in British Columbia for lithogeochemical analysis. Following a preliminary evaluation of the bulk-rock geochemical data, a subset of these samples were selected for electron microprobe (EMP) mineral chemistry analyses, scanning electron microscopy (SEM) and Sm-Nd isotope geochemistry; all conducted at Carleton University.

\subsection{Petrography}

Thin section pucks were sent to Vancouver Petrographics where polished thin sections $(30 \mu \mathrm{m})$ were produced, however, a subset (i.e. 20$)$ were either too 
thick, or too thin. This caused some difficulty in mineral identification under XPL, but minerals and their textures could be identified through a combination of PPL and cautious XPL work. Polished thin sections were examined at Carleton University with a Nikon Optiphot Pol petrographic microscope under plane polarized, cross polarized, and reflected light (PPL, XPL, and RL, respectively) on 4x, 10x, and 20x magnification. PPL and XPL were used to document the silicate phases of the samples, and RL was used to observe oxide and sulphide mineral phases.

\subsection{Photography and Microphotography}

Microphotographs in PPL, XPL and RL were taken at Carleton University using a ProgRes SpeedXTcore5 petrographic microscope camera and software. Field photographs were captured during the 2014 and 2015 mapping programs by various members of the bedrock mapping team. These images were taken on Canon PowerShot G11 cameras on various camera settings. Photographs of thin section pucks and slabs were taken on a Canon compact camera.

High-resolution whole thin section scans were acquired from the GSC's Epson Perfection V700 Photo Scanner in both PPL and XPL at 2400 dots per inch (dpi). These images were printed in colour and bound, for reference while probing and completing petrography.

In conjunction with electron beam analyses on Carleton University's Cameca Camebax, digital BSE (back-scattered electron) images were collected in areas where EMPA mineral chemical analyses were obtained. These images 
were collected with an Electron Optic Services digital imaging system at $512 \mathrm{x}$ 512 pixel resolution with a Lamont 4 element solid state BSE detector and BSE Quad Summing Amplifier. BSE images were interfaced to a 4Pi Analysis Inc. digital imaging and EDX x-ray system, and Power Macintosh computer running NIH image and NIST desktop spectrum analyzer programs.

BSE imaging was also conducted on mounted zircon grains (discussed in section 3.5.4) prior to $\mathrm{U}-\mathrm{Pb}$ geochronological analysis on the sensitive high resolution ion microprobe (SHRIMP) at the GSC. This form of imaging allowed for the internal features of the zircons to be examined (e.g. zoning, structures, alteration). The imaging was conducted on a Zeiss $\mathrm{EVO}^{\circledR} 50$ scanning electron microscope (SEM) at the GSC.

\subsection{Analytical Methods}

Rock powders prepared by ALS Chemex were used for both whole-rock and $\mathrm{Sm}-\mathrm{Nd}$ isotope geochemistry, and polished thin sections were used for mineral chemistry via EMPA. All data were processed using a combination of Microsoft Excel and Igpet (2012; by Terrasoft). The former was used for calculations and data organization, while both were used for plotting major- and trace-element geochemical data.

\subsubsection{Whole Rock Geochemistry}


Eighty samples were analysed at ALS Chemex in Vancouver, British Columbia, for bulk-rock geochemical analysis by X-ray fluorescence (XRF) and mass spectrometry techniques. A minimum of one standard (Certified Reference Material) was analyzed using each method described below, to determine the precision and accuracy of results.

Major oxide determinations were undertaken using XRF (code MEXRF06), whereby each sample $(0.9 \mathrm{~g})$ was calcinated or ignited and then added to a $9.0 \mathrm{~g}$ solution of lithium borate flux $\left(50 \% \mathrm{Li}_{2} \mathrm{~B}_{4} \mathrm{O}_{7}-50 \% \mathrm{LiBO}_{2} ;\right.$ WEI-GRA06). This solution was mixed thoroughly and fused in an auto fluxer between 1050 $1100^{\circ} \mathrm{C}$ and then quenched. The flat glass disc was then analyzed by XRF. This method involves the glass sample disc being analyzed by an XRF spectrometer, where an X-ray incident beam strikes the glass disc, exciting the atoms within the sample and causes them to release energy spectra specific to each element contained within the sample. The intensities of each individual spectrum are proportional to their elemental abundance within the sample. These intensities are converted to oxide wt.\% by the instrument's software and reported. Table 4.1a contains a list of the major oxides determined, along with their units and lower detection limits. All iron was reported as $\mathrm{Fe}_{2} \mathrm{O}_{3}$, but was converted to $\mathrm{FeO}$, when necessary, using the conversion equation:

FeO'wt. \% $=\mathrm{Fe}_{2} \mathrm{O}_{3}{ }^{\top}$ wt. \% $/ 1.1111$ (weight ratio between $\mathrm{Fe}_{2} \mathrm{O}_{3}$ and $\mathrm{FeO}$ ) 
Loss on ignition (LOI) was obtained through method OA-GRA05, whereby $1.0 \mathrm{~g}$ of prepared sample was placed in a furnace at $1000^{\circ} \mathrm{C}$ for an hour, cooled and then weighed. The difference in weight gave the weight percent loss on ignition. Table 4.1a contains the units and lower detection limits for LOI analyses.

Data for the 30 trace element package, including the rare-earth elements (REEs), were obtained through Inductively Coupled Plasma - Mass Spectrometry (ICP-MS) method ME-MS81, which involved the addition of a prepared $0.200 \mathrm{~g}$ sample to $0.90 \mathrm{~g}$ of lithium metaborate flux. The solution was then mixed and fused in a furnace at $1000^{\circ} \mathrm{C}$. Following fusion, the resulting melt was cooled, dissolved in a $100 \mathrm{~mL}$ solution of $4 \% \mathrm{HNO}_{3}+2 \% \mathrm{HCl}_{3}$, and then analyzed by ICPMS. In ICP-MS, the sample is subjected to argon plasma that dissociates the molecules and creates charged atoms. The ions then move through a magnetic field, which separates them based on mass, and then the ions strike the precisely positioned detection plates. Upon impact, their energy produces an electric pulse that is amplified and then the intensity is compared with a standard curve to determine its concentration. Table $4.1 \mathrm{c}$ contains a list of the trace elements analyzed, along with their units and lower detection limits. Ti concentrations in ppm were not determined with the rest of the trace elements, and were instead calculated from the $\mathrm{TiO}_{2}$ wt.\% concentrations obtained through XRF, using the equation:

$\mathrm{Ti}(\mathrm{ppm})=\mathrm{TiO}_{2}$ wt. $\% \times 0.5993 \%\left(\right.$ percent of $\mathrm{Ti}$ in $\left.\mathrm{TiO}_{2}\right) \times 10000$ 
Base metal values were obtained using the Inductively Coupled Plasma Atomic Emission spectroscopy (ICP-AES) method ME-MS81, where each sample is dissolved using four acid digestion (ME-4ACD81) and analyzed on an ICP-AES. A four acid digestion is typically preferred when dealing with more resistive mineralization (i.e. those associated with $\mathrm{Ni}$ and $\mathrm{Co}$ ). Table $4.1 \mathrm{~d}$ contains a list of the base metals analyzed, along with their units and lower detection limits.

Total sulphur (S) and carbon (C) was measured using the Leco sulphur analyzer (S-IR08). In this method, the sample $(0.01-0.1 \mathrm{~g})$ is heated in an induction furnace to a temperature of approximately $1350^{\circ} \mathrm{C}$, while passing a stream of oxygen through the sample. The IR detection system then measures the sulphur dioxide released from the sample and provides the total sulphur value. Table $4.1 \mathrm{~b}$ contains a list of the units and lower detection limits for $\mathrm{S}$ and $\mathrm{C}$ analyses.

Platinum $(\mathrm{Pt})$, palladium $(\mathrm{Pd})$ and gold $(\mathrm{Au})$ analysis were obtained using standard lead oxide collection fire assay method PGM-ICP23 (for rocks with intermediate levels of precious metal mineralization), finishing with ICP-AES. In this method, $30 \mathrm{~g}$ of sample is fused with a mixture of lead oxide, sodium carbonate, borax and silica, inquarted (i.e. gold content in alloy was reduced to $25 \%)$ with $6 \mathrm{mg}$ of gold-free silver and then cupelled to yield a precious metal bead. The bead was then digested at high power by microwave in dilute nitric acid. The solution is cooled, hydrochloric acid is added and then the solution digested at half power by microwave. The digested solution was then cooled, 
diluted with hydrochloric acid, homogenized, and then analyzed for $\mathrm{Au}, \mathrm{Pt}$ and $\mathrm{Pd}$ by ICP-MS analysis. Table 4.1e contains a list of the units and lower detection limits for $\mathrm{Pt}, \mathrm{Pd}$, and $\mathrm{Au}$ analyses.

Each of ALS Minerals' laboratories in North America are registered to ISO 9001:2008 for the "provision of assay and geochemical analytical services" by QMI Quality Registrars. The North America analytical laboratories are also accredited by the Standards Council of Canada (SCC) for specific tests listed in their Scope of Accreditation No. 579, http://palcan.scc.c-a/specs/pdf/677_e.pdf. This accreditation is based on ISO 17025:2005 international standards and involves extensive site audits and performance evaluations. Detailed descriptions of all the analytical methods can be found on ALS Global's website through the search bar using the method code (e.g. PGM-ICP23).

A total of six different standards were used throughout the two batches of geochemical analyses (2014 and 2015 datasets): WGB-1, TDB-1, UMT-1, WPR-1, WMG-1 and 10-LT-05. These samples were given southern Baffin sample code names from 14SAB-Z001 to 14SAB-Z008 and from 15SAB-Z001 to 15SAB-Z006. All standards, except for 10-LT-05, are certified reference materials from the Canadian Certified Reference Materials Project (CCRMP).

All standards show that the geochemical data for major and trace elements produced by ALS Chemex are accurate, as they generally fall within a 95\% confidence interval of the certified (and provisional) values outlined by the Canadian Certified Reference Materials Project (CCRMP; see Figures 4.1, 4.2, 4.3). Due to the large sample size required for fire assay (minimum of $30 \mathrm{~g}$ ), 
there was insufficient standard powder to analyze for $\mathrm{Au}, \mathrm{Pt}$, and $\mathrm{Pd}$. Consequently, the accuracy and precision of fire assay results could not be verified. All data from standards and submitted samples can be found in Appendices I-III.

\subsubsection{Mineral Geochemistry}

Quantitative mineral analyses were obtained on an automated 4 spectrometer Cameca Camebax MBX electron probe (EMP) at the Earth Sciences Department of Carleton University, under the supervision of Peter Jones. The group of samples $(n=57)$ selected for EMP analyses were the least altered samples from mafic, ultramafic, and layered mafic-ultramafic sills from both field areas, spanning every significant geochemical group, and providing sufficient geographical coverage of the two field areas. Mineral compositional data were also obtained from the mafic-ultramafic Chidliak and Killapait sills. Every mineral phase in each sample analyzed was probed at least once, with the exception of retrograde metamorphic mineral phases (i.e. serpentine, epidote, sericite).

The polished thin sections of samples selected for mineral analyses were evaluated under a Nikon petrographic microscope and areas $\sim 1 \mathrm{~mm}$ in diameter were marked and photographed using the circular petrographic marker and petrographic microscope camera, respectively. These circular areas outlined the locations of subsequent mineral analyses on the EMP. 
Prior to analysis, the polished thin sections were coated with a thin film of carbon in a high-vacuum carbon coater. The carbon-coated thin sections were then placed in a vacuum sample chamber within the EMP and selected mineral phases were bombarded with an accelerated and focused electron beam. When the electron beam strikes the surface of the mineral being analyzed, the incident electrons collide inelastically with electrons in the inner shells of atoms within the mineral. The inner-shell electrons are ejected, creating a vacancy, and electrons from a higher orbital shell drop down into their place, shedding energy in the form of an X-ray; each quantized X-ray energy is characteristic of a particular element. The raw X-ray data is then converted to elemental weight $\%$ by the Cameca PAP matrix correction program. Additional calculations undertaken produce cation proportions and mineral formulae.

Operating conditions for the wavelength dispersive $\mathrm{x}$-ray analysis method (WDX) were: focused ( $2 \mu \mathrm{m}$ diameter) beam; $20 \mathrm{kv}$ accelerating potential and a beam current of 20 nano-amperes $(\mathrm{nA})$ for silicates and oxides, and $20 \mathrm{kv}$ and 30 nA for sulfide minerals. Beam-sensitive minerals such as feldspar and mica were analyzed using a rastered electron beam of from $5 \times 5$ to $10 \times 10$ microns in size. Peak-counting times for analyzed elements were: 15-40 seconds or 40,000 accumulated counts. Background positions were chosen carefully to avoid interferences from adjacent elemental peaks. Background measurements were made at $50 \%$ peak counting time on each side of the analyzed peak. Analyses are accurate to $1-2 \%$ relative for major elements (>10 wt \%) and $3-10 \%$ relative 
for minor elements ( $<10 w t \%$ to $>0.5 w t \%)$. As detection limit is approached $(<0.1$ wt \%), relative errors approach $100 \%$.

A group of well-characterized natural and synthetic minerals and compounds were used as calibration standards for EMP mineralogical analysis. The elements calibrated prior to analyses are listed in Table 4.2, along with the X-ray lines and mineral standards used.

\subsubsection{Isotope Geochemistry}

Following the preliminary characterization of the Frobisher suite using bulk-rock geochemistry, a batch of 12 samples was selected for Sm-Nd isotope geochemical analysis. Sample were selected such that all eight geochemical groups (groups defined in Chapter 7) were covered, and samples were chosen from mafic, ultramafic, and mafic-ultramafic sills in both field areas; including the one that had been dated. A subsequent batch of 12 samples was selected based on the results from the first batch of analyses obtained. Preparation and analyses were completed at the Isotope Geochemistry and Geochronology Research Centre (IGGRC) at Carleton University. The Sm-Nd isotope data was acquired via a 9-cup ThermoFinnigan Triton $\mathrm{TI}$ multicollector thermal ionization mass spectrometer (MC-TIMS).

Silicate rock powders, were weighed, transferred into individual $15 \mathrm{~mL}$

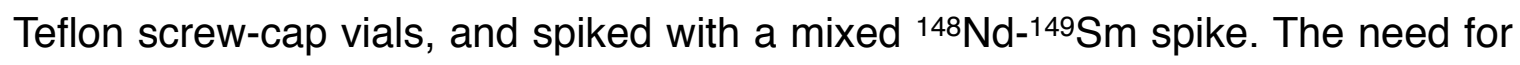
a spike is due to the Paleoproterozoic age of the samples, and the $\mathrm{Nd}$ and $\mathrm{Sm}$ concentrations cannot be precisely determined without having added a known 
concentration of ${ }^{148} \mathrm{Nd}-{ }^{149} \mathrm{Sm}$ spike. The precise sample powder weight (between 30 and $200 \mathrm{mg}$ ) and spike weight for each sample were calculated on an Excel spreadsheet based on the measured $\mathrm{Nd}$ concentration (in ppm) obtained from the ICP-MS analysis conducted by ALS Chemex. The spiked sample powders were dissolved in an acidic solution (2-3 $\mathrm{mL})$ of $\sim 29 \mathrm{M} \mathrm{HF}$ and 16 $\mathrm{M} \mathrm{HNO}_{3}$. The samples were then dried down on the hotplate before being redissolved with $8 \mathrm{M} \mathrm{HNO}_{3}$ and $6 \mathrm{M} \mathrm{HCl}$, sequentially. The dried residue of samples were dissolved in $2.5 \mathrm{M} \mathrm{HCl}$ and subsequently loaded into 14-mL BioRad borosilicate glass chromatography columns containing $3.0 \mathrm{~mL}$ of Dowex AG50W-X8 cation resin. Columns were then washed with $23 \mathrm{~mL}$ of $2.5 \mathrm{M} \mathrm{HCl}$ before the rare earth elements (REE) were eluted using $9 \mathrm{~mL}$ of $6 \mathrm{M} \mathrm{HCl}$. The REE fractions were dissolved in $0.26 \mathrm{M} \mathrm{HCl}$ and then loaded onto Eichrom $\mathrm{Ln}$ Resin chromatographic columns containing Teflon powder coated with HDEHP [di(2-ethylhexyl) orthophosphoric acid; Richard et al., 1976). Nd was eluted using $4.5 \mathrm{~mL}$ of $0.26 \mathrm{M} \mathrm{HCl}$, followed by eluting of Sm with $4 \mathrm{~mL}$ of $0.5 \mathrm{M} \mathrm{HCl}$. Both $\mathrm{Sm}$ and $\mathrm{Nd}$ vials were then dried down.

The samples were loaded with $2 \mu \mathrm{L}$ of $\mathrm{H}_{3} \mathrm{PO}_{4}$ in a double rhenium filament assembly. Samples with a higher Nd concentration were initially dissolved in $4 \mu \mathrm{L}$ of $\mathrm{H}_{3} \mathrm{PO}_{4}$ prior to loading, leaving $2 \mu \mathrm{L}$ behind in the vial for use as a re-run in the event of a failed initial run. The sample solutions were then partially dried by progressively increasing the current passing through the filament from 0.0 to 1.9 amperes (A), in 0.2 A stages. As the filaments heated up, they began to smoke (at $\sim 1.7 \mathrm{~A}$ ). After $\sim 30 \mathrm{~s}$ of smoking, the current was cut and the sample and 
ionization filaments were loaded on a 21-position sample wheel. The sample and ionization filaments were then carefully aligned and a metal cover was clipped on top of them. Finally, the sample wheel was loaded into the TIMS sample chamber.

The isotope ratios were measured using the ThermoFinnigan Triton $\mathrm{TI}$ MC-TIMS. The MC-TIMS operates by utilizing the thermal ionization effect, whereby the sample is heated to a point where the atoms ionize. These ions are then focused by electrostatic lenses, and the resulting beam passes through a magnet field which splits the ions into a number of beams based on their mass/ charge ratios. The mass-resolved beam is directed into collectors, which convert the ion beam into voltage. Through the comparison of voltages corresponding to specific ions, precise isotope ratios can be determined.

lons were ionized at temperatures between 1600 and $1800^{\circ} \mathrm{C}$. Isotope ratios were normalized to ${ }^{146} \mathrm{Nd} /{ }^{144} \mathrm{Nd}=0.72190$. IGGRC's in-house $\mathrm{Nd}$ standard was routinely measured with ${ }^{143} \mathrm{Nd} / 144 \mathrm{Nd}=0.511831 \pm 0.000006(1 \sigma)$ over a period of three years; this value is equivalent to ${ }^{143} \mathrm{Nd} / 144 \mathrm{Nd}=0.511860$ for the $\mathrm{La}$ Jolla Nd standard. Sm and Nd concentrations were measured precisely within $1 \%$, while ${ }^{147} \mathrm{Sm} / 144 \mathrm{Nd}$ ratios are reproducible to $0.5 \%$. Analyses of the USGS

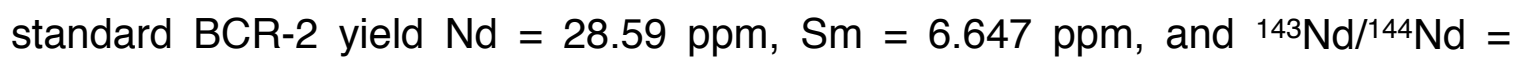
$0.512644 \pm 0.000006(1 \sigma, n=4)$, consistent with accepted values. Total procedural blanks for $\mathrm{Nd}$ were consistently less than 50 picograms. Isotopic data is located in Appendix II. 
Additional data including Sm and Nd concentrations, epsilon $\mathrm{Nd}$ values, initial $\mathrm{Nd}$ isotopic ratios, and depleted mantle model ages were calculated using an Excel program written by Drs. George Tilton and Brian Cousens of Carleton University. All samples were corrected for post-crystallization decay using the minimum crystallization age of $1900 \mathrm{Ma}$; an age obtained through the $\mathrm{U}-\mathrm{Pb}$ geochronological dating of a leuco-gabbroic sample from the Killapait layered mafic-ultramafic sill (Liikane et al., 2015). Initial ${ }^{143} \mathrm{Nd} /{ }^{144} \mathrm{Nd}$ ratios were calculated by the rearranging of equation 3.1.

$\left(\frac{{ }^{143} N d}{{ }^{144} N d}\right)_{\text {sample }}=\left(\frac{{ }^{143} N d}{{ }^{144} N d}\right)_{\text {initial }}+\left(\frac{{ }^{147} S m}{{ }^{144} N d}\right)_{\text {sample }} \times\left(e^{\lambda t}-1\right)$

where: $\lambda=6.54^{*} 10^{-12} \mathrm{y}^{-1}$

Epsilon-Nd values at time $\mathrm{T}$ were calculated using equation 3.2, and indicate whether rocks were derived from either a depleted or enriched mantle source (i.e. depleted or enriched in ${ }^{143} \mathrm{Nd}$ relative to $\mathrm{CHUR}$, respectively; Faure and Mensing, 2005). The ${ }^{143} \mathrm{Nd} /{ }^{144} \mathrm{Nd}$ values were corrected for fractionation using ${ }^{146} \mathrm{Nd} /{ }^{144} \mathrm{Nd}=0.72190$.

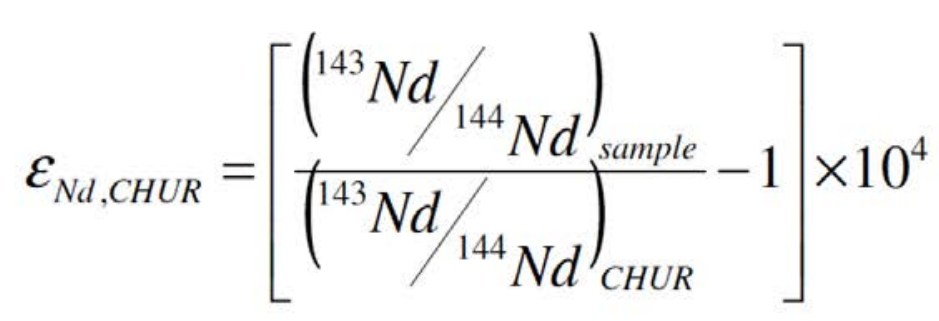


where: CHUR = Chondrite Uniform Reservoir

$T=$ time of formation of the rock

The DePaolo depleted mantle model ages were calculated using equation 3.3, and the assumed upper mantle ${ }^{147} \mathrm{Sm} /{ }^{144} \mathrm{Nd}$ ratio of 0.214 and ${ }^{143} \mathrm{Nd} /{ }^{144} \mathrm{Nd}$ ratio of 0.513115 .

$$
T_{D M}^{N d}=\frac{1}{\lambda} \ln \left[\frac{\left({ }^{143} N d /{ }^{144} N d\right)_{\text {sample,today }}-\left({ }^{143} N d /{ }^{144} N d\right)_{D M, \text { today }}}{\left({ }^{147} \mathrm{Sm} /{ }^{144} N d\right)_{\text {sample,today }}-\left({ }^{147} \mathrm{Sm} /{ }^{144} \mathrm{Nd}\right)_{D, \text {,today }}}+1\right]
$$

Quality data was obtained from all samples except for one (15SABL076A01). The sample 15SAB-L076A01 failed to produce accurate data due to an insufficient amount of $\mathrm{Nd}$ on the filament; the $\mathrm{Nd}$ was exhausted during heating, before analysis could commence. This is believed to have resulted from a combination of issues. The first issue is that this particular sample has a very low Nd concentration (1.2 ppm). The second issue is that during sample dissolution in hydrofluoric acid $(\mathrm{HF})$ the formation of calcium fluoride $\left(\mathrm{CaF}_{2}\right)$, which is known to accommodate $\mathrm{Nd}$ in its structure, likely left the remaining solution depleted in $\mathrm{Nd}$. The result was a sample with too low a concentration to allow for proper analysis.

\subsection{Potential Error in Geochemical Analyses}


Geochemical error is an important issue when it comes to evaluating the accuracy of geochemical data. If the proper precautions aren't taken to minimize potential causes of error, inaccurate data may be produced and this may further lead to false results and interpretations of a geochemical dataset. Potential sources of error commonly include equipment error, human error (i.e. mislabelling samples, sample contamination, etc.), sample heterogeneity, redistribution of chemical components during metamorphism/alteration, etc., and can lead to misidentification, misinterpretation, and anomalous values. All of these sources of error can occur beginning at the time of sample collection.

In the field, there exists the possibility that the samples collected may not be geochemically representative of the sills from which they came. Even while textural differences throughout a sill are visually evident, other geochemical variations elusive to the naked eye often exist in layered intrusions; namely the presence of cryptic layering (e.g. the Eastern Lobe of the Bushveld Complex of South Africa; Wager and Brown, 1968). Unfortunately, there is no way to identify these variations in the field without a detailed geochemical profile of an intrusion. In light of this, much care was taken throughout the sampling process, but one cannot be fully certain of the homogeneity of any sill sampled under these conditions. Based on the "well-behaved" trace element patterns within each geochemical group, it appears that sampling error was not a significant issue. This may partial be to the consistently large samples that were collected where/ when possible. 


\section{Prior to geochemical analysis, samples were divided into subsets}

numerous times as they progressed through the sample preparation process. After every spilt, there is a possibly that the specific subset of sample material chosen to move to the next stage of sample preparation (and eventually on to geochemical analysis) may not be representative of the original sample collected. Within this sample set specifically, the greatest causes of potential heterogeneity amongst the powdered sample sub-sets are coarse grain-sizes, relict phenocrysts, and $\mathrm{mm}$ - to $\mathrm{cm}$-scale layering within samples. Although unlikely, there was also ample opportunity for samples to be mislabelled as they moved from one form (or vessel) to another during preparation.

Sample contamination is a major source of error in geochemical data. It can occur at any stage, and can occur simply by the sample coming into contact with another surface containing a chemical component of interest (i.e. carbon, iron, chromium, etc.). The main sources of these contaminants are those instruments used in sample collection and preparation, including sledgehammers, saw blades, jaw crushers and "puck-and-ring" style grinding mills. The chrome-steel ring mill used in the 2014 samples does not appear to have affected samples, as suggested by the lack of anomalous Cr values in plots in the geochemistry chapter (Chapter 7). The specific saw blade currently being used at the GSC, where these samples were cut and trimmed, contains "some or all of: $\mathrm{Al}_{2} \mathrm{O}_{3}, \mathrm{Co}, \mathrm{Fe}, \mathrm{Ni}, \mathrm{SiC}, \mathrm{W}, \mathrm{B}_{4} \mathrm{C}, \mathrm{Cu}, \mathrm{Mn}, \mathrm{P}, \mathrm{Ag}, \mathrm{WC}, \mathrm{Cr}, \mathrm{C}, \mathrm{Mo}$, steel" (pers. comm. J. Pinard, 2017). If any of these components were added to the sample, the effects of these components on the geochemical data cannot be recognized, 
as there was no standards subjected to the saw blade (all standards were already in powdered form). However, these saw blades have been used in sample preparation for decades without any significant issues arising with inaccurate data.

During sample preparation, other potential sources of contamination include improper cleaning of equipment, rock dust/powder on preparation surfaces or pails. In the process of collecting REEs, Sm, and $\mathrm{Nd}$ for Sm-Nd for isotope work, contaminants can be introduced from vials or Teflon columns in the form of ions or sample residues. However, this is only likely to occur if lab procedures and methods deviate from accepted practice, or standard cleaning and preparation tasks are overlooked.

All along the way, every effort was made to avoid the possibly of sample contamination prior to submitting the samples to ALS Chemex for crushing, pulverizing and geochemical analysis. Representative samples collected from the field were trimmed of all weathered surfaces and veining. Additionally, large sample-sizes were submitted in the majority of cases, to offset the potential heterogeneity arising from coarser grain sizes.

Instrumental error is also a potential source of invalid data. However, this is typically easier to track and identify versus the contamination that occurs during preparation. However, slight unrecognized changes or fluctuations in machine settings may have occurred during XRF, ICP-MS, and ICP, AES geochemical analyses. However, data obtained from standards indicate that the 
data are accurate. Samples analyzed for Sm-Nd isotopes were also run with standards to assess the functionality of equipment and result validity. 


\section{References}

Faure G. and Mensing T.M. (2005). Isotopes. Principles and Applications, 3rd Edition. John Wiley and Sons, New York. ISBN 0-471-38437-2.

Liikane, D.A., St-Onge, M.R., Kjarsgaard, B.A., Rayner, N.M., Ernst, R.E. and Kastek, N. (2015). Frobisher suite mafic, ultramafic and layered maficultramafic sills, southern Baffin Island, Nunavut; in Summary of Activities 2015, Canada-Nunavut Geoscience Office, p. 21-32.

Richard, P., Shimizu, N. and Allègre, C.J. (1976). $143 \mathrm{Nd} / 146 \mathrm{Nd}$, a natural tracer: an application to oceanic basalts, Earth Planet. Sci. Lett., 31, 269-278.

Stacey, J.S. and Kramers, J.D. (1975). Approximation of Terrestrial Lead Isotope Evolution by a 2-Stage Model. Earth and Planetary Science Letters 26(2): 207-221.

St-Onge, M.R., Rayner, N.M., Steenkamp, H.M. and Skipton, D.R. 2015b: Bedrock mapping of eastern Meta Incognita Peninsula, southern Baffin Island, Nunavut; in Summary of Activities 2014, Canada-Nunavut Geoscience Office, p. 105-118.

Wager, L.R. \& Brown, G.M., 1967. Layered igneous rocks. xv + 588 p., 278 figs., and 13 pls. (half-tone and coloured). Oliver and Boyd, Ltd., Edinburgh.

Weller, O.M., Dyck, B.J., St-Onge, M.R., Rayner, N.M. and Tschirhart, V. 2015: Completing the bedrock mapping of southern Baffin Island, Nunavut: plutonic suites and regional stratigraphy; in Summary of Activities 2015, Canada-Nunavut Geoscience Office, p. 33-48. 
Figure 4.1a-c: Known-value-normalized major oxide data obtained from ALS Chemex for the gabbro standards WGB-1 (a) and WMG-1 (b) in the 2014 dataset, and for WGB-1 (c) in the 2015 dataset. Analyses compared to certified reference values are bold and in a larger font, while analyses compared to provisional reference values are italicized and in a smaller font. 


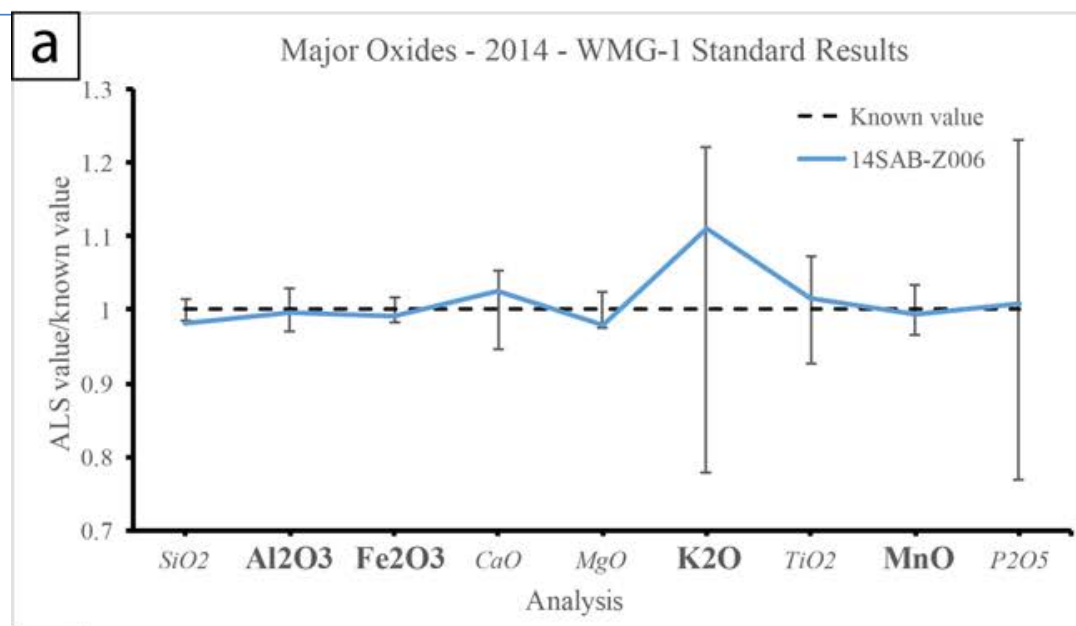

b Major Oxides - 2014 - WGB-1 Standard Results

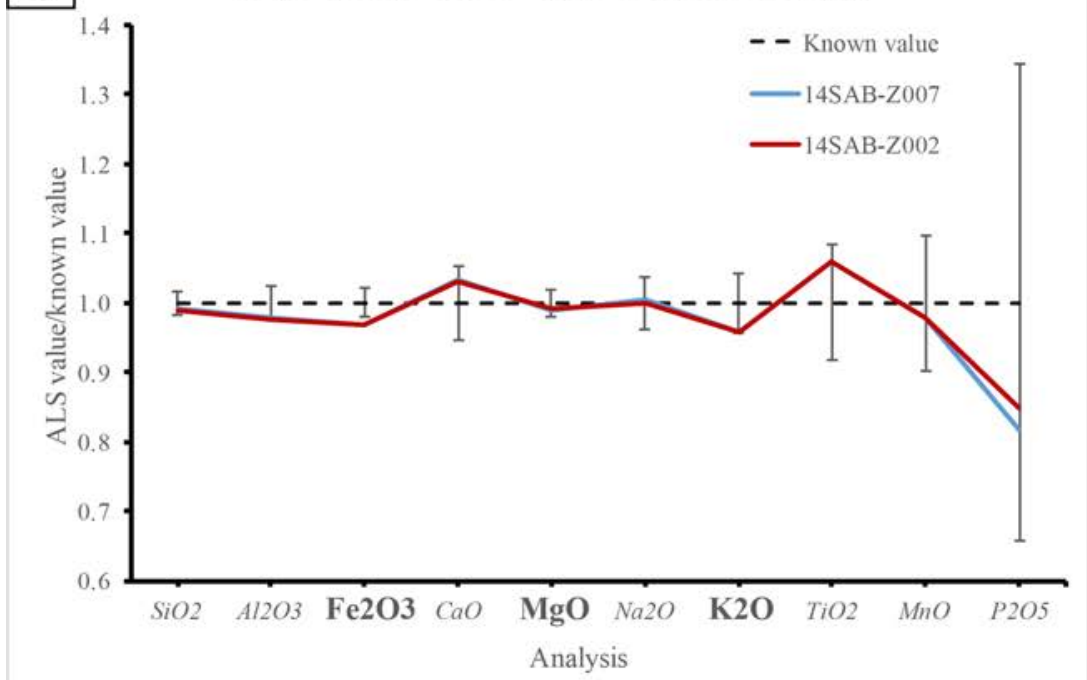

C Major Oxides - 2015 - WGB -1 Standard Results

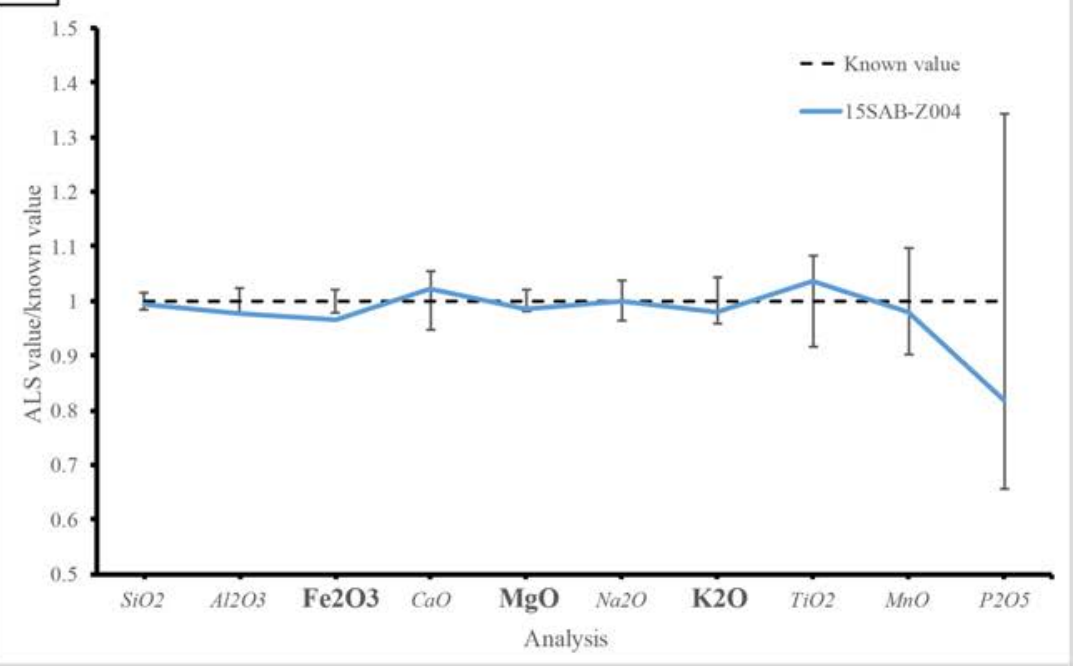


Figure 4.2: Known-value-normalized trace element data obtained from ALS Chemex for the diabase standard TDB-1 in the 2014 dataset. Analyses compared to certified reference values are bold and in a larger font, while analyses compared to provisional reference values are italicized and in a smaller font. 


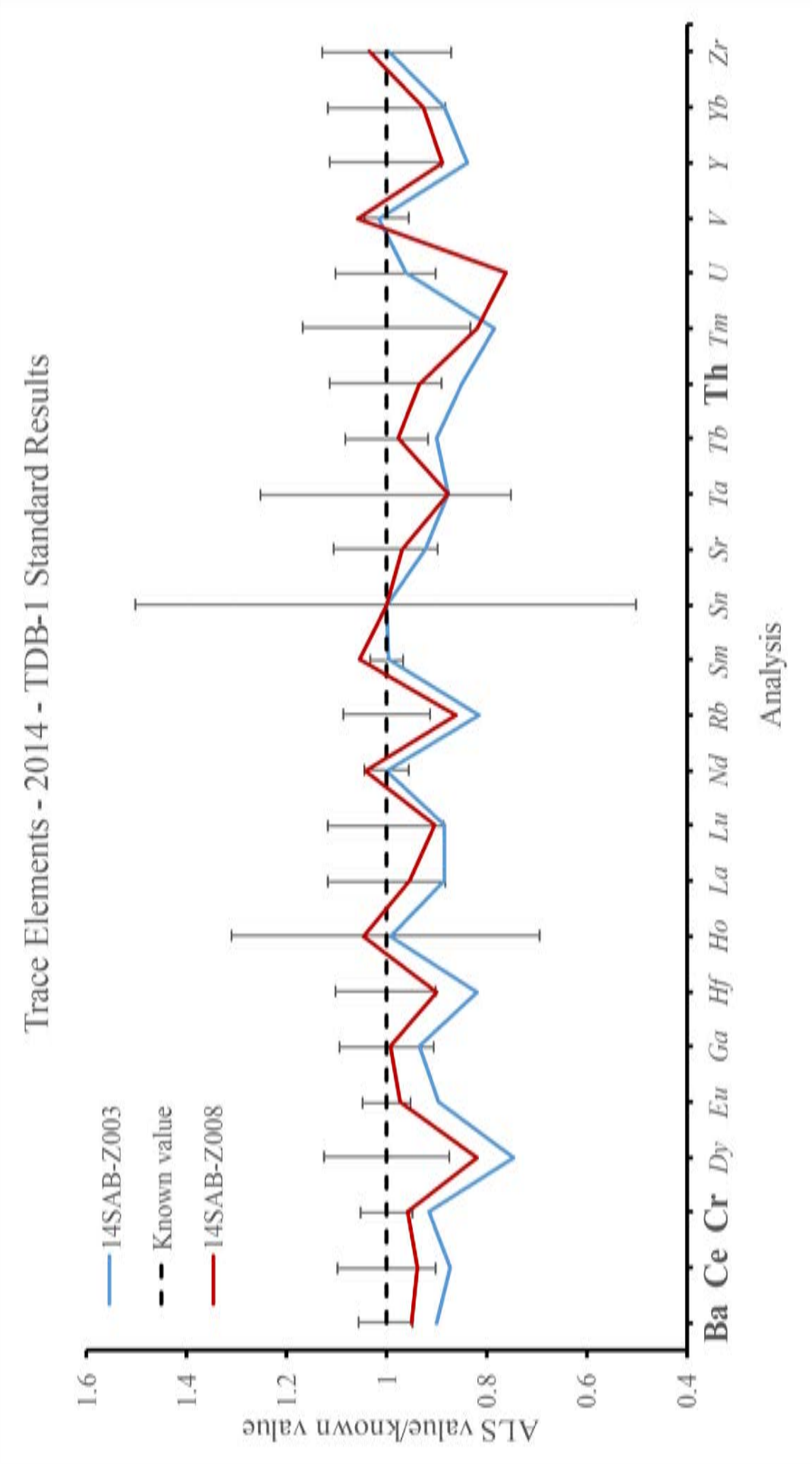


Figure 4.3a-b: Known-value-normalized base metal data obtained from ALS Chemex for the diabase standard TDB-1 in the 2014 (a) and 2015 (b) datasets. Analyses compared to certified reference values are bold and in a larger font, while analyses compared to provisional reference values are italicized and in a smaller font. 


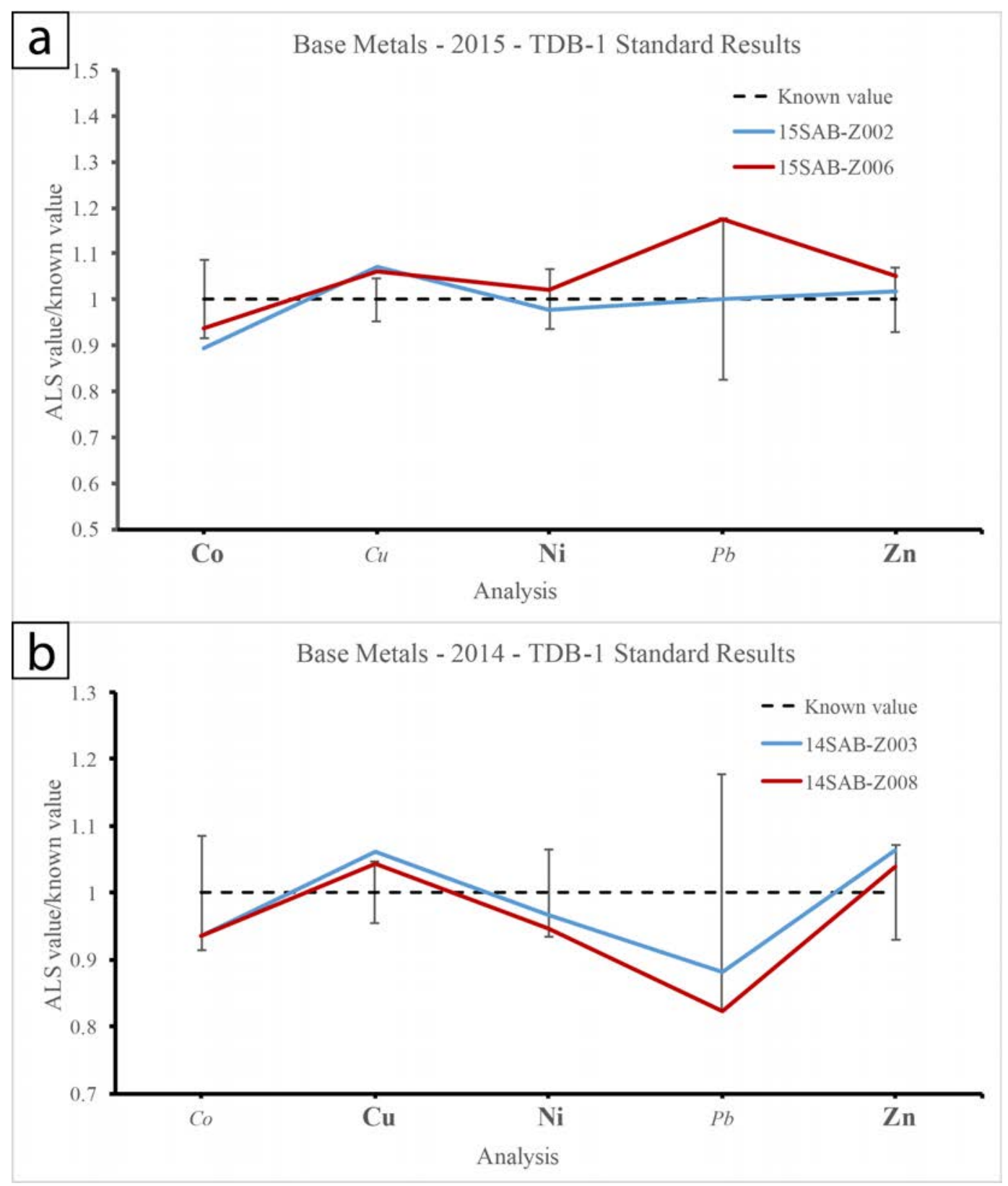


Table 4.1a-e: List of analytes, their lower detection limits and units: a) Major oxides were digested in a lithium borate flux solution and analyzed via X-Ray Fluorescence (XRF). LOI was determined using a thermal decomposition furnace and measured gravimetrically; b) Sulphur (S) and carbon (C) were analyzed via the Leco Method in an induction furnace and measured gravimetrically; c) Trace elements were digested through lithium metaborate fusion and analyzed via Inductively Coupled Plasma - Mass Spectroscopy (ICP-MS); d) Base metals were digested using four acid digestion and analyzed via Inductively Coupled Plasma - Atomic Emission spectroscopy (ICP-AES); e) Precious metals (except silver) were determined using standard lead oxide collection fire assay, and finishing with ICP-AES. 


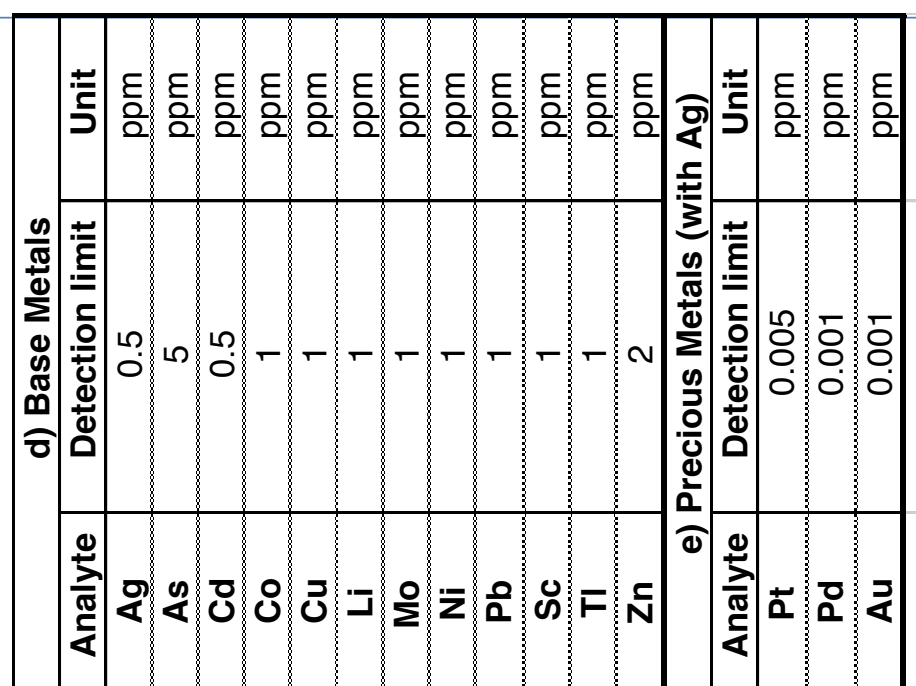

崩

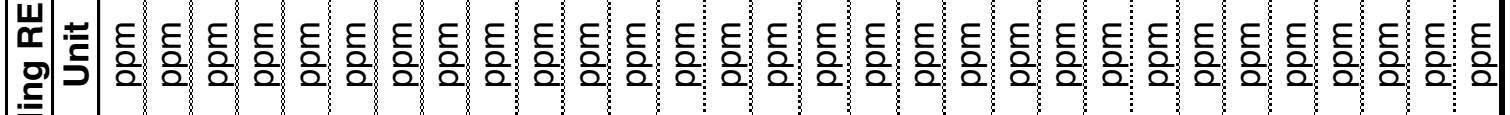

$\frac{\bar{c}}{\frac{7}{2}}$

空:

(ิ)

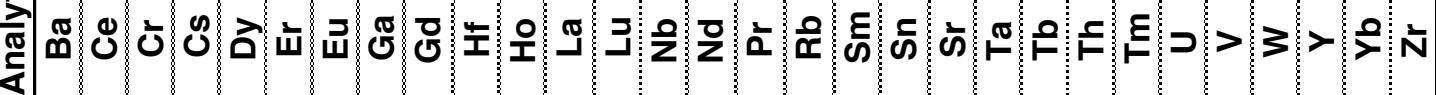

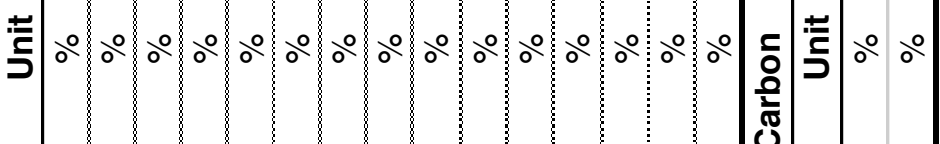

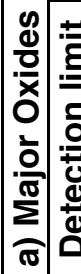

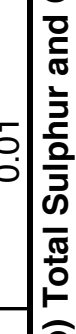

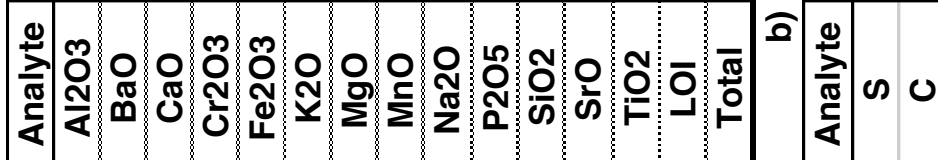


Table 4.2: Elements, X-ray lines and standards used in electron microprobe (EMP) standard calibration.

\begin{tabular}{|c|c|c|c|c|c|}
\hline \multicolumn{3}{|c|}{ Silicate Standards } & \multicolumn{3}{|c|}{ Sulphide Standards } \\
\hline Element & Line & Standard & Element & Line & Standard \\
\hline $\mathbf{S i}$ & $\mathrm{Ka}$ & olivine & As & $\mathrm{La}$ & $\mathrm{NiAs}$ \\
\hline $\mathrm{Al}$ & $\mathrm{Ka}$ & spinel (synthetic) & $\mathbf{S}$ & $\mathrm{Ka}$ & pyrite \\
\hline $\mathbf{M g}$ & $\mathrm{Ka}$ & olivine & $\mathrm{Ni}$ & $\mathrm{Ka}$ & $\mathrm{NiAs}$ \\
\hline $\mathrm{Na}$ & $\mathrm{Ka}$ & albite & $\mathrm{Fe}$ & $\mathrm{Ka}$ & pyrite \\
\hline $\mathbf{K}$ & $\mathrm{Ka}$ & microcline (USNM) & $\mathrm{Cu}$ & $\mathrm{Ka}$ & chalcopyrite \\
\hline $\mathbf{C a}$ & $\mathrm{Ka}$ & wollastonite & Mn & $\mathrm{Ka}$ & MnS (synthetic) \\
\hline Ti & $\mathrm{Ka}$ & MnTiQ (synthetic) & Co & $\mathrm{Ka}$ & Co \\
\hline $\mathrm{Cr}$ & $\mathrm{Ka}$ & $\mathrm{CE}_{6}$ (synthetic) & $\mathbf{C d}$ & $\mathrm{La}$ & $\mathrm{CdS}$ \\
\hline Mn & $\mathrm{Ka}$ & MnTiQ (synthetic) & $\mathrm{ZnS}$ & $\mathrm{Ka}$ & ZnS (synthetic) \\
\hline $\mathrm{Fe}$ & $\mathrm{Ka}$ & Fayalite (synthetic) & & & \\
\hline $\mathrm{Ni}$ & $\mathrm{Ka}$ & $\mathrm{NiO}$ (synthetic) & & & \\
\hline $\mathrm{Ba}$ & $\mathrm{La}$ & barite & & & \\
\hline $\mathbf{S}$ & $\mathrm{Ka}$ & barite & & & \\
\hline $\mathrm{Cl}$ & $\mathrm{Ka}$ & tugtupite & & & \\
\hline $\mathbf{F}$ & $\mathrm{Ka}$ & lithium fluoride (synthetic) & & & \\
\hline $\mathrm{Zn}$ & $\mathrm{Ka}$ & gahnite (USNM) & & & \\
\hline
\end{tabular}


Chapter 5 - Petrography 


\subsection{General Observations}

Geochemical groups mentioned below are defined on the basis of wholerock geochemistry (Chapter 7$)$.

\subsubsection{Mineral assemblages}

Mineral assemblages found within units spanning all geochemical groups, which are defined in Chapter 7, are quite variable in terms of constituent phases, modal percentages and grain size. However, the mafic to ultramafic mineral assemblages are generally characteristic of amphibolite to granulite facies metamorphic conditions (see Chapter 2).

The majority of the mafic samples collected contain the assemblage plagioclase + hornblende + orthopyroxene + clinopyroxene, with a lesser number containing the assemblage plagioclase + hornblende. A significant number also contain the assemblage plagioclase + hornblende + clinopyroxene, or plagioclase + hornblende + orthopyroxene. Other samples contain a combination of hornblende, olivine, clinopyroxene, orthopyroxene and spinel, in variable abundances. Plagioclase is present in a subset of ultramafic samples, up to 10 modal\%.

The metamorphic mineral assemblages replace the primary magmatic minerals and consequently few primary magmatic textures are preserved. However, in some cases, relict magmatic textures (e.g. porphyritic texture, relict magmatic layering) are preserved and thus provide information on the petrogenesis of this sills. 
Rock samples were named on the basis of their modal mineral content (Figure 5.1) through the use of ternary diagrams adapted from the IUGS classification and nomenclature of igneous rocks (Le Bas \& Streckeisen, 1991) to reflect the igneous protolith, despite the metamorphic origin of mineral assemblages. This method of classification was chosen in order to provide the maximum amount of information about the sample's modal mineralogical composition. Standard metamorphic naming schemes yield names that are too broad and generalized (e.g. granulite, amphibolite, gneiss, etc.) to highlight the significant variation that exists in the suite of mafic and ultramafic samples. Thus, these rocks are secondary, recrystallized gabbros, peridotites, pyroxenites and hornblendites.

\subsubsection{Textures}

Sample textures vary from well-layered (Figure 5.2b) to massive (Figure 5.3c). Massive samples show significant textural variability, with samples exhibiting both homogeneous and heterogeneous mineral grain distribution. Samples may be equigranular (e.g. granoblastic), or inequigranular [e.g. seriate (Figure 5.3a), porphyritic (Figure 5.2a)] in character. Some samples appear to have been annealed, as exhibited by the granoblastic textures and 120-degree triple junction grain boundaries. However, many samples have retained strain textures as amphibole-defined foliations. The granoblastic textures and 120degree triple junction grain boundaries are suggestive of slow cooling at high temperatures, such as during regional metamorphism. In granoblastic samples, 
grain boundaries are generally sharp and straight, however, rounded grain boundaries occur as well. Porphyritic samples contain megacrysts of either orthopyroxene (Figure 5.3a), olivine (Figure 5.2c), or plagioclase (Figure 5.2a). Matrix grains are often granular or polygonal, with crystal shapes dictated by close packing, rather than crystal structures. However, amphibole defines a weakly to moderately developed foliation fabric in many samples (Figure 5.3c). A very limited number of samples exhibit reaction textures (Figure 5.4a-b), and many samples contain pyroxene or amphibole grains that exhibit exsolution laminae (Figure 5.4c). Additionally, a relict cumulate texture (Figure 5.3b) can be observed in a few samples also. The average matrix mineral grain size is 1.0 $\mathrm{mm}$, with the full range of grain size generally ranging between 0.3 and $3.0 \mathrm{~mm}$.

\subsubsection{Metamorphism}

It is difficult to attribute many of the mineral assemblages to a specific metamorphic event $\left(\mathrm{M}_{1 a}\right.$ or $\left.\mathrm{M}_{2}\right)$, given that $\mathrm{Hbl}+\mathrm{Pl}$ occur well into the granulite facies in mafic rocks. Consequently, it is not clear whether these assemblages formed during the initial prograde granulite facies metamorphism, or whether they are part of the retrograde overprinting assemblage formed during the later upper amphibolite metamorphic event. However, the assemblages observed in metamorphosed ultramafic samples suggest that many sills preserved granulite facies $\left(\mathrm{M}_{1 \mathrm{a}}\right)$ metamorphic assemblages, highlighted by the coexistence of clinopyroxene, orthopyroxene, and spinel. The presence of spinel, as opposed to garnet or plagioclase, indicates an intermediate pressure of metamorphism. 
Effects of greenschist-facies retrogression are apparent in select samples, where serpentine or sericite have partially broken down olivine or plagioclase, respectively. Overall, these observations are consistent with conclusions made through P-T studies on the host metasedimentary units of the Lake Harbour Group by St-Onge et al. (2007; see Chapter 3).

\subsection{Mineralogical Characteristics of Geochemical Groups}

With respect to mineral abundance descriptions, the percentages used are modal volume percentages. In the text below, the term " $n$ " represents the number of samples studied, and "s" represents the number of sills with a mafic or ultramafic component that are part of a given geochemical group. Geochemical groups are described in detail later in Chapter 7 (Geochemistry). A comparison of the mineral contents in each of the geochemical groups is found in Table 5.1.

\subsubsection{Group A1}

Group A1 $(n=6)$ is limited to ultramafic units sampled from ultramafic $(s=3)$ and mafic-ultramafic $(\mathrm{s}=2)$ sills. Mineral assemblages are generally dominated by hornblende $(39-80 \%)$ and olivine (15-60\%), with some samples containing orthopyroxene and spinel, up to $25 \%$ and $1 \%$, respectively. Plagioclase and clinopyroxene are absent in samples from this group. Magnetite+ilmenite contents are $<1 \%$, and all samples contain trace amounts of sulphide. Sulphides are dominantly pyrrhotite and chalcopyrite. There is one occurrence of pentlandite, and two contain only pyrite. 


\subsubsection{Group A2}

Group A2 $(n=17)$ comprises mafic and ultramafic units from mafic $(s=7)$, ultramafic $(s=1)$, and mafic-ultramafic $(s=3)$ sills. Ultramafic samples $(n=3)$ are dominantly composed of hornblende (20-70\%) and olivine (14-70\%), with orthopyroxene up to $16 \%$. One ultramafic unit contains $4 \%$ spinel. Trace amounts of magnetite+ilmenite are also present, and the majority of samples contain trace sulphides. Mafic samples $(n=14)$ from Group A2 are primarily composed of hornblende $(2-70 \%)$ and plagioclase $(20-50 \%)$, and $>60 \%$ of samples contain clinopyroxene and orthopyroxene in variable abundances of $10-53 \%$ and $5-25 \%$, respectively. A few samples collected contain up to $4 \%$ biotite, and one sample (15SAB-L056B01) contains a garnet porphyroblast. Most samples contain trace amounts of magnetite+ilmenite and sulphides, with the latter dominantly comprising pyrrhotite or pyrite, both with lesser chalcopyrite and one occurrence of pentlandite. Four samples are sulphide-barren.

\subsubsection{Group B}

Group B ( $n=5)$ comprises mafic and ultramafic units from mafic $(s=1)$ and mafic-ultramafic $(s=2)$ sills. The single ultramafic sample (15SAB-L113B01) contains mostly hornblende (84\%) with minor amounts of clinopyroxene (8\%) and orthopyroxene (8\%). Trace amounts of sulphide, but no magnetite+ilmenite are present. The mafic samples $(n=4)$ are plagioclase-rich, and contain variable proportions of hornblende (15-30\%), clinopyroxene (15-25\%) and orthopyroxene 
$(0-20 \%)$. One of the samples (15SAB-D196B01) contains 5\% olivine. The samples generally contain trace amounts of sulphide and trace to $4 \%$ magnetite+ilmenite. One sample (15SAB-M005A01) contains $2 \%$ sulphide. Sulphides are dominantly pyrrhotite with lesser chalcopyrite with two samples containing pentlandite.

\subsubsection{Group C1}

Group C1 $(n=8)$ comprises mafic and ultramafic samples from mafic $(s=1)$, ultramafic $(s=1)$ and mafic-ultramafic $(s=1)$ sills. Ultramafic samples $(n=5)$ are hornblende-rich (20-88\%), and contain variable amounts of clinopyroxene (0-35\%), orthopyroxene (0-28\%) and olivine (0-40\%). Samples contain 0 to $10 \%$ spinel, and one sample contains $5 \%$ plagioclase (15SAB-F013B01). Most samples contain trace sulphides, and some contain trace magnetite+ilmenite. Mafic samples $(n=3)$ contain approximately equal proportions of plagioclase $(40-55 \%)$ and hornblende (45-55\%), and are devoid of clinopyroxene, orthopyroxene or olivine. These samples are relatively enriched in sulphides (1 and $5 \%$ sulphide) compared to other sample groups, and have magnetite+ilmenite contents up to $4 \%$. Sulphides are dominantly either pyrrhotite with minor chalcopyrite and pyrite, or pyrite with minor chalcopyrite. The majority of the Group C1 samples were collected during a detailed sampling traverse across the Killapait sill, located on the south coast of central Meta Incognita Peninsula. 


\subsubsection{Group C2}

Group C2 ( $n=12)$ comprises mafic and ultramafic samples from mafic $(s=1)$ and mafic-ultramafic $(s=2)$ sills. The ultramafic samples $(n=3)$ contain olivine $(55-70 \%)$, hornblende $(20-35 \%)$, and up to $5 \%$ spinel. One sample contains $5 \%$ orthopyroxene (14SAB-L014A01). The samples also contain trace sulphides and magnetite+ilmenite. The mafic samples contain plagioclase (13-96\%) and hornblende (4-50\%), with a few also featuring orthopyroxene (0-20\%), olivine $(0-30 \%)$, biotite $(0-5 \%)$, and spinel (0-1\%). Clinopyroxene (30\%) was only identified in one sample (14SAB-L011A02). Most samples contain at least trace sulphides, while magnetite+ilmenite were only identified in a couple. A large number of samples contain only pyrite, while the others contain pyrrhotite and/or pyrite with chalcopyrite, with the latter in lesser amounts. The majority of these samples were collected during a detailed sampling traverse across the Killapait sill (the same sill that hosts the bulk of samples of Group C2).

\subsubsection{Group D}

Group D $(n=17)$ comprises mafic and ultramafic samples from mafic $(s=1)$, ultramafic $(s=5)$ and mafic-ultramafic $(s=2)$ sills. The ultramafic samples $(n=11)$ contain hornblende $(23-80 \%)$, and variable amounts of orthopyroxene $(0-52 \%)$ and olivine (0-40\%). Three ultramafic samples contain between 15 and 50\% clinopyroxene, two contain $5-15 \%$ biotite, and another two contain $1-2 \%$ spinel. Almost all ultramafic samples contain at least trace amounts of sulphide, with four containing 1-10\% sulphide (14SAB-L004A01; 14SAB-L009A01; 14SAB- 
L009A02; 14SAB-L009B02), and typically $\sim 1 \%$ magnetite+ilmenite. Mafic samples $(n=6)$ from Group D are composed mostly of hornblende (30-65\%), a narrow range of clinopyroxene (20-30\%), and variable plagioclase (4-34\%). The sample from this group that is the most mineralized ( $10 \%$ sulphide) contains $48 \%$ plagioclase, 39\% clinopyroxene and 3\% spinel. All other mafic samples contain only trace amounts of sulphide and up to $2 \%$ magnetite+ilmenite, when present. Sulphides include pyrrhotite and/or pyrite with minor chalcopyrite. Some samples contain variable amounts of pentlandite as well.

\subsubsection{Group E}

Group $E(n=4)$ comprises mafic samples from mafic $(s=2)$ sills. The samples contain variable amounts of plagioclase (28-30\%), hornblende (24-32\%), clinopyroxene (18-20\%) and orthopyroxene (5-23\%), and some samples contain trace levels of sulphides and magnetite+ilmenite. One mineralized sample (15SAB-M003A01) from this group contains $70 \%$ plagioclase, $23 \%$ orthopyroxene, $5 \%$ sulphides and $2 \%$ magnetite+ilmenite. Two samples contain pyrrhotite and/or pyrite with chalcopyrite, and one sample contains pyrite as the only sulphide phase.

\subsubsection{Group F}

Group $F(n=11)$ comprises mafic and ultramafic samples from ultramafic $(s=1)$ and mafic-ultramafic $(s=1)$ sills. Ultramafic samples $(n=8)$ contain hornblende (50-90\%) and variable amounts of orthopyroxene (0-40\%), olivine 
$(0-46 \%)$ and spinel (0-7\%). The two pyroxene-free ultramafic samples each contain $10 \%$ plagioclase. Mafic samples $(n=3)$ contain hornblende $(45-60 \%)$ and plagioclase (40-45\%). In addition, one sample contains $10 \%$ orthopyroxene. Most samples contain trace sulphides, are generally devoid of magnetite+ilmenite, with one exception containing ilmenite. Sulphides within these samples include variable amounts of pyrrhotite, pentlandite and pyrite. Most of the samples were collected during a detailed sampling traverse across the Chidliak sill, located in southernmost portion of the field area on Hall Peninsula.

\subsection{Silicate Mineralogy}

Given that this is a reconnaissance study, the occurrences, abundances and characteristics of the main mineral constituents are the focus of the petrographic portion of the study, and therefore, the minerals present in trace abundances throughout the Frobisher suite are not described.

\subsubsection{Olivine}

Olivine typically occurs as anhedral grains that are transected by serpentine-filled interconnecting arcuate fractures, with the degree of serpentinization varying from weak to extreme. In most areas where olivine is completely serpentinized, serpentine pseudomorphs retain relict olivine crystal shapes. Also associated with retrograde serpentinization is fine-grained magnetite. Olivine grains often occur in clusters, where they are commonly 
associated with spinel (proper) or hercynite. Select samples from Groups A1, A2, and F contain anhedral to subhedral megacrysts of olivine (Figure 5.2c), which may represent relict primary igneous grains. In general, olivine grains are considered to be metamorphic, given that they coexist with amphibole grains. If the amphibole formed via metamorphic reactions involving the introduction of $\mathrm{H} 2 \mathrm{O}$, it is unlikely primary olivine would persist through these conditions. In one sample, serpentinized olivine is surrounded by a reaction rim of orthopyroxene, which is then rimmed by hornblende (Figure 5.4a).

\subsubsection{Clinopyroxene}

Clinopyroxene generally occurs as equant, anhedral grains that display a granoblastic texture. The grains are often fractured, and in rare instances, serpentine fills the fractures. Clinopyroxene from Groups A2, B, D, and E displays exsolution textures with thin ( 2 um) orthopyroxene exsolution laminae (Figure 5.4c). This texture is common in clinopyroxene from sills in the southcentral Baffin area $(n=7)$, as opposed to those from Meta Incognita Peninsula $(n=2)$. In a few samples, hornblende is observed overgrowing clinopyroxene grains (Figure 5.4b). Clinopyroxenes lack oscillatory zoning.

\subsubsection{Orthopyroxene}

Orthopyroxene grains are anhedral, sometimes ovoid in shape, and display red-green pleochroism under plane-polarized light (PPL). Orthopyroxene megacrysts (Figure 5.3a) are observed in samples from Groups B, D, and C2. In 
some cases, they exhibit poikilitic textures, with chadacrysts of hornblende and/ or ilmenite. Orthopyroxenes lack oscillatory zoning.

\subsubsection{Amphibole}

Amphibole is anhedral and defines a foliation fabric (Figure 5.3c) in numerous samples. The grains can vary greatly in size within a single sample, creating a seriate texture. Amphibole is of the hornblende variety and appears green to green-brown to brown in PPL, corresponding to an increase in Ticontent with increasing metamorphic grade. Through BSE microscopy, very-thin exsolution laminae can be observed within hornblende in select samples. The nature of the laminae could not be identified due to their sub-micrometer ( $<1 \mathrm{um}$ ) thickness. Amphiboles lack oscillatory zoning, and are interpreted to have replaced pyroxene at high temperature, catalyzed by the ingress of $\mathrm{H}_{2} \mathrm{O}$ during metamorphism and deformation.

\subsubsection{Plagioclase}

Plagioclase occurs as anhedral grains, displaying characteristic polysynthetic twinning and occasional Carlsbad twinning. Within a subsection of the ultramafic portion of the Killapait sill, plagioclase occurs as round megacrysts (Figure 5.2a). The megacrystic plagioclase is commonly variably sericitized. Plagioclase grains lack oscillatory zoning. 


\subsubsection{Phlogopite}

Phlogopite occurs as subhedral grains and appears medium brown in PPL. It occurs most commonly in Groups D and C2, generally between 15 and 5 modal \%. Phlogopite grains often form weak to strong foliations, and outline micro-folding in a few samples.

\subsection{Oxide Mineralogy}

\subsubsection{Spinel}

Spinel occurs as dark-green (in PPL; Figure 5.2a), anhedral grains that typically form clusters. A minority display arcuate fracturing. Spinel is found in ultramafic samples and is associated with either olivine or orthopyroxene. Its presence is not confined to any particular geochemical group, though it is relatively common and in higher abundances (up to 10\%) in samples from Groups A1, C2, and F. Sample 15SAB-L112A01 contains spinel exhibiting a vermicular texture, characteristic of formation through metamorphic growth. Additionally, spinel (proper) is known to form almost exclusively through metamorphism.

\subsubsection{Magnetite and ilmenite}

Magnetite and/or ilmenite (Figure 5.5g) are found in almost all samples, where these magnetite+ilmenite are generally distributed evenly in trace amounts, and in some cases occur up to $4 \mathrm{wt} . \%$. Abundance is highest in mafic 
units. Occasionally, magnetite+ilmenite exhibit network textures associated with the serpentinization of olivine, and in some samples have crystallized along fractures and grain boundaries. In a number of samples from the Killapait sill, magnetite exsolution laminae were observed in ilmenite grains. No magnetite or ilmenite were geochemically analyzed for this study.

\subsection{Ore Mineralogy}

The majority of samples from each group contain at least trace amounts of sulphide, which is typically pyrrhotite intergrown with minor amounts of chalcopyrite and/or pentlandite (a typical magmatic assemblage). The sulphides are typically anhedral, though euhedral grains are observed. Some samples exhibit remobilization of sulphide along grain boundaries or fractures, and in a few samples the sulphides appear round or ovoid in shape, perhaps preserving their primary shape from formation as immiscible sulphide droplets. The various textures and ore mineral associates are shown in Figure 5.5a-h.

\subsubsection{Pyrrhotite}

Pyrrhotite is the most common sulphide mineral (Figure 5.5a-g), and by far the most abundant. The Fe-rich end-member of pyrrhotite, troilite, was identified in two samples; one from an intensely folded, and locally brecciated, layered mafic-ultramafic sill from the west coast of Cumberland Sound (15SAB-D196B01

- Group B), and the other from an ultramafic sill on Hall Peninsula (14SUB- 
H029B2 - Group F).

\subsubsection{Chalcopyrite}

Chalcopyrite commonly occurs intergrown with pyrrhotite and occasionally pentlandite (Figure 5.5a-f,h); however, it also occurs as a single-mineral phase.

\subsubsection{Pentlandite}

Pentlandite was observed in samples from Groups B, D, and F (Figure $5.5 c, e-f, h)$.

\subsubsection{Pyrite}

Pyrite generally occurs in samples from Groups $\mathrm{C} 1$ and $\mathrm{C} 2$, with few exceptions. Sample 15SAB-F013B01 contains pyrite with exsolution laminae of pyrrhotite.

\subsection{Mineralogy of Detailed Sample Transects Across Two Mafic-}

\section{Ultramafic Sills}

\subsubsection{Chidliak mafic-ultramafic sill}

Mineralogical variation throughout the Chidliak sill is illustrated in Figure 5.6, with thin section scan and microphotographs shown in Figure 5.7. From the base to the top of the sill, there is an increase the $\%$ of hornblende, while other mineral phases (i.e. orthopyroxene, olivine and plagioclase) demonstrate variable modal 
vol.\%.

\subsubsection{Killapait mafic-ultramafic sill}

Mineralogical variation throughout the Killapait sill is illustrated in Figure 5.8, with thin section scan and microphotographs shown in Figure 5.9. From the base to the top of the sill, there is an increase the mod. al vol. $\%$ of plagioclase, relatively consistent olivine content, and variable modal vol.\% of orthopyroxene, spinel and hornblende. 


\section{References}

Le Bas, M.J. and Streckeisen, A. (1991). The IUGS systematics of igneous rocks. Journal of the Geological Society, 148, 825-833.

St-Onge, M.R., Wodicka, N. and ljewliw, O. (2007). Polymetamorphic evolution of the Trans Hudson Orogen, Baffin Island, Canada: Integration of petrological, structural and geochronological data; Journal of Petrology, v. 48, p. 271- 302. doi:10.1093/petrology/eg1060.

Whitney, D.L. and Evans, B.W. (2010). American Mineralogist, Volume 95, pages $185-187$. 
Figure 5.1: Ternary diagrams for the classification of rock samples based on the IUGS classification scheme for igneous rocks. 


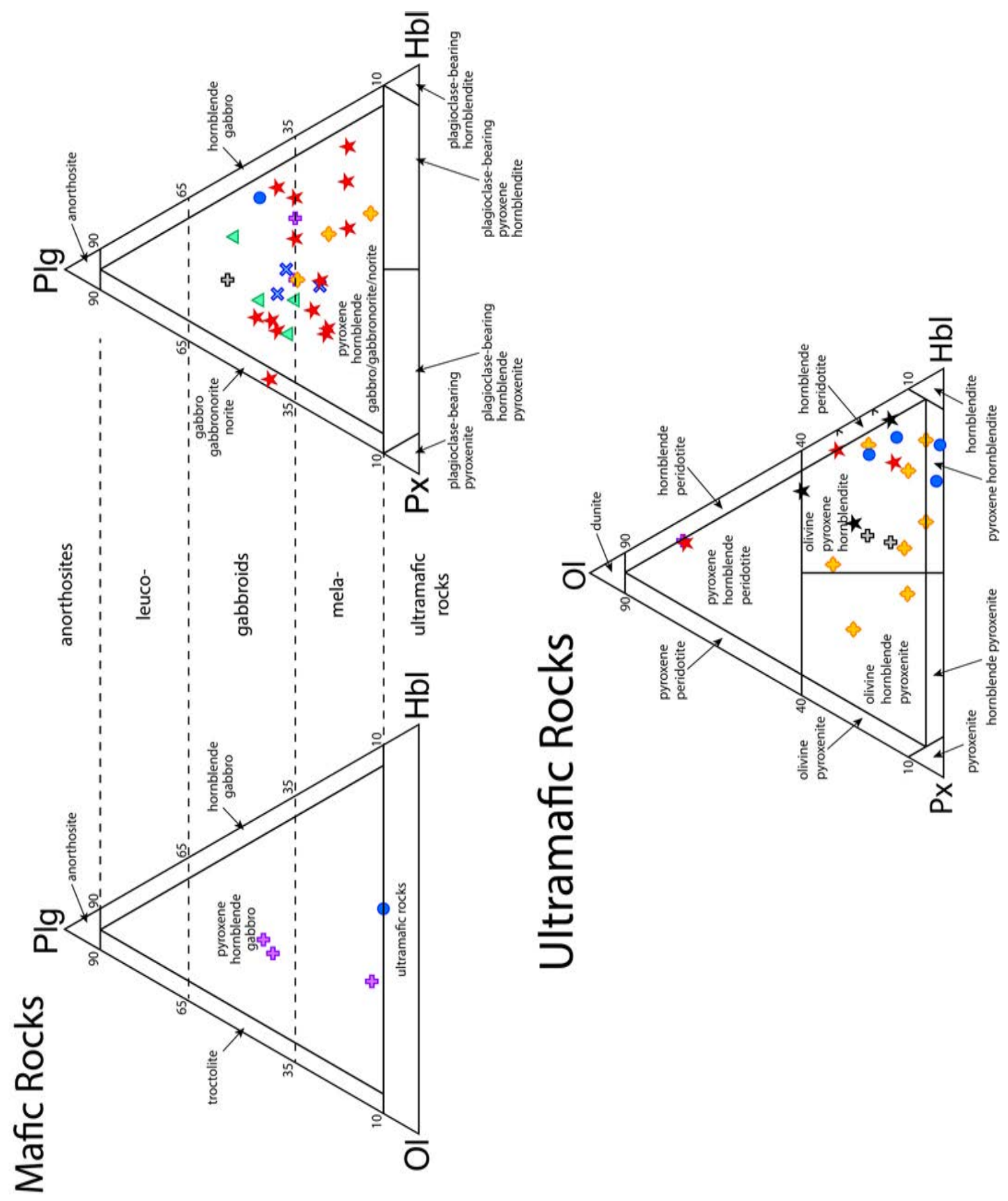


Figure 5.2a-c: Textures shown in rock slabs and thin section scans. a) Plagioclase megacrysts in a hornblende troctolite (14SAB-L013A01); b) Relict igneous layering in an olivine-bearing hornblende pyroxene gabbronorite (14SAB-L011A02), controlled by varying amounts of $\mathrm{Hbl}$, Cpx and Pl; c) Olivine megacryst in an orthopyroxene olivine hornblendite (14SAB-L003A02). Mineral abbreviations after Whitney and Evans (2010). 


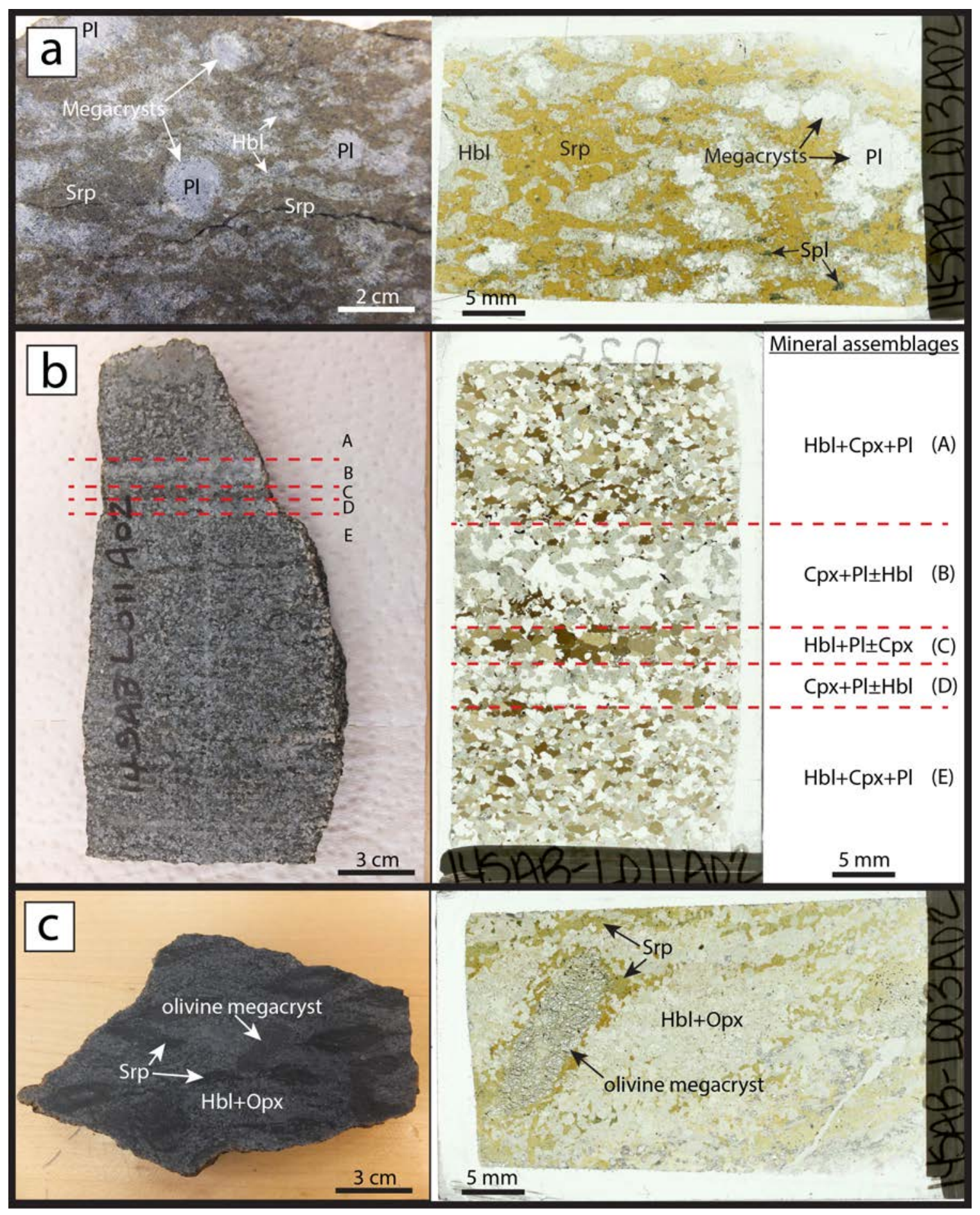


Figure 5.3a-c: Textures shown in thin sections (left) and micrographs (right). a) Orthopyroxene megacryst in an olivine orthopyroxene hornblendite (14SABH080A01) displaying seriate texture - thin section scan on left and micrograph (x5 magnification) on right; b) Relict orthocumulate texture (interpreted) preserved in an olivine hornblendite (14SAB-H080B01), where metamorphic hornblende represents the cumulate phase, while olivine represents the groundmass; c) Weak metamorphic foliation, outlined by the hashed red line, created by oriented hornblende in a pyroxene hornblende mela-gabbronorite (14SAB-L003B01). Mineral abbreviations after Whitney and Evans (2010). 


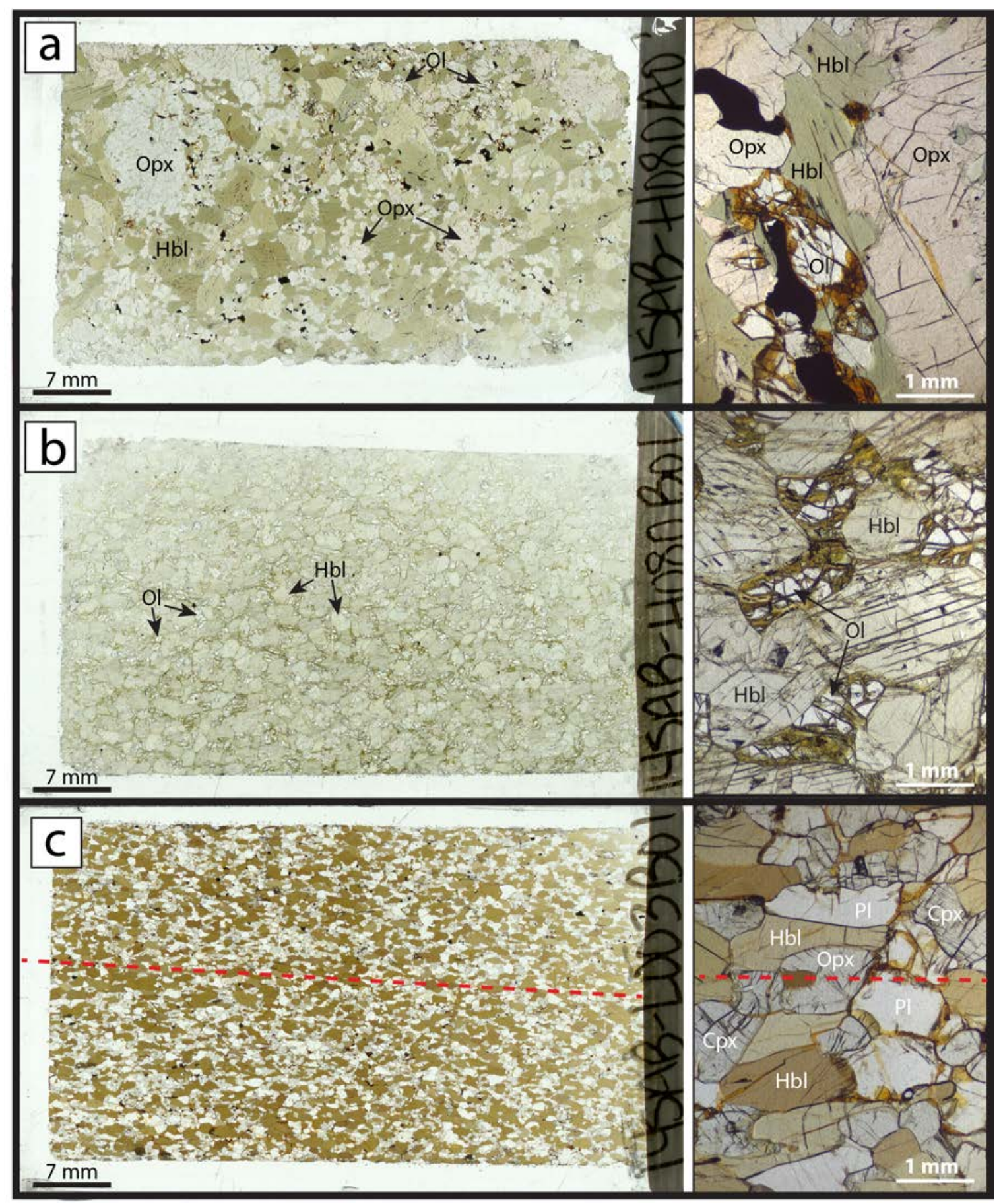


Figure 5.4a-c: Reaction textures in PPL on left and XPL on right. a) Corona texture in an olivine-bearing hornblende pyroxene gabbronorite from the Killapait sill (14SAB-L012A02). The sequence of minerals is: completely serpentinized olivine (center), orthopyroxene, hornblende (outermost); b) Hornblende replacing zoned clinopyroxene (uralitization) in an olivine-bearing hornblende pyroxene gabbronorite (14SAB-L012A02) from the Killapait sill; c) Calcic clinopyroxene displaying exsolution laminae of orthopyroxene (14SAB-L011A02). Mineral abbreviations after Whitney and Evans (2010). 


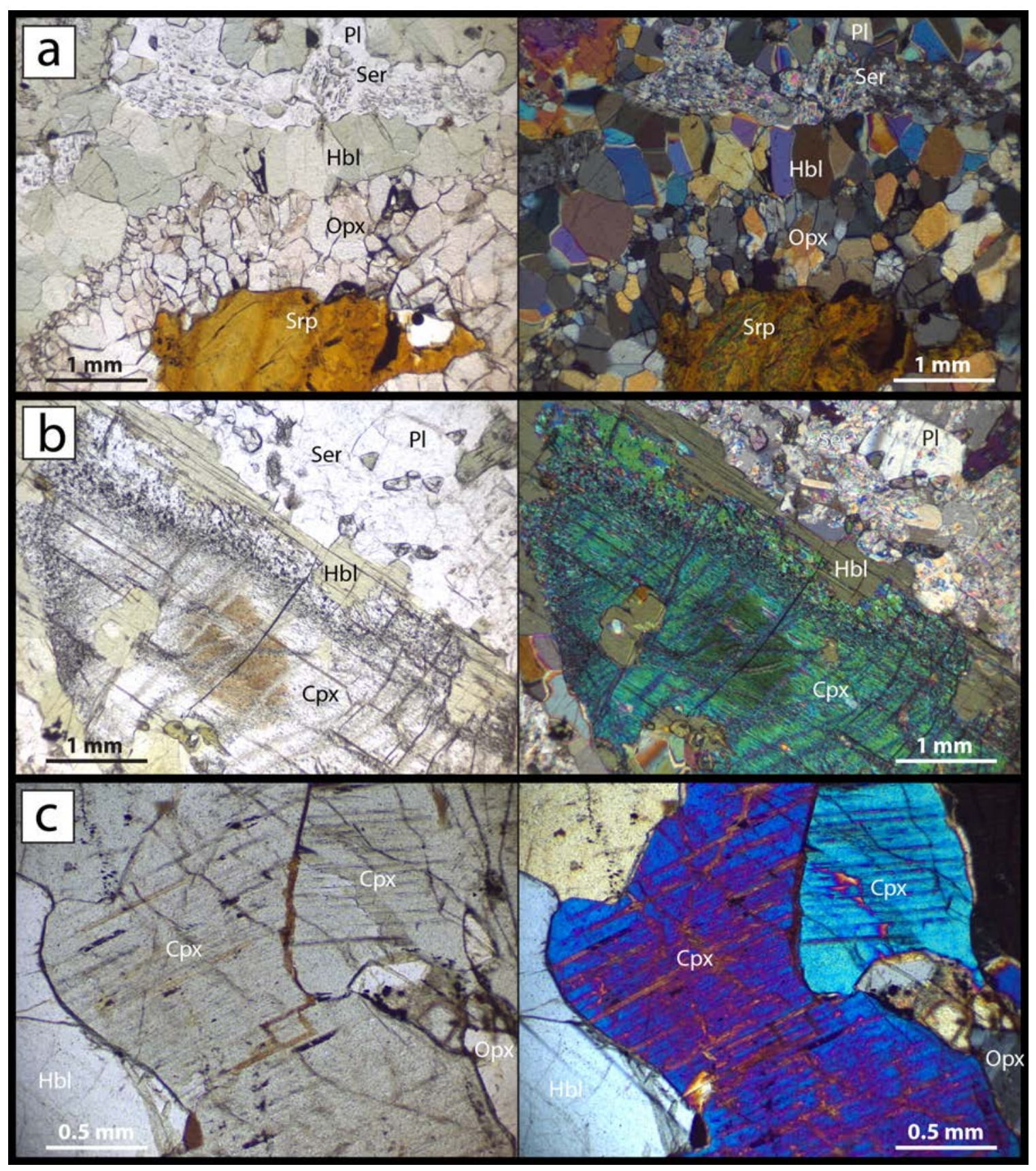


Figure 5.5a-h: Photomicrographs of ore minerals and associations taken at $10 \mathrm{x}$ magnification [except for $h$, taken at $5 x$ magnification]. a) Anhedral pyrrhotite grain intergrown with minor chalcopyrite (14SAB-L010A02); b) Pyrrhotite grains intergrown with pentlandite and chalcopyrite (15SAB-L076A02); c) Pyrrhotite grain intergrown with chalcopyrite and pentlandite, and remobilized sulphide just above grain (15SAB-D196B01); d) Anhedral pyrrhotite intergrown with chalcopyrite (15SAB-L080A03); e) Anhedral pyrrhotite grain intergrown with chalcopyrite and pentlandite (14SAB-L007A01); f) Anhedral pyrrhotite grains intergrown with pentlandite and minor chalcopyrite (14SAB-L009A02); g) Intergrown ilmenite and magnetite with minor pyrrhotite (15SAB-M005A01); h) Round (top-left) and euhedral (bottom-right) grains of pentlandite intergrown with chalcopyrite (15SAB-L078A02). 


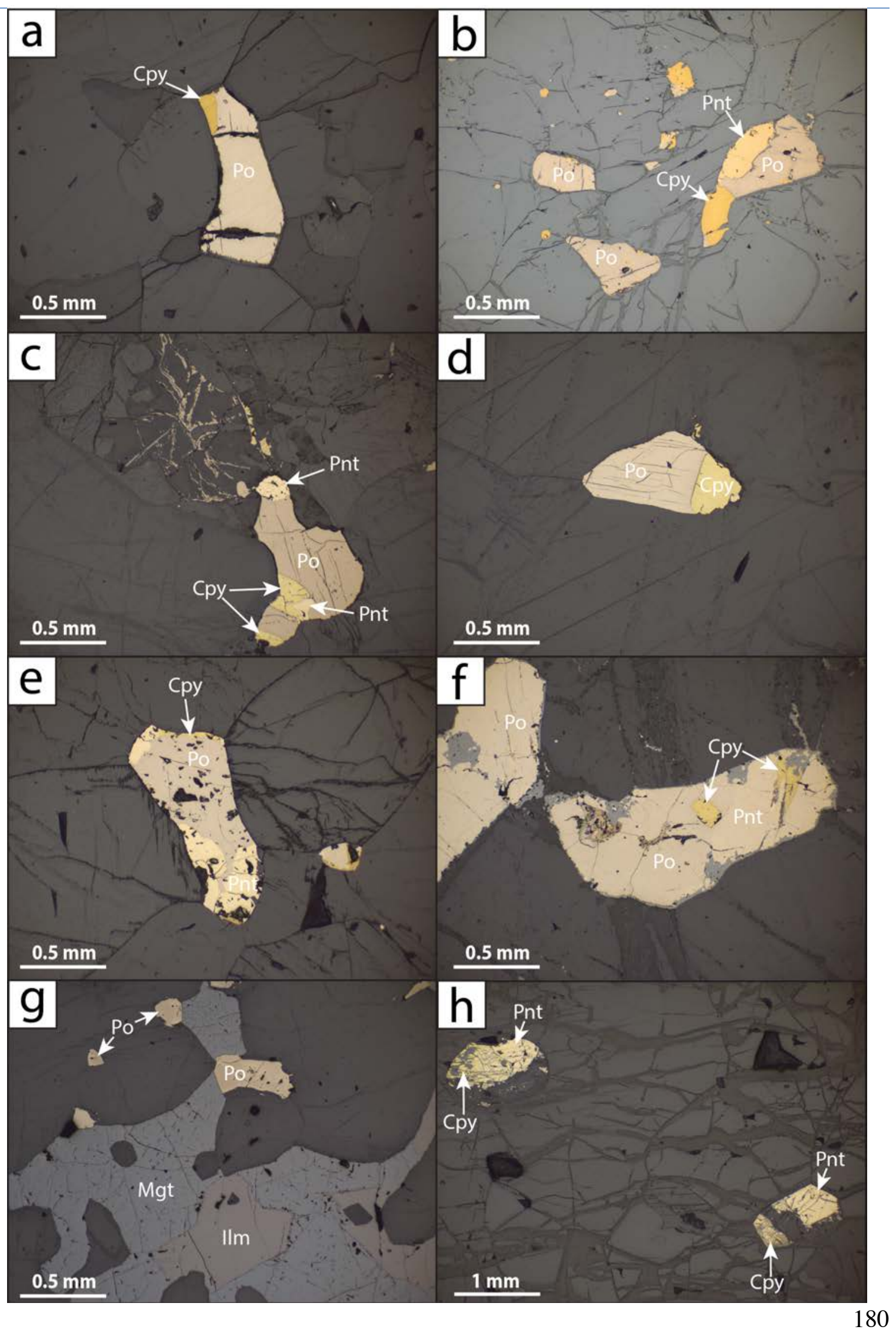


Figure 5.6: Mineralogical changes (mineral chemistry and modal mineralogy) documented in the Chidliak sill of Meta Incognita Peninsula, Baffin Island, Nunavut, going up section. Symbols indicate (defined in Chapter 7) which geochemical group the sample belongs to, and correspond to the groups outlined in Figure 5.1. 


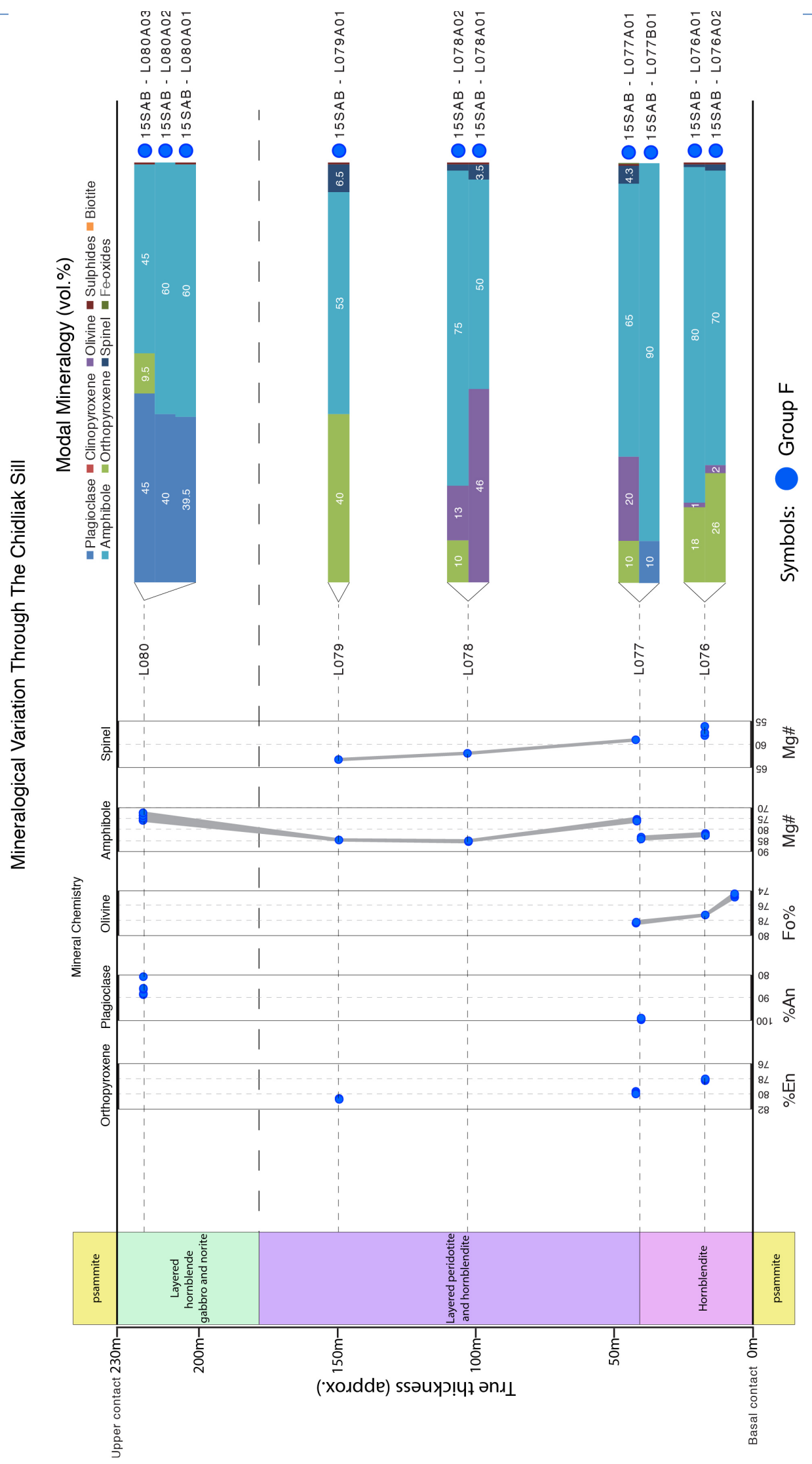


Figure 5.7: Mineralogical and textural variations through the Chidliak sill, illustrated by representative hand sample photos, thin section scans, and microphotographs from each station, from stratigraphic base to top. Symbols indicate which geochemical group (defined in Chapter 7) the sample belongs to, and correspond to the groups outlined in Figure 5.1. 


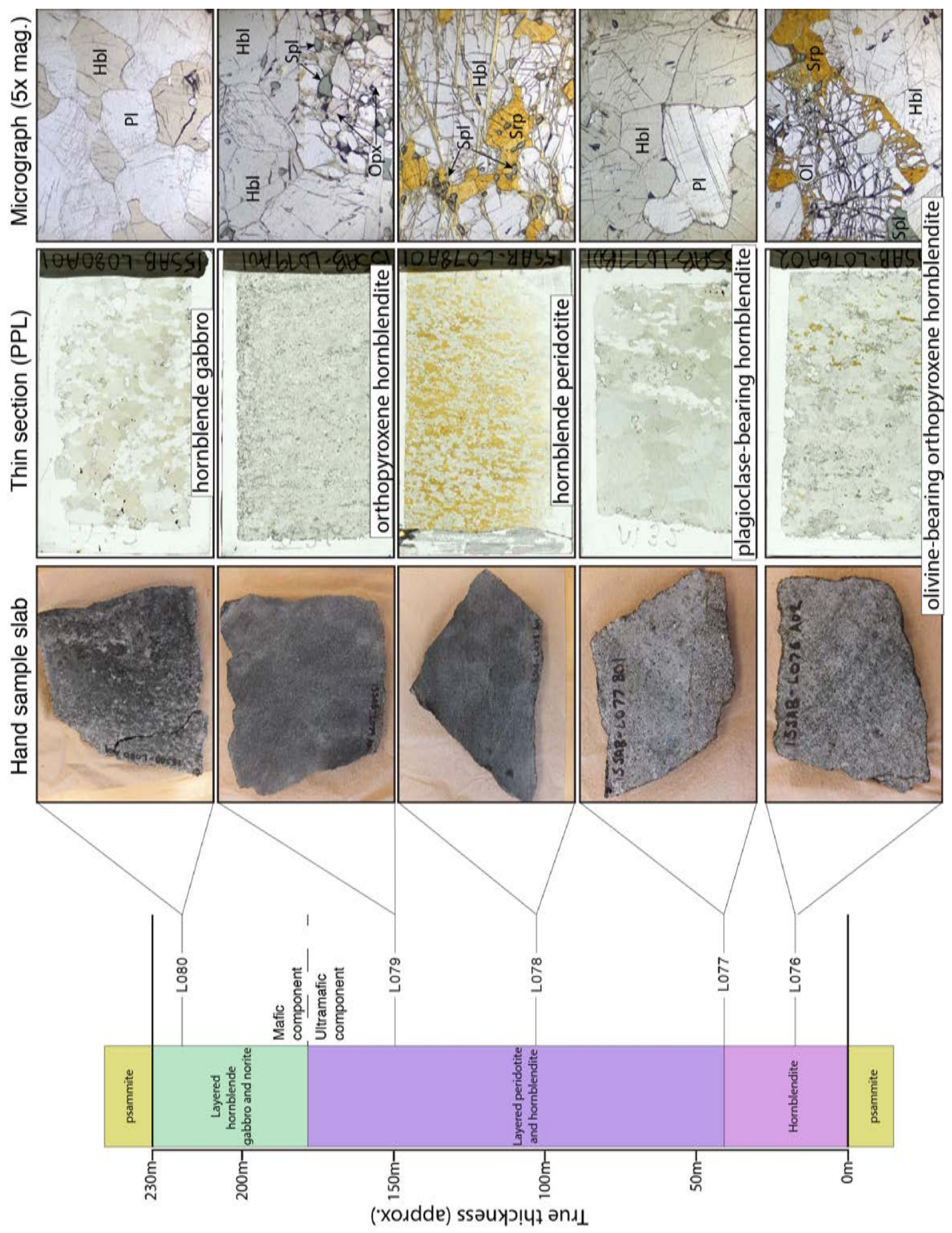


Figure 5.8: Mineralogical changes (mineral chemistry and modal mineralogy) documented in the Killapait sill of Meta Incognita Peninsula, Baffin Island, Nunavut, going up section. Symbols indicate which geochemical group (defined in Chapter 7) the sample belongs to, and correspond to the groups outlined in Figure 5.1. 


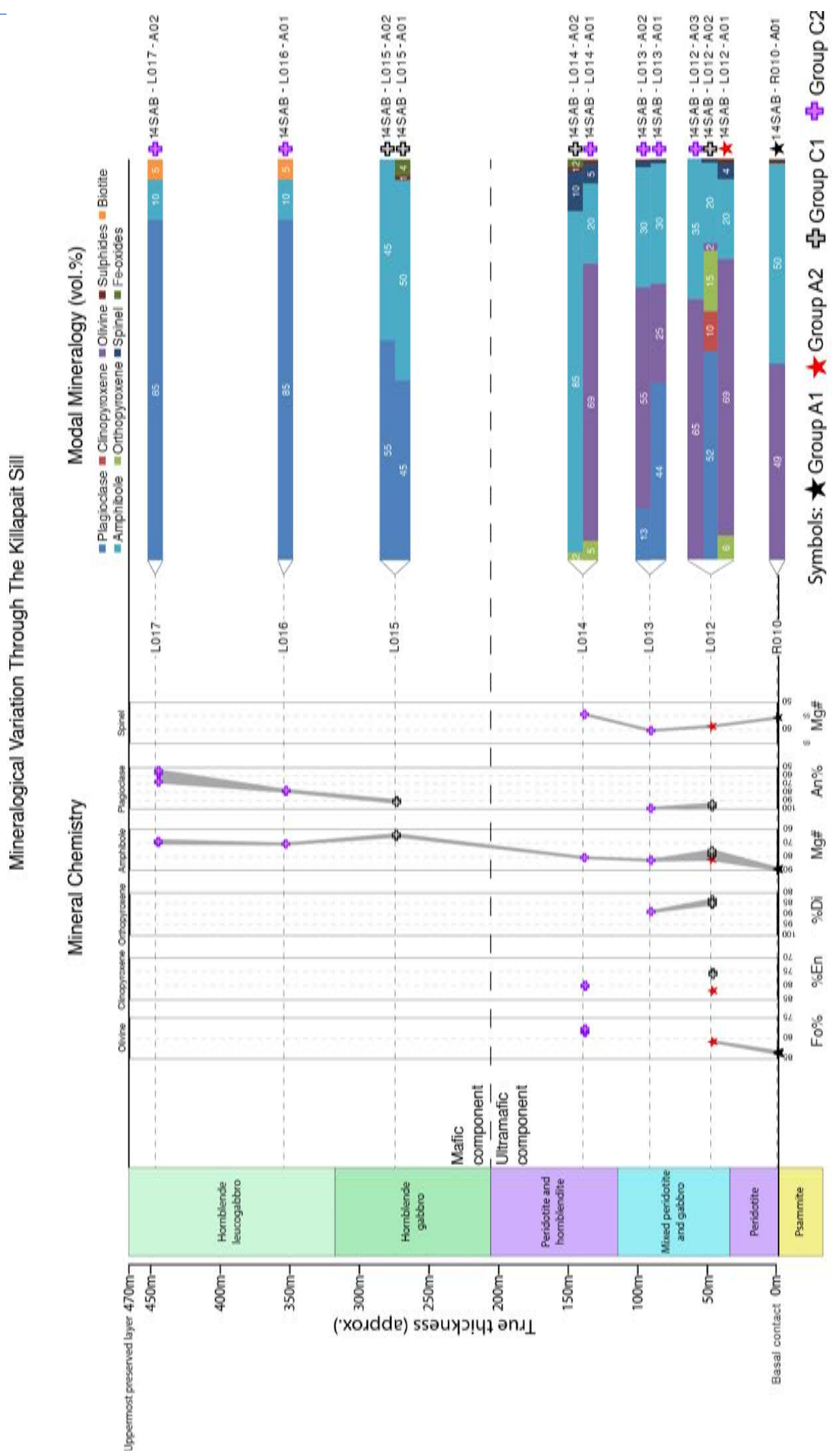


Figure 5.9: Mineralogical and textural variations through the Chidliak sill, illustrated by representative hand sample photos, thin section scans, and microphotographs from each station, from stratigraphic base to top. Symbols indicate which geochemical group (defined in Chapter 7) the sample belongs to, and correspond to the groups outlined in Figure 5.1. 





Table 5.1: Comparison of the average and range of mineral contents and within all eight geochemical groups (groups defined in Chapter 7).

\begin{tabular}{|c|c|c|c|c|c|c|c|c|}
\hline Average & Group A1 & Group A2 & Group D & Group B & Group C1 & Group C2 & Group E & Group F \\
\hline Plagioclase & 0 & 26 & 8 & 33 & 25 & 45 & 42 & 13 \\
\hline Clinopyroxene & 0 & 18 & 15 & 19 & 6 & 3 & 15 & 0 \\
\hline Orthopyroxene & 7 & 12 & 17 & 12 & 5 & 4 & 17 & 10 \\
\hline Olivine & 38 & 7 & 9 & 1 & 10 & 20 & 0 & 11 \\
\hline Amphibole & 56 & 37 & 44 & 35 & 52 & 26 & 20 & 63 \\
\hline Biotite & 0 & 0 & 2 & 0 & 0 & 1 & 0 & 0 \\
\hline Spinel & 0 & 0 & 0 & 0 & 2 & 1 & 0 & 2 \\
\hline Range & Group A1 & Group A2 & Group D & Group B & Group C1 & Group C2 & Group E & Group F \\
\hline Plagioclase & 0 & $0-50$ & $0-48$ & $0-49$ & $0-55$ & $0-96$ & $28-70$ & $0-45$ \\
\hline Clinopyroxene & 0 & $0-53$ & $0-50$ & $8-25$ & $0-35$ & $0-30$ & $0-20$ & 0 \\
\hline Orthopyroxene & $0-25$ & $0-25$ & $0-52$ & $0-20$ & $0-15$ & $0-20$ & $5-23$ & $0-40$ \\
\hline Olivine & $15-60$ & $0-70$ & $0-40$ & $0-5$ & $0-40$ & $0-70$ & 0 & $0-46$ \\
\hline Amphibole & $39-80$ & $2-70$ & $0-70$ & $15-84$ & $20-90$ & $4-50$ & $0-32$ & $45-80$ \\
\hline Biotite & 0 & $0-4$ & $0-15$ & 0 & 0-trace & $0-5$ & 0 & 0 \\
\hline Spinel & $0-1$ & $0-4$ & $0-2$ & $0-3$ & $0-10$ & $0-5$ & 0 & $0-7$ \\
\hline
\end{tabular}


Chapter 6-Mineral Chemistry 


\subsection{Mineral Chemistry}

Geochemical groups mentioned below are defined on the basis of wholerock geochemistry (Chapter 7).

\subsubsection{Silicate Mineral Chemistry}

\subsubsection{Olivine}

Olivine compositions show limited variation within the same geochemical group (up to 9\% Fo variation, where "Fo" content equals the molar Mg/(Mg+Fe) ratio of olivine analyses). Within individual samples, olivine grains show little variation, with olivine compositions falling within a maximum of $1 \%$ Fo-content range. Groups D and C1 contain olivine with relatively low Fo content (64-73 Fo), group A1 contains olivine with relatively high Fo content (77-84 Fo), and olivine from Groups A2, C2, and F contain an intermediate Fo content (70-81 Fo). A summary of the ranges in Fo content within olivine from the various groups can be found in Table 6.1. Olivine analyses are reported in Appendix III.

$\mathrm{Ni}$ concentration does not correlate with Fo content, however, olivine analyses from each group form a distinct field in Fo-Ni space (illustrated in Figure 6.1). Groups $\mathrm{D}$ and $\mathrm{A} 1$ contain relatively high-Ni olivine (1780-3020 ppm), Groups C1 and C2 contain relatively low-Ni olivine (190-1330 ppm), and group F contains olivine with intermediate Ni contents (1370-1850 ppm). Olivine analyzed from Group A2 falls in all three categories of $\mathrm{Ni}$ content. Olivine grains that have compositions that fall outside the field of igneous olivine may be: (1) of metamorphic origin; (2) derived from magmas in which sulphide saturation was 
achieved prior to olivine crystallization; or (3) derived from magmas which reequilibrated with Ni-sulphide prior to olivine fractionation. This includes all olivine analyzed from group C2 (metamorphic or crystallization after sulphide saturation), most olivine from Group D (metamorphic or crystallization after sulphide re-equilibration), and two olivine from Group A2 (metamorphic or crystallization after sulphide saturation).

$\mathrm{MnO}$ negatively correlates with Fo content in olivine (Figure 6.2), as is expected with fractionation as $\mathrm{Mn}^{2+}$ substitutes readily for $\mathrm{Fe}^{2+}$ in minerals (Ure and Berrow, 1982). Groups D and C1 contain relatively high MnO content (0.31-0.47 wt.\%), Group A1 contains relatively low MnO content (0.25-0.34 wt. $\%$, and Groups F and C2 contain intermediate MnO content (0.28-0.39 wt.\%). Group A2 spans the three divisions (0.22-0.42 wt.\%).

\subsubsection{Clinopyroxene}

Clinopyroxene is Ca-rich and almost exclusively diopside (Figure 6.3). The diopside ( $\mathrm{Di}$ ) content ranges from 49-89\%Di. Cr contents generally range from 0 to 920 ppm, and as high as 3810 ppm. All clinopyroxene grains contain low, but variable amounts of $\mathrm{Al}_{2} \mathrm{O}_{3}\left(0.65-3.95\right.$ wt.\%), $\mathrm{TiO}_{2}\left(0.03-0.57\right.$ wt.\%), and $\mathrm{Na}_{2} \mathrm{O}$ (<0.51 wt.\%). The diopside and chromium content of clinopyroxene in the various geochemical groups is provided in Table 6.2. Clinopyroxene analyses are reported in Appendix III. 


\subsubsection{Orthopyroxene}

The enstatite $(\mathrm{En})$ content of orthopyroxene ranges from 45-81\%En (Figure 6.4). The pyroxene is characterized by a small range in $\mathrm{CaO}(0.17-0.87$ wt.\%) and $\mathrm{Al}_{2} \mathrm{O}_{3}(0.67-3.73$ wt. $\%)$, and $\mathrm{MnO}$ content generally varies between $0.25-0.87$ wt.\%. Enstatite also has low $\mathrm{TiO}_{2}\left(<0.23\right.$ wt.\%) and $\mathrm{Na}_{2} \mathrm{O}(<0.04$ wt.\%), with no clear correlation with Mg\# (not shown). The enstatite and chromium content of orthopyroxene from the various geochemical groups are presented in Table 6.3. Orthopyroxene analyses are reported in Appendix III.

\subsubsection{Amphibole}

Amphibole forms two separate trends on the Leake (1978) amphibole classification diagram (Figure 6.5). Amphibole from mafic rocks trends in composition from magnesiohornblende to tschermakite. Amphibole from ultramafic rocks forms a trend at a higher Mg\#, from actinolite through magnesiohornblende to tschermakite, and from actinolite through magnesiohornblende, ferrohornblende to ferrotschermakite. The Si content ranges from 6.03 to 7.66 [atoms per formula unit (apfu)], and Mg\# ranges from greatly from 33-89. $\mathrm{Cr}_{2} \mathrm{O}_{3}$ in hornblende is generally $<0.78$ wt.\%, except for Group A1, which shows a range from 0.52 to 0.78 wt. $\%$. $\mathrm{TiO}_{2}$ shows a negative correlation with Mg\#, ranging from 0.07 up to 2.85 wt.\%. Amphibole analyses are reported in Appendix III. 


\subsubsection{Plagioclase}

Anorthite (An) content ranges from 38 (andesine) to 99\% (pure anorthite), however, the majority of plagioclase grains analyzed have labradorite, bytownite, and anorthite compositions (Figure 6.6). In differentiated basic rocks, the range in An-content of plagioclase is normally restricted between An30 and An85 (Gribble \& Hall, 1992), suggesting that the more anorthitic compositions are metamorphic. Phinney \& Halls (2001) noted that high-An content $\left(A n_{80-85}\right)$ of plagioclase megacrysts indicates the melts experienced a protracted stay in crustal magma chambers $<10$ kbar. This suggests that plagioclase in select samples from Groups A2, C1, C2, D and F are may be igneous in origin, however, they are most likely reflect the high degree of metamorphism achieved. Groups A2 and D exhibit the greatest variability in An-content, spanning compositions from andesine to anorthite. Group C2 spans compositions from labradorite through anorthite. Group B is confined to labradorite compositions, Group F grains all fall within the bytownite field, and Group C1 is almost exclusively anorthitic. The An content content of plagioclase from the various geochemical groups, is presented in Table 6.4. Plagioclase analyses are reported in Appendix III.

\subsubsection{Phlogopite}

Phlogopite grains analyzed (Figure 6.7) in a sample from Group C2 are distinctly richer in FeO ( 13 wt.\%) compared to the sample from Group D ( 7 wt. $\%$, respectively). Based on the classification from Deer et al. (1992), the micas fall in the eastonite field, an aluminous variety of phlogopite. Phlogopite analyses 
are reported in Appendix III.

\subsubsection{Oxide Mineralogy}

\subsubsection{Spinel}

The spinel grains are Al-rich and have an $\mathrm{MgO}$ content ranging between 11-17 wt.\%, as per Figure 6.8. Most grains plot in the spinel field, while four grains from Groups A1 and D are classified as hercynite (less Mg-rich). The Alrich character (Figure 6.9) of spinel is controlled by Al exchange with coexisting pyroxene. The low $\mathrm{Cr} /(\mathrm{Cr}+\mathrm{Al})$ ratio may result from spinel-clinopyroxene subsolidus exchange, which effectively exsolves significant amounts of Al from clinopyroxene resulting in highly aluminous spinel mineral phases (Sinton 1977; Barnes, 2001).

A positive correlation of $\mathrm{Al}_{2} \mathrm{O}_{3}$ with $\mathrm{MgO}$ content is observed. There is a narrow range in $\mathrm{Al}_{2} \mathrm{O}_{3}$ from $57-64$ wt.\%, with the exception of Group $\mathrm{A} 1$ spinel which has $\mathrm{Al}_{2} \mathrm{O}_{3}$ content as low as 48 wt. \%. Similarly, there is a relatively narrow range in $\mathrm{Cr}_{2} \mathrm{O}_{3}(0.02-4.26$ wt.\%), with the exception of Group A1 spinel which has $\mathrm{Cr}_{2} \mathrm{O}_{3}$ content as high as 16 wt.\%. $\mathrm{Cr} /(\mathrm{Cr}+\mathrm{Al})$ of spinel ranges between 0.00-0.05. Spinel analyses are reported in Appendix III.

\subsubsection{Ore Mineralogy}

Sulphide analyses are reported in Appendix III. 


\subsubsection{Pyrrhotite}

Fe and S contents of pyrrhotite range between 57-64 and 33-41 wt. \%, respectively. Ni values are highest is Groups D and C2, up to 1.23 wt.\%. Across all groups, trace amounts of $\mathrm{Cu}(<1550 \mathrm{ppm}), \mathrm{Zn}(<340 \mathrm{ppm})$, As (<200 ppm), and $\mathrm{Mn}(<270 \mathrm{ppm})$ are also present.

\subsubsection{Chalcopyrite}

$\mathrm{Fe}, \mathrm{S}$ and $\mathrm{Cu}$ contents in chalcopyrite ranges between 29-31, 33-35, and 33-36 wt.\%, respectively. Grains contain Co and Ni up to 1010 and 2690 ppm, respectively. Trace amounts of $\mathrm{Zn}$, As, and $\mathrm{Mn}$ reach levels of 2120, 990, and 220 ppm, respectively.

\subsubsection{Pentlandite}

Fe and $S$ contents in pentlandite range between $28-41 \%$ and $31-34 \%$, respectively, and Ni varies between $25-38$ wt. \%. Pentlandite grains from Groups $\mathrm{D}$ and $\mathrm{F}$ contain the highest \% of Ni. Co and Cu content is generally $<2.15$ wt.\% and $<1700$ ppm, respectively. Grains from Group B yield Co and Cu contents up to 13 wt.\% and 5140 ppm. Pentlandite grains also contain trace Zn (<520 ppm), As (<330 ppm), and $\mathrm{Mn}(<220 \mathrm{ppm})$.

\subsubsection{Pyrite}

Fe and $S$ contents in pyrite range between $45-48 \%$ and $52-54 \%$, respectively. Cobalt $(\mathrm{Co})$ is generally low $(<1280 \mathrm{ppm})$, but in the Killapait sill, 
pyrite grains are typically more Co-rich, up to 1.12 wt.\% Co. All pyrite grains contain at least some amount of $\mathrm{Ni}(<1610 \mathrm{ppm})$, and half contain some amount of $\mathrm{Cu}(<280 \mathrm{ppm})$. There are also trace amounts of $\mathrm{Zn}(<240 \mathrm{ppm})$, As $(<100$ ppm), and $\mathrm{Mn}$ (<60 ppm). Pyrite is devoid of $\mathrm{Pb}, \mathrm{Sb}$ and $\mathrm{Cd}$.

\subsubsection{Mineralogy of Detailed Sample Transects Across Two Mafic-Ultramafic}

\section{Sills}

\subsubsection{Chidliak mafic-ultramafic sill}

Mineral chemistry variation throughout the Chidliak sill is illustrated in Figure 6.10. Going up through the magmatic section, assuming a basal pyroxenite overlain by peridotite and capped by gabbro, there is a marked increase in the En-content of orthopyroxene, Fo-content of olivine, and $\mathrm{Mg \#}$ of spinel. Conversely, there is a progressive decrease in the An-content of plagioclase. The Mg\# of amphibole increases within the basal pyroxenite unit, decreases through the transition into the overlying layered peridotite + pyroxenite unit, and continues to increase briefly followed by a decline into the hornblende gabbroic + noritic portion of the sill. Given that these assemblages are metamorphic, the chemistry of any single mineral phase is likely reflective of the overall bulk chemistry of the sample, as opposed to being representative of the chemistry of primary mineral phases crystallizing from a magma. Thus, mineral chemistry variation with height in the sill is suggested to merely reflect bulk geochemistry.

\subsubsection{Killapait mafic-ultramafic sill}


Mineral chemistry variation throughout the Killapait sill is illustrated in Figure 6.11. Going up magmatic section, there is an overall decrease in the Fo-content of olivine, An-content of plagioclase and Mg\# of amphibole. There is an increase in the En-component of orthopyroxene. There is no consistent trend apparent in the variation of the $\mathrm{Mg \#}$ of spinel and $\mathrm{Di}$-component of clinopyroxene.

Where geochemical trends with height in the sill are apparent, these are suggested to be coincidental, based on the interpretation that the Killapait sill formed through multiple intrusions of geochemically distinct magma types. 


\section{References}

Bucher, K. and Grapes, R. (2011). Petrogenesis of Metamorphic Rocks. Springer-Verlag Berlin Heidelberg: pp. 191-224 \& 339-393. ISBN: 978-3-540-74168-8.

Deer, W. A., Howie, R. A., and Zussman J. (1963). Rock-forming Minerals, 5, Non-silicates. Longmans, London.

Deer WA, Howie A and Zussman J. (1986). An interdiction to rock- forming Minerals, 17th edition. Longman Ltd, UK, 528.

Deer, W.A.; Howie, R.A.; Zussman, J. (1992). An introduction to the rock forming minerals. Engleand Editors. Longamn Scientific and Technical: 695 p. Harlow.

Gribble, C.D. and Hall, A.J. (1992). Optical Mineralogy: Principles and Practice. UCL Press, London, 303 pp.

Leake, B.E., Woolley, A.R., Arps, C.E.S., Birch, W.D., Gilbert, M.C., Grice, J.D., Hawthrone, F.C., Kato, A., Kisch, H.J., Krivovischev, V.G., Linthout, K., Laird, J., Mandarino, J.A., Maresch, W.V., Nickel, E.H., Rock, N.M.S., Schumacher, J.C., Smith, D.C., Stephenson, N.C.N., Ungaretti, L., Whittaker, E.J.W. \& Youzhi, G. (1997). Nomenclature of amphiboles: Report of the subcommittee on amphiboles on the International Mineralogical Association, Commission on new minerals and mineral names. American Mineralogist 82, 1019-1037.

Morimoto, N., Fabries, J., Ferguson, A. K., Ginzburg, I. V., Ross, M.,Seifert, F. A., Zussman, J., Aoki, K. \& Gottardi, G. (1988). Nomenclature of pyroxenes: 
Report of the Subcommittee on Pyroxenes of the International Mineralogical Association, Commission on New Minerals and Mineral Names. American Mineralogist 73, 1123-1133.

Phinney, Wm.C., and Halls, H.C. (2001). Petrogenesis of the Early Proterozoic Matachewan dyke swarm, Canada, and implications for magma emplacement and subsequent deformation. Canadian Journal of Earth Sciences 38: 1541-1563.

Simkin, T. and Smith, J.V. (1970). Minor element distribution in olivine. Journal of Geology, 78, 304-325.

St-Onge, M.R., Wodicka, N. and ljewliw, O. (2007). Polymetamorphic evolution of the Trans Hudson Orogen, Baffin Island, Canada: Integration of petrological, structural and geochronological data; Journal of Petrology, v. 48, p. 271- 302. doi:10.1093/petrology/eg1060.

Ure, A.M. and Berrow, M.L. (1982). The elemental constituents of soils. In: Bowen HJM (ed) Environmental chemistry. Royal Society of Chemistry, London, pp 94-203.

Whitney, D.L., and Evans, B.W. (2010). American Mineralogist, Volume 95, pages 185-187. 


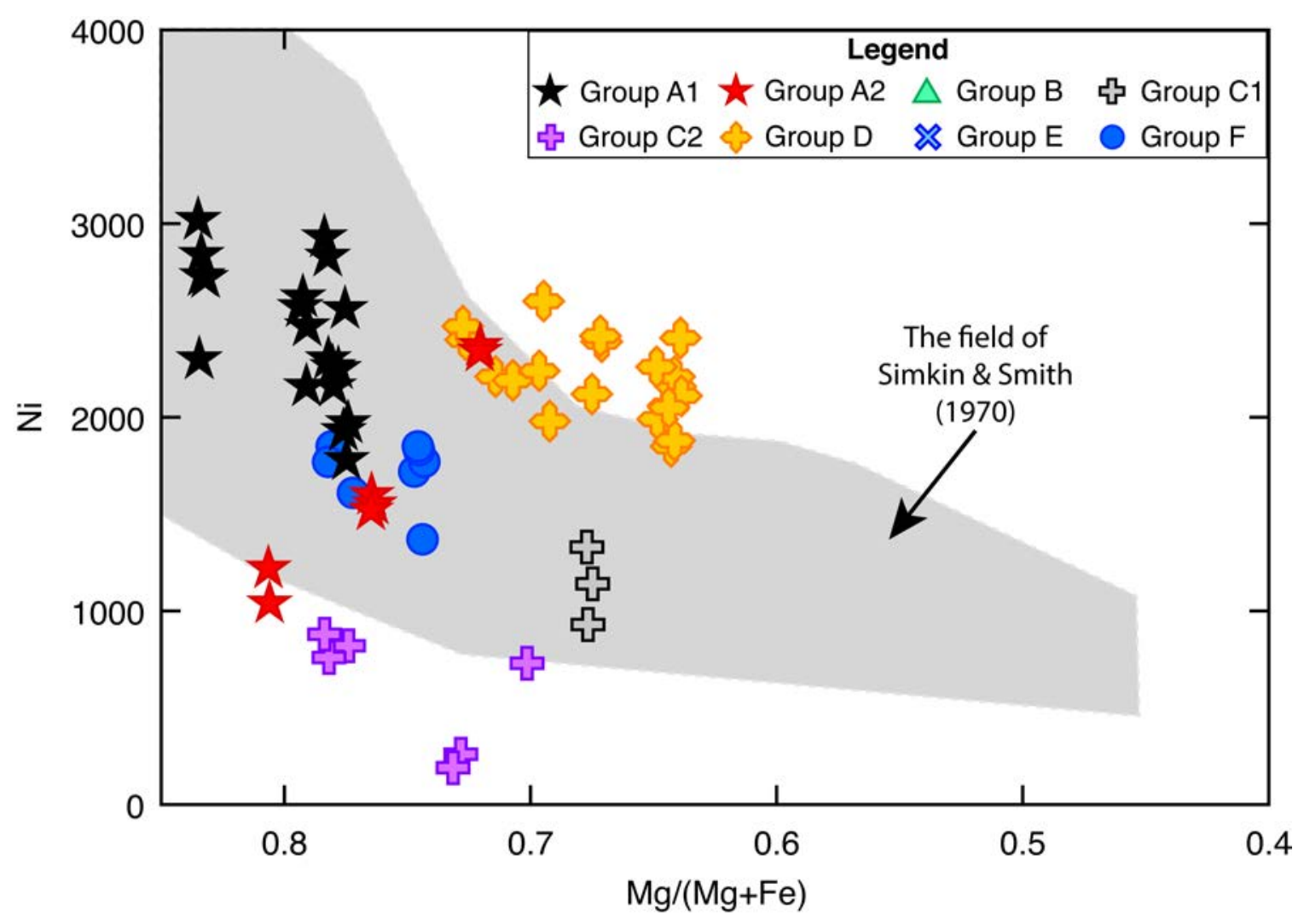

Figure 6.1: Bivariate plot illustrating the changes in Ni content (ppm) with respect to forsterite (Fo) content in olivine. Overlain on this plot is the Simkin and Smith (1970) field for olivine in layered intrusions. Symbols indicate which geochemical group (groups defined in Chapter 7) the olivine grain belongs to. 


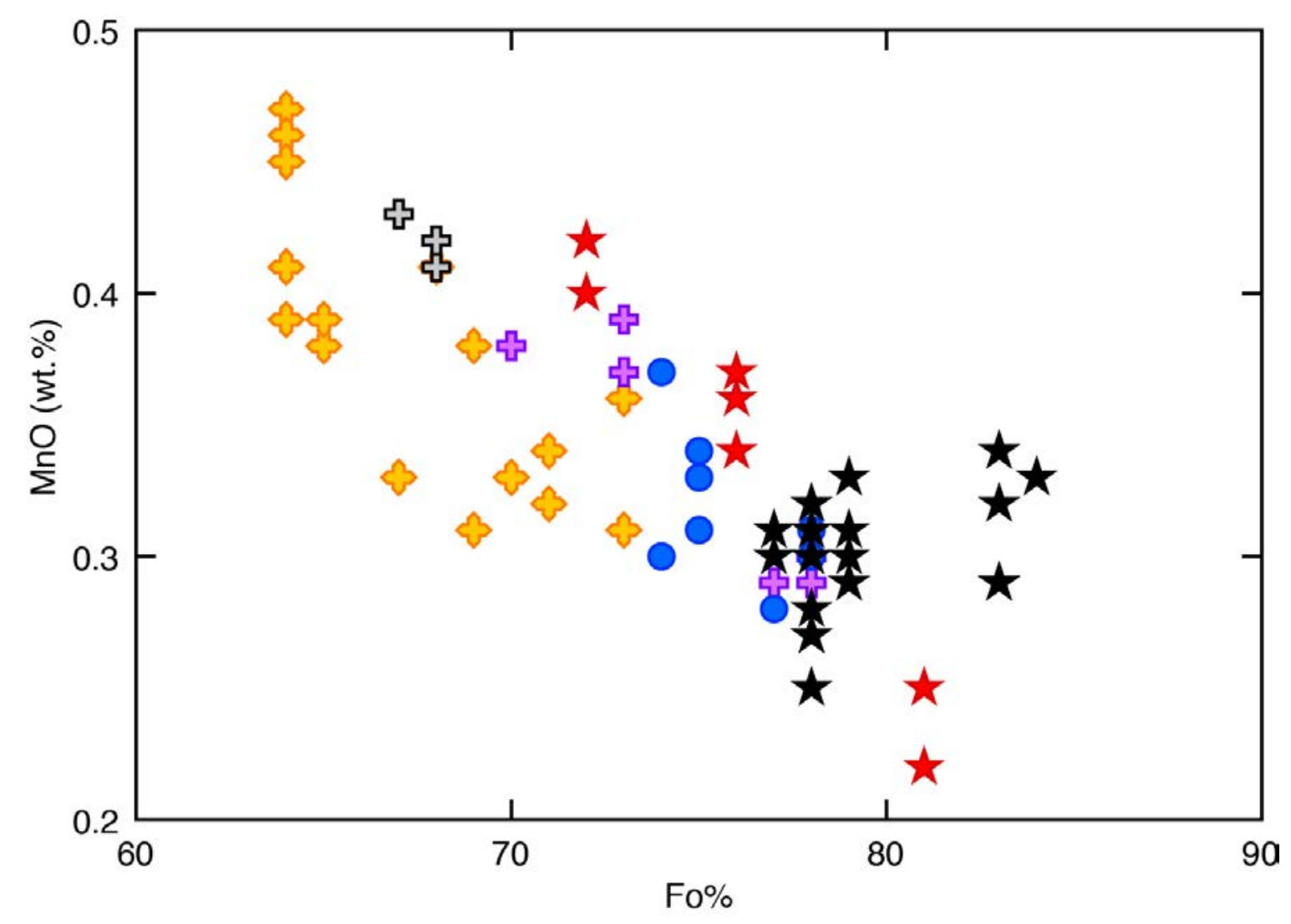

Figure 6.2: Bivariate plot illustrating the increase in $\mathrm{MnO}$ content (wt.\%) with decreasing forsterite (Fo) content in olivine. Symbols indicate which geochemical group (groups defined in Chapter 7) the olivine grain belongs to. 
Figure 6.3: Compositional range of calcic clinopyroxene from sills sampled throughout southern Baffin Island (sample locations provided on Figures 2.8 \& 2.9). Symbols indicate which geochemical group (groups defined in Chapter 7) the clinopyroxene grain belongs to. Diagram from Morimoto et al. (1988). 

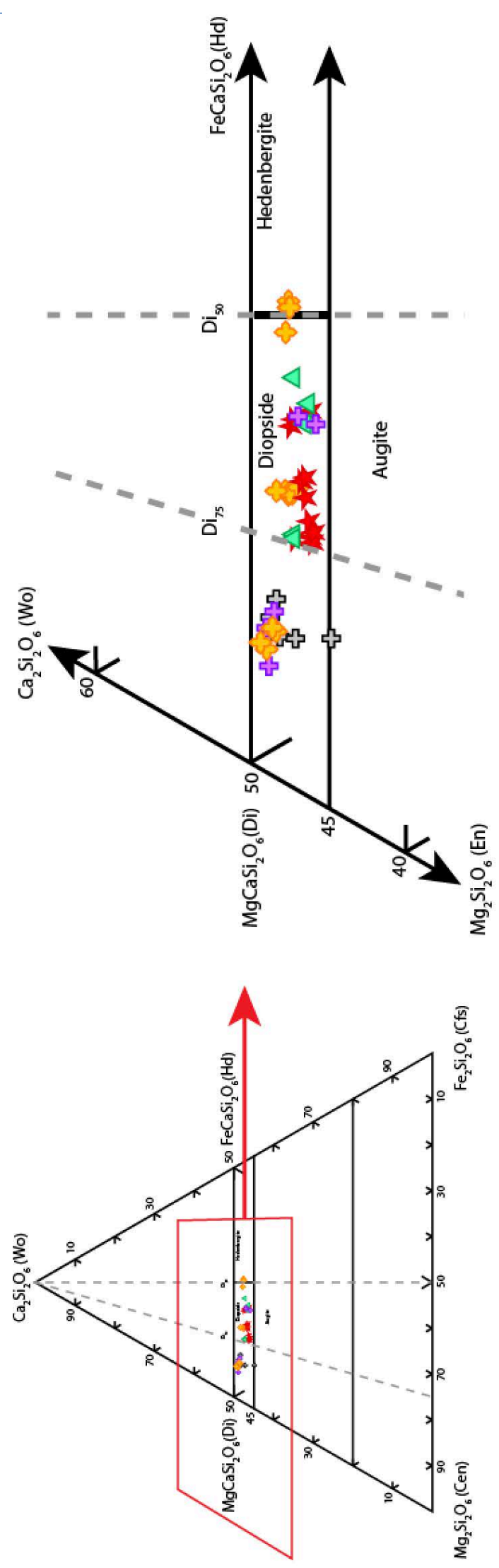
Figure 6.4: Compositional range of the orthopyroxene from sills sampled throughout southern Baffin Island. Symbols indicate which geochemical group (groups defined in Chapter 7) the orthopyroxene belongs to. Diagram from Morimoto et al. (1988). 

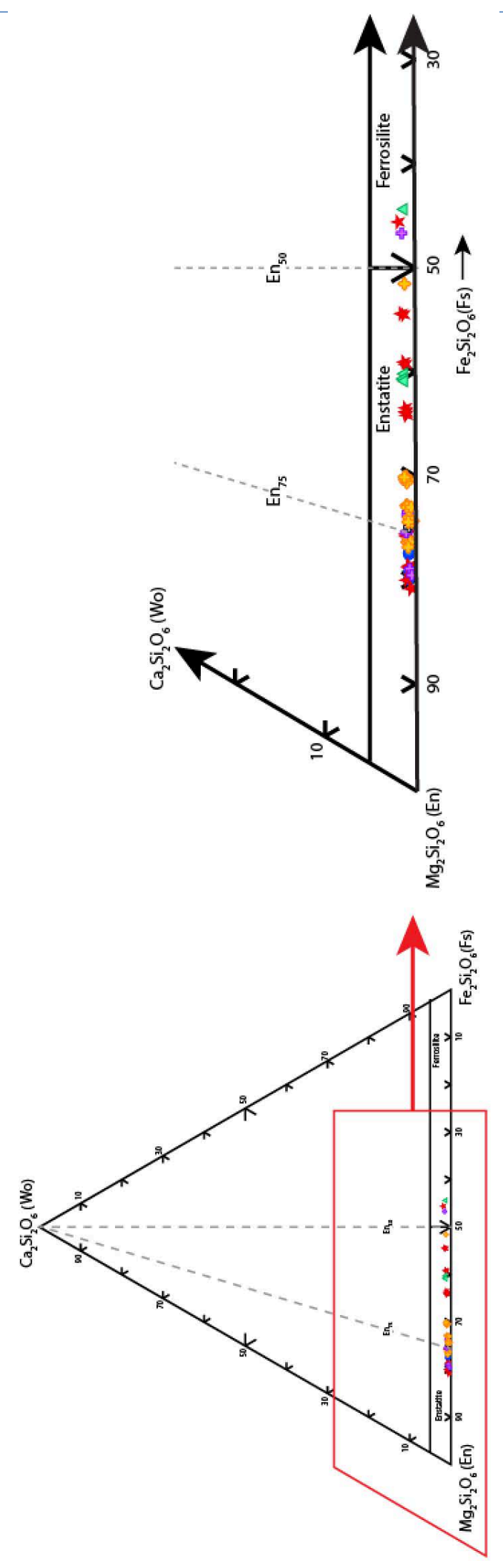
Figure 6.5: Classification of amphibole from Leake et al. (1997). Amphibole compositions define two separate trends: amphibole from mafic rocks trend from magnesiohornblende to tschermakite. Amphibole from ultramafic rocks define a higher Mg\# trend from actinolite through magnesiohornblende to tschermakite, and from actinolite through magnesiohornblende, ferrohornblende to ferrotschermakite. Symbols indicate which geochemical group (groups defined in Chapter 7) the amphibole grain belongs to. 


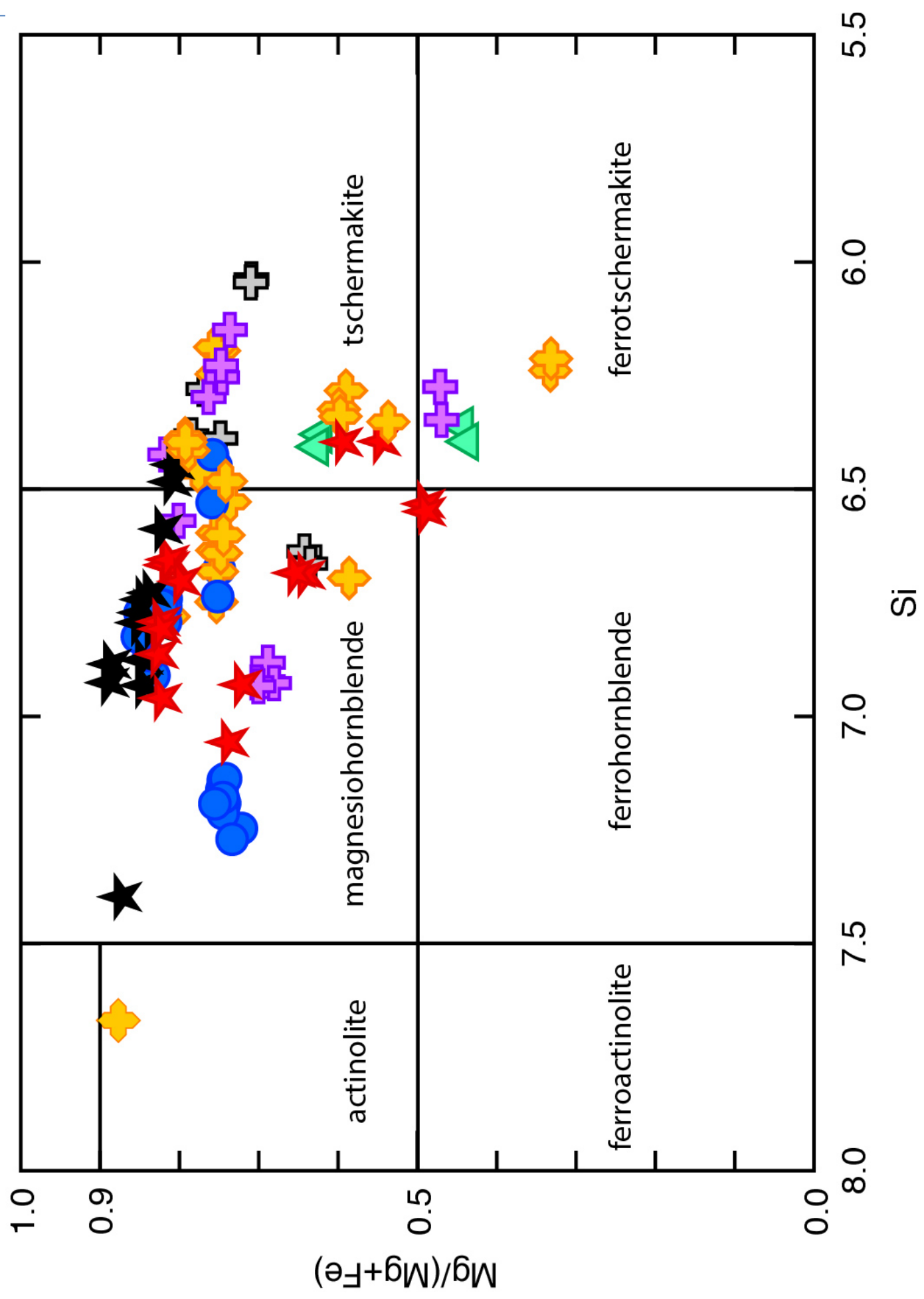


Figure 6.6: Classification of plagioclase from sills sampled through southern Baffin Island (after Deer et al., 1963). Symbols indicate which geochemical group (groups defined in Chapter 7) the plagioclase belongs to. 


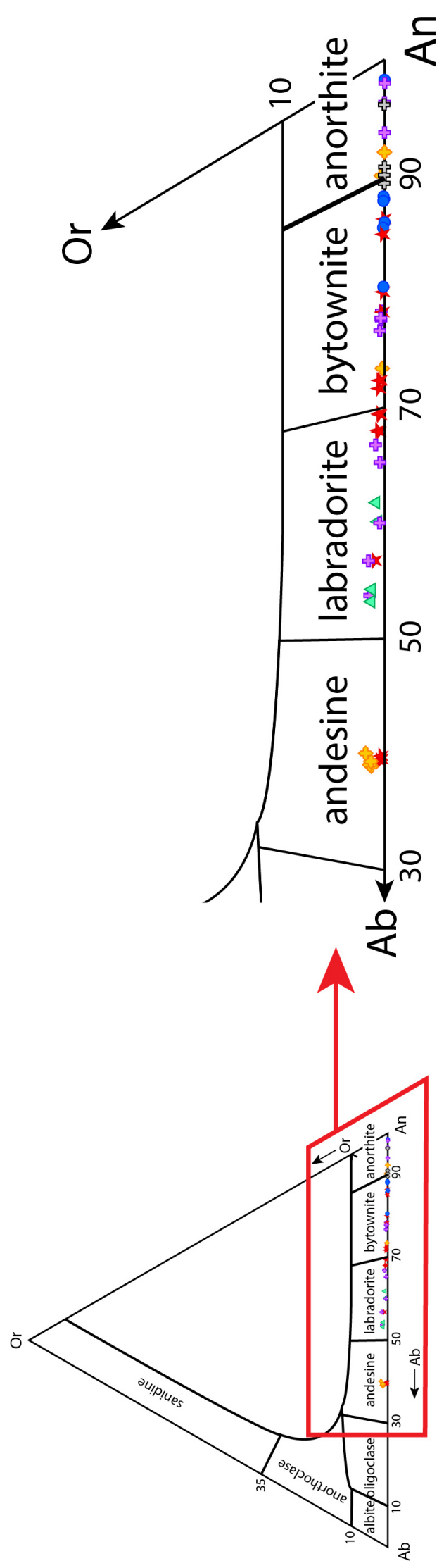


Figure 6.7: Compositional classification of phlogopite (after Deer et al., 1992). Phlogopite shows an eastonite affinity (Al-rich phlogopite). Symbols indicate which geochemical group (groups defined in Chapter 7) the phlogopite grain belongs to. 


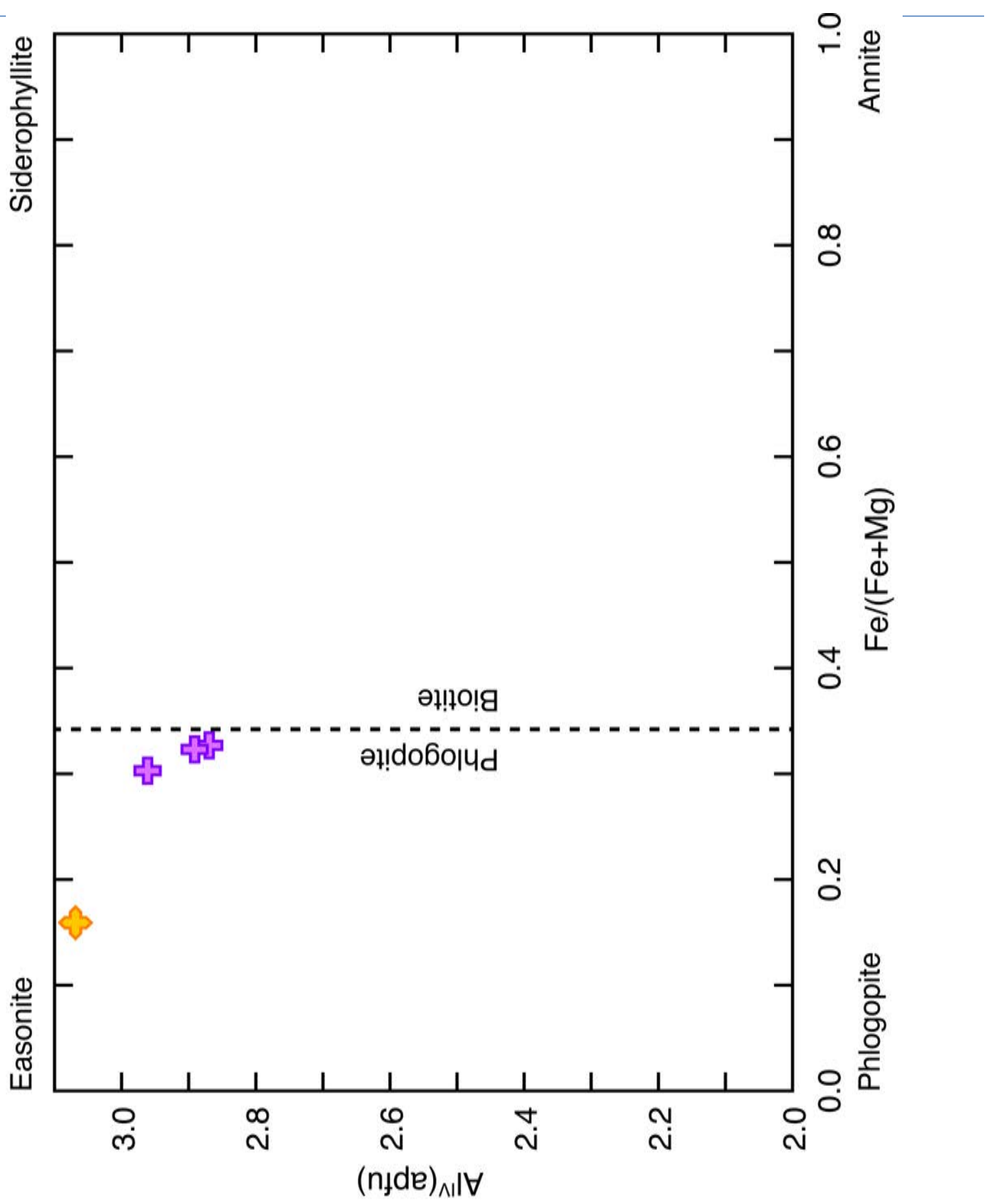


Figure 6.8: Classification of spinel from sills sampled throughout southern Baffin Island (after Deer et al., 1992), showing the spinel to hercynitic character. Symbols indicate which geochemical group (groups defined in Chapter 7) the spinel belongs to. 


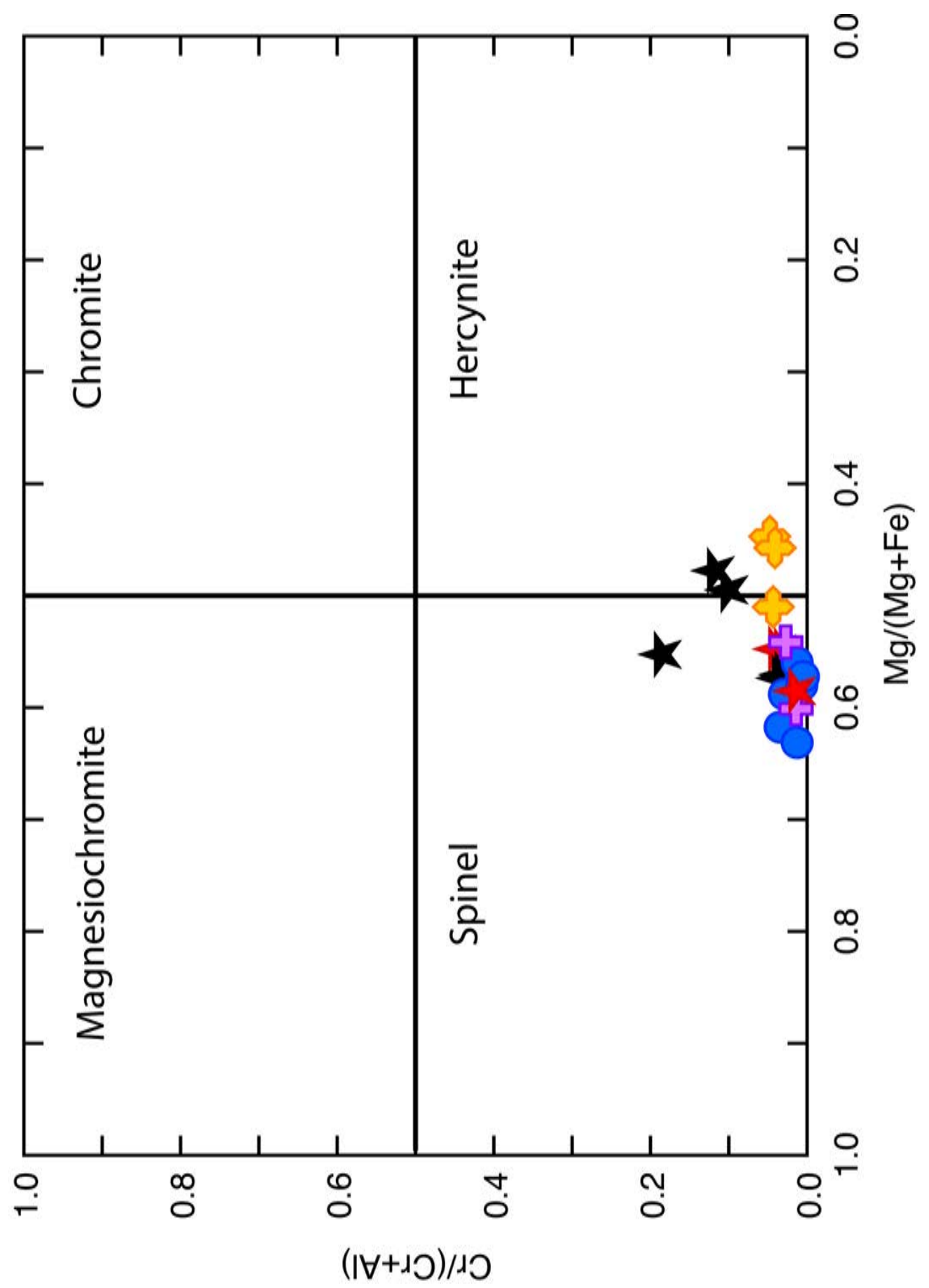




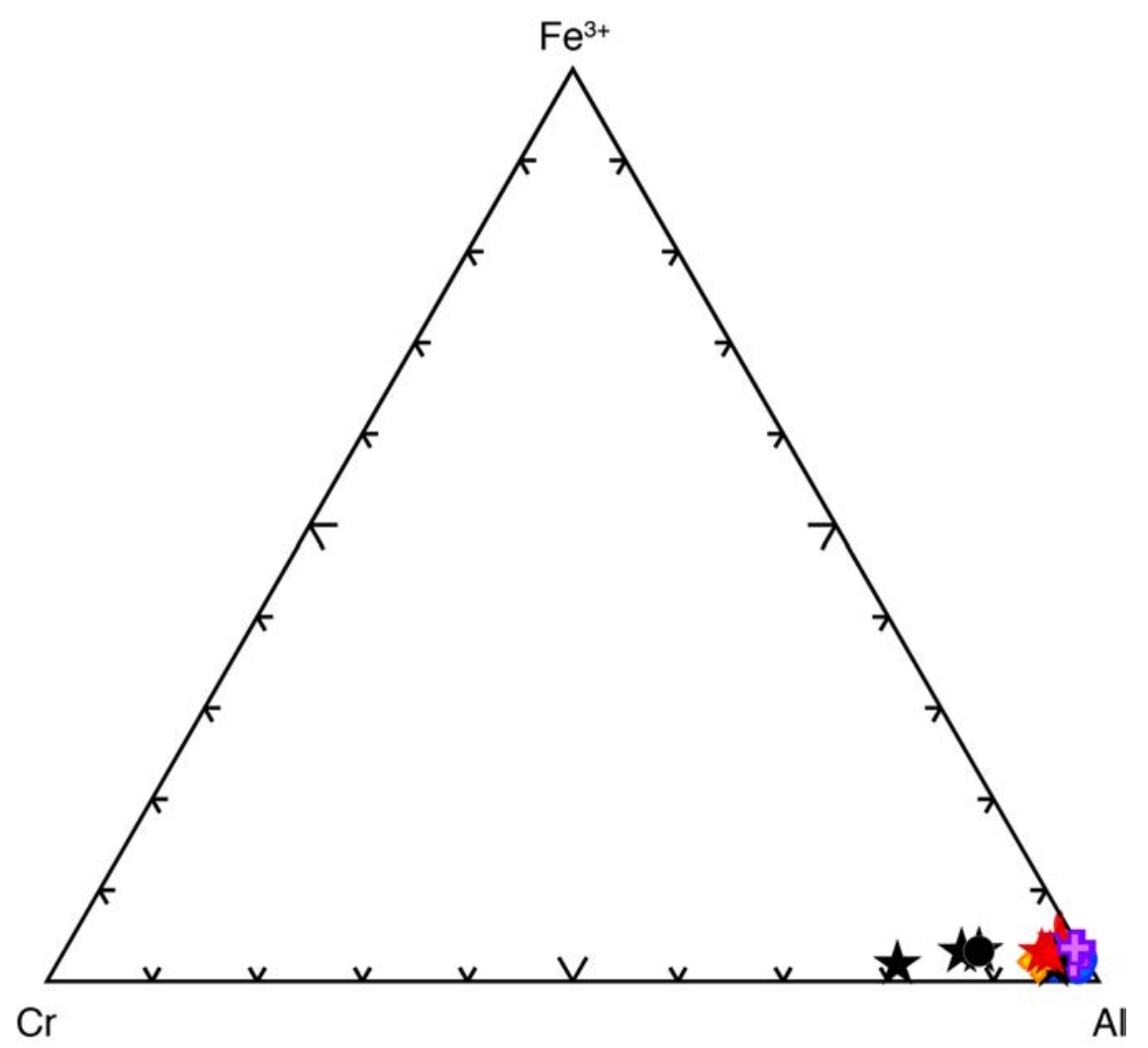

Figure 6.9: $\mathrm{Cr}_{-} \mathrm{Fe}^{3+-} \mathrm{Al}$ ternary plot of spinel mineral chemistry from samples of sills collected from southern Baffin Island, illustrating their Al-rich character. Symbols indicate which geochemical group (groups defined in Chapter 7) the spinel grain belongs to. 
Table 6.1: Ranges in forsterite (\%) and $\mathrm{Ni}(\mathrm{ppm})$ content in olivine from mafic and ultramafic rocks for each geochemical groups (groups defined in Chapter 7). "N/ A" (not available) signifies olivine absent; "Not Analyzed" indicates that the mineral is present but was not analyzed.

\begin{tabular}{|l|l|l|l|l|l|}
\hline Mineral & Geochemical & \multicolumn{2}{|c|}{ Mafic } & \multicolumn{2}{c|}{ Ultramafic } \\
\hline Olivine & & \multicolumn{1}{|c|}{ Fo (\%) } & \multicolumn{1}{|c|}{ Ni (ppm) } & \multicolumn{1}{c|}{ Fo (\%) } & Ni (ppm) \\
\hline & Group A1 & N/A & N/A & $77-84(n=5)$ & $1780-3020(n=5)$ \\
\hline & Group A2 & Not Analyzed & Not Analyzed & $72-81(n=3)$ & $1040-2370(n=3)$ \\
\hline & Group B & Not Analyzed & Not Analyzed & N/A & N/A \\
\hline & Group C1 & N/A & N/A & $67-68(n=1)$ & $930-1330(n=1)$ \\
\hline & Group C2 & $70-73(n=2)$ & $190-730(n=2)$ & $77-78(n=1)$ & $760-880(n=1)$ \\
\hline & Group D & N/A & N/A & $64-73(n=6)$ & $1850-2600(n=6)$ \\
\hline & Group E & N/A & N/A & N/A & N/A \\
\hline & Group F & N/A & N/A & $74-78(n=4)$ & $1370-1850(n=4)$ \\
\hline
\end{tabular}


Table 6.2: Range in diopside (\%) and $\mathrm{Cr}(\mathrm{ppm})$ content of calcic clinopyroxene grains from mafic and ultramafic rocks of each geochemical groups (groups defined in Chapter 7). "N/A" signifies clinopyroxene absent; "Not Analyzed" indicates that the mineral is present but was not analyzed.

\begin{tabular}{|l|l|l|l|l|l|}
\hline \multirow{2}{*}{$\begin{array}{l}\text { Mineral } \\
\text { Group }\end{array}$} & \multicolumn{2}{|c|}{ Mafic } & \multicolumn{2}{c|}{ Ultramafic } \\
\hline Clinopyroxene & & \multicolumn{1}{|c|}{ Di (\%) } & \multicolumn{1}{|c|}{ Cr (ppm) } & \multicolumn{1}{c|}{ Di (\%) } & Cr (ppm) \\
\hline & Group A1 & N/A & N/A & N/A & N/A \\
\hline & Group A2 & $60-74(n=3)$ & $40-780(n=3)$ & N/A & N/A \\
\hline & Group B & $59-74(n=2)$ & $0-220(n=2)$ & N/A & N/A \\
\hline & Group C1 & N/A & N/A & $81-85(n=2)$ & $1100-3810(n=2)$ \\
\hline & Group C2 & $61-85(n=1)$ & $50-260(n=1)$ & $89(n=1)$ & $20(n=1)$ \\
\hline & Group D & $42-69(n=3)$ & $0-920(n=3)$ & $84-87(n=2)$ & $220-670(n=2)$ \\
\hline & Group E & Not Analyzed & Not Analyzed & N/A & N/A \\
\hline & Group F & N/A & N/A & N/A & N/A \\
\hline
\end{tabular}


Table 6.3: Range in enstatite (En\%) and $\mathrm{Cr}(\mathrm{ppm})$ content of orthopyroxene from mafic and ultramafic rocks from each geochemical groups (groups defined in Chapter 7). "N/A" signifies orthopyroxene absent; "Not Analyzed" indicates that the mineral is present but was not analyzed.

\begin{tabular}{|l|l|l|l|l|l|}
\hline Mineral & Geochemical & \multicolumn{3}{|c|}{ Mafic } & \multicolumn{2}{c|}{ Ultramafic } \\
\hline Orthopyroxene & & \multicolumn{1}{|c|}{ En (\%) } & \multicolumn{1}{|c|}{ Cr (ppm) } & \multicolumn{1}{c|}{ En (\%) } & Cr (ppm) \\
\hline & Group A1 & N/A & N/A & $81(n=1)$ & $1010(n=1)$ \\
\hline & Group A2 & $46-65(n=4)$ & $0-560(n=4)$ & $76-81(n=3)$ & $0-1020(n=3)$ \\
\hline & Group B & $45-61(n=2)$ & $0-100(n=2)$ & N/A & N/A \\
\hline & Group C1 & Not Analyzed & Not Analyzed & $75(n=2)$ & $100-180(n=2)$ \\
\hline & Group C2 & $47-76(n=3)$ & $0-230(n=3)$ & $79-80(n=1)$ & $270-450(n=2)$ \\
\hline & Group D & $52(n=1)$ & $160(n=1)$ & $71-77(n=6)$ & $290-950(n=6)$ \\
\hline & Group E & Not Analyzed & Not Analyzed & N/A & N/A \\
\hline & Group F & Not Analyzed & Not Analyzed & $78-81(n=4)$ & $0-300(n=4)$ \\
\hline
\end{tabular}


Table 6.4: Ranges in anorthite (\%) content of plagioclase from mafic and ultramafic rocks from each geochemical group (groups defined in Chapter 7). "N/ A" signifies plagioclase absent; "Not Analyzed" indicates that the mineral is present but was not analyzed.

\begin{tabular}{|l|l|l|l|}
\hline Mineral & $\begin{array}{l}|c| \\
\text { Group }\end{array}$ & \multicolumn{1}{|c|}{ Mafic $(\%)$} & Ultramafic \\
\hline Plagioclase & & N/A & An (\%) \\
\hline & Group A1 & $39-86(n=4)$ & N/A \\
\hline & Group A2 & $53-61(n=2)$ & N/A \\
\hline & Group B & $90-96(n=1)$ & N/A \\
\hline & Group C1 & $53-99(n=6)$ & N/A \\
\hline & Group C2 & $38-92(n=2)$ & Not Analyzed \\
\hline & Group D & Not Analyzed & N/A \\
\hline & Group E & $81-99(n=2)$ & $99(n=1)$ \\
\hline
\end{tabular}


Chapter 7 - Geochemistry 


\subsection{Whole Rock Geochemistry}

The sills of southern Baffin Island have had a long history of metamorphism and deformation (Chapter 3). As a result, the rock units have been recrystallized, forming polygonal grains in most cases, and primary igneous textures have been obliterated (Chapter 5), with a few rare exceptions. This makes recognizing cumulate vs non-cumulate units extremely difficult. However, certain trace elements can be used to infer accumulation or removal of specific mineral phases from the magma, based on anomalies present in normalized trace element diagrams. To negate the effects of fractional crystallization, trace element ratios and patterns are primarily utilized for geochemical discrimination, from which eight geochemical groups are defined (see legend in Figure 7.1, and geochemical discrimination in Figure 7.3)

A significant number of samples (i.e. 79 samples) were utilized in the study of the suite of sills, however, as exhibited to by the layered Killapait sill, there is potential for vast differences in the trace element geochemistry within a single sill. Given that only one or two samples were collected from the majority of sills sampled, there is a relatively high probability that many of the layered sills contain additional geochemical signatures that were not recognized due to lack of detailed sampling. For these reasons, it is quite challenging to understand the relationship between the different geochemical groups and the magmatic processes that occurred on a sill-scale. 


\subsubsection{Element mobility}

Given that the supracrustal rocks of southern Baffin Island have experienced amphibolite to granulite facies metamorphism, it is essential to consider the effects of secondary remobilization of elements and oxides. To assess element mobility, the method of Cann (1970) was implemented, whereby the elements to be evaluated are plotted in separate bivariate diagrams against a generally accepted immobile element (e.g., $\mathrm{Zr}$ used in this study). If both variables are incompatible during fractionation, and remain immobile through metamorphism, samples from suites of igneous rocks derived from the same mantle source should produce straight lines. A large degree of scatter indicates that one of the elements was mobile and secondary processes have altered its concentration. Alternatively, scatter may indicate the samples are unrelated, or that one of the samples represents a cumulate, with higher or lower concentrations of that that particular element.

Incompatible elements generally considered to be immobile (e.g., Ti, Y, P) form coherent trends with small degrees of scatter (Figure 7.2a-c). However, most large-ion lithophile elements (LILE; e.g., $\mathrm{Ba}, \mathrm{Rb}, \mathrm{Pb}^{2+}, \mathrm{Sr}, \mathrm{Cs}, \mathrm{K}$ ) show significant scatter (Figure 7.2d-f). The coherent patterns observed in chondritenormalized rare-earth elements (REE) diagrams (Figure 7.3a) and primitive mantle-normalized spider diagrams (Figure 7.3b) further support the limited mobility of the aforementioned immobile geochemical constituents. This suggests limited remobilization of these elements due to metamorphism or metasomatism. 
These observations are consistent with numerous other geochemical studies on high-grade Archean rocks that indicate the major elements $\mathrm{Al}, \mathrm{Ti}, \mathrm{Fe}$ and $\mathrm{P}$, the high-field-strength elements (HFSE; Th, Nb,Ta, $\mathrm{Zr}, \mathrm{Hf}$ ), the REE (except $\mathrm{Eu})$, transition metals $(\mathrm{Cr}, \mathrm{Ni}, \mathrm{Sc}, \mathrm{V})$, and $\mathrm{Y}$ are relatively immobile during metamorphism and alteration (e.g. Winchester and Floyd, 1976; Sun and Nesbitt, 1978; Ludden et al., 1982; Arndt and Nesbitt, 1982, Jochum et al., 1991; Lafleche et al., 1992a; Arndt, 1994; Condie, 1994; Barley et al., 2000; Hanski et al., 2001; Shimizu et al., 2004; Arndt, 2008). A number of studies also demonstrate that, in contrast, LILE (e.g., $\mathrm{Cs}, \mathrm{Na}, \mathrm{K}, \mathrm{Rb}, \mathrm{Ba}, \mathrm{Ca}, \mathrm{Pb}, \mathrm{Sr}$ ) are often mobile during metamorphism and alteration (Lesher et al., 2001; Arndt, 2008). Accordingly, this study will focus mostly on elements and oxides that appear to have been immobile during the high-grade regional metamorphism.

\subsubsection{Classification through chondrite-normalized rare-earth element plots}

Samples from the mafic and ultramafic units of various sills throughout most of southern Baffin Island were discriminated into eight unique geochemical groups (Figure 7.1) on the basis of a variety of geochemical diagrams, but primarily by chondrite-normalized rare-earth element diagrams (Figure 7.3a). The few samples that displayed a unique chondrite-normalized REE patterns were removed from the dataset. Further refinement was conducted on the basis of sample relationships on a number of immobile-element-based bivariate and trivariate diagrams (i.e. $>50$ ), some of which are shown. This refinement removed samples that consistently did not plot with, or form trends with, the other samples 
designated to same geochemical group. Furthermore, every group, contains both mafic and ultramafic samples, with the exception of Groups A1 and E, which contain only ultramafic and mafic units, respectively. In many cases, multiple geochemical groups exist in the same sill. Table 7.1 contains information on the occurrences of the various geochemical groups within the different types of sills.

Based on number of occurrences and their spatial distribution, Group D (high- $\mathrm{TiO}_{2}$ group) and Groups $\mathrm{A} 1$ and $\mathrm{A} 2$ (low- $-\mathrm{TiO}_{2}$ groups) are considered to be major constituents of Frobisher suite magmatism, whereas Groups B, C1, C2, E and $\mathrm{F}$ are minor components. The samples within each group exhibit very similar patterns, indicating crystallization from magmas with broadly similar composition. Throughout the rest of this thesis, the samples will be described with respect to their assigned geochemical group.

The rare-earth elements (REEs) are considered to be immobile during metamorphism, but remobilization of the light rare-earth elements (LREE) may occur during high-flux passage of metasomatic fluids through rocks during metamorphism. However, metasomatism does not appear to have significantly affected LREE, given the general lack of scatter in the fractionation trends of most REE (Figure 7.2; most REE not shown). The resilience of this subgroup of high-field-strength elements (HFSE) is also illustrated in the consistency of patterns in chondrite-normalized REE diagrams (Figure 7.3a).

Group A1 exhibits a relatively flat REE chondrite-normalized REE pattern (very weakly LREE-enriched), similar to chondrite. Total REE contents vary from $\sim 5 \mathrm{x}$ to $8 \mathrm{x}$ chondrite, with normalized La/Yb ratios varying from $\sim 1.27$ to 1.70. 
Two samples have very minor negative Eu anomalies. Lithologically, this group is comprised of hornblendite $(n=4)$ and peridotite $(n=2)$ units from ultramafic and mafic-ultramafic sills.

Group $A 2$, similar to $A 1$, has a flat heavy rare-earth element (HREE) pattern, and exhibits increasing fractionation from middle rare-earth elements (MREEs) to LREEs. This pattern resembles E-MORB (Schilling, 1973). Total REE contents vary from $\sim 10 x$ to $39 x$ chondrite, with $L a / G d$ and $G d / Y b$ ratios varying from $\sim 1.18$ to 2.36 and $\sim 1.17$ to 1.62 , respectively. Half of the samples contain minor negative Eu anomalies. Lithologically, this group contains gabbro $(n=5)$, norite $(n=3)$, gabbronorite $(n=6)$, hornblendite $(n=2)$ and peridotite $(n=1)$ units from mafic, ultramafic and mafic-ultramafic sills.

Group D has a sinusoidal, enriched REE pattern with weakly fractionated LREE, and significantly more fractionated MREE to HREE, similar to average OIB. Total REE contents vary from $\sim 18 \mathrm{x}$ to $87 \mathrm{x}$ chondrite with $\mathrm{La} / \mathrm{Gd}$ and $\mathrm{Gd} / \mathrm{Yb}$ ratios $\sim 1.63$ to 3.68 and $\sim 2.02$ to 3.74 , respectively. Half of samples in this group exhibit either weak positive or weak negative Eu anomalies. Lithologically, this group contains gabbro $(n=2)$, gabbronorite $(n=2)$, pyroxenites $(n=2)$, peridotites $(n=1)$, and hornblendites $(n=7)$ from mafic, ultramafic, and mafic-ultramafic sills.

Group B's enriched REE pattern is characterized by a relatively flat HREE and moderately enriched LREE and MREE. Total REE contents vary from $\sim 5 x$ to 23x chondrite, with $\mathrm{La} / \mathrm{Gd}$ and $\mathrm{Gd} / \mathrm{Yb}$ ratios varying from $\sim 1.33$ to 1.63 and $\sim 2.86$ to 3.41 , respectively. Three samples have moderate negative Eu anomalies, which vary from weak to moderate. Lithologically, this group contains 
gabbronorite $(n=3)$, gabbro $(n=1)$ and hornblendite $(n=1)$ units from mafic and mafic-ultramafic sills. Most samples from this group exhibit positive Eu anomalies, indicating plagioclase accumulation.

Group $\mathrm{C} 1$ is characterized by its highly enriched REE pattern, where LREE to MREE are steep and the HREE are moderately inclined and undulating. Total REE contents vary from $\sim 12 x$ to $53 x$ chondrite, with La/Gd and $\mathrm{Gd} / \mathrm{Yb}$ ratios varying from $\sim 3.16$ to 6.74 and $\sim 2.32$ to 3.23 , respectively. Generally, the samples with higher REE concentrations contain negative Eu anomalies, and those with lower REE contents contain positive Eu anomalies. Lithologically, it contains gabbro $(n=5)$, gabbronorite $(n=6)$, hornblendite $(n=2)$ and peridotite $(n=1)$ units found within ultramafic and mafic-ultramafic sills.

Group C2, similar to $\mathrm{C} 1$, is also highly LREE enriched. Total REE contents vary from $\sim 3 x$ to $29 x$ chondrite, with $\mathrm{La} / \mathrm{Gd}$ and $\mathrm{Gd} / \mathrm{Yb}$ ratios varying from $\sim 5.87$ to 16.65 and $\sim 1.19$ to 3.24 , respectively. In some samples, HREE concentrations are below chondrite. All samples contain positive Eu anomalies, with the large majority with $\mathrm{Eu} / \mathrm{Eu}^{*}>1.6$ (up to 3.2 ). As the magma becomes more evolved, this anomaly becomes less pronounced. Lithologically, it comprises anorthosite $(n=1)$, gabbro $(n=6)$, norite $(n=2)$, gabbronorite $(n=1)$, and peridotite $(n=2)$ units from mafic and mafic-ultramafic sills.

Group E has a relatively flat, MORB-like REE pattern, all with distinctive major negative europium anomalies between 0.6-0.5 Eu/Eu*. Total REE contents vary from $\sim 13 x$ to $20 x$ chondrite, with La/Yb ratio $\sim 0.93$ to 1.57 . Lithologically, this 
group contains only gabbronorite $(n=3)$ units within mafic and mafic-ultramafic sills. Samples in this group exhibit significant Eu anomalies.

Group $F$ has a REE pattern in which samples become weakly enriched from LREE to HREE, typical of komatiitic magmas (e.g. Condie, 1976, 1981; Zhai \& Santosh, 2011). Total REE contents vary from 2x to 5x chondrite (lowest of all groups), with $\mathrm{La} / \mathrm{Yb}$ ratios $\sim-0.50$ to -1.29 . A number of samples display weak positive Eu anomalies and one is weakly negative. Lithologically, it contains gabbro $(n=2)$, norite $(n=1)$, hornblendite $(n=7)$, and peridotite $(n=1)$ units, and is found within mafic-ultramafic and ultramafic sills.

The relationships between the different patterns is illustrated in Figure 7.4, where the $(\mathrm{La} / \mathrm{Sm})_{N}$ ratio reflects the slope of the LREE and $(\mathrm{Gd} / \mathrm{Yb})_{N}$ reflects the slope of the MREE to HREE. In general, Groups $\mathrm{C} 1, \mathrm{C} 2$ and $\mathrm{D}$ have relatively high $\mathrm{Gd} / \mathrm{Yb}$ ratios ( 2 to 3.3), though Group C2 samples fall as low as 1.2. Within this range, there is a significant increase in La/Sm ratios from group $D$ through Group C1 into Group C2, with a progressive drop in $\mathrm{Gd} / \mathrm{Yb}$ ratio and increasing spread with increasing La/Sm (the latter may be due to contamination, which is discussed later in the chapter). The remaining groups (i.e. $A 1, A 2, B, E, F$ ) have relatively low $\mathrm{Gd} / \mathrm{Yb}$ ratios, where Groups $\mathrm{A} 1, \mathrm{~A} 2$ and $\mathrm{B}$ show a very similar range in $\mathrm{Gd} / \mathrm{Yb}$ ratios $(\sim 1.2$ to 1.7$)$, and Groups $\mathrm{E}$ and $\mathrm{F}$ together show a similar spread. Within these ranges, there is a distinct increase in La/Sm ratios from Group A1 through Group A2 to Group B, and from Group F to Group E. 


\subsubsection{Major elements}

\subsubsection{Major and minor oxides versus Mg\#}

Major element variations $\left[\mathrm{SiO}_{2}(\mathrm{a}), \mathrm{CaO}\right.$ (b), $\mathrm{Al}_{2} \mathrm{O}_{3}$ (c), $\mathrm{Cr}_{2} \mathrm{O}_{3}$ (d), $\mathrm{P}_{2} \mathrm{O}_{5}$ (e) \& $\left.\mathrm{TiO}_{2}(\mathrm{f})\right]$ with $\mathrm{Mg} \#\left[100^{*} \mathrm{MgO} /(\mathrm{MgO}+\mathrm{FeO})\right]$ as an index of fractionation are shown in Figure 7.5. Mg\# appears to be the best proxy for index of fractionation, compared to other proxies (e.g., $\mathrm{SiO}_{2}, \mathrm{MgO}, \mathrm{Zr}$ ). Within all Mg\# diagrams (with FeO calculated directly from $\mathrm{Fe}_{2} \mathrm{O}_{3}$, representing total $\mathrm{Fe}$ ), Groups $\mathrm{B}, \mathrm{C} 1$ and $\mathrm{E}$ are the only groups that do not consistently demonstrate coherent trends, and consequently, are not be described in terms of geochemical trends in all cases. For Groups B and E, the apparent lack of trends may partially be due to a lack of data. Additionally, Group A1 has too narrow of an Mg\# range to decipher trends. Major and trace element diagrams reveal significant scatter in large-ion lithophile elements (LILE) amongst all groups through the range of Mg\#, with the exception of Group F. This indicates that the LILE became mobile during metamorphismrelated metasomatism, supporting previous observations of LILE plotted against Zr.

Groups A2 and D show a very broad range in Mg\# (27-66 and 22-65, respectively) but are mostly concentrated between Mg\#s 35-50 and 57-65, respectively. Group A1 has a narrow range in Mg\# (between 68 and 71), with the exception of one sample containing an Mg\# of 77 . Group C2 is restricted to high Mg\#s (>48), with samples containing Mg\# as high as 70. Group C1 contains a wide range of $\mathrm{Mg \#}$ from 32 to 69 , and Group $\mathrm{E}$ samples range from 47 to 58 .

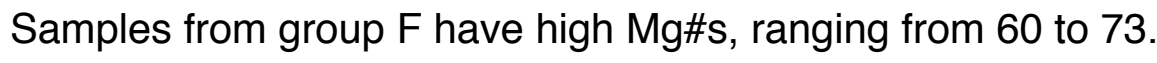


The $\mathrm{Cr}_{2} \mathrm{O}_{3}$ contents of the sills decrease with increasing Mg\#, indicating removal of either $\mathrm{Cr}$ - bearing spinel, clinopyroxene or olivine during fractionation. Group A1 forms a cluster at high $\mathrm{Cr}_{2} \mathrm{O}_{3}$ and Mg\#. Groups A2 and D form similar trends with similar concentrations of $\mathrm{Cr}_{2} \mathrm{O}_{3}$ at identical Mg\#, while Groups B, C1 and $\mathrm{C} 2$ generally contain significant less $\mathrm{Cr}_{2} \mathrm{O}_{3}$ contents than the rest of the groups, at constant Mg\#. Group F contains intermediate $\mathrm{Cr}_{2} \mathrm{O}_{3}$ contents.

$\mathrm{TiO}_{2}, \mathrm{P}_{2} \mathrm{O}_{5}$, and $\mathrm{Al}_{2} \mathrm{O}_{3}$ contents in all groups increase with decreasing $\mathrm{Mg}$ \#, with Group $\mathrm{D}$ containing greater concentrations of $\mathrm{TiO}_{2}, \mathrm{P}_{2} \mathrm{O}_{5}$ and lower concentration of $\mathrm{Al}_{2} \mathrm{O}_{3}$, at similar $\mathrm{Mg \#}$. This indicates that these oxides remained incompatible during fractionation and suggests that fractionation of Fe-Ti-oxides, such as ilmenite or titano-magnetite (also titanite or rutile, in some cases), and phosphate-bearing minerals (e.g. apatite, monazite) were not significant fractionating mineral phases during the evolution of the parental magmas to all groups. $\mathrm{Al}_{2} \mathrm{O}_{3}$ and $\mathrm{CaO}$ increase with fractionation until they level out at around an $\mathrm{Mg} \#$ of 60 , suggesting the initiation of plagioclase fractionation. This is consistent with a change in lithology from ultramafic to mafic as Mg\# in samples

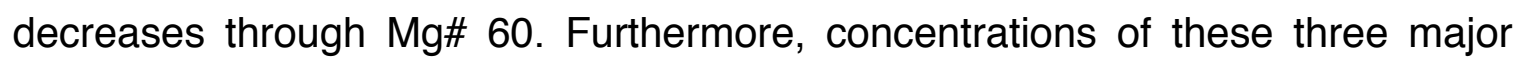
element oxides are distinctly lower in Groups B, C2, E and F as compared to A (and D).

In numerous diagrams, trends extrapolated from Group A2 intersect the "cloud" of Group A1 samples (e.g. Figure 7.5a,c,e-f), suggesting the two groups may be co-genetic and that common petrogenetic processes (e.g. fractional crystallization or cumulate addition) control their chemical compositions. 


\subsubsection{High- and low-Ti groups}

Many sill provinces, and LIPs in general, have been subdivided into highTi and low-Ti magma types (e.g. Emeishan, Karoo-Ferrar LIPs; Duncan et al., 1997). The high-Ti/low-Ti division reflects the groups' overall incompatible element or oxide levels, and is primarily discriminated based on differing $\mathrm{TiO}_{2}$ and $\mathrm{P}_{2} \mathrm{O}_{5}$ concentrations (Hooper, 1982). Based on a $\mathrm{TiO}_{2}$ versus $\mathrm{Mg} \#$ diagram (Figure 7.6), the geochemical groups for the Frobisher suite can be subdivided into high- $\mathrm{Ti}$ and low-Ti groups. Group $\mathrm{D}$ is considered high- $\mathrm{Ti}$ (also richest in $\mathrm{P}$ ), while the remainder of the groups are low-Ti. However, given the high abundance of sills containing geochemical signatures of Groups A1, A2 and D, and the rest of the groups existing as minor components, the term "low-Ti" will be applied strictly to Groups $\mathrm{A} 1$ and $\mathrm{A} 2$. Furthermore, $\mathrm{P}_{2} \mathrm{O}_{5}$ occurs at trace levels in all or most samples from Groups A1, A2, B, C1, C2, E, and F, and $\mathrm{TiO}_{2}$ occurs at trace levels in most group C2 samples.

In continental flood basalts of LIPs, a low-Ti character of tholeiitic basaltic magmas has been interpreted to reflect either mantle melting conditions, such as shallow depths of melting or higher degrees of partial melting in the upper mantle (Arndt et al., 1993; Xu et al., 2004a) or crustal contamination by continental crust and/or subcontinental lithospheric mantle (Carlson, 1991; Peate, 1997; Ewart et al., 1998, 2004). High-Ti character, on the other hand, show geochemical and isotopic similarities to OIBs (i.e. intraplate geochemistry), and are interpreted to contain an asthenospheric mantle or plume component (Arndt et al., 1993; Zhao et al., 1994; Ewart et al., 1998, 2004a). 
Similar to the continental flood-basalts (CFBs) in the Afro-Arabian LIP (e.g. Arndt and Menzies, 2005), the low-Ti groups exhibit relatively flat chondritenormalized REE patterns, and the more alkaline samples (i.e. high-Ti Group D; discussed in 7.1.2) contain higher incompatible element concentrations at similar $\mathrm{Mg} \#$ and more fractionated REE patterns. Causes for the difference in $\mathrm{TiO}_{2}$ concentration at similar Mg\# may reflect either a heterogeneous source, difference in degrees of partial melting, or contamination.

\subsubsection{FeO versus $\mathrm{MgO}$}

The variation in $\mathrm{FeO}$ with respect to decreasing $\mathrm{MgO}$ (Figure 7.7), an oxide that typically decreases as magmas evolve, illustrates different trends between certain geochemical groups. Groups A1, A2, and D show weak (tholeiitic) Fe-enrichment trend, as FeO content increases with decreasing MgO. In contrast, Groups C2 and F demonstrate decreasing FeO with decreasing $\mathrm{MgO}$, suggestive of Fe-saturation attainment (moving towards a 'calc-alkaline trend'). However, Group $\mathrm{F}$ is tholeiitic and its $\mathrm{Ti}$ concentrations continue to

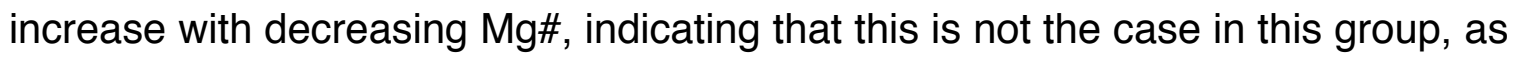
$\mathrm{Fe}+\mathrm{Ti}$ would normally be removed from the magma together. Groups B, C1 and E do not display clear trends, however, $\mathrm{FeO}$ contents at constant $\mathrm{MgO}$ in Group C1 are very similar to that of Groups A2 and D while Group B bears a stronger resemblance to Groups C2 and F. 


\subsubsection{Trace elements}

\subsubsection{Trace elements versus Mg\#}

Trace element variations with $\mathrm{Mg} \#$ as an index of fractionation are shown in Figure 7.8. Included in these diagrams are highly compatible trace elements (Co, Ni), high-field strength elements (Th, La, Sm, Y, Zr, Sc and Nb), and total REE. Incompatible trace elements which have distinctly higher concentrations in the high-Ti Group D compared to all other groups include Ce, Eu, Ga, Gd, Hf, La, $\mathrm{Nb}, \mathrm{Nd}$, $\mathrm{Pr}, \mathrm{Sm}, \mathrm{Ta}, \mathrm{Zr}$, and $\mathrm{Hf}$, as well as the compatible element $\mathrm{Ni}$ (some elements are not shown in Figure 7.8).

The Ni concentrations in Group D are high, decreasing in a linear trend from Mg\# 62 to 23. Group A1 (highest Ni contents) shows a steep trend, while Group A2 has lower values, forming a shallower trend decreasing with decreasing Mg\#. Ni contents in Groups C2 and F rapidly decline from Mg\# $\sim 70$ to 65 , from $\sim 750 \mathrm{ppm}$ to $\sim 200 \mathrm{ppm}$, suggesting partitioning into early olivine, or a potentially an immiscible sulphide liquid phase. Groups $\mathrm{B}$ and $\mathrm{C} 1 \mathrm{Ni}$ values decrease only slightly through the fractionation index, but correlate with the Group C2 and F data. The inflection point at Mg\# $\sim 65$ for these groups may indicate that olivine is no longer a fractionating phase. Groups A2 and D show shallow linear trends of decreasing Co with decreasing Mg\# to Co values of $\sim 50$ ppm. Groups C2 and F show steep linear trends, with Group C2 decreasing more steeply with decreasing Mg\# than Group F, to low values of Co (5 and 35 ppm, respectively). The depletion of Co in both Groups C2 and F suggests very 
significant olivine fractionation, or depletion resulting from scavenging of chalcophile elements into an immiscible sulphide liquid.

Th contents in Group D and A1 increase with decreasing Mg\#, while all other groups show significant scatter, with the exception of Group F which maintains relatively constant concentrations. La, Sm, and $\mathrm{Y}$ contents in all groups generally increase with decreasing Mg\#, though Group C1 shows a high degree of scatter in La and Sm. Group C2 shows some significant scatter in La. Zr contents in all groups generally increase with decreasing Mg\#, those of Group C1 show significant scatter. The $\mathrm{V}$ values in all groups increase with decreasing Mg\#, with the exception of those values for Group C2 which remain relatively constant. $\mathrm{Nb}$ increases with decreasing $\mathrm{Mg} \#$ in Groups $\mathrm{A} 1, \mathrm{~A} 2, \mathrm{D}$, and $\mathrm{E}$, remain relatively constant Groups C2 and F, and show significant scatter in Group C1. Sc contents are highest in Groups A2, B, and E. Groups D and A2 show significant scatter in Sc concentrations, which very weakly increase with decreasing Mg\#. Group F decreases with Mg\# until Mg\# 69, and increases steeply. Group C2 shows significant scatter and a weak negative trend with decreasing Mg\#.

The HFSE concentrations in group D are significantly greater than those in Groups A1 and A2 (and all other groups) at constant Mg\#. The only exceptions are $\mathrm{V}$ and $\mathrm{Y}$, where Group D shows very similar concentrations to Groups A1 and A2 at constant Mg\#. Groups B, C2 and F generally contain lower concentrations of HFSE compared to the rest of the groups. Concentrations in Group E are 
variable with relation to the other groups. Again, Group C1 often displays a high degree of scatter and thus, highly variable concentrations as Mg\# decreases.

\subsubsection{Primitive mantle-normalized spider diagrams}

Primitive mantle-normalized spider diagrams (Figure $7.3 \mathrm{~b}$ ) reveal some characteristics consistent across a number of geochemical groups, as well as some that are unique to a single geochemical group. A subset of incompatible elements were used in these diagrams to reduce scatter and to express the variations between the geochemical groups.

Group A1 displays a flat PM-normalized trace element pattern with prominent negative $\mathrm{P}$ and positive $\mathrm{Zr}-\mathrm{Hf}$ anomalies that become less pronounced as total REE increases. La and Yb contents are 2x primitive mantle.

Similar to Group A1, all Group A2 samples also contain strong negative P anomalies that become less prominent as total REE increases, however, Group $\mathrm{A} 2$ exhibits weak enrichment in the most incompatible trace elements. $\mathrm{Nb}-\mathrm{Ta}$ anomalies in Group A2 vary from strongly negative (i.e. typical of lower crustal contamination) to weakly positive, and there are two minor positive and one moderately negative Ti anomaly. Additionally, there are very strongly positive, but mostly negative, Th anomalies. La and $\mathrm{Yb}$ contents vary from 5-11x and 2-8x primitive mantle, respectively.

Group B exhibits a moderate enrichment in the most incompatible trace elements, strong negative $\mathrm{P}$ anomalies and moderate negative $\mathrm{Zr}-\mathrm{Hf}$ anomalies. The only samples with $\mathrm{Nb}$ and Ta concentrations above the detection limit have a 
strong negative $\mathrm{Nb}-\mathrm{Ta}$ anomaly. One sample has a moderate negative $\mathrm{Ti}$ anomaly, and another has a positive $\mathrm{Ti}$ anomaly of the same size. La and $\mathrm{Yb}$ contents vary from $2-11 x$ and $0.5-3 x$ primitive mantle, respectively, and overall these patterns exhibit variable (scattered) incompatible trace elements.

Group $\mathrm{C} 1$ exhibits a moderate to strong enrichment in the most incompatible trace elements. All samples show either positive or negative $\mathrm{Ti}$ anomalies that vary from weak to strong, and weak positive or negative Eu anomalies. Samples with the lowest trace element concentrations show moderate to strong negative $\mathrm{P}$ anomalies, while those with higher concentrations of trace elements are weak to moderate positive. Weak to moderate negative $\mathrm{Zr}$ $\mathrm{Hf}$ anomalies are associated with the negative $\mathrm{P}$ anomalies, decreasing in size with increasing trace element abundance. Most samples with $\mathrm{Nb}-\mathrm{Ta}$ abundances above detection limit have sizeable negative $\mathrm{Nb}$-Ta anomalies. $\mathrm{La}$ and $\mathrm{Yb}$ contents vary from $7-40 x$ and $0.6-2 x$ primitive mantle, respectively. This group also shows less parallelism between patterns in the most incompatible trace elements.

Group C2 shows high enrichment in the most incompatible trace elements, and moderate to strong $P$ anomalies in almost all samples. Samples with the lowest trace element abundance display moderate negative $\mathrm{Zr}-\mathrm{Hf}$ anomalies. Samples with $\mathrm{Nb}-\mathrm{Ta}$ abundances above detection limit have moderately to strongly negative $\mathrm{Nb}-\mathrm{Ta}$ anomalies. La and $\mathrm{Yb}$ contents vary from 3-30x and 0.1-1x primitive mantle, respectively. Similar to what is observed in 
Groups B and C1, these patterns are less parallel in the most incompatible trace elements.

Group $D$ contains weak to moderate negative $P$ anomalies in all but one sample, and also consistent weak to moderate positive $\mathrm{Ti}$ anomalies that become less pronounced as total REE contents increase. A highly distinguishing feature of Group $\mathrm{D}$ is the weak to moderate positive $\mathrm{Nb}-\mathrm{Ta}$ anomalies. The $\mathrm{Ti}$ and $\mathrm{Nb}-\mathrm{Ta}$ anomalies may reflect ilmenite cumulates, however, evidence of ilmenite accumulation is not clear in thin section. $\mathrm{La}$ and $\mathrm{Yb}$ contents vary from 8-60x and 2-5x primitive mantle, respectively.

Group $E$ is unique in the sense that it displays only a range of different negative anomalies. These include moderate to strong negative $\mathrm{Ti}, \mathrm{Zr}-\mathrm{Hf}, \mathrm{Eu}, \mathrm{P}$, and $\mathrm{Ta}$ (the latter only when above the detection limit). La and $\mathrm{Yb}$ contents vary from 5-6x and 4-7x primitive mantle, respectively.

Most Group F samples show weak negative $\mathrm{Ti}$ anomalies, and weak to moderate negative $\mathrm{P}$ anomalies. The presence of $\mathrm{Nb}$ - $\mathrm{Ta}$ anomalies cannot be determined due to the values for these elements falling beneath their respective detection limits. La and $\mathrm{Yb}$ contents vary from $0.4-1 \mathrm{x}$ and $0.7-2 \mathrm{x}$ primitive mantle, respectively.

\subsubsection{MORB-normalized plots}

Mid-ocean ridge basalt (MORB) is the most common mafic rock on Earth, and is often utilized for comparative purposes. MORB-normalized spider diagrams (Figure 7.3c) provide a different view of the relative abundance of 
elements within the various groups. However, the MORB-normalized diagrams demonstrate very similar patterns to the primitive mantle-normalized diagrams, with anomalies approximately of the same magnitudes, with the exception of $P$ anomalies, which disappear. The only notable differences are the lower degrees of overall enrichment relative to the normalizing values and greater enrichment in the most incompatible trace elements, since the MORB normalizing values are greater than primitive mantle normalizing values.

\subsubsection{Immobile trace element ratio discrimination}

Application of trace element ratios of the most immobile trace elements (HFSE) and REE, in the form of bivariate plots or ternary diagrams distinguishes the various geochemical groups. As previously stated, HFSE are considered generally immobile during metamorphism. Ratios of HFSE are not significantly modified by processes of fractional crystallization and partial melting (e.g. Luttinen and Furnes, 2000). Ternary diagrams in Figure 7.9a-b demonstrate the differences between the various geochemical groups. Figure $7.9 \mathrm{a}$ utilizes chondrite-normalized REEs (i.e. La, Gd, and Yb) as the discriminating variables, which more or less reflect the differences in the LREE (La/Sm), HREE (Gd/Yb) and overall slopes $(\mathrm{La} / \mathrm{Yb})$ of the REE. Figure $7.9 \mathrm{~b}$ further illustrates the differences in geochemical composition between the eight geochemical groups, using $\mathrm{Nb}, \mathrm{Y}$ and $\mathrm{La}$. The latter diagram utilized the variables chosen for the Cabanis and Lecolle (1989) basalt-discrimination diagram. The fields from this 
diagram are not used, as some samples do not necessarily correspond to them, due to either their ultramafic composition or cumulate nature.

In Figure 7.9a, the trend from Group D up through to Group F may represent depth/degree of partial melting, based on the decrease in enrichment, apparent in chondrite-normalized REE diagrams (Figure 7.3a) and trace element bivariate diagrams (Figure 7.8). Closer to the La corner of the plot are Groups B, C1, and C2. Their separation from the other groups likely reflects contamination, as La would be expected to increase significantly and $\mathrm{Nb}$ would decrease, relatively, consistent with the generation of a negative $\mathrm{Nb}$-Ta anomaly. Trends observed in Figure 7.9b also distinguish the different geochemical groups and reflect these changes in degrees of melting and contamination.

\subsubsection{Alkaline versus tholeiitic}

Typically, LIP-related tholeiitic magmas are produced from high-degrees of partial melting (often $20-30 \%$ ) of near-anhydrous peridotitic mantle sources, while alkaline magmas are produced from small-degree partial melts of an enriched source or a source containing a high proportion of eclogitic or basaltic material (i.e. subducted oceanic slab components; Ernst, 2014). Eclogite geochemistry can have great influence on the geochemistry of low-degree partial melts, when present, since it melts far easier than peridotite (Ernst, 2014). Alkalinity is typically attributed to low degrees of partial melting, or source-enrichment. However, it may also be attributed to high-pressure melting where the opx-ol peritectic reaction may not occur (J.Mungall, pers. comm., 2017) 
The $\mathrm{Nb} / \mathrm{Y}$ ratio is considered a reliable chemical separator of alkaline $(>1)$ and tholeiitic $(<1)$ magmas (Sun and McDonough, 1989). The $\mathrm{Nb} / \mathrm{Y}$ diagram in Figure 7.10 (modified from Greenough et al., 2005) demonstrates difference in alkalinity between the different groups. The diagram indicates that all groups are tholeiitic, with the exception of Group D, which appears to be transitional from tholeiitic to mildly alkaline in nature. The observation of lower Mg\# at similar elemental concentrations compared to other groups is consistent with the more alkaline nature of Group D, given that lower-degree partial melts are more FeOrich relative to $\mathrm{MgO}$. It should be noted that the $\mathrm{Nb} / \mathrm{Y}$ ratio preserved in these rock may be affected by ilmenite accumulation (increasing the $\mathrm{Nb} / \mathrm{Y}$ ratio), however, the lack of clear evidence of ilmenite accumulation suggests that the high $\mathrm{Nb} / \mathrm{Y}$ ratio is a parental magmatic feature.

Experimental studies, such as those by Hirose and Kushiro (1993), have shown that at depths $>3 \mathrm{GPa}$, small degree melts ( $<5 \mathrm{wt} . \%)$ of peridotite can produce primary alkalic, basaltic magmas, and at larger degree of partial melting of the same source at shallow depths can produce tholeiitic series magmas. It may be suggested that based on the slight alkalinity of Group D, relative to the tholeiitic composition of the rest of the groups, the primary magma to the Group D samples may have been derived at a greater depth, with a lower degree of partial melting. This notion is further investigated below (see section 7.4.4). 


\subsection{Sm-Nd Isotopes Geochemistry}

To assess the source characteristics of the parental magmas of the various geochemical groups, $\mathrm{Sm}-\mathrm{Nd}$ isotope data were collected. The $\mathrm{Sm}-\mathrm{Nd}$ isotopic system is comprised of parent ${ }^{147} \mathrm{Sm}$ that decays through alpha-emission to ${ }^{143} \mathrm{Nd}$. Both Sm and $\mathrm{Nd}$ are incompatible elements that are part of the LREE, meaning that their concentrations increase with increasing degree of fractionation (Faure and Mensing, 2005). However, Nd is slightly more incompatible than Sm during melting due to its slightly larger ionic radius ( $1.08 \AA \AA$ compared to $1.04 \AA$ ). As a result, $\mathrm{Nd}$ becomes more concentrated in the melt relative to $\mathrm{Sm}$ during crystal fractionation, and this has led to generally low $\mathrm{Sm} / \mathrm{Nd}$ ratios in crustal rocks compared to rocks derived from the upper mantle. Over time, crustal rocks have developed increasing lower ${ }^{143} \mathrm{Nd} / 144 \mathrm{Nd}$ ratios compared to the upper mantle. The reason this isotopic ratio works is because isotopes of the same element (e.g. ${ }^{143} \mathrm{Nd},{ }^{144} \mathrm{Nd}$ ) cannot be fractionated through processes of crystal fractionation or partial melting, hence the ratios between them should reflect characteristics of the source from which the primary melts were extracted. However, the information extracted from this data is relatively limited compared to what can be revealed in conjunction with a second isotopic system (e.g. Rb-Sr, $\mathrm{Pb}-\mathrm{Pb})$.

${ }^{143} \mathrm{Nd} /{ }^{144} \mathrm{Nd}$ isotopic ratios are most often expressed in epsilon $(\varepsilon)$ units, which is a measure of the difference between the initial ${ }^{143} \mathrm{Nd} / 144 \mathrm{Nd}$ ratio of the sample, and the corresponding ratio of the chondritic uniform reservoir (CHUR) 
at the time of crystallization. The $\varepsilon$ notation (DePaulo and Wasserburg, 1976) is used to resolve the issue of inter-laboratory differences in normalization procedures. When $\varepsilon N d$ values are positive, the ${ }^{143} \mathrm{Nd} /{ }^{144} \mathrm{Nd}$ isotopic ratios are radiogenic, indicating that the magmas were derived from the depleted mantle. In contrast, negative $\varepsilon N d$ values indicate non-radiogenic ${ }^{143} \mathrm{Nd} /{ }^{144} \mathrm{Nd}$ isotopic ratios, meaning that the magmas were derived from enriched mantle sources or continental crust. Crustal contamination of depleted mantle derived basaltic magmas will drive $\varepsilon N d$ to more negative values.

\subsubsection{Epsilon-Nd $(\varepsilon N d)$}

Epsilon-Nd ( $\varepsilon \mathrm{Nd}$ ) values (at $1900 \mathrm{Ma}$ ) for Groups A1 (1.23 to 3.69), A2 (0.25 to 2.79$), D(0.89$ to 2.39$)$ and $F(4.58$ to 6.13$)$ are juvenile and reveal that they were derived from a depleted asthenospheric mantle. The exception is a Group A2 sample with $\varepsilon N d$ of -6.64 (15SAB-L057B02), suggesting it is significantly crustally-contaminated. The primitive mantle-normalized spider diagram of all samples collected from that particular sill supports this reasoning, as a significant negative $\mathrm{Nb}-\mathrm{Ta}$ anomaly is observed in only that sample (Figure 7.11a). The $\varepsilon N d$ values suggest there is a common or similar source for Groups A1, A2 and D, while the source Group F appears to be even more depleted in nature. Samples from Groups B, C1, and C2 have evolved, less radiogenic $\varepsilon N d$ values $-3.00,-4.31$, and -3.99 , respectively, suggesting that these rocks were derived from an enriched mantle source or had significant interaction with continental crust. The three $\varepsilon N d$ values from Groups B, C1, and C2 fall within a 
close enough range to potentially suggest a common or similar source, however, their source characteristics are obscured by contamination from either crustal material, or metasomatized subcontinental lithosphere.

\subsection{2 $\varepsilon \mathrm{Nd}$ versus ${ }^{147} \mathrm{Sm} /{ }^{144} \mathrm{Nd}$ diagram}

In the $\varepsilon N d$ versus ${ }^{147} \mathrm{Sm} /{ }^{144} \mathrm{Nd}$ diagram (Figure $7.11 \mathrm{~b}$ ), there are two trends apparent amongst Groups A1, A2, and D. The first is interpreted to reflect changes in partial melting of the source, a process that influences the ${ }^{147} \mathrm{Sm} /$ ${ }^{144} \mathrm{Nd}$ ratio. The $147 \mathrm{Sm} / 144 \mathrm{Nd}$ ratios increase from Group D to A2 which is higher than in Group A1 because of differences in partial melting (lower degree of melting $=$ less $\mathrm{Sm}$ in melt phase). $\varepsilon N d$ may be increasing with $\mathrm{Sm} / \mathrm{Nd}$ because Group A1 is from a more depleted source. The second trend may reflect crustal contamination by the upper crustal rocks of the Meta Incognita microcontinent. This inference is supported by the $\varepsilon \mathrm{Nd}-\mathrm{Ti} / \mathrm{Yb}$ diagram (Figure 7.12) adapted from Leeman \& Hawkesworth, (1986), which indicates that the low $\varepsilon N d$ values are a result of contamination, as opposed to source enrichment. Furthermore, samples apparently trending toward the fields of the Meta Incognita microcontinent upper crustal units (data from Theriault et al., 2001 and R.J. Theriault, unpublished data) in the $\varepsilon \mathrm{Nd}-\mathrm{Ti} / \mathrm{Yb}$ diagram exhibit greater $\mathrm{La} / \mathrm{Nb}$ values on the $\varepsilon \mathrm{Nd}$ versus La/Nb diagram (Figure 7.17b), which is a proxy for crustal contamination (Lightfoot et al., 1993). 


\subsection{Geochemistry of Detailed Sample Transects Across Two}

\section{Mafic-Ultramafic Sills}

In the detailed sample sets collected from the Killapait and Chidliak sills, attempting to identify the phases controlling fractionation is challenging, as the primary minerals and textures have been subjected to subsequent amphibolite to granulite facies metamorphism. The limited number of samples also make it difficult to distinguish trends, however, some trends are observed that may represent fractionation of certain mineral phases.

In a study on the Golden Valley sill of the Karoo LIP (Galerne et al., 2010), it was revealed that a single saucer-shaped sill can exhibit significant geochemical variation through the stratigraphic thickness of an individual sill. This was proposed to be the result of post-emplacement porous melt flow driven by forces related to the saucer shape geometry. Consequently, if the sills were not emplaced in flat sheets, and exhibited more of a saucer shape, the following compositional profiles may be unique to the transect randomly chosen.

The geochemical variation through the Killapait sill is shown in Figure 7.13, and the geochemical variation through the Chidliak sill is illustrated in Figure 7.14 (both described in 7.4.1). The Killapait sills contains 4 different magma types (Groups A1, A2, C1 and C2), whereas the Chidliak sill only contains one (Group F). As a whole, there are no trends that appear to represent in-situ differentiation of a single magma batch, however, within certain lithological units some trends are exhibited that may have resulted from fractional 
crystallization processes. However, the non-systematic change in geochemical signature through the stratigraphy of the sill suggests these sills represent either composite or a vertically-stacked package of sills (i.e. distinct sills emplaced within a host sill or distinct sills which have underplated one another, respectively).

\subsection{Interpretation}

\subsubsection{Single injection versus multiple injection origin of layered sills}

The occurrence of various combinations of geochemical groups within, what appeared to be individual differentiated sills while in the field, poses the question of whether these sills formed through the injection of a single sill which later differentiated, or whether they represent a much more complex history, whereby multiple sills were injected.

Recent geochronology has revealed small age differences between ultramafic and more mafic portions of both the Bushveld Complex (Scoates et al., 2012; Mungall et al., 2017) and Stillwater Complex (Wall et al., 2012). Age differences between the two portions of the sill in each case are $\sim 2-5 \mathrm{Ma}$. In the case of the Frobisher suite, sills that exhibit distinctly different trace-element signatures may represent the injection of multiple pulses of distinct magma batches, of unique magmatic lineage.

Comparative geochemistry between the mafic and ultramafic portions of individual sills, initially thought to have been derived through in situ differentiation of single magma batches, reveal geochemical variations that do not reflect 
change through simple crystal fractionation. The chondrite-normalized REE patterns for the metapyroxenitic and metaperidotitic units of two individual layered ultramafic sills are presented (Figure $7.15 a$ ), along with the REE patterns for two individual non-layered ultramafic sills. What this diagram reveals is that two different geochemical signatures are present within these layered ultramafic sills (Groups A1 and D). The process of fractional crystallization, which only slightly increases LREE contents relative to HREE contents as the magma evolves, cannot explain the transition from the relatively flat Group A1 pattern to the highly LREE-enriched Group D pattern without significantly greater $\mathrm{Yb}$ contents in Group D, which is not observed. It seems highly plausible that these layered ultramafic sills were generated through at least two injections of distinct geochemically different magmas.

In Figure $7.15 \mathrm{~b}$, the chondrite-normalized REE patterns for the layered mafic-ultramafic Killapait sill are shown, along with sample location with respect to stratigraphic height within the sill. In a layered sill derived from closed-system in-situ crystal fractionation from a single magma pulse, it would be expected that HREE contents would generally increase from the base upwards through the sill and the chondrite-normalized REE patterns would remain same, with the exception of progressive, but minor, increases in the LREE slope as the samples evolve. Essentially, the lowest abundance of HREE through to the highest abundance of HREE should reflect the sample location from stratigraphically lowest to highest in the sill. Instead, what is observed are four different geochemical groups, with unique geochemical characteristics, and no specific 
correlation between increasing HREE concentrations and height in sill stratigraphy. For example, a Group A2 sample collected $40 \mathrm{~m}$ above the contact has significantly higher HREE contents than the rest of the samples collected from the sill. The samples collected at the basal contact $(\sim 5 \mathrm{~m})$ and proximal to an obscure upper contact ( 445 m), 14SAB-R010A01 and 14SAB-L017A01, respectively, contain intermediate HREE contents with respect to the rest of the samples, and appear to represent two distinctly different magma types. The sample with the lowest HREE content is situated $\sim 90 \mathrm{~m}$ upwards through magmatic stratigraphy from the basal contact. Furthermore, the Group A2 signature is found at a higher stratigraphic level within the ultramafic portion of Killapait sill than the Group A1 signature, which occurs at the basal contact. Given the significantly higher $\mathrm{Yb}$ values of the Group A2 sample, the difference in patterns may simply reflect fractional crystallization. However, stratigraphically higher in the sill, the mafic portion of the sill contains the geochemical signatures of Groups C1 and C2. The $\mathrm{Yb}$ contents of the samples selected from these two groups are generally lower than that of the Group A1 sample found at the basal contact, precluding simple fractional crystallization as an origin of the former signatures. However, if significant assimilation occurred within Group C1 and C2 parental magmas, there is an argument for their derivation through assimilationfractional-crystallization (AFC) processes.

Furthermore, while mafic and ultramafic components of a single sill may exhibit similar geochemical signatures, this does not indicate that it was differentiated in situ. For example, the metaperidotitic and gabbroic components 
of the Chidliak sill exhibit REE patterns that are very similar (Figure $7.15 \mathrm{c}$ ), with the gabbroic unit containing slightly higher $\mathrm{Yb}$ (and overall REE) contents than the metaperidotitc sample, consistent with the gabbro's origin through fractional crystallization. However, the $\mathrm{Sm}-\mathrm{Nd}$ isotopic data obtained from both units suggest that they were derived from isotopically distinct magma batches, as the epsilon Nd values of the metaperidotitic and metagabbroic units are 4.58 and 6.13 , respectively. If derived from the same source, minor contamination of the parental magma to the metaperidotite, which would reduce the $\varepsilon N d$, could explain the different $\varepsilon \mathrm{Nd}$ values. $\mathrm{Nb}$ anomalies are present in both of these samples, however, they are similar in magnitude. A difference in the isotopic composition of the respective contaminants could potentially explain this. Another possibility is that the parental magmas to the two units have similar trace element characteristics, while representing two distinct sources.

All the geochemical evidence presented supports the notion that at least some of the layered intrusions of Frobisher suite may have been formed through multiple injections of geochemically similar or distinct magma types, as opposed to a single injection, that may or may not have differentiated in-situ into mafic and ultramafic components.

\subsubsection{Mineral fractionation}

The crystallization of minerals has a significant impact on the composition of any primary magma, leading to either significant accumulation or depletion of specific geochemical entities within the magma. In mafic or ultramafic magmas, 
there is typically a decrease in $\mathrm{MgO}$ content, and concomitant increase in $\mathrm{FeO}$, as Mg-rich ferromagnesian minerals are crystallized (decreasing the Mg\#). A number of fractionating mineral phases have high partition coefficients $(>>1)$ for certain elements (e.g. $\mathrm{Ni}$ in olivine or sulphides, or $\mathrm{Eu}^{2+}$ in plagioclase), which leads to the depletion of these elements as the magma evolves and $\mathrm{Mg \#}$ decreases (Figures 7.5 and 7.8). For example, the low Mg\#s and relatively low compatible element contents characteristic of Group A2 suggest that the compositions are far removed from that of the primary magma, presumably due to extensive fractional crystallization.

In the determination of mineral phases controlling fractionation, we are handicapped by the effects of regional high-grade metamorphism, which appears to have obliterated primary minerals and primary igneous textures. However, a significant amount of information can be obtained by studying the geochemistry of the samples alone.

\subsubsection{Olivine and pyroxene fractionation}

Samples with the highest Mg\#s (> 70), which includes primarily samples from Group A1 and F, may represent cumulates of olivine or pyroxene because of the very high $\mathrm{Ni}$ and Co contents, and low total REE contents (Figure 7.8). This may partially explain the large gap in Mg\# between Group A1 and A2. The petrographic observation of a relict pyroxene (pseudomorphed by hornblende) cumulate texture in sample 14SAB-H080B01 supports this notion (Figure 5.3b). Cumulates usually have higher $\mathrm{MgO}$ and low incompatible trace elements than 
their parental magma (Maier, 2015) Additionally, these samples are limited to an ultramafic composition. This high $\mathrm{Ni}$ is not attributed to the presence of $\mathrm{Ni}$ sulphide, as only one of six Group A1 samples contains any amount (i.e. $<1 \%$ ) of Ni-sulphide (i.e. pentlandite). The high Mg\# Group A1 samples have a narrow range in $\mathrm{Mg \#}$ and compatible elements $\mathrm{Ni}$ and $\mathrm{Cr}$, which may possibly be to due high-MgO olivine or pyroxene of similar composition.

High $\mathrm{Cr}$ contents of some samples in other groups may indicate accumulation of orthopyroxene, clinopyroxene or chromite. In a similar manner, high concentrations of $\mathrm{Ni}$ in some samples may indicate accumulation of olivine or Ni-sulphide.

\subsubsection{Plagioclase fractionation}

The REE are all trivalent $(3+)$, with the exception of $\mathrm{Ce}^{2+}$ and $\mathrm{Eu}^{2+}$ which form under reducing conditions. When $\mathrm{Eu}$ is in its divalent state $(2+)$, it is preferentially incorporated into plagioclase, where it substitutes for $\mathrm{Ca}^{2+}$. As a result, when plagioclase is accumulated within a magma or crystallized and removed from a magma, positive or negative Eu anomalies will be present in chondrite-normalized diagrams. Furthermore, a negative Eu anomaly may indicate that the melt was in equilibrium with plagioclase at one time, however, it cannot distinguish whether plagioclase phenocrysts were removed from the magma or whether plagioclase remained in the source during melting; the latter only occurs at very low pressures. Another typically incompatible element that accumulates in plagioclase is $\mathrm{Sr}$. 
An additional explanation for the presence of minor Eu anomalies is regional metamorphism. While $\mathrm{Eu}^{3+}$ is considered largely immobile, $\mathrm{Eu}^{2+}$ is considered a LILE and thus, can be remobilized relatively easily compared to its $3+$ charge counterpart. Its effects could be most easily recognized in samples where inconsistencies exist, such as plagioclase-barren samples with positive Eu anomalies. In this example, the positive Eu anomaly would indicate accumulated plagioclase. However, the absence of plagioclase in this hypothetical situation suggests that the anomaly was generated by other processes (e.g. high-grade metamorphism). Furthermore, care must be exercised in the attribution of these anomalies to metamorphism and element mobility, as secondary mineral assemblages can mask the presence of primary plagioclase in the now nonexistent magmatic mineral assemblage.

Samples from Groups A1, A2, and D show weak positive and negative Eu anomalies with Eu/Eu* typically between 0.80 and 1.20 (Figure 7.16), indicating that the fractionation of plagioclase was not particularly important in their petrogenesis. In contrast, samples from Groups B, C1 and C2 show significant, mostly positive, europium anomalies. Group C2 samples have the highest positive europium anomalies, with $\mathrm{Eu} / \mathrm{Eu}^{*}$ up to 3.25 . The variation in Eu/ $\mathrm{Eu}^{*}$ values versus $\mathrm{Mg} \#$ is illustrated in Figure 7.16. These significant positive anomalies coincide with a notable accumulation of plagioclase. The most magnesian Group C2 and B samples contain incompatible element concentrations lower than primitive mantle, while maintaining enriched LREE patterns, suggesting they contain a cumulate component (Sills et al., 1982). 
While $\mathrm{Sr}$ is a LILE and shows some evidence of remobilization (not shown), the appearance of coexisting positive $\mathrm{Sr}$ and $\mathrm{Eu}$ anomalies and coexistence of negative $\mathrm{Sr}$ and Eu anomalies supports the interpretation that Eu anomalies represent the accumulation or removal of plagioclase within the parental magmas to these samples.

Within the Killapait sill, all Group C1 and C2 samples, with the exception of one, display significant positive Eu anomalies (Figure 7.15b). The interval through which these samples were collected represents the $>\sim 90 \%$ of the sill's total volume, assuming uniform unit thickness during its formation, suggesting that the majority of the magma injected into the sill had accumulated plagioclase, possibly through entrainment of a plagioclase crystal mush en route to the site of final emplacement, or through plagioclase accumulation during in situ crystal fractionation within a crustal magma chamber.

\subsubsection{Apatite fractionation}

All samples from all groups, with one exception, exhibit negative $P$ anomalies in PM-normalized diagrams that vary from weak to strong (Figure 7.3b). However, $\mathrm{P}$ anomalies are typically absent in MORB-normalized diagrams of Groups A1, A2, D, and F (Figure 7.3c). As samples become more evolved, there is a progressive decrease in the $\mathrm{P}$ anomalies exhibited by samples. Possible explanations for negative anomalies were explored and synthesized by McCuaig et al. (1994), and include: (1) crustal contamination; (2) hydrous metasomatism of depleted mantle; (3) crystal fractionation of P-bearing phase(s) 
from the magma; and (4) retention of P-bearing phases in the mantle source region during partial melting.

If the negative $\mathrm{P}$ anomalies were derived from either (1) crustal contamination or (2) hydrous metasomatism of the depleted mantle, negative $\mathrm{Nb}$ Ta and $\mathrm{Ti}$ anomalies would be expected to coincide with these negative $\mathrm{P}$ anomalies. Group D contains negative $\mathrm{P}$ anomalies with coexisting positive $\mathrm{Nb}$ Ta and Ti anomalies, and Groups $\mathrm{A} 1$ and $\mathrm{A} 2$ do contain some $\mathrm{Nb}-\mathrm{Ta}$ anomalies but most often lack significant Ti anomalies. Additionally, $\varepsilon N d$ values of samples from Groups A1, A2 and D would all be negative (enriched source), however, isotopic data indicates they are derived from a depleted source. Consequently, the possibility of (1) and (2) being responsible for negative $P$ anomalies in Groups A1, A2 and D is quite low. Groups $C 1, C 2$, and F display coexisting negative $\mathrm{Nb}$, and often negative $\mathrm{Ti}$ anomalies, with negative $\mathrm{P}$ anomalies, suggesting that crustal contamination or metasomatized mantle may have led to these anomalies. Group E displays negative $\mathrm{Ta}$ and $\mathrm{Ti}$ anomalies with negative phosphorous anomalies, also suggesting a similar processes to (1) and (2).

The remaining possibilities for Groups A1, A2 and D are now (3) and (4), but it is difficult to decipher between fractional crystallization of P-bearing phases and retention of $\mathrm{P}$ in the mantle source. The most significant $\mathrm{P}$-bearing repositories in high-MgO rocks and the upper mantle include fluoroapatite and whitlockite (Beswick \& Carmichael, 1978; Watson, 1980). However, apatite is one of the last minerals to crystallize from a mafic magma and it is nearly impossible to retain apatite in the mantle source during partial melting of the source 
(Watson, 1980). An alternative explanation may be that the $P$ data is simply just bad data, as the concentrations fall very close to the detection limit.

\subsubsection{Fe-Ti-oxide fractionation}

Increasing $\mathrm{TiO}_{2}$ and $\mathrm{V}$ with fractionation (i.e., decreasing $\mathrm{Mg \#}$ ) is observed in all groups except for Group C2 (not shown), and is characteristic of tholeiitic suites (Myashiro and Shido, 1975). It is interpreted to reflect low oxygen fugacities in the magma which suppresses magnetite and ilmenite fractionation (Osborn, 1962). However, there are still many samples that bear Ti anomalies.

Those samples exhibiting negative Ti anomalies (all or some of Groups $\mathrm{A} 2, \mathrm{~B}, \mathrm{C} 1, \mathrm{C} 2, \mathrm{E}$ and $\mathrm{F}$ ) in spider diagrams provides potential evidence for removal of (Fe-)Ti-oxides (e.g. rutile) or Ti-bearing amphibole, whereas those with positive anomalies (all or some of Group A2, C1, and D) may have accumulated Fe-Ti-oxides and Ti-bearing amphibole (e.g., Ionov and Hofmann, 1995; Tiepolo et al., 2000,2001; Klemme et al., 2005, 2006; Coltorti et al., 2007;). Alternatively, a negative $\mathrm{Ti}$ anomaly could reflect residual (Fe-)Ti-oxides or Tibearing amphibole in the source. Group A1 lacks a Ti anomaly and hence does not appear to have accumulated or fractionated away Fe-Ti-oxides. All samples from high-Ti Group $\mathrm{D}$ contain weak positive $\mathrm{Ti}$ anomalies, which may reflect presence of magnetite or other (Fe-)Ti-oxides. Select samples from Groups B and $\mathrm{C} 1$ also contain moderate positive $\mathrm{Ti}$ anomalies. 
Another possibility is that the partial melting may have been watersaturated, as this would allow for rutile to be stable in the source, accounting for the HFSE depletion (Prouteau et al., 1999) in some but not all cases.

According to Pearce (1996), Ti anomalies are an effective indicator of the extent of fractionation, as the negative $\mathrm{Ti}$ anomaly typically increases with progressive fractionation. Most crystallizing phases in basaltic magma do not influence $\mathrm{Ti} / \mathrm{Zr}$, however, when magnetite becomes a fractionating phase, $\mathrm{Ti}$ is progressively depleted while $\mathrm{Zr}$ continues to increase (decreasing $\mathrm{Ti} / \mathrm{Zr}$ ratio). The latter only seems to be the case for samples from Groups B and C1.

The relatively constant values of $\mathrm{V}$ with decreasing $\mathrm{Mg} \#$ in Groups $\mathrm{C} 1$ and C2 could be due to fractionation of rutile, clinopyroxene, or magnetite.

\subsubsection{Contamination}

The presence of a negative $\mathrm{Nb}$ anomaly, along with other negative HFSE anomalies (e.g. $\mathrm{Hf}, \mathrm{Zr}$, Ta), is a well-established feature of many LIP magmas (Bertrand, 1991; Arndt et al., 1993; Molzahn et al., 1996; Puffer, 2001; lacumin et al., 2003; Ewart et al., 2004). These anomalies are interpreted to reflect either (1) crustal assimilation by mantle-derived magmas (Arndt et al., 1993; Taylor \& McLennan, 1995); (2) a mantle source that was previously modified by metasomatic enrichment induced by the percolation of hydrous fluids or silicate melt, which may reflect ancient subduction (Duncan et al., 1984; Puffer et al., 2001; Ewart et al., 2004); or (3) interaction of plume- or asthenosphere-derived magmas with lithospheric mantle (Arndt \& Christensen, 1992). It is important to 
note that in all three scenarios, the $\mathrm{Nb}$ anomaly was inherited within the lithosphere. Given that sills (and dykes) represent the plumbing system to LIPS, these same processes should account for these anomalies observed in mafic to ultramafic intrusions. In addition to the isotopic evidence for contamination already presented (Figures $7.11 \& 7.12$ ), certain trace element ratios reveal further evidence for the influence of lithospheric material on the chemical compositions of most groups, and potential contaminant sources [i.e. subcontinental lithospheric mantle (SCLM) versus continental crust].

The ratio $\mathrm{La} / \mathrm{Nb}$ is a well-established proxy for the contamination of maficultramafic magmas. Pearce (2008) also highlighted its usefulness for monitoring crustal contamination, as well as $\mathrm{Ti} / \mathrm{Yb}$ for depth of melting. These two ratios were used in Figure 7.17 a to identify samples that have been contaminated. Samples with $\mathrm{La} / \mathrm{Nb}<1$ are considered to have been uncontaminated and this field is typical of OIB, kimberlites, and continental alkali basalts, while those samples plotting above the line are considered to have experienced variable amounts of contamination; LIPs plot between 0.5 to 7 (Wilson, 1989). It is apparent that all samples from all groups, with the exception of most samples of Group D, some of Group A2 and one of Group F, experienced at least some degree of contamination. The contamination in Groups A1, A2, E, and F appears to be relative minor $(\mathrm{La} / \mathrm{Nb}=\sim 1-3)$ compared to that of Groups $\mathrm{B}, \mathrm{C} 1$, and $\mathrm{C} 2$ $(\mathrm{La} / \mathrm{Nb}=\sim 3-20)$. Based on the relatively high $\mathrm{La} / \mathrm{Nb}$ ratios in the $\varepsilon \mathrm{Nd}$ versus $\mathrm{La} /$ $\mathrm{Nb}$ diagram (Figure 7.17b), it is suggested the low $\varepsilon N d$ values of Groups $\mathrm{B}, \mathrm{C} 1$ and $\mathrm{C} 2$ are due to contamination. 
To demonstrate that the LREE-enriched character of Group D is due to source enrichment (i.e. ancient subducted oceanic crust component), rather than crustal contamination, the diagram $(\mathrm{Th} / \mathrm{Yb})_{\mathrm{PM}}$ versus $(\mathrm{Nb} / \mathrm{Yb})_{\mathrm{PM}}$ is used (Figure 7.18), which segregates enrichment arising from crustal contamination, from enrichment due to enrichment of the source. The result is Group D samples demonstrating a clear trend of source enrichment, while samples from Groups B, C1 and C2 exhibit a trend typically caused by crustal contamination.

In attempting to distinguish between crustal and SCLM contamination, the ratios $\mathrm{Ti} / \mathrm{Yb}$ and $\mathrm{Nb} / \mathrm{La}$, when plotted against $\mathrm{La} / \mathrm{Sm}$ (Figures $7.19 \mathrm{a} \& 7.19 \mathrm{~b}$, respectively), should produce a correlation if the development of $\mathrm{Ti}$ and $\mathrm{Nb}-\mathrm{Ta}$ anomalies are due to lithospheric contributions (Condie, 1997). The correlation results from the negative $\mathrm{Nb}$ and $\mathrm{Ti}$ anomalies that accompany crustal contamination-induced LREE-enrichment. The weak negative correlation produced by Group C2 suggests that the geochemical signature may have been produced through crustal contamination, whereas Groups B and C1 exhibit constant $\mathrm{La} / \mathrm{Sm}$ with decreasing $\mathrm{Ti} / \mathrm{Yb}$ and $\mathrm{Nb} / \mathrm{La}$, perhaps indicating lithospheric contamination. Furthermore, Groups A2 and F do produce a slight correlation consistent with the crustal contamination of these two groups. The decrease in $\mathrm{Nb} / \mathrm{La}$ ratio with constant $\mathrm{La} / \mathrm{Sm}$ (a ratio that should increase with increasing upper crustal contamination or moderate-degree lower crust contamination) suggests Group A2 incorporated various quantities of lithospheric material. The trends exhibited by Groups B and C1 also cannot be produced by upper crustal 
contamination. The correlation of near-constant $\mathrm{La} / \mathrm{Sm}$ with decreasing $\mathrm{Nb} / \mathrm{La}$ is interpreted to reflect assimilation of SCLM melts depleted in HFSE.

Additionally, if the $\mathrm{Nb}$ depletion in these samples is due to crustal contamination, then a high $\mathrm{La} / \mathrm{Sm}$ ratio without depletion in $\mathrm{Yb}$ would be expected. What is observed in Groups B, C1 and C2 is a depletion in Yb relative to the rest of the groups; $\mathrm{Yb}=0.4$ to $9 \mathrm{x}$ chondrite in Groups $\mathrm{B}, \mathrm{C} 1$ and $\mathrm{C} 2$, compared to $\mathrm{Yb}=7$ to $10 \mathrm{x}$ chondrite in all other groups. This may suggest that the latter three groups contain a SCLM component.

Crustal contamination may also be indicated by negative $\mathrm{Nb}-\mathrm{Ta}$ anomalies in the absence of $\mathrm{Zr}-\mathrm{Hf}$ anomalies, along with positive $(\mathrm{La}-\mathrm{Yb})_{\mathrm{N}}($ Condie, 2001). This is observed in the PM-normalized diagrams (Figure 7.3b) of Groups A1, A2 and $\mathrm{F}$, but negative $\mathrm{Zr}-\mathrm{Hf}$ anomalies are present in most samples from Groups B, $\mathrm{C} 1, \mathrm{C} 2$ and $\mathrm{E}$.

In contrast, positive $\mathrm{Nb}$ anomalies, may be derived from a residual eclogitic component of a partially-melted subducting oceanic slab (which releases LREE and Th into the overlying mantle; Saunders, 1996; Sobolev et al., 2011). This would infer the recycling of an eclogitic slab in its mantle source.

Furthermore, the strong resemblance between Group C2 and both the Ramsay River Orthogneiss and Lake Harbour Group (Figure 7.20) support the idea that this group may have been subjected to significant crustal contamination. However, the $\mathrm{SiO}_{2}$ contents of this group are generally quite low ( 35-50 wt.\%), which opposes the suggestion that significant amounts of $\mathrm{SiO}_{2-}$ rich crustal material were incorporated into the Group C2 parental magma. The 
low $\mathrm{SiO}_{2}$ character could also be generated by olivine cumulates, which compositionally have low $\mathrm{SiO}_{2}$. However, mafic units also exhibit this pattern, meaning it cannot be the result of olivine cumulates. Therefore, Group C2 is considered to either represent (or contain a significant amount of) direct melt from metasomatized subcontinental lithospheric mantle (SCLM).

\subsubsection{Depth and degree of partial melting}

In order to understand the petrogenesis of the magmas which fed the Frobisher suite mafic to ultramafic sills, a general idea of the depth and degree of melting must be known. Certain ratios have been utilized as proxies for depth and degree of partial melting, including $\mathrm{Gd} / \mathrm{Yb}$ and $\mathrm{Ti} / \mathrm{Yb}$, and $\mathrm{La} / \mathrm{Sm}$, respectively. These ratios essentially reflect the slope of the most compatible, incompatible trace elements or REE, which changes with depth (and degree) of melting. Groups B, C1, and C2 are not plotted in this section due to the fact they appear to be contaminated.

The $(\mathrm{Gd} / \mathrm{Yb})_{\mathrm{N}}$ versus $(\mathrm{La} / \mathrm{Sm})_{\mathrm{N}}$ diagram (Figure 7.21$)$ from Álvero et al. (2014) defines garnet- and spinel-stability fields based on the primitive mantlenormalized HREE ratio of $G d / Y b$, which increases with increasing depth. All Group D samples plot within the garnet-stability field, with the exception of 1 sample. This indicates that the primary magmas to this group melted at great depths, where garnet is stable as the aluminous phase within mantle peridotite (consistent with other figures, e.g. chondrite-normalized REE diagrams). All samples from Groups A1, A2, E and F plot well-within the spinel stability field, 
indicating a much a higher degree of melting at shallower depths in comparison to the Group D samples.

An alternate diagram of $(\mathrm{Tb} / \mathrm{Yb})_{\mathrm{PM}}$ versus $(\mathrm{La} / \mathrm{Sm})_{\mathrm{PM}}$ (Figure 7.22$)$ by Wang (2002) further supports these observations in the aforementioned diagram, however, significantly fewer samples from Group D plot within the garnet-stability field. But nonetheless, it supports the indication of a greater depth melting in the petrogenesis of this group, compared to the groups that fall strictly within the spinel-stability field.

The $(\mathrm{La} / \mathrm{Sm})_{\mathrm{PM}}$ ratios of Group D are higher than those of Groups $\mathrm{A} 1$ and A2, indicating these melts were derived from a lower-degree of partial melting. The absence of $\mathrm{Nb}-\mathrm{Ta}$ anomalies in Group $\mathrm{D}$ confirm that the higher $(\mathrm{La} / \mathrm{Sm})_{\mathrm{PM}}$ ratio is not a result of contamination. Furthermore, Group A2 has higher (La/ Sm) $\mathrm{PM}$ ratios than Group $\mathrm{A} 1$, but same $(\mathrm{Gd} / \mathrm{Yb})_{\mathrm{PM}}$, which supports a higher degree of melting in the generation of Group A1 magmas compared to Group A2. Alternatively, this may suggest Group A2 is a more evolved, and thus more fractionated, magma of Group A1.

The distinct difference between the major low-Ti (Groups A1 \& A2) and high-Ti (Group D) groups in their contrasting trace element patterns (Figure 7.3ac), specifically, the fractionation systematics of MREE/HREE, should be highlighted. While the two groups show considerable overlap in LREE/MREE ratios (Figure 7.4), the MREE/HREE ratios of the high-Ti group are systematically higher and exhibit much more variation $\left[(\mathrm{Sm} / \mathrm{Yb})_{N}=\sim 2-3.8\right]$ than those of the low-Ti group $\left[(\mathrm{Sm} / \mathrm{Yb})_{\mathrm{N}}=\sim 1.2-2.7\right]$. The $(\mathrm{Sm} / \mathrm{Yb})_{\mathrm{N}}$ ratios do not correlate with 
Mg\#, indicating that such variations cannot be explained by crustal contamination or fractional crystallization, which would have a very minor influence on this ratio. Furthermore, these ratios indicate different depths of melting, where the high $(\mathrm{Sm} / \mathrm{Yb})_{N}$ ratio of the high-Ti group reflects the presence of significant amounts of garnet in the source, whereas the low $(\mathrm{Sm} / \mathrm{Yb})_{\mathrm{N}}$ ratios (nearly flat trend) of the low-Ti group excludes garnet in the source, indicating a spinel-bearing source. These differences in $(\mathrm{Sm} / \mathrm{Yb})_{\mathrm{N}}$ correspond to deeper $(>90 \mathrm{~km})$ and shallower $(<90 \mathrm{~km})$ depths of melting, respectively. This is because $\mathrm{Sm}$ is incompatible in mineral phases in spinel and garnet peridotite; however, $\mathrm{Yb}$ is compatible $(\mathrm{Kd}>3)$ in garnet. (Thirlwall et al., 1994). Furthermore, these interpretations are supported by diagrams from Wang (2002) and Álvero et al (2014), which outline the garnet and spinel peridotite melting fields.

The interpretation of a lower degree of partial melting for Group D (and Groups C1 \& C2) is also supported by the enrichment in LREE and other incompatible elements (Figures 7.3, 7.4, and 7.7), which is typical of magmas derived from lower degrees of partial melting. In a similar manner, higher degrees of partial melting lead to more even abundances of LREE and HREE, or even a depletion in LREE relative to HREE, which is observed in Groups A1 and A2 (and Groups B, E \& F). However, relatively flat REE patterns may be produced by lowdegree partial melts of a depleted source (i.e. MORB).

While none of the eight geochemical groups are likely representative of a primary magma (i.e. direct melt of mantle source), these trace element ratios should not have changed significantly through crystal fractionation processes in 
the crust. Note that contamination may have affected the $(\mathrm{La} / \mathrm{Yb})_{N}$ ratios of Groups B, C1 and C2 to a higher degree, but the depth/degree of melting results are still consistent with the rest of the observations, except for isotope data.

\subsubsection{Magma mixing}

\subsubsection{Group A1-like Group A2 samples}

Basic modelling (Figure 7.24) was undertaken in order to determine the origin of the only two ultramafic Group A2 samples (assigned based on similar chondrite-normalized REE patterns (Figure 7.3a; 14SAB-S130A01 \& 14SABL001A01) that have an apparent affinity to Group A1 geochemistry, including concentrations of compatible and incompatible elements and degree of fractionation, but are distinct from the rest of the Group A2 samples, which are mafic in composition. Mixing was conducted to produce the pattern of $14 \mathrm{SAB}$ L001A01, while the same origin is suggested for 14SAB-S130A01 by their similar chemistries (see all previous figures).

There is evidence for some mixing between Groups A1 and D, which may have produced two samples that were assigned to Group A2 on the basis of their similar chondrite-normalized REE patterns. For example, within the $\varepsilon N d$ versus ${ }^{147} \mathrm{Sm} / 144 \mathrm{Nd}$ diagram, $14 \mathrm{SAB}-\mathrm{S} 130 \mathrm{~A} 01$ plots within the field of Group D samples (Figure 7.11a), whereas the rest of Group A2 and A1 samples display greater

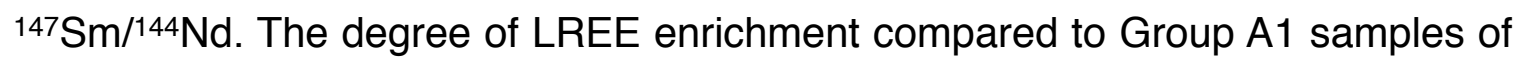
similar composition is not likely to have been produced by crystal fractionation, considering the very small difference in $\mathrm{Mg \#}(<4)$. In the $\mathrm{La} / \mathrm{Sm}$ versus $\mathrm{Yb}$ 
diagram (Figure 7.23), these two samples have similar $\mathrm{Yb}$ values to Group $\mathrm{A} 1$ samples, which are significantly lower in $\mathrm{Yb}$ than the rest of Group A2 samples. However, the La/Sm ratios are higher and very similar to Group A2 samples in these samples.

Another possibility for this enrichment, given that it is similar to Group A1 samples, is a difference in partial melting. This would likely result in different $\mathrm{Gd} /$ $\mathrm{Yb}$ ratios from those samples in Group $\mathrm{A} 1$, and marginally higher $\mathrm{Gd} / \mathrm{Yb}$ ratios are observed in these two samples.

Using the mixing feature in Igpet, $70 \%$ of Group A1 sample 14SABL003A01 was mixed with $30 \%$ of Group D sample 14SAB-L009A02, which produced a chondrite-normalized REE pattern very similar to Group A2 sample 14SAB-L001A01 (Figure 7.24). This is not conclusive evidence, but it illustrates the plausibility that the high-MgO-Cr-Ni Group A2 samples were produced by mixing between magma of Groups $A 1$ and D. 


\section{References}

Álvaro, J. J., Pouclet, A., Ezzouhairi, H., Soulaimani, A., Bouougri, E. H., Imaz, A. G., and Fekkak, A. (2014). Early Neoproterozoic rift-related magmatism in the Anti-Atlas margin of the West African craton, Morocco: Precambrian Research, v. 255, Part 1, p. 433-442. http://dx.doi.org/10.1016/ j.precamres.2014.10.008.

Arndt, N.T. (1994). Archean komatiites. In: Condie, K.C. (Ed.), Archean Crustal Evolution, Developments in Precambrian Geology, vol. 11. Elsevier, Amsterdam, pp. 11-44.

Arndt, N.T. (2008). Komatiite. Cambridge University Press, Cambridge.

Arndt, N.T. \& Christensen, U. (1992). Role of lithospheric mantle in continental volcanism: thermal and geochemical constraints. Journal of Geophysical Research, 97: 10,967-10,981.

Arndt, N. T., Czamanske, G. K., Wooden, J. L. \& Fedorenko, V. A. (1993). Mantle and crustal contributions to continental flood volcanism. Tectonophysics 223, 39-52.

Arndt, N., Menzies, M.A. (2005). The Ethiopian Large Igneous Province. January 2005 LIP of the Month. http://www.largeigneousprovinces.org/05jan.

Arndt, N.T., Nesbitt, R.W. (1982). Geochemistry of Munro Township basalts. In: Arndt, N.T., Nisbet, E.G. (Eds.), Komatiites. George Allen and Unwin, London, pp. 19-28.

Barley, M.E., Kerrich, R., Reudavy, I., Xie, Q. (2000). Late Archean Ti-rich, Aldepleted komatiites and komatiitic volcaniclastic rocks from the Murchison 
Terrane in Western Australia. Australian Journal of Earth Sciences 47, 873-883.

Bertrand, H. (1991). The Mesozoic tholeiitic province of Northwest Africa: a volcano-tectonic record of the early opening of Central Atlantic. In: Kampunzu, A. B. \& Lubala, R. T. (eds) Magmatism in extensional structural settings. Berlin: Springer, pp. 147-188.

Beswick, A.E. and Carmichael, I.S.E. (1978). Constraints on mantle source compositions imposed by phosphorous and the rare-earth elements, Contributions to Mineralogy and Petrology 67, pp. 317-330.

Cabanis, B. and Lecolle, M. (1989). Le diagramme La/10-Y/15-Nb/8: an outil pour la discrimination des series volcaniques et la mise en evidence des processus de melange et /ou de contamination crustale. Comptes Rendus de l'Academie des Sciences Series II 309, 2023-2029.

Cann, J.R. (1970). Rb, Sr, Y, Zr and $\mathrm{Nb}$ in some ocean floor basaltic rocks, Earth and Planetary Science Letters, vol.10, pp. 7-11.

Carlson, R.W. (1991). Physical and chemical evidence on the cause and source characteristics of flood basalt volcanism. Australian Journal of Earth Sciences, 38: 525-544.

Coltorti, M., Bonadiman, C., Faccini, B., Grégoire, M., O’Reilly, S.Y. and Powell, W. (2007). Amphiboles from suprasubduction and intraplate lithospheric mantle. Lithos 99, 68-84.

Condie, K.C. (1976). Trace-element geochemistry of Archean greenstone belts. Earth-Science Reviews, 12, 393-417. 
Condie, K.C. (1981a). Archean Greenstone Belts. Elsevier, Amsterdam-OxfordNew York. 275-311 pp.

Condie, K.C. (1981b). Archean Greenstone Belts. Elsevier, Amsterdam, pp. 434.

Condie, K.C. (1994). Greenstones through time. In: Condie, K.C. (Ed.), Archean Crustal Evolution. Elsevier, Amsterdam, pp. 85-120 (Chapter 3).

Condie, K.C. (1997). Sources of Proterozoic mafic dyke swarms: constraints from $\mathrm{Th} / \mathrm{Ta}$ and La/Yb ratios. Precambrian Research. 81: 3-14.

Condie, K.C., 2001, Mantle plumes and their record in Earth history: Cambridge, Cambridge University Press, pp. 306

DePaolo, D.J. and Wasserburg, G.J. (1976). Nd isotopic variation and petrogenetic models. Geophysical Research Letters 3, 249-252.

Duncan, A. R., Erlank, A. J. \& Marsh, J. S. (1984). Regional geochemistry of the Karoo igneous province. In: Erlank, A. J. (ed.) Petrogenesis of the Volcanic Rocks of the Karoo Province. Special Publication of the Geological Society of South Africa 13, 355-388.

Duncan R.A., Hooper P.R., Rehacek J., Marsh J.S. and Duncan A.R. (1997). The timing and duration of the Karoo igneous event, southern Gondwana: Journal of Geophysical Research, v. 102, p. 1812718138, doi: 10.1029/97JB00972.

Ewart, A., Milner, S.C., Armstrong, R.A. and Duncan, A.R. (1998). Etendeka volcanism of the Goboboseb Mountains and Messum Igneous Complex, Namibia. Part I: geochemical evidence of Early Cretaceous Tristan plume 
melts and the role of crustal contamination in the Paraná-Etendeka CFB. Journal of Petrology, 39: 191-225.

Ewart, A., Marsh, J. S., Milner, S. C., Duncan, A. R., Kamber, B. S. \& Armstrong, R. A. (2004). Petrology and geochemistry of Early Cretaceous bimodal continental flood volcanism of the NW Etendeka, Namibia. Part 1: Introduction, mafic lavas and re-evaluation of mantle source components. Journal of Petrology 45, 59-105.

Faure, G. and Mensing, T.M. (2005). Isotopes. John Wiley \& Sons, New Jersey, pp. 897.

Galerne, C.Y., Neumann, E.R., Aarnes, I., Planke, S. (2010). Magmatic differentiation processes in saucer-shaped sills: evidence from the Golden Valley Sill in the Karoo Basin, South Africa. Geosphere, 6, pp. 163-188 (Special Issue LASI III Conference).

Greenough, J.D., Dostal, J., \& Mallory-Greenough, L.M. (2005). Igneous rock associations 5. Oceanic island volcanism II: mantle processes. Geoscience Canada, 32: 77-90.

Hanski, E., Huhma, H., Rastas, P., Kamenetsky, V.S. (2001). The Palaeoproterozoic komatiite-picrite association of Finnish Lapland. Journal of Petrology 42, pp. 855-876.

Hirose, K. and Kushiro, I. (1993). Partial Melting of Dry Peridotites at High Pressures: Determination of Compositions of Melts Segregated from Peridotite Using Aggregates of Diamond. Earth and Planetary Science Letters, 114, 477-489. https://doi.org/10.1016/0012-821X(93)90077-M 
Hooper P.R. (1982). The Columbia River Basalts: Science, v. 215, p. 1463 1468, doi:10.1126/science.215.4539.1463.

lacumin, M., De Min, A., Piccirillo, E. M. \& Bellieni, G. (2003). Source mantle heterogeneity and its role in the genesis of Late Archaean-Proterozoic (27-10 Ga) and Mesozoic (200 and 130Ma) tholeiitic magmatism in the South American Platform. Earth-Science Reviews 62, 365-397

Ionov, D.A., Hofmann, A.W., (1995). Nb-Ta-rich mantle amphiboles and micas: implications for subduction-related metasomatic trace element fractionations. Earth Planet. Sci. Lett. 131, 341-356.

Jochum, K.P., Arndt, N.T., Hofmann, A.W. (1991). Nb-Th-La in komatiites and basalts: constraints on komatiite petrogenesis and mantle evolution. Earth and Planetary Science Letters 107, 272-289.

Klemme, S., Gunther, D., Hametner, K., Prowatke, S., Zack, T., 2006. The partitioning of trace elements between ilmenite, ulvospinel, armalcolite and silicate melts with implications for the early differentiation of the moon. Chemical Geology, 234, 251-263.

Klemme, S., Prowatke, S., Hametner, K., Gunther, D. (2005). Partitioning of trace elements between rutile and silicate melts: implications for subduction zones. Geochimica et Cosmochimica Acta 69, 2361-2371.

Lafleche, M.R., Dupy, C., Dostal, J. (1992a). Tholeiitic volcanic rocks of the Late Archean Blake River Group, Southern Abitibi greenstone belt: origin and geodynamic implications. Canadian Journal of Earth Sciences 29, 14481458. 
Leeman, W.P., and Hawkesworth, C.J. (1986). Open magmatic systems - some isotopic and trace element constraints. Journal of Geophysical Research $91,5901-5912$.

Lesher, C.M., Arndt, N.T. (1995). REE and Nd isotope geochemistry, petrogenesis and volcanic evolution of contaminated komatiites at Kambalda, Western Australia. Lithos 34, 127-157.

Lesher, C. M., Burnham, O. M., Keays, R. R., Barnes, S. J., and Hulbert, L., (2001). Geochemical discrimination of barren and mineralized komatiites associated with magmatic Ni-Cu-(PGE) sulfide deposits: Canadian Mineralogist, v. 39, p. 673-696.

Lightfoot, P.C., Hawkesworth, C.J., Hergt, J., Naldrett, A.J., Gorbachev, N.S., Fedorenko, V.A., Doherty, W. (1993). Remobilisation of the continental lithosphere by a mantle plume: major-, trace-element, and $\mathrm{Sr}-$, $\mathrm{Nd}-$, and Pb-isotopic evidence from picritic and tholeiitic lavas of the Noril'sk District, Siberian Trap, Russia. Contributions to Mineralogy and Petrology, 114: 171-188.

Loewen, M.W., Duncan, R.A., Kent, A.J.R. \& Krawl, K. (2013). Prolonged plume volcanism in the Caribbean Large Igneous Province: New insights from Curaçao and Haiti. Geochemistry Geophysics Geosystems. 14: 42414259. doi:10.1002/ggge.20273.

Ludden, J., Gelinas, L., Trudel, P. (1982). Archean metavolcanics from the Rouyn-Noranda district, Abitibi greenstone belt, Quebec. 2. Mobility of 
trace elements and petrogenetic constraints. Canadian Journal of Earth Sciences 19, 2276-2287.

Luttinen, A.V., Furnes, H. (2000). Flood basalts of Vestfjella: Jurassic magmatism across an Archaean-Proterozoic lithospheric boundary in Dronning Maud Land, Antarctica. Journal of Petrology 41, 1271-1305.

Mahoney, J.J.; Coffin, M.R., eds. (1997). Large igneous provinces: continental, oceanic, and planetary flood volcanism. Washington DC, USA, American Geophysical Union, 438pp. (AGU Geophysical Monograph, 100).

Maier, W., Rasmussen, B., Fletcher, I., Godel, B., Barnes, S.J., Fisher, L., and Yang, S. (2015). Petrogenesis of the 2.77 Ga Monts de Cristal complex, Gabon: Evidence for direct precipitation of Pt-arsenides from basaltic magma. Journal of Petrology, 56, 1285-1308.

McCuaig, T.C., Kerrich, R., \& Xie, Q. (1994). Phosphorus and high field strength element anomalies in Archean high-magnesian magmas as possible indicators of source mineralogy and depth. Earth and planetary science letters , 124 (1), 221-239.

McDonough, W.F. and Sun, S.-S. (1995). Composition of the Earth. Chemical Geology 120: 223-253. doi: 10.1016/0009-2541(94)00140-4.

Molzahn, M., Reisberg, L. \& Wo. rner, G. (1996). Os, Sr, Nd, Pb, O isotope and trace element data from the Ferrar flood basalts, Antarctica: evidence for an enriched subcontinental lithospheric source. Earth and Planetary Science Letters 144, 529-545.

Mungall, J.E. (2016). U-Pb geochronology documents out-of-sequence 
emplacement of ultramafic layers in the Bushveld Igneous Complex of South Africa. Nature Communications, 7:13385 doi:10.1038/ ncomms13385.

Myashiro, A. and Shido, F. (1975). Tholeiitic and calc-alkaline series in relation to the behaviours of titanium, vanadium, chromium and nickel, American Journal of Science, 275 (1975) 265-277.

Naldrett, A.J., Lightfoot, P.C., Fedorenko, V.A., Doherty, W. \& Gorbachev, N.A. (1992). Geology and geochemistry of intrusions and flood basalts of the Noril'sk region, USSR, with implications for the origin of the $\mathrm{Ni}-\mathrm{Cu}$ ores. Economic Geology, 87: 975-1004.

Osborn, E.F., 1962. Reaction series for sub-alkaline igneous rocks based on different oxygen pressure conditions, American Mineralogy, 47 (1962) 211-266.

Pearce, J.A. (2008). Geochemical fingerprinting of oceanic basalts with applications to ophiolite classification and the search for Archean oceanic crust. Lithos, 100, pp. 14-48, 10.1016/j.lithos.2007.06.016

Pearce, J.A. and Parkinson, I.J. (1993). Trace element models for mantle melting: application to volcanic arc patrogenesis; in Prichard, H.M., Alabaster, T., Harris, N.B.W., and Neary, C.R., eds., Magmatic Processes and Plate Tectonics, Geological Society Special Publications, no. 76, p. 373-403.

Pearce, J.A. (1996). A User's Guide to Basalt Discrimination Diagrams, in Wyman, D.A., ed., Trace Element Geochemistry of Volcanic Rocks: 
Applications for Massive Sulphide Exploration: Geological Association of Canada, Short Course Notes, v. 12, p. 79-113.

Peate, D.W. (1997). The Parana-Etendeka Province. In: Mahoney, J. J. \& Coffin, M. F. (eds) Large Igneous Provinces: Continental, Oceanic, and Planetary Flood Volcanism. Geophysical Monograph, American Geophysical Union $100,247-272$.

Puffer, J. H. (2001). Contrasting high field strength element contents of continental flood basalts from plume versus reactivated-arc sources. Geology 28, 675-678.

Schilling, J.-G. (1973). Iceland mantle plume: geochemical study of Reykjanes Ridge. Nature, 242:565-571.

Scoates, J. S., Wall, C. J., Friedman, R. M., VanTongeren, J. A. \& Mathez, E. A (2012). Age of the Bushveld Complex. Abstract, Goldschmidt Conference, Montreal, Canada, session 04G (2012).

Shimizu, K., Nakamura, E., Maruyama, S., Kabayashi, K. (2004). Discovery of Archean continental and mantle fragments inferred from xenocrysts in komatiites, the Belingwe greenstone belts, Zimbabwe. Geology 32, 285288.

Sills, J.D., Savage, D., Watson, J.V., Windley, B.F. (1982). Layered ultramafic gabbrobodies in the Lewisian of northwest Scotland: geochemistry and petrogenesis. Earth and Planetary Science Letters 58, 345-360.

Sobolev S. V. Sobolev A. V. Kuzmin D. V. Krivolutskaya N. A. Petrunin A. G. Arndt N. T. Radko V. A. Vasiliev Y. R. ( 2011 ). Linking mantle plumes, large 
igneous provinces and environmental catastrophes. Nature 477 , pp. 312 $-316$

Sun, S.S. and McDonough, W.F. (1989). Chemical and isotopic systematics of oceanic basalts; implications for mantle composition and processes. In: Magmatism in the ocean basins. Saunders, A.D. and Norry, M.J. (Editors), Geological Society of London, London. 42: 313-345.

Sun, S.S., Nesbitt, R.W. (1978). Petrogenesis of Archean ultrabasic and basic volcanics - evidence from rare earth elements. Contributions to Mineralogy and Petrology 65, 301-325.

Taylor, S. R. \&McLennan, S.M. (1995). The geochemical evolution of the continental crust. Review of Geophysics 33, 241-265.

Tiepolo, M., Bottazzi, P., Foley, S.F., Oberti, R., Vannucci, R., Zanetti, A. (2001). Fractionation of $\mathrm{Nb}$ and $\mathrm{Ta}$ from $\mathrm{Zr}$ and $\mathrm{Hf}$ at mantle depths: the role of titanian pargasite and kaersutite. Journal of Petrology 42, 221-232.

Tiepolo, M., Vannucci, R., Oberti, R., Foley, S., Bottazzi, P., Zanetti, A. (2000). Nb and Ta incorporation and fractionation in titanian pargasite and kaersutite: crystal chemical constraints and implications for natural systems. Earth Planetary Science Letters, 176, 185-201.

Thirlwall, M.F., Upton, B.G.J., and Jenkins, C. (1994). Interaction between continental lithosphere and the Iceland plume: Sr-Nd-Pb isotope geochemistry of Tertiary basalts, NE Greenland. Journal of Petrology, 35:839-879. 
Wall, C.J, Scoates, J.S., Friedman, R.M., Meurer, W.P., 2012, Age of the Stillwater Complex, Goldschmidt 2012 Conference Abstract, Mineralogical Magazine.

Wang, K., T. Plank, J. D. Walker, and E. I. Smith (2002). A mantle melting profile across the Basin and Range, SW USA, J. Geophys. Res., 107(B1), http://.dx.doi.org/10.1029/2001JB000209.

Watson, E.B. (1980). Apatite and phosphorous in mantle source regions: an experimental study of apatite/melt equilibria at pressures to $25 \mathrm{kbar}$, Earth Planetary Science Letters 51, 322-335.

Wilson, M. (1989). Igneous Petrogenesis: A Global Tectonic Approach. Unwin Hyman, London. http://dx.doi.org/10.1007/978-1-4020-6788-4.

Winchester, J.A., Floyd, P.A. (1976). Geochemical magma type discrimination application to altered and metamorphosed basic igneous rocks. Earth and Planetary Science Letters 28, 459-469.

Xu, Y.-G., He, B., Chung, S.-L., Menzies, M.A., and Frey, F.A. (2004). Geologic, geochemical, and geophysical consequences of plume involvement in the Emeishan flood-basalt province. Geology, 32: 917-920.

Zhai M G, Santosh M. (2011). The early Precambrian odyssey of the North China Craton: A synoptic overview. Gondwana Research, 20: 6-25

Zhao, J.-X., Malcolm, M.T., \& Korsch, R.J. (1994). Characterisation of a plumerelated c. 800 Ma magmatic event and its implications for basin formation in central-southern Australia. Earth and Planetary Science Letters, 121: 349-367. 


\section{Legend}

\section{$\star$ Group A1}

$\wedge$ Group A2 -Low-Ti

T Group A2

$\triangle$ Group B

ङ Group C1

ऍ Group C2

\& Group D_-High-Ti

$凶$ Group E

Group F

Figure 7.1: Legend of the eight geochemical groups (A1, A2, B, C1, C2, D, E, \&

F) recognized within the Frobisher suite sill geochemistry. Major geochemical groups (most commonly occurring) within the sill suite are bolded. Of these, Group D is considered the high-Ti group, and Groups A1 and A2 are considered low-Ti. 
Figure 7.2: Assessment of element mobility using the method of Cann (1970), whereby elements are plotted against $Z$ r. a-c) Incompatible elements $\mathrm{Y}, \mathrm{P} \& \mathrm{Ti}$ form coherent trends with small degrees of scatter, and are thus considered to have been immobile during metamorphism. $d-f)$ Large-ion lithophile elements (LILE) $\mathrm{K}, \mathrm{Ba}, \& \mathrm{~Pb}$ show significant scatter, and are thus considered to have become mobile during metamorphism. All values are in ppm. 

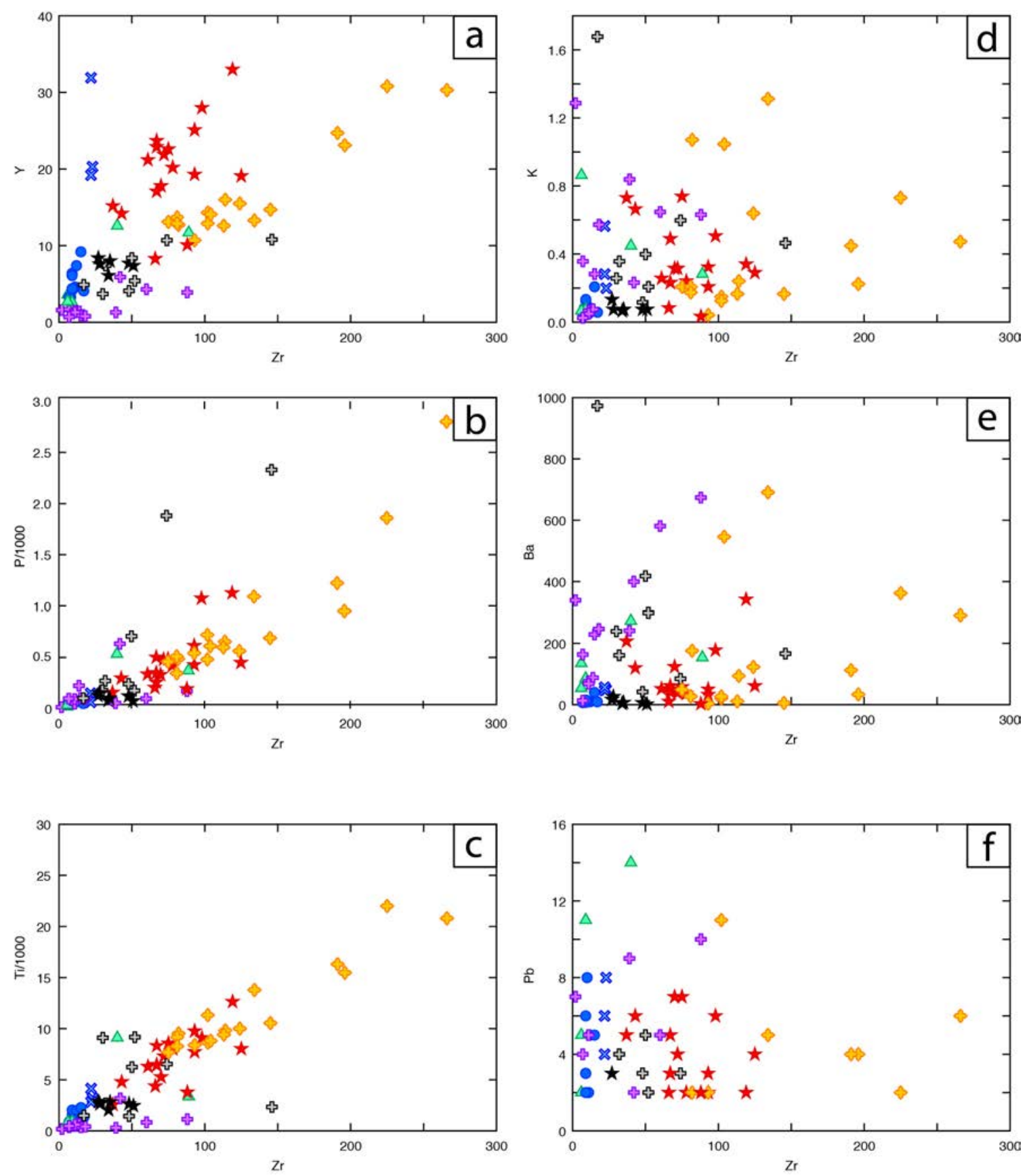
Figure 7.3a-c: a) Chondrite-normalized REE diagrams for all geochemical groups. b) Primitive mantle-normalized spider diagrams for all geochemical groups. c) MORB-normalized spider diagrams for all geochemical groups. Chondrite and primitive mantle(PM)-normalization values from Sun and McDonough (1989), and MORB normalization values from Pearce (1993). Abbreviations: $\mathrm{M}=$ mafic; $\mathrm{UM}=$ ultramafic. 

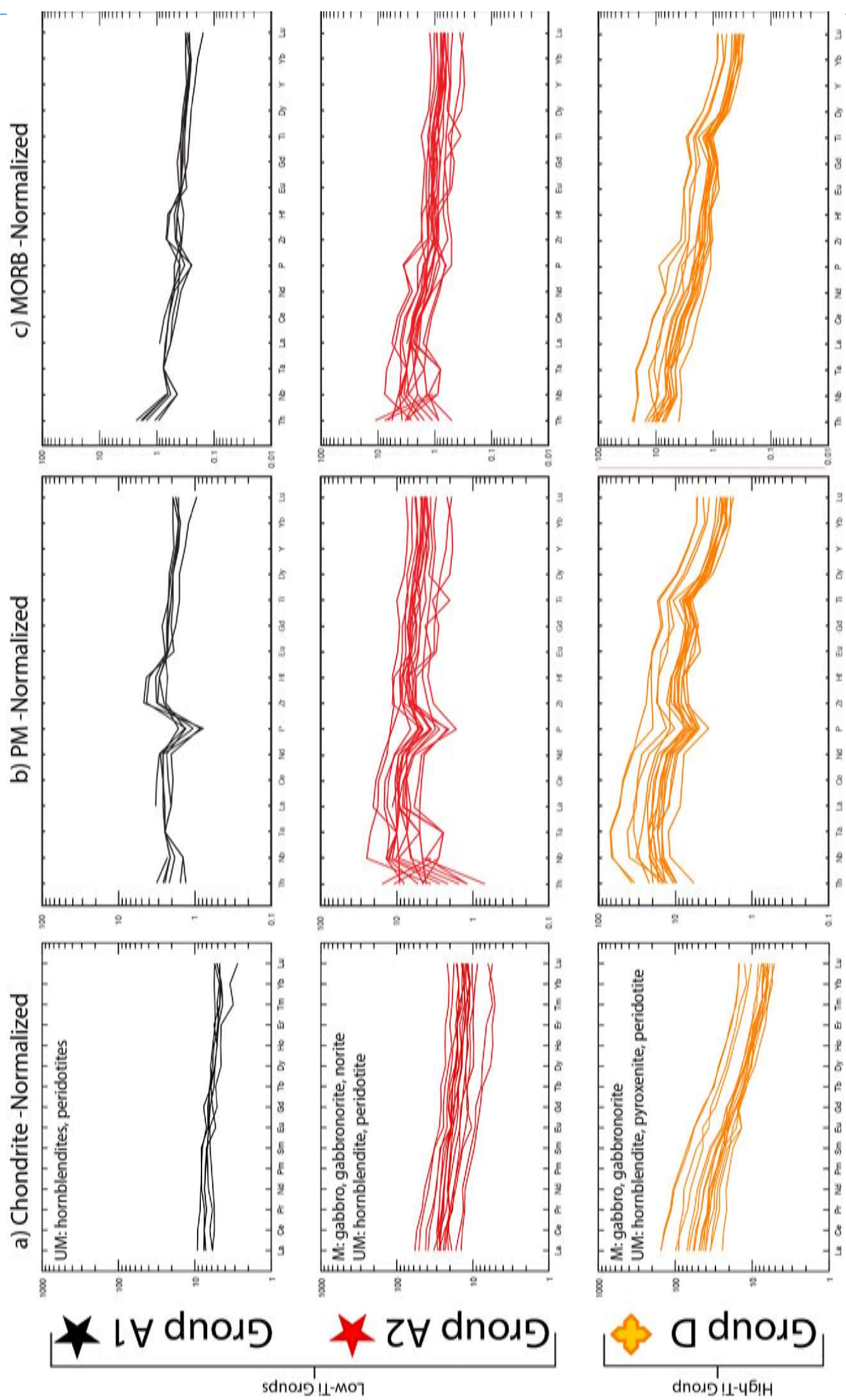

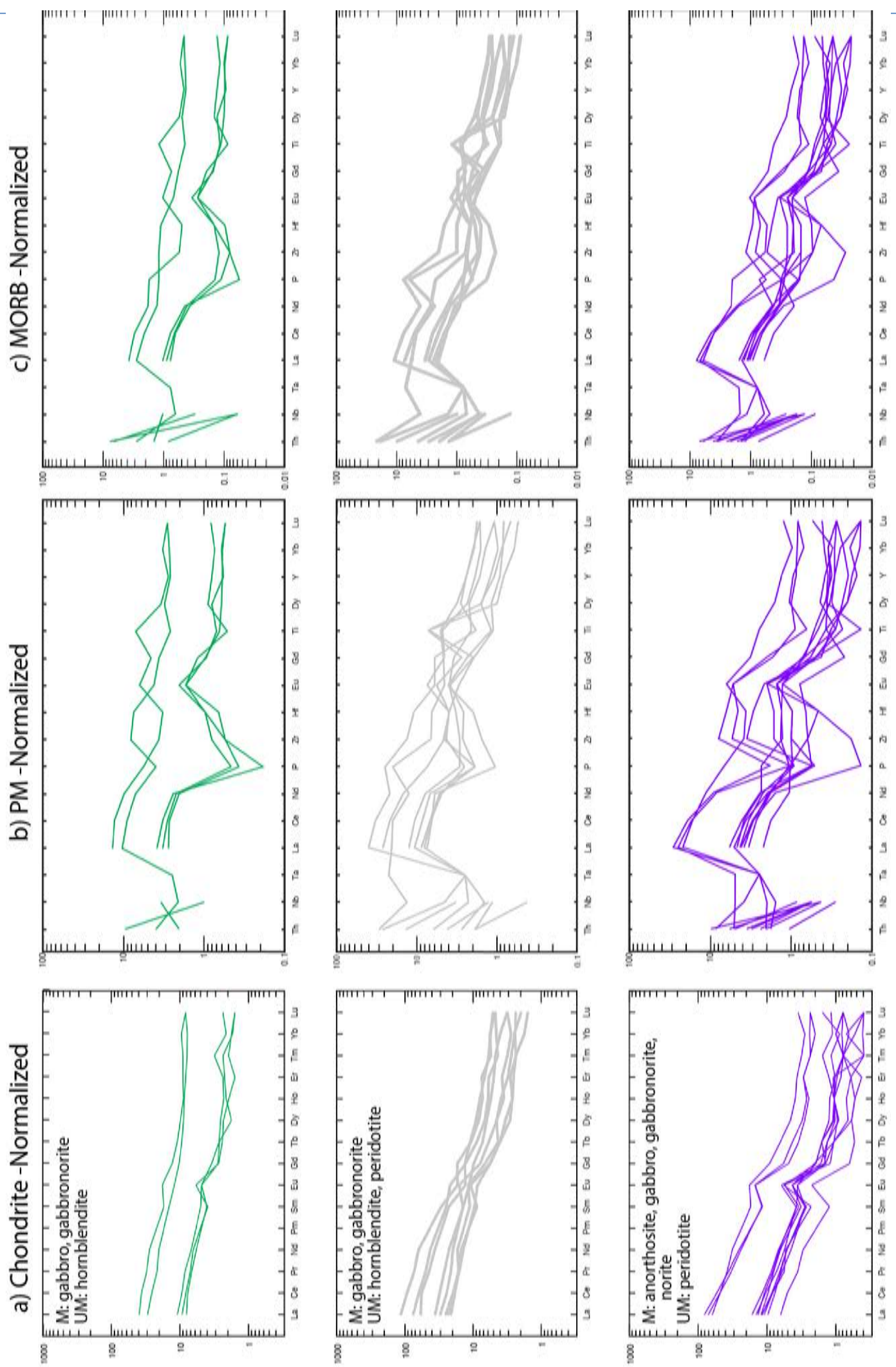

ק gdnoג

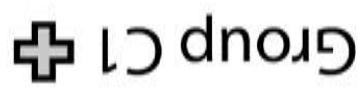

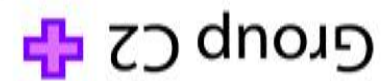



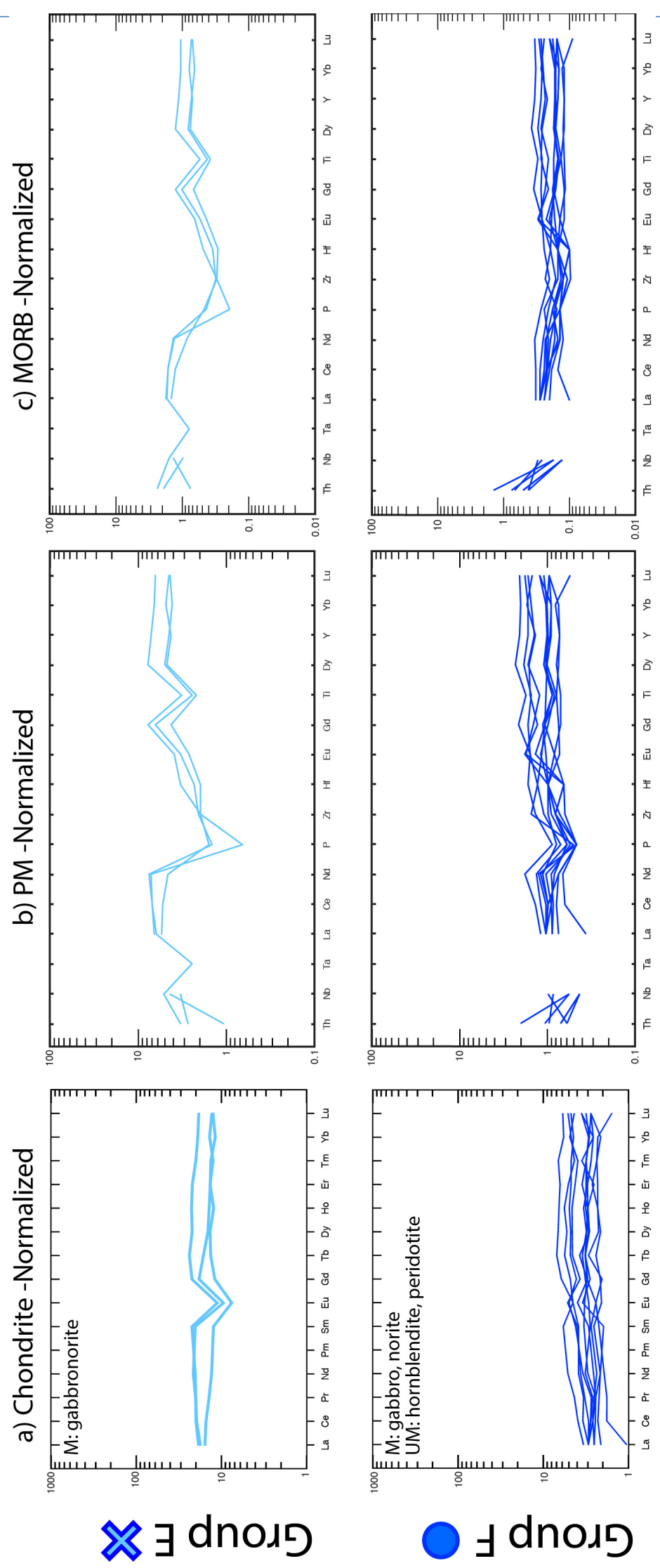


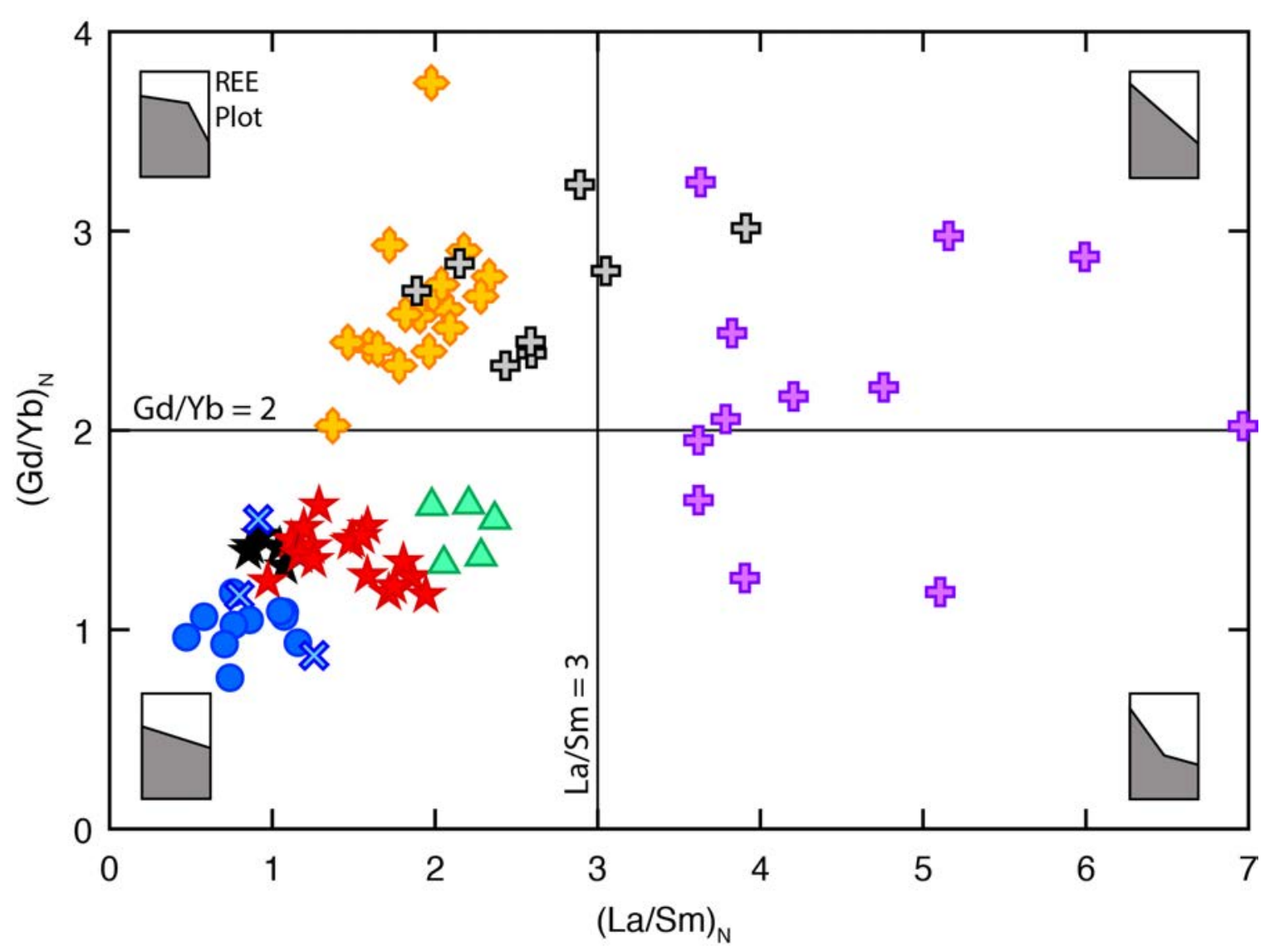

Figure 7.4: Bivariate diagram of $(\mathrm{Gd} / \mathrm{Yb})_{\mathrm{N}}$ and $(\mathrm{La} / \mathrm{Sm})_{\mathrm{N}}$ illustrating the differences in HREE and LREE slopes between the different geochemical groups in chondrite-normalized REE diagrams. Template from Naldrett et al. (1992). 

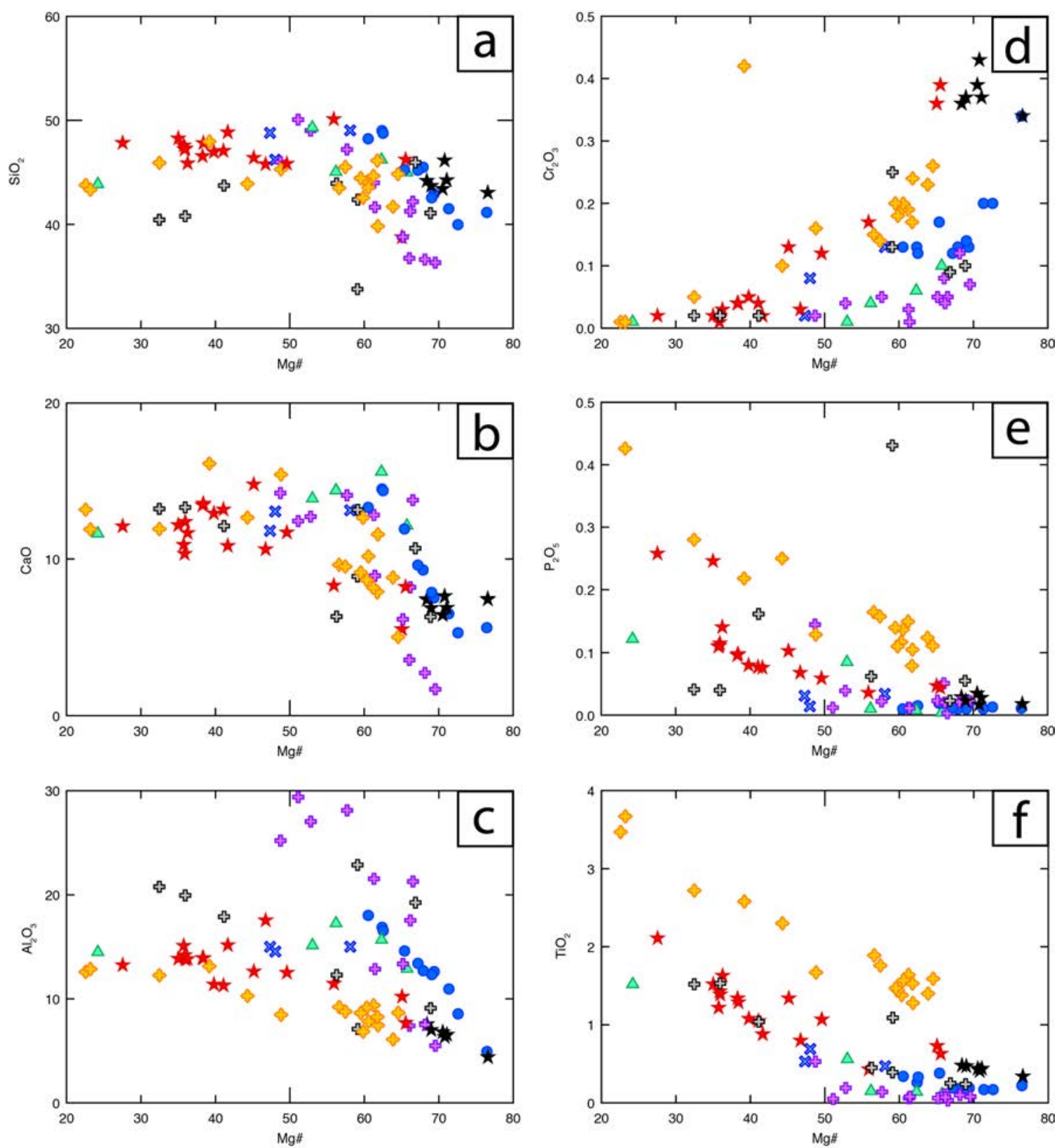

Figure 7.5: Major oxide variations $\left[\mathrm{SiO}_{2}(\mathrm{a}), \mathrm{CaO}\right.$ (b), $\mathrm{Al}_{2} \mathrm{O}_{3}$ (c), $\mathrm{Cr}_{2} \mathrm{O}_{3}$ (d), $\mathrm{P}_{2} \mathrm{O}_{5}$ (e) \& $\mathrm{TiO}_{2}$ (f)] with $\mathrm{Mg} \#$ as an index of fractionation. 


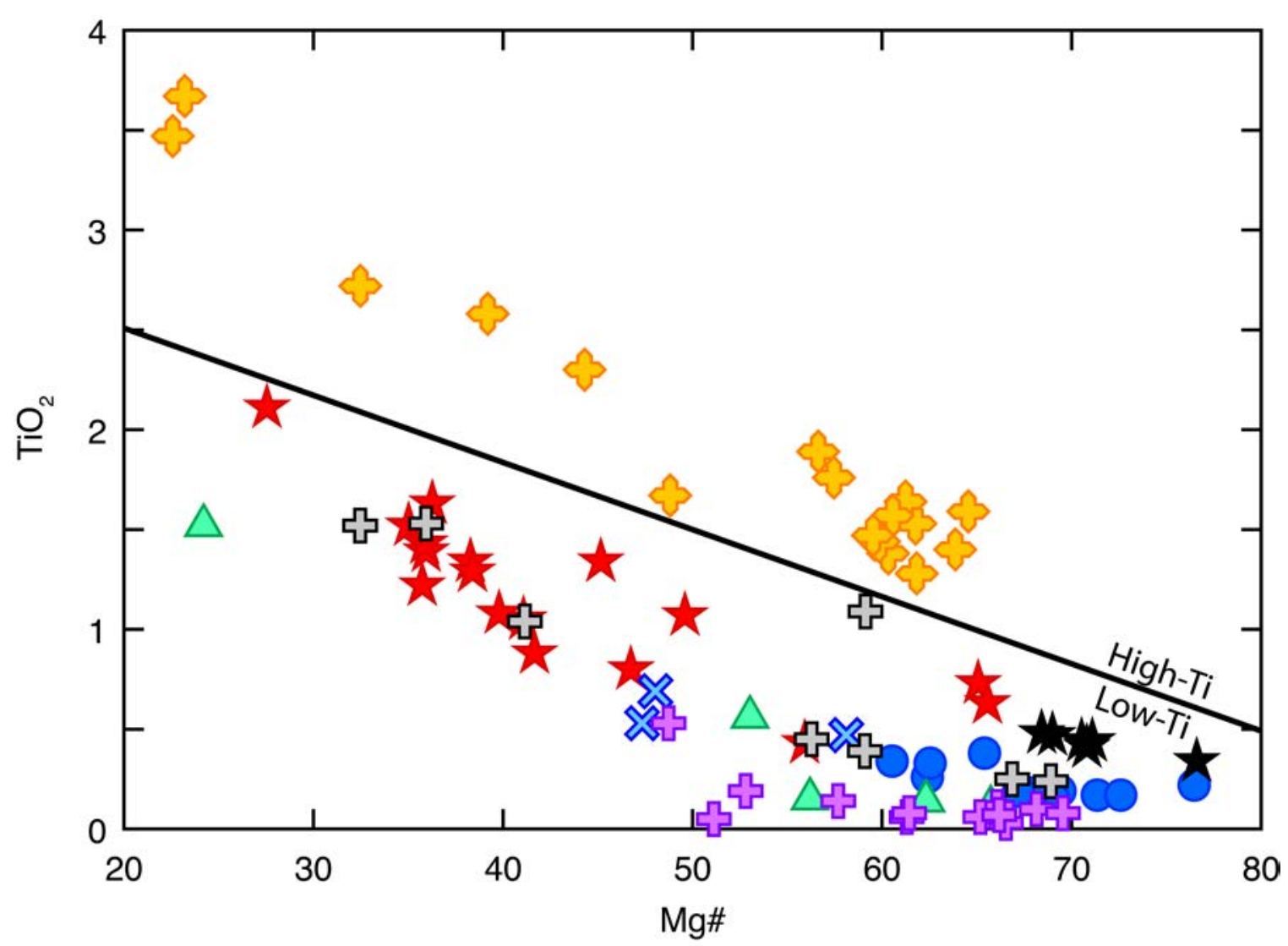

Figure 7.6: Division between low-Ti and high-Ti groups, which reflects the groups' overall incompatible element or oxide level concentrations, and is primarily discriminated based on differing $\mathrm{TiO}_{2}$ and $\mathrm{P}_{2} \mathrm{O}_{5}$ concentrations (Hooper, 1982). Group D is considered high-Ti, while the remainder of the groups are low-Ti. However, given the high abundance of sills containing geochemical signatures of Groups $A 1, A 2$ and $D$, with the rest of the groups as minor components, the term "low-Ti" will be applied strictly to Groups A1 and A2, and high-Ti strictly to Group D. 


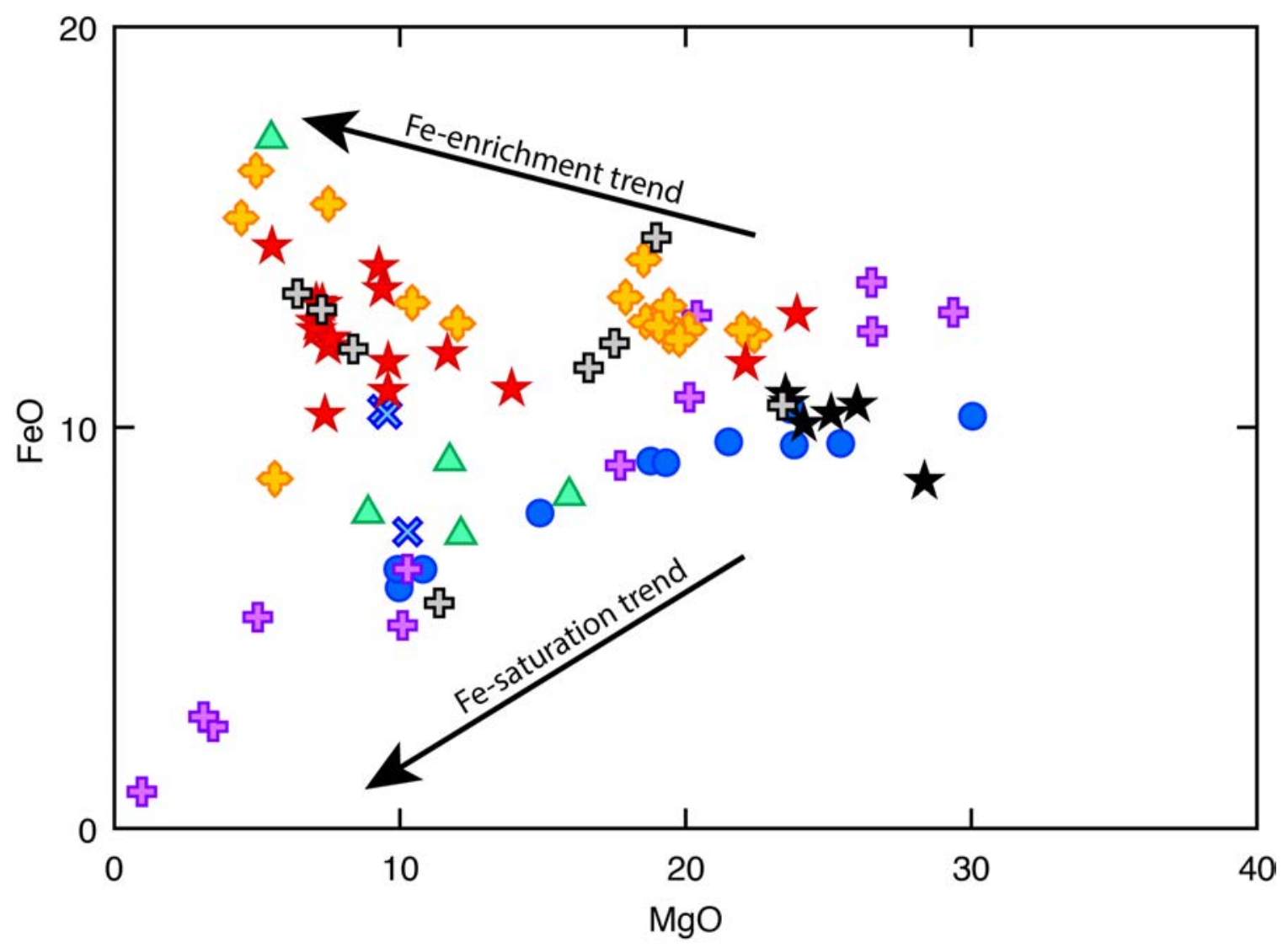

Figure 7.7: The variation in $\mathrm{FeO}$ with respect to decreasing $\mathrm{MgO}$, an oxide that typically decreases as magmas evolve, illustrates different trends between certain geochemical groups. 
Figure 7.8: Trace element variations with $\mathrm{Mg \#}$ as an index of fractionation. Included are highly compatible trace elements ( $\mathrm{Ni}, \mathrm{Co}$ ), high-field strength elements (Th, La, Sm, Y, Zr, Sc and $\mathrm{Nb}$ ), and total REE. Incompatible trace elements which have distinctly higher concentrations in the high-Ti Group D compared to all other groups including $\mathrm{Ce}, \mathrm{Eu}, \mathrm{Ga}, \mathrm{Gd}, \mathrm{Hf}, \mathrm{La}, \mathrm{Nb}, \mathrm{Nd}, \mathrm{Pr}, \mathrm{Sm}$, $\mathrm{Ta}, \mathrm{Zr}$, and $\mathrm{Hf}$ (some not shown). 

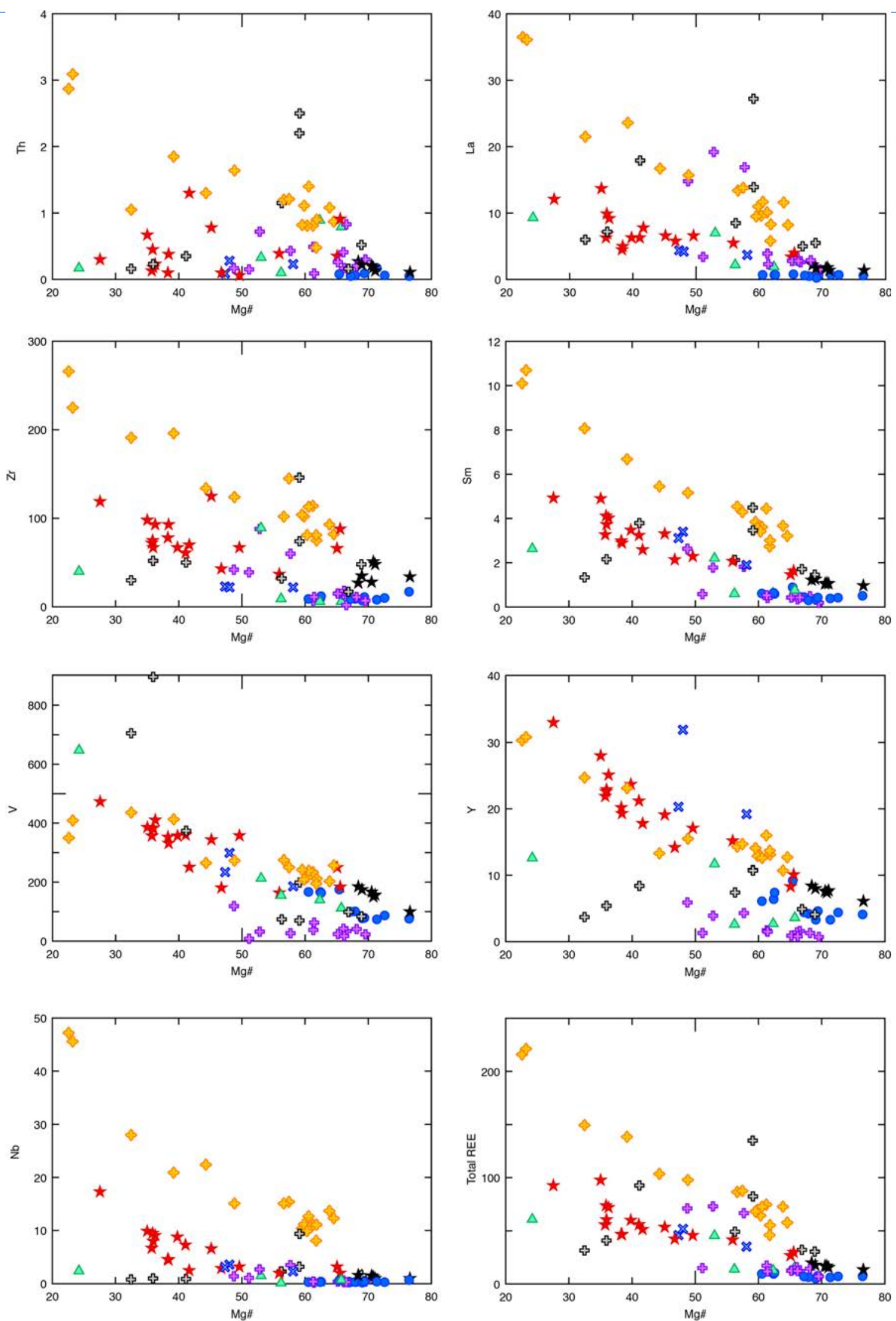

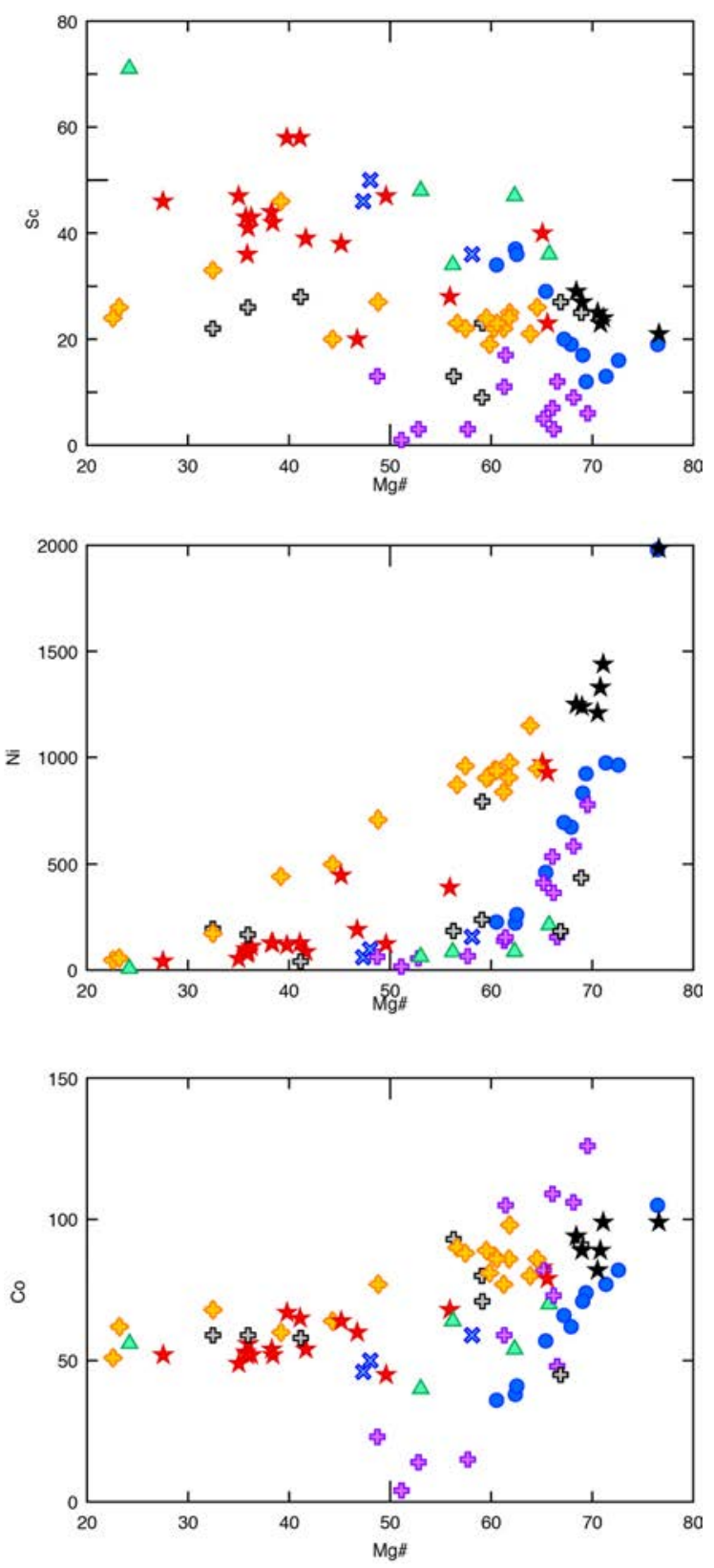
Figure 7.9a-b: Ternary diagrams demonstrating the geochemical uniqueness of the various geochemical groups, using the discriminating power of HFSE and REE. a) chondrite-normalized REEs (i.e. La, Gd, and Yb) utilized as discriminating variables, which more or less reflect the differences in the LREE (La/Sm), HREE (Gd/Yb) and overall slopes ( $\mathrm{La} / \mathrm{Yb})$ of the REE. B) Nb, Y and La used as discriminating variables. These are the variables chosen for the Cabanis and Lecolle (1989) basalt-discrimination diagram. 

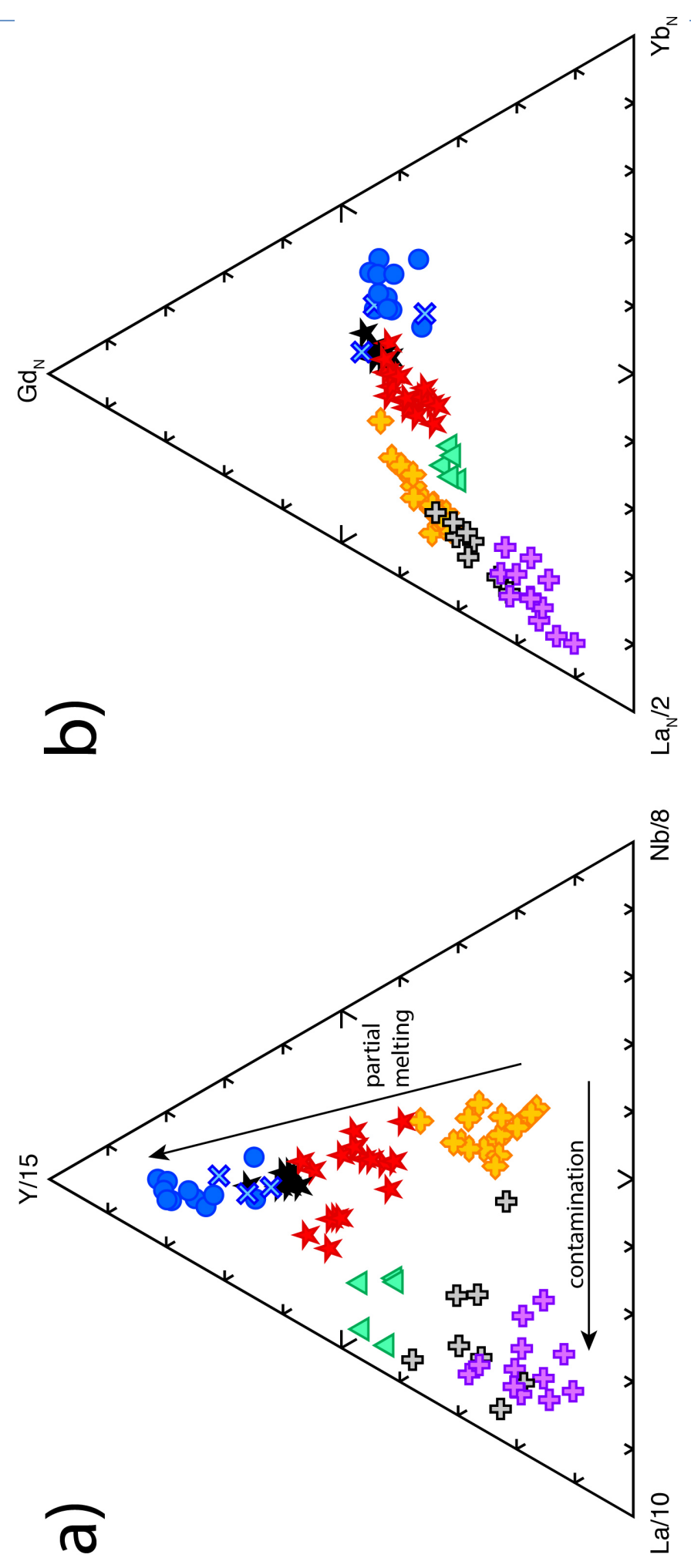


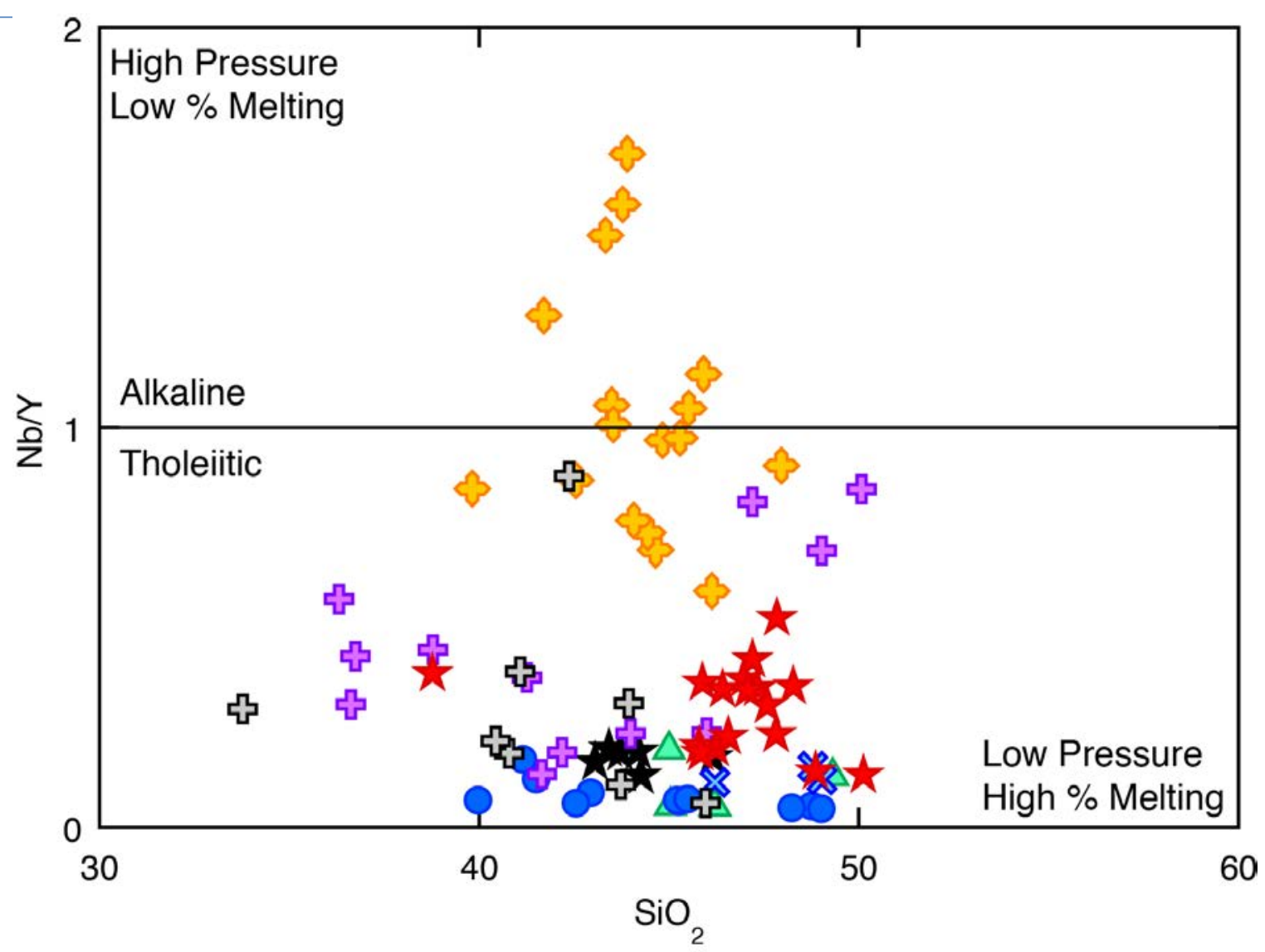

Figure 7.10: Bivariate diagram of $\mathrm{SiO}_{2}$ versus $\mathrm{Nb} / \mathrm{Y}$. Low degree partial melts at great depths beneath cold, old, thick lithosphere produce highly alkaline magmas (hence high $\mathrm{Nb} / \mathrm{Y}$ ). The opposite conditions produce tholeiitic magmas. Alkaline/ tholeiitic division from Greenough et al. (2005). 
Figure 7.11a-b: a) Bivariate diagram of $\varepsilon N d$ versus ${ }^{147} \mathrm{Sm} /{ }^{144} \mathrm{Nd}$. Two trends apparent amongst Groups A1, A2, and D, interpreted to reflect changes in partial melting of the source, and another that may reflect crustal contamination by the upper crustal rocks of the Meta Incognita microcontinent, as suggested by the trend of the samples. b) Primitive mantle-normalized trace element diagram displaying the trace element patterns from sill \#27, demonstrating the difference in 15SAB-L057B02's pattern compared to the others. This is interpreted to reflect contamination. Fields for Lake Harbour Group and Ramsay River orthogneiss were derived from isotopic data from Theriault et al. (2001) and R.J. Theriault (unpublished data). 

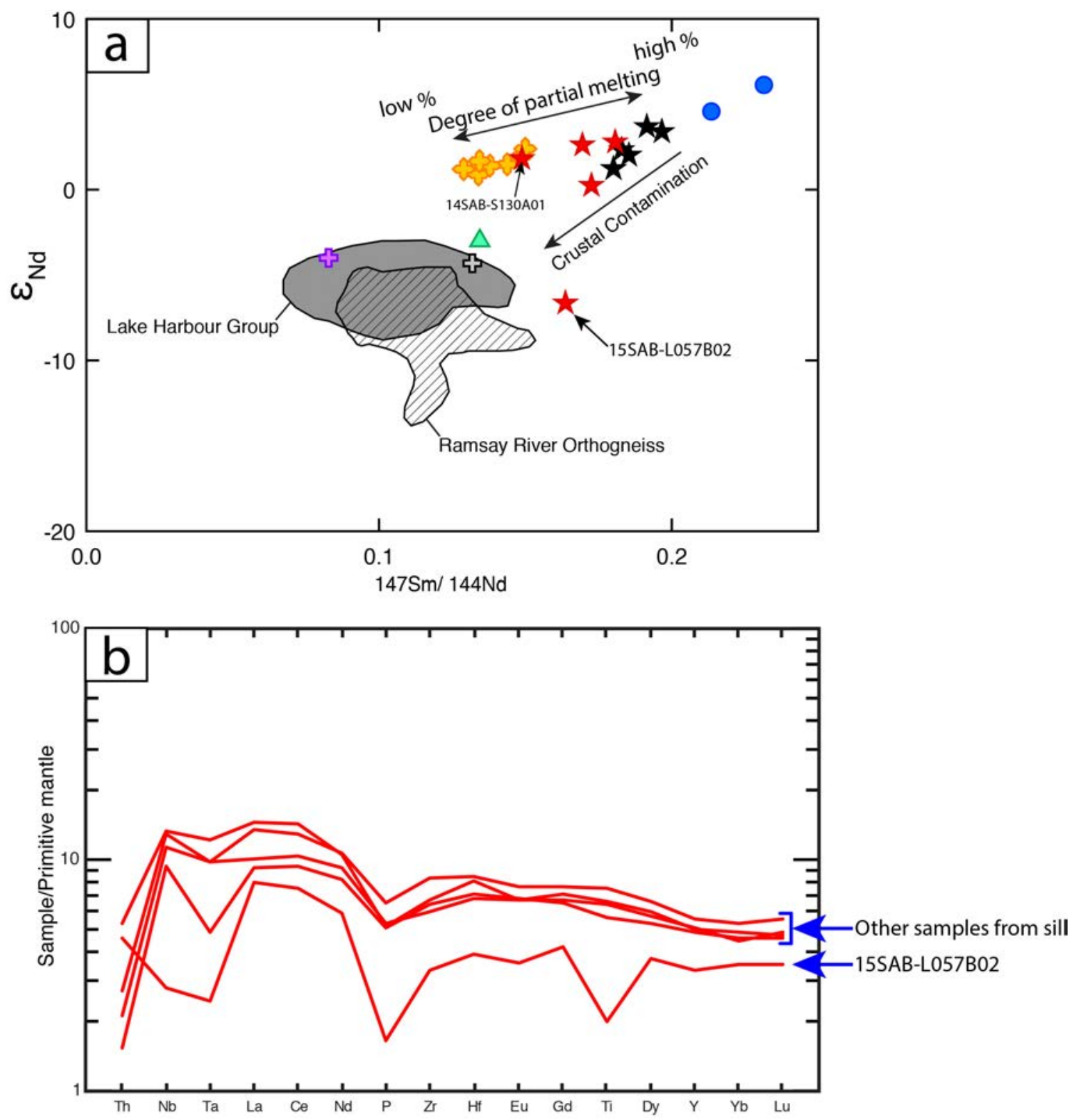


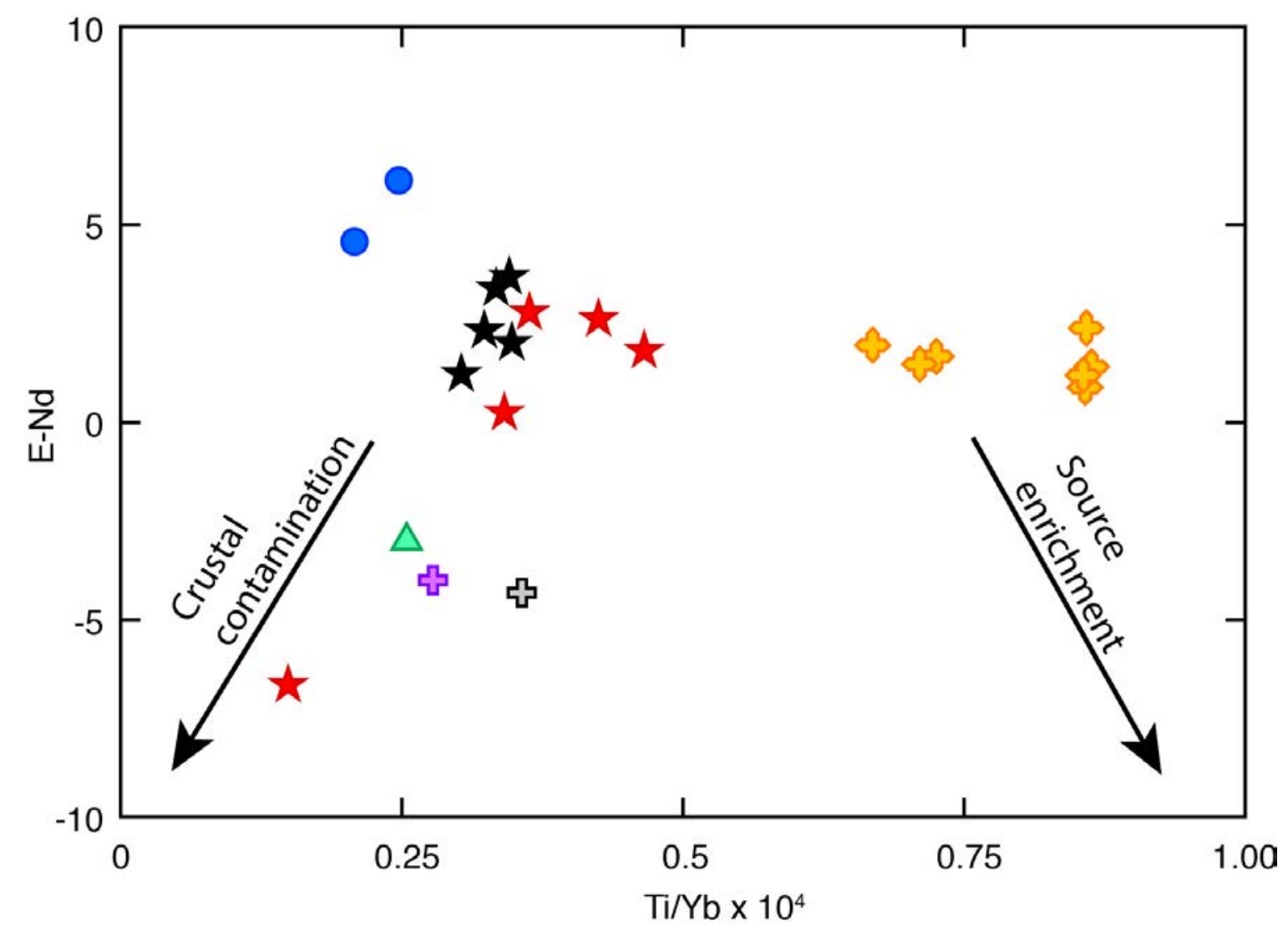

Figure 7.12: Bivariate diagram of $\varepsilon N d$ versus $\mathrm{Ti} / \mathrm{Yb}$. Indicates that low $\varepsilon N d$ values are a result of contamination, as opposed to source enrichment. Adapted from Leeman and Hawkesworth (1986). 
Figure 7.13: Geochemical variation through the Killapait sill. Grey fields represent the variation in composition through the sill. 


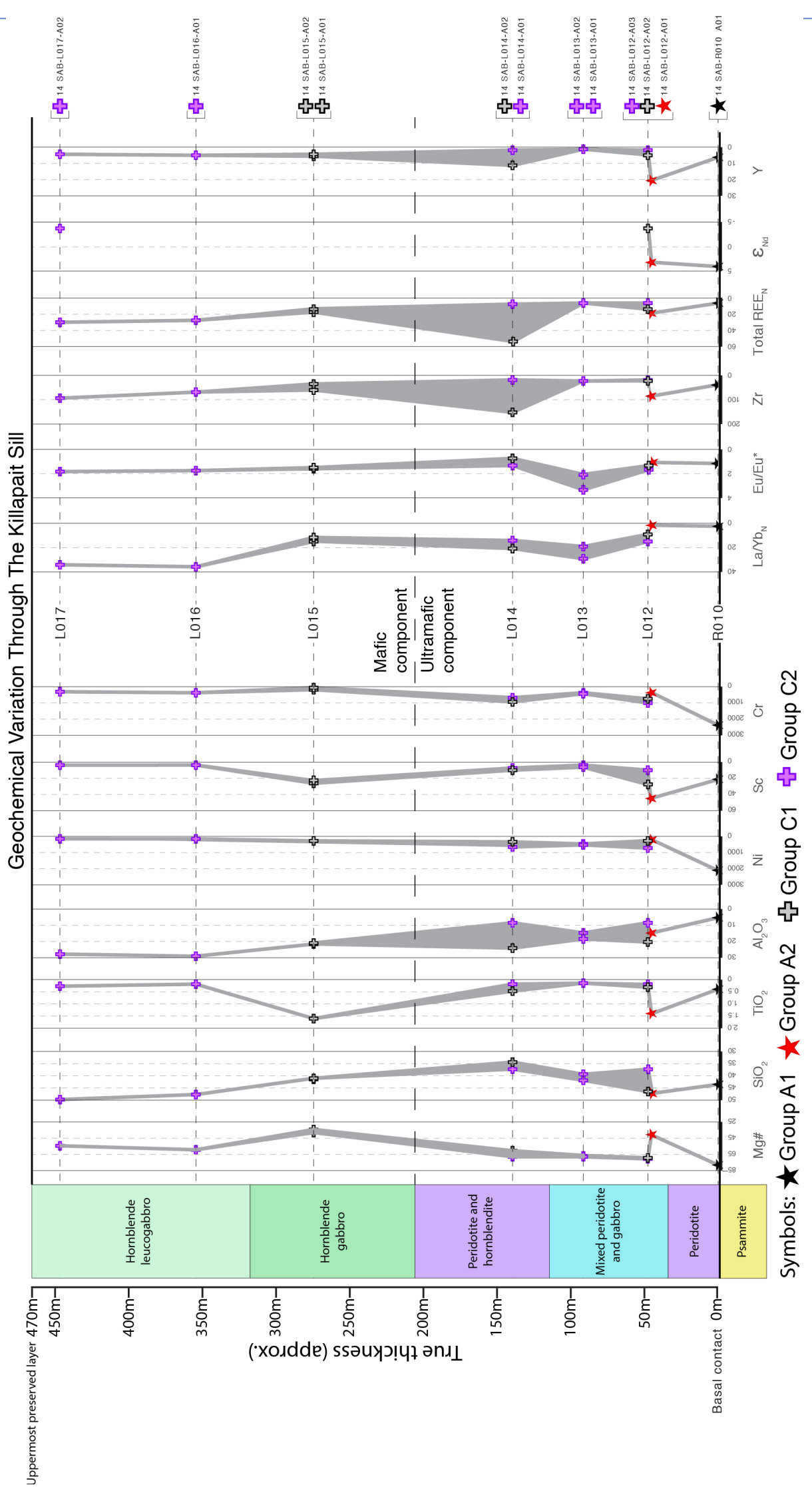


Figure 7.14: Geochemical variation through the Chidliak sill. Grey fields represent the variation in composition through the sill. 


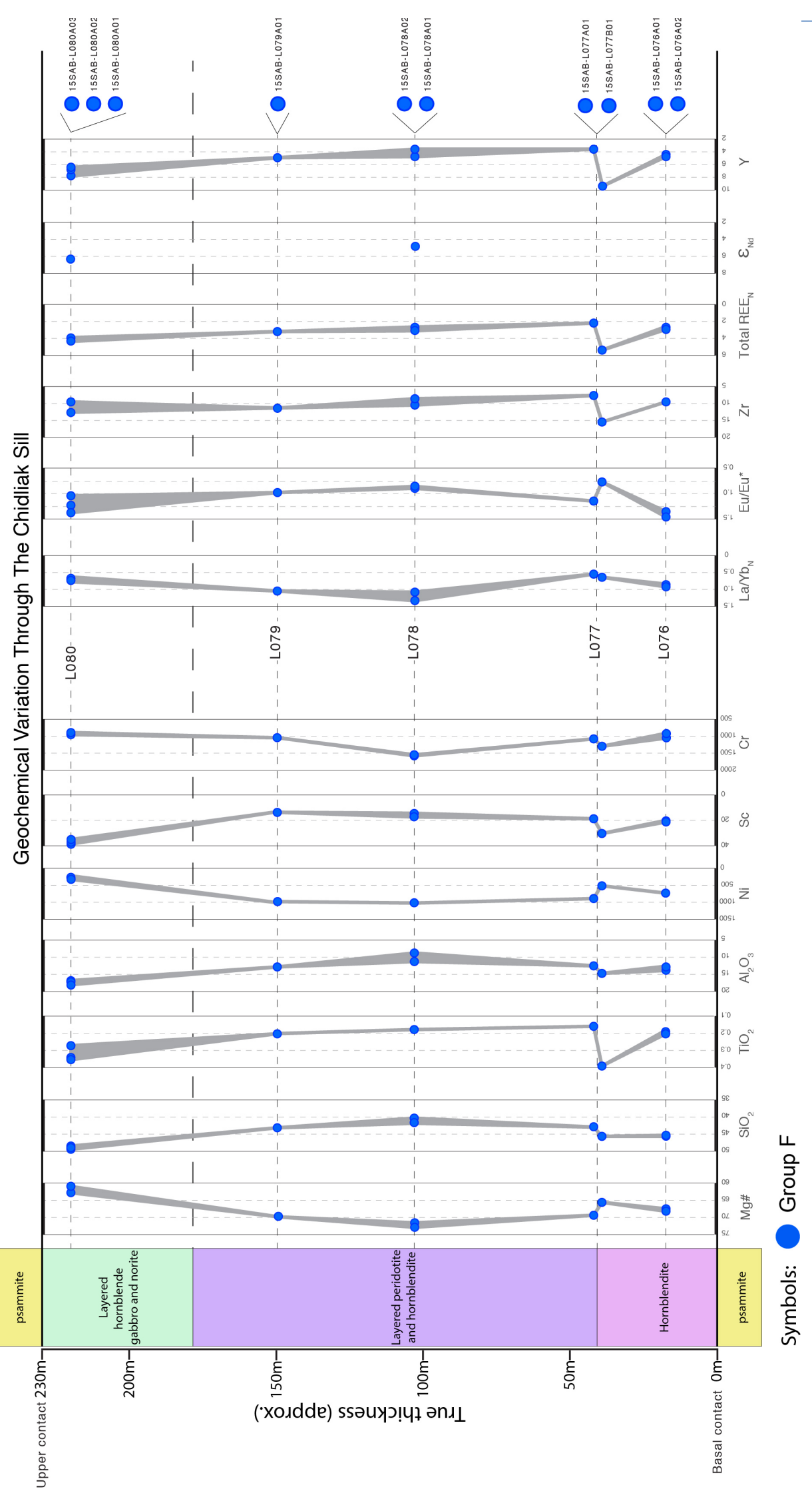


Figure 7.15a-c: a) Chondrite-normalized REE patterns for the metapyroxenitic and metaperidotitic units of two individual layered ultramafic sills, along with the REE patterns for two individual non-layered ultramafic sills. Two different geochemical signatures are apparent within these layered ultramafic sills and they were likely generated through at least two injections of distinct geochemically different magmas. b) Chondrite-normalized REE patterns for the layered mafic-ultramafic Killapait sill are shown, along with their location with respect to stratigraphic height within the sill. No systematic evolution in REE pattern is evident with increasing stratigraphic height in sill. c) Metaperidotitic and metagabbroic components of the Chidliak sill exhibit REE patterns that are very similar, with the gabbroic unit containing slightly higher $\mathrm{Yb}$ (and overall REE) contents than the metaperidotitic sample, consistent with the gabbro's origin through fractional crystallization. 

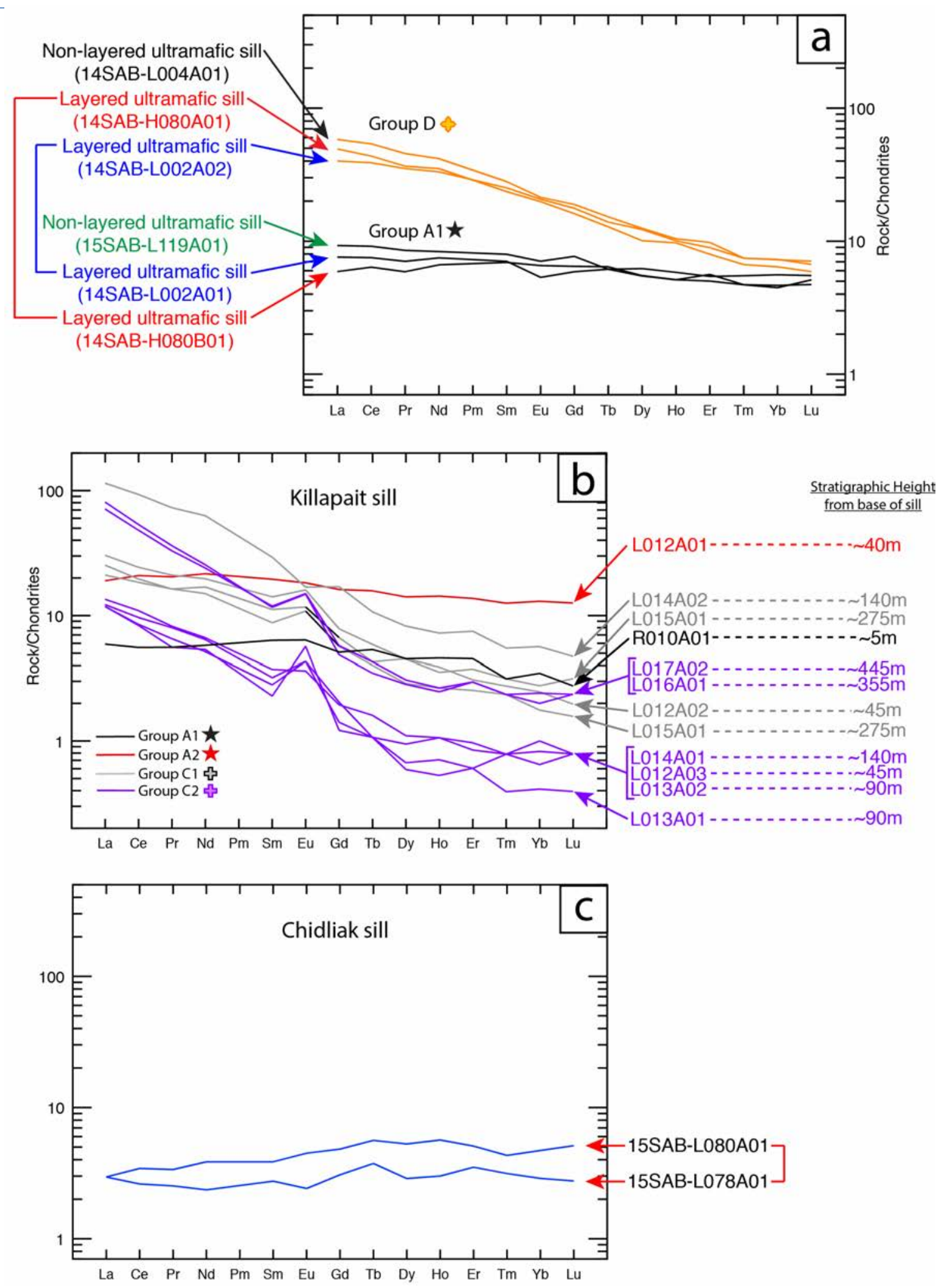


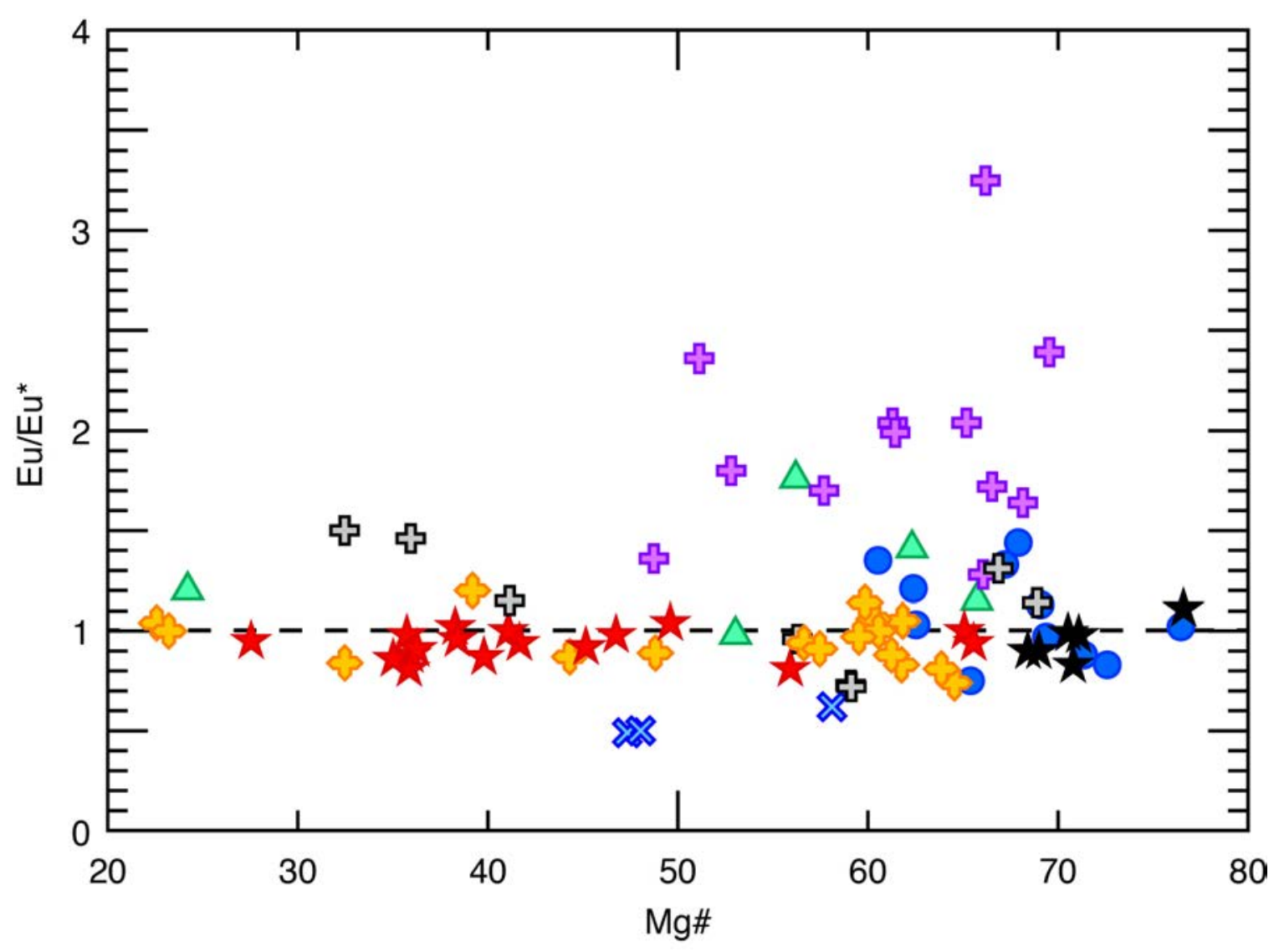

Figure 7.16: Variation in $\mathrm{Eu} / \mathrm{Eu}^{*}$ values versus $\mathrm{Mg \#}$. Eu/Eu* values $>1$ indicate plagioclase accumulation, and $\mathrm{Eu} / \mathrm{Eu}^{*}$ values $<1$ indicate plagioclase removal from the magma. 

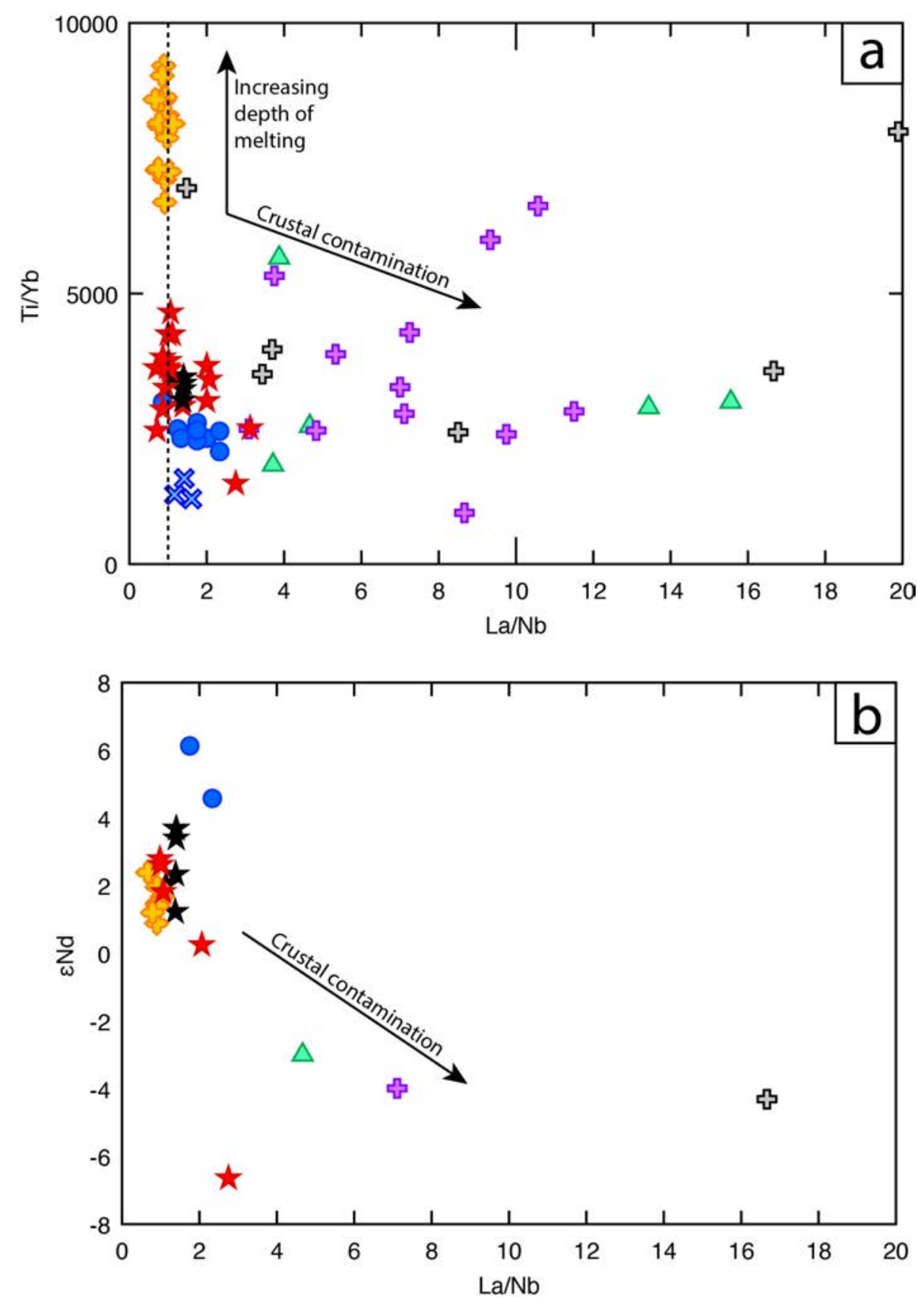

Figure 7.17: a) Ti/Yb versus La/Nb diagram. b) $\varepsilon N d$ versus La/Nb diagram. La/ $\mathrm{Nb}$ increases with increasing contamination and $\mathrm{Ti} / \mathrm{Yb}$ increases with increasing depth of melting. From Pearce (2008) and Lightfoot et al. (1993), respectively. 


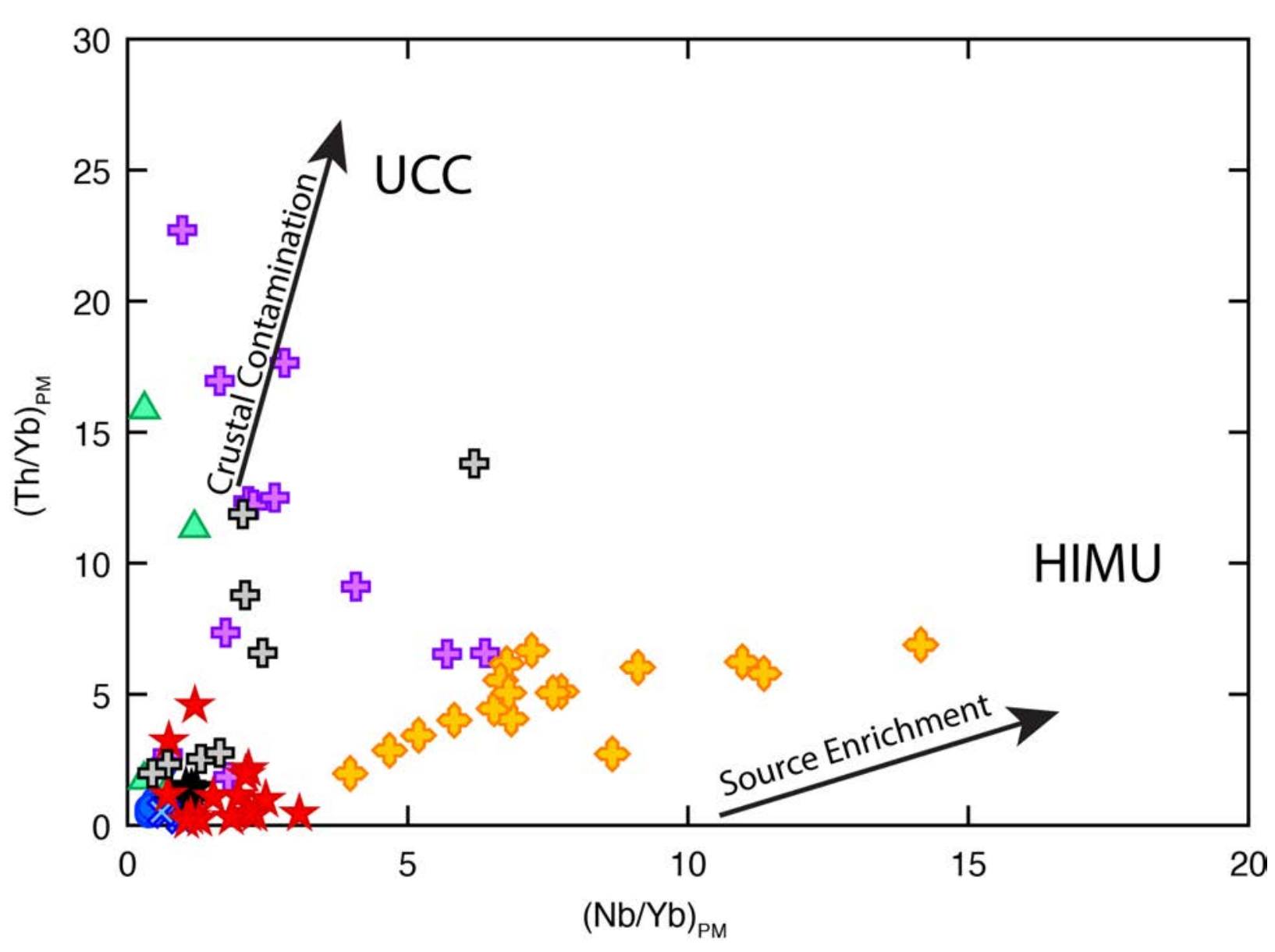

Figure 7.18: Bivariate diagram of $(\mathrm{Th}-\mathrm{Yb})_{\mathrm{PM}}$ versus $(\mathrm{Nb}-\mathrm{Yb})_{\mathrm{PM}}$, distinguishing enrichment due to source enrichment, as opposed to enrichment due to crustal contamination. Adapted from Pearce (2008). 

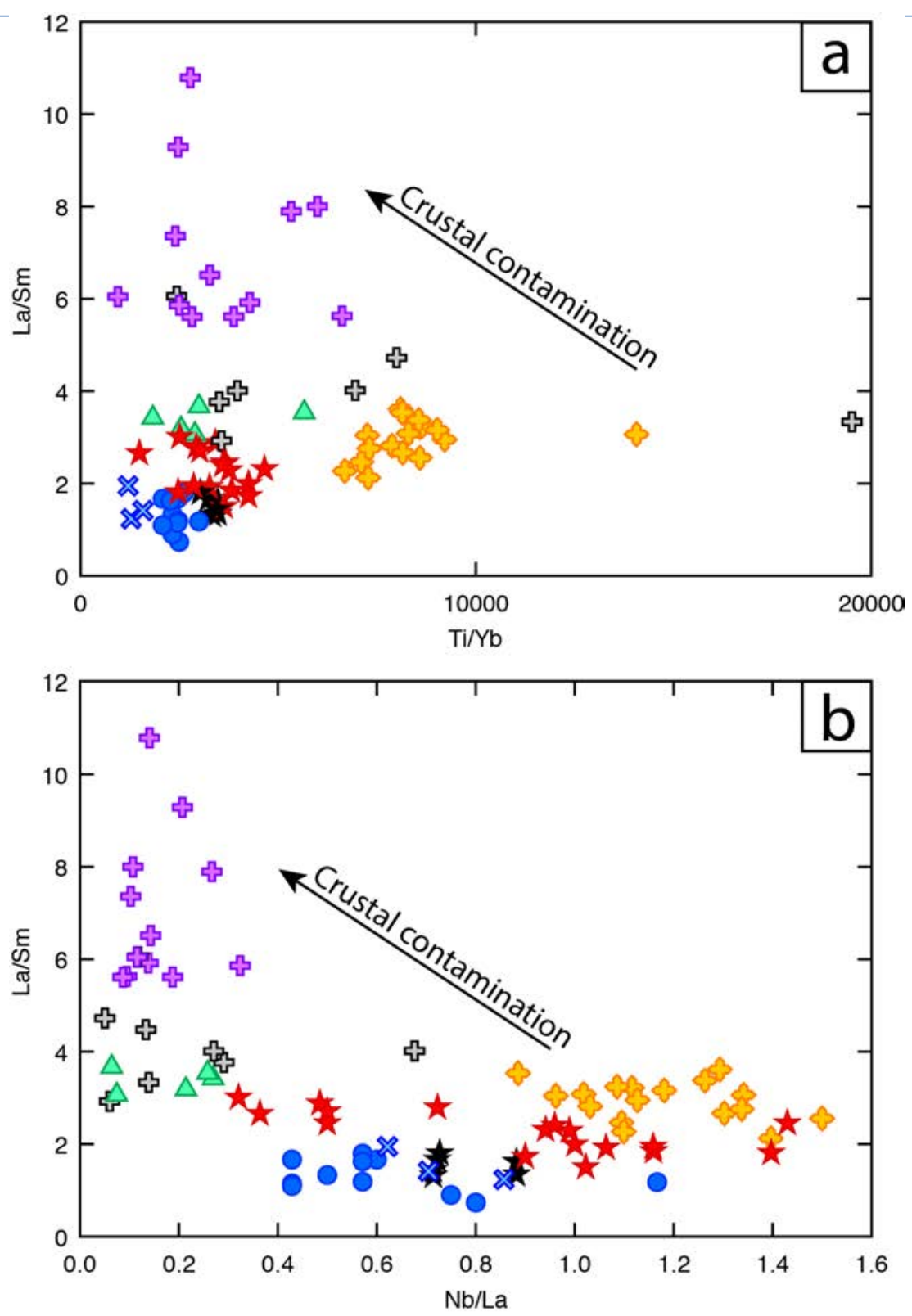

Figure 7.19a-b: a) Bivariate diagram of La/Sm versus Ti-Yb. b) Bivariate diagram of $\mathrm{La} / \mathrm{Sm}$ versus $\mathrm{Nb} / \mathrm{La}$. Distinguishing crustal contamination from lithospheric contamination. Crustal contamination increases $\mathrm{La} / \mathrm{Sm}$ ratio with increasing $\mathrm{Ti}$ and $\mathrm{Nb}$ anomalies. $\mathrm{Ti} / \mathrm{Yb}$ and $\mathrm{Nb} / \mathrm{La}$ are used as proxies for these anomalies, respectively. From Pearce (2008) and Lightfoot et al. (1993), respectively. 


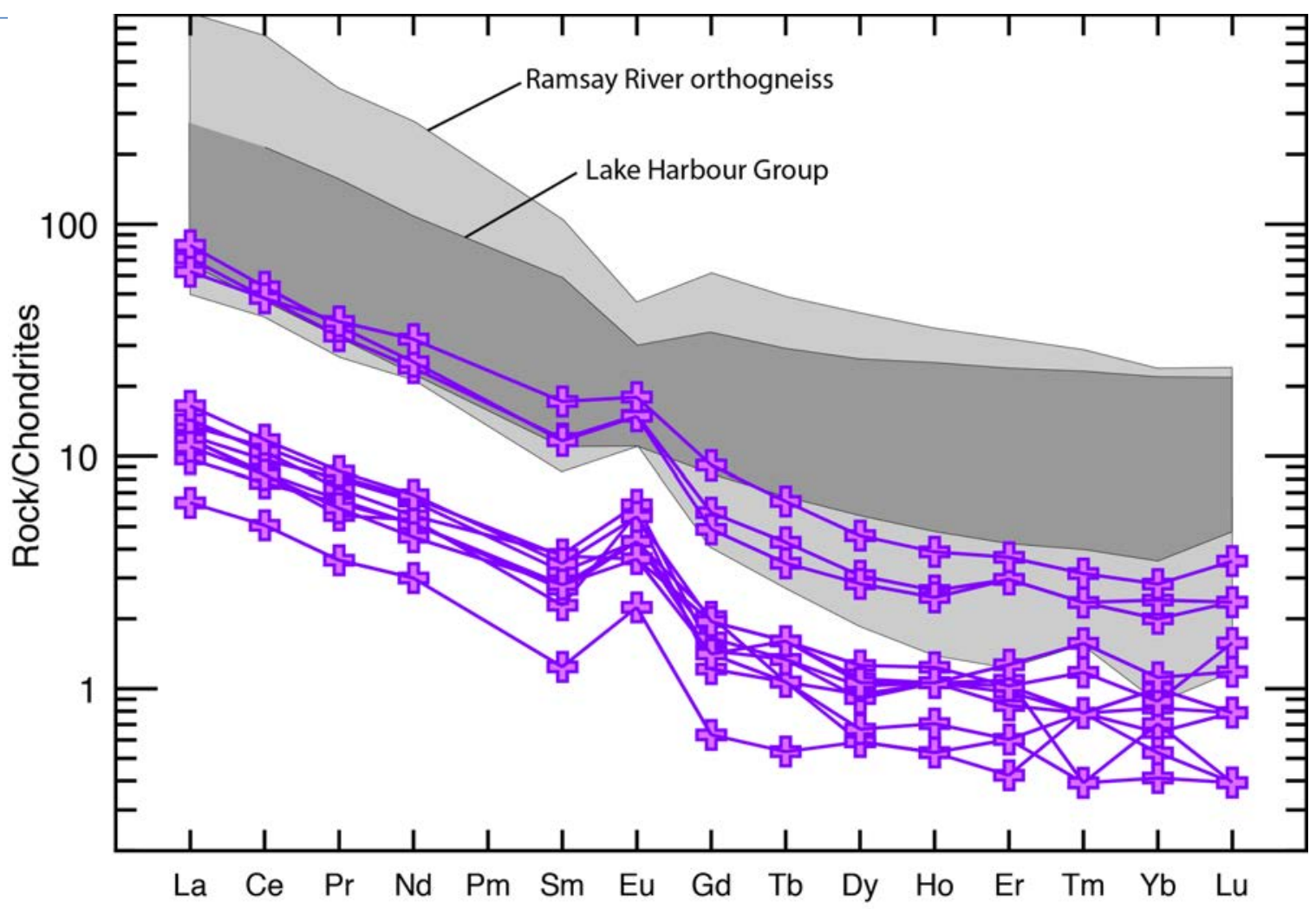

Figure 7.20: Chondrite-normalized REE patterns of Group C2 compared to upper crustal units of the Meta Incognita Microcontinent. Fields for Lake Harbour Group and Ramsay River orthogneiss were derived from isotopic data from Theriault et al. (2001) and R.J. Theriault (unpublished data). 


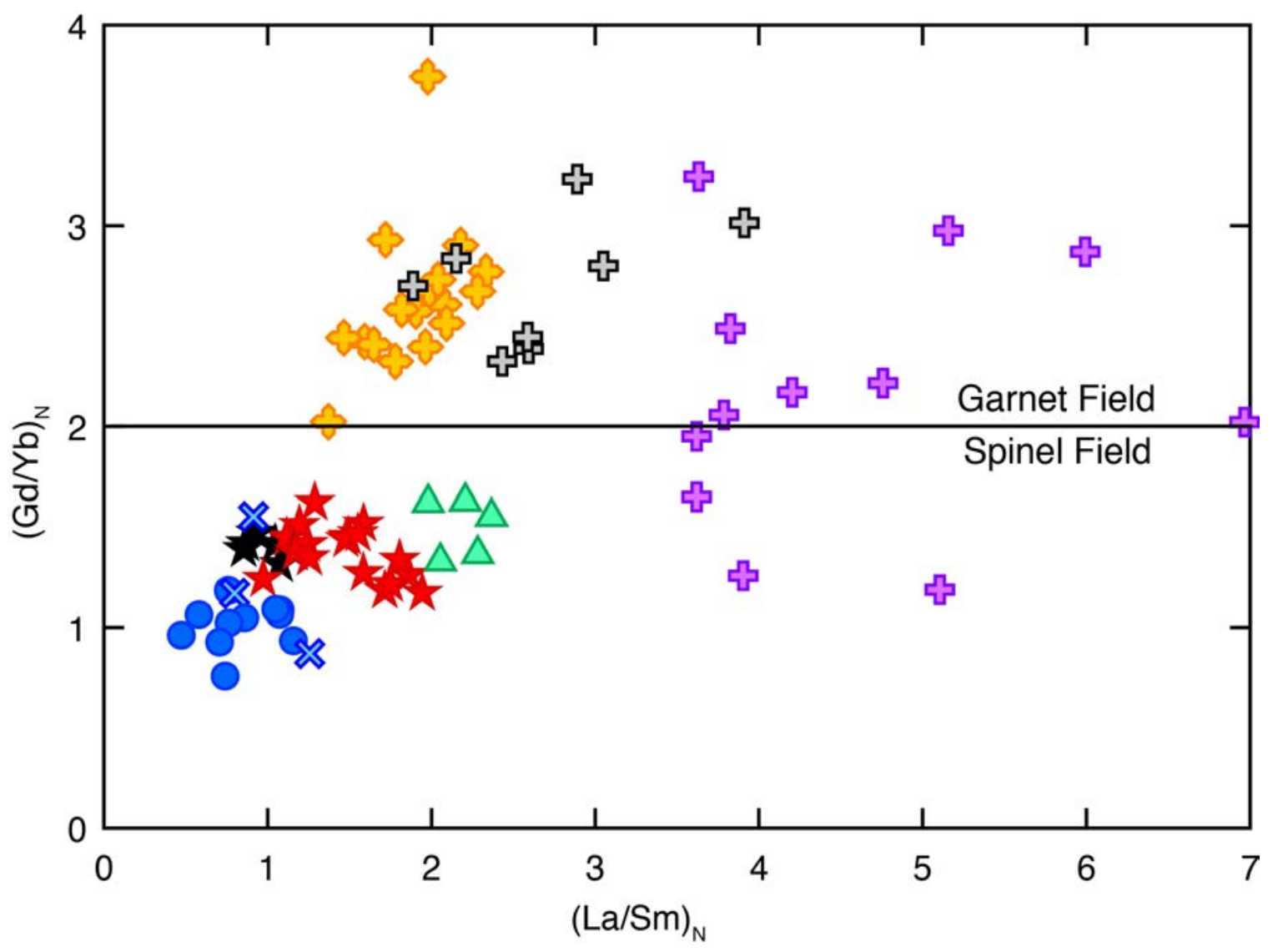

Figure 7.21: Bivariate diagram of $(\mathrm{Gd} / \mathrm{Yb})_{\mathrm{N}}$ and $(\mathrm{La} / \mathrm{Sm})_{\mathrm{N}}$ illustrating the difference in depth of melting between the various geochemical groups. Primary magmas of samples with $(\mathrm{Gd} / \mathrm{Yb})_{N}>2$ were generated by melting of garnetperidotite. Primary magmas of samples with $(\mathrm{Gd} / \mathrm{Yb})_{\mathrm{N}}<2$ were generated by melting of spinel-peridotite. From Álvero et al. (2014). 


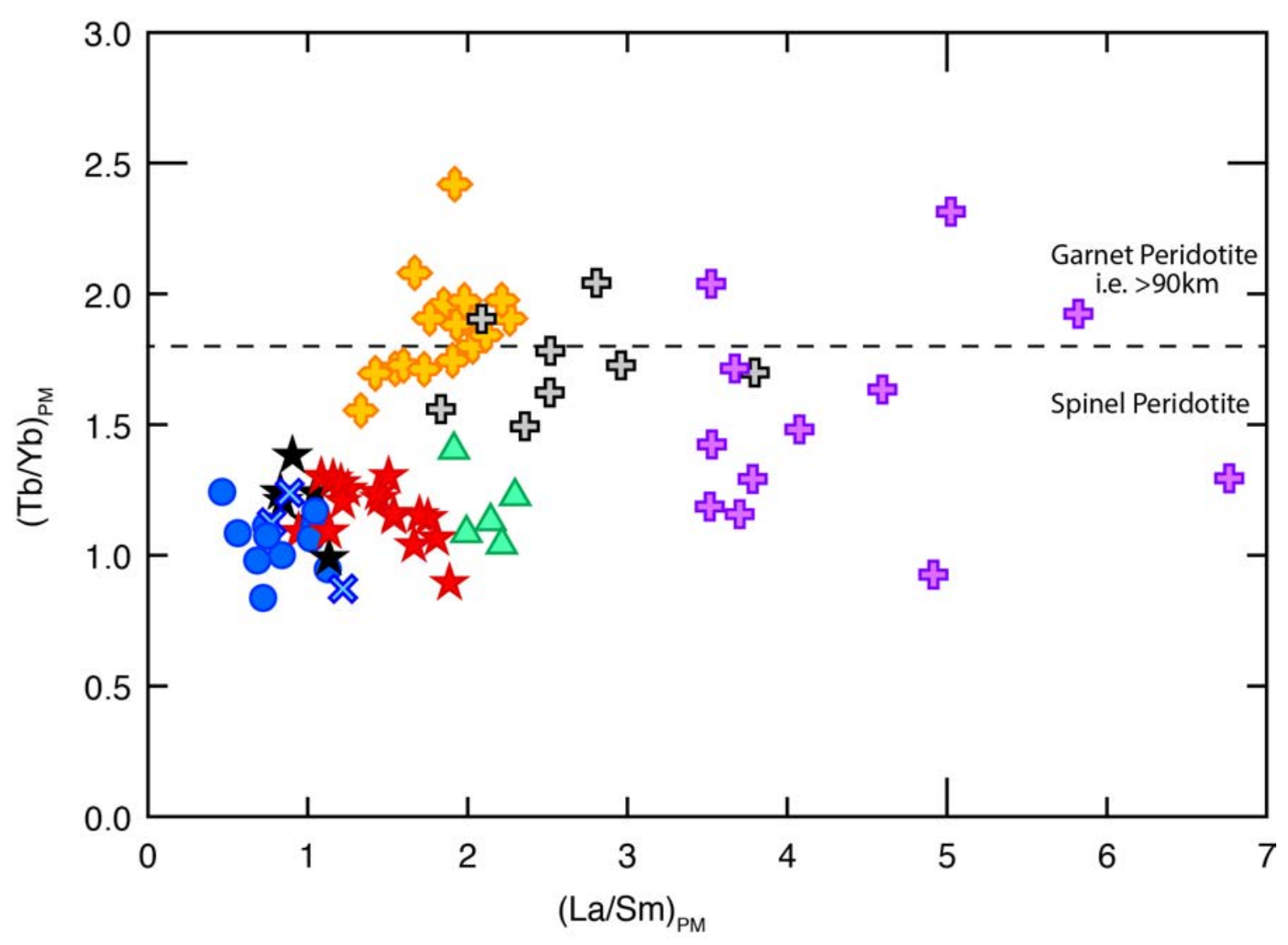

Figure 7.22: Bivariate diagram of $(\mathrm{Tb} / \mathrm{Yb})_{\mathrm{PM}}$ and $(\mathrm{La} / \mathrm{Sm})_{\mathrm{PM}}$ illustrating the difference in depth of melting between the various geochemical groups. Primary magmas of samples with $(\mathrm{Tb} / \mathrm{Yb})_{\mathrm{N}}>1.8$ were generated by melting of garnetperidotite at great depths. Primary magmas of samples with $(\mathrm{Tb} / \mathrm{Yb})_{\mathrm{N}}<1.8$ were generated by melting of spinel-peridotite at shallower depths. From Wang (2002). 


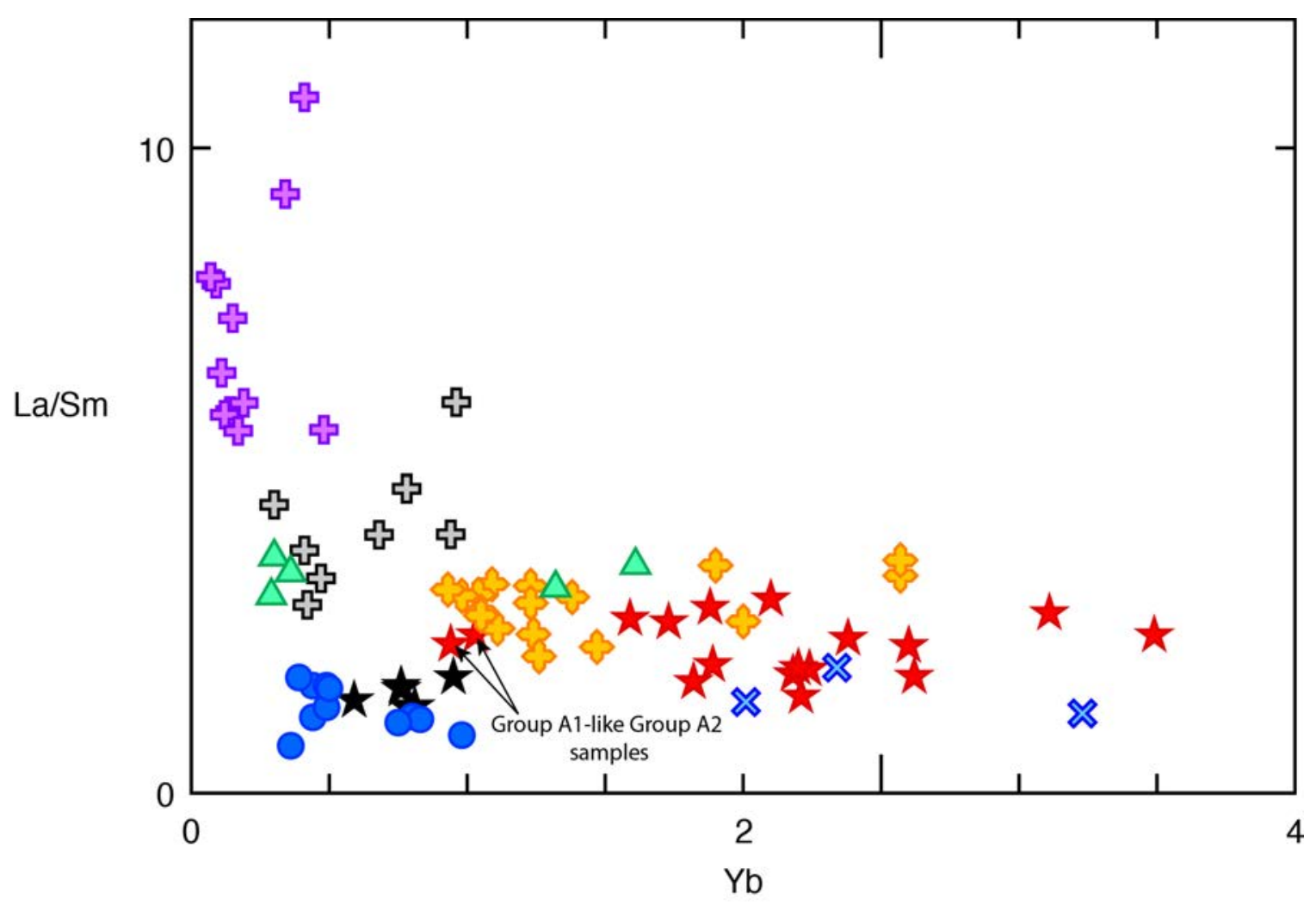

Figure 7.23: Bivariate diagram of La/Sm versus $\mathrm{Yb}$. 


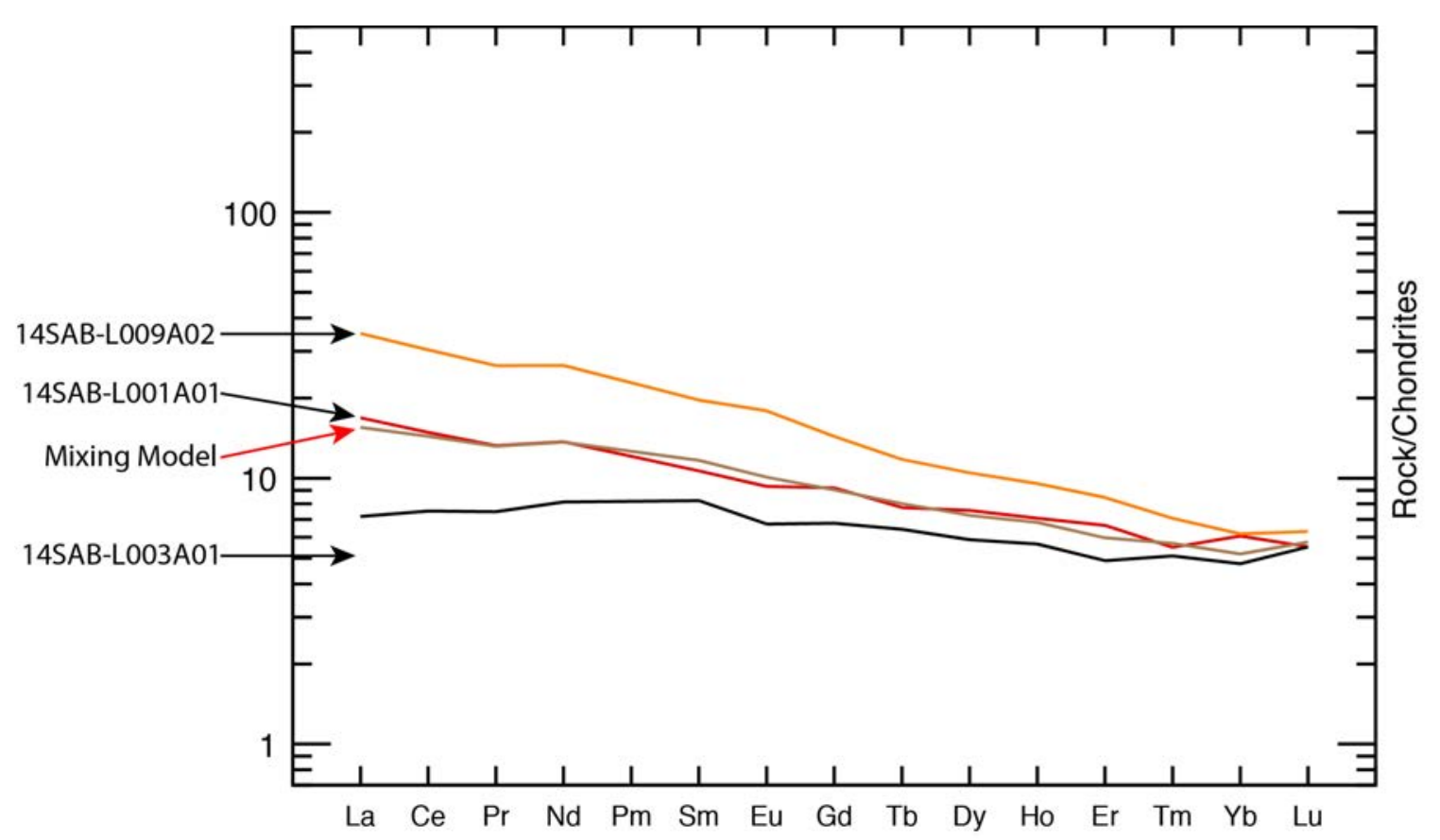

Figure 7.24: Mixing of Group D and A1 magmas to produce unique Group A2 samples. Using the mixing feature in Igpet, $70 \%$ of Group A1 (low-Ti) sample 14SAB-L003A01 was mixed with $30 \%$ of Group D (high-Ti) sample 14SABL009A02, which produced a chondrite-normalized REE pattern very similar to Group A2 sample 14SAB-L001A01. 
Table 7.1: The occurrences of the various geochemical groups on both Meta Incognita and Hall peninsulas, as well as the type of sills they occur in. Abbreviations: $\mathrm{MI}=$ Meta Incognita Peninsula; $\mathrm{H}=$ Hall Peninsula; $\mathrm{UM}=$ ultramafic sill; $M=$ mafic sill; $M U M=$ mafic-ultramafic sill.

\begin{tabular}{|c|c|c|l|}
\hline Group & Number of occurances in different sills & Location & \multicolumn{1}{|c|}{ Sill Type } \\
\hline A1 & 5 & $4 \mathrm{Ml}-1 \mathrm{H}$ & $3 \mathrm{UM}-2 \mathrm{M} / \mathrm{M}$ \\
\hline $\mathrm{A} 2$ & 11 & $5 \mathrm{Ml}-6 \mathrm{H}$ & $7 \mathrm{M}-1 \mathrm{UM}-3 \mathrm{MUM}$ \\
\hline $\mathrm{B}$ & 3 & $1 \mathrm{MI}-2 \mathrm{H}$ & $1 \mathrm{M}-2 \mathrm{MUM}$ \\
\hline $\mathrm{C} 1$ & 4 & $3 \mathrm{MI}-1 \mathrm{H}$ & $1 \mathrm{M}-1 \mathrm{UM}-2 \mathrm{MUM}$ \\
\hline $\mathrm{C} 2$ & 3 & $2 \mathrm{Ml}-1 \mathrm{H}$ & $1 \mathrm{M}-2 \mathrm{MUM}$ \\
\hline $\mathrm{D}$ & 8 & $8 \mathrm{Ml}$ & $1 \mathrm{M}-4 \mathrm{UM}-3 \mathrm{MUM}$ \\
\hline $\mathrm{E}$ & 2 & $2 \mathrm{H}$ & $2 \mathrm{M}$ \\
\hline $\mathrm{F}$ & 2 & $2 \mathrm{H}$ & $2 \mathrm{M}$ \\
\hline
\end{tabular}


Table 7.2: The occurrences of certain geochemical groups with other geochemical groups, as well as the type of sills they occur in. Boxes highlighted in grey show the occurrences of sills with only the one geochemical group.

\begin{tabular}{|c|c|c|c|c|c|c|c|c|}
\hline Group & A1 & A2 & B & C1 & C2 & D & E & F \\
\hline A1 & 1 UM & - & - & - & - & - & - & - \\
\hline A2 & $2 \mathrm{MUM}$ & $1 \mathrm{MUM}-1 \mathrm{UM}-6 \mathrm{M}$ & - & - & - & - & - & - \\
\hline $\mathrm{B}$ & 0 & 0 & $1 \mathrm{M}$ & - & - & - & - & - \\
\hline $\mathrm{C} 1$ & $1 \mathrm{MUM}$ & $1 \mathrm{MUM}$ & $2 \mathrm{MUM}$ & $1 \mathrm{UM}-1 \mathrm{M}$ & - & - & - & - \\
\hline $\mathrm{C} 2$ & $1 \mathrm{MUM}$ & $1 \mathrm{MUM}-1 \mathrm{M}$ & $1 \mathrm{MUM}$ & $1 \mathrm{MUM}$ & 0 & - & - & - \\
\hline $\mathrm{D}$ & $2 \mathrm{UM}$ & $1 \mathrm{M}$ & 0 & 0 & 0 & $3 \mathrm{MUM}-1 \mathrm{M}-2 \mathrm{UM}$ & - & - \\
\hline $\mathrm{E}$ & 0 & $1 \mathrm{MUM}$ & 0 & 0 & 0 & 0 & $2 \mathrm{M}$ & - \\
\hline $\mathrm{F}$ & 0 & 0 & 0 & 0 & 0 & 0 & 0 & $1 \mathrm{MUM}-1 \mathrm{UM}$ \\
\hline
\end{tabular}


Chapter 8 - Discussion \& Conclusion 


\subsection{Petrogenesis}

Based on the number of occurrences of each geochemical group within sills of the Frobisher suite (Table 7.1), the groups may be divided into major and minor geochemical groups. The major components include low- and high-Ti Groups A1 and A2, and D, respectively. The minor component includes contaminated Groups B, C1 and C2, and samples from Groups E and F.

\subsubsection{Petrogenesis of major geochemical groups}

The major geochemical groups of the suite, the low-Ti Groups A1 \& A2 and high-Ti Group D, appear to have experienced multiple, distinct differentiation processes during their petrogenesis, as highlighted by the rather diverse major and trace element compositions described in Chapter 7. These processes include, fractional crystallization, and crustal or lithospheric contamination.

\subsubsection{High-Ti magma type (Group D)}

The high-Ti magma type, Group D, occurs exclusively on Meta Incognita Peninsula, both along the coast in the west, and adjacent to the eastern boundary of the Narsajuaq terrane in the east (Liikane et al., 2015). With respect to emplacement within a reference (pre-collision and deformation) Meta Incognita microcontinent, the high-Ti magmas were emplaced in the more proximal facies Lake Harbour Group (a.k.a. inland-ward in the microcontinent). This signature most often occurs in monogenetic sills (i.e. only one geochemical signature within a single sill). However, in two layered ultramafic sills the high-Ti magma 
type occurs with low-Ti Group A1, indicating that some layered sills were derived from multiple pulses of magma. High-Ti group samples vary from mafic to ultramafic in composition.

Geochemical evaluation of the high-Ti group indicates that its primary magma was derived from low degrees of partial melting within the garnet stability field (i.e. at depths $>90 \mathrm{~km}$ ), such that garnet remained in the mantle source (e.g. Arndt et al., 1993; Ewart et al., 1998; 2004a). This produced a mildly alkalic tholeiitic parental magma and OIB-like chondrite-normalized REE patterns (Puffer, 2001). Positive Nb-Ta anomalies characteristic of this group indicate an enriched component within the source, which may have been eclogite, which is typically the first rock type to melt in ascending asthenospheric mantle, or perhaps eclogite (e.g. Sobolev et al., 2011). The presence of a thick lithospheric cap would limit melting to a short pressure interval at greater depths within the garnet stability field, and a smaller melt volume would be produced (typical of alkali basalt fields; e.g. Hole and Saunders, 1996; Niu et al., 2011).

The parental magmas to the high-Ti magmas may have been vertically fed from the asthenosphere under a thicker lithospheric area, given the apparent depth of the melting and its location of emplacement relative to the reference Meta Incognita microcontinent. En route to the level of emplacement, the high-Ti magmas arrived more directly (i.e. less crustal residence time) compared to those of the low-Ti groups, as indicated by their high Mg\# (generally > 56) and the lack of contamination. Dykes were likely established at the base of the lithosphere transferring magma to upper crustal levels, with no residence time in 
crustal magma chambers, as is typically the case with alkaline magmas extruded from monogenetic volcanoes (Muraoka, 1997). The generally low silica, high $\mathrm{MgO}$ nature of the more alkaline magmas results in less dense magma that is less likely to get trapped in crustal magma chambers.

In plume-derived provinces, the more alkalic magmas (e.g. Figure 7.10), such as that of the high-Ti Group, are thought to either represent melting of the eclogitic or basaltic component of a plume head. In passive magma generation, parental magmas to high-Ti groups are interpreted to simply reflect low-degree melting of the mantle material. If the Frobisher suite was plume-derived, the later process of high-Ti melt generation is supported by the fact the epsilon-Nd values of the high- and low-Ti groups span approximately the same range, as expected for two melts of differing melting degrees from the same source. However this can also apply to differences in the partial melting of a plume head. If there were major eclogitic or basaltic contributions to the high-Ti group, this should be reflected in the $\mathrm{Sm}-\mathrm{Nd}$ isotope geochemistry, with distinctly different epsilon $\mathrm{Nd}$ values for the high-Ti group compared to the low-Ti group. However, generation of the high-Ti melt from eclogitic streaks within the plume head could also explain the positive $\mathrm{Nb}$ anomaly, and perhaps, if the $\mathrm{Sm}-\mathrm{Nd}$ isotopic characteristics of the eclogitic or basaltic components were similar to that of the rest of the plume head, overlapping $\varepsilon N d$ values within both high- and low-Ti groups would still be observed. The presence of eclogite increases the fertility of the source (Sobolev et al., 2011; Saunders, 2005), and the Nb-anomaly is interpreted to represent residual eclogite in the mantle source. If eclogitic streaks within the plume head 
were a major contributor to the high-Ti magmas, this component must have had a similar isotopic composition as bulk of plume head material.

\subsubsection{Low-Ti magma types (Groups A1 \& A2)}

The low-Ti magma types, Groups A1 and A2, occur on both Meta Incognita Peninsula and northern Hall Peninsula. With respect to emplacement within a reference Meta Incognita microcontinent, the low-Ti magmas were mostly emplaced in the distal facies Lake Harbour Group (aka the deeper water, off-shelf strata). Group A2 occurs with geochemical Groups A1, C1 and C2, while Group A1 only occurs with Groups A2 and D (Table 7.2). On northern Hall Peninsula, Group A2 occurs only in monogenetic sills. Group A2 samples are almost exclusively mafic, while Group A1 samples are exclusively ultramafic in composition.

The low-Ti Group was derived from high degrees of partial melting within the spinel stability field (i.e. at depths $<90 \mathrm{~km}$ ), resulting in a tholeiitic magma (e.g. Arndt et al., 1993; Xu et al., 2004; Herzberg \& Gazel, 2009). However, it could have been derived from melting in the garnet stability field if garnet was fully exhausted from the source. Variable negative $\mathrm{Nb}-\mathrm{Ta}$ anomalies indicate that the parental magmas of this geochemical group were variably contaminated. In route to the level of emplacement, substantial fractionation from primary melts occurred in Group A2, likely in staging chambers within the crust (e.g. Cox, 1980, 1993), as evidenced by the more evolved compositions (low MgO contents, generally between 7-9wt.\%). Assimilation and resulting contamination, which is 
often concurrent with fractional crystallization (i.e. assimilation fractional crystallization (AFC) processes) is apparent in some samples (Figures 7.11,7.18 \& 7.19). In contrast, Group A1 appears to have either traveled directly from the mantle or represents olivine cumulates, given its high $\mathrm{Mg \#} \mathrm{(} \mathrm{70).} \mathrm{However,} \mathrm{all}$ samples from this group appear to have suffered contamination, unlike Group A2 samples, of which only a select few are contaminated.

In comparison, Groups A1 and A2 display a very similar, overlapping range of $\mathrm{Gd} / \mathrm{Yb}$ ratios, indicating they were derived from the same or a similar depth and degree of melting. In sills where both groups are present, Group A1 always comprises the ultramafic component, while Group A2 is the mafic component. It appears that Groups $\mathrm{A} 1$ and $\mathrm{A} 2$ were derived from the same parental magma, and Group A2 simply represents a more evolved $(<M g \#)$ equivalent of Group A1. However, the gap in the data between the bulk of Group A2 samples and the Group A1 samples makes it difficult to establish the relationship through crystal fractionation, so geochemical modelling is required to conclusively establish this relationship.

The occurrence of consistently contaminated, less evolved Group A1 samples with largely uncontaminated, more highly evolved Group A2 samples suggests that perhaps fractionation of a parental magma occurred in a magma chamber where the host rocks were unable to generate a contamination signature within the fractionating magma during AFC processes (e.g. base of lithosphere). 
Ito \& Mahoney (2005) suggest OIB and MORB sources are identical and that these two end-members merely reflect different degrees of melting within a heterogeneous source of $90 \%$ depleted peridotite and variable proportions of enriched peridotite and pyroxenite. In a similar manner, I propose that the lowand high-Ti magmas are interpreted to represent the same (or similar) heterogeneous mantle source and that differences in trace element patterns represent different degrees of partial melting at different depths with contributions from eclogite in the latter. This is supported by their similar $\varepsilon N d$ values and similar patterns that appear to differ by only slight LREE-enrichment (La/Sm) and depth of melting (i.e. Gd/Yb ratio). If low-Ti magmas resulted from mixing of OIB source with depleted MORB source, a significantly higher $\varepsilon N d$ would be expected in Groups A1 and A2 compared to Group D (OIB-like source).

\subsubsection{Petrogenesis of minor geochemical groups}

\subsubsection{Groups $B, C 1$, and C2 magma types}

Groups B, C1, and C2 occur on both Meta Incognita and northern Hall peninsulas. With respect to emplacement within reference Meta Incognita microcontinent, the Group B and C2 magmas were emplaced in both proximal and distal Lake Harbour Group (LHG) sequences (similar to Group A1 and A2's geographic occurrence), whereas Group C1 was emplaced exclusively in proximal facies Lake Harbour Group (similar to Group D's geographic occurrence). These groups generally occur together within the same intrusions and all show the characteristic signs of contamination (Table 7.2). Samples from 
these groups are mostly mafic in composition, however ultramafic samples are also present. All three groups contain at least one sample containing both plagioclase and olivine (implications discussed in 8.1.4).

The large majority of samples from Groups B, C1 and C2 have experienced significant plagioclase accumulation, as indicated by the presence of prominent positive Eu anomalies and high plagioclase abundances observed in thin section and hand sample. On geochemical diagrams, samples show significant scatter and exhibit clear signs of contamination or derivation from metasomatized SCLM.

It is proposed that Groups B and C1 represent contaminated variants of Groups A2 and D, respectively, based on observations from trace element patterns and relationships between these two pairs of groups within 2D-space on bivariate plots. In Figure 7.6a-b, a similarity is observed in both chondritenormalized REE and primitive mantle-normalized trace element patterns, specifically in the HREE, which are the least affected by crustal contamination. The relationship between their slopes on the chondrite-normalized REE diagrams are further illustrated and compared on Figure 7.4. A side-by-side comparison is illustrated in Figure 8.1 for more clarity. Both Groups B and C1 show lower concentrations of REE compared to their suggested uncontaminated equivalents. Lower concentrations may be achieved by mixing with the depleted and metasomatically enriched Group C2. This notion is supported by the observation that Groups A2 (or A1) and B do not occur within the same sills, and Groups D and $\mathrm{C} 1$ do not occur together in sills. 
Furthermore, Group C2 is proposed to have been derived primarily from metasomatized subcontinental lithospheric mantle, with a source previously depleted by a prior melting event (a restite) and later enriched in LREE and other more incompatible trace elements via a subduction-related metasomatic event, all occurring prior to partial melting to the produce the Frobisher Bay event.

\subsection{Group C2 - an in-depth look}

Group C2 is particularly odd with regard to its geochemistry. Its pattern appears to represent extensive crustal contamination, which is supported by the significant negative $\mathrm{Nb}-\mathrm{Ta}$ anomalies and high La/Sm ratios. However, Group C2 has similar or lower $\mathrm{SiO}_{2}$ content compared to the rest of the samples, so simple crustal assimilation cannot explain its chemistry. The group is also quite depleted in HREE compared to upper crustal Meta Incognita microcontinent basement and supracrustal units, and no in-situ assimilation of this material was observed.

It is proposed that Group C2 parental magmas may have been generated from melting of metasomatized lithospheric mantle. Melts from descending slabs in subduction environments are initially $\mathrm{SiO}_{2}$-rich, but become progressively less $\mathrm{SiO}_{2}$-rich as melting progresses (i.e. $\mathrm{SiO}_{2}$ is low in high-degree of melts of subducting slabs). The melts of the eclogitic slab (i.e. garnet+amphibole) are characteristically Sr-enriched (no plagioclase remaining in restite), Y-HREEdepleted (abundant garnet in restite), and high LREE/HREE ratios (Drummond \& Defant, 1990). The MgO-rich character of the magma is attained via contamination with peridotite from the overlying mantle wedge. The low-SiO ${ }_{2}$ and 
high mafic elements can be explained by re-melting of peridotite previously modified by slab-melt (Shirley and Hanson, 1984; Martin et al., 2005). These processes mostly explain what is observed in Group C2.

Furthermore, significant HREE depletion indicates that Group C2 was generated from partial melting of a source where garnet or amphibole remained in the restite, retaining HREE (HREE compatible in amphibole and garnet). Support for residual garnet in the source is the high $\mathrm{Gd} / \mathrm{Yb}$ ratio. Trace element patterns in Group C2 differ from most arc-rocks, but they do contain depleted HFSE (Nb-Ta, Ti) like arc rocks. This suggests that $\mathrm{Nb}$ and $\mathrm{Ti}$ are retained in amphibole and accessory rutile and titanite phases. The LREE-enrichment in Group C2 is easily explained by prior metasomatism of the source (i.e. lithospheric mantle).

The very low $\mathrm{TiO}_{2}$ and $\mathrm{P}_{2} \mathrm{O}_{5}$ values in Group $\mathrm{C} 2$ (oxides that acts incompatibly during melting of peridotite) may have resulted from a previous melting event, removing incompatible elements from residual mantle source.

Alternatively, high-T, high-MgO primary picritic or komatiitic magmas may have interacted with the lithosphere during their ascent and became heavily contaminated. This is plausible because fusible lithosphere is generally that which has been previously re-fertilized by a metasomatic event, which allows it to melt more easily. The question is whether Group C2 represents direct melting of metasomatized SCLM, or whether it represents an asthenospheric source that interacted with and assimilated great amounts of metasomatized SCLM or Archean tonalitic basement (J.Mungall, pers.comm. 2017; e.g. Mungall, 2007; 
Mungall, 2010; Mungall et al. 2016). The common thread in both scenarios is the dominating SCLM or crustal component in the melt. Regardless of origin, the volume of Group C2 magma emplaced during this event is very minor. However, if Groups B and C1 do contain a significant metasomatized-SCLM or crustal component, its overall presence within the Frobisher suite is actually quite significant.

\subsubsection{Group E magma type}

Group E was documented in one monogenetic sill and one polygenetic sill, both located in northern Hall Peninsula, and includes samples that are mafic in composition. The low $\mathrm{Gd} / \mathrm{Yb}$ ratio indicates that it was derived from melting within the spinel stability field, or it may have been derived from the garnet stability field with garnet being completely exhausted from the source. The distinctly higher $\mathrm{Yb}$ contents compared to other groups at similar Mg\# and prominent negative $\mathrm{Ta}, \mathrm{P}$, $\mathrm{Ti}$, and $\mathrm{Zr}-\mathrm{Hf}$ anomalies indicates that it was differentiated to a great extent following melt- generation. Based on geochemical similarities and its geographic proximity with Group F, it is proposed that Group E may potentially represent a more highly evolved magma of Group F.

\subsubsection{Group F magma type}

Group F was documented in only two monogenetic sills, located on northern Hall Peninsula, and samples range from mafic to ultramafic in composition. With respect to emplacement within a reference Meta Incognita 
microcontinent, Group F magmas were mostly emplaced in the distal facies Lake Harbour Group sequence (aka deeper water, off-shelf strata). The parental magma to Group F was likely derived from a high degree of partial melting at shallow depths within the spinel stability field, consistent with its komatiite-like chondrite-normalized REE pattern, in which it is depleted in the most incompatible elements with relative HREE enrichment, its high-MgO content, and its location with respect to the reference microcontinent. Other sources attribute this pattern to melting of depleted upper mantle (e.g. Workman and Hart, 2005), or this mantle source is representing a significant component of the magma. All samples exhibit some degree of minor contamination, which is expected in high$\mathrm{T}, \mathrm{MgO}$-rich high-degree partial melts, given their tendency to flow turbulently (Huppert and Sparks, 1985).

Sills of the Group F magma type lack a spatial association with the other geochemical groups, and their geochemical fingerprint is distinctly different from the other geochemical groups, including in terms of normalized trace element patterns, trace element ratios, and $\varepsilon N d$ values. The $\varepsilon N d$ values of Group $F$ are significantly higher $(+4.58$ to +6.13$)$ than those in the rest of the Frobisher suite (<3.69). Uncontaminated equivalents of Group F would have epsilon Nd values even higher than these. This observation supports an increased depleted upper mantle component in the magma, as opposed to this group simply reflecting a very high degree of partial melting of the same or similar source to the high-Ti and low-Ti magmas. 


\subsubsection{Potential parental magma compositions}

Samples from Group A1 appear to represent the best candidates for parental magmas to the low-Ti groups, with Mg\# 66 (up to 78), and $\mathrm{Ni}$ and $\mathrm{Cr}$ up to $\sim 3000 \mathrm{ppm}$ and $\sim 2000 \mathrm{ppm}$, respectively. This is consistent with experimental results, which have shown that melting of Iherzolite mantle will produce melts with Mg\#66-75, $\mathrm{Cr}>1000$ ppm, and $\mathrm{Ni}>400-500$ ppm (Winter, 2001). However, this group may also represent olivine or pyroxene cumulates associated with a magma parental to both low-Ti groups. The best candidates for parental magma compositions for the high-Ti group are the large number of Group D samples with Mg\#s 64, and $\mathrm{Ni}$ and $\mathrm{Cr}$ greater than $>900 \mathrm{ppm}$ and $>1600 \mathrm{ppm}$.

\subsubsection{Petrogenesis of the Killapait sill}

The Killapait sill is a layered mafic-ultramafic layered intrusion located on the south coast of central Meta Incognita Peninsula. Its true thickness is at least $\sim 470 \mathrm{~m}$, but its upper contact was not observed due to erosion. The sill is preserved in a $F_{3}$ synformal basin, or syncline, if the mafic layers were situated on top of the ultramafic component at the time of emplacement.

A combination of bulk-rock, mineral and isotope geochemistry, petrography, and field observations has led to the conclusion that the Killapait sill reflects a complex history of formation, involving multiple injections of compositionally distinct magma batches into a single growing intrusion. The first indication of its complexity was the non-systematic variation in trace-element and isotope geochemistry from the basal contact to the uppermost portion of the 
intrusion, which was further supported by hand sample and petrographic observations.

In a sill derived from in-situ magmatic differentiation, systematic variation in trace-element and isotope geochemistry would be expected (e.g. Egorova \& Latypov, 2013) from the basal contact to the uppermost portion of the intrusion, mostly reflecting the depletion of $\mathrm{MgO}$ in the magma and increase in incompatible trace element concentrations. However, this is not observed in the Killapait sill. In fact, within a small stratigraphic interval, major changes in chemistry are observed that cannot be explained simply by crystal fractionation. For example, through the stratigraphy of the sill, there were four geochemical groups identified ( $A 1, A 2, C 1, C 2)$, with Group $C 2$ appearing to represent the most voluminous component. Adding to the complexity, instead of the geochemical signatures occurring as four separate packages within the intrusion, the same group occurs at multiple levels within the magmatic stratigraphy, and in one instance, samples from three different geochemical groups $(A 2, C 1, C 2)$ were collected from a single station (14SAB-L012). Differences in Sm-Nd isotope geochemistry obtained from the various groups within the sill supports the recognition of separate magma batches. Assuming sills were continually injected into the centre of the partially crystallized intrusion, it could be proposed that at least 5 injections of four geochemically distinct magmas were injected into the sill. Each individual sill was likely emplaced after significant crystallization had occurred (e.g. 50\%, as per general estimates of cooling rates by Cawthorn, 2012), such that repeated injections didn't mix and the sills retained their physical 
identity and geochemical character. Truncation of layering within a sample collected within the gabbroic portion of the sill is shown in Figure 8.2a, which appears to represent a gabbro with finer-grained gabbroic xenoliths. However, given that this sample is of the Group $\mathrm{C} 1$ geochemical group and the geochemistry represents the sample as a whole, it is possible that the sample represents mixing of Group D and Group C2 magmas, with the fine grained gabbro being one magma type and the coarse-grained gabbro being the other. Chilling was not observed in the field, which may be due to the fact that chilling may or may not have occurred depending on the temperature contrast between sills (i.e. $100{ }^{\circ} \mathrm{C}$ difference will result in chilled contact formation) or perhaps it was due to lack of exposure or coarsening through high-grade metamorphism. Another possibility is that after the initial sill injection, subsequent injections underplated the sills which preceded them (i.e. vertically stacked succession of sills). This could produce the non-systematic variation in geochemistry that is observed within the Killapait sill.

In the upper $200 \mathrm{~m}$ of the sill, which is comprised of Group C2 magma type, bulk-rock geochemical compositions suggest that magmas experienced FeO-saturation and began following a calc-alkaline trend of magmatic evolution

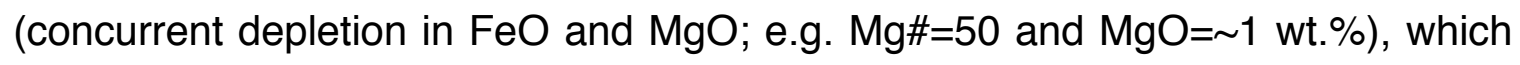
coincides with the crystallization of Fe-, Ti- oxides. In this upper stratigraphic level within the sill, oxides appear to be absent, with the exception of dismembered pods of oxides in the unit below it (Figure 8.3). This may be explained by crystallization and removal of oxides from the magma prior to the 
emplacement of this respective magma batch, or the oxides were separated via gravitational settling in-situ. A high-oxygen-fugacity environment may have been present, as low oxygen fugacities typically suppress ilmenite and magnetite fractionation (e.g. Snyder et al., 1993)

Two Group C2 samples from the ultramafic component of the Killapait sill (14SAB-L013A01 and 14SAB-L013A02) have significantly higher positive Eu/Eu* than the rest of the samples in the sill, and contain large plagioclase megacrysts (Figure 8.2b) in coexistence with significant amounts of olivine. The occurrence of these two minerals together requires low pressures and very high temperatures $\left(>800^{\circ} \mathrm{C}\right)$, so they are typically found in crustal mafic intrusions (i.e. $<600 \mathrm{MPa}$ ) within units olivine gabbro or troctolite in composition (Bucher and Grapes, 2011). There has been no documented occurrence of prograde plagioclase formation in olivine-rich rocks, to date, but they could theoretically form in low-P granulite facies terrane (Bucher and Grapes, 2011). In light of this, the plagioclase within the ultramafic portion of the Killapait sill is interpreted to have grown prior to the emplacement of magma (cognate xenocryst) from which the sill crystallized, and is considered to be a primary magmatic relict; of course An-content has changed through progressive prograde metamorphism. A common and plausible site of crystallization of this plagioclase is within a shallow crustal magma chamber where it crystallized from its slowly cooling parental magma. Given the abundance of plagioclase grains within the basal area of the sill, the parental magma to the sill may have interacted with a crystal mush of plagioclase grains (e.g. Sheth, 2016) near the top of a magma chamber. The 
lower pressures in the upper crust may have allowed plagioclase to float and accumulate toward the surface of the magma chamber (e.g. Higgins and Chandrasekharam, 2007).

In spite of having established that the Killapait sill does not represent one simple sill (i.e. one injection of magma that differentiated in-situ into mafic and ultramafic components), it's precise history of formation remains elusive. I propose two models for the formation of the Killapait sill: (1) composite sill formation, through multiple injections of magma into a single intrusion; and (2) vertical stacking of discrete sills through underplating (overplating is far less likely, as per Menand, (2008); see also chapter 2). These models are based on the available data and assume continuity between the occurrences of specific geochemical groups. Note that in reality, this is not likely the case, based on the complexity observed in the limited sampled collected. In both models, sills are injected as discrete bodies that do not mix with previous injections.

\subsubsection{Models of Killapait sill formation}

In the composite sill model (Figure 8.4), the sequence of events may have been as follows:

(1) A batch of low-Ti group magma (Group A1) is first injected into the Lake Harbour Group, where it begins to differentiate into Group A2. This is supported by the presence of a fine-grained unit of Group A1 character at the basal intrusive contact, and the recognition of a Group A2 sample as the next 
geochemical group higher in the stratigraphy. Alternatively, Group A2 may have been injected as a separate magma batch.

(2) A minor injection of Group C1 magma was emplaced in the sill.

(3) A significant volume of plagioclase-charged Group C2 mafic and ultramafic magma were emplaced, significantly increasing the size and thickness of the sill. Prior to this emplacement, a crystal mush of plagioclase was entrained by the magma, likely from the top of a magma chamber. Due to the viscosity of the ultramafic magma and density of the overlying magma, the plagioclase cannot escape through floatation to higher levels within the sill. Or perhaps some of it was able to escape, and its presence is masked by a combination of naturally plagioclase-abundant mafic rocks and high-grade metamorphism. Alternatively, if other magma batches were already mostly crystallized, this would also act as a barrier to plagioclase floatation.

(4) Final injections into the sills comprised Group C1 magmas, which were able to retain their geochemical character and perhaps physical identity. Alternatively, if Group C1 represents contaminated Group D magma, then Group D magma may have been injected into the sills, mixing with Group C2 magmas, forming the Group C1 magma type. However, given the consistency and distinguishability of chondrite-normalized REE patterns, mixing would have likely occurred at depth in a separate magma chamber, prior to emplacement in the sill. 
If the Killapait sill represents the emplacement of multiple sills comprised of geochemically distinct batches of magma, each underplating the previous sill (Figure 8.5), then the order of injection is as follows:

(1) First injection of magma would have been a voluminous batch (or batches) of Group C2 mafic magma, assuming Group C2 continues to the upper contact.

(2) Injections of mafic magma alternating between Group C1 and C2 types underplate the first sill as discrete bodies themselves.

(3) Injections of ultramafic magma would have come last, underplating the mafic sills as discrete sills of differing geochemical character. At this stage of stacked-sill complex formation, the Group C2 magmas entrained a crystal mush of plagioclase prior to emplacement, likely from the top of a magma chamber.

There also exists the possibility the actual formation of the Killapait sill involved a combination of these models. For example, Group C1 and C2 magmas may have formed a composite sill that was later underplated by the Group A1 and A2 magmas (or magma if the latter two share a parental magma). The exact sequence of events to led to this sill's formation is not clear, and there are surely more variants of the models stated above. Additional field work, more detailed sampling (as much as allowed by the current exposure) and geochemical modelling is required to further test these models. Furthermore, this detailed study on the Killapait sill sheds light on the complex process that occurred during the formation of the Frobisher suite. There is a good possibility that a number of other sills may have been derived through similar process, to 
greater or lesser extents. It should be also noted that these models assume that there is a basal feeder (dyke or sill) to the Killapait sill, but there is a possibility that this sill was fed laterally by dykes. In the latter case, other models of emplacement may be proposed.

\subsubsection{Petrogenesis of the Chidliak sill}

The Chidliak sill is a layered mafic-ultramafic layered intrusion located on northern Hall Peninsula, south of Chidliak Bay (and west of Ptarmigan Fjord). It is $\sim 230 \mathrm{~m}$ in thickness (true thickness) and is preserved as an overturned string of boudins. It has three main components, including a basal metapyroxenite, volumetrically dominant metaperidotite, and an upper metagabbroic cap.

A combination of bulk-rock, mineral and isotope geochemistry, petrography, and field observations was used to understand the petrogenesis of the Chidliak sill, revealing a much more simpler history of formation, compared to the Killapait sill. One key difference is that the formation of the Chidliak sill involved multiple injections of a single magma type (Group F). Key evidence for multiple injections includes clasts of basal pyroxenite suspended within the peridotite unit (Figure 8.6), immediately above the pyroxenite-peridotite contact, indicating that the pyroxenite had crystallized prior to emplacement of the parental magma to the peridotite and had been entrained through erosion of the sill floor. This notion is further supported by variations in trace element geochemistry through the sill, specifically, the more primitive character of the core of the peridotite unit, and intermediate composition of the basal pyroxenite. 
Further investigation reveals that the pyroxenite contains an intermediate composition (e.g. in $\mathrm{Mg \# ,} \mathrm{Cr}, \mathrm{Ni}$ ) between the peridotite unit and gabbroic units, as would be expected for a parental magma composition to the peridotitic and gabbroic units. The REE concentrations of the pyroxenite are equal or lower than the other two lithologies. This, along with the other evidence, seems to suggest that the basal pyroxenite may represent "frozen" magma at the base of the sill, due to conductive cooling, prior to the onset of crystal fractionation and gravitational setting. Additionally, if the basal pyroxenite is of cumulate origin, $\mathrm{Cr}$ contents would be significantly higher in this unit compared to the peridotite or gabbro, which it is not. Cr contents in the pyroxenite are equal to the gabbroic unit, and significantly lower than the peridotite unit. Basal pyroxenites have been observed elsewhere in mafic-ultramafic intrusions, for example in the Chukotat Group of the Circum-Superior LIP, where they are interpreted to be a "chilled border phase" (e.g., Bédard et al., 1984; St-Onge et al., 1987; Thibert et al., 1989).

Samples from the centre of the peridotite unit (15SAB-L078A01 and 15SAB-L078A02) are distinctly more primitive (>Mg\#, $\mathrm{Cr}, \mathrm{Ni})$ than peridotite located closer to the contacts with the gabbroic and pyroxenitic units. However, given the very similar $\mathrm{Yb}$ contents, these samples may just reflect a difference in the mineralogical nature of that horizon in the sill (i.e. greater abundance of olivine, or olivine cumulates). Furthermore, these remain geochemically distinct from the rest of the sill. 
Two possible origins for the gabbroic cap are: formation through in-situ differentiation of the parental magma to the peridotite, or it may have differentiated from the magma which produced basal pyroxenite, which was later intruded by additional magma which formed the peridotite. The gabbro exhibits a more elevated chondrite-normalized REE patterns than both pyroxenite and peridotite, making it feasible that it could have formed from either unit. The concordant contact between peridotite and gabbro supports differentiation of the gabbro from the peridotite unit, as well as lack of gabbroic clasts suspended in the peridotite, as is the case with the pyroxenite. Sm-Nd isotopic data indicate that the gabbroic unit is derived from a more depleted mantle source $(\varepsilon N d=$ 6.13) compared to the peridotitic unit $(\varepsilon N d=4.58)$. However, this difference may be the result of a combination of increased instrumental error due to such low concentrations of $\mathrm{Nd}$ within the Group F samples (range of $0.9-2.4 \mathrm{ppm} \mathrm{Nd}$ ), natural variations within the magma reservoirs, and higher degree of crustal contamination in that sample (observed in primitive-mantle normalized diagram as $\mathrm{Nb}$-anomalies).

The aforementioned evidence indicates that the Chidliak sill does not represent one simple sill (i.e. one injection of magma and differentiated in-situ into mafic and ultramafic components), but is best explained through the composite sill model of formation (proposed below).

\subsubsection{Models of Chidliak sill formation}


In this first model (Figure 8.7), the Chidliak sill formed through opensystem in-situ differentiation, with continuous pulses of magma. The basal pyroxenite represents magma that was "frozen" at the base prior to initiation of olivine crystal fractionation and gravity-induced settling. The thin gabbroic unit that caps the rest of the sequence may be interpreted to represent a late differentiate from the parental magma to the sill. Sill formation was initiated by a first pulse of magma, from which the pyroxenite began to crystallize, due to loss of heat, through conduction, to the relatively cool wall rocks. Within komatiitic basalts, pyroxene is known to crystallize before olivine, as the dominant phenocrysts, which may accumulate at the base of the flows (e.g. Arndt et al. 1997). The timing of crystal settling may have been offset because of continual injections of magma into the sill, or perhaps the sill served as a conduit for magma through-flow. Turbulent flow resulting from the low viscosity, ultramafic nature of the magma and additional influx of magma partially eroded the continually crystallizing basal pyroxenite, as evidenced by pyroxenitic clasts suspended in the peridotite unit (Figure 8.6). These clasts serve as the only constraint on relative ages between units within the Chidliak sill. There are no clasts of gabbro within the peridotite, however, but this does not mean that the parental magma to the peridotite cannot have intruded between the partially crystallized gabbroic and pyroxenititic units of the sill (e.g. the second model). Crystal fractionation and gravity-induced settling (laying the peridotite unit) were only able to commence once turbidity in the system had ended. Through this differentiation process, the gabbroic cap of the sill was formed. 
The second possible model (Figure 8.8) involves an initial injection of magma, which begins the in-situ differentiation into the pyroxenitic basal unit and the upper gabbroic unit. Before the sill was completely crystallized, vast amounts of primitive magma were injected into its core, forming the peridotite unit. The presence of clasts of pyroxenite "floating" with peridotite units supports this model, however, the absence of gabbroic clasts in the peridotite does not. In addition, the pyroxenitic sample right at the pyroxenite-peridotite contact has a similar but more evolved chondrite-normalized REE pattern compared to the gabbroic samples. This sample also contains thin section-scale discontinuous anorthositic layers, indicating this portion of the sill was quite evolved, approaching a mafic (gabbroic) composition.

This second model is also supported by the very different, but still depleted, $\mathrm{Nd}$ isotope signatures, the observation of rip-up clasts of pyroxenite just above the pyroxenite/peridotite contact, the smooth decrease in $\mathrm{MgO}$ with decreasing $\mathrm{FeO}$ from base of pyroxenite to top of pyroxenite and then into gabbro (essentially slicing out peridotite, which appears to be out of place, with higher $\mathrm{MgO}$ and $\mathrm{FeO}$ contents). Contents of $\mathrm{Cr}$ are similar between the basal pyroxenite and gabbroic unit, but $\mathrm{Ni}$ is significantly higher, which may suggest that as the pyroxenite was "freezing," some fractionated olivine was allowed to settle.

An example of an intrusion, that has a similar stratigraphic lithological profile to the Chidliak sill, is the ca. 1075 Ma Wingellina Hills intrusion of the ca. 1090-1040 Giles event in the Musgrave Province of central Australia. This 
intrusion contains a basal orthopyroxenite that is overlain by a clinopyroxenite, then peridotite, wehrlite and finally gabbronorite (Ballhaus and Glikson, 1989). This intrusion and others like it in the Giles Complex, are interpreted to represent intrusions that have experienced magma replenishment, resulting in changes in the geochemistry and fractionating mineral phase(s) (Ballhaus and Glikson, 1989). This is consistent with both models proposed here.

However, the model that appears to be most appropriate is the first model, where the basal pyroxenite formed as a "freeze" layer and the gabbroic unit formed as a product of differentiation of the peridotite. But it should be noted that these models assume that there is a basal feeder (dyke or sill) to the Chidliak sill, but there is a possibility that this sill was fed laterally by dykes. In the latter case, other models of emplacement may be proposed.

\subsubsection{Candidacy for a Large Igneous Province (LIP)}

\subsubsection{Areal Extent}

One criteria that the Frobisher suite must meet in order to be considered the plumbing system to a LIP, is a minimum areal extent of c. $100,000 \mathrm{~km}^{2}$, as per the definition of a LIP (Ernst, 2014) and other studies on intrusive provinces and plumbing systems of LIPs (e.g., Yale and Carpenter, 1998; Marzoli et al., 1999; Ernst et al., 2005). Based on a rough, very conservative estimate, the suite's areal extent has been determined to be approximately $130,000 \mathrm{~km}^{2}$. This areal extent is based on the extent of the Lake Harbour Group, which is pervasively intruded by Frobisher suite sills of varying thicknesses. 


\subsubsection{Volume of magma}

The high volume of magmatism within LIPs is another critical attribute. While most sills are not very thick (averaging $\sim 50 \mathrm{~m}$ thickness), there is a large areal extent of sill emplacement, and enough sill material to consider the suite to have resulted from an anomalously high-degree of mantle melt production, typical of the generation of mafic-ultramafic components of LIPs.

\subsubsection{Duration and pulsed nature of magmatism}

Criteria regarding the duration of magmatism cannot yet be considered due to the lack of geochronological data from this suite of sills. Once systematic dating is conducted on the suite of sills, it could be determined whether the magmatism was emplaced within a short duration pulse (or multiple pulses spanning several 10s of myr; Ernst, 2014; Ernst and Youbi, 2017).

\subsubsection{Intraplate character}

The intraplate character of the Frobisher suite is indicated by the Group D magma type, which is mildly alkaline and exhibits OIB-source-like characteristics (e.g., positive $\mathrm{Nb}-\mathrm{Ta}$ anomalies, LREE-enrichment with fractionated HREE indicating low-degree partial melting of peridotite within the garnet stability field, high-Ti character). These characteristics are suggestive of intraplate magmatism (i.e. mantle plume-derived magmatism). 
High $\mathrm{Ti} / \mathrm{Y}$ ratios are characteristic of intraplate setting, as $\mathrm{Y}$ is preferentially retained in garnet in restite. This doesn't occur at plate margin setting where melting is shallower (hence no garnet present), and also the addition of $\mathrm{H}_{2} \mathrm{O}$ allows for higher degrees of partial melting that can consume garnet even if deep melting occurs (Pearce, 1996).

\subsubsection{Provinciality within Frobisher suite}

While not a characteristic feature of LIPs, the marked provinciality in the distribution of high- and low-Ti geochemical groups is common amongst LIPs, such as in the Paraná-Etendeka (e.g. Peate, 1997), Karoo (e.g. Jourdan et al., 2007a), and Emeishan (e.g. Xu et al, 2001) LIPs. As a specific example, within the Golden Valley Sill Complex of the Karoo LIP (Neumann, 2011), various sills within a confined area appear to be derived from different magma batches, or a combination of them. This same observation is apparent in the Frobisher suite. In many cases, individual intrusions appear to be derived from separate, distinct magma batches, and sills in relatively close proximity (i.e. kilometers apart) have different geochemical signatures. Despite having been obscured by several deformation events, a spatial relationship still appears to exist. Furthermore, the emplacement of Group D into proximal facies Lake Harbour Group strata suggests a "central" location with respect to a reference Meta Incognita microcontinent (as described above). In contrast, the low-Ti magmas, interpreted to reflect high-degree partial melting at shallower depths, primarily occur in distal 
facies Lake Harbour Group strata and therefore near the margins of the reference microcontinent.

In support of the implications of this observation, the mildly alkalic tholeiitic magmas (high-Ti group) are generally produced and emplaced or extruded proximal to the plume centre. If there is mantle plume involvement, a speculative potential plume centre may have been in the vicinity of western Meta Incognita Peninsula, proximal to the current location of the Big Island suture.

\subsubsection{Broad geochemical similarities to LIPs}

Almost all continental LIPs are volumetrically basic (<54 wt.\% $\mathrm{SiO}_{2}$ ), which is consistent with the chemistry of the Frobisher suite sills. The majority of continental-flood basalts also have low $\mathrm{Mg \#}$ and low $\mathrm{Ni}$ contents, similar to A2 magmas. This is interpreted to result from extensive fractionation of primary picritic magmas (e.g. Cox, 1980; Thompson, 1983; Garfunkel, 2008).

\subsubsection{LIP versus non-LIP?}

Until further geochronological data is obtained or the Frobisher suite is linked to an already-existing LIP event, the Frobisher suite can tentatively be considered to be part of its own Large Igneous Province, informally called the "Frobisher LIP." Given the approximate age of c. 1900 Ma obtained for the Frobisher LIP, then the Frobisher suite sills should be examined for their potential genetic relationship to LIPs in the region ranging in age from c. 1.85-1.95 Ga (see section 8.2.2). 


\subsubsection{Evidence for mantle plume-involvement}

A non-essential, but common, aspect of LIPs is the involvement of an anomalously hot thermal anomaly (i.e. mantle plume), which allows for the vast amounts of melt production necessary for the magmatic event to be considered a LIP.

It is possible that the mafic (-ultramafic) sills and pillow-basalts found within the initial rifted margin sediments (Wodicka et al., 2010) of the Schooner Harbour sequence (Sanborn-Barrie et al., 2008) represent initial plume-derived rift magmatism, which was later followed by the magmatism that formed the sills of the Frobisher suite.

\subsubsection{Field evidence}

The extensive outcropping of the Frobisher suite sills within the Lake Harbour Group across most of southern Baffin Island supports the idea of mass magma production beneath the Meta Incognita microcontinent at ca. $1900 \mathrm{Ma}$, and subsequent emplacement into crustal strata. The most well recognized mechanism for large volumes of melt production is mantle plume impingement on the base of the lithosphere.

\subsubsection{Geochemical evidence}

The formation of ocean-island basalts has long been attributed to mantle plumes, which have a characteristic geochemical signature. The chondrite- 
normalized REE patterns of OIBs globally were averaged by Sun and McDonough (1989) and can be used for comparison to identify plume-related magmatism. However, it should be noted that plume-derived LIPs can have highly variable chemistry, depending on numerous factors, such as contamination, crystal fractionation, degree of partial melting, depth of partial melting, plume composition, and other differentiation processes. Samples from the high-Ti group (Group D) have chondrite-normalized REE patterns that closely resemble that of OIBs, but are not quite as enriched as OIB. This could perhaps be due to the fact LIPs are the product of plume heads, whereas OIBs form from plume tails (i.e. less extensive melting occurs in tails, so lower-degree melting; Richards et al., 1989). Thus, the high-Ti group may share a similar source with OIBs (i.e. mantle plumes).

In LIPs such as the Wrangellia LIP, the high-Ti signature has been interpreted to be plume-related, unaffected by lithosphere. The low-Ti lavas from Wrangellia are HFSE-depleted and formed from plume head impingement on the base of the arc lithosphere (Greene et al., 2009). The equivalent magma type in the Frobisher for the low-Ti lavas of Wrangellia could potentially be the HFSEdepleted Groups B, C1, C2.

Differences in $(\mathrm{La} / \mathrm{Yb})_{\mathrm{N}}$ between the high-Ti and low-Ti groups can be most easily attributed to differences in degree of partial melting of plumeinfluenced mantle source. Their similar $\mathrm{Zr} / \mathrm{Nb}$ ratios support this suggestion, as differences in degree of partial melting barely affect it. Therefore, it reflects the 
character of the mantle source and low-Ti and high-Ti appear to share one. The similar spread of $\varepsilon N d$ values $(\sim 1-3)$ also suggests this.

It was suggested by Ernst \& Buchan (2003) that uncontaminated, basaltic rocks generated from mantle plumes should either have flat REE patterns or OIB-enriched patterns, both with an absence of $\mathrm{Nb}-\mathrm{Ta}$ and $\mathrm{Ti}$ anomalies. This closely describes Group A1 and Group D, respectively. The only exception being weak contamination in Group A1 ( $\mathrm{La} / \mathrm{Nb}=\sim 1-1.5)$.

Regardless of the potential Paleoproterozoic uplift history recorded in southern Baffin Island, recent work by Burov and Guillou-Frottier (2005) suggests that the amount of uplift above a plume may be small or absent in some circumstances. Therefore, this should not influence or be used to disprove plume presence at 1900 Ma beneath the microcontinent.

Other observations supporting plume involvement include:

(1) Mafic to ultramafic-dominated magmatic provinces are commonly associated with mantle plumes;

(2) The presence of a plume component is the only widely accepted way to generate E-MORB magmatism (e.g. Group A1+A2; Whitmarsh et al., 1996), which is widely recognized as having resulted from mixing of depleted (i.e. N-MORB) and enriched (i.e. OIB) sources (e.g. Serrano, 2011).

Overall, the best geochemical indication for plume-involvement is the highTi Group D. It exhibits LREE-enrichment and fractionated HREE, similar to OIBsourced magmas, and it has generally high $\mathrm{MgO}$ (mostly $>18 w \mathrm{t} . \%)$. Furthermore, 
the presence of OIB-sourced magmas indicates the involvement of a source deeper than that of the MORB upper mantle source (Ernst, 2014).

Finally, it should be noted that OIB signatures can also be produced by non-plume processes, such as volatile-induced melting of ambient mantle and lithospheric mantle fracture-transport (Herzberg and Gazel, 2009). But high degrees of melting (e.g. Group $\mathrm{A} 1+\mathrm{A} 2$ ) require a thermal anomaly such as a plume (Herzberg and Gazel, 2009).

\subsubsection{Sill emplacement}

Sills of the Frobisher suite appear to have been emplaced as both single injections of a single magma type, and as multiple sheet-like intrusions (e.g. Duluth Complex; Miller et al., 2002), as the variation in chondrite-normalized REE patterns cannot be accounted for by closed-system in-situ differentiation. The intrusions involving multiple sill injections may have either formed composite sills (i.e. sills emplace inside one another), or a stacked sequence of sills, in which each successive sill may have underplated the last. In the latter case, it is possible that within some sills where the mafic and ultramafic components appear to represent different magma types, an ultramafic sill may have preceded the injection of the mafic component, meaning that certain sills that appear to be overturned may actually be the right way up.

Given the evidence for multiple injections of different magma types into the same sill, it is highly likely that all magma types utilized the same established melt transport network, as one of the critical elements of an established melt 
transport network is that it is susceptive to reopening and exploitation by subsequent magma pulses (Marsh, 2004).

At this point in time, there is no dyke swarm that has been linked to the Frobisher suite, so the plumbing system to this suite of sills is not yet fully understood. This is one line of evidence that might be used to support the passive rift-related origin of the Frobisher suite. However, the apparent absence of dyke-like feeders to the sills could be due to a lack of preservation, and the few that might be exposed at surface may not have been identified during regional mapping. Alternatively, the absence of dykes may also indicate that the suite was not fed directly from a single central plume region, that sills were fed by other sills, such as in the Karoo basin of South Africa (Svensen et al., 2012), or that sills were fed by dykes outside the sedimentary basin that are emplaced as sills once the mean enters the sedimentary basin (e.g. Ernst, 2014).

Within individual sills, there is a general absence of observed assimilated metasedimentary material (e.g. xenoliths, granophyric margins), with the Chidliak sill as the single exception. The lack of crustal xenoliths may suggest the flow was more laminar, as opposed to turbulent. The absence of granophyric margins may indicate the host rocks were cold, therefore requiring substantial thermal energy to push them past the solidus and generate partial melting. This is consistent with the Frobisher suite's emplacement in a sedimentary basin $(<\sim 10$ $\mathrm{km}$ thick).

Due to relatively thin nature of many sills within the Frobisher suite (e.g. $<50 \mathrm{~m}$ ), they would have cooled relatively fast (i.e 50\% crystallized at ca. 10 yrs 
and completely solid at ca. 20 yrs, as per general estimates of cooling rates of sills by Cawthorn, 2012), not allowing enough time for significant in situ differentiation and assimilation processes to take place. The sills also formed chilled margins at their contacts, which prevented heat transfer to the country rocks, which suggests that the variable amounts of contamination that occurs in certain groups (e.g. Group A2) occurred at depth, prior to final emplacement.

With regard to overall geometry of the Frobisher suite at emplacement, the sills were more likely emplaced as a sill province, similar to sills of the Karoo basin (of the Karoo-Ferrar LIP), as opposed to a dismembered stratiform sill, like those of the Giles Complex of central Australia (of the Warakurna LIP). This notion is supported by: (1) Sills present at different levels within the Lake Harbour Group stratigraphy, as well as difference in composition between those emplaced in proximal (furthest from edge of microcontinent) and distal facies (closest to edge of microcontinent); (2) The diversity of geochemical groups within sills; (3) The close proximity of sills derived from different magma types; (4) High variation in the mineralogy of different sills, however, this may partially be due to regional differences in metamorphic grade (variable from amphibolite to granulite facies); and (5) the absence of shear zones at the along-strike terminations of the sills.

As mentioned above, sills derived from high-Ti magmas occur only in the proximal LHG facies (i.e. in southern to western Meta Incognita Peninsula), while low-Ti magma-derived sills are concentrated in the distal LHG facies (i.e. on northern Hall Peninsula). The occurrence of the low-Ti magmas in the proximal LHG facies could occur as a result of any of the following: (1) interconnecting 
lithospheric faults carrying low-Ti magmas further inland; (2) low-Ti magmas travelling great distances within dykes or sills to the more proximal facies; or (3) intense erosion of the subcontinental lithospheric root, such that melting below the Meta Incognita microcontinent occurs at increasing shallower depths, to the point where high-degrees of melting are occurring within the spinel-stability field.

\subsubsection{Post-emplacement modification}

Lithologies that are mafic to ultramafic in composition can be highly resistant to metamorphism if anhydrous conditions are maintained, even up to high grades. The pervasiveness of hornblende, and lesser biotite, throughout the sills indicates that these sills were thoroughly hydrated, and consequently recrystallized, during the high-grade metamorphic events of the Trans-Hudson Orogen (THO). Influx of water was likely facilitated by post-emplacement deformation within the sills and adjacent host rocks, as evidenced by sills forming $F_{3}$ and $F_{4}$ synclines and anticlines, where overturning of stratigraphy has occurred in some cases. The present lithologies are metamorphic in nature, however, relict primary features such as magmatic layering and pristine cores in phenocrysts (e.g. clinopyroxene in hornblende) are often present.

During the progressive closure of the Manikewan Ocean, the Meta Incognita microcontinent was thrust upward onto the Narsajauq arc. Through this process, the leading edge of the microcontinent was eroded away, leaving the trailing half of the microcontinent preserved, which today is bounded between the 
Big Island and Baffin sutures, representing the approximate transition from the central region of the microcontinent to the edge of it, respectively.

\subsubsection{Metamorphic Character of sills}

Given the pervasiveness of upper amphibolite- to granulite-facies metamorphic assemblages throughout Lake Harbour Group (which host the sills) and later intruding phases of Cumberland Batholith, the mineral assemblages within the Frobisher suite sills are considered to be metamorphic. Beyond the regional context, further evidence for the metamorphic origin of most minerals in this mafic to ultramafic suite of sills includes: 1) mineral assemblages within both mafic and ultramafic units are consistent with amphibolite- to granulite-facies metamorphic conditions; 2) weakly to strongly developed foliation fabric, defined by amphibole (and biotite, when present), is present in numerous samples; 3 ) the presence of a granoblastic texture present in many samples, typical of nonfoliated, high-grade metamorphic rocks; 4) the presence of amphibole in every sample, with the exception of one; 5) the coexistence of olivine (anhydrous) and amphibole (hydrous) in rocks where the former is only very weakly serpentinized along fractures; 6$)$ An-rich character ( $>85 \%$ An) of plagioclase grains from numerous sills, indicative of high-grade metamorphism; 7) spinel, of similar chemical composition to all others analyzed, exhibiting a vermicular texture, which is characteristic of formation through metamorphic growth. However, the presence of relict primary minerals is permissible given the chemistry of select mineral phases (e.g. olivine within field of layered intrusion olivine compositions, 
plagioclase grains of andesine to labradorite compositions). The most likely candidates for samples retaining primary magmatic mineral assemblages (or primary minerals) are those which lack all or most of the observations stated above.

\subsection{Regional Implications}

\subsubsection{Regional comparison with other LIP and non-LIP events}

The recent unpublished age of $1900 \mathrm{Ma}$ is considered to be a minimum crystallization age for the suite (N.Rayner, unpublished data, 2017). With this age, the maximum age of the Lake Harbour Group (ca. 1934+/-2 Ma; Scott, 1997), the age of the M1a granulite-facies metamorphic event (ca. 1845-1842 Ma; see chapter 3), and the knowledge that LIP magmatism can have a maximum duration of 10 s of myr, it is possible that the Frobisher suite is related to LIP events that occurred in the timeframe between ca. $1845 \mathrm{Ma}$ and ca. 1934 Ma (Figure 8.9). Currently recognized LIPS, and interpreted-LIP fragments, that were emplaced (or extruded) during the ca. 1934 - 1845 Ma time period are listed in Table 8.1 and their locations are shown in Figure 7.9.

Given the potential size of a flattened plume head (i.e. up to $2000 \mathrm{~km}$ across), additional magmatism from the same event may have occurred away from the Meta Incognita microcontinent and emplaced elsewhere. In modern day plate geometry, this is approximately the equivalent to the distance from Iqaluit, Baffin Island, Nunavut, to Ottawa, Ontario, which is precisely $2088 \mathrm{~km}$ (calculated by software on http://www.distancefromto.net/). With this in mind, it 
does not seem unreasonable to entertain the idea of a relationship between Frobisher suite magmatism and another LIP- or non-LIP-scale event greatly displaced from the centre of magmatism beneath the Meta Incognita microcontinent at ca. 1900. Furthermore, given that the Manikewan Ocean closed within a short time interval after Frobisher suite magmatism, there is a good chance that any other mafic-ultramafic suites related to this LIP event are contained within Baffin Island, or proximal to it (e.g. northern Québec; Greenland). In addition to this, it is well-recognized that magma can travel great distances via dykes and sills (>2000 km) before finally being emplaced or erupted (e.g. Mackenzie dyke swarm of the Mackenzie LIP; Baragar et al., 1996). Due to a lack of available geochemical data in literature for most LIPs that occurred between 1925 and 1875, only comparative geochemistry between the c. 1880 Ma Circum-Superior LIP and Frobisher LIP is presented.

Through the use of primitive-normalized trace element patterns, the fields of Circum-Superior Province volcanic and intrusive rocks were compared with the average values from the Frobisher suite geochemical groups. While no exact matches in geochemical patterns were observed, select groups from the Frobisher suite show some similarities to certain Circum-Superior LIP groups (Figure 8.10), mainly based in their $\left[(\mathrm{La} / \mathrm{Yb})_{N}\right]$ ratios. In all cases, the CircumSuperior LIP contains greater total REE contents than the Frobisher suite geochemical groups:

(1) Group B (averaged) demonstrates a similar pattern to the ca.1874 Ma Gunflint Formation (Fralik et al., 2002) of the Circum-Superior LIP (Figure 
8.10a). The primary differences are negative $\mathrm{Zr}$ - $\mathrm{Hf}$ anomalies in average Group B, as well as its much more prominent negative $\mathrm{Nb}$-Ta anomalies.

(2) Group F (averaged) demonstrates a similar pattern to the ca. 1864-1891 Ma Winnipegosis Belt (Hulbert et al, 1994; Burnham et al., 2004) of the CircumSuperior LIP (Figure 8.10b). The primary difference is that Group F of the Frobisher suite shows a negative $\mathrm{Nb}$ anomaly, whereas the Winnipegosis Belt exhibits positive $\mathrm{Nb}$-anomalies, signifying a contaminated and noncontaminated geochemical pattern, respectively.

(3) Group F (averaged) demonstrates a similar pattern to petrographic group 3 (i.e. plagiocalse-phyric basalts) of the ca. $1882 \mathrm{Ma}$ Chukotat Formation (Wodicka et al., 2002; Randall, 2005) of the Circum-Superior LIP (Figure 8.10c). The primary difference is that Group F of the Frobisher suite shows a negative $\mathrm{Nb}$ anomaly, whereas the Chukotat Formation exhibits positive $\mathrm{Nb}$ anomalies, signifying a contaminated and non-contaminated geochemical pattern, respectively.

Given the similar age and presence of geochemical similarities amongst these two LIPs, further work should be conducted to determine if the Frobisher LIP and Circum-Superior LIP are in-fact related. In the event that the Frobisher and Circum-Superior LIPs are related, this would have implications in expanding the areal extent of the c. 1880 Ma Circum-Superior LIP. In addition, further comparative work should be conducted between the Frobisher LIP and other LIPs, pending availability of geochemical data from the latter. Additional highprecision U-Pb geochronology should be conducted to better constrain the age of 
Frobisher suite magmatism, and greater narrow the number of possible related LIP events. Furthermore, the compositional ranges of the Frobisher suite can be seen alongside the geochemistry of some major LIPs in Table 8.2. LIPs exhibiting significant similarities with the Frobisher LIP in each respective geochemical parameter are highlighted in bold.

\subsection{Model for Frobisher Suite Formation}

Based on all the evidence presented in this thesis, but primarily, earlier in this chapter, it appears that the Frobisher suite mafic, ultramafic and maficultramafic sills were derived from the melting of a mantle plume head. A plan view of the tectonic setting is illustrated in Figure 8.11, and a cross section is in Figure 8.12. A detailed model of Frobisher suite formation is presented below, in four stages, with no specific time interval separating any of them. The model is also illustrated in Figure 8.13.

\subsubsection{Pre-Stage 1}

Prior to the initial stage of the plume-based model, the Meta Incognita microcontinent was rifted from an established continental margin, and the Schooner Harbour sequence was deposited during this initial stage of rifting (Wodicka, 2010; N. Wodicka, pers. comm., 2017). Following this rifting event, the attendant shelf succession to the microcontinent, the Lake Harbour Group, was established. 


\subsubsection{Stage 1}

In stage 1 (Figure 8.13), a mantle plume departs from the core-mantle boundary, or somewhere within the lower mantle, and begins to ascend upward toward the base of the Meta Incognita microcontinent.

\subsubsection{Stage 2}

In stage 2 (Figure 8.13), the mantle plume impinges upon the base of the subcontinental lithospheric mantle (SCLM), beneath the Meta Incognita microcontinent, and flattens.

\subsubsection{Stage 3}

In stage 3 (Figure 8.13), low-degree partial melting occurs at the base of the lithosphere (within the garnet-stability field) as a result of a reduction in pressure (adiabatic decompression melting), which reduces the solidus of the

plume-head material, allowing it to melt. This produces the primary magmas to the high-Ti group (Group D). The low-degree melt then begins to pool at the base of the lithosphere, and some high-Ti magma ascends through the thicker portion of the lithosphere, without experiencing significant fractionation or contamination, and directly into the crust where it is emplaced as sills within proximal facies strata of the Lake Harbour Group. Due to the buoyancy of the plume head, the plume material begins to traverse the base of the SCLM to shallower levels.

\subsubsection{Stage 4}


In stage 4 (Figure 8.13), the plume head material reaches shallower depths beneath the most distal facies (seaward) sequence of the Lake Harbour Group. It is there where a significantly higher degree of melting occurs as a result of continued adiabatic decompression melting. This results in the generation of low-Ti primary magmas (i.e. Groups A1 and A2). Low-Ti magmas pass through the lithosphere and pool at the base of the crust, where fractionation occurs, lowering the $\mathrm{Mg \#}$ of most magmas and depleting them of $\mathrm{Ni}$ and $\mathrm{Cr}$. After extensive fractionation and variable contamination, the low-Ti magmas ascend further to the level of emplacement within the Lake Harbour Group as sills. The high levels of thermal energy introduced to the base of the lithosphere, by the mantle plume, allow for thermal erosion of the metasomatized component of the SCLM, which has a significantly lower solidus temperature due to its hydrous mineral assemblage (e.g. amphibole, phlogopite), producing primary magmas to Group C2. After these Group C2 magmas are generated, they begin to mix with both high- and low-Ti magmas, producing Group C1 and Group B, respectively. These magmas ascend through the lithosphere and are also emplaced within the Lake Harbour Group as sills. High-degrees of melting of mixed plume head and depleted upper mantle material likely led to the production of the apparently limited Group F magmas.

\subsection{Mineral Deposit Potential of Frobisher Suite}

By virtue of their LIP affiliation and apparent plume-associated characteristics, there is considerable mineralization potential within the Frobisher 
suite and their adjacent host rocks. Large magmatic events may cause increased heat flux into the crust, which may trigger crustal melting, devolatization and large-scale fluid flow (Ernst and Jowitt, 2013; Maier, 2015). Deposits commonly associated with these conditions include magmatic PGE-Cr-V-Fe-P deposits within layered intrusions, magmatic $\mathrm{Ni}-\mathrm{Cu}$ sulfide deposits in magma feeder conduits or at the basal portion of intrusions, and various hydrothermal deposits in the host rocks (Ernst and Jowitt, 2013; Maier, 2015).

\subsubsection{Field and petrographic observations}

Sulphides were observed in hand sample and in thin section, from almost every sample collected from the Frobisher suite sills. In samples with high sulphide abundances, associated gossans were noted in the field. Sulphide phases are dominantly pyrite and pyrrhotite, however, minor amounts of chalcopyrite are often intergrown with pyrrhotite grains. A number of sills also contain variable amounts of pentlandite associated with pyrrhotite and chalcopyrite.

A primary magmatic origin for these sulphides is suspected, in most cases, based on their textural relationships with the main silicate phases in the samples. In some samples sulphide grains exhibit a round to ovoid shape, and in most other cases sulphides are anhedral, forming interstitially between silicate mineral phases. The thicknesses of sills is quite variable, however, most are relatively thin. This may pose an issue, as thinner sills cool much more rapidly than their thicker equivalents (Cawthorn, 2012), meaning that there may not have 
been sufficient time (and thermal energy) to assimilate crustal material in-situ, segregate immiscible sulphide blebs, and accumulate them at the base of the sill (effectively increasing the tenor of the prospective ore). However, if any sills had a high magma flux, complete crystallization would be delayed and any sulphides formed within the sill, or prior to emplacement and subsequently entrained by the injected magma, would significantly increase in tenor due to extensive interaction with large volumes of magma (Barnes et al., 2015).

\subsubsection{14SAB-L009 gossan}

The largest gossan identified (lat: 63.22945021, long:-71.55833542) is associated with high-Ti group D, and is located in western Meta Incognita, at station 14SAB-L009. Stakes observed on the outcrop indicate that the area is currently, or was previously, staked by an exploration company. The bright orange-weathering gossan (Figure 2.6a) appears mostly within the LHG psammitic unit directly adjacent to the sill, however, visible mineralization occurs both within the sill and the metasedimentary rocks. Sulphides within the sill appear in both mafic (Figure 8.14a) and ultramafic (Figure 8.14b) components and interpreted to have formed magmatically. However, the mineralized psammite (Figure 8.14c) is presumed to have formed post- or syn-magmatically, through hydrothermal processes remobilizing primary magmatic sulphide mineralization. The most mineralized samples obtained from the LHG are mostly comprised of coarse-grained quartz, with round to ovoid shaped sulphide grains. Within the sill, sulphides are quite anhedral, forming interstitially between 
plagioclase and clinopyroxene grains. The presence of graphite in the gabbroic part of the sill indicates remobilization of elemental components within the psammite, and perhaps within sill lithologies as well. Sulphides within both the mafic (gabbroic) component of the sill and the psammite comprise primarily pyrrhotite, with minor amounts of chalcopyrite. Within the ultramafic (pyroxenitic) component of the sill, the same sulphide assemblage exists, but pentlandite is also present, in abundances less than both pyrrhotite and chalcopyrite. Given the sulphide assemblage within the sill, the mineralization within this sill is considered to be Cu-Ni (-PGE).

\subsubsection{Geochemical perspective}

It has been recognized that when multiple magma suites are contained within the same province, Ni-Cu-PGE ores are characteristically associated with the suite that was generated by the greatest degree of partial melting (Zhou et al., 2008; Godel et al., 2011). A reliable proxy, for example, is low Ti content (Zhou et al., 2008; Godel et al., 2011), which is characteristic of Groups A1, A2, $\mathrm{B}, \mathrm{C} 1, \mathrm{C} 2, \mathrm{E}$, and $\mathrm{F}$, and suggests that Group D is the least prospective for NiCu-PGE mineralization.

The tholeiitic low-Ti Groups A1 and A2 are believed to represent highdegree melts (i.e. larger volume of melt) from the plume source that rose to a thin lithospheric area, whereas the mildly alkaline high-Ti Group D is suggested to have been extracted from the source at far deeper levels and to a lower degree (i.e. smaller volume). Because of the high degree of melting experienced by the 
primary magma to the low-Ti groups, they are more enriched in $\mathrm{Ni}$, Cu and PGEs (Keays, 1995; Rehkämper et al., 1999) compared to Group D, and are thus more capable of producing high-tenor ores. However, some authors suggest that lowdegree partial melting can produce magmas that may be prospective for $\mathrm{Ni}-\mathrm{Cu}$ PGE sulfide mineralization (e.g., Mungall et al., 2006; Naldrett, 2010). The presence of a significant gossan (L009; Figure 3.6a) in a Group D sill is attributed to highly sulphidic LHG host rocks, and the low-tenor of the sulphides within it is consistent with the low prospectivity of high-Ti Group D.

\subsubsection{Chalcophile element geochemistry}

In Figure 8.15, the $\mathrm{Ni}, \mathrm{Cu}, \mathrm{Pt}$, and $\mathrm{Pd}$ compositions of samples are plotted against Mg\#. Prior to assessment of the concentrations of these chalcophile elements, it must be noted that these particular chemical species can be remobilized via hydrothermal fluids, and thus, current elemental abundances of chalcophile elements may not reflect the original abundance in the unmetamorphosed, and unaltered, primary magmatic rock.

Samples from Groups $\mathrm{A} 1$ and $\mathrm{D}$ generally contain the highest $\mathrm{Ni}$ concentrations (1200-1500 ppm and 800-1000 ppm, respectively), mainly because they are ultramafic in nature. Groups $\mathrm{C} 2$ and $\mathrm{F}$ display a range of $\mathrm{Ni}$ contents spanning from high (900-1000 ppm) to low (0-200 ppm) concentrations. Groups A2 and E exhibit quite low Ni concentrations ( $<200$ ppm), generally.

About half of all the samples have Pt concentrations below detection and the majority of samples have Pd contents above detection, but are considered 
low in concentration (i.e. $<30 \mathrm{ppb}$ ). Amongst those samples with detectable concentration of $\mathrm{Pt}$ and $\mathrm{Pd}$, distinct differences can be seen between geochemical groups. Groups $\mathrm{A} 1$ and $\mathrm{D}$ exhibit relatively low concentrations of $\mathrm{Pt}$ and Pd compared to other groups above detection. All of Group A1 is above detection, while the majority of Group $\mathrm{D}$ samples are below detection in $\mathrm{Pt}$ and a few fall below detection in Pd. Pt and Pd concentrations are distinctly higher in Groups A2 and F, with the least evolved Group F samples attainting Pt and Pd concentrations of 25 and $37 \mathrm{ppb}$, respectively. Most Group C1 and C2 samples have Pt levels below detection, but Pd levels are most above it. Those samples with $\mathrm{Pt}$ and $\mathrm{Pd}$ above detection in Groups $\mathrm{C} 1$ and $\mathrm{C} 2$ show similar concentrations to those observed in Group D, with few of the least evolved Group C2 samples with concentrations of $\mathrm{Pt}$ and $\mathrm{Pd}$ up to 25 and $50 \mathrm{ppb}$, respectively. All Group B and E samples fall beneath the detection limit.

Groups B, C1, D and E exhibit a wide range of $\mathrm{Cu}$ values, mostly ranging between 0 and $\sim 140 \mathrm{ppm}$, with some concentrations in the most evolved samples up to $\sim 170,180,220$ and 280 ppm, respectively. These Cu contents are considered generally low. Groups A1, A2, C2 and F contain relatively low concentration of $\mathrm{Cu}$ concentrations, generally falling between 0 and $800 \mathrm{ppm}$, with a few Group A2 samples up to $\sim 130$ ppm and Group F samples up to $\sim 170$ ppm. In Groups D and C1, Cu content increases as samples evolve (decreasing Mg\#), consistent with Cu's incompatible behaviour in sulfur-undersaturated magmas. In Groups A2 and $\mathrm{C} 2, \mathrm{Cu}$ stays at an approximately consistent concentration through evolution. 
In the $\log (\mathrm{Cu} / \mathrm{Pd}$ ) versus $\mathrm{Mg} \#$ diagram (Figure 8.16), samples display a wide range in $\mathrm{Cu} / \mathrm{Pd}$ ratios, with some Frobisher suite sills being PGE-depleted relative to primitive mantle, and others Pd-enriched. Group $\mathrm{C} 1$ and $\mathrm{D}$ samples appear to be mostly depleted in PGEs relative to primitive mantle, while Group C2 and F samples are PGE-enriched. Samples from the low-Ti groups (Groups A1+A2) show both PGE-depletion and -enrichment relative to primitive mantle, however, Group A2 samples show PGE-depletion and -enrichment to greater degrees, while Group A1 Cu/Pd ratios straddle that of the primitive mantle. The PGE-depleted nature of Group C1 and D samples could reflect a number of things, including magmatic equilibration with sulphide prior to final emplacement of their parental magmas, assimilation of $\mathrm{Cu}$-rich crust, relative enrichment in $\mathrm{Cu}$ in the mantle source (Maier, 2015), PGE remaining in the mantle, or modification of the $\mathrm{Cu} / \mathrm{Pd}$ ratio by remobilization of $\mathrm{Cu}$ and $\mathrm{Pd}$. The PGE-enrichment in Groups C2 and F could reflect precipitation of immiscible sulphide droplets during magma mixing, sulfide liquid saturation resulting from magmatic fractionation or initiated by crustal contamination (Maier, 2015), or modification of the Cu/Pd ratio by remobilization of $\mathrm{Cu}$ and $\mathrm{Pd}$. In the case of Group $\mathrm{D}$, it is also possible that PGE-depletion in samples resulted from the small-degree of mantle melting (i.e. PGE retained in mantle source), which is evident in the generation of its primary magmas.

Based on this preliminary assessment, it appears that the tholeiitic low-Ti groups serve as the best targets for Ni-Cu-PGE exploration, and have the greatest potential to host high-tenor magmatic sulphide mineralization. 


\subsection{Conclusions}

This study on the Frobisher suite has revealed considerable variation in size, mineralogy and geochemistry within individual sills, and has led to the following main conclusions:

1. Eight different geochemical groups were recognized within the Frobisher suite, and include Groups A1, A2, B, C1, C2, D, E and F. High-Ti (Group D) and Low-Ti (Group A1+A2) magmas appear to be derived from the same source, but reflect differences in degree of partial melting and perhaps an eclogitic or basaltic components in the former, generating its consistent positive $\mathrm{Nb}$-Ta anomaly. Group $\mathrm{D}$ magma was generated by low-degree partial melting beneath a thick portion of lithosphere beneath the Meta Incognita microcontinent (within the garnet stability field). This resulted in LREE-enrichment and fractionated HREE. As magma ascended to shallower levels into the spinel-stability field, via sub-lithospheric channeling, a higher degree of partial melting was achieved, resulting in significantly flatter trace element contents with flat HREE. High-Ti magmas arrived more directly from the mantle compared to low-Ti magmas, except for Group A1, which appears largely undifferentiated.

2. Group C2 magmas are derived from direct melting of previously metasomatized SCLM, likely triggered by the addition of thermal energy via mantle plume, bringing it above the solidus. The source may have experienced a pervious partial melting event, as per the generally depleted 
HREE contents, and was subsequently enriched by slab-derived fluids, prior to the plume arriving to produce the Frobisher LIP event.

3. Parental magmas of Groups B and C1 are interpreted to reflect interaction of Group A1+A2 and Group D magmas with SCLM- or crustally-contaminated Group C2 magmas.

4. Sills of the Frobisher suite appear to have been emplaced as both single injections of a single magma type, and as multiple injections of either single or multiple magma types.

5. On the basis of sufficient geographic areal extent $\left(>100,000 \mathrm{~km}^{2}\right)$, high $\mathrm{MgO}$ content of the majority of samples, chondrite-normalized REE patterns trace element patterns, the significant ultramafic component to the suite, provinciality of magma types (i.e. high- and low-Ti), and other geochemical characteristics, it is proposed that the Frobisher suite represents the plumbing system of a newly-recognized mantle plume-derived LIP, tentatively called the "Frobisher LIP."

6. Based on this preliminary assessment, it appears that the tholeiitic low-Ti groups serve as the best targets for Ni-Cu-PGE exploration, and have the greatest potential to host high-tenor magmatic sulphide mineralization. 


\section{References}

Arndt, N.T., Albarede, F., and Nisbet, E.G. (1997). Mafic and ultramafic magmatism, in de Wit, M.J. and Ashwal, L. D., eds., Greenstone Belts: Oxford University Press, Oxford, p. 233-254.

Arndt, N.T., Czamanske, G.K., Wooden, J.L. and Fedorenko, V.A. (1993). Mantle and crustal contributions to continental flood volcanism. Tectonophysics, 223: 39-52.

Ballhaus, E.G. and Glikson, A.Y. (1989). Magma mixing and intraplutonic quenching in the Wingellina Hills Intrusion, Giles Complex, central Australia. Journal of Petrology, 30, 1443-1469.

Baragar, W.R.A., Ernst, R.E., Hulbert, L. and Peterson, T. (1996). Longitudinal petrochemical variation in the Mackenzie dyke swarm, northwestern Canadian Shield. Journal of Petrology, 37: 317-359.

Bédard, J.H. (2001). Parental magmas of the Nain Plutonic Suite anorthosites and mafic cumulates: a trace element modelling approach. Contributions to Mineralogy and Petrology 141 (6), 747-771.

Belica, M.E., E.J. Piispa, J.G. Meert, et al. (2014). Paleoroterozoic mafic dyke swarms from the Dharwar craton; paleomagnetic poles for India from 2.37 to $1.88 \mathrm{Ga}$ and rethinking the Columbia supercontinent. Precambrian Research, 244: 100-122.

Bleeker, W. (2005). North America: Precambrian continental nucleus. In Encyclopedia of geology. Edited by R.C. Selley, L.R.M. Cocks and I.R. Plimer. Elsevier, Oxford, UK., pp. 8-21. 
Buchan, K.L., Ernst, R.E., Bleeker, W., Davis, W.J., Villeneuve, M., van Breemen, O.,Hamilton, M., Söderlund, U., 2010. Proterozoic magmatic events of the Slave Craton,Wopmay Orogen and Environs. Geological Survey of Canada Open File 5985.

Large Igneous Provinces and supercontinents: Toward completing the plate tectonic revolution (PDF Download Available). Available from: https:// w w w. researchgate.net/pub/ication/ 256806733_Large_Igneous_Provinces_and_supercontinents_Toward_co mpleting_the_plate_tectonic_revolution [accessed Jun 19, 2017].

Bucher, K., \& Grapes, R. H. (2011). Petrogenesis of metamorphic rocks (8th ed.). Berlin ; New York: Springer.

Burnham, O.M., Halden, N.M., Layton-Matthews, D., Lesher, C.M., Liwanag, J., Heaman, L.M., Hulbert, L.J., Machado, N., Michalak, D., Pacey, M., Peck, D.C., Potrel, A., Theyer, P., Toope, K., Zwanzig, H.V. (2004). Geology, stratigraphy, petrogenesis, and metallogenesis of the Thompson Nickel Belt, Manitoba: final report for CAMIRO Project 97E-02. Mineral Exploration Research Centre, Laurentian University, Sudbury. 410pp.

Burov, E. and Guillou-Frottier, L. (2005). The plume head-continental lithosphere interaction using a tectonically realistic formulation for the lithosphere. Geophysical Journal International, 161: 469-490.

Condie, K.C., Des Marais, D.J., Abbott, D. (2000). Geologic evidence for a mantle superplume event at $1.9 \mathrm{Ga}$. Geo-physics, Geochemistry, Geosystems, Vol. 1. Paper No. 2000GC000095. 
Cox, K.G. (1980). A model for flood basalt vulcanism. Journal of Petrology, 21: $629-650$.

Cox, K.G. (1993). Continental Magmatic Underplating. Philosophical Transactions of the Royal Society, A 1993342 155-166; DOI: 10.1098/ rsta.1993.0011.

Drummond, M. S., and Defant, M. J. (1990). A model for trondhjemite-tonalitedacite genesis and crustal growth via slab melting: Archean to modern comparisons: Journal of Geophysical Research, v. 95, no. B13, p. 21503-21521.

Egorova, V. and Latypov, R. (2013). Mafic-ultramafic sills: New Insights from Mand S-shaped mineral and whole-rock compositional profiles. Journal of Petrology 54, 10, 2155-2191.

Ernst, R.E. (2014). Large Igneous Provinces: Cambridge, UK, Cambridge University Press, pp. 653.

Ernst, R.E. and Bell, K. (2010). Large Igneous Provinces (LIPs) and carbonatites. Mineralogy and Petrology, 98: 55-76.

Ernst, R.E. and Bleeker, W. (2010). Large igneous provinces (LIPs), giant dyke swarms, and mantle plumes: significance for breakup events within Canada and adjacent regions from $2.5 \mathrm{Ga}$ to present: Canadian Journal of Earth Sciences, v. 47, p. 695-739, doi: 10.1139/E10-025.

Ernst, R.E. and Buchan, K.L. (2003). Recognizing mantle plumes in the geological record. Annual Reviews Earth and Planetary Science, 31: 469523. 
Ernst, R.E. and Buchan, K.L. and Campbell, I.H. (2005). Frontiers in large igneous province research. Lithos, 79: 271-297.

Ernst, R.E., and Jowitt, S.M. (2013). Large Igneous Provinces (LIPs) and metallogeny, in Tectonics, metallogeny, and discovery: The North American Cordillera and similar accretionary settings edited by $M$. Colpron, T. Bissig, B.G. Rusk and J.F.H. Thompson: Society of Economic Geologists Special Publication 17, p. 17-51.

Ernst, R.E., Hamilton, M.A., Söderlund, U., Hanes, J.A., Gladkochub, D.P., Okrugin, A.V., Kolotilina, T., Mekhonoshin, A.S., Bleeker, W., LeCheminant, A.N., Buchan, K.L., Chamberlain, K.R., \& Didenko , A.N. (2016). Long-lived connection between southern Siberia and northern Laurentia in the Proterozoic. Nature Geoscience (in press), doi: 10.1038/ NGEO2700.

Ernst, R.E., Srivastava, R.K. (2008). India's place in the Proterozoic world: constraints from the large igneous provinces (LIP) record. In: R.K. Srivastava, Ch. Sivaji, and N.V. Chalapathi Rao (eds.) Indian Dykes: Geochemistry, Geophysics, and Geochronology, Narosa Publishing House Pvt. Ltd, New Delhi, India, pp. 41-56.

Ernst, R.E., Youbi, N. (2017). How Large Igneous Provinces affect global climate, sometimes cause mass extinctions, and represent natural markers in the geological record. Palaeogeography, Palaeoclimatology, Palaeoecology v. 478 , p. $30-52$. 
Ewart, A., Marsh, J.S., Milner, S.C., Duncan, A.R., Kamber, B.S. and Armstrong, R.A. (2004). Petrology and Geochemistry of Early Cretaceous Bimodal Continental Flood Volcanism of the NW Etendeka, Namibia. Part 1: Introduction, Mafic Lavas and Re-evaluation of Mantle Source Components. J Petrology, 45 (1): 59-105. doi: 10.1093/petrology/egg083

Ewart, A., Milner, S.C., Armstrong, R.A, and Duncan, A.R. (1998). Etendeka volcanism of the Goboboseb Mountains and Messum Igneous Complex, Namibia. Part I: geochemical evidence of Early Cretaceous Tristan plume melts and the role of crustal contamination in the Paraná-Etendeka CFB. Journal of Petrology, 39: 191-225.

Fralick, P.W., Davis, D.W., Kissin, S.A. (2002). The age of the Gunflint Formation, Ontario, Canada: single U-Pb age determinations from reworked volcanic ash, Canadian Journal of Earth Science, 39, pp. 1085-1091.

French, J.E. , Heaman, L.M. , Chacko, T. , \& Srivastava, R.K. (2008). 1891-1883 Ma Southern Bastar-Cuddapah mafic igneous events, India: a newly recognized large igneous province. Precambrian Research, 160: 308-322.

Gladkochub, D.P, Pisarevsky, S.A, Donskaya, T.V, et al. (2010). Proterozoic mafic magmatism in Siberian craton: an overview and implications for paleocontinental reconstruction. Precambrian Research, 183: 660-668.

Godel B., Barnes, S.-J. and Wolfgang M.D. (2011). Parental magma composition inferred from trace element in cumulus and intercumulus silicate minerals : 
an example from the Lower and Lower Critical Zones of the Bushveld Complex, South-Africa. Lithos, 125, (1-2), p. 537-552.

Greene, A.R., Scoates, J.S., Weis, D., Nixon, G.T. and Kieffer , B. (2009). Melting history and magmatic evolution of basalts and picrites from the accreted Wrangellia oceanic plateau, Vancouver Island, Canada. Journal of Petrology 50: 467-505.

Hanson, R.E., Crowley, J.L., Bowring, S.A., et al. (2004a). Coeval large-scale magmatism in the Kalahari and Laurentian cratons during Rodinia assembly. Science, 304: 1126-1129.

Hanson, R.E., Crowley, J.L. , Bowring, S.A., et al. (2004b). Coeval large-scale magmatism in the Kalahari and Laurentian cratons during Rodinia assembly. Science, 304: 1126-1129.

Herzberg, C. and Gazel, E. (2009). Petrological evidence for secular cooling in mantle plumes.Nature Publishing Group 619-622.

Higgins, M.D., and Chandrasekharam, D. (2007). Nature of sub-volcanic magma chambers, Deccan province, India: Evidence from quantitative textural analysis of plagioclase megacrysts in the giant plagioclase basalts: Journal of Petrology, v. 48, p. 885-900, doi: 10 .1093/petrology /egm005 .

Hole, M.J. and Saunders, A.D. (1996). The generation of small melt-fractions in truncated melt columns: constraints from magmas erupted above slab windows and implications from MORB genesis: Mineralogical Magazine, v. 60 , p. $173-189$. 
Hulbert, L.J., Kyser, K., Carlson, R., Lesher, C.M., Joudrie, C. (1994). The Winnipegosis Komatiites; a New Komatiite Belt, Central Manitoba. Minerals Colloquium Program with Abstracts Geological Survey of Canada, Ottawa.

Huppert H. E. and Sparks R. S. J. (1985a) Cooling and contamination of mafic and ultramafic magmas during ascent through continental crust. Earth Planetary Science Letters 74, 371-386.

Ito, G. and Mahoney, J.J. (2005). Flow and melting of a heterogeneous mantle: 1. Method and importance to the geochemistry of ocean island and mid ocean ridge basalts. Earth and Planetary Science Letters 230, pp. 29-46.

Jourdan, F., Bertrand, H., Sharer, U., Blitchert-Toft, J., Féraud, G., and Kampunzu, A.B. (2007). Major-trace element and $\mathrm{Sr}-\mathrm{Nd}-\mathrm{Hf}-\mathrm{Pb}$ isotope compositions of the Karoo large igneous province in BotswanaZimbabwe. Journal of Petrology, 48: 1043-1077.

Keays, R.R. (1995). The role of komatiitic and picritic magmatism and Ssaturation in the formation of ore deposits. Lithos, 34: 1-18.

Le Bas, M.J. (2000). IUGS Reclassification of the high-Mg and picritic volcanic rocks: Journal of Petrology, v. 41, p. 1467-1470.

Liikane, D.A., St-Onge, M.R., Kjarsgaard, B.A., Rayner, N.M., Ernst, R.E. and Kastek, N. (2015). Frobisher suite mafic, ultramafic and layered maficultramafic sills, southern Baffin Island, Nunavut; in Summary of Activities 2015, Canada-Nunavut Geoscience Office, p. 21-32.

Maier, W., Rasmussen, B., Fletcher, I., Godel, B., Barnes, S.J., Fisher, L., and 
Yang, S. (2015). Petrogenesis of the $\sim 2.77$ Ga Monts de Cristal complex, Gabon: Evidence for direct precipitation of Pt-arsenides from basaltic magma. Journal of Petrology, 56, 1285-1308.

Marsh, B. (2004). A magmatic mush column Rosetta Stone: the McMurdo dry valleys of Antarctica. EOS Transactions, American Geophysical Union 85:497-508.

Martin, H., Smithies, R.H., Rapp, R., Moyen, J.-F. and Campion, D. (2005). An overview of adakite, tonalite-trondhjemite-granodiorite (TTG), and sanukitoid: Relationships and some implications for crustal evolution: Lithos, v. 79, p. 1-24, doi: 10.1016/j.lithos.2004.04.048.

Marzoli, A., Renne, P.R., Piccirillo, E.M., Ernesto, M., Bellieni, G., De Minet, A. (1999). Extensive 200-million-year-old continental flood basalts of the Central Atlantic Magmatic Province. Science, 284: 616-618.

Menand, T. (2008). The mechanics and dynamics of sills in layered elastic rocks and their implications for the growth of laccoliths and other igneous complexes. Earth Planetary Science Letters 267, 93-99. doi: 10.1016/ j.epsl.2007.11.043.

McDonough, W.F. and Sun, S.-S. (1995). Composition of the Earth. Chemical Geology 120: 223-253. doi: 10.1016/0009-2541(94)00140-4.

Miller, J.D., Jr., Green, J.C., Severson, M.J., Chandler, V.W., Hauck, S.A., Peterson, D.M., and Wahl, T.E. (2002). Geology and mineral potential of the Duluth Complex and related rocks of northeastern Minnesota: Minnesota Geological Survey Report of Investigations 58, 207 p. 
Minifie, M.J., Kerr, A.C., Ernst, R.E., et al. (2013). The northern and southern sections of the western ca. 1880 Ma Circum-Superior Large Igneous Province, North America: the Pickle Crow dyke connection? Lithos, 174: 217-235.

Mungall J. E. (2007). Crustal contamination of picritic magmas during transport through dikes: the Expo Intrusive Suite, Cape Smith fold belt, New Quebec. Journal of Petrology 48, 1021-1039.

Mungall, J.E. (2016). U-Pb geochronology documents out-of-sequence emplacement of ultramafic layers in the Bushveld Igneous Complex of South Africa. Nature Communication 7:13385 doi:10.1038/ncomms13385. Mungall, J.E., Hanley, J.J., Arndt, N.T., and Debecdelievre, A. (2006). Evidence from meimechites and other low-degree mantle melts for redox controls on mantle-crust fractionation of platinum-group elements: Proceedings of the National Academy of Sciences of the United States of America, v. 103, p. $12,695-12,700$.

Mungall, J.E., Harvey, J.D, Balch S.J., Azar, B., Atkinson, J. and Hamilton, M.A. (2010). Eagle's Nest: 2010, A Magmatic Ni-Sulfide Deposit in the James Bay Lowlands, Ontario, Canada 2010 Society of Economic Geologists, Inc. Special Publication 15, pp. 539-557

Muraoka, H. (1997). Conceptual model for emplacement depth of magma chambers and genesis of hydrothermal systems. Proc. International Geological Congress Vol. 9, pp. 143-155. 
Naldrett, A.J. (2010). From the mantle to the bank: The life of a Ni-Cu-(PGE) sulfide deposit: South African Journal of Geology, v. 113, p. 1-32.

Neumann, E.-R., Svensen, H., Galerne, C.Y. and Planke, S., (2011). Multistage evolution of dolerites in the Karoo Large Igneous Province, Central South Africa. Journal of Petrology, 52: 959-984.

Niu, Y., Wilson, M., Humphreys, E.R., O'Hara, M. J. (2011). The origin of intraplate ocean island basalts (OIB): the lid effect and its geodynamic implications. Journal of Petrology, 52 (7-8): 1443-1468. doi:10.1093/ petrology/egr030.

Olsson, J.R., Klausen, M.B., Hamilton, M.A., Marz, N., Söderlund, U. \& Roberts, J.A., (2016). Baddeleyite U-Pb ages and geochemistry of the 1875-1835 Ma Black Hills Dyke Swarm across northeastern South Africa: part of a trans-Kalahari Craton back-arc setting? GFF. doi: $10.1080 / 11035897.2015 .1103781$

Pearce. J. A. (1996). A user's guide to basalt discrimination diagrams. in Wyman. D.A.. ed.. Trace element geochemistry of volcanic rocks: applications for massive sultide exploration: Geological Association of Canada. Short Course Notes. v. 12. p. 79- 113.

Peate, D.W. (1997). The Parana-Etendeka Province. In: Mahoney, J. J. \& Coffin, M. F. (eds) Large Igneous Provinces: Continental, Oceanic, and Planetary Flood Volcanism. Geophysical Monograph, American Geophysical Union 100, 247-272. 
Peng, P., 2014. Precambrian mafic dyke swarms in the North China Craton and their geological implications. Science China-Earth Sciences, Volume 58, Issue 5, pp. 649-675.

Peng, P., Zhai, M.-G., Zhang, H.-F., \& Guo, J.-H. (2005). Geochronological constraints on the Paleoproterozoic evolution of the North China craton: SHRIMP zircon ages of different types of mafic dykes. International Geology Review, 47: 492-508.

Puffer, J.H. (2001). Contrasting HFSE contents of plume sourced and reactivated arc-sourced continental flood basalts. Geology, 29: 675-678.

Randall, W. (2005). U-Pb geochronology of the Expo Igneous Suite, Cape Smith Belt, and the Kyak Bay intrusion, New Quebec Orogen: implications for the tectonic evolution of the northeastern Trans- Hudson Orogen MSc thesis University of Toronto, Toronto $51 \mathrm{pp}$.

Rehkämper, M., Halliday, A.N., Alt, J.C., Fitton, J.G., Zipfel, J., and Takazawa, E. (1999): Non-chondritic platinum-group element ratios in oceanic mantle lithosphere: petrogenetic signature of melt percolation? Earth and Planetary Science Letters, 172(1-2), 65-81, doi:10.1016/ S0012-821X(99)00193-4

Richards, M.A., Duncan, R.A., and Courtillot, V.E. (1989). Flood basalts and hotspot tracks - plume heads and tails. Science, 246: 103-107.

Robinson J.A., and Wood B.J. (1998). The depth of the spinel to garnet transition at the peridotite solidus. Earth and Planetary Science Letters 164: 277284. 
Sanborn-Barrie, M., St-Onge, M.R., Young, M.D., and James, D.T. (2008).

Bedrock geology of south-western Baffin Island, Nunavut: explanding the tectonostratigraphic framework with relevance to mineral resources; Geological Survey of Canada, Current Research 2008-6, 16p.

Saunders, A.D. (2005). Large igneous provinces: origin and environmental consequences. Elements, 1: 259-263.

Scott, D.J. (1997). Geology, U-Pb, and Pb-Pb geochronology of the Lake Harbour area, southern Baffin Island: implications for the Paleoproterozoic tectonic evolution of northeastern Laurentia. Canadian Journal of Earth Sciences, 34: 140-155.

Serrano, L., L. Ferrari, M. L. Martınez, C. M. Petrone, and C.Jaramillo (2011). An integrative geologic, geochronologicand geochemical study of Gorgona Island, Colombia: Implications for the formation of the Caribbean Large Igneous Province, Earth Planetary Science Letters, 309(3-4), 324-336, doi:10.1016/j.epsl.2011.07.011.

Sheth, H. (2016). Giant plagioclase basalts: continental flood basalt-induced remobilization of anorthositic mushes in a deep crustal sill complex. Geological Society of America Bulletin, v. 128, pp. 916-925.

Shirey, S.B. and Hanson, G.N. (1984). Mantle-derived Archean monzodiorites and trachyandesites. Nature, v310, pp. 222-224.

Snyder, D., Carmichael, I.S.E. and Wiebe, R.A. (1993). Experimental study of liquid evolution in an Fe-rich, layered mafic intrusion: constraints of $\mathrm{Fe}-\mathrm{Ti}$ 
oxide precipitation on the $\mathrm{T}-\mathrm{fO} 2$ and $\mathrm{T}-e$ paths of tholeitic magmas. Contributions to Mineralogy and Petrology (1993) 113: 73. doi:10.1007/ BF00320832

Sobolev, ,S.V., Sobolev, A.V., Kuzmin, D.R., Krivolutskaya, N.A., Petrunin, A.G., Arndt, N.T., Radko, V.A. \& Vasiliev, Y.R. (2011). Linking mantle plumes, large igneous provinces and environmental catastrophes. Nature, 477: 312-316.

Söderlund, U., Hofmann, A., Klausen, M.B, et al. (2010). Towards a complete magmatic barcode for the Zimbabwe craton: baddeleyite $\mathrm{U}-\mathrm{Pb}$ dating of regional dolerite dyke swarms and sill provinces. Precambrian Research, 183: 388-398.

St-Onge, M.R., Lucas, S.B., Scott, D.J., and Bégin, N.J. (1987). Tectonostratigraphy and structure of the lac Watts-lac Cross-rivière, Déception area, central Cape Smith Belt, northern Quebec; in Current Research, Part A; Geological Survey of Canada, Paper 87-1A, p. 619-632.

Svensen, H., Corfu, F., Polteau, S., Hammer, Ø., Planke, S., 2012. Rapid magma emplacement in the Karoo Large Igneous Province. Earth Planet. Sci. Lett. 325-326, 1-9. http://dx.doi.org/10.1016/j.epsl.2012.01.015

Sun, S.S. and McDonough, W.F. (1989). Chemical and isotopic systematics of oceanic basalts; implications for mantle composition and processes. In: Magmatism in the ocean basins. Saunders, A.D. and Norry, M.J. (Editors), Geological Society of London, London. 42: 313-345. 
Thériault R.J., St-Onge M.R., Scott D.J. (2001). Nd isotopic and geochemical signature of the Paleoproterozoic Trans-Hudson Orogen, southern Baffin Island, Canada: implications for the evolution of eastern Laurentia. Precambrian Research, 108: 113-138.

Thibert, F., Picard, C., and Trzciencki, W. (1989). Pétrologie des filons-couches differenciés Roméo 1 et 2 dans la partie centrale de la bande du Cap Smith; Geoscience Canada, v.16, p. 140-144.

Thompson, R.N., Morrison, M.A., Dickin, A.P. and Hendry, G.L. (1983). Continental flood basalts... arachnids rule OK? In Continental basalts and mantle xenoliths, C.J. Hawkesworth \& M.J. Norry (eds), Cheshire, U.K., Shiva Publishing Limited, p. 158-185.

Whitmarsh, R.B., Sawyer, D.S., Klaus, A., and Masson, D.G. (Eds.) (1996). Proceedings of the Ocean Drilling Program, Scientific Results, Vol. 149, pp. 506.

Winter, J.D. (2001). An Introduction to Igneous and Metamorphic Petrology: Prentice Hall, Upper Saddle River, New Jersey, 697p.

Wodicka, N., Madore, L., Larbi, Y., Vicker, P. (2002). Géochronologie U-Pb de filons-couches mafiques de la Ceinture de Cape Smith et de la Fosse du Labrador. In: L'exploration minérale au Québec: notre savoir, vos découvertes. Séminaire d'information sur la recherche géologique. Programme et résumés 2002-10. Ministère des Ressources Naturelles, Québec. 48pp. 
Wodicka, N., Whalen, J. B., St-Onge, M. R., and Corrigan, D. (2010). Meta Incognita microcontinent revisited: insights from U-Pb geochronology and $\mathrm{Nd}$ isotopes. In Geological Association of Canada-Mineralogical Association of Canada, Abstract (Vol. 35).

Workman, R.K. and Hart, S.R. (2005). Major and trace element composition of the depleted MORB mantle (DMM). Earth and Planetary Science Letters 231: 53-72. doi: 10.1016/j.epsl.2004.12.005.

Xu, Y., Chung, S.L., Jahn, B.-M., Wu, G. (2001). Petrologic and geochemical constraints on the petrogenesis of Permian-Triassic Emeishan flood basalts in southwestern China Lithos, 58, pp. 145-168

Xu, Y.-G., He, B., Chung, S.-L., Menzies, M.A., and Frey, F.A. (2004). Geologic, geochemical, and geophysical consequences of plume involvement in the Emeishan flood-basalt province. Geology, 32: 917-920.

Yale, L.B. and Carpenter, S.J. (1998). Large igneous provinces and giant dike swarms: proxies for supercontinent cyclicity and mantle convection. Earth and Planetary Science Letters, 163: 109-122.

Zhou, M.-F., Arndt, N.T., Malpas, J., Wang, C.Y., Kennedy, A.K. (2008). Two magma series and associated ore deposit types in the Permian Emeishan Large Igneous Province, SW China Lithos, 103, pp. 352-368. 
Figure 8.1: Chondrite-normalized REE and primitive mantle-normalize trace element diagrams illustrating the geochemical similarity between Groups $\mathrm{C} 1$ and D, and A2 and B. Normalization values from Sun and McDonough (1989). 

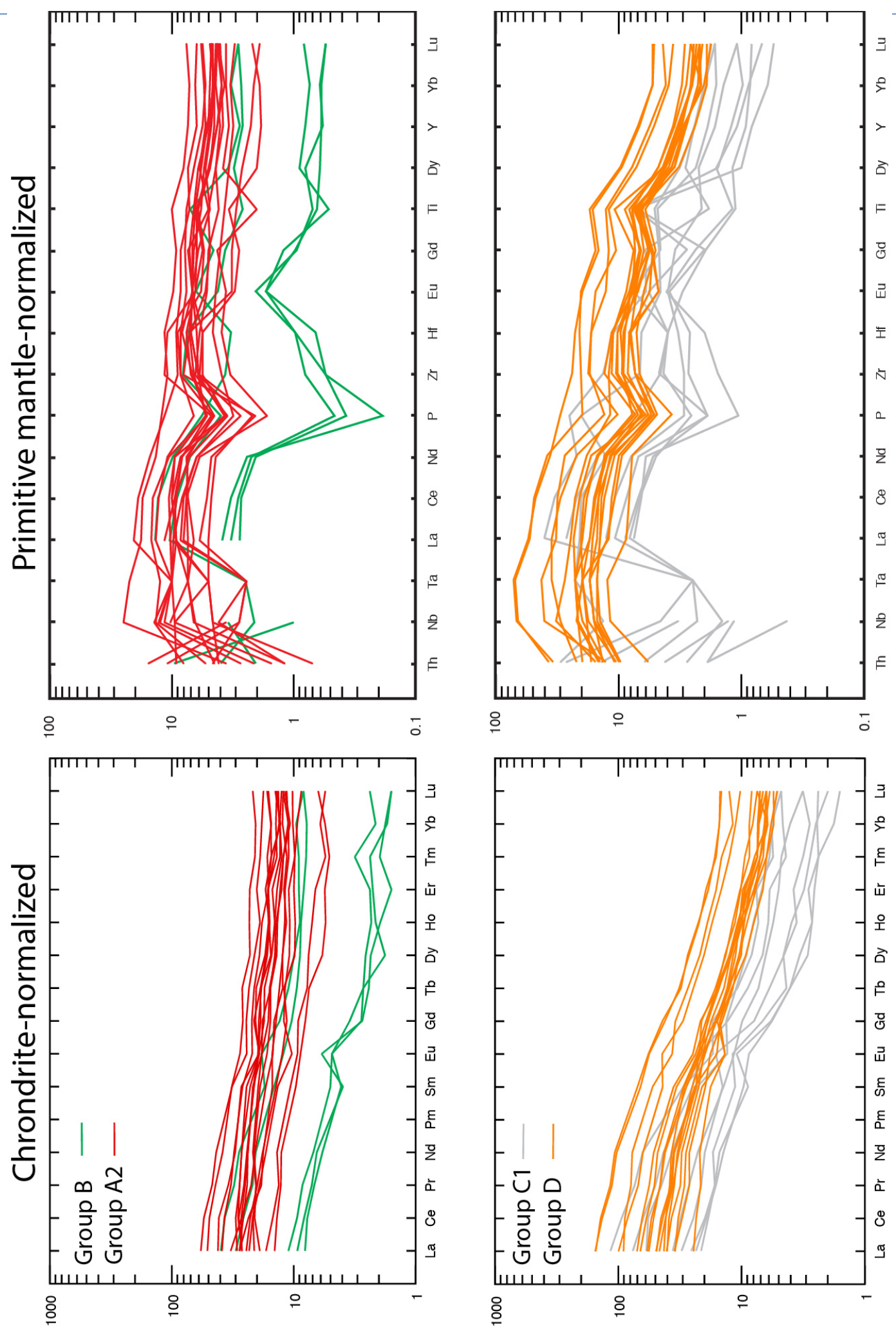
Figure 8.2a-b: a) Gabbro (14SAB-L015A01) with apparent finer-grained gabbroic xenoliths, from the Killapait sill, Meta Incognita Peninsula; b) Plagioclase megacrysts within the ultramafic portion of the Killapait sill. 


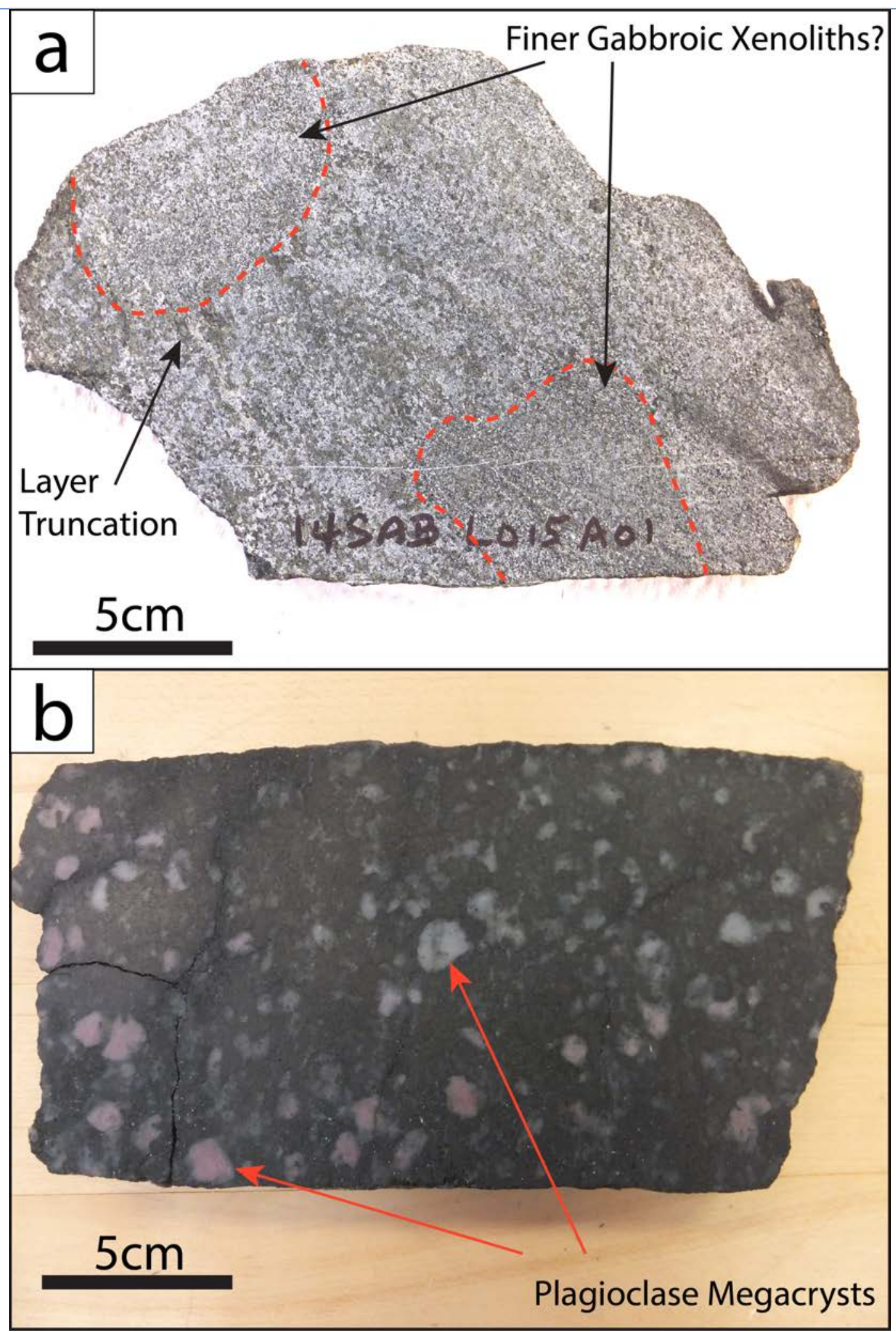




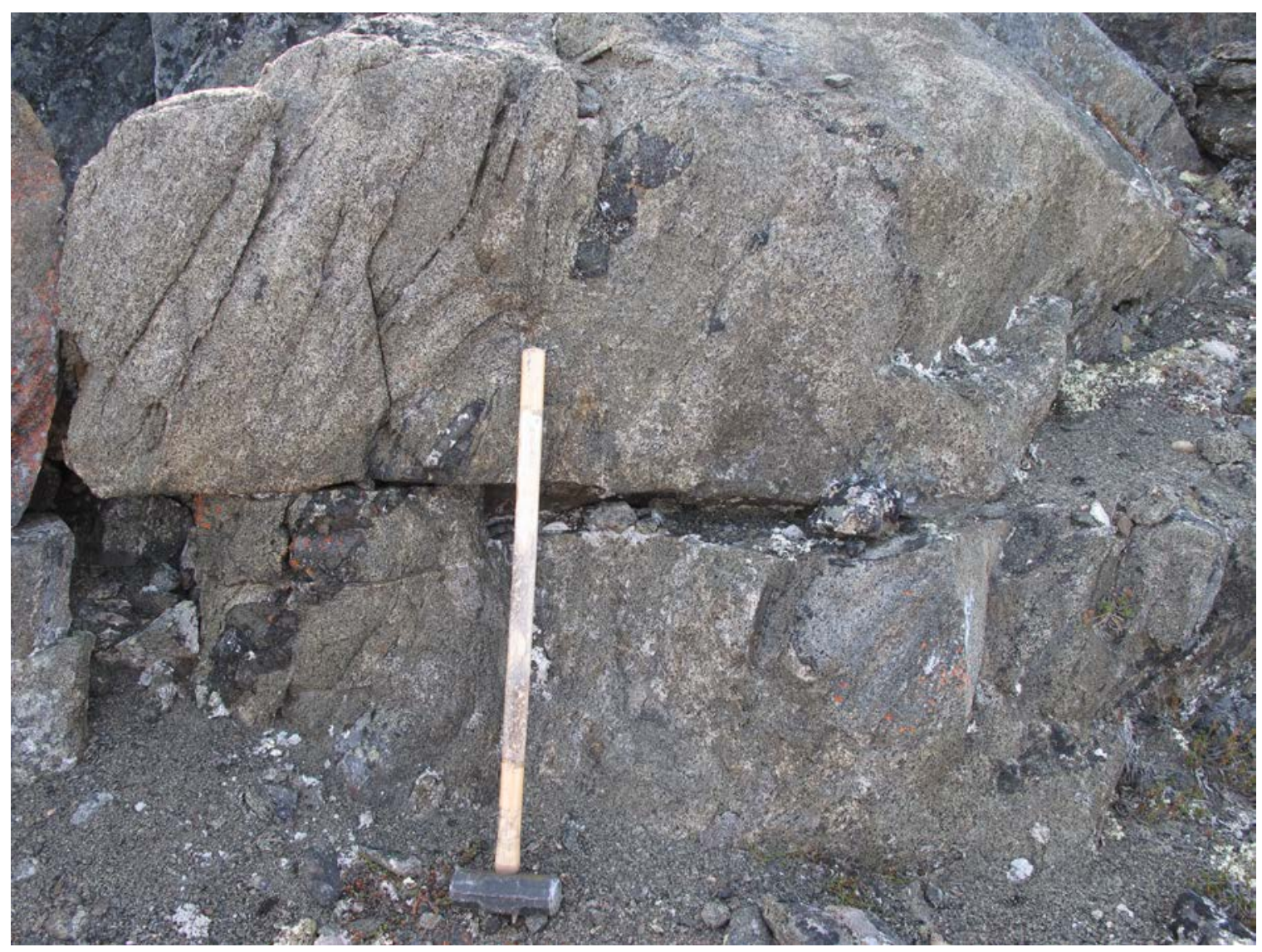

Figure 8.3: Pods of Fe-oxide within the gabbroic portion of the Killapait sill. Photo was taken at station 14SAB-L015 (Lat: 62.280; Long: -68.068). 
Figure 8.4: Model \#1 for the formation of the Killapait sill of Meta Incognita Peninsula, southern Baffin Island. Stages 1-5 are described within illustration and text. The distinction between solidified and non-solidified portions of the sills are not distinguished in this diagram. 

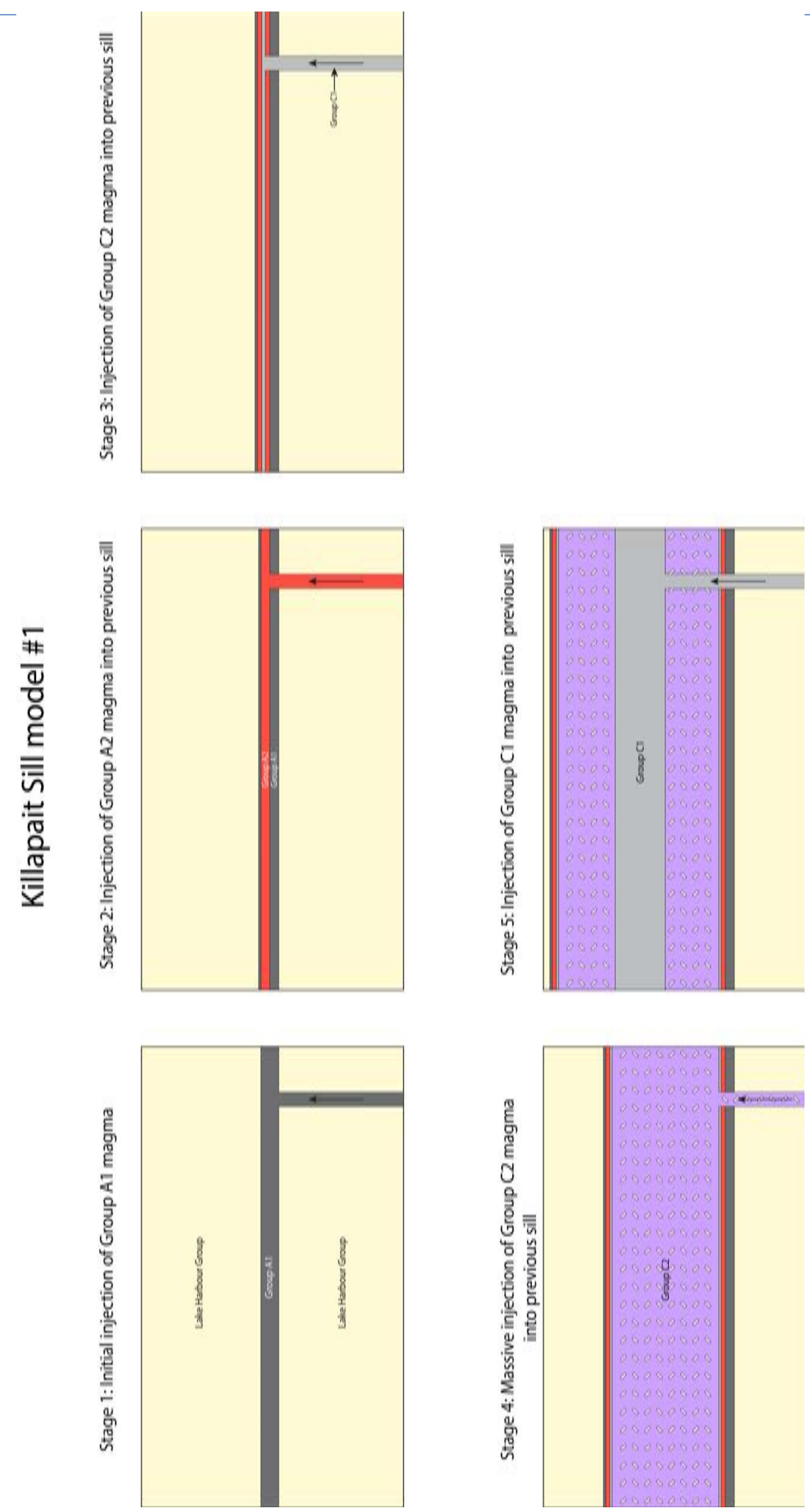
Figure 8.5: Model \#2 for the formation of the Killapait sill of Meta Incognita Peninsula, southern Baffin Island. Stages 1-6 are described within illustration and text. The distinction between solidified and non-solidified portions of the sills are not distinguished in this diagram. 

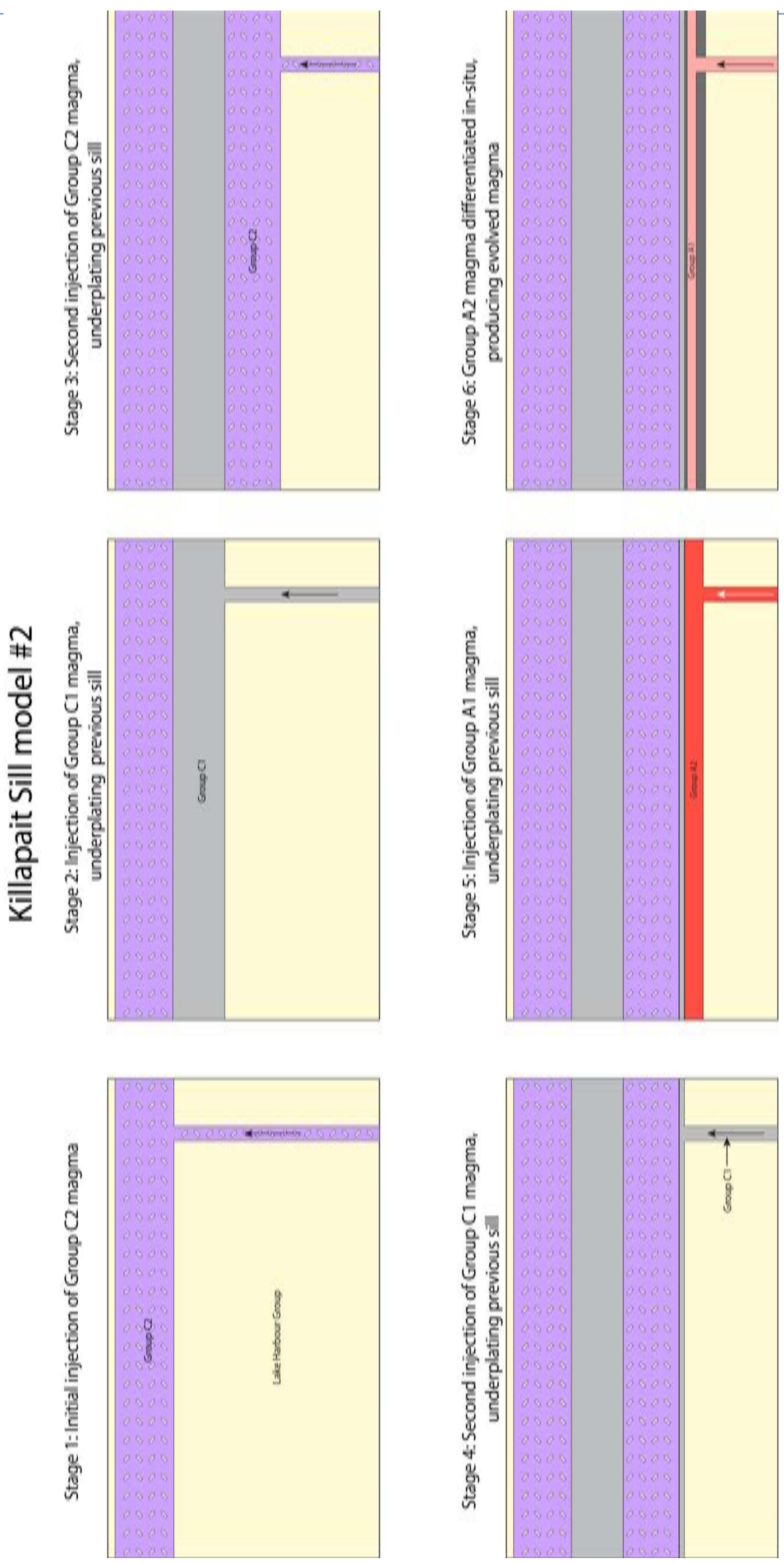


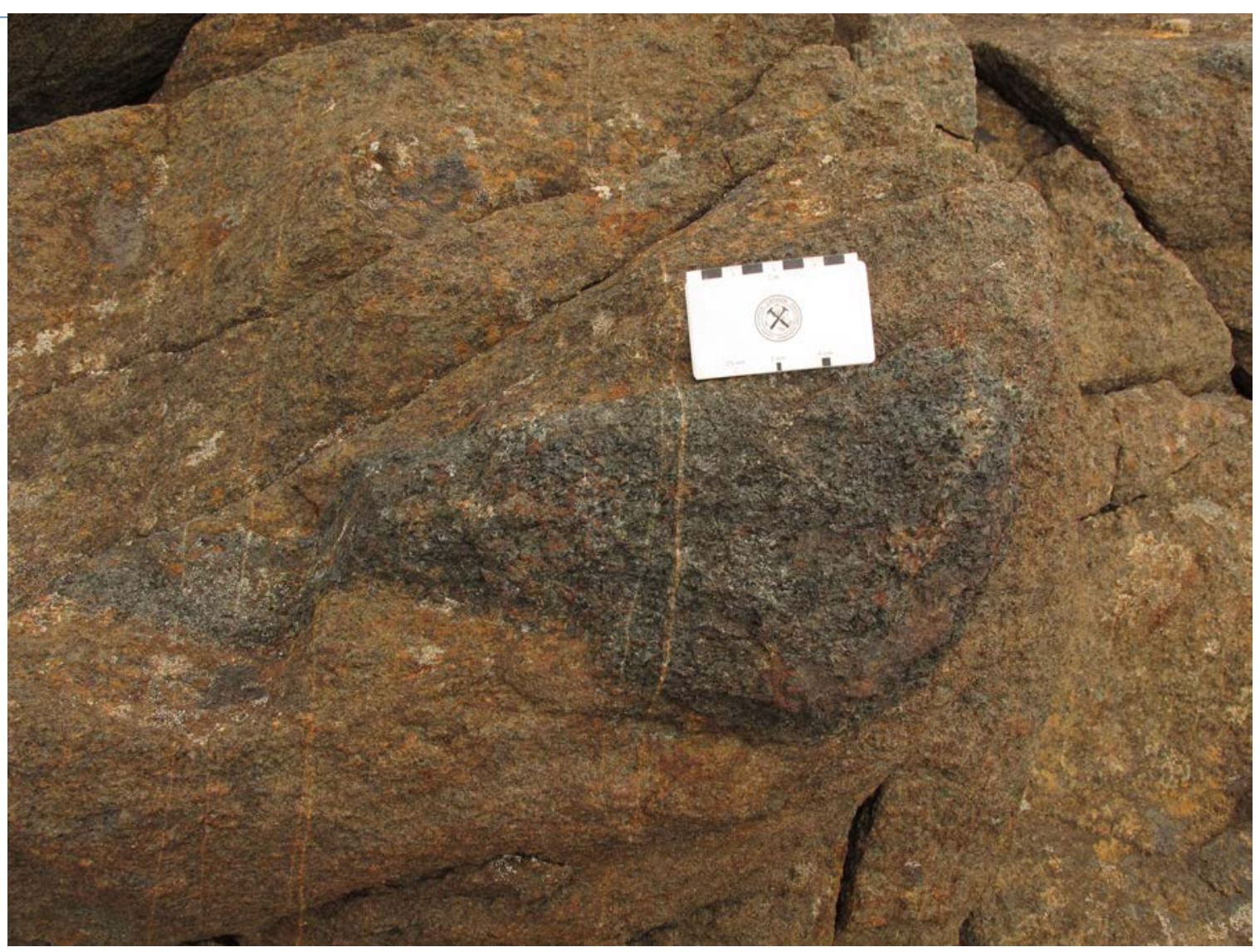

Figure 8.6: Metapyroxenitic xenolith within stratigraphically overlying metaperidotitic unit of the Chidliak sill. Photo was taken at station 15SAB-L077 (Lat: 64.562; Long: -66.916). 
Figure 8.7: Model \#1 for the formation of the Chidliak sill of northern Hall Peninsula, southern Baffin Island. Stages 1-4 are described within illustration and text. 

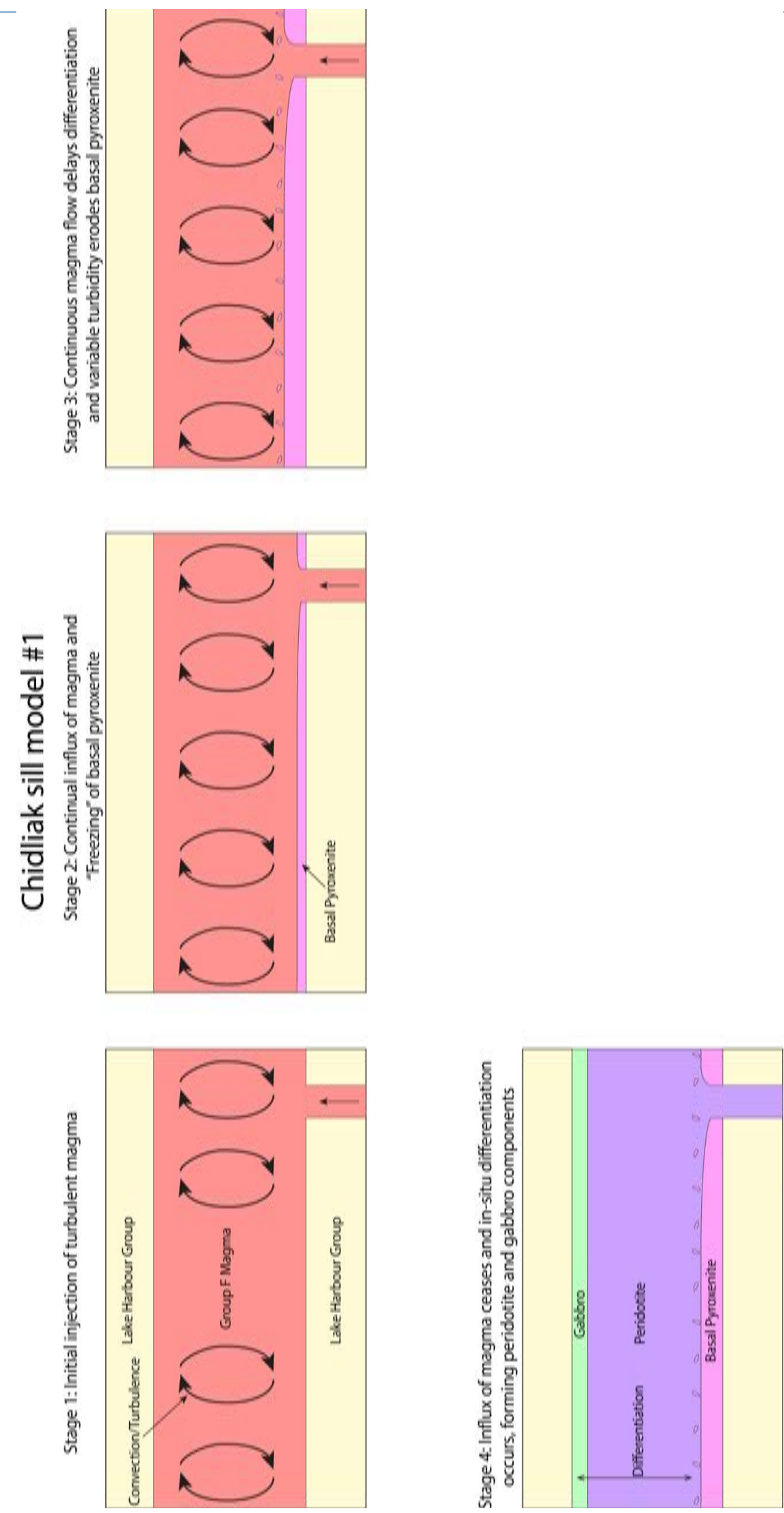
Figure 8.8: Model \#2 for the formation of the Chidliak sill of northern Hall Peninsula, southern Baffin Island. Stages 1-4 are described within illustration and text. 

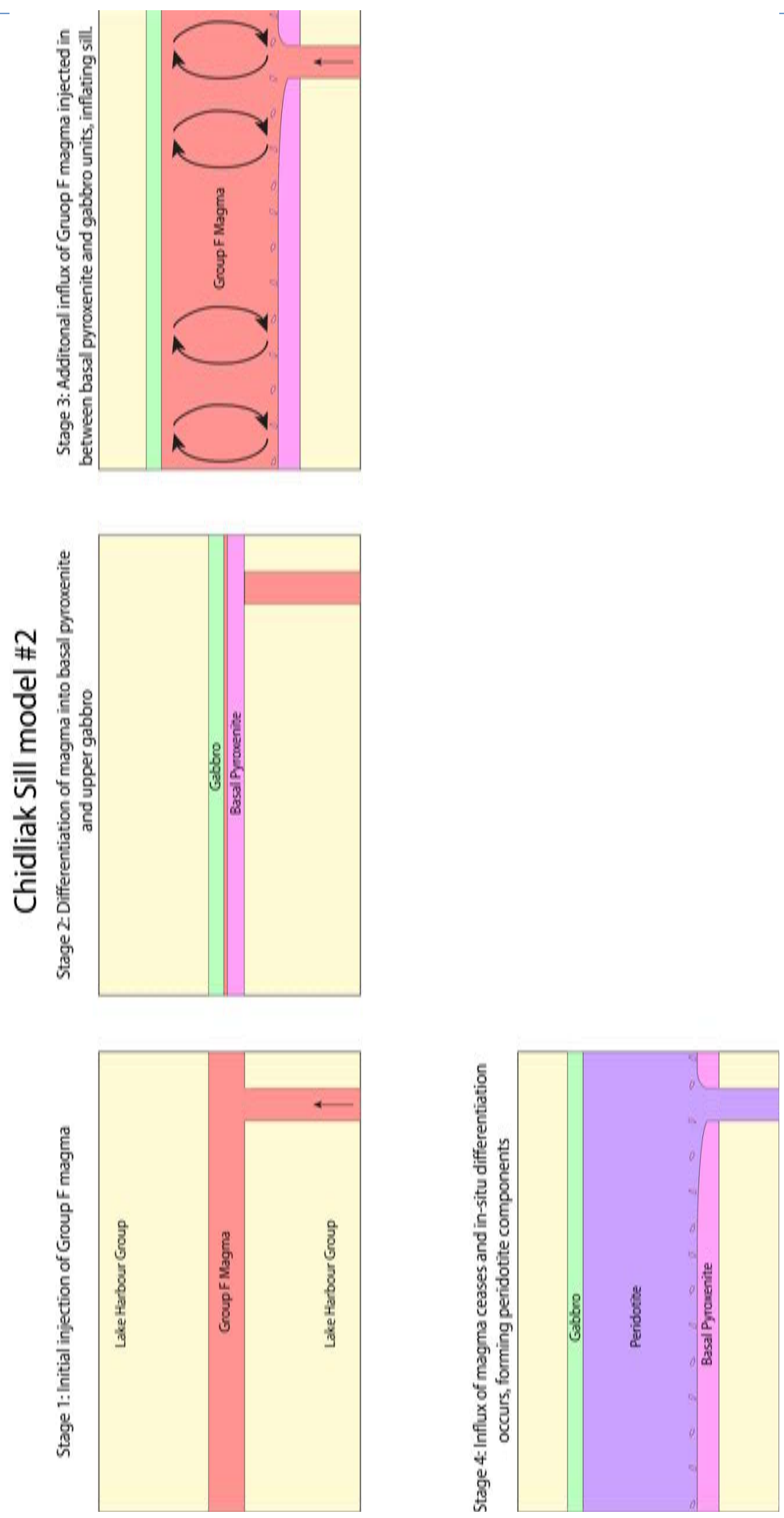
Figure 8.9: Global map showing the schematic distribution of LIPs which occurred between 1845 and 1934 Ma. Modified from Ernst (2014). See Table 8.1 for more information on each LIP. Map is configured in the Robinson projection. 


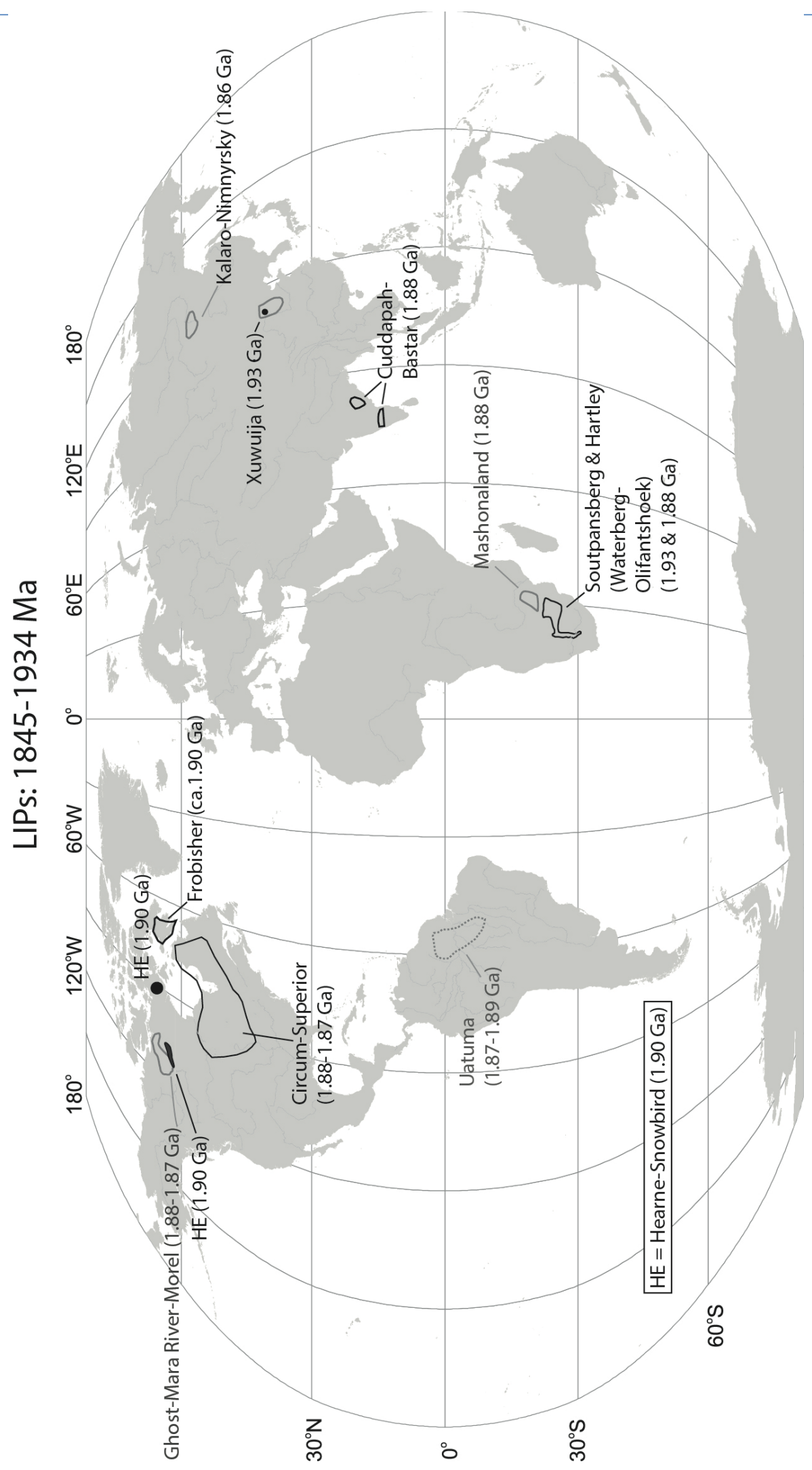


Figure 8.10: Comparison of select Frobisher suite magma types with select geochemical groups from the Circum-Superior LIP. 


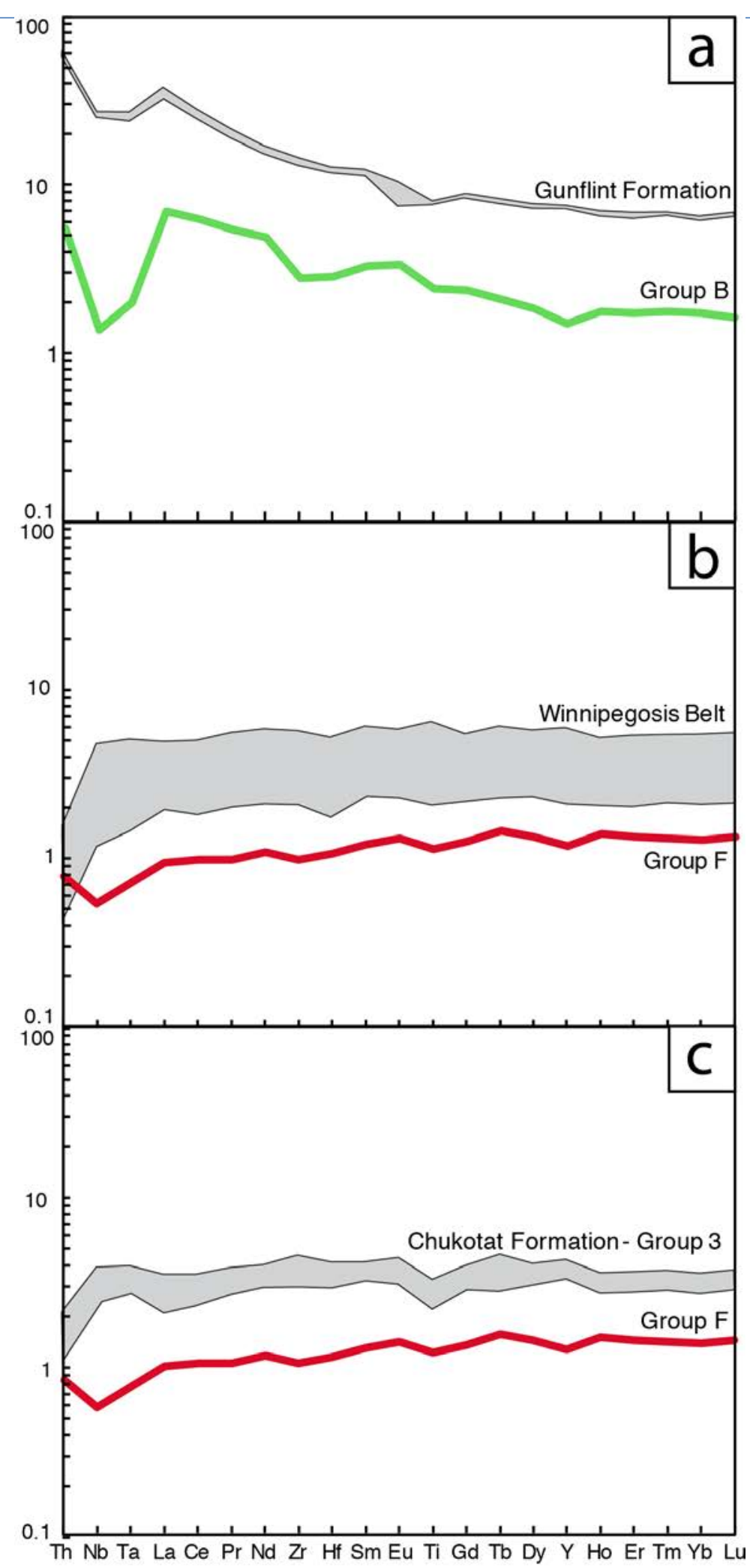


Figure 8.11: Map-view of the relative positioning of the main lithotectonic elements in the north-eastern segment of the Trans-Hudson orogen (THO) at ca. 1900 Ma. Possible Moho-level extensions of the Superior craton are traced by the blue coloured hashed lines. Abbreviations: Am, Amer group; B, Burwell arc; Bf, Bravo formation; FFG, Flin Flon-Glennie Complex; GFtz, Great Falls tectonic zone; Ke, Ketyet group; LL, La Ronge-Lynn Lake belts; M.I., Meta Incognita micro-continent; Pe, Penrhyn group; Pi, Piling group; STZ, Snowbird Tectonic Zone; TA, Tasiuyak domain; TNB, Thompson Nickel Belt. Modified from Corrigan et al. (2009). 
ca. $1900 \mathrm{Ma}$

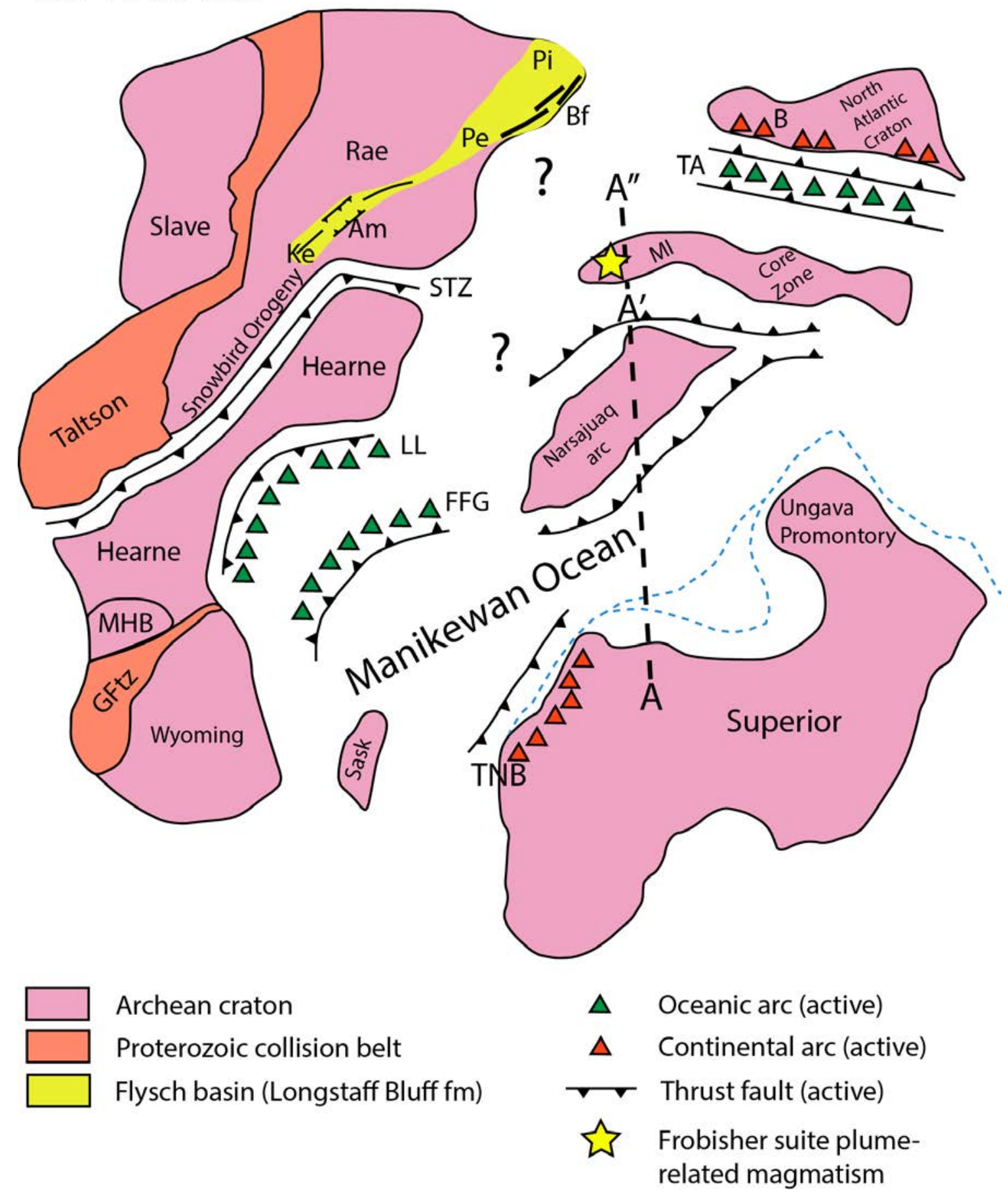


Figure 8.12: Cross-section of a transect from the Superior craton through to the Meta Incognita microcontinent. Not to scale. Based on Figure 9 from Thériault et al. (2001). 


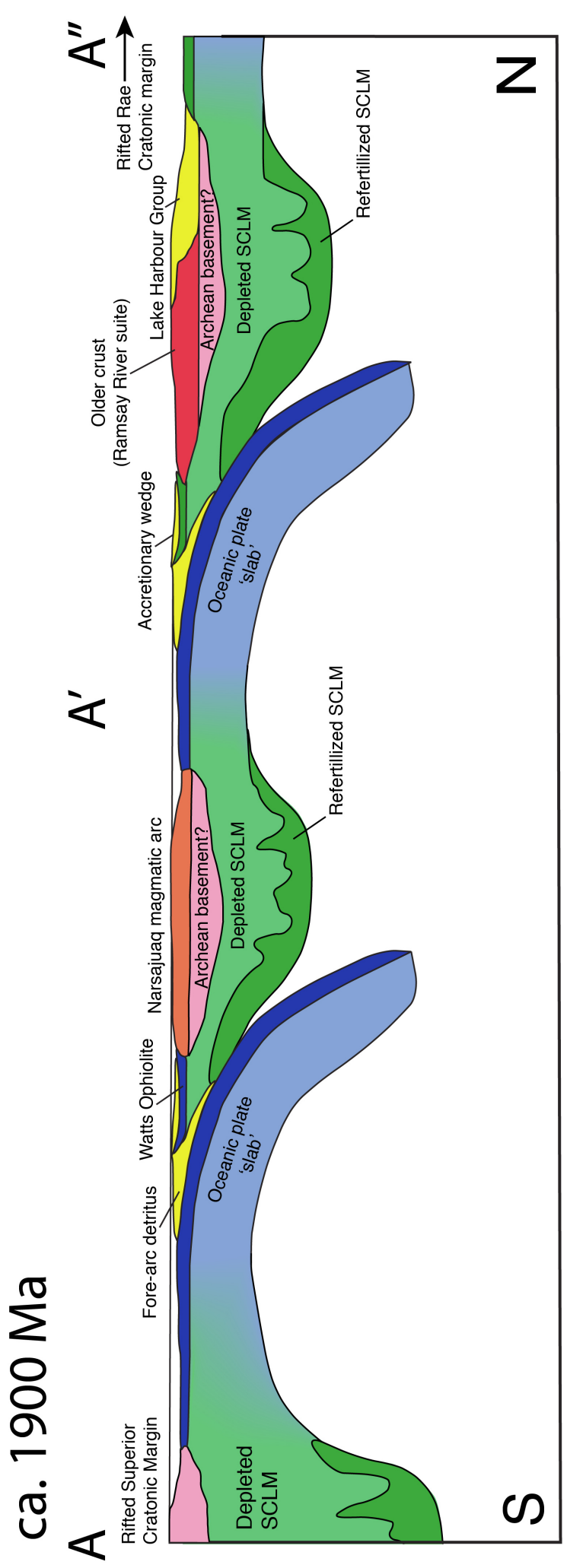


Figure 8.13: Model of Frobisher suite formation. At stage 1, the mantle plume is ascending towards the base of the subcontinental lithospheric mantle, below the Meta Incognita microcontinent. At stage 2, the mantle plume impinges upon the base of the lithosphere and flattens. At stage 3, low-degree partial melting occurs at the base of the lithosphere, generating high-Ti magmas (Group D), which ascend through the lithosphere directly to the Lake Harbour Group, without significant fractionation or contamination. The plume head then spreads to shallower depths where higher-degree melting occurs. At stage 4, low- $\mathrm{Ti}$ magmas are injected into the lithosphere and ascend to the base of the crust where extensive fractionation occurs, and are later emplaced as sills within the more distal sequence of the Lake Harbour Group. Thermal erosion of metasomatized SCLM produces Group C2 magmas. Mixing between Group C2 and Groups A2 and D produce Group B and C1 magmas. Based on Figure 9 from Thériault et al., (2001). 

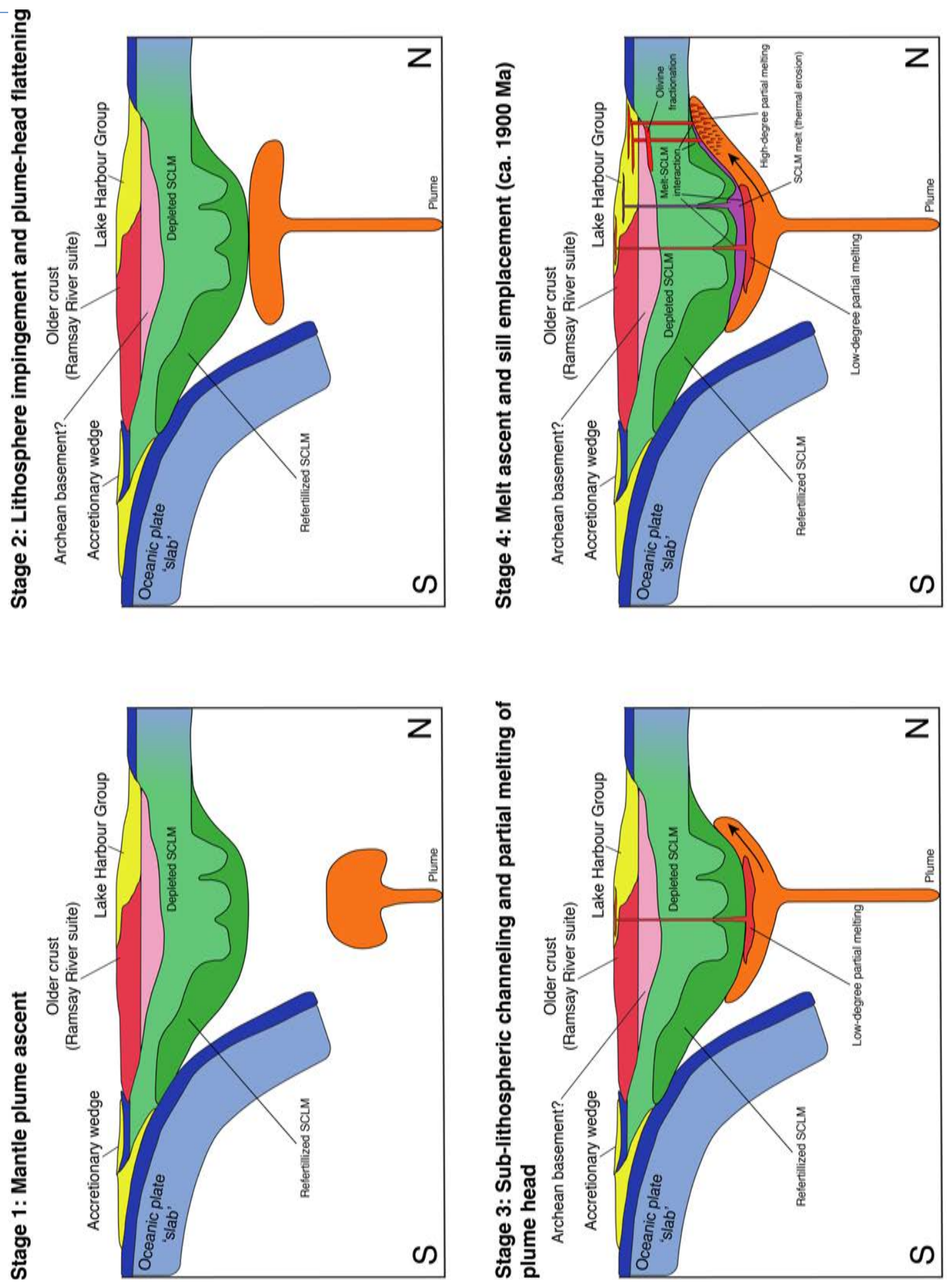
Figure 8.14a-c: Mineralized hand-samples from the gossan at station 14SABL009. Wet hand sample slab on left and close-up of it on right a) Mineralized ultramafic sample (14SAB-L009A02) containing Po+Cpy+Pn; b) Mineralized mafic sample (14SAB-L009B02) containing Po+Cpy; c) Mineralized metasedimentary host-rock sample (14SAB-L009B01) containing Po+Cpy. 


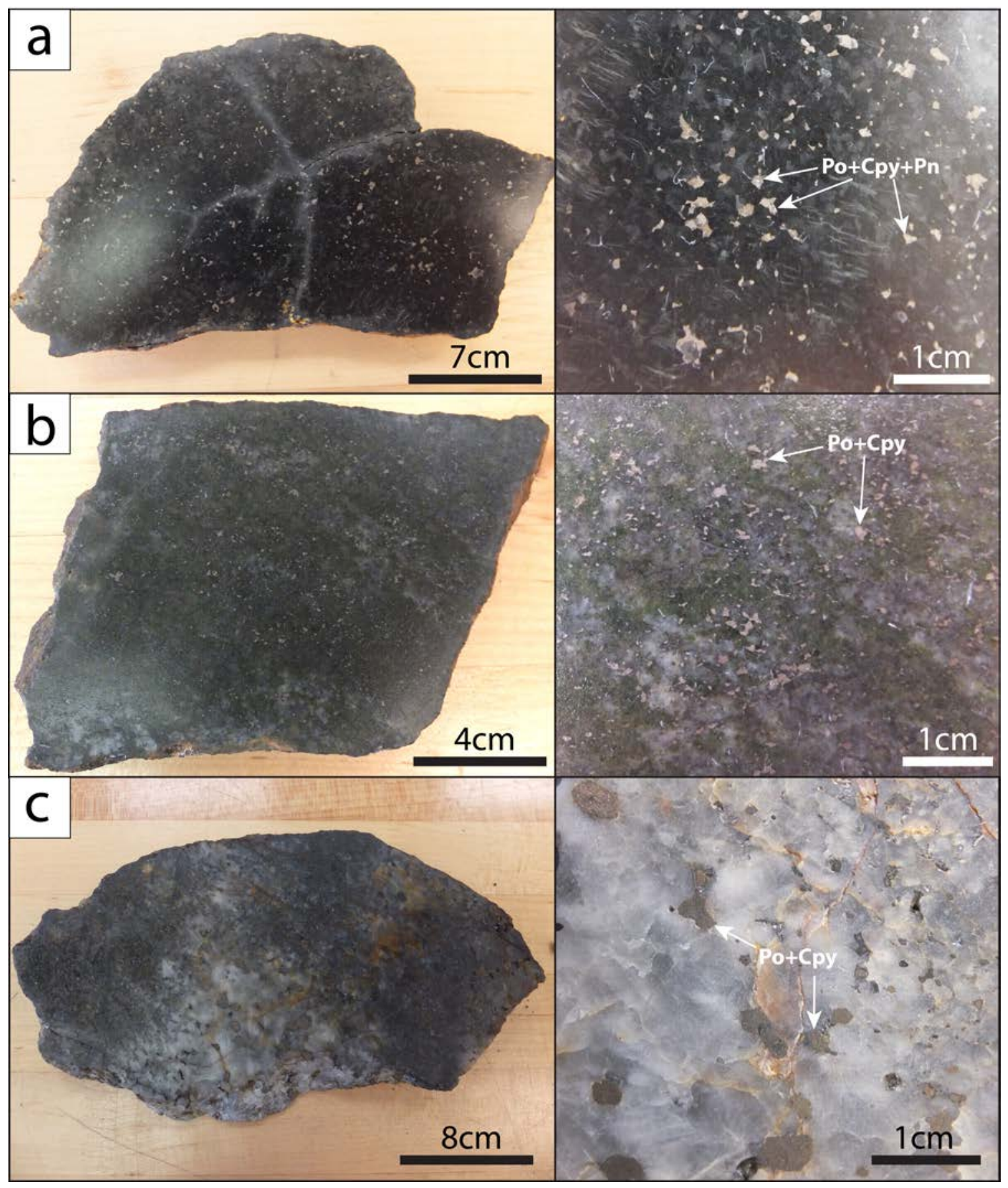



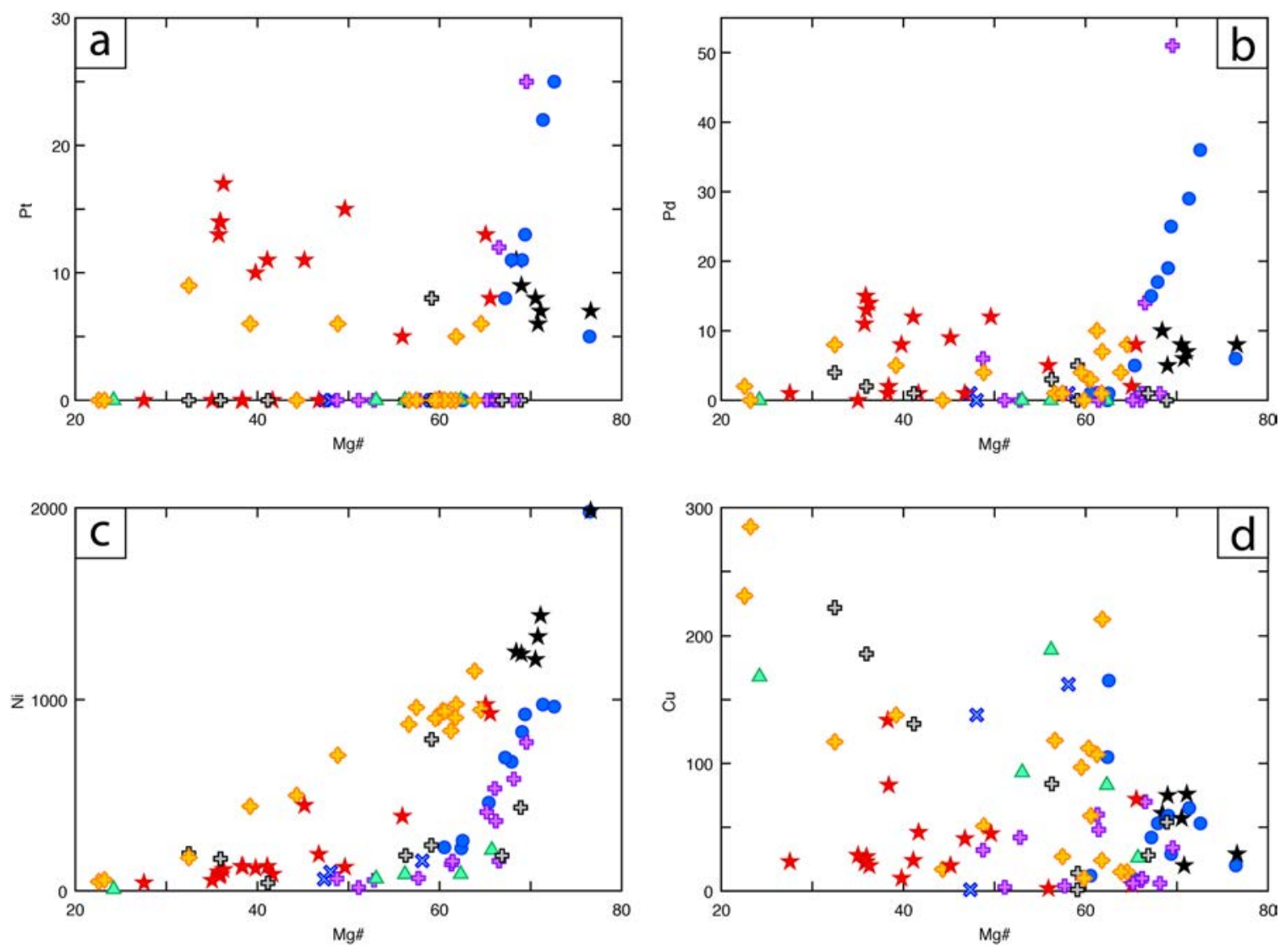

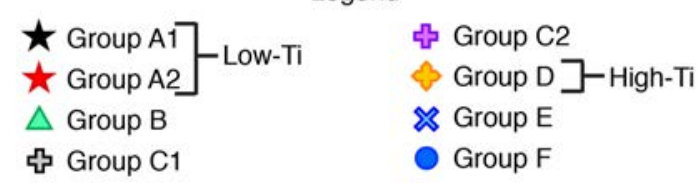

Figure 8.15: Chalcophile element variations within the Frobisher suite, showing

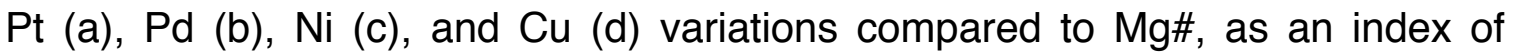
fractionation. $\mathrm{Cu}+\mathrm{Ni}$ values are in $\mathrm{ppm}$, and $\mathrm{Pt}+\mathrm{Pd}$ values are in $\mathrm{ppb}$. Samples with Pt or Pd concentrations below detection are plotted at zero. 


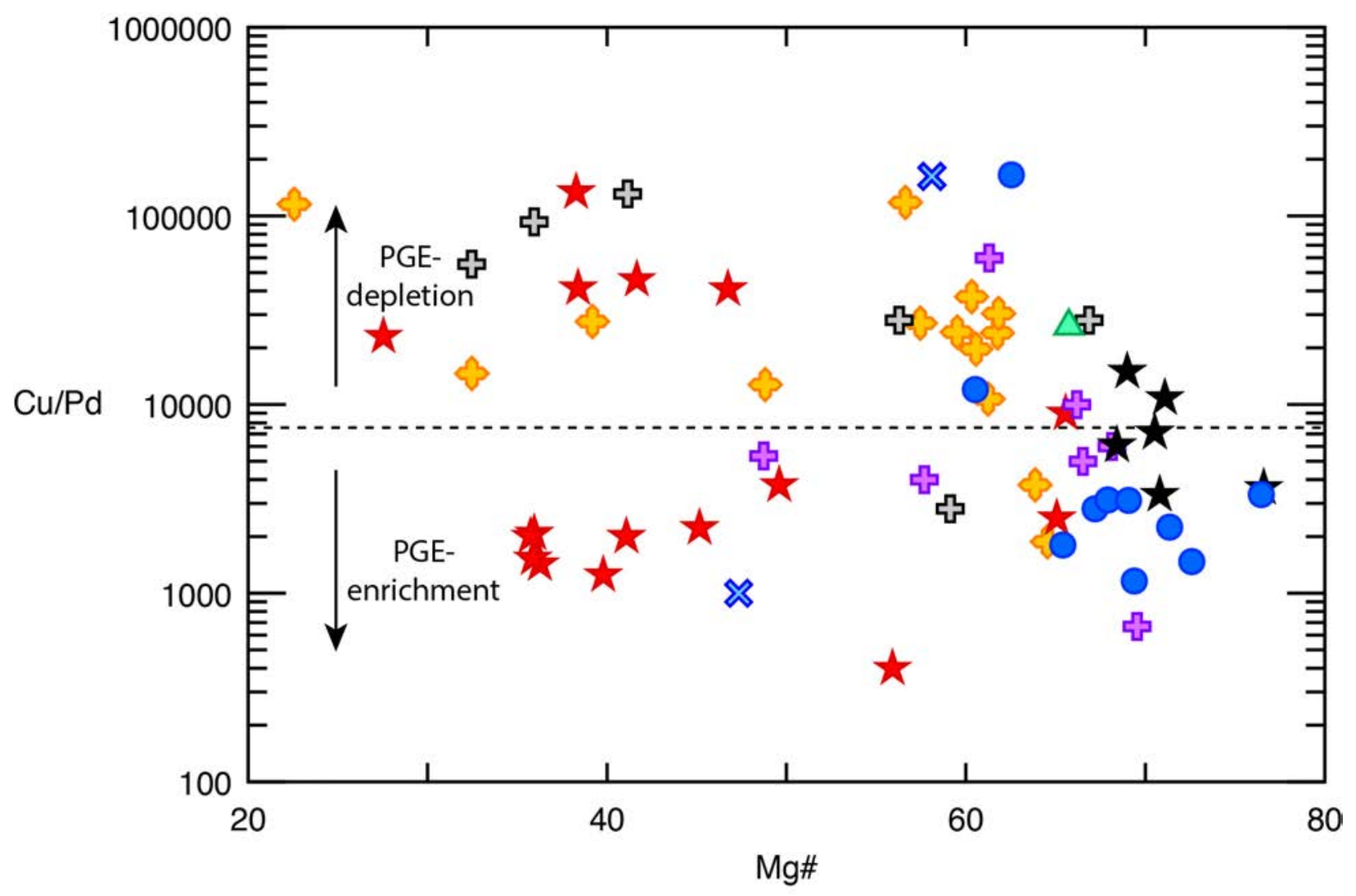

Figure 8.16: $\log (\mathrm{Cu} / \mathrm{Pd})$ versus Mg\# diagram illustrating PGE-enrichment and PGE-depletion in Frobisher suite samples. 
Table 8.1: Details of LIPs which occurred between 1845 - $1934 \mathrm{Ma}$.

\begin{tabular}{|c|c|c|c|c|c|}
\hline Age & LIP Name & Type & Location(s) & Area $\left(\mathrm{Mkm}^{2}\right.$ & Selected references \\
\hline $1.87-1.85$ & Kalaro-Nimnyrsky & & Siberia craton & $A=0.10$ & Gladkochub et al., 2010; Ernst et al. , 2016a \\
\hline 1.88 & Circum-Superior Pan Superior) & $\mathrm{C}$ & Superior craton & $A=0.60$ & Ernst and Bell, 2010; Minifie et al., 2013 \\
\hline 1.88 & River-Morel & $\mathrm{C}$ & Slave craton & $A=0.06$ & Buchan et al., 2010, 2016 \\
\hline 1.88 & Mashonaland & $\mathrm{C}$ & Zimbabwe craton & $A=0.16$ & Soderlund et al., 2010 \\
\hline $1.88-1.84$ & Soutpansberg-Black Hills & $\mathrm{C}$ & Kaapvaal craton & & Hanson et al., 2004b; Olsson et al., 2016 \\
\hline $1.89-1.87$ & Uatumã & $\mathrm{S}$ & Amazonian & $A=1.50$ & Klein et al., 2012 \\
\hline 1.89 & Cuddapah-Bastar & $\mathrm{C}$ & Bastar & $A=0.03$ & 2008; Belica et al., 2014 \\
\hline 1.90 & Hearne-Snowbird & $\mathrm{C}$ & cratons & & Ernst and Bleeker, 2010 \\
\hline 1.92 & Hartley (Waterberg-Olifantshoek) & $\mathrm{C}$ & Kaapvaal craton & & Hanson et al., 2004a \\
\hline 1.93 & Xuwujia & $\mathrm{C}$ & North China craton & $A=0.01$ & Peng et al., 2005; Peng, 2015 \\
\hline \multicolumn{6}{|c|}{ Type: $\mathrm{C}=$ continental, $\mathrm{O}=$ oceanic and $\mathrm{S}=$ silicic. } \\
\hline \multicolumn{3}{|c|}{ Area/Volume are minimum estimates and very approximate } & & & \\
\hline
\end{tabular}


Table 8.2: Comparison of geochemistry between Frobisher Suite and other major continental and oceanic LIPs. Values with ranges similar to that of the Frobisher Suite are in bold. 


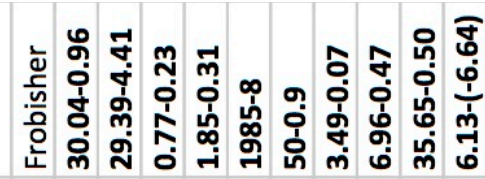

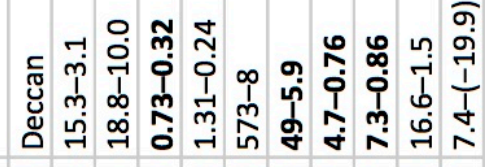

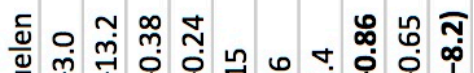
总

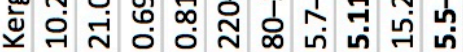
ग)

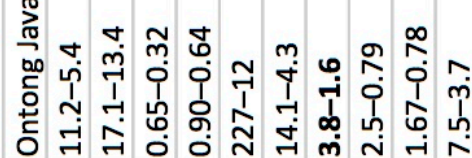

กูกู ॠ চ సं

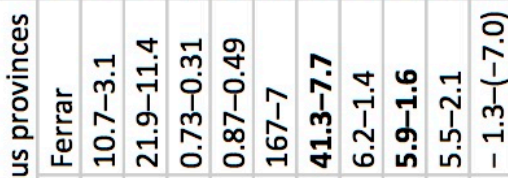

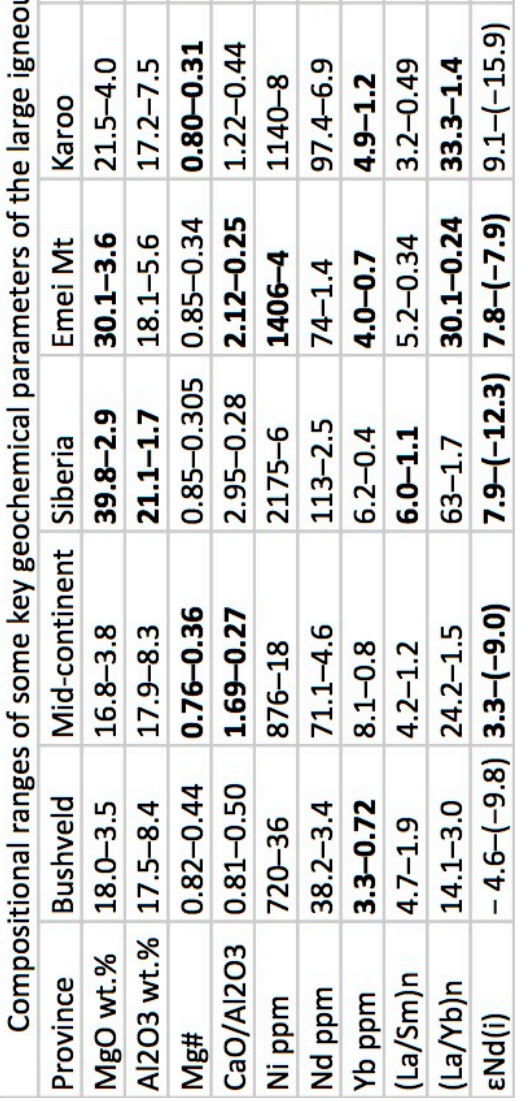




\section{Appendix A - Sample Coordinates}




\begin{tabular}{|c|c|c|c|c|c|}
\hline Sample ID & Latitude & Longitude & Sample ID & Latitude & Longitude \\
\hline 14SAB-H006A01 & 62.384508 & -67.867314 & 15SAB-D196A01 & 66.268850 & -67.817625 \\
\hline 14SAB-H080A01 & 62.747432 & -67.917699 & 15SAB-D196A02 & 66.268850 & -67.817625 \\
\hline 14SAB-H080B01 & 62.747432 & -67.917699 & 15SAB-D196B01 & 66.268850 & -67.817625 \\
\hline 14SAB-L001A01 & 62.918385 & -69.075670 & 15SAB-D237A01 & 66.921363 & -69.181112 \\
\hline 14SAB-L001B01 & 62.918385 & -69.075670 & 15SAB-F013B01 & 64.812520 & -68.320195 \\
\hline 14SAB-L002A01 & 62.977125 & -68.528075 & 15SAB-F034B01 & 65.073013 & -67.816722 \\
\hline 14SAB-L002A02 & 62.977125 & -68.528075 & 15SAB-L028A01 & 64.738937 & -67.350467 \\
\hline 14SAB-L003A01 & 62.885507 & -68.543792 & 15SAB-L056B01 & 64.824098 & -66.920294 \\
\hline 14SAB-L003A02 & 62.885507 & -68.543792 & 15SAB-L056B02 & 64.824098 & -66.920294 \\
\hline 14SAB-L003B01 & 62.885507 & -68.543792 & 15SAB-L057B01 & 64.825702 & -66.918307 \\
\hline 14SAB-L004A01 & 62.806867 & -68.092280 & 15SAB-L057B02 & 64.825702 & -66.918307 \\
\hline 14SAB-L004A02 & 62.806867 & -68.092280 & 15SAB-L059A01 & 64.829712 & -66.918999 \\
\hline 14SAB-L005A01 & 62.755075 & -68.109577 & 15SAB-L059B01 & 64.829712 & -66.918999 \\
\hline 14SAB-L005A02 & 62.755075 & -68.109577 & 15SAB-L066B01 & 66.818655 & -67.353518 \\
\hline 14SAB-L006A01 & 63.569594 & -71.307382 & 15SAB-L076A01 & 64.562237 & -66.916107 \\
\hline 14SAB-L006A02 & 63.569594 & -71.307382 & 15SAB-L076A02 & 64.562237 & -66.916107 \\
\hline 14SAB-L006B01 & 63.569594 & -71.307382 & 15SAB-L077A01 & 64.562167 & -66.915524 \\
\hline 14SAB-L007A01 & 63.474285 & -71.225592 & 15SAB-L077B01 & 64.562167 & -66.915524 \\
\hline 14SAB-L007A02 & 63.474285 & -71.225592 & 15SAB-L078A01 & 64.562375 & -66.914344 \\
\hline 14SAB-L007A03 & 63.474285 & -71.225592 & 15SAB-L078A02 & 64.562375 & -66.914344 \\
\hline 14SAB-L008A01 & 63.475609 & -71.442489 & 15SAB-L079A01 & 64.562303 & -66.913217 \\
\hline 14SAB-L008A02 & 63.475609 & -71.442489 & 15SAB-L080A01 & 64.562303 & -66.913217 \\
\hline 14SAB-L009A01 & 63.229450 & -71.558335 & 15SAB-L080A02 & 64.564432 & -66.914869 \\
\hline 14SAB-L009A02 & 63.229450 & -71.558335 & 15SAB-L080A03 & 64.564432 & -66.914869 \\
\hline 14SAB-L009B02 & 63.229450 & -71.558335 & 15SAB-L112A01 & 66.267307 & -67.806855 \\
\hline 14SAB-L010A01 & 63.238899 & -71.407389 & 15SAB-L113A01 & 66.267262 & -67.807957 \\
\hline 14SAB-L010C01 & 63.238890 & -71.407389 & 15SAB-L113B01 & 66.267262 & -67.807957 \\
\hline 14SAB-L011A01 & 63.428252 & -70.244096 & 15SAB-L119A01 & 65.254222 & -67.080111 \\
\hline 14SAB-L011A02 & 63.428252 & -70.244096 & 15SAB-M005A01 & 65.253933 & -69.987772 \\
\hline 14SAB-L012A01 & 62.281523 & -68.078272 & 15SAB-M008A01 & 65.296073 & -69.983567 \\
\hline 14SAB-L012A02 & 62.281523 & -68.078272 & 15SAB-M009A01 & 65.314663 & -69.958581 \\
\hline 14SAB-L012A03 & 62.281523 & -68.078272 & 15SAB-R174C01 & 65.120800 & -67.661760 \\
\hline 14SAB-L013A01 & 62.281397 & -68.076061 & 15SAB-R174C02 & 65.120800 & -67.661760 \\
\hline 14SAB-L013A02 & 62.281397 & -68.076061 & & & \\
\hline 14SAB-L014A01 & 62.280957 & -68.073719 & & & \\
\hline 14SAB-L014A02 & 62.280957 & -68.073719 & & & \\
\hline 14SAB-L015A01 & 62.279553 & -68.068479 & & & \\
\hline 14SAB-L015A02 & 62.279553 & -68.068479 & & & \\
\hline 14SAB-L016A01 & 62.278300 & -68.066164 & & & \\
\hline 14SAB-L017A02 & 62.274693 & -68.061174 & & & \\
\hline 14SAB-R005A01 & 62.281342 & -68.078134 & & & \\
\hline 14SAB-R006A01 & 62.279788 & -68.070389 & & & \\
\hline 14SAB-R006A02 & 62.279788 & -68.070389 & & & \\
\hline 14SAB-R010A01 & 62.281057 & -68.047466 & & & \\
\hline 14SAB-S130A01 & 62.700590 & -67.967291 & & & \\
\hline 14SUB-H029 B2 & 64.435592 & -65.245080 & & & \\
\hline
\end{tabular}




\section{Appendix B - Field \& Petrographic Data}




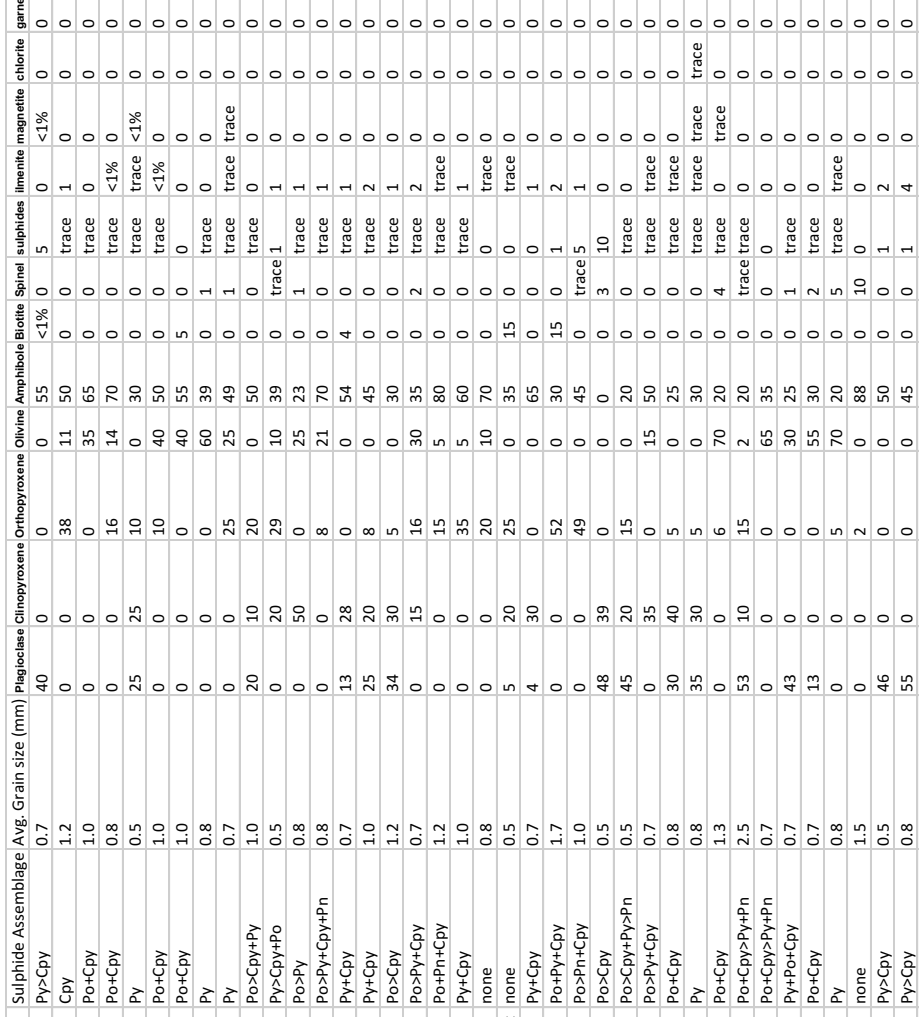

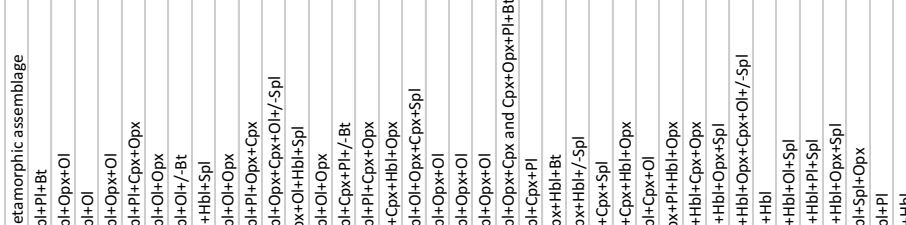

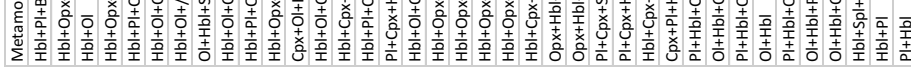

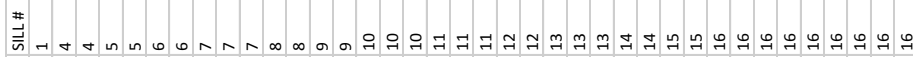

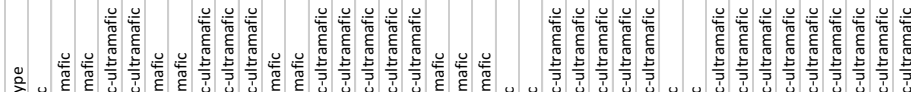

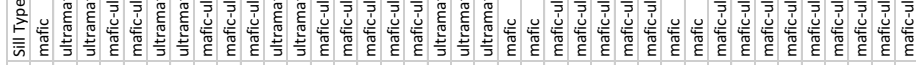

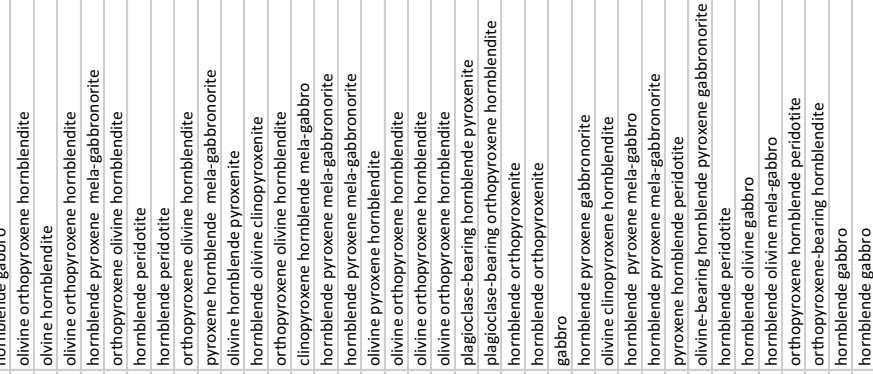

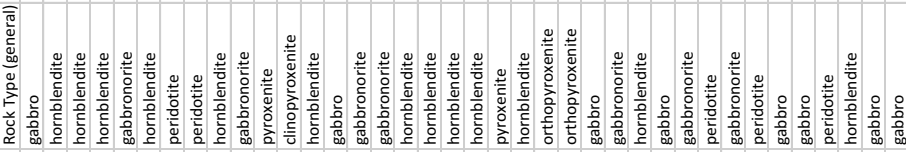

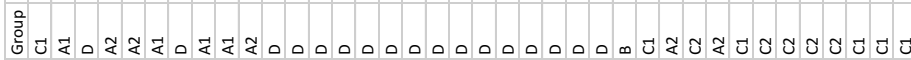

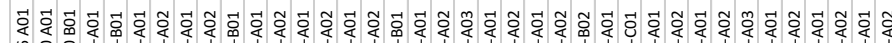

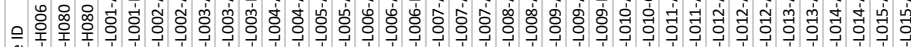

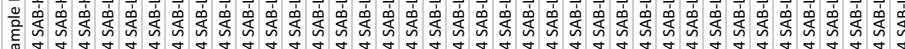




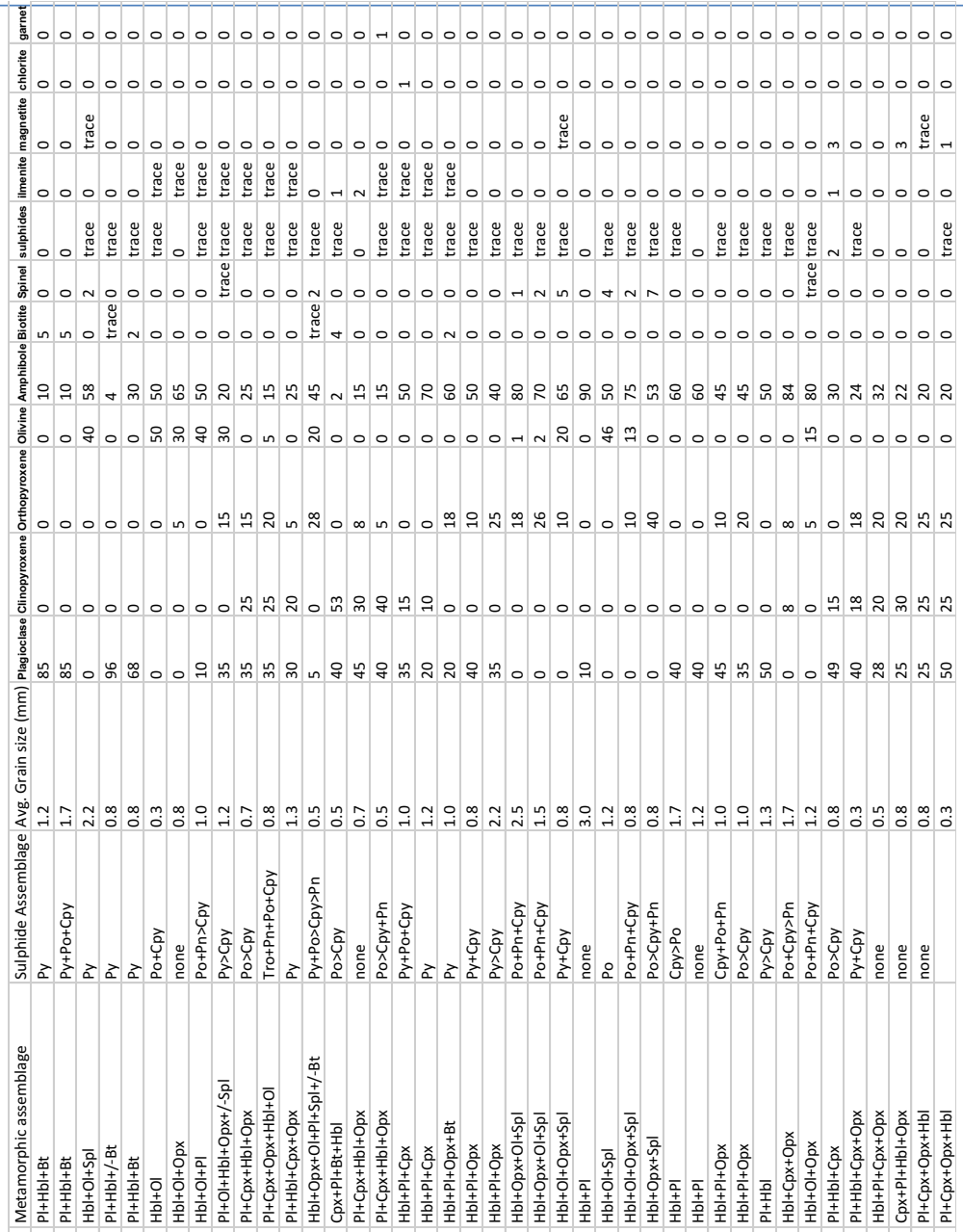

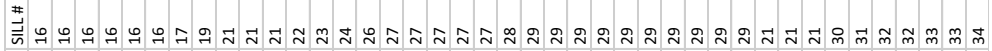

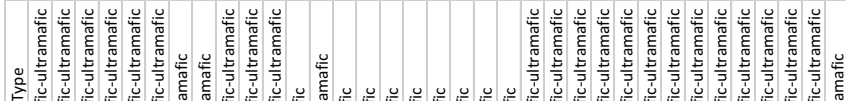

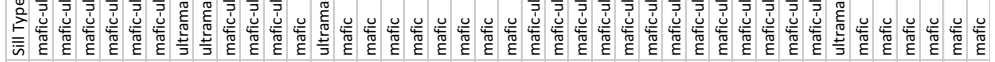

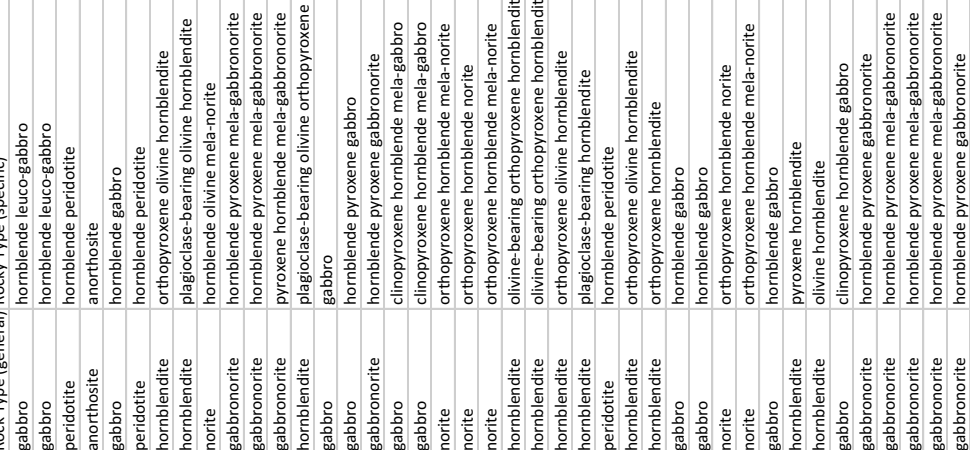

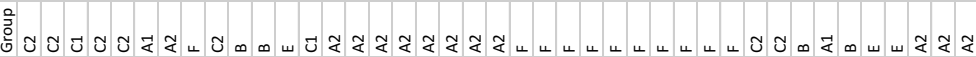

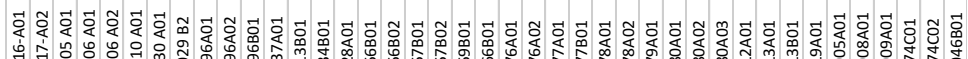

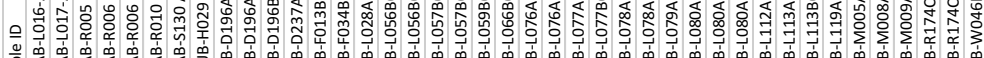

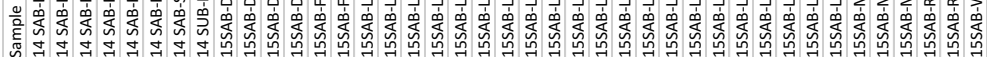




\section{Appendix C - Bulk-Rock Geochemical Data}




\begin{tabular}{|c|c|c|c|c|c|c|c|c|c|c|c|c|c|c|c|c|c|c|}
\hline SAMPLE & $\mathrm{Ba}$ & $\mathrm{Ce}$ & $\mathrm{Cr}$ & Cs & Dy & $\mathrm{Er}$ & $\mathrm{Eu}$ & $\overline{G a}$ & $\mathrm{Gd}$ & $\mathrm{Hf}$ & Ho & La & $\mathrm{Lu}$ & $\mathrm{Nb}$ & $\mathrm{Nd}$ & $\mathrm{Pr}$ & $\mathrm{Rb}$ & Sm \\
\hline 14 SAB-H006 A01 & 418 & 38.1 & 70 & & 1.7 & 0.97 & 1.25 & 19.7 & 2.64 & 1.2 & 0.34 & 17.9 & 0.12 & 0.9 & 19.9 & 4.71 & 3.5 & 3.79 \\
\hline 14 SAB-H080 A01 & 5.4 & 33 & 930 & 0.37 & 3.17 & 1.62 & 1.24 & 16.6 & 3.88 & 3.5 & 0.59 & 13.8 & 0.18 & 15.4 & 19.5 & 4.33 & 2.6 & 4.29 \\
\hline 14 SAB-H080 B01 & 6.1 & 3.9 & 2550 & & 1.4 & 0.93 & 0.38 & 8.2 & 1.33 & 1.2 & 0.29 & 1.4 & 0.12 & 1 & 3.1 & 0.56 & 1 & 1.06 \\
\hline 14 SAB-L001-A01 & 3.1 & 9.1 & 2770 & 0.01 & 1.92 & 1.1 & 0.54 & 10.8 & 1.89 & 2.2 & 0.4 & 4 & 0.14 & 2 & 6.4 & 1.26 & 0.4 & 1.63 \\
\hline 14 SAB-L001-B01 & 61.3 & 15.9 & 940 & & 3.63 & 2.08 & 1.06 & 15.6 & 3.71 & 3.3 & 0.79 & 6.6 & 0.29 & 6.6 & 11.1 & 2.29 & 3 & 3.31 \\
\hline 14 SAB-L002-A01 & 1.7 & 4.6 & 3020 & 0.02 & 1.39 & 0.83 & 0.31 & 7.5 & 1.21 & 1.3 & 0.29 & 1.8 & 0.13 & 1.3 & 3.5 & 0.67 & 1 & 1.08 \\
\hline 14 SAB-L002-A02 & 546 & 23.8 & 1400 & 2.99 & 3.11 & 1.48 & 1.2 & 14.1 & 3.63 & 2.8 & 0.57 & 9.5 & 0.17 & 10.4 & 15.5 & 3.34 & 38.6 & 3.85 \\
\hline 14 SAB-L003-A01 & 7.1 & 4.6 & 2710 & 0.05 & 1.49 & 0.81 & 0.39 & 8.2 & 1.39 & 1 & 0.32 & 1.7 & 0.14 & 1.5 & 3.8 & 0.71 & 1.8 & 1.26 \\
\hline 14 SAB-L003-A02 & 26.4 & 4.6 & 2820 & 0.16 & 1.39 & 0.81 & 0.38 & 7.5 & 1.3 & 0.9 & 0.29 & 1.7 & 0.13 & 1.5 & 3.5 & 0.67 & 2.1 & 1.05 \\
\hline 14 SAB-L003-B01 & 61.3 & 14.4 & 830 & 0.17 & 3.13 & 1.95 & 0.87 & 13.1 & 2.87 & 2.1 & 0.67 & 6.6 & 0.31 & 3.2 & 8.3 & 1.75 & 5.5 & 2.29 \\
\hline 14 SAB-L004-A01 & 11.1 & 26.7 & 1440 & 0.03 & 2.56 & 1.32 & 1.15 & 13.6 & 3.31 & 3.1 & 0.55 & 11.7 & 0.15 & 12.7 & 16.4 & 3.48 & 2.3 & 3.61 \\
\hline 14 SAB-L004-A02 & 26.8 & 25.4 & 1310 & 0.04 & 2.57 & 1.44 & 1.31 & 13.3 & 3.37 & 2.7 & 0.54 & 11 & 0.19 & 11.2 & 15.1 & 3.42 & 2 & 3.57 \\
\hline 14 SAB-L005-A01 & 20.4 & 31.7 & 1080 & 0.03 & 3.2 & 1.48 & 1.32 & 16.8 & 3.83 & 2.9 & 0.61 & 13.4 & 0.16 & 15.1 & 19.9 & 4.36 & 1.4 & 4.54 \\
\hline 14 SAB-L005-A02 & 691 & 39.3 & 750 & 0.91 & 3.08 & 1.29 & 1.44 & 22.1 & 4.43 & 3.4 & 0.59 & 16.7 & 0.13 & 22.4 & 24.1 & 5.33 & 81.7 & 5.45 \\
\hline 14 SAB-L006-A01 & 362 & 85.2 & 20 & 0.02 & 6.97 & 3.08 & 3.31 & 25.3 & 9.02 & 6.3 & 1.27 & 36.1 & 0.37 & 45.6 & 50 & 11.05 & 12.5 & 10.7 \\
\hline 14 SAB-L006-A02 & 291 & 82.8 & 20 & & 6.79 & 3.22 & 3.26 & 23 & 8.61 & 6.9 & 1.25 & 36.5 & 0.38 & 47.2 & 48.2 & 10.7 & 5.4 & 10.1 \\
\hline 14 SAB-L006-B01 & 3.4 & 27.6 & 1620 & 0.01 & 2.35 & 1.11 & 0.92 & 11.6 & 3.07 & 2.5 & 0.45 & 11.6 & 0.14 & 13.7 & 16.7 & 3.56 & 0.5 & 3.67 \\
\hline 14 SAB-L007-A01 & 26.6 & 22.7 & 1340 & 0.4 & 2.97 & 1.54 & 1.18 & 14.1 & 3.28 & 2.4 & 0.56 & 9.6 & 0.16 & 9.9 & 14.3 & 2.98 & 5 & 3.41 \\
\hline 14 SAB-L007-A02 & 93.9 & 25.2 & 1410 & 0.28 & 3.41 & 1.7 & 1.28 & 14.6 & 4.34 & 3.1 & 0.67 & 10.1 & 0.21 & 11.1 & 17.3 & 3.64 & 6.9 & 4.45 \\
\hline 14 SAB-L007-A03 & 27.5 & 14.3 & 1180 & 0.1 & 2.84 & 1.57 & 0.79 & 12.4 & 3.08 & 2.4 & 0.59 & 5.8 & 0.18 & 8.1 & 10.2 & 2.04 & 5.3 & 2.73 \\
\hline 14 SAB-L008-A01 & 112.5 & 54.2 & 370 & 0.34 & 5.55 & 2.66 & 2.12 & 23.4 & 7.08 & 5.1 & 1.07 & 21.5 & 0.32 & 28 & 36 & 7.5 & 17 & 8.07 \\
\hline 14 SAB-L008-A02 & 123 & 36.2 & 1190 & 1.06 & 3.47 & 1.68 & 1.37 & 14.9 & 4 & 3.4 & 0.64 & 15.7 & 0.19 & 15.1 & 22.4 & 4.84 & 26.9 & 5.16 \\
\hline 14 SAB-L009-A01 & 176 & 20 & 1930 & 166 & 2.67 & 1.27 & 0.79 & 13.3 & 3.23 & 2.5 & 0.51 & 8.2 & 0.16 & 12.3 & 13.2 & 2.76 & 374 & 3.21 \\
\hline 14 SAB-L009-A02 & 49 & 18.6 & 1760 & 1.15 & 2.66 & 1.4 & 1.04 & 15.6 & 2.95 & 2.2 & 0.54 & 8.3 & 0.16 & 11.1 & 12.4 & 2.52 & 6.4 & 3.01 \\
\hline 14 SAB-L009-B02 & 33.4 & 51.5 & 3010 & 0.51 & 5.13 & 2.42 & 2.56 & 18.5 & 6.14 & 5.1 & 0.98 & 23.6 & 0.26 & 20.9 & 29.5 & 6.56 & 5 & 6.68 \\
\hline 14 SAB-L010-A01 & 154 & 15.7 & 130 & 0.04 & 2.24 & 1.36 & 0.7 & 13.8 & 2.12 & 2.3 & 0.49 & 7 & 0.21 & 1.5 & 9.5 & 2.05 & 2.2 & 2.2 \\
\hline 14 SAB-L010-C01 & 84.3 & 34.8 & 1710 & 0.19 & 2.3 & 1.12 & 0.75 & 11.2 & 2.71 & 2 & 0.45 & 13.9 & 0.13 & 9.4 & 17 & 4.2 & 20.9 & 3.46 \\
\hline 14 SAB-L011-A01 & 32.9 & 13.2 & 290 & 0.02 & 3.5 & 2.14 & 0.96 & 17 & 3.19 & 2.7 & 0.77 & 5 & 0.3 & 4.5 & 9.9 & 1.92 & 1.6 & 2.89 \\
\hline 14 SAB-L011-A02 & 13 & 3.1 & 560 & 0.03 & 0.15 & 0.07 & 0.13 & 3.8 & 0.13 & 0.2 & 0.03 & 1.5 & 0.01 & 0.4 & 1.4 & 0.34 & 0.5 & 0.19 \\
\hline 14 SAB-L012-A01 & 36.1 & 12.8 & 310 & 0.02 & 3.58 & 2.27 & 1.06 & 17.5 & 3.32 & 2.3 & 0.81 & 4.5 & 0.32 & 4.6 & 10.1 & 1.94 & 2.3 & 2.99 \\
\hline 14 SAB-L012-A02 & 973 & 11.3 & 690 & 0.18 & 1.15 & 0.51 & 0.68 & 14.6 & 1.37 & 0.6 & 0.22 & 5 & 0.05 & 0.3 & 7.9 & 1.55 & 23.5 & 1.71 \\
\hline 14 SAB-L012-A03 & 68.2 & 5.9 & 950 & 0.05 & 0.24 & 0.16 & 0.25 & 5.5 & 0.42 & 0.3 & 0.06 & 2.9 & 0.02 & 0.4 & 3 & 0.76 & 2.7 & 0.49 \\
\hline 14 SAB-L013-A01 & 247 & 5.1 & 350 & 0.14 & 0.15 & 0.1 & 0.33 & 10.6 & 0.25 & 0.5 & 0.03 & 2.8 & 0.01 & 0.3 & 2.5 & 0.53 & 8 & 0.35 \\
\hline 14 SAB-L013-A02 & 229 & 5.2 & 410 & 0.17 & 0.17 & 0.1 & 0.25 & 8.6 & 0.29 & 0.4 & 0.04 & 2.8 & 0.02 & 0.4 & 2.4 & 0.62 & 5.9 & 0.43 \\
\hline 14 SAB-L014-A01 & 87.9 & 6.7 & 660 & 0.09 & 0.28 & 0.14 & 0.21 & 5.6 & 0.4 & 0.4 & 0.06 & 3.2 & 0.02 & 0.6 & 3.1 & 0.78 & 2 & 0.57 \\
\hline 14 SAB-L014-A02 & 166.5 & 57 & 910 & 0.2 & 2.09 & 1.24 & 0.98 & 28.6 & 3.5 & 3.3 & 0.41 & 27.2 & 0.12 & 3.2 & 29.4 & 6.93 & 5.6 & 4.49 \\
\hline 14 SAB-L015-A01 & 299 & 14.9 & 130 & 0.03 & 1.14 & 0.62 & 0.93 & 29.1 & 1.61 & 1.2 & 0.2 & 7.2 & 0.08 & 1 & 9.2 & 2 & 3.6 & 2.16 \\
\hline 14 SAB-L015-A02 & 239 & 12 & 40 & 0.02 & 0.73 & 0.42 & 0.63 & 23.4 & 1.17 & 0.8 & 0.15 & 6 & 0.04 & 0.8 & 7 & 1.55 & 2.9 & 1.34 \\
\hline 14 SAB-L016-A01 & 581 & 29.5 & 320 & 0.53 & 0.78 & 0.49 & 0.87 & 18 & 1.18 & 1.4 & 0.15 & 16.9 & 0.06 & 3.5 & 11.2 & 3.13 & 19.7 & 1.82 \\
\hline 14 SAB-L017-A02 & 674 & 32.8 & 270 & 0.45 & 0.72 & 0.49 & 0.86 & 19.3 & 1 & 1.9 & 0.14 & 19.2 & 0.06 & 2.7 & 11.9 & 3.44 & 19.6 & 1.78 \\
\hline 14 SAB-R005 A01 & 41.9 & 11.7 & 680 & 0.03 & 0.85 & 0.47 & 0.5 & 7.7 & 1.15 & 1.2 & 0.15 & 5.5 & 0.06 & 1.6 & 6.5 & 1.52 & 1.6 & 1.46 \\
\hline 14 SAB-R006 A01 & 241 & 6.4 & 20 & 0.21 & 0.23 & 0.18 & 0.36 & 18.1 & 0.3 & 0.9 & 0.06 & 3.4 & 0.01 & 1.1 & 2.6 & 0.69 & 15.1 & 0.58 \\
\hline 14 SAB-R006 A02 & 400 & 29.3 & 130 & 0.04 & 1.16 & 0.61 & 1.04 & 18.2 & 1.88 & 1.1 & 0.22 & 14.8 & 0.09 & 1.4 & 14.9 & 3.61 & 2.2 & 2.63 \\
\hline 14 SAB-R010 A01 & 4.1 & 3.4 & 2340 & & 1.15 & 0.75 & 0.37 & 5.5 & 1.05 & 0.9 & 0.26 & 1.4 & 0.07 & 1 & 2.7 & 0.53 & 1 & 0.97 \\
\hline 14 SAB-S130 A01 & 10.6 & 8.4 & 2450 & & 1.48 & 0.92 & 0.51 & 10.7 & 1.65 & 1.7 & 0.31 & 3.4 & 0.16 & 3.2 & 5.9 & 1.21 & 0.7 & 1.47 \\
\hline 14 SUB-H029 B2 & 9.3 & 1.6 & 2250 & 0.24 & 0.73 & 0.42 & 0.19 & 5.3 & 0.63 & 0.4 & 0.17 & 0.6 & 0.07 & 0.7 & 1.4 & 0.23 & 0.7 & 0.51 \\
\hline 15SAB-D196A01 & 75.9 & 4.7 & 120 & 0.01 & 0.26 & 0.17 & 0.25 & 8.6 & 0.34 & 0.3 & 0.06 & 2.3 & 0.02 & 0.2 & 2.4 & 0.6 & 1.6 & 0.41 \\
\hline 15SAB-D196A02 & 53.9 & 4.7 & 460 & 0.06 & 0.45 & 0.37 & 0.28 & 9.2 & 0.57 & 0.3 & 0.12 & 1.9 & 0.04 & 0.141 & 2.7 & 0.64 & 1.5 & 0.62 \\
\hline 15SAB-D196B01 & 85.2 & 5 & 200 & 0.04 & 0.59 & 0.26 & 0.34 & 12.4 & 0.56 & 0.3 & 0.11 & 2.2 & 0.04 & 0.141 & 3 & 0.67 & 2.6 & 0.6 \\
\hline 15SAB-D237A01 & 56.8 & 12 & 580 & 0.07 & 5.62 & 3.64 & 0.65 & 15.5 & 4.57 & 1 & 1.27 & 4.2 & 0.47 & 3.6 & 9.5 & 1.9 & 5.9 & 3.4 \\
\hline 15SAB-F013B01 & 161 & 18.9 & 50 & 0.31 & 1.6 & 0.82 & 0.66 & 10.5 & 2.01 & 1 & 0.31 & 8.5 & 0.08 & 2.3 & 10.5 & 2.51 & 10.6 & 2.12 \\
\hline 15SAB-F034B01 & 178 & 33.4 & 150 & 0.03 & 5.33 & 3.33 & 1.41 & 18.6 & 5.03 & 2.8 & 1.07 & 13.7 & 0.45 & 9.9 & 20.2 & 4.44 & 4.6 & 4.9 \\
\hline 15SAB-L028A01 & 342 & 30.1 & 100 & 0.03 & 5.81 & 3.8 & 1.6 & 19.2 & 5.37 & 3.5 & 1.31 & 12.1 & 0.55 & 17.3 & 17.9 & 4.16 & 1.8 & 4.93 \\
\hline 15SAB-L056B01 & 50.5 & 22.7 & 240 & 0.35 & 4.85 & 2.66 & 1.27 & 19.6 & 4.53 & 2.6 & 1.03 & 9.2 & 0.41 & 9.1 & 14.4 & 3.11 & 5.7 & 4.02 \\
\hline 15SAB-L056B02 & 58.5 & 25.2 & 100 & 3.8 & 4.36 & 2.7 & 1.12 & 20.6 & 4.23 & 2.5 & 0.91 & 9.9 & 0.35 & 9.5 & 14.1 & 3.27 & 38.8 & 4.12 \\
\hline 15SAB-L057B01 & 40.9 & 18.3 & 160 & 0.1 & 4.18 & 2.67 & 1.12 & 18.2 & 3.98 & 2.1 & 0.89 & 6.9 & 0.36 & 8 & 12.5 & 2.64 & 2.3 & 3.73 \\
\hline 15SAB-L057B02 & 207 & 13.3 & 1220 & 0.19 & 2.76 & 1.82 & 0.6 & 13.3 & 2.48 & 1.2 & 0.61 & 5.5 & 0.26 & 2 & 7.9 & 1.81 & 19.3 & 2.07 \\
\hline 15SAB-L059B01 & 38.2 & 16.5 & 160 & 0.04 & 3.91 & 2.67 & 1.14 & 18 & 3.84 & 2.2 & 0.9 & 6.3 & 0.34 & 6.7 & 11.1 & 2.38 & 2.6 & 3.27 \\
\hline 15SAB-L066B01 & 120 & 13.9 & 240 & 0.14 & 2.49 & 1.65 & 0.72 & 17.6 & 2.34 & 1.4 & 0.55 & 5.8 & 0.22 & 2.9 & 8.4 & 1.89 & 23.6 & 2.14 \\
\hline 15SAB-L076A01 & 15.2 & 1.5 & 870 & 0.03 & 0.75 & 0.52 & 0.23 & 9.5 & 0.62 & 0.2 & 0.18 & 0.6 & 0.08 & 0.3 & 1.2 & 0.23 & 3.9 & 0.45 \\
\hline 15SAB-L076A02 & 13.4 & 1.4 & 980 & 0.04 & 0.79 & 0.5 & 0.2 & 9 & 0.58 & 0.3 & 0.17 & 0.5 & 0.09 & 0.3 & 1 & 0.21 & 3.9 & 0.3 \\
\hline 15SAB-L077A01 & 6.4 & 1.1 & 1040 & 0.03 & 0.57 & 0.44 & 0.14 & 8.6 & 0.42 & 0.2 & 0.13 & 0.25 & 0.07 & 0.2 & 0.9 & 0.17 & 0.9 & 0.34 \\
\hline 15SAB-L077B01 & 39.8 & 2.4 & 1260 & 1.37 & 1.7 & 1.05 & 0.26 & 11.6 & 1.26 & 0.5 & 0.37 & 0.8 & 0.15 & 0.6 & 2.4 & 0.41 & 8.8 & 0.89 \\
\hline 15SAB-L078A01 & 9.1 & 1.6 & 1540 & 0.1 & 0.73 & 0.58 & 0.14 & 6.7 & 0.63 & 0.3 & 0.17 & 0.7 & 0.07 & 0.3 & 1.1 & 0.24 & 0.9 & 0.42 \\
\hline 15SAB-L078A02 & 10 & 1.7 & 1480 & 0.01 & 0.54 & 0.38 & 0.12 & 7.8 & 0.44 & 0.3 & 0.13 & 0.7 & 0.04 & 0.4 & 1 & 0.23 & 1.1 & 0.39 \\
\hline 15SAB-L079A01 & 9.3 & 1.7 & 990 & 0.01 & 0.79 & 0.5 & 0.17 & 9.1 & 0.66 & 0.3 & 0.19 & 0.7 & 0.09 & 0.4 & 1.5 & 0.25 & 1.2 & 0.43 \\
\hline 15SAB-L080A01 & 9.7 & 2.1 & 890 & 0.03 & 1.34 & 0.84 & 0.26 & 13 & 0.99 & 0.4 & 0.32 & 0.7 & 0.13 & 0.4 & 1.8 & 0.32 & 0.9 & 0.59 \\
\hline 15SAB-L080A02 & 13.7 & 1.8 & 880 & 0.07 & 1.16 & 0.7 & 0.3 & 11.5 & 0.76 & 0.3 & 0.26 & 0.7 & 0.11 & 0.3 & 1.7 & 0.31 & 0.9 & 0.61 \\
\hline 15SAB-L080A03 & 7.5 & 1.7 & 840 & 0.1 & 1.21 & 0.78 & 0.29 & 12.1 & 0.84 & 0.2 & 0.28 & 0.7 & 0.12 & 0.3 & 1.6 & 0.26 & 0.7 & 0.64 \\
\hline 15SAB-L112A01 & 163.5 & 7.2 & 90 & 0.08 & 0.32 & 0.17 & 0.32 & 12.3 & 0.4 & 0 & 0.07 & 3.9 & 0.04 & 0.4 & 3.2 & 0.82 & 9.1 & 0.53 \\
\hline 15SAB-L113A01 & 339 & 5.1 & 340 & 0.19 & 0.27 & 0.21 & 0.21 & 9.5 & 0.29 & 0 & 0.06 & 2.6 & 0.03 & 0.3 & 2.1 & 0.57 & 37.8 & 0.43 \\
\hline 15SAB-L113B01 & 135 & 5.7 & 680 & 0.2 & 0.65 & 0.39 & 0.28 & 7.2 & 0.71 & 0.2 & 0.13 & 2.6 & 0.06 & 0.7 & 3.2 & 0.8 & 12 & 0.76 \\
\hline 15SAB-L119A01 & 17.2 & 5.6 & 2410 & 0.03 & 1.58 & 0.9 & 0.41 & 8.1 & 1.58 & 0.7 & 0.33 & 2.2 & 0.14 & 1.6 & 3.9 & 0.81 & 1.8 & 1.22 \\
\hline 15SAB-M005A01 & 273 & 22.3 & 10 & 0.07 & 2.5 & 1.49 & 1.05 & 17.6 & 2.66 & 1 & 0.5 & 9.3 & 0.21 & 2.4 & 13 & 2.9 & 1.9 & 2.63 \\
\hline 15SAB-M008A01 & 46.6 & 9.3 & 860 & 0.03 & 3.46 & 2.25 & 0.44 & 13.2 & 2.46 & 0.6 & 0.7 & 3.7 & 0.33 & 2.3 & 6.1 & 1.33 & 3.1 & 1.9 \\
\hline 15SAB-M009A01 & 48.4 & 12.2 & 140 & 0.01 & 3.67 & 2.24 & 0.55 & 15.8 & 3.77 & 0.7 & 0.79 & 4.4 & 0.32 & 3.1 & 10 & 1.91 & 1 & 3.11 \\
\hline 15SAB-R174C01 & 50.8 & 17.5 & 250 & & 4.3 & 2.82 & 1.11 & 14.9 & 4.36 & 1.9 & 0.9 & 6.3 & 0.42 & 8.8 & 12.5 & 2.64 & 0.5 & 3.48 \\
\hline 15SAB-R174C02 & 51.9 & 17.3 & 270 & & 3.85 & 2.48 & 1.12 & 14 & 3.59 & 1.7 & 0.81 & 6.3 & 0.35 & 7.3 & 11.3 & 2.43 & 0.6 & 3.24 \\
\hline 15SAB-W046B01 & 124 & 16.4 & 120 & 0.08 & 3.14 & 1.99 & 0.86 & 16.8 & 2.98 & 1.8 & 0.65 & 7.8 & 0.31 & 2.5 & 9.7 & 2.12 & 7.5 & 2.59 \\
\hline
\end{tabular}




\begin{tabular}{|c|c|c|c|c|c|c|c|c|c|c|c|c|c|c|c|c|c|c|}
\hline SAMPLE & $\mathrm{Sr}$ & Ta & Tb & Th & $\mathrm{Tm}$ & $\mathrm{U}$ & V & W & $\mathrm{Y}$ & $\mathrm{Yb}$ & $\mathrm{Zr}$ & $\mathrm{Ag}$ & As & $\mathrm{Cd}$ & Co & $\mathrm{Cu}$ & $L i$ & Mo \\
\hline 14 SAB-H006 A01 & 989 & & 0.33 & 0.35 & 0.11 & 0.05 & 374 & $<1$ & 8.4 & 0.78 & 50 & $<0.5$ & $<5$ & $<0.5$ & 58 & 131 & 10 & $<1$ \\
\hline 14 SAB-H080 A01 & 44.2 & 0.8 & 0.57 & 1.21 & 0.19 & 0.3 & 250 & 2 & 14.7 & 1.23 & 145 & $<0.5$ & $<5$ & 0.9 & 88 & 27 & 10 & $<1$ \\
\hline 14 SAB-H080 B01 & 47.8 & 0.1 & 0.24 & 0.13 & 0.12 & 0.06 & 157 & $<1$ & 7.7 & 0.79 & 48 & $<0.5$ & $<5$ & 0.6 & 99 & 76 & 10 & $<1$ \\
\hline 14 SAB-L001-A01 & 12.6 & 0.1 & 0.29 & 0.91 & 0.14 & 0.24 & 184 & $<1$ & 10.1 & 1.03 & 88 & $<0.5$ & $<5$ & 0.5 & 79 & 72 & $<10$ & $<1$ \\
\hline 14 SAB-L001-B01 & 443 & 0.4 & 0.58 & 0.78 & 0.31 & 0.7 & 344 & $<1$ & 19.1 & 1.89 & 125 & $<0.5$ & $<5$ & $<0.5$ & 64 & 20 & 10 & $<1$ \\
\hline 14 SAB-L002-A01 & 34.7 & 0.1 & 0.23 & 0.18 & 0.12 & 0.06 & 151 & $<1$ & 7.4 & 0.76 & 51 & $<0.5$ & $<5$ & $<0.5$ & 89 & 20 & 10 & $<1$ \\
\hline 14 SAB-L002-A02 & 153 & 0.6 & 0.52 & 0.82 & 0.19 & 0.24 & 242 & $<1$ & 14.1 & 1.24 & 104 & $<0.5$ & $<5$ & 0.7 & 89 & 97 & 10 & $<1$ \\
\hline 14 SAB-L003-A01 & 56.9 & 0.1 & 0.24 & 0.22 & 0.13 & 0.08 & 175 & $<1$ & 8 & 0.81 & 35 & $<0.5$ & $<5$ & 0.5 & 89 & 75 & 10 & $<1$ \\
\hline 14 SAB-L003-A02 & 59.5 & 0.1 & 0.21 & 0.21 & 0.11 & 0.07 & 167 & $<1$ & 7.6 & 0.76 & 28 & $<0.5$ & $<5$ & $<0.5$ & 82 & 57 & 10 & $<1$ \\
\hline 14 SAB-L003-B01 & 216 & 0.2 & 0.49 & 0.06 & 0.28 & & 358 & $<1$ & 17.1 & 1.88 & 67 & $<0.5$ & $<5$ & 0.6 & 45 & 45 & 20 & $<1$ \\
\hline 14 SAB-L004-A01 & 221 & 0.8 & 0.48 & 1.4 & 0.17 & 0.28 & 239 & $<1$ & 12.6 & 1.09 & 113 & $<0.5$ & $<5$ & 0.6 & 86 & 59 & 10 & $<1$ \\
\hline 14 SAB-L004-A02 & 381 & 0.7 & 0.48 & 1.11 & 0.18 & 0.31 & 209 & $<1$ & 12.9 & 1.04 & 102 & $<0.5$ & $<5$ & 0.6 & 81 & 10 & 20 & $<1$ \\
\hline 14 SAB-L005-A01 & 154.5 & 0.9 & 0.59 & 1.2 & 0.19 & 0.23 & 275 & $<1$ & 14.3 & 1.23 & 102 & $<0.5$ & $<5$ & 0.7 & 90 & 118 & 20 & $<1$ \\
\hline 14 SAB-L005-A02 & 325 & 1.1 & 0.58 & 1.3 & 0.16 & 0.37 & 265 & $<1$ & 13.3 & 0.98 & 134 & $<0.5$ & $<5$ & 1 & 64 & 17 & 10 & $<1$ \\
\hline 14 SAB-L006-A01 & 752 & 2.8 & 1.16 & 3.09 & 0.42 & 0.64 & 409 & $<1$ & 30.8 & 2.57 & 225 & $<0.5$ & $<5$ & 0.5 & 62 & 285 & 10 & 2 \\
\hline 14 SAB-L006-A02 & 558 & 2.9 & 1.2 & 2.87 & 0.41 & 0.65 & 350 & $<1$ & 30.3 & 2.57 & 266 & $<0.5$ & $<5$ & 0.6 & 51 & 231 & 10 & 1 \\
\hline 14 SAB-L006-B01 & 230 & 0.9 & 0.45 & 1.08 & 0.16 & 0.24 & 203 & $<1$ & 10.7 & 0.93 & 93 & $<0.5$ & 306 & $<0.5$ & 80 & 15 & 10 & $<1$ \\
\hline 14 SAB-L007-A01 & 173.5 & 0.6 & 0.49 & 0.81 & 0.2 & 0.21 & 217 & $<1$ & 12.9 & 1.05 & 81 & $<0.5$ & $<5$ & 0.5 & 87 & 112 & 50 & $<1$ \\
\hline 14 SAB-L007-A02 & 165.5 & 0.7 & 0.61 & 0.81 & 0.22 & 0.19 & 234 & $<1$ & 16 & 1.47 & 114 & $<0.5$ & $<5$ & 0.5 & 77 & 107 & 60 & $<1$ \\
\hline 14 SAB-L007-A03 & 167.5 & 0.5 & 0.48 & 0.48 & 0.19 & 0.09 & 195 & $<1$ & 13.7 & 1.26 & 81 & $<0.5$ & $<5$ & 0.6 & 86 & 24 & 50 & $<1$ \\
\hline 14 SAB-L008-A01 & 257 & 1.7 & 1.02 & 1.05 & 0.37 & 0.49 & 436 & $<1$ & 24.7 & 2 & 191 & $<0.5$ & $<5$ & 0.5 & 68 & 117 & 30 & $<1$ \\
\hline 14 SAB-L008-A02 & 308 & 0.9 & 0.59 & 1.64 & 0.24 & 0.57 & 273 & $<1$ & 15.5 & 1.38 & 124 & $<0.5$ & $<5$ & $<0.5$ & 77 & 51 & 20 & $<1$ \\
\hline 14 SAB-L009-A01 & 77.7 & 0.8 & 0.47 & 0.87 & 0.18 & 0.21 & 257 & $<1$ & 12.7 & 1.11 & 82 & $<0.5$ & 591 & $<0.5$ & 86 & 15 & 90 & $<1$ \\
\hline 14 SAB-L009-A02 & 142 & 0.7 & 0.44 & 0.9 & 0.18 & 0.24 & 212 & $<1$ & 13.1 & 1.05 & 75 & $<0.5$ & 61 & $<0.5$ & 98 & 213 & 10 & $<1$ \\
\hline 14 SAB-L009-B02 & 201 & 1.4 & 0.92 & 1.85 & 0.32 & 2.68 & 413 & 1 & 23.1 & 1.9 & 196 & $<0.5$ & 27 & 0.9 & 60 & 138 & 30 & 1 \\
\hline 14 SAB-L010-A01 & 277 & 0.1 & 0.35 & 0.33 & 0.2 & 0.16 & 213 & $<1$ & 11.7 & 1.32 & 89 & $<0.5$ & $<5$ & $<0.5$ & 40 & 93 & 30 & $<1$ \\
\hline 14 SAB-L010-C01 & 189.5 & 0.9 & 0.41 & 2.5 & 0.15 & 1.52 & 199 & 1 & 10.7 & 0.94 & 74 & $<0.5$ & 565 & 0.7 & 71 & 14 & 10 & $<1$ \\
\hline 14 SAB-L011-A01 & 199 & 0.3 & 0.58 & 0.38 & 0.31 & 0.28 & 332 & $<1$ & 19.3 & 1.82 & 93 & $<0.5$ & $<5$ & 0.5 & 52 & 83 & 10 & $<1$ \\
\hline 14 SAB-L011-A02 & 51.6 & & 0.02 & 0.3 & 0.02 & 0.08 & 23 & $<1$ & 0.7 & 0.09 & 7 & $<0.5$ & $<5$ & $<0.5$ & 126 & 34 & 10 & $<1$ \\
\hline 14 SAB-L012-A01 & 187.5 & 0.3 & 0.59 & 0.1 & 0.32 & 0.09 & 353 & $<1$ & 20.2 & 2.21 & 78 & $<0.5$ & $<5$ & $<0.5$ & 54 & 134 & 20 & $<1$ \\
\hline 14 SAB-L012-A02 & 1275 & & 0.16 & 0.16 & 0.07 & & 99 & $<1$ & 4.9 & 0.42 & 17 & $<0.5$ & $<5$ & $<0.5$ & 45 & 28 & 10 & $<1$ \\
\hline 14 SAB-L012-A03 & 187 & & 0.04 & 0.2 & 0.02 & & 41 & $<1$ & 1.3 & 0.14 & 11 & $<0.5$ & $<5$ & $<0.5$ & 106 & 6 & 20 & $<1$ \\
\hline 14 SAB-L013-A01 & 927 & & 0.04 & 0.17 & 0.01 & 0.06 & 17 & $<1$ & 0.8 & 0.07 & 18 & $<0.5$ & $<5$ & $<0.5$ & 73 & 10 & 30 & $<1$ \\
\hline 14 SAB-L013-A02 & 592 & & 0.04 & 0.26 & 0.02 & 0.05 & 24 & $<1$ & 0.9 & 0.11 & 15 & $<0.5$ & $<5$ & 0.5 & 82 & 6 & 30 & $<1$ \\
\hline 14 SAB-L014-A01 & 303 & & 0.06 & 0.41 & 0.02 & 0.09 & 42 & $<1$ & 1.4 & 0.17 & 14 & $<0.5$ & $<5$ & $<0.5$ & 109 & 8 & $<10$ & $<1$ \\
\hline 14 SAB-L014-A02 & 846 & 0.1 & 0.4 & 2.2 & 0.14 & 0.78 & 70 & 1 & 10.8 & 0.96 & 146 & $<0.5$ & $<5$ & 0.7 & 80 & 1 & 30 & $<1$ \\
\hline 14 SAB-L015-A01 & 1370 & 0.1 & 0.22 & 0.23 & 0.08 & 0.07 & 894 & 1 & 5.4 & 0.47 & 52 & $<0.5$ & $<5$ & 0.5 & 59 & 186 & 10 & $<1$ \\
\hline 14 SAB-L015-A02 & 1120 & & 0.15 & 0.16 & 0.06 & & 705 & $<1$ & 3.7 & 0.3 & 30 & $<0.5$ & $<5$ & 0.5 & 59 & 222 & 20 & $<1$ \\
\hline 14 SAB-L016-A01 & 1435 & 0.2 & 0.16 & 0.43 & 0.06 & 0.14 & 27 & $<1$ & 4.3 & 0.34 & 60 & $<0.5$ & $<5$ & $<0.5$ & 15 & 4 & 20 & $<1$ \\
\hline 14 SAB-L017-A02 & 1410 & 0.1 & 0.13 & 0.72 & 0.06 & 0.23 & 32 & $<1$ & 3.9 & 0.41 & 88 & $<0.5$ & $<5$ & $<0.5$ & 14 & 42 & 20 & $<1$ \\
\hline 14 SAB-R005 A01 & 195.5 & 0.1 & 0.15 & 0.52 & 0.06 & 0.11 & 84 & 2 & 4.1 & 0.41 & 48 & $<0.5$ & $<5$ & 0.5 & 91 & 54 & 10 & $<1$ \\
\hline 14 SAB-R006 A01 & 656 & 0.1 & 0.05 & 0.15 & 0.01 & 0.12 & 8 & $<1$ & 1.3 & 0.12 & 39 & $<0.5$ & $<5$ & $<0.5$ & 4 & 3 & 20 & $<1$ \\
\hline 14 SAB-R006 A02 & 1330 & 0.1 & 0.24 & 0.17 & 0.08 & & 119 & $<1$ & 5.9 & 0.48 & 42 & $<0.5$ & $<5$ & $<0.5$ & 23 & 32 & 10 & $<1$ \\
\hline 14 SAB-R010 A01 & 221 & 0.1 & 0.2 & 0.11 & 0.08 & 0.05 & 100 & 1 & 6.1 & 0.59 & 34 & $<0.5$ & 243 & 0.6 & 99 & 29 & 10 & $<1$ \\
\hline 14 SAB-S130 A01 & 148.5 & 0.2 & 0.28 & 0.35 & 0.13 & 0.1 & 250 & $<1$ & 8.3 & 0.94 & 66 & $<0.5$ & 17 & $<0.5$ & 83 & 5 & 10 & $<1$ \\
\hline 14 SUB-H029 B2 & 48.7 & 0.7 & 0.12 & 0.05 & 0.09 & & 76 & $<1$ & 4.1 & 0.44 & 17 & $<0.5$ & 7 & 0.5 & 105 & 20 & $<10$ & $<1$ \\
\hline 15SAB-D196A01 & 262 & & 0.05 & 0.09 & 0.02 & & 63 & $<1$ & 1.5 & 0.17 & 11 & $<0.5$ & $<5$ & $<0.5$ & 105 & 48 & $<10$ & $<1$ \\
\hline 15SAB-D196A02 & 266 & & 0.1 & 0.89 & 0.06 & 0.06 & 140 & $<1$ & 2.7 & 0.29 & 6 & $<0.5$ & $<5$ & $<0.5$ & 54 & 83 & $<10$ & $<1$ \\
\hline 15SAB-D196B01 & 334 & & 0.09 & 0.1 & 0.05 & & 155 & $<1$ & 2.6 & 0.3 & 9 & $<0.5$ & $<5$ & $<0.5$ & 64 & 189 & $<10$ & $<1$ \\
\hline 15SAB-D237A01 & 195.5 & 0.1 & 0.89 & 0.28 & 0.51 & 0.05 & 299 & $<1$ & 31.9 & 3.23 & 22 & $<0.5$ & $<5$ & $<0.5$ & 50 & 138 & 30 & $<1$ \\
\hline 15SAB-F013B01 & 383 & & 0.27 & 1.15 & 0.12 & 0.29 & 74 & 1 & 7.4 & 0.68 & 32 & $<0.5$ & $<5$ & $<0.5$ & 93 & 84 & $<10$ & $<1$ \\
\hline 15SAB-F034B01 & 206 & 0.4 & 0.87 & 0.67 & 0.48 & 0.31 & 386 & 1 & 28 & 3.11 & 98 & $<0.5$ & $<5$ & $<0.5$ & 49 & 28 & 20 & 1 \\
\hline 15SAB-L028A01 & 205 & 0.9 & 0.99 & 0.3 & 0.53 & 0.25 & 473 & $<1$ & 33 & 3.49 & 119 & $<0.5$ & $<5$ & $<0.5$ & 52 & 23 & 20 & 1 \\
\hline 15SAB-L056B01 & 185.5 & 0.4 & 0.79 & 0.23 & 0.42 & 0.08 & 411 & $<1$ & 25.1 & 2.6 & 93 & $<0.5$ & $<5$ & $<0.5$ & 52 & 20 & 30 & $<1$ \\
\hline 15SAB-L056B02 & 138.5 & 0.5 & 0.76 & 0.45 & 0.35 & 0.51 & 382 & 1 & 22.6 & 2.38 & 75 & $<0.5$ & $<5$ & 0.5 & 52 & 23 & 10 & 1 \\
\hline 15SAB-L057B01 & 170 & 0.4 & 0.69 & 0.18 & 0.39 & 0.11 & 384 & $<1$ & 22.9 & 2.18 & 67 & $<0.5$ & $<5$ & $<0.5$ & 56 & 27 & 20 & 1 \\
\hline 15SAB-L057B02 & 71.4 & 0.1 & 0.44 & 0.39 & 0.25 & 0.14 & 164 & $<1$ & 15.2 & 1.73 & 37 & $<0.5$ & $<5$ & $<0.5$ & 68 & 2 & 10 & $<1$ \\
\hline 15SAB-L059B01 & 168.5 & 0.2 & 0.7 & 0.13 & 0.37 & 0.07 & 357 & $<1$ & 21.9 & 2.24 & 72 & $<0.5$ & $<5$ & $<0.5$ & 53 & 22 & 10 & $<1$ \\
\hline 15SAB-L066B01 & 137 & 0.1 & 0.45 & 0.1 & 0.25 & 0.07 & 181 & 1 & 14.2 & 1.59 & 43 & $<0.5$ & $<5$ & $<0.5$ & 60 & 41 & $<10$ & 1 \\
\hline 15SAB-L076A01 & 45.2 & 0.3 & 0.12 & 0.05 & 0.08 & & 100 & 1 & 4.4 & 0.49 & 9 & $<0.5$ & $<5$ & $<0.5$ & 66 & 42 & 10 & $<1$ \\
\hline 15SAB-L076A02 & 42.8 & 0.3 & 0.12 & 0.06 & 0.07 & & 101 & $<1$ & 4.2 & 0.44 & 9 & $<0.5$ & $<5$ & $<0.5$ & 62 & 53 & 10 & $<1$ \\
\hline 15SAB-L077A01 & 47.5 & 0.2 & 0.11 & & 0.06 & & 77 & $<1$ & 3.3 & 0.36 & 7 & $<0.5$ & $<5$ & $<0.5$ & 71 & 59 & 10 & $<1$ \\
\hline 15SAB-L077B01 & 173 & 0.6 & 0.26 & 0.08 & 0.17 & & 175 & $<1$ & 9.2 & 0.98 & 15 & $<0.5$ & $<5$ & $<0.5$ & 57 & 9 & 50 & $<1$ \\
\hline 15SAB-L078A01 & 19.3 & 0.3 & 0.14 & 0.06 & 0.08 & & 87 & 3 & 4.4 & 0.49 & 10 & $<0.5$ & $<5$ & $<0.5$ & 82 & 53 & $<10$ & $<1$ \\
\hline 15SAB-L078A02 & 33.6 & 0.4 & 0.09 & 0.17 & 0.06 & 0.38 & 74 & $<1$ & 3.3 & 0.39 & 8 & $<0.5$ & $<5$ & $<0.5$ & 77 & 65 & $<10$ & $<1$ \\
\hline 15SAB-L079A01 & 45.4 & 0.4 & 0.13 & 0.09 & 0.08 & & 79 & $<1$ & 4.6 & 0.5 & 11 & $<0.5$ & $<5$ & $<0.5$ & 74 & 29 & $<10$ & $<1$ \\
\hline 15SAB-L080A01 & 80.9 & 0.4 & 0.21 & & 0.11 & & 164 & $<1$ & 7.4 & 0.8 & 12 & $<0.5$ & $<5$ & $<0.5$ & 41 & 165 & 10 & $<1$ \\
\hline 15SAB-L080A02 & 114 & 0.3 & 0.17 & & 0.1 & & 167 & $<1$ & 6.1 & 0.83 & 9 & $<0.5$ & $<5$ & $<0.5$ & 36 & 12 & 10 & $<1$ \\
\hline 15SAB-L080A03 & 82.7 & 0.3 & 0.18 & & 0.12 & & 167 & 1 & 6.4 & 0.75 & 9 & $<0.5$ & $<5$ & $<0.5$ & 38 & 105 & 10 & $<1$ \\
\hline 15SAB-L112A01 & 460 & & 0.06 & 0.49 & 0.03 & 0.08 & 38 & $<1$ & 1.7 & 0.15 & 7 & $<0.5$ & $<5$ & $<0.5$ & 59 & 60 & $<10$ & 1 \\
\hline 15SAB-L113A01 & 198 & & 0.06 & 0.83 & 0.04 & 0.23 & 34 & 1 & 1.6 & 0.19 & 2 & $<0.5$ & $<5$ & $<0.5$ & 48 & 70 & 10 & $<1$ \\
\hline 15SAB-L113B01 & 116 & & 0.1 & 0.79 & 0.08 & 0.33 & 112 & 1 & 3.6 & 0.36 & 6 & $<0.5$ & $<5$ & $<0.5$ & 70 & 26 & $<10$ & $<1$ \\
\hline 15SAB-L119A01 & 56.7 & & 0.23 & 0.27 & 0.14 & 0.08 & 185 & 1 & 8.4 & 0.95 & 27 & $<0.5$ & $<5$ & $<0.5$ & 94 & 61 & $<10$ & $<1$ \\
\hline 15SAB-M005A01 & 296 & & 0.41 & 0.17 & 0.23 & 0.07 & 647 & $<1$ & 12.6 & 1.61 & 40 & $<0.5$ & $<5$ & 0.5 & 56 & 168 & $<10$ & 2 \\
\hline 15SAB-M008A01 & 121.5 & & 0.5 & 0.23 & 0.32 & 0.07 & 186 & $<1$ & 19.2 & 2.34 & 22 & $<0.5$ & $<5$ & $<0.5$ & 59 & 162 & $<10$ & $<1$ \\
\hline 15SAB-M009A01 & 165 & & 0.61 & 0.09 & 0.34 & & 234 & $<1$ & 20.3 & 2.01 & 23 & $<0.5$ & $<5$ & $<0.5$ & 46 & 1 & $<10$ & 1 \\
\hline 15SAB-R174C01 & 151.5 & 0.4 & 0.7 & & 0.39 & & 357 & $<1$ & 23.7 & 2.62 & 67 & $<0.5$ & $<5$ & $<0.5$ & 67 & 10 & 20 & $<1$ \\
\hline 15SAB-R174C02 & 151.5 & 0.3 & 0.65 & & 0.33 & & 360 & $<1$ & 21.2 & 2.2 & 61 & $<0.5$ & $<5$ & 0.5 & 65 & 24 & 30 & $<1$ \\
\hline 15SAB-W046B01 & 131.5 & & 0.46 & 1.3 & 0.29 & 0.25 & 251 & 1 & 17.8 & 2.1 & 70 & $<0.5$ & $<5$ & $<0.5$ & 54 & 46 & 10 & 1 \\
\hline
\end{tabular}




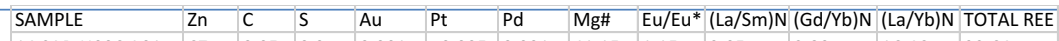
\begin{tabular}{|l|l|l|l|l|l|l|l|l|l|l|l|l|}
\hline 14 SAB-H006 A01 & 67 & 0.05 & 0.3 & 0.001 & $<0.005$ & 0.001 & 41.15 & 1.15 & 3.05 & 2.80 & 16.46 & 92.64 \\
\hline 14 SAB-H080 A01 & 118 & 0.01 & $<0.01$ & 0.001 & $<0.005$ & 0.001 & 57.46 & 0.91 & 2.08 & 2.61 & 8.05 & 87.59
\end{tabular} \begin{tabular}{|l|l|l|l|l|l|l|l|l|l|l|l|l|}
\hline $14 \mathrm{SAB}-\mathrm{H} 080 \mathrm{~A} 01$ & 118 & 0.01 & $<0.01$ & 0.001 & $<0.005$ & 0.001 & 57.46 & 0.91 & 2.08 & 2.61 & 8.05 & 87.59
\end{tabular} \begin{tabular}{|l|l|l|l|l|l|l|l|l|l|l|l|l|}
\hline 14 SAB-H080 B01 & 69 & 0.06 & 0.05 & 0.001 & 0.007 & 0.007 & 71.09 & 0.98 & 0.85 & 1.39 & 1.27 & 15.62
\end{tabular} \begin{tabular}{|l|l|l|l|l|l|l|l|l|l|l|l|l|}
\hline 14 SAB-LO01-A01 & 34 & 0.06 & $<0.01$ & 0.006 & 0.008 & 0.008 & 65.56 & 0.94 & 1.58 & 1.52 & 2.79 & 29.84
\end{tabular} \begin{tabular}{|l|l|l|l|l|l|l|l|l|l|l|l|l|}
\hline 14 SAB-LO01-B01 & 89 & 0.1 & 0.01 & 0.001 & 0.011 & 0.009 & 45.16 & 0.92 & 1.29 & 1.62 & 2.50 & 53.54 \\
\hline
\end{tabular} \begin{tabular}{|l|l|l|l|l|l|l|l|l|l|l|l|l|}
\hline 14 SAB-LO02-A01 & 43 & 0.02 & 0.01 & 0.001 & 0.006 & 0.006 & 70.80 & 0.83 & 1.08 & 1.32 & 1.70 & 16.92 \\
\hline
\end{tabular} \begin{tabular}{|l|l|l|l|l|l|l|l|l|l|l|l|l|}
\hline 14 SAB-L002-A02 & 101 & 0.01 & $<0.01$ & 0.004 & $<0.005$ & 0.004 & 59.52 & 0.97 & 1.59 & 2.42 & 5.50 & 68.1 \\
\hline
\end{tabular} \begin{tabular}{|l|l|l|l|l|l|l|l|l|l|l|l|l|}
\hline 14 SAB-LO03-A01 & 46 & 0.07 & 0.02 & $<0.001$ & 0.009 & 0.005 & 68.99 & 0.90 & 0.87 & 1.42 & 1.51 & 17.79
\end{tabular} \begin{tabular}{|l|l|l|l|l|l|l|l|l|l|l|l|l|}
\hline 14 SAB-L003-A02 & 32 & 0.02 & 0.02 & 0.001 & 0.008 & 0.008 & 70.53 & 0.99 & 1.05 & 1.42 & 1.60 & 16.9 \\
\hline
\end{tabular} \begin{tabular}{|l|l|l|l|l|l|l|l|l|l|l|l|l|}
\hline 14 SAB-LO03-B01 & 101 & 0.01 & 0.1 & 0.002 & 0.015 & 0.012 & 49.60 & 1.04 & 1.86 & 1.26 & 2.52 & 45.79
\end{tabular} \begin{tabular}{|l|l|l|l|l|l|l|l|l|l|l|l|l|}
\hline 14 SAB-L004-A01 & 45 & 0.53 & 0.03 & 0.001 & $<0.005$ & 0.003 & 60.56 & 1.00 & 2.09 & 2.51 & 7.70 & 72.67
\end{tabular} \begin{tabular}{|l|l|l|l|l|l|l|l|l|l|l|l|l|}
\hline 14 SAB-LO04-A02 & 32 & 0.26 & 0.01 & $<0.001$ & $<0.005$ & $<0.001$ & 59.84 & 1.14 & 1.99 & 2.68 & 7.59 & 69.61
\end{tabular} \begin{tabular}{|l|l|l|l|l|l|l|l|l|l|l|l|l|}
\hline 14 SAB-L005-A01 & 81 & 0.07 & 0.02 & 0.003 & $<0.005$ & 0.001 & 56.63 & 0.94 & 1.91 & 2.58 & 7.81 & 86.51
\end{tabular} \begin{tabular}{|l|l|l|l|l|l|l|l|l|l|l|l|l|}
\hline 14 SAB-LO05-A02 & 203 & 0.59 & 0.02 & 0.001 & $<0.005$ & $<0.001$ & 44.31 & 0.87 & 1.98 & 3.74 & 12.22 & 103.56
\end{tabular} \begin{tabular}{|l|l|l|l|l|l|l|l|l|l|l|l|l|}
\hline 14 SAB-L006-A01 & 147 & 0.11 & 0.03 & 0.001 & $<0.005$ & $<0.001$ & 23.21 & 1.00 & 2.18 & 2.90 & 10.08 & 221.22 \\
\hline
\end{tabular} \begin{tabular}{|l|l|l|l|l|l|l|l|l|l|l|l|l|}
1 14 SAB-LO06-A02 & 130 & 0.35 & 0.11 & 0.001 & $<0.005$ & 0.002 & 22.57 & 1.04 & 2.33 & 2.77 & 10.19 & 215.99
\end{tabular} \begin{tabular}{|l|l|l|l|l|l|l|l|l|l|l|l|l|}
\hline 14 SAB-LO06-B01 & 25 & 0.54 & 0.01 & 0.008 & $<0.005$ & 0.004 & 63.86 & 0.81 & 2.04 & 2.73 & 8.95 & 72.71
\end{tabular} \begin{tabular}{|l|l|l|l|l|l|l|l|l|l|l|l|l|}
\hline 14 SAB-LO07-A01 & 99 & 0.33 & 0.07 & $<0.001$ & $<0.005$ & 0.003 & 60.32 & 1.06 & 1.82 & 2.58 & 6.56 & 64.42 \\
\hline
\end{tabular} \begin{tabular}{|l|l|l|l|l|l|l|l|l|l|l|l|l|}
\hline 14 SAB-LO07-A02 & 93 & 0.01 & 0.01 & 0.004 & $<0.005$ & 0.01 & 61.24 & 0.88 & 1.47 & 2.44 & 4.93 & 74.6 \\
\hline
\end{tabular} \begin{tabular}{|l|l|l|l|l|l|l|l|l|l|l|l|l|}
\hline 14 SAB-LO07-A03 & 102 & 0.02 & $<0.01$ & 0.001 & $<0.005$ & 0.001 & 61.76 & 0.83 & 1.37 & 2.02 & 3.30 & 46.05
\end{tabular} \begin{tabular}{|l|l|l|l|l|l|l|l|l|l|l|l|l|}
\hline 14 SAB-L008-A01 & 133 & 0.03 & 0.09 & 0.003 & 0.009 & 0.008 & 32.47 & 0.84 & 1.72 & 2.93 & 7.71 & 149.46 \\
\hline
\end{tabular} \begin{tabular}{|l|l|l|l|l|l|l|l|l|l|l|l|l|}
\hline 14 SAB-L008-A02 & 96 & 0.1 & 0.01 & 0.003 & 0.006 & 0.004 & 48.82 & 0.89 & 1.96 & 2.40 & 8.16 & 97.86
\end{tabular} \begin{tabular}{|l|l|l|l|l|l|l|l|l|l|l|l|l} 
14 SAB-LOOS-A01 & 73 & 0.02 & 0.05 & 0.017 & 0.006 & 0.008 & 64.55 & 0.74 & 1.65 & 2.41 & 5.30 & 57.76
\end{tabular} \begin{tabular}{|l|l|l|l|l|l|l|l|l|l|l|l|l}
\hline 14 SAB-LOOS-A02 & 46 & 0.08 & 1.4 & 0.003 & 0.005 & 0.007 & 61.83 & 1.05 & 1.78 & 2.32 & 5.67 & 55.25
\end{tabular} \begin{tabular}{|l|l|l|l|l|l|l|l|l|l|l|l|l|}
\hline 14 SAB-L009-B02 & 223 & 0.13 & 3.27 & 0.005 & 0.006 & 0.005 & 39.19 & 1.20 & 2.28 & 2.67 & 8.91 & 138.47 \\
\hline
\end{tabular} \begin{tabular}{|l|l|l|l|l|l|l|l|l|l|l|l|l|}
\hline 14 SAB-L010-A01 & 61 & 0.07 & 0.1 & $<0.001$ & $<0.005$ & $<0.001$ & 53.03 & 0.98 & 2.05 & 1.33 & 3.80 & 45.44 \\
\hline
\end{tabular} \begin{tabular}{|l|l|l|l|l|l|l|l|l|l|l|l|l}
\hline 14 SAB-L010-C01 & 197 & 0.09 & 0.14 & 0.005 & 0.008 & 0.005 & 59.13 & 0.72 & 2.59 & 2.38 & 10.61 & 82.32
\end{tabular} \begin{tabular}{|l|l|l|l|l|l|l|l|l|l|l|l|l|}
\hline 14 SAB-L011-A01 & 90 & 0.01 & 0.1 & 0.001 & $<0.005$ & 0.002 & 38.39 & 0.96 & 1.12 & 1.45 & 1.97 & 46.48
\end{tabular} \begin{tabular}{|l|l|l|l|l|l|l|l|l|l|l|l|l|}
\hline 14 SAB-L011-A02 & 97 & 0.06 & 0.03 & 0.001 & 0.025 & 0.051 & 69.54 & 2.39 & 5.10 & 1.19 & 11.95 & 7.18 \\
\hline
\end{tabular} \begin{tabular}{|l|l|l|l|l|l|l|l|l|l|l|l|l|}
\hline 14 SAB-L012-A01 & 91 & 0.01 & 0.09 & 0.001 & $<0.005$ & 0.001 & 38.28 & 1.02 & 0.97 & 1.24 & 1.46 & 46.81
\end{tabular} \begin{tabular}{|l|l|l|l|l|l|l|l|l|l|l|l|l|}
\hline 14 SAB-L012-A02 & 122 & 0.07 & 0.02 & 0.001 & $<0.005$ & 0.001 & 66.87 & 1.31 & 1.89 & 2.70 & 8.54 & 32.09
\end{tabular}

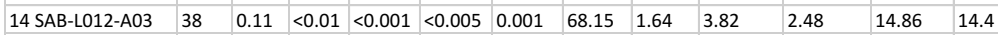
\begin{tabular}{|l|l|l|l|l|l|l|l|l|l|l|l|l|}
\hline 14 SAB-L013-A01 & 42 & 0.15 & 0.02 & $<0.001$ & $<0.005$ & 0.001 & 66.18 & 3.25 & 5.16 & 2.95 & 28.69 & 12.27
\end{tabular} \begin{tabular}{|l|l|l|l|l|l|l|l|l|l|l|l|l|}
14 SAB-L013-A02 & 35 & 0.19 & 0.01 & 0.001 & $<0.005$ & $<0.001$ & 65.18 & 2.04 & 4.20 & 2.18 & 18.26 & 12.49
\end{tabular} \begin{tabular}{|l|l|l|l|l|l|l|l|l|l|l|l|l|}
\hline 14 SAB-L014-A01 & 53 & 0.11 & 0.02 & $<0.001$ & $<0.005$ & $<0.001$ & 66.06 & 1.28 & 3.62 & 1.95 & 13.50 & 15.71
\end{tabular} \begin{tabular}{|l|l|l|l|l|l|l|l|l|l|l|l|l|l|}
\hline 14 SAB-L014-A02 & 227 & 0.01 & $<0.01$ & $<0.001$ & $<0.005$ & $<0.001$ & 59.09 & 0.73 & 3.91 & 3.02 & 20.32 & 134.86 \\
\hline 14 SAB-015-A01 & 46 & 0.14 & 0.29 & 0.001 & $<0.005$ & 0.002 & 35.94 & 1.46 & 2.15 & 2.83 & 10.99 & 40.81 \\
\hline
\end{tabular} \begin{tabular}{|l|l|l|l|l|l|l|l|l|l|l|l|l|}
\hline 14 SAB-L015-A01 & 46 & 0.14 & 0.29 & 0.001 & $<0.005$ & 0.002 & 35.94 & 1.46 & 2.15 & 2.83 & 10.99 & 40.81 \\
\hline 14 SAB-L015A02 & 4 & 0.14 & 0.37 & 0.002 & $<0.005$ & 0.004 & 32.46 & 1.50 & 2.89 & 3.23 & 14.35 & 31.54
\end{tabular} \begin{tabular}{|l|l|l|l|l|l|l|l|l|l|l|l|l} 
14 SAB-L015-A02 & 49 & 0.14 & 0.37 & 0.002 & $<0.005$ & 0.004 & 32.46 & 1.50 & 2.89 & 3.23 & 14.35 & 31.54
\end{tabular} \begin{tabular}{|l|l|l|l|l|l|l|l|l|l|l|l|l|}
\hline 14 SAB-L016-A01 & 26 & 0.06 & $<0.01$ & $<0.001$ & $<0.005$ & 0.001 & 57.69 & 1.70 & 5.99 & 2.87 & 35.65 & 66.64 \\
\hline
\end{tabular} \begin{tabular}{|l|l|l|l|l|l|l|l|l|l|l|l|l|}
\hline 14 SAB-L017-A02 & 26 & 0.01 & 0.09 & 0.002 & $<0.005$ & $<0.001$ & 52.80 & 1.80 & 6.96 & 2.02 & 33.59 & 72.99 \\
\hline
\end{tabular} \begin{tabular}{|l|l|l|l|l|l|l|l|l|l|l|l|l}
14 SAB-R005 A01 & 33 & 0.01 & 0.06 & $<0.001$ & $<0.005$ & $<0.001$ & 68.91 & 1.14 & 2.43 & 2.32 & 9.62 & 30.48
\end{tabular} \begin{tabular}{|l|l|l|l|l|l|l|l|l|l|l|l|l|}
\hline 14 SAB-R006 A01 & 14 & 0.06 & 0.01 & $<0.001$ & $<0.005$ & $<0.001$ & 51.12 & 2.36 & 3.78 & 2.07 & 20.32 & 14.99
\end{tabular}

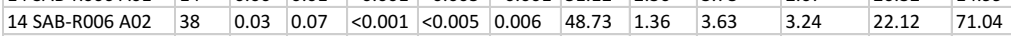
\begin{tabular}{|l|l|l|l|l|l|l|l|l|l|l|l|l|}
\hline 14 SAB-R010 A01 & 40 & 0.22 & 0.01 & 0.01 & 0.007 & 0.008 & 76.60 & 1.11 & 0.93 & 1.47 & 1.70 & 13.52 \\
\hline
\end{tabular} \begin{tabular}{|l|l|l|l|l|l|l|l|l|l|l|l|l|}
14 SAB-S130 A01 & 34 & 0.02 & $<0.01$ & $<0.001$ & 0.013 & 0.002 & 65.07 & 1.00 & 1.49 & 1.45 & 2.59 & 26.76
\end{tabular} \begin{tabular}{|l|l|l|l|l|l|l|l|l|l|l|l|l|}
14 SUB-H029 B2 & 55 & 0.65 & 0.12 & $<0.001$ & 0.005 & 0.006 & 76.46 & 1.02 & 0.76 & 1.18 & 0.98 & 7.2
\end{tabular} \begin{tabular}{|l|l|l|l|l|l|l|l|l|l|l|l|l|l|}
\hline 15SAB-D196A01 & 75 & 0.04 & 0.04 & 0.001 & $<0.005$ & $<0.001$ & 61.43 & 1.99 & 3.62 & 1.65 & 9.70 & 11.75 \\
\hline
\end{tabular} \begin{tabular}{|l|l|l|l|l|l|l|l|l|l|l|l|l|}
\hline 15SAB-D196A02 & 42 & 0.07 & 0.06 & 0.001 & $<0.005$ & $<0.001$ & 62.32 & 1.41 & 1.98 & 1.63 & 4.70 & 12.84 \\
\hline
\end{tabular} \begin{tabular}{|l|l|l|l|l|l|l|l|l|l|l|l|l|}
\hline 15SAB-D196B01 & 49 & 0.04 & 0.15 & 0.001 & $<0.005$ & $<0.001$ & 56.2 & 1.76 & 2.37 & 1.54 & 5.26 & 13.81
\end{tabular} \begin{tabular}{|l|l|l|l|l|l|l|l|l|l|l|l|l|}
\hline 15SAB-D237A01 & 86 & 0.02 & 0.06 & 0.001 & $<0.005$ & $<0.001$ & 48.04 & 0.50 & 0.80 & 1.17 & 0.93 & 51.85
\end{tabular}

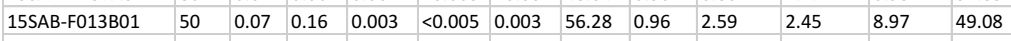
\begin{tabular}{|l|l|l|l|l|l|l|l|l|l|l|l|l|}
\hline 15SAB-F034B01 & 109 & 0.05 & 0.05 & $<0.001$ & $<0.005$ & $<0.001$ & 35.02 & 0.86 & 1.80 & 1.34 & 3.16 & 97.72 \\
\hline
\end{tabular} \begin{tabular}{|l|l|l|l|l|l|l|l|l|l|l|l|l}
\hline 15SAB-L028A01 & 123 & 0.06 & 0.09 & 0.001 & $<0.005$ & 0.001 & 27.54 & 0.95 & 1.58 & 1.27 & 2.49 & 92.64
\end{tabular} \begin{tabular}{|l|l|l|l|l|l|l|l|l|l|l|l|l|}
\hline 15SAB-L056B01 & 116 & 0.79 & 0.43 & 0.007 & 0.017 & 0.014 & 36.26 & 0.91 & 1.48 & 1.44 & 2.54 & 71.99 \\
\hline
\end{tabular} \begin{tabular}{|l|l|l|l|l|l|l|l|l|l|l|l|l|}
\hline 15SAB-L056B02 & 155 & 0.26 & 0.09 & 0.004 & 0.014 & 0.015 & 35.87 & 0.81 & 1.55 & 1.47 & 2.98 & 73.75 \\
\hline
\end{tabular} \begin{tabular}{|l|l|l|l|l|l|l|l|l|l|l|l|l|}
\hline 15SAB-L057B01 & 114 & 0.31 & 0.06 & 0.006 & 0.014 & 0.013 & 35.95 & 0.88 & 1.19 & 1.51 & 2.27 & 60.53 \\
\hline
\end{tabular} \begin{tabular}{|l|l|l|l|l|l|l|l|l|l|l|l|l|}
\hline 15SAB-L057B02 & 96 & 0.05 & 0.01 & 0.002 & 0.005 & 0.005 & 55.91 & 0.81 & 1.72 & 1.19 & 2.28 & 41.53
\end{tabular} \begin{tabular}{|l|l|l|l|l|l|l|l|l|l|l|l|l|}
\hline 15SAB-L059B01 & 104 & 0.07 & 0.02 & 0.003 & 0.013 & 0.011 & 35.74 & 0.98 & 1.24 & 1.42 & 2.02 & 55.66 \\
\hline
\end{tabular} \begin{tabular}{|l|l|l|l|l|l|l|l|l|l|l|l|l|}
\hline 15SAB-L066B01 & 81 & 0.02 & 0.07 & 0.001 & $<0.005$ & 0.001 & 46.74 & 0.98 & 1.75 & 1.22 & 2.62 & 42.39 \\
\hline
\end{tabular} \begin{tabular}{|l|l|l|l|l|l|l|l|l|l|l|l|l|}
\hline 15SAB-L076A01 & 23 & 0.08 & 0.04 & 0.001 & 0.008 & 0.015 & 67.2 & 1.33 & 0.86 & 1.05 & 0.88 & 7.05 \\
\hline
\end{tabular} \begin{tabular}{|l|l|l|l|l|l|l|l|l|l|l|l|l|}
\hline 15SAB-L076A02 & 12 & 0.05 & 0.05 & 0.002 & 0.011 & 0.017 & 67.91 & 1.44 & 1.08 & 1.09 & 0.82 & 6.37
\end{tabular} \begin{tabular}{|l|l|l|l|l|l|l|l|l|l|l|l|l|}
\hline 15SAB-LO77A01 & 32 & 0.07 & 0.02 & 0.004 & 0.011 & 0.019 & 69.06 & 1.13 & 0.47 & 0.97 & 0.50 & 5.06 \\
\hline
\end{tabular} \begin{tabular}{|l|l|l|l|l|l|l|l|l|l|l|l|l}
\hline 15SAB-LO77B01 & 18 & 0.02 & 0.01 & 0.001 & $<0.005$ & 0.005 & 65.4 & 0.75 & 0.58 & 1.06 & 0.59 & 13.1
\end{tabular} \begin{tabular}{|l|l|l|l|l|l|l|l|l|l|l|l|l|}
\hline 15SAB-LO78A01 & 53 & 0.1 & 0.01 & 0.002 & 0.025 & 0.036 & 72.59 & 0.83 & 1.08 & 1.06 & 1.02 & 7.09
\end{tabular} \begin{tabular}{|l|l|l|l|l|l|l|l|l|l|l|l|l|}
\hline 15SAB-LO78A02 & 18 & 0.05 & 0.03 & 0.001 & 0.022 & 0.029 & 71.35 & 0.88 & 1.16 & 0.93 & 1.29 & 6.21 \\
\hline
\end{tabular} \begin{tabular}{|l|l|l|l|l|l|l|l|l|l|l|l|l|}
\hline 15SAB-L079A01 & 25 & 0.03 & 0.02 & $<0.001$ & 0.013 & 0.025 & 69.39 & 0.97 & 1.05 & 1.09 & 1.00 & 7.69 \\
\hline
\end{tabular} \begin{tabular}{|l|l|l|l|l|l|l|l|l|l|l|l|l|}
\hline 15SAB-L08OA01 & 43 & 0.04 & 0.04 & 0.002 & $<0.005$ & 0.001 & 62.54 & 1.03 & 0.77 & 1.02 & 0.63 & 10.51
\end{tabular} \begin{tabular}{|l|l|l|l|l|l|l|l|l|l|l|l|l|}
\hline 15SAB-L08OA02 & 50 & 0.02 & 0.01 & $<0.001$ & $<0.005$ & 0.001 & 60.53 & 1.35 & 0.74 & 0.76 & 0.60 & 9.51
\end{tabular} \begin{tabular}{|l|l|l|l|l|l|l|l|l|l|l|l|l|}
\hline 15SAB-L080A03 & 41 & 0.05 & 0.08 & 0.002 & $<0.005$ & $<0.001$ & 62.39 & 1.21 & 0.71 & 0.93 & 0.67 & 9.47 \\
\hline
\end{tabular} \begin{tabular}{|l|l|l|l|l|l|l|l|l|l|l|l|l|}
\hline 15SAB-L112A01 & 41 & 0.04 & 0.06 & $<0.001$ & $<0.005$ & 0.001 & 61.3 & 2.04 & 4.75 & 2.21 & 18.65 & 17.21 \\
\hline
\end{tabular} \begin{tabular}{|l|l|l|l|l|l|l|l|l|l|l|l|l|}
\hline 15SAB-L113A01 & 31 & 0.05 & 0.04 & 0.003 & 0.012 & 0.014 & 66.54 & 1.72 & 3.90 & 1.26 & 9.82 & 12.16
\end{tabular} \begin{tabular}{|l|l|l|l|l|l|l|l|l|l|l|l|l|}
\hline 15SAB-L113B01 & 58 & 0.07 & 0.02 & $<0.001$ & $<0.005$ & 0.001 & 65.74 & 1.15 & 2.21 & 1.63 & 5.18 & 15.82 \\
\hline
\end{tabular} \begin{tabular}{|l|l|l|l|l|l|l|l|l|l|l|l|l|}
\hline 15SAB-L119A01 & 64 & 0.25 & 0.08 & $<0.001$ & 0.011 & 0.01 & 68.42 & 0.90 & 1.16 & 1.38 & 1.66 & 19.99 \\
\hline
\end{tabular} \begin{tabular}{|l|l|l|l|l|l|l|l|l|l|l|l|l|}
\hline 15SAB-M005A01 & 155 & 0.02 & 0.42 & $<0.001$ & $<0.005$ & $<0.001$ & 24.2 & 1.20 & 2.28 & 1.37 & 4.14 & 60.79
\end{tabular} \begin{tabular}{|l|l|l|l|l|l|l|l|l|l|l|l|l|}
\hline 15SAB-M008A01 & 81 & 0.03 & 0.11 & $<0.001$ & $<0.005$ & 0.001 & 58.1 & 0.62 & 1.26 & 0.87 & 1.13 & 35.13 \\
\hline
\end{tabular} \begin{tabular}{|l|l|l|l|l|l|l|l|l|l|l|l|l|}
\hline 15SAB-M009A01 & 105 & 0.02 & 0.02 & $<0.001$ & $<0.005$ & 0.001 & 47.34 & 0.49 & 0.91 & 1.55 & 1.57 & 45.92 \\
\hline
\end{tabular} \begin{tabular}{|l|l|l|l|l|l|l|l|l|l|l|l|l|}
\hline 15SAB-R174C01 & 116 & 0.08 & 0.02 & $<0.001$ & 0.01 & 0.008 & 39.79 & 0.87 & 1.17 & 1.38 & 1.72 & 60.04 \\
\hline
\end{tabular} \begin{tabular}{|l|l|l|l|l|l|l|l|l|l|l|l|l|}
\hline 15SAB-R174C02 & 113 & 0.09 & 0.02 & $<0.001$ & 0.011 & 0.012 & 41.08 & 1.00 & 1.26 & 1.35 & 2.05 & 55.95 \\
\hline
\end{tabular} \begin{tabular}{|l|l|l|l|l|l|l|l|l|l|l|l|l|}
\hline 15SAB-W046B01 & 89 & 0.03 & 0.14 & $<0.001$ & $<0.005$ & 0.001 & 41.66 & 0.94 & 1.94 & 1.17 & 2.66 & 51.39
\end{tabular} 


\section{Appendix D - Mineral Geochemical Data}




\begin{tabular}{|c|c|c|c|c|c|c|c|c|c|c|c|c|c|c|c|c|c|}
\hline \multicolumn{18}{|c|}{ Olivine - Electron Microprobe Data } \\
\hline SAMPLE & Mineral & $\mathrm{SiO} 2$ & $\mathrm{Al} 2 \mathrm{O} 3$ & $\mathrm{TiO} 2$ & $\mathrm{Cr} 2 \mathrm{O} 3$ & $\mathrm{FeO}$ & $\mathrm{MnO}$ & $\mathrm{MgO}$ & $\mathrm{NiO}$ & $\mathrm{ZnO}$ & $\mathrm{CaO}$ & $\mathrm{Na} 2 \mathrm{O}$ & K2O & $\mathrm{BaO}$ & $\mathrm{F}$ & $\mathrm{Cl}$ & Total \\
\hline 14SAB-H080A01-spot1-1 & Olivine & 36.74 & 0.01 & 0.02 & 0.00 & 30.44 & 0.38 & 31.54 & 0.29 & 0.00 & 0.00 & 0.00 & 0.00 & 0.00 & 0.00 & 0.00 & 99.43 \\
\hline 14SAB-H080A01-spot1-2 & Olivine & 36.42 & 0.00 & 0.02 & 0.01 & 30.41 & 0.39 & 31.45 & 0.25 & 0.00 & 0.02 & 0.00 & 0.00 & 0.00 & 0.00 & 0.00 & 98.97 \\
\hline 14SAB-H080A01-spot2-5 & Olivine & 37.35 & 0.00 & 0.00 & 0.01 & 31.09 & 0.39 & 31.39 & 0.24 & 0.00 & 0.02 & 0.00 & 0.00 & 0.00 & 0.00 & 0.00 & 100.48 \\
\hline 14SAB-H080A01-spot2-6 & Olivine & 37.03 & 0.00 & 0.00 & 0.02 & 31.59 & 0.46 & 31.32 & 0.27 & 0.00 & 0.02 & 0.00 & 0.00 & 0.00 & 0.00 & 0.00 & 100.70 \\
\hline 14SAB-H080B01 area 1-2 & Olivine & 38.88 & 0.00 & 0.00 & 0.01 & 19.30 & 0.31 & 40.91 & 0.31 & 0.00 & 0.02 & 0.00 & 0.00 & 0.00 & 0.00 & 0.00 & 99.74 \\
\hline 14SAB-H080B01 area $1-3$ & Olivine & 38.19 & 0.00 & 0.00 & 0.00 & 19.66 & 0.33 & 41.74 & 0.27 & 0.00 & 0.03 & 0.00 & 0.00 & 0.00 & 0.00 & 0.00 & 100.22 \\
\hline 14SAB-H080B01 area 2-1 & Olivine & 38.69 & 0.00 & 0.00 & 0.00 & 19.29 & 0.29 & 41.59 & 0.33 & 0.00 & 0.03 & 0.00 & 0.00 & 0.00 & 0.00 & 0.00 & 100.21 \\
\hline 14SAB-H080B01 area $2-2$ & Olivine & 38.71 & 0.01 & 0.00 & 0.00 & 19.25 & 0.30 & 41.22 & 0.33 & 0.00 & 0.02 & 0.00 & 0.00 & 0.00 & 0.00 & 0.00 & 99.84 \\
\hline 14SAB-L001A01-spot2-3 & Olivine & 38.01 & 0.00 & 0.00 & 0.00 & 25.10 & 0.42 & 36.28 & 0.30 & 0.00 & 0.00 & 0.00 & 0.00 & 0.00 & 0.00 & 0.00 & 100.11 \\
\hline 14SAB-L001A01-spot2-4 & Olivine & 38.04 & 0.00 & 0.00 & 0.00 & 24.95 & 0.40 & 36.08 & 0.30 & 0.00 & 0.03 & 0.00 & 0.00 & 0.00 & 0.00 & 0.00 & 99.79 \\
\hline 14SAB-L002A01-spot1-1 & Olivine & 38.01 & 0.00 & 0.00 & 0.00 & 19.73 & 0.27 & 40.11 & 0.37 & 0.00 & 0.02 & 0.00 & 0.00 & 0.00 & 0.00 & 0.00 & 98.50 \\
\hline 14SAB-L002A01-spot1-2 & Olivine & 38.97 & 0.00 & 0.00 & 0.00 & 19.87 & 0.31 & 40.08 & 0.36 & 0.00 & 0.02 & 0.00 & 0.00 & 0.00 & 0.00 & 0.00 & 99.60 \\
\hline 14SAB-L002A01-spot2-3 & Olivine & 39.19 & 0.00 & 0.00 & 0.01 & 19.91 & 0.27 & 40.10 & 0.29 & 0.00 & 0.01 & 0.00 & 0.00 & 0.00 & 0.00 & 0.00 & 99.79 \\
\hline 14SAB-L002A02-spot1-1 & Olivine & 36.78 & 0.00 & 0.00 & 0.00 & 31.02 & 0.45 & 31.48 & 0.26 & 0.00 & 0.01 & 0.00 & 0.00 & 0.00 & 0.00 & 0.00 & 100.00 \\
\hline 14SAB-L002A02-spot1-2 & Olivine & 36.57 & 0.00 & 0.01 & 0.00 & 31.32 & 0.41 & 31.39 & 0.27 & 0.00 & 0.02 & 0.00 & 0.00 & 0.00 & 0.00 & 0.00 & 100.01 \\
\hline 14SAB-L002A02-spot2-2 & Olivine & 37.14 & 0.00 & 0.01 & 0.01 & 30.93 & 0.47 & 30.71 & 0.31 & 0.00 & 0.03 & 0.00 & 0.00 & 0.00 & 0.00 & 0.00 & 99.60 \\
\hline 14SAB-L002A02-spot2-3 & Olivine & 37.04 & 0.00 & 0.00 & 0.01 & 30.92 & 0.46 & 31.03 & 0.28 & 0.00 & 0.04 & 0.00 & 0.00 & 0.00 & 0.00 & 0.00 & 99.79 \\
\hline 14SAB-L003A01-spot1-2 & Olivine & 38.84 & 0.00 & 0.00 & 0.00 & 20.60 & 0.31 & 39.60 & 0.25 & 0.00 & 0.02 & 0.00 & 0.00 & 0.00 & 0.00 & 0.00 & 99.61 \\
\hline 14SAB-L003A01-spot1-3 & Olivine & 38.32 & 0.00 & 0.00 & 0.03 & 20.43 & 0.25 & 39.56 & 0.33 & 0.00 & 0.01 & 0.00 & 0.00 & 0.00 & 0.00 & 0.00 & 98.93 \\
\hline 14SAB-L003A01-spot2-2 & Olivine & 38.67 & 0.00 & 0.00 & 0.00 & 20.13 & 0.00 & 40.04 & 0.27 & 0.00 & 0.00 & 0.00 & 0.00 & 0.00 & 0.00 & 0.00 & 99.11 \\
\hline 14SAB-L004A01-spot1-4 & Olivine & 37.53 & 0.00 & 0.00 & 0.00 & 28.76 & 0.00 & 32.90 & 0.30 & 0.00 & 0.01 & 0.00 & 0.00 & 0.00 & 0.00 & 0.00 & 99.51 \\
\hline 14SAB-L004A01-spot2-6 & Olivine & 37.39 & 0.00 & 0.00 & 0.01 & 28.50 & 0.41 & 33.22 & 0.27 & 0.00 & 0.01 & 0.00 & 0.00 & 0.00 & 0.00 & 0.00 & 99.81 \\
\hline 14SAB-L004A01-spot2-7 & Olivine & 37.09 & 0.00 & 0.00 & 0.00 & 28.62 & 0.33 & 32.84 & 0.31 & 0.00 & 0.02 & 0.00 & 0.00 & 0.00 & 0.00 & 0.00 & 99.21 \\
\hline 14SAB-L005A01-spot1-3 & Olivine & 36.84 & 0.00 & 0.00 & 0.00 & 31.33 & 0.41 & 31.43 & 0.24 & 0.00 & 0.02 & 0.00 & 0.00 & 0.00 & 0.00 & 0.00 & 100.27 \\
\hline 14SAB-L005A01-spot2-1 & Olivine & 36.75 & 0.00 & 0.00 & 0.00 & 31.31 & 0.45 & 31.74 & 0.26 & 0.00 & 0.01 & 0.00 & 0.00 & 0.00 & 0.00 & 0.00 & 100.51 \\
\hline 14SAB-L006B01-spot1-5 & Olivine & 37.84 & 0.00 & 0.00 & 0.00 & 24.41 & 0.36 & 36.34 & 0.31 & 0.00 & 0.03 & 0.00 & 0.00 & 0.00 & 0.00 & 0.00 & 99.29 \\
\hline 14SAB-L006B01-spot1-5 & Olivine & 37.99 & 0.00 & 0.00 & 0.00 & 24.51 & 0.31 & 36.70 & 0.31 & 0.00 & 0.02 & 0.00 & 0.00 & 0.00 & 0.00 & 0.00 & 99.84 \\
\hline 14SAB-L006B01-spot2-1 & Olivine & 37.70 & 0.00 & 0.00 & 0.00 & 25.41 & 0.34 & 35.62 & 0.28 & 0.00 & 0.04 & 0.00 & 0.00 & 0.00 & 0.00 & 0.00 & 99.39 \\
\hline 14SAB-L007A02-spot1-1 & Olivine & 37.94 & 0.00 & 0.00 & 0.00 & 26.22 & 0.32 & 35.51 & 0.28 & 0.00 & 0.03 & 0.00 & 0.00 & 0.00 & 0.00 & 0.00 & 100.30 \\
\hline 14SAB-L007A02-spot1-2 & Olivine & 37.89 & 0.00 & 0.00 & 0.00 & 27.05 & 0.33 & 34.81 & 0.29 & 0.00 & 0.00 & 0.00 & 0.00 & 0.00 & 0.00 & 0.00 & 100.37 \\
\hline 14SAB-L007A02-spot2-4 & Olivine & 37.85 & 0.01 & 0.00 & 0.00 & 27.34 & 0.38 & 34.48 & 0.25 & 0.00 & 0.01 & 0.00 & 0.00 & 0.00 & 0.00 & 0.00 & 100.32 \\
\hline 14SAB-L007A02-spot2-5 & Olivine & 37.71 & 0.01 & 0.00 & 0.00 & 27.23 & 0.31 & 34.75 & 0.33 & 0.00 & 0.00 & 0.00 & 0.00 & 0.00 & 0.00 & 0.00 & 100.35 \\
\hline 14SAB-L010C01-spot1-3 & Olivine & 37.13 & 0.00 & 0.00 & 0.02 & 28.55 & 0.41 & 33.58 & 0.17 & 0.00 & 0.02 & 0.00 & 0.00 & 0.00 & 0.00 & 0.00 & 99.88 \\
\hline 14SAB-L010C01-spot1-4 & Olivine & 36.89 & 0.00 & 0.00 & 0.00 & 29.07 & 0.43 & 33.83 & 0.15 & 0.00 & 0.03 & 0.00 & 0.00 & 0.00 & 0.00 & 0.00 & 100.40 \\
\hline 14SAB-L010C01-spot2-1 & Olivine & 37.14 & 0.00 & 0.00 & 0.03 & 28.67 & 0.42 & 33.66 & 0.12 & 0.00 & 0.02 & 0.00 & 0.00 & 0.00 & 0.00 & 0.00 & 100.06 \\
\hline 14SAB-R010A01-spot1-1 & Olivine & 40.14 & 0.00 & 0.01 & 0.01 & 15.52 & 0.29 & 43.93 & 0.29 & 0.00 & 0.01 & 0.00 & 0.00 & 0.00 & 0.00 & 0.00 & 100.21 \\
\hline 14SAB-R010A01-spot1-2 & Olivine & 40.26 & 0.00 & 0.01 & 0.02 & 15.63 & 0.34 & 43.88 & 0.35 & 0.00 & 0.03 & 0.00 & 0.00 & 0.00 & 0.00 & 0.00 & 100.52 \\
\hline 14SAB-R010A01-spot2-2 & Olivine & 39.97 & 0.00 & 0.00 & 0.00 & 15.49 & 0.32 & 43.58 & 0.36 & 0.00 & 0.03 & 0.00 & 0.00 & 0.00 & 0.00 & 0.00 & 99.74 \\
\hline 14SAB-R010A01-spot2-3 & Olivine & 40.15 & 0.00 & 0.00 & 0.01 & 15.45 & 0.33 & 43.86 & 0.38 & 0.00 & 0.02 & 0.00 & 0.00 & 0.00 & 0.00 & 0.00 & 100.20 \\
\hline 14SAB-R010A01-spot2-4 & Olivine & 39.89 & 0.00 & 0.00 & 0.00 & 15.85 & 0.29 & 44.05 & 0.35 & 0.00 & 0.00 & 0.00 & 0.00 & 0.00 & 0.00 & 0.00 & 100.44 \\
\hline 14SAB-S130A01-spot1-1 & Olivine & 38.86 & 0.00 & 0.00 & 0.00 & 21.37 & 0.37 & 38.92 & 0.20 & 0.00 & 0.01 & 0.00 & 0.00 & 0.00 & 0.00 & 0.00 & 99.73 \\
\hline 14SAB-S130A01-spot1-2 & Olivine & 38.88 & 0.00 & 0.00 & 0.00 & 21.60 & 0.34 & 39.10 & 0.20 & 0.00 & 0.01 & 0.00 & 0.00 & 0.00 & 0.00 & 0.00 & 100.13 \\
\hline 14SAB-S130A01-spot2-7 & Olivine & 38.51 & 0.00 & 0.00 & 0.00 & 21.48 & 0.36 & 39.19 & 0.19 & 0.00 & 0.01 & 0.00 & 0.00 & 0.00 & 0.00 & 0.00 & 99.75 \\
\hline 15SAB-D196A01-spot2-5 & Olivine & 38.63 & 0.00 & 0.00 & 0.00 & 24.84 & 0.37 & 37.35 & 0.03 & 0.00 & 0.01 & 0.00 & 0.00 & 0.00 & 0.00 & 0.00 & 101.24 \\
\hline 15SAB-D196A01-spot3-2 & Olivine & 38.30 & 0.00 & 0.02 & 0.00 & 24.24 & 0.39 & 37.03 & 0.02 & 0.00 & 0.01 & 0.00 & 0.00 & 0.00 & 0.00 & 0.00 & 100.01 \\
\hline 15SAB-L076A01 area 1-5 & Olivine & 37.82 & 0.00 & 0.00 & 0.00 & 23.21 & 0.30 & 37.82 & 0.17 & 0.00 & 0.02 & 0.00 & 0.00 & 0.00 & 0.00 & 0.00 & 99.36 \\
\hline 15SAB-L076A01 area 1-6 & Olivine & 38.19 & 0.00 & 0.00 & 0.00 & 23.38 & 0.37 & 37.94 & 0.23 & 0.00 & 0.02 & 0.00 & 0.00 & 0.00 & 0.00 & 0.00 & 100.12 \\
\hline 15SAB-L076A01 area 2-1 & Olivine & 38.59 & 0.00 & 0.00 & 0.00 & 23.08 & 0.33 & 37.89 & 0.23 & 0.00 & 0.04 & 0.00 & 0.00 & 0.00 & 0.00 & 0.00 & 100.16 \\
\hline 15SAB-L076A01 area 2-2 & Olivine & 38.14 & 0.00 & 0.00 & 0.00 & 22.93 & 0.31 & 37.73 & 0.24 & 0.00 & 0.02 & 0.00 & 0.00 & 0.00 & 0.00 & 0.00 & 99.36 \\
\hline 15SAB-L112A01-spot2-5 & Olivine & 37.57 & 0.00 & 0.00 & 0.01 & 26.91 & 0.38 & 35.46 & 0.09 & 0.00 & 0.03 & 0.00 & 0.00 & 0.00 & 0.00 & 0.00 & 100.45 \\
\hline 15SAB-L119A01-spot1-1 & Olivine & 39.77 & 0.00 & 0.00 & 0.00 & 20.38 & 0.32 & 40.61 & 0.29 & 0.00 & 0.00 & 0.00 & 0.00 & 0.00 & 0.00 & 0.00 & 101.36 \\
\hline 15SAB-L119A01-spot1-2 & Olivine & 39.34 & 0.00 & 0.00 & 0.00 & 20.23 & 0.28 & 39.78 & 0.29 & 0.00 & 0.00 & 0.00 & 0.00 & 0.00 & 0.00 & 0.00 & 99.91 \\
\hline 15SAB-L119A01-spot2-3 & Olivine & 38.67 & 0.03 & 0.01 & 0.03 & 20.54 & 0.30 & 39.63 & 0.23 & 0.00 & 0.03 & 0.00 & 0.00 & 0.00 & 0.00 & 0.00 & 99.47 \\
\hline 15SAB-L119A01-spot2-4 & Olivine & 38.50 & 0.00 & 0.01 & 0.01 & 20.39 & 0.30 & 39.62 & 0.25 & 0.00 & 0.03 & 0.00 & 0.00 & 0.00 & 0.00 & 0.00 & 99.09 \\
\hline L012A01-circle2-1 & Olivine & 39.65 & 0.01 & 0.00 & 0.02 & 18.02 & 0.22 & 41.99 & 0.13 & 0.00 & 0.00 & 0.00 & 0.00 & 0.00 & 0.00 & 0.00 & 100.05 \\
\hline L012A01-circle2-2 & Olivine & 39.51 & 0.00 & 0.00 & 0.00 & 17.67 & 0.25 & 41.30 & 0.16 & 0.00 & 0.02 & 0.00 & 0.00 & 0.00 & 0.00 & 0.00 & 98.90 \\
\hline L014-A01-spot2-1 & Olivine & 39.08 & 0.00 & 0.01 & 0.02 & 20.34 & 0.30 & 40.89 & 0.10 & 0.00 & 0.00 & 0.00 & 0.00 & 0.00 & 0.00 & 0.00 & 100.72 \\
\hline L014-A01-spot2-2 & Olivine & 39.06 & 0.02 & 0.00 & 0.00 & 20.18 & 0.29 & 41.00 & 0.11 & 0.00 & 0.01 & 0.00 & 0.00 & 0.00 & 0.00 & 0.00 & 100.66 \\
\hline L014A01-spot1-3 & Olivine & 38.83 & 0.00 & 0.00 & 0.00 & 20.58 & 0.29 & 40.29 & 0.10 & 0.00 & 0.01 & 0.00 & 0.00 & 0.00 & 0.00 & 0.00 & 100.10 \\
\hline L014A01-spot1-4 & Olivine & 38.76 & 0.00 & 0.00 & 0.00 & 20.80 & 0.29 & 39.95 & 0.10 & 0.00 & 0.01 & 0.00 & 0.00 & 0.00 & 0.00 & 0.00 & 99.91 \\
\hline L076-A02-spot2-2 & Olivine & 38.61 & 0.00 & 0.02 & 0.01 & 23.21 & 0.34 & 38.49 & 0.22 & 0.00 & 0.00 & 0.00 & 0.00 & 0.00 & 0.00 & 0.00 & 100.90 \\
\hline L077-A01-spot2-2 & Olivine & 39.17 & 0.03 & 0.01 & 0.01 & 21.02 & 0.28 & 39.95 & 0.20 & 0.00 & 0.00 & 0.00 & 0.01 & 0.00 & 0.00 & 0.00 & 100.68 \\
\hline L079-A01-spot1-1 & Olivine & 39.23 & 0.03 & 0.00 & 0.00 & 20.37 & 0.30 & 40.70 & 0.24 & 0.00 & 0.01 & 0.00 & 0.00 & 0.00 & 0.00 & 0.00 & 100.88 \\
\hline L079-A01-spot2-3 & Olivine & 39.16 & 0.00 & 0.00 & 0.01 & 20.21 & 0.31 & 40.71 & 0.23 & 0.00 & 0.00 & 0.00 & 0.00 & 0.00 & 0.00 & 0.00 & 100.63 \\
\hline
\end{tabular}




\begin{tabular}{|c|c|c|c|c|c|c|c|c|c|c|c|c|c|c|c|c|c|}
\hline \multicolumn{18}{|c|}{ Olivine - Atoms Per Formula Unit } \\
\hline SAMPLE & $\mathrm{Si}$ & Al & $\mathrm{Ti}$ & $\mathrm{Cr}$ & $\mathrm{Fe}$ & $\mathrm{Mn}$ & $\mathrm{Mg}$ & $\mathrm{Ni}$ & $\mathrm{Zn}$ & $\mathrm{Ca}$ & $\mathrm{Na}$ & K & $\mathrm{Ba}$ & $\sum$ cations & $\mathrm{F}$ & $\mathrm{Cl}$ & Fo\% \\
\hline 14SAB-H080A01-spot1-1 & 1.008 & 0.000 & 0.000 & 0.000 & 0.383 & 0.005 & 1.592 & 0.003 & 0.000 & 0.000 & 0.000 & 0.000 & 0.000 & 2.991 & 0 & 0 & 81 \\
\hline 14SAB-H080A01-spot1-2 & 1.015 & 0.000 & 0.000 & 0.000 & 0.380 & 0.005 & 1.582 & 0.003 & 0.000 & 0.001 & 0.000 & 0.000 & 0.000 & 2.985 & 0 & 0 & 81 \\
\hline 14SAB-H080A01-spot2-5 & 1.000 & 0.000 & 0.000 & 0.000 & 0.443 & 0.006 & 1.547 & 0.002 & 0.000 & 0.000 & 0.000 & 0.000 & 0.000 & 3.000 & 0 & 0 & 78 \\
\hline 14SAB-H080A01-spot2-6 & 1.001 & 0.000 & 0.000 & 0.000 & 0.450 & 0.006 & 1.539 & 0.002 & 0.000 & 0.000 & 0.000 & 0.000 & 0.000 & 2.999 & 0 & 0 & 77 \\
\hline 14SAB-H080B01 area 1-2 & 0.999 & 0.000 & 0.000 & 0.000 & 0.435 & 0.007 & 1.558 & 0.002 & 0.000 & 0.000 & 0.000 & 0.000 & 0.000 & 3.001 & 0 & 0 & 78 \\
\hline 14SAB-H080B01 area 1-3 & 0.998 & 0.001 & 0.000 & 0.000 & 0.431 & 0.006 & 1.562 & 0.002 & 0.000 & 0.000 & 0.000 & 0.000 & 0.000 & 3.001 & 0 & 0 & 78 \\
\hline 14SAB-H080B01 area 2-1 & 0.999 & 0.000 & 0.000 & 0.000 & 0.503 & 0.007 & 1.485 & 0.005 & 0.000 & 0.000 & 0.000 & 0.000 & 0.000 & 3.000 & 0 & 0 & 75 \\
\hline 14SAB-H080B01 area 2-2 & 1.005 & 0.001 & 0.000 & 0.000 & 0.451 & 0.006 & 1.527 & 0.004 & 0.000 & 0.000 & 0.000 & 0.000 & 0.000 & 2.995 & 0 & 0 & 77 \\
\hline 14SAB-L001A01-spot2-3 & 1.002 & 0.001 & 0.000 & 0.000 & 0.435 & 0.007 & 1.549 & 0.005 & 0.000 & 0.000 & 0.000 & 0.000 & 0.000 & 2.998 & 0 & 0 & 78 \\
\hline 14SAB-L001A01-spot2-4 & 1.002 & 0.000 & 0.000 & 0.000 & 0.432 & 0.007 & 1.553 & 0.005 & 0.000 & 0.000 & 0.000 & 0.000 & 0.000 & 2.998 & 0 & 0 & 78 \\
\hline 14SAB-L002A01-spot1-1 & 0.995 & 0.000 & 0.000 & 0.000 & 0.432 & 0.006 & 1.565 & 0.008 & 0.000 & 0.000 & 0.000 & 0.000 & 0.000 & 3.005 & 0 & 0 & 78 \\
\hline 14SAB-L002A01-spot1-2 & 1.007 & 0.000 & 0.000 & 0.000 & 0.429 & 0.007 & 1.543 & 0.007 & 0.000 & 0.000 & 0.000 & 0.000 & 0.000 & 2.993 & 0 & 0 & 78 \\
\hline 14SAB-L002A01-spot2-3 & 1.009 & 0.000 & 0.000 & 0.000 & 0.429 & 0.006 & 1.540 & 0.006 & 0.000 & 0.000 & 0.000 & 0.000 & 0.000 & 2.990 & 0 & 0 & 78 \\
\hline 14SAB-L002A02-spot1-1 & 1.000 & 0.000 & 0.000 & 0.000 & 0.706 & 0.010 & 1.277 & 0.006 & 0.000 & 0.000 & 0.000 & 0.000 & 0.000 & 2.999 & 0 & 0 & 64 \\
\hline 14SAB-L002A02-spot1-2 & 0.997 & 0.000 & 0.000 & 0.000 & 0.714 & 0.010 & 1.276 & 0.006 & 0.000 & 0.001 & 0.000 & 0.000 & 0.000 & 3.003 & 0 & 0 & 64 \\
\hline 14SAB-L002A02-spot2-2 & 1.013 & 0.000 & 0.000 & 0.000 & 0.706 & 0.011 & 1.249 & 0.007 & 0.000 & 0.001 & 0.000 & 0.000 & 0.000 & 2.987 & 0 & 0 & 64 \\
\hline 14SAB-L002A02-spot2-3 & 1.009 & 0.000 & 0.000 & 0.000 & 0.704 & 0.011 & 1.260 & 0.006 & 0.000 & 0.001 & 0.000 & 0.000 & 0.000 & 2.991 & 0 & 0 & 64 \\
\hline 14SAB-L003A01-spot1-2 & 1.003 & 0.000 & 0.000 & 0.000 & 0.541 & 0.008 & 1.437 & 0.007 & 0.000 & 0.001 & 0.000 & 0.000 & 0.000 & 2.997 & 0 & 0 & 73 \\
\hline 14SAB-L003A01-spot1-3 & 1.002 & 0.000 & 0.000 & 0.000 & 0.540 & 0.007 & 1.442 & 0.007 & 0.000 & 0.001 & 0.000 & 0.000 & 0.000 & 2.998 & 0 & 0 & 73 \\
\hline 14SAB-L003A01-spot2-2 & 1.003 & 0.000 & 0.000 & 0.000 & 0.566 & 0.008 & 1.413 & 0.006 & 0.000 & 0.001 & 0.000 & 0.000 & 0.000 & 2.997 & 0 & 0 & 71 \\
\hline 14SAB-L004A01-spot1-4 & 1.000 & 0.000 & 0.000 & 0.000 & 0.415 & 0.007 & 1.570 & 0.007 & 0.000 & 0.001 & 0.000 & 0.000 & 0.000 & 2.999 & 0 & 0 & 79 \\
\hline 14SAB-L004A01-spot2-6 & 0.982 & 0.000 & 0.000 & 0.000 & 0.423 & 0.007 & 1.600 & 0.006 & 0.000 & 0.001 & 0.000 & 0.000 & 0.000 & 3.018 & 0 & 0 & 79 \\
\hline 14SAB-L004A01-spot2-7 & 0.992 & 0.000 & 0.000 & 0.000 & 0.414 & 0.006 & 1.589 & 0.007 & 0.000 & 0.001 & 0.000 & 0.000 & 0.000 & 3.008 & 0 & 0 & 79 \\
\hline 14SAB-L005A01-spot1-3 & 0.996 & 0.000 & 0.000 & 0.000 & 0.414 & 0.007 & 1.581 & 0.007 & 0.000 & 0.000 & 0.000 & 0.000 & 0.000 & 3.004 & 0 & 0 & 79 \\
\hline 14SAB-L005A01-spot2-1 & 0.996 & 0.000 & 0.000 & 0.000 & 0.511 & 0.007 & 1.485 & 0.004 & 0.000 & 0.001 & 0.000 & 0.000 & 0.000 & 3.004 & 0 & 0 & 74 \\
\hline 14SAB-L006B01-spot1-5 & 0.998 & 0.000 & 0.000 & 0.000 & 0.511 & 0.008 & 1.479 & 0.005 & 0.000 & 0.001 & 0.000 & 0.000 & 0.000 & 3.002 & 0 & 0 & 74 \\
\hline 14SAB-L006B01-spot1-5 & 1.006 & 0.000 & 0.000 & 0.000 & 0.503 & 0.007 & 1.472 & 0.005 & 0.000 & 0.001 & 0.000 & 0.000 & 0.000 & 2.994 & 0 & 0 & 75 \\
\hline 14SAB-L006B01-spot2-1 & 1.003 & 0.000 & 0.000 & 0.000 & 0.504 & 0.007 & 1.478 & 0.005 & 0.000 & 0.001 & 0.000 & 0.000 & 0.000 & 2.997 & 0 & 0 & 75 \\
\hline 14SAB-L007A02-spot1-1 & 1.008 & 0.000 & 0.000 & 0.000 & 0.326 & 0.006 & 1.645 & 0.006 & 0.000 & 0.000 & 0.000 & 0.000 & 0.000 & 2.992 & 0 & 0 & 83 \\
\hline 14SAB-L007A02-spot1-2 & 1.009 & 0.000 & 0.000 & 0.000 & 0.328 & 0.007 & 1.639 & 0.007 & 0.000 & 0.001 & 0.000 & 0.000 & 0.000 & 2.991 & 0 & 0 & 83 \\
\hline 14SAB-L007A02-spot2-4 & 1.009 & 0.000 & 0.000 & 0.000 & 0.327 & 0.007 & 1.640 & 0.007 & 0.000 & 0.001 & 0.000 & 0.000 & 0.000 & 2.991 & 0 & 0 & 83 \\
\hline 14SAB-L007A02-spot2-5 & 1.009 & 0.000 & 0.000 & 0.000 & 0.325 & 0.007 & 1.643 & 0.008 & 0.000 & 0.000 & 0.000 & 0.000 & 0.000 & 2.991 & 0 & 0 & 84 \\
\hline 14SAB-L010C01-spot1-3 & 1.002 & 0.000 & 0.000 & 0.000 & 0.333 & 0.006 & 1.650 & 0.007 & 0.000 & 0.000 & 0.000 & 0.000 & 0.000 & 2.998 & 0 & 0 & 83 \\
\hline 14SAB-L010C01-spot1-4 & 1.003 & 0.000 & 0.000 & 0.000 & 0.580 & 0.007 & 1.400 & 0.006 & 0.000 & 0.001 & 0.000 & 0.000 & 0.000 & 2.997 & 0 & 0 & 71 \\
\hline 14SAB-L010C01-spot2-1 & 1.005 & 0.000 & 0.000 & 0.000 & 0.600 & 0.008 & 1.377 & 0.006 & 0.000 & 0.000 & 0.000 & 0.000 & 0.000 & 2.995 & 0 & 0 & 70 \\
\hline 14SAB-R010A01-spot1-1 & 1.006 & 0.000 & 0.000 & 0.000 & 0.608 & 0.009 & 1.366 & 0.005 & 0.000 & 0.000 & 0.000 & 0.000 & 0.000 & 2.994 & 0 & 0 & 69 \\
\hline 14SAB-R010A01-spot1-2 & 1.002 & 0.000 & 0.000 & 0.000 & 0.605 & 0.007 & 1.376 & 0.007 & 0.000 & 0.000 & 0.000 & 0.000 & 0.000 & 2.998 & 0 & 0 & 69 \\
\hline 14SAB-R010A01-spot2-2 & 1.006 & 0.000 & 0.000 & 0.000 & 0.446 & 0.007 & 1.529 & 0.005 & 0.000 & 0.000 & 0.000 & 0.000 & 0.000 & 2.994 & 0 & 0 & 77 \\
\hline 14SAB-R010A01-spot2-3 & 1.000 & 0.000 & 0.000 & 0.001 & 0.446 & 0.006 & 1.540 & 0.007 & 0.000 & 0.000 & 0.000 & 0.000 & 0.000 & 2.999 & 0 & 0 & 78 \\
\hline 14SAB-R010A01-spot2-4 & 1.004 & 0.000 & 0.000 & 0.000 & 0.437 & 0.000 & 1.549 & 0.006 & 0.000 & 0.000 & 0.000 & 0.000 & 0.000 & 2.996 & 0 & 0 & 78 \\
\hline 14SAB-S130A01-spot1-1 & 1.009 & 0.000 & 0.000 & 0.000 & 0.432 & 0.007 & 1.536 & 0.006 & 0.000 & 0.000 & 0.000 & 0.000 & 0.000 & 2.991 & 0 & 0 & 78 \\
\hline 14SAB-S130A01-spot1-2 & 1.013 & 0.000 & 0.000 & 0.000 & 0.436 & 0.006 & 1.527 & 0.006 & 0.000 & 0.000 & 0.000 & 0.000 & 0.000 & 2.987 & 0 & 0 & 78 \\
\hline 14SAB-S130A01-spot2-7 & 1.003 & 0.001 & 0.000 & 0.001 & 0.446 & 0.007 & 1.533 & 0.005 & 0.000 & 0.001 & 0.000 & 0.000 & 0.000 & 2.996 & 0 & 0 & 77 \\
\hline 15SAB-D196A01-spot2-5 & 1.002 & 0.000 & 0.000 & 0.000 & 0.444 & 0.007 & 1.538 & 0.005 & 0.000 & 0.001 & 0.000 & 0.000 & 0.000 & 2.997 & 0 & 0 & 78 \\
\hline 15SAB-D196A01-spot3-2 & 1.003 & 0.000 & 0.000 & 0.000 & 0.695 & 0.009 & 1.283 & 0.006 & 0.000 & 0.000 & 0.000 & 0.000 & 0.000 & 2.997 & 0 & 0 & 65 \\
\hline 15SAB-L076A01 area 1-5 & 0.999 & 0.000 & 0.000 & 0.000 & 0.698 & 0.009 & 1.287 & 0.006 & 0.000 & 0.000 & 0.000 & 0.000 & 0.000 & 3.000 & 0 & 0 & 65 \\
\hline 15SAB-L076A01 area 1-6 & 1.009 & 0.000 & 0.000 & 0.000 & 0.702 & 0.009 & 1.264 & 0.005 & 0.000 & 0.000 & 0.000 & 0.000 & 0.000 & 2.991 & 0 & 0 & 64 \\
\hline 15SAB-L076A01 area 2-1 & 1.002 & 0.000 & 0.000 & 0.001 & 0.715 & 0.010 & 1.264 & 0.006 & 0.000 & 0.001 & 0.000 & 0.000 & 0.000 & 2.998 & 0 & 0 & 64 \\
\hline 15SAB-L076A01 area 2-2 & 1.011 & 0.000 & 0.000 & 0.000 & 0.648 & 0.000 & 1.322 & 0.007 & 0.000 & 0.000 & 0.000 & 0.000 & 0.000 & 2.989 & 0 & 0 & 67 \\
\hline 15SAB-L112A01-spot2-5 & 1.006 & 0.000 & 0.000 & 0.000 & 0.641 & 0.009 & 1.332 & 0.006 & 0.000 & 0.000 & 0.000 & 0.000 & 0.000 & 2.994 & 0 & 0 & 68 \\
\hline 15SAB-L119A01-spot1-1 & 1.005 & 0.000 & 0.000 & 0.000 & 0.649 & 0.008 & 1.327 & 0.007 & 0.000 & 0.000 & 0.000 & 0.000 & 0.000 & 2.995 & 0 & 0 & 67 \\
\hline 15SAB-L119A01-spot1-2 & 1.009 & 0.000 & 0.000 & 0.000 & 0.464 & 0.008 & 1.506 & 0.004 & 0.000 & 0.000 & 0.000 & 0.000 & 0.000 & 2.991 & 0 & 0 & 76 \\
\hline 15SAB-L119A01-spot2-3 & 1.006 & 0.000 & 0.000 & 0.000 & 0.467 & 0.008 & 1.508 & 0.004 & 0.000 & 0.000 & 0.000 & 0.000 & 0.000 & 2.994 & 0 & 0 & 76 \\
\hline 15SAB-L119A01-spot2-4 & 1.001 & 0.000 & 0.000 & 0.000 & 0.467 & 0.008 & 1.519 & 0.004 & 0.000 & 0.000 & 0.000 & 0.000 & 0.000 & 2.999 & 0 & 0 & 76 \\
\hline L012A01-circle2-1-oliv & 1.002 & 0.000 & 0.000 & 0.000 & 0.554 & 0.009 & 1.426 & 0.006 & 0.000 & 0.000 & 0.000 & 0.000 & 0.000 & 2.998 & 0 & 0 & 72 \\
\hline L012A01-circle2-2-oliv & 1.005 & 0.000 & 0.000 & 0.000 & 0.551 & 0.009 & 1.422 & 0.006 & 0.000 & 0.001 & 0.000 & 0.000 & 0.000 & 2.995 & 0 & 0 & 72 \\
\hline L014-A01-spot2-1 & 0.996 & 0.000 & 0.000 & 0.000 & 0.596 & 0.009 & 1.401 & 0.002 & 0.000 & 0.001 & 0.000 & 0.000 & 0.000 & 3.004 & 0 & 0 & 70 \\
\hline L014-A01-spot2-2 & 1.003 & 0.000 & 0.000 & 0.000 & 0.539 & 0.008 & 1.446 & 0.001 & 0.000 & 0.000 & 0.000 & 0.000 & 0.000 & 2.997 & 0 & 0 & 73 \\
\hline L014A01-spot1-3 & 1.005 & 0.000 & 0.000 & 0.000 & 0.532 & 0.009 & 1.448 & 0.001 & 0.000 & 0.000 & 0.000 & 0.000 & 0.000 & 2.995 & 0 & 0 & 73 \\
\hline L014A01-spot1-4 & 0.998 & 0.000 & 0.000 & 0.000 & 0.642 & 0.009 & 1.346 & 0.004 & 0.000 & 0.001 & 0.000 & 0.000 & 0.000 & 3.001 & 0 & 0 & 68 \\
\hline L076-A02-spot2-2 & 0.990 & 0.000 & 0.000 & 0.000 & 0.653 & 0.010 & 1.354 & 0.003 & 0.000 & 0.001 & 0.000 & 0.000 & 0.000 & 3.010 & 0 & 0 & 67 \\
\hline L077-A01-spot2-2 & 0.997 & 0.000 & 0.000 & 0.001 & 0.644 & 0.010 & 1.347 & 0.003 & 0.000 & 0.001 & 0.000 & 0.000 & 0.000 & 3.002 & 0 & 0 & 68 \\
\hline L079-A01-spot1-1 & 1.000 & 0.000 & 0.000 & 0.000 & 0.711 & 0.009 & 1.273 & 0.005 & 0.000 & 0.001 & 0.000 & 0.000 & 0.000 & 3.000 & 0 & 0 & 64 \\
\hline L079-A01-spot2-3 & 0.996 & 0.000 & 0.000 & 0.000 & 0.710 & 0.010 & 1.282 & 0.006 & 0.000 & 0.000 & 0.000 & 0.000 & 0.000 & 3.004 & 0 & 0 & 64 \\
\hline
\end{tabular}




\begin{tabular}{|c|c|c|c|c|c|c|c|c|c|c|c|c|c|c|c|c|c|}
\hline \multicolumn{18}{|c|}{ Clinopyroxene - Electron Microprobe Data } \\
\hline SAMPLE & Mineral & $\mathrm{SiO} 2$ & $\mathrm{Al} 2 \mathrm{O} 3$ & $\mathrm{TiO} 2$ & $\mathrm{Cr} 2 \mathrm{O} 3$ & $\mathrm{FeO}$ & $\mathrm{MnO}$ & MgO & $\mathrm{NiO}$ & $\mathrm{ZnO}$ & $\mathrm{CaO}$ & $\mathrm{Na} 2 \mathrm{O}$ & $\mathrm{K} 2 \mathrm{O}$ & $\mathrm{BaO}$ & $\mathrm{F}$ & $\mathrm{Cl}$ & Total \\
\hline 14SAB-L012A02-spot1-3 & Clinopyroxene (rim) & 54.16 & 1.59 & 0.12 & 0.16 & 4.82 & 0.13 & 15.27 & 0.00 & 0.00 & 23.28 & 0.22 & 0.01 & 0.00 & 0.00 & 0.00 & 99.77 \\
\hline 14SAB-L012A02-spot1-4 & Clinopyroxene (body) & 53.21 & 2.19 & 0.21 & 0.27 & 4.99 & 0.14 & 15.33 & 0.00 & 0.00 & 22.58 & 0.33 & 0.00 & 0.00 & 0.08 & 0.01 & 99.33 \\
\hline 14SAB-L012A02-spot1-5 & Clinopyroxene (core) & 51.91 & 3.83 & 0.37 & 0.56 & 5.48 & 0.09 & 15.04 & 0.00 & 0.00 & 20.55 & 0.51 & 0.10 & 0.00 & 0.03 & 0.00 & 98.46 \\
\hline 14SAB-L013A02-spot1-2- & Clinopyroxene & 54.03 & 1.97 & 0.03 & 0.00 & 3.70 & 0.15 & 16.23 & 0.01 & 0.00 & 24.42 & 0.07 & 0.00 & 0.00 & 0.00 & 0.00 & 100.63 \\
\hline 14SAB-L006A01-spot1-1 & Clinopyroxene & 50.28 & 2.12 & 0.32 & 0.02 & 15.74 & 0.41 & 8.40 & 0.01 & 0.00 & 21.82 & 0.41 & 0.00 & 0.00 & 0.00 & 0.00 & 99.52 \\
\hline 14SAB-L006A01-spot1-3 & Clinopyroxene & 50.68 & 1.73 & 0.28 & 0.00 & 15.62 & 0.40 & 8.55 & 0.00 & 0.00 & 21.88 & 0.42 & 0.00 & 0.00 & 0.00 & 0.00 & 99.57 \\
\hline 14SAB-L006A01-spot2-3 & Clinopyroxene & 50.67 & 2.02 & 0.31 & 0.00 & 15.57 & 0.40 & 8.55 & 0.02 & 0.00 & 21.91 & 0.47 & 0.00 & 0.00 & 0.00 & 0.00 & 99.90 \\
\hline 14SAB-L006A01-spot2-4 & Clinopyroxene & 51.45 & 0.79 & 0.09 & 0.00 & 15.06 & 0.43 & 9.19 & 0.02 & 0.00 & 22.53 & 0.30 & 0.00 & 0.00 & 0.00 & 0.00 & 99.86 \\
\hline 14SAB-L006B01-spot1-2 & Clinopyroxene & 53.94 & 1.92 & 0.32 & 0.03 & 4.19 & 0.18 & 15.63 & 0.04 & 0.00 & 24.11 & 0.02 & 0.00 & 0.00 & 0.00 & 0.00 & 100.39 \\
\hline 14SAB-L006B01-spot2-3 & Clinopyroxene & 52.07 & 2.91 & 0.57 & 0.09 & 4.24 & 0.11 & 15.25 & 0.04 & 0.00 & 24.01 & 0.03 & 0.00 & 0.00 & 0.00 & 0.00 & 99.32 \\
\hline 14SAB-L008A02-spot1-3 & Clinopyroxene & 51.63 & 2.44 & 0.40 & 0.07 & 9.68 & 0.19 & 12.24 & 0.06 & 0.00 & 23.09 & 0.23 & 0.01 & 0.00 & 0.00 & 0.00 & 100.04 \\
\hline 14SAB-L008A02-spot1-4 & Clinopyroxene & 51.72 & 2.45 & 0.39 & 0.06 & 9.79 & 0.21 & 12.25 & 0.07 & 0.00 & 22.70 & 0.19 & 0.01 & 0.00 & 0.00 & 0.00 & 99.83 \\
\hline 14SAB-L008A02-spot2-1 & Clinopyroxene & 51.41 & 2.42 & 0.40 & 0.13 & 9.60 & 0.22 & 12.27 & 0.07 & 0.00 & 22.40 & 0.18 & 0.00 & 0.00 & 0.00 & 0.00 & 99.11 \\
\hline 14SAB-L008A02-spot2-2 & Clinopyroxene & 51.66 & 2.53 & 0.45 & 0.12 & 9.81 & 0.18 & 12.34 & 0.05 & 0.00 & 22.38 & 0.22 & 0.00 & 0.00 & 0.00 & 0.00 & 99.73 \\
\hline 14SAB-L010A01-spot1-1 & Clinopyroxene & 52.41 & 2.18 & 0.25 & 0.03 & 8.49 & 0.24 & 13.26 & 0.00 & 0.00 & 22.52 & 0.39 & 0.00 & 0.00 & 0.00 & 0.00 & 99.78 \\
\hline 14SAB-L010A01-spot2-2 & Clinopyroxene & 52.83 & 2.14 & 0.29 & 0.01 & 8.34 & 0.22 & 13.28 & 0.02 & 0.00 & 22.43 & 0.37 & 0.00 & 0.00 & 0.00 & 0.00 & 99.95 \\
\hline 14SAB-L004A01-spot2-2 & Clinopyroxene & 53.37 & 2.12 & 0.37 & 0.06 & 4.90 & 0.12 & 15.06 & 0.04 & 0.00 & 23.32 & 0.07 & 0.00 & 0.00 & 0.00 & 0.00 & 99.42 \\
\hline 14SAB-L004A01-spot2-5 & Clinopyroxene & 52.31 & 2.68 & 0.46 & 0.10 & 4.96 & 0.14 & 14.97 & 0.06 & 0.00 & 23.43 & 0.08 & 0.00 & 0.00 & 0.00 & 0.00 & 99.18 \\
\hline 14SAB-L001B01-spot1-1 & Clinopyroxene & 53.05 & 0.65 & 0.05 & 0.06 & 10.68 & 0.25 & 12.55 & 0.05 & 0.00 & 22.74 & 0.15 & 0.00 & 0.00 & 0.00 & 0.00 & 100.22 \\
\hline 14SAB-L001B01-spot1-2 & Clinopyroxene & 53.44 & 1.11 & 0.18 & 0.11 & 10.71 & 0.17 & 12.30 & 0.05 & 0.00 & 22.17 & 0.27 & 0.00 & 0.00 & 0.00 & 0.00 & 100.50 \\
\hline 14SAB-L001B01-spot2-2 & Clinopyroxene & 52.03 & 1.95 & 0.30 & 0.08 & 9.97 & 0.24 & 12.64 & 0.04 & 0.00 & 22.10 & 0.28 & 0.00 & 0.00 & 0.00 & 0.00 & 99.63 \\
\hline 14SAB-L001B01-spot2-3 & Clinopyroxene & 52.96 & 1.36 & 0.22 & 0.06 & 9.31 & 0.22 & 13.25 & 0.08 & 0.00 & 22.19 & 0.26 & 0.00 & 0.00 & 0.00 & 0.00 & 99.89 \\
\hline 14SAB-L003B01-spot1-3 & Clinopyroxene & 53.10 & 1.28 & 0.14 & 0.05 & 8.85 & 0.42 & 13.62 & 0.02 & 0.00 & 22.22 & 0.27 & 0.00 & 0.00 & 0.00 & 0.00 & 99.96 \\
\hline 14SAB-L003B01-spot1-4 & Clinopyroxene & 53.21 & 1.29 & 0.16 & 0.04 & 9.13 & 0.33 & 13.65 & 0.00 & 0.00 & 22.26 & 0.27 & 0.00 & 0.00 & 0.00 & 0.00 & 100.35 \\
\hline 14SAB-L003B01-spot2-4 & Clinopyroxene & 52.79 & 1.28 & 0.14 & 0.06 & 8.72 & 0.32 & 13.79 & 0.01 & 0.00 & 22.27 & 0.24 & 0.00 & 0.00 & 0.00 & 0.00 & 99.62 \\
\hline 14SAB-L003B01-spot2-5 & Clinopyroxene & 53.29 & 1.32 & 0.14 & 0.08 & 8.47 & 0.35 & 13.53 & 0.01 & 0.00 & 22.81 & 0.30 & 0.00 & 0.00 & 0.00 & 0.00 & 100.30 \\
\hline 15SAB-L056B01-spot1-1 & Clinopyroxene & 51.79 & 1.42 & 0.19 & 0.01 & 12.45 & 0.31 & 11.07 & 0.02 & 0.00 & 22.57 & 0.23 & 0.00 & 0.00 & 0.00 & 0.00 & 100.06 \\
\hline 15SAB-L056B01-spot1-3 & Clinopyroxene & 52.04 & 1.40 & 0.19 & 0.02 & 12.08 & 0.27 & 11.08 & 0.04 & 0.00 & 22.47 & 0.25 & 0.00 & 0.00 & 0.00 & 0.00 & 99.86 \\
\hline 15SAB-L056B01-spot2-3 & Clinopyroxene & 51.57 & 1.79 & 0.25 & 0.04 & 12.84 & 0.31 & 10.88 & 0.00 & 0.00 & 21.64 & 0.34 & 0.00 & 0.00 & 0.00 & 0.00 & 99.66 \\
\hline 15SAB-D196A01-spot2-1 & Clinopyroxene & 51.06 & 3.95 & 0.11 & 0.01 & 5.51 & 0.22 & 14.57 & 0.00 & 0.00 & 23.23 & 0.17 & 0.00 & 0.00 & 0.00 & 0.00 & 98.84 \\
\hline 15SAB-D196A01-spot2-2 & Clinopyroxene & 52.17 & 2.97 & 0.13 & 0.01 & 4.90 & 0.18 & 15.07 & 0.01 & 0.00 & 23.90 & 0.15 & 0.00 & 0.00 & 0.00 & 0.00 & 99.47 \\
\hline 15SAB-M005A01-spot1-2 & Clinopyroxene & 51.61 & 1.18 & 0.13 & 0.00 & 12.50 & 0.59 & 11.25 & 0.01 & 0.00 & 22.18 & 0.27 & 0.00 & 0.00 & 0.00 & 0.00 & 99.72 \\
\hline 15SAB-M005A01-spot2-3 & Clinopyroxene & 51.32 & 1.40 & 0.13 & 0.00 & 13.10 & 0.60 & 10.77 & 0.01 & 0.00 & 21.86 & 0.30 & 0.02 & 0.00 & 0.00 & 0.00 & 99.53 \\
\hline 14SAB-L011A02-spot1-1 & Clinopyroxene & 51.30 & 2.28 & 0.30 & 0.04 & 12.57 & 0.38 & 11.28 & 0.00 & 0.00 & 21.66 & 0.36 & 0.00 & 0.00 & 0.00 & 0.00 & 100.18 \\
\hline 14SAB-L011A02-spot2-2 & Clinopyroxene & 51.26 & 2.78 & 0.36 & 0.04 & 12.35 & 0.28 & 10.81 & 0.03 & 0.00 & 21.95 & 0.43 & 0.00 & 0.00 & 0.00 & 0.00 & 100.28 \\
\hline 14SAB-L010C01-spot1-1 & Clinopyroxene & 52.50 & 3.16 & 0.48 & 0.17 & 5.31 & 0.14 & 14.82 & 0.01 & 0.00 & 23.65 & 0.14 & 0.00 & 0.00 & 0.00 & 0.00 & 100.37 \\
\hline 14SAB-L010C01-spot2-2 & Clinopyroxene & 51.94 & 3.14 & 0.45 & 0.20 & 6.06 & 0.24 & 14.53 & 0.02 & 0.00 & 23.45 & 0.22 & 0.00 & 0.00 & 0.00 & 0.00 & 100.25 \\
\hline 14SAB-L005A02-spot1-3 & Clinopyroxene & 52.71 & 0.75 & 0.11 & 0.05 & 10.28 & 0.23 & 12.52 & 0.00 & 0.00 & 22.57 & 0.20 & 0.00 & 0.00 & 0.00 & 0.00 & 99.43 \\
\hline 14SAB-L005A02-spot2-4 & Clinopyroxene & 52.28 & 0.81 & 0.08 & 0.06 & 10.01 & 0.24 & 12.60 & 0.03 & 0.00 & 23.03 & 0.18 & 0.01 & 0.00 & 0.00 & 0.00 & 99.33 \\
\hline
\end{tabular}




\begin{tabular}{|c|c|c|c|c|c|c|c|c|c|c|c|c|c|c|c|c|c|c|}
\hline \multicolumn{19}{|c|}{ Clinopyroxene - Atoms Per Formula Unit } \\
\hline SAMPLE & Mineral & $\mathrm{Si}$ & Al & $\mathrm{Ti}$ & $\mathrm{Cr}$ & $\mathrm{Fe}$ & $\mathrm{Mn}$ & $\mathrm{Mg}$ & $\mathrm{Ni}$ & $\mathrm{Zn}$ & $\mathrm{Ca}$ & $\mathrm{Na}$ & $\mathrm{K}$ & $\mathrm{Ba}$ & $\sum$ cations & $\mathrm{F}$ & $\mathrm{Cl}$ & $\% \mathrm{Di}$ \\
\hline 14SAB-L012A02-spot1-3 & Clinopyroxene (rim) & 1.99 & $\begin{array}{ll}9 & 0.07\end{array}$ & 0.00 & 0.00 & 0.15 & 0.00 & 0.84 & 0.00 & 0.00 & 0.91 & 0.02 & 0.00 & 0.00 & 3.98 & 0.00 & 0.00 & 85 \\
\hline 14SAB-L012A02-spot1-4 & Clinopyroxene (body) & 1.96 & 0.10 & 0.01 & 0.01 & 0.15 & 0.00 & 0.84 & 0.00 & 0.00 & 0.89 & 0.02 & 0.00 & 0.00 & 3.99 & 0.01 & 0.00 & 85 \\
\hline 14SAB-L012A02-spot1-5 & Clinopyroxene (core) & 1.93 & 0.17 & 0.01 & 0.02 & 0.17 & 0.00 & 0.83 & 0.00 & 0.00 & 0.82 & 0.04 & 0.00 & 0.00 & 3.99 & 0.00 & 0.00 & 83 \\
\hline 14SAB-L013A02-spot1-2- & Clinopyroxene & 1.96 & 0.08 & 0.00 & 0.00 & 0.11 & 0.00 & 0.88 & 0.00 & 0.00 & 0.95 & 0.01 & 0.00 & 0.00 & 4.00 & 0.00 & 0.00 & 89 \\
\hline 14SAB-L006A01-spot1-1 & Clinopyroxene & 1.95 & 0.10 & 0.01 & 0.00 & 0.51 & 0.01 & 0.49 & 0.00 & 0.00 & 0.91 & 0.03 & 0.00 & 0.00 & 4.01 & 0.00 & 0.00 & 49 \\
\hline 14SAB-L006A01-spot1-3 & Clinopyroxene & 1.96 & 0.08 & 0.01 & 0.00 & 0.51 & 0.01 & 0.49 & 0.00 & 0.00 & 0.91 & 0.03 & 0.00 & 0.00 & 4.00 & 0.00 & 0.00 & 49 \\
\hline 14SAB-L006A01-spot2-3 & Clinopyroxene & 1.96 & 0.09 & 0.01 & 0.00 & 0.50 & 0.01 & 0.49 & 0.00 & 0.00 & 0.91 & 0.03 & 0.00 & 0.00 & 4.01 & 0.00 & 0.00 & 49 \\
\hline 14SAB-L006A01-spot2-4 & Clinopyroxene & 1.98 & 0.04 & 0.00 & 0.00 & 0.49 & 0.01 & 0.53 & 0.00 & 0.00 & 0.93 & 0.02 & 0.00 & 0.00 & 4.01 & 0.00 & 0.00 & 52 \\
\hline 14SAB-L006B01-spot1-2 & Clinopyroxene & 1.97 & 0.08 & 0.01 & 0.00 & 0.13 & 0.01 & 0.85 & 0.00 & 0.00 & 0.94 & 0.00 & 0.00 & 0.00 & 3.98 & 0.00 & 0.00 & 87 \\
\hline 14SAB-L006B01-spot2-3 & Clinopyroxene & 1.92 & 0.13 & 0.02 & 0.00 & 0.13 & 0.00 & 0.84 & 0.00 & 0.00 & 0.95 & 0.00 & 0.00 & 0.00 & 4.00 & 0.00 & 0.00 & 87 \\
\hline 14SAB-L008A02-spot1-3 & Clinopyroxene & 1.94 & 0.11 & 0.01 & 0.00 & 0.30 & 0.01 & 0.69 & 0.00 & 0.00 & 0.93 & 0.02 & 0.00 & 0.00 & 4.00 & 0.00 & 0.00 & 69 \\
\hline 14SAB-L008A02-spot1-4 & Clinopyroxene & 1.94 & 0.11 & 0.01 & 0.00 & 0.31 & 0.01 & 0.69 & 0.00 & 0.00 & 0.91 & 0.01 & 0.00 & 0.00 & 4.00 & 0.00 & 0.00 & 69 \\
\hline 14SAB-L008A02-spot2-1 & Clinopyroxene & 1.94 & 0.11 & 0.01 & 0.00 & 0.30 & 0.01 & 0.69 & 0.00 & 0.00 & 0.91 & 0.01 & 0.00 & 0.00 & 3.99 & 0.00 & 0.00 & 69 \\
\hline 14SAB-L008A02-spot2-2 & Clinopyroxene & 1.94 & 0.11 & 0.01 & 0.00 & 0.31 & 0.01 & 0.69 & 0.00 & 0.00 & 0.90 & 0.02 & 0.00 & 0.00 & 4.00 & 0.00 & 0.00 & 69 \\
\hline 14SAB-L010A01-spot1-1 & Clinopyroxene & 1.96 & 0.10 & 0.01 & 0.00 & 0.27 & 0.01 & 0.74 & 0.00 & 0.00 & 0.90 & 0.03 & 0.00 & 0.00 & 4.00 & 0.00 & 0.00 & 74 \\
\hline 14SAB-L010A01-spot2-2 & Clinopyroxene & 1.97 & 0.09 & 0.01 & 0.00 & 0.26 & 0.01 & 0.74 & 0.00 & 0.00 & 0.89 & 0.03 & 0.00 & 0.00 & 3.99 & 0.00 & 0.00 & 74 \\
\hline 14SAB-L004A01-spot2-2 & Clinopyroxene & 1.97 & 0.09 & 0.01 & 0.00 & 0.15 & 0.00 & 0.83 & 0.00 & 0.00 & 0.92 & 0.01 & 0.00 & 0.00 & 3.98 & 0.00 & 0.00 & 85 \\
\hline 14SAB-L004A01-spot2-5 & Clinopyroxene & 1.94 & 0.12 & 0.01 & 0.00 & 0.15 & 0.00 & 0.83 & 0.00 & 0.00 & 0.93 & 0.01 & 0.00 & 0.00 & 3.99 & 0.00 & 0.00 & 84 \\
\hline 14SAB-L001B01-spot1-1 & Clinopyroxene & 1.99 & 0.03 & 0.00 & 0.00 & 0.34 & 0.01 & 0.70 & 0.00 & 0.00 & 0.91 & 0.01 & 0.00 & 0.00 & 4.00 & 0.00 & 0.00 & 68 \\
\hline 14SAB-L001B01-spot1-2 & Clinopyroxene & 1.99 & 0.05 & 0.00 & 0.00 & 0.33 & 0.01 & 0.68 & 0.00 & 0.00 & 0.89 & 0.02 & 0.00 & 0.00 & 3.98 & 0.00 & 0.00 & 67 \\
\hline 14SAB-L001B01-spot2-2 & Clinopyroxene & 1.96 & 0.09 & 0.01 & 0.00 & 0.31 & 0.01 & 0.71 & 0.00 & 0.00 & 0.89 & 0.02 & 0.00 & 0.00 & 4.00 & 0.00 & 0.00 & 69 \\
\hline 14SAB-L001B01-spot2-3 & Clinopyroxene & 1.98 & 0.06 & 0.01 & 0.00 & 0.29 & 0.01 & 0.74 & 0.00 & 0.00 & 0.89 & 0.02 & 0.00 & 0.00 & 3.99 & 0.00 & 0.00 & 72 \\
\hline 14SAB-L003B01-spot1-3 & Clinopyroxene & 1.98 & 0.06 & 0.00 & 0.00 & 0.28 & 0.01 & 0.76 & 0.00 & 0.00 & 0.89 & 0.02 & 0.00 & 0.00 & 4.00 & 0.00 & 0.00 & 73 \\
\hline 14SAB-L003B01-spot1-4 & Clinopyroxene & 1.98 & 0.06 & 0.00 & 0.00 & 0.28 & 0.01 & 0.76 & 0.00 & 0.00 & 0.89 & 0.02 & 0.00 & 0.00 & 4.00 & 0.00 & 0.00 & 73 \\
\hline 14SAB-L003B01-spot2-4 & Clinopyroxene & 1.98 & 0.06 & 0.00 & 0.00 & 0.27 & 0.01 & 0.77 & 0.00 & 0.00 & 0.89 & 0.02 & 0.00 & 0.00 & 4.00 & 0.00 & 0.00 & 74 \\
\hline 14SAB-L003B01-spot2-5 & Clinopyroxene & 1.98 & 0.06 & 0.00 & 0.00 & 0.26 & 0.01 & 0.75 & 0.00 & 0.00 & 0.91 & 0.02 & 0.00 & 0.00 & 4.00 & 0.00 & 0.00 & 74 \\
\hline 15SAB-L056B01-spot1-1 & Clinopyroxene & 1.97 & 0.06 & 0.01 & 0.00 & 0.40 & 0.01 & 0.63 & 0.00 & 0.00 & 0.92 & 0.02 & 0.00 & 0.00 & 4.00 & 0.00 & 0.00 & 61 \\
\hline 15SAB-L056B01-spot1-3 & Clinopyroxene & 1.98 & 0.06 & 0.01 & 0.00 & 0.38 & 0.01 & 0.63 & 0.00 & 0.00 & 0.91 & 0.02 & 0.00 & 0.00 & 4.00 & 0.00 & 0.00 & 62 \\
\hline 15SAB-L056B01-spot2-3 & Clinopyroxene & 1.96 & 0.08 & 0.01 & 0.00 & 0.41 & 0.01 & 0.62 & 0.00 & 0.00 & 0.88 & 0.03 & 0.00 & 0.00 & 4.00 & 0.00 & 0.00 & 60 \\
\hline 15SAB-D196A01-spot2-1 & Clinopyroxene & 1.90 & 0.17 & 0.00 & 0.00 & 0.17 & 0.01 & 0.81 & 0.00 & 0.00 & 0.93 & 0.01 & 0.00 & 0.00 & 4.01 & 0.00 & 0.00 & 82 \\
\hline 15SAB-D196A01-spot2-2 & Clinopyroxene & 1.93 & 0.13 & 0.00 & 0.00 & 0.15 & 0.01 & 0.83 & 0.00 & 0.00 & 0.95 & 0.01 & 0.00 & 0.00 & 4.01 & 0.00 & 0.00 & 85 \\
\hline 15SAB-M005A01-spot1-2 & Clinopyroxene & 1.97 & 0.05 & 0.00 & 0.00 & 0.40 & 0.02 & 0.64 & 0.00 & 0.00 & 0.91 & 0.02 & 0.00 & 0.00 & 4.01 & 0.00 & 0.00 & 62 \\
\hline 15SAB-M005A01-spot2-3 & Clinopyroxene & 1.97 & 0.06 & 0.00 & 0.00 & 0.42 & 0.02 & 0.62 & 0.00 & 0.00 & 0.90 & 0.02 & 0.00 & 0.00 & 4.01 & 0.00 & 0.00 & 59 \\
\hline 14SAB-L011A02-spot1-1 & Clinopyroxene & 1.94 & 0.10 & 0.01 & 0.00 & 0.40 & 0.01 & 0.64 & 0.00 & 0.00 & 0.88 & 0.03 & 0.00 & 0.00 & 4.01 & 0.00 & 0.00 & 62 \\
\hline 14SAB-L011A02-spot2-2 & Clinopyroxene & 1.94 & 0.12 & 0.01 & 0.00 & 0.39 & 0.01 & 0.61 & 0.00 & 0.00 & 0.89 & 0.03 & 0.00 & 0.00 & 4.00 & 0.00 & 0.00 & 61 \\
\hline 14SAB-L010C01-spot1-1 & Clinopyroxene & 1.92 & 0.14 & 0.01 & 0.00 & 0.16 & 0.00 & 0.81 & 0.00 & 0.00 & 0.93 & 0.01 & 0.00 & 0.00 & 4.00 & 0.00 & 0.00 & 83 \\
\hline 14SAB-L010C01-spot2-2 & Clinopyroxene & 1.92 & 0.14 & 0.01 & 0.01 & 0.19 & 0.01 & 0.80 & 0.00 & 0.00 & 0.93 & 0.02 & 0.00 & 0.00 & 4.01 & 0.00 & 0.00 & 81 \\
\hline 14SAB-L005A02-spot1-3 & Clinopyroxene & 1.99 & 0.03 & 0.00 & 0.00 & 0.32 & 0.01 & 0.70 & 0.00 & 0.00 & 0.91 & 0.02 & 0.00 & 0.00 & 4.00 & 0.00 & 0.00 & 68 \\
\hline 14SAB-L005A02-spot2-4 & Clinopyroxene & 1.98 & 0.04 & 0.00 & 0.00 & 0.32 & 0.01 & 0.71 & 0.00 & 0.00 & 0.93 & 0.01 & 0.00 & 0.00 & 4.01 & 0.00 & 0.00 & 69 \\
\hline
\end{tabular}


Orthopyroxene - Electron Microprobe Data

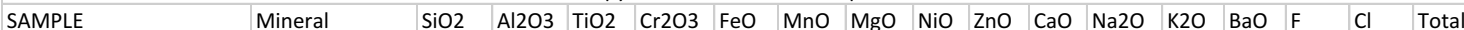

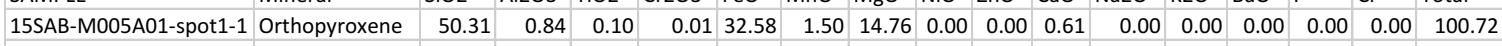
\begin{tabular}{|l|l|l|l|l|l|l|l|l|l|l|l|l|l|l|l|l|l|l|l|l|l|l|}
\hline 15SAB-L056B01-spot1-2 & Orthopyroxene & 50.26 & 0.71 & 0.10 & 0.03 & 31.41 & 0.70 & 14.96 & 0.04 & 0.00 & 0.87 & 0.00 & 0.01 & 0.00 & 0.00 & 0.00 & 99.08 \\
\hline
\end{tabular} \begin{tabular}{|l|l|l|l|l|l|l|l|l|l|l|l|l|l|l|l|l|l|l|l|l|l|l|l|l|l|}
\hline 14SAB-L011A02-spot2-3 & Orthopyroxene & 50.60 & 0.91 & 0.08 & 0.03 & 31.14 & 0.73 & 15.49 & 0.00 & 0.00 & 0.71 & 0.00 & 0.02 & 0.00 & 0.00 & 0.00 & 99.72 \\
\hline
\end{tabular} \begin{tabular}{|l|l|l|l|l|l|l|l|l|l|l|l|l|l|l|l|l|l|l|l|l|l|l|l|}
\hline 14SAB-L005A02-spot1-2 & Orthopyroxene & 51.53 & 0.67 & 0.09 & 0.02 & 28.78 & 0.61 & 17.43 & 0.00 & 0.00 & 0.57 & 0.00 & 0.00 & 0.00 & 0.00 & 0.00 & 99.71 \\
\hline
\end{tabular} \begin{tabular}{|l|l|l|l|l|l|l|l|l|l|l|l|l|l|l|l|l|l|l|l|l|l|l|}
\hline 14SAB-L001B01-spot2-5 & Orthopyroxene & 51.28 & 1.09 & 0.14 & 0.00 & 26.91 & 0.50 & 18.34 & 0.04 & 0.00 & 0.74 & 0.00 & 0.00 & 0.00 & 0.00 & 0.00 & 99.05 \\
\hline
\end{tabular} \begin{tabular}{|l|l|l|l|l|l|l|l|l|l|l|l|l|l|l|l|l|l|l|l|l|l|l|l|l|}
\hline 14SAB-L001B01-spot2-4 & Orthopyroxene & 52.11 & 0.83 & 0.10 & 0.02 & 27.07 & 0.64 & 18.53 & 0.04 & 0.00 & 0.61 & 0.00 & 0.00 & 0.00 & 0.00 & 0.00 & 99.94 \\
\hline
\end{tabular} \begin{tabular}{|l|l|l|l|l|l|l|l|l|l|l|l|l|l|l|l|l|l|l|l|l|l|l|l|}
\hline 14SAB-L003B01-spot2-2 & Orthopyroxene & 52.69 & 0.87 & 0.08 & 0.04 & 24.88 & 0.79 & 20.54 & 0.00 & 0.00 & 0.63 & 0.00 & 0.00 & 0.00 & 0.00 & 0.00 & 100.50 \\
\hline
\end{tabular}

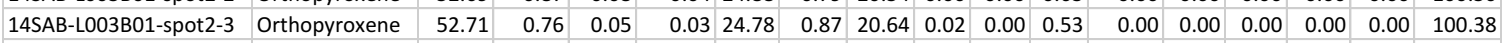

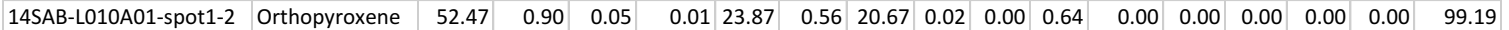
\begin{tabular}{|l|l|l|l|l|l|l|l|l|l|l|l|l|l|l|l|l|l|l|l|l|l|l|}
\hline 14SAB-L010A01-spot2-4 & Orthopyroxene & 52.37 & 1.29 & 0.08 & 0.00 & 23.71 & 0.54 & 20.97 & 0.00 & 0.00 & 0.69 & 0.00 & 0.00 & 0.00 & 0.00 & 0.00 & 99.65 \\
\hline
\end{tabular}

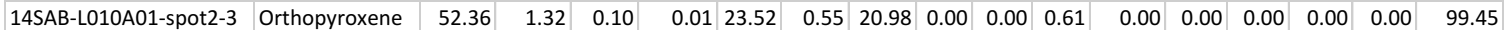
\begin{tabular}{|l|l|l|l|l|l|l|l|l|l|l|l|l|l|l|l|l|l|l|l|l|l|l|}
\hline 14SAB-L057B02-spot2-2 & Orthopyroxene & 53.70 & 1.04 & 0.03 & 0.08 & 22.12 & 0.56 & 22.07 & 0.02 & 0.00 & 0.53 & 0.02 & 0.00 & 0.00 & 0.00 & 0.00 & 100.18 \\
\hline
\end{tabular}

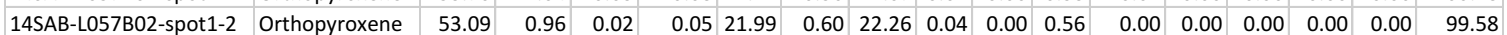

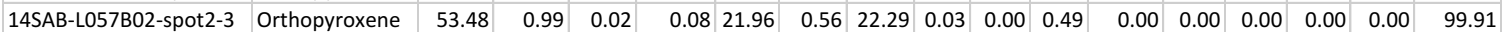
\begin{tabular}{|l|l|l|l|l|l|l|l|l|l|l|l|l|l|l|l|l|l|l|l|l|l|l|}
\hline 14SAB-L057B02-spot1-3 & Orthopyroxene & 53.31 & 0.95 & 0.04 & 0.03 & 21.75 & 0.62 & 22.36 & 0.05 & 0.00 & 0.49 & 0.04 & 0.00 & 0.00 & 0.00 & 0.00 & 99.63 \\
\hline
\end{tabular}

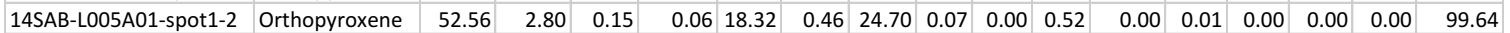
\begin{tabular}{|l|l|l|l|l|l|l|l|l|l|l|l|l|l|l|l|l|l|l|l|l|l|l|l|l|l|}
\hline 14SAB-L005A01-spot2-2 & Orthopyroxene & 52.49 & 3.12 & 0.17 & 0.06 & 18.25 & 0.43 & 24.74 & 0.04 & 0.00 & 0.61 & 0.00 & 0.00 & 0.00 & 0.00 & 0.00 & 99.91 \\
\hline
\end{tabular} \begin{tabular}{|l|l|l|l|l|l|l|l|l|l|l|l|l|l|l|l|l|l|l|l|l|l|l|l|}
\hline 14SAB-H080A01-spot1-3 & Orthopyroxene & 53.66 & 2.17 & 0.23 & 0.06 & 18.48 & 0.43 & 25.26 & 0.05 & 0.00 & 0.40 & 0.00 & 0.00 & 0.00 & 0.00 & 0.00 & 100.73 \\
\hline
\end{tabular}

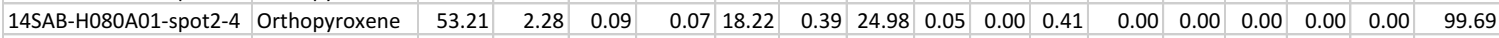
\begin{tabular}{|l|l|l|l|l|l|l|l|l|l|l|l|l|l|l|l|l|l|l|l|l|l|l|l|l|l|l|l|l|l|}
\hline 14SAB-H080A01-spot1-8 & Orthopyroxene & 53.83 & 2.18 & 0.11 & 0.06 & 18.09 & 0.40 & 24.80 & 0.05 & 0.00 & 0.57 & 0.00 & 0.00 & 0.00 & 0.00 & 0.00 & 100.11 \\
\hline
\end{tabular}

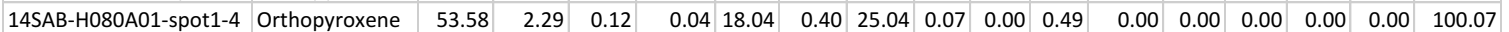

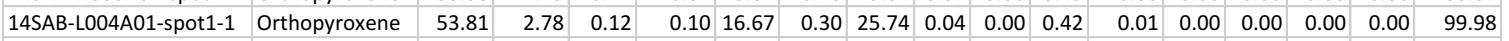

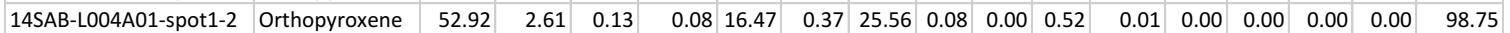
\begin{tabular}{|l|l|l|l|l|l|l|l|l|l|l|l|l|l|l|l|l|l|l|l|l|l|l|l|l|l|}
\hline 14SAB-L004A01-spot2-4 & Orthopyroxene & 54.66 & 0.90 & 0.03 & 0.05 & 16.95 & 0.39 & 26.34 & 0.07 & 0.00 & 0.24 & 0.00 & 0.00 & 0.00 & 0.00 & 0.00 & 99.63 \\
\hline
\end{tabular}

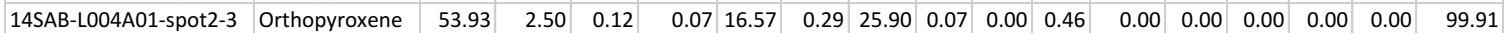
\begin{tabular}{|l|l|l|l|l|l|l|l|l|l|l|l|l|l|l|l|l|l|l|l|l|l|}
\hline 15SAB-L112A01-spot1-3 & Orthopyroxene & 52.77 & 3.09 & 0.00 & 0.02 & 16.37 & 0.37 & 26.23 & 0.02 & 0.00 & 0.42 & 0.00 & 0.00 & 0.00 & 0.00 & 0.00 & 99.29 \\
\hline
\end{tabular} \begin{tabular}{|l|l|l|l|l|l|l|l|l|l|l|l|l|l|l|l|l|l|l|l|l|l|l|l|l|l|l|l|l|l|}
\hline 15SAB-L112A01-spot2-2 & Orthopyroxene & 53.08 & 3.73 & 0.02 & 0.01 & 15.95 & 0.39 & 26.00 & 0.02 & 0.00 & 0.46 & 0.00 & 0.00 & 0.00 & 0.00 & 0.00 & 99.68 \\
\hline
\end{tabular} \begin{tabular}{|l|l|l|l|l|l|l|l|l|l|l|l|l|l|l|l|l|l|l|l|l|l|l|l|}
\hline 14SAB-L007A02-spot1-4 & Orthopyroxene & 53.93 & 2.54 & 0.13 & 0.06 & 16.26 & 0.26 & 26.71 & 0.05 & 0.00 & 0.34 & 0.00 & 0.00 & 0.00 & 0.00 & 0.00 & 100.28 \\
\hline
\end{tabular}

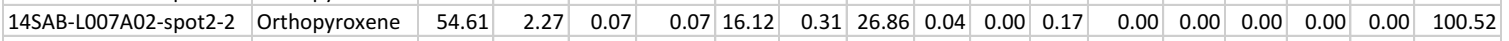

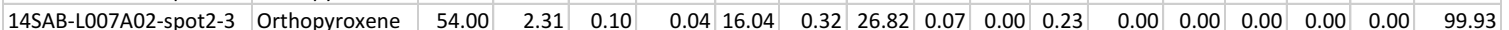
\begin{tabular}{|l|l|l|l|l|l|l|l|l|l|l|l|l|l|l|l|l|l|l|l|l|l|l|l|l|l|l|l|l|l|l|}
\hline L012A02-spot2-2 & Orthopyroxene & 54.19 & 2.25 & 0.02 & 0.01 & 16.02 & 0.31 & 26.90 & 0.00 & 0.00 & 0.33 & 0.00 & 0.01 & 0.00 & 0.00 & 0.00 & 100.05 \\
\hline
\end{tabular} \begin{tabular}{|l|l|l|l|l|l|l|l|l|l|l|l|l|l|l|l|l|l|l|l|l|l|}
\hline 14SAB-L007A02-spot1-3 & Orthopyroxene & 53.65 & 2.59 & 0.13 & 0.08 & 15.90 & 0.38 & 26.80 & 0.05 & 0.00 & 0.41 & 0.00 & 0.00 & 0.00 & 0.00 & 0.00 & 99.99 \\
\hline
\end{tabular} \begin{tabular}{|l|l|l|l|l|l|l|l|l|l|l|l|l|l|l|l|l|l|l|l|l|l|l|l|l|}
\hline L012A02-spot2-1 & Orthopyroxene & 54.78 & 1.67 & 0.01 & 0.03 & 15.85 & 0.33 & 27.35 & 0.00 & 0.00 & 0.35 & 0.03 & 0.00 & 0.00 & 0.00 & 0.00 & 100.41 \\
\hline
\end{tabular}

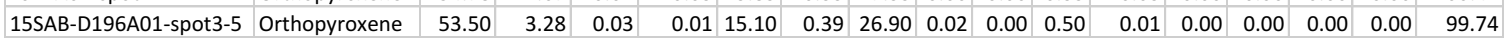

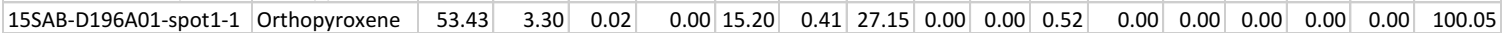

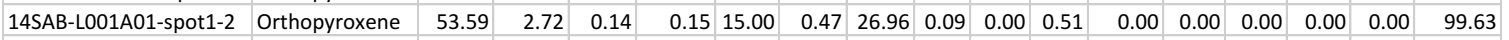
\begin{tabular}{|l|l|l|l|l|l|l|l|l|l|l|l|l|l|l|l|l|l|l|l|l|l|l|}
\hline 14SAB-L001A01-spot1-3 & Orthopyroxene & 53.66 & 2.44 & 0.09 & 0.11 & 15.07 & 0.41 & 27.10 & 0.09 & 0.00 & 0.38 & 0.00 & 0.00 & 0.00 & 0.00 & 0.00 & 99.35 \\
\hline
\end{tabular}

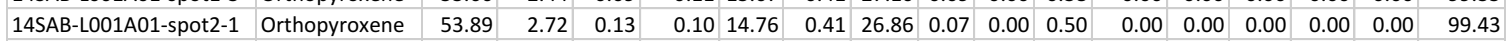
\begin{tabular}{|l|l|l|l|l|l|l|l|l|l|l|l|l|l|l|l|l|l|l|l|l|l|l|l|}
\hline 14SAB-L009A01-area1-2 & Orthopyroxene & 54.15 & 3.01 & 0.19 & 0.10 & 14.78 & 0.32 & 27.24 & 0.04 & 0.00 & 0.40 & 0.01 & 0.00 & 0.00 & 0.00 & 0.00 & 100.23 \\
\hline
\end{tabular} \begin{tabular}{|l|l|l|l|l|l|l|l|l|l|l|l|l|l|l|l|l|l|l|l|l|l|l|}
\hline 14SAB-L009A01-area1-1 & Orthopyroxene & 54.56 & 2.97 & 0.14 & 0.09 & 14.81 & 0.31 & 27.49 & 0.02 & 0.00 & 0.31 & 0.02 & 0.00 & 0.00 & 0.00 & 0.00 & 100.70 \\
\hline
\end{tabular} \begin{tabular}{|l|l|l|l|l|l|l|l|l|l|l|l|l|l|l|l|l|l|l|l|l|l|l|l|l|l|l|l|}
\hline 14SAB-LO09A01-area2-2 & Orthopyroxene & 54.09 & 2.88 & 0.13 & 0.14 & 14.72 & 0.32 & 27.46 & 0.04 & 0.00 & 0.29 & 0.00 & 0.00 & 0.00 & 0.00 & 0.00 & 100.06 \\
\hline
\end{tabular} \begin{tabular}{|l|l|l|l|l|l|l|l|l|l|l|l|l|l|l|l|l|l|l|l|l|l|l|l|l|}
\hline 14SAB-L006B01-spot1-2 & Orthopyroxene & 54.43 & 2.58 & 0.17 & 0.05 & 14.63 & 0.31 & 27.39 & 0.04 & 0.00 & 0.45 & 0.03 & 0.00 & 0.00 & 0.00 & 0.00 & 100.07 \\
\hline
\end{tabular}

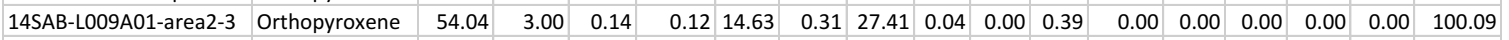

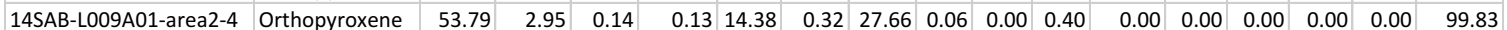

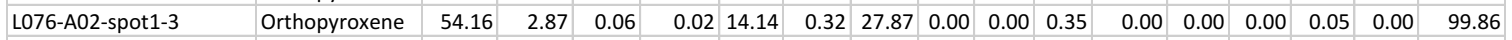
\begin{tabular}{|l|l|l|l|l|l|l|l|l|l|l|l|l|l|l|l|l|l|l|l|l|l|l|l|}
\hline 15SAB-L076A01 area 2-3 & Orthopyroxene & 54.53 & 2.96 & 0.04 & 0.03 & 14.09 & 0.33 & 28.00 & 0.03 & 0.00 & 0.38 & 0.00 & 0.00 & 0.00 & 0.00 & 0.00 & 100.39 \\
\hline
\end{tabular}

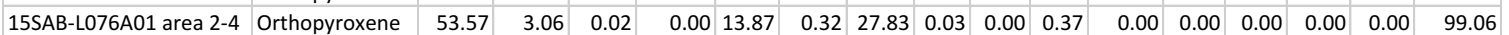
\begin{tabular}{|l|l|l|l|l|l|l|l|l|l|l|l|l|l|l|l|l|l|l|l|l|l|l|l|l|l|l|l|l|l|l|}
\hline 14SAB-S130A01-spot2-5 & Orthopyroxene & 54.40 & 2.91 & 0.12 & 0.07 & 13.42 & 0.35 & 28.54 & 0.05 & 0.00 & 0.32 & 0.00 & 0.00 & 0.00 & 0.00 & 0.00 & 100.18 \\
\hline
\end{tabular}

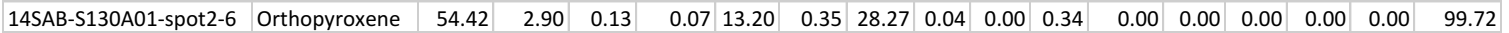
\begin{tabular}{|l|l|l|l|l|l|l|l|l|l|l|l|l|l|l|l|l|l|l|l|l|l|l|l|l|l|l|l|l|l|}
\hline 14SAB-S130A01-spot2-4 & Orthopyroxene & 54.26 & 0.00 & 0.00 & 0.00 & 13.27 & 0.34 & 28.66 & 0.03 & 0.00 & 0.34 & 0.00 & 0.00 & 0.00 & 0.00 & 0.00 & 96.89 \\
\hline
\end{tabular}

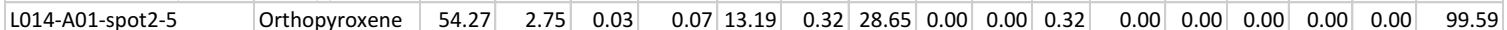
\begin{tabular}{|l|l|l|l|l|l|l|l|l|l|l|l|l|l|l|l|l|l|l|l|l|l|l|l|l|}
\hline L077-A01-spot2-1 & Orthopyroxene & 54.67 & 2.77 & 0.06 & 0.04 & 13.14 & 0.33 & 28.75 & 0.03 & 0.00 & 0.29 & 0.00 & 0.00 & 0.00 & 0.00 & 0.00 & 100.06 \\
\hline
\end{tabular} \begin{tabular}{|l|l|l|l|l|l|l|l|l|l|l|l|l|l|l|l|l|l|l|l|l|l|l|l|l|l|l|}
\hline L077-A01-spot3-3 & Orthopyroxene & 55.11 & 3.02 & 0.02 & 0.01 & 13.03 & 0.32 & 28.85 & 0.00 & 0.00 & 0.36 & 0.00 & 0.00 & 0.00 & 0.00 & 0.00 & 100.72 \\
\hline
\end{tabular}

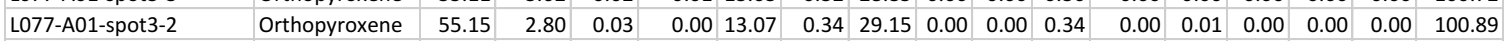

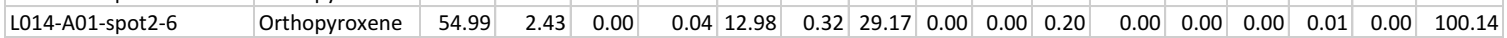
\begin{tabular}{|l|l|l|l|l|l|l|l|l|l|l|l|l|l|l|l|l|l|l|l|l|l|l|l|l|}
\hline L079-A01-spot1-3 & Orthopyroxene & 54.30 & 3.07 & 0.01 & 0.03 & 12.58 & 0.29 & 29.17 & 0.00 & 0.00 & 0.38 & 0.01 & 0.01 & 0.00 & 0.00 & 0.00 & 99.86 \\
\hline
\end{tabular} \begin{tabular}{|l|l|l|l|l|l|l|l|l|l|l|l|l|l|l|l|l|l|l|l|l|l|l|l|l|l|}
\hline L079-A01-spot2-1 & Orthopyroxene & 54.53 & 3.17 & 0.05 & 0.04 & 12.61 & 0.30 & 29.41 & 0.00 & 0.00 & 0.35 & 0.01 & 0.01 & 0.00 & 0.00 & 0.01 & 100.50 \\
\hline
\end{tabular}

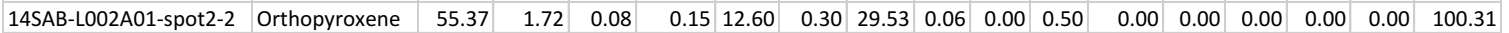

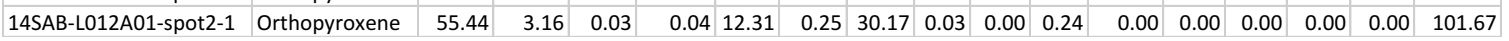


Orthopyroxene - Atoms Per Formula Unit

\begin{tabular}{|c|c|c|c|c|c|c|c|c|c|c|c|c|c|c|c|c|}
\hline \multicolumn{17}{|c|}{ Orthopyroxene - Atoms Per Formula Unit } \\
\hline SAMPLE & Mineral & $\mathrm{Si}$ & Al & $\mathrm{Ti}$ & $\mathrm{Cr}$ & $\mathrm{Fe}$ & $\mathrm{Mn}$ & $\mathrm{Mg}$ & $\mathrm{Ni}$ & $\mathrm{Zn}$ & $\mathrm{Ca}$ & $\mathrm{Na}$ & $\mathrm{K}$ & $\mathrm{Ba}$ & $\sum$ cations & $\%$ En \\
\hline 15SAB-M005A01-spot1-1 & Orthopyroxene & 1.97 & 0.04 & 0.00 & 0.00 & 1.07 & 0.05 & 0.86 & 0.00 & 0.00 & 0.03 & 0.00 & 0.00 & 0.00 & 4.01 & 45 \\
\hline 15SAB-L056B01-spot1-2 & Orthopyroxene & 1.98 & 0.03 & 0.00 & 0.00 & 1.04 & 0.02 & 0.88 & 0.00 & 0.00 & 0.04 & 0.00 & 0.00 & 0.00 & 4.00 & 46 \\
\hline 14SAB-L011A02-spot2-3 & Orthopyroxene & 1.98 & 0.04 & 0.00 & 0.00 & 1.02 & 0.02 & 0.90 & 0.00 & 0.00 & 0.03 & 0.00 & 0.00 & 0.00 & 4.00 & 47 \\
\hline 14SAB-L005A02-spot1-2 & Orthopyroxene & 1.99 & 0.03 & 0.00 & 0.00 & 0.93 & 0.02 & 1.00 & 0.00 & 0.00 & 0.02 & 0.00 & 0.00 & 0.00 & 3.99 & 52 \\
\hline 14SAB-L001B01-spot2-5 & Orthopyroxene & 1.97 & 0.05 & 0.00 & 0.00 & 0.87 & 0.02 & 1.05 & 0.00 & 0.00 & 0.03 & 0.00 & 0.00 & 0.00 & 4.00 & 55 \\
\hline 14SAB-L001B01-spot2-4 & Orthopyroxene & 1.99 & 0.04 & 0.00 & 0.00 & 0.86 & 0.02 & 1.05 & 0.00 & 0.00 & 0.02 & 0.00 & 0.00 & 0.00 & 3.99 & 55 \\
\hline 14SAB-L003B01-spot2-2 & Orthopyroxene & 1.98 & 0.04 & 0.00 & 0.00 & 0.78 & 0.02 & 1.15 & 0.00 & 0.00 & 0.03 & 0.00 & 0.00 & 0.00 & 4.00 & 60 \\
\hline 14SAB-L003B01-spot2-3 & Orthopyroxene & 1.98 & 0.03 & 0.00 & 0.00 & 0.78 & 0.03 & 1.16 & 0.00 & 0.00 & 0.02 & 0.00 & 0.00 & 0.00 & 4.00 & 60 \\
\hline 14SAB-L010A01-spot1-2 & Orthopyroxene & 1.99 & 0.04 & 0.00 & 0.00 & 0.76 & 0.02 & 1.17 & 0.00 & 0.00 & 0.03 & 0.00 & 0.00 & 0.00 & 3.99 & 61 \\
\hline 14SAB-L010A01-spot2-4 & Orthopyroxene & 1.97 & 0.06 & 0.00 & 0.00 & 0.75 & 0.02 & 1.18 & 0.00 & 0.00 & 0.03 & 0.00 & 0.00 & 0.00 & 4.00 & 61 \\
\hline 14SAB-L010A01-spot2-3 & Orthopyroxene & 1.97 & 0.06 & 0.00 & 0.00 & 0.74 & 0.02 & 1.18 & 0.00 & 0.00 & 0.02 & 0.00 & 0.00 & 0.00 & 4.00 & 61 \\
\hline 14SAB-L057B02-spot2-2 & Orthopyroxene & 1.99 & 0.05 & 0.00 & 0.00 & 0.69 & 0.02 & 1.22 & 0.00 & 0.00 & 0.02 & 0.00 & 0.00 & 0.00 & 3.99 & 64 \\
\hline 14SAB-L057B02-spot1-2 & Orthopyroxene & 1.98 & 0.04 & 0.00 & 0.00 & 0.69 & 0.02 & 1.24 & 0.00 & 0.00 & 0.02 & 0.00 & 0.00 & 0.00 & 4.00 & 64 \\
\hline 14SAB-L057B02-spot2-3 & Orthopyroxene & 1.99 & 0.04 & 0.00 & 0.00 & 0.68 & 0.02 & 1.23 & 0.00 & 0.00 & 0.02 & 0.00 & 0.00 & 0.00 & 3.99 & 64 \\
\hline 14SAB-L057B02-spot1-3 & Orthopyroxene & 1.99 & 0.04 & 0.00 & 0.00 & 0.68 & 0.02 & 1.24 & 0.00 & 0.00 & 0.02 & 0.00 & 0.00 & 0.00 & 3.99 & 65 \\
\hline 14SAB-L005A01-spot1-2 & Orthopyroxene & 1.93 & 0.12 & 0.00 & 0.00 & 0.56 & 0.01 & 1.35 & 0.00 & 0.00 & 0.02 & 0.00 & 0.00 & 0.00 & 4.01 & 71 \\
\hline 14SAB-L005A01-spot2-2 & Orthopyroxene & 1.92 & 0.13 & 0.00 & 0.00 & 0.56 & 0.01 & 1.35 & 0.00 & 0.00 & 0.02 & 0.00 & 0.00 & 0.00 & 4.01 & 71 \\
\hline 14SAB-H080A01-spot1-3 & Orthopyroxene & 1.95 & 0.09 & 0.01 & 0.00 & 0.56 & 0.01 & 1.37 & 0.00 & 0.00 & 0.02 & 0.00 & 0.00 & 0.00 & 4.00 & 71 \\
\hline 14SAB-H080A01-spot2-4 & Orthopyroxene & 1.95 & 0.10 & 0.00 & 0.00 & 0.56 & 0.01 & 1.36 & 0.00 & 0.00 & 0.02 & 0.00 & 0.00 & 0.00 & 00 & 71 \\
\hline 14SAB-H080A01-spot1-8 & Orthopyroxene & 1.96 & 0.09 & 0.00 & 0.00 & 0.55 & 0.01 & 1.35 & 0.00 & 0.00 & 0.02 & 0.00 & 0.00 & 0.00 & 3.99 & 71 \\
\hline 14SAB-H080A01-spot1-4 & Orthopyroxene & 1.95 & 0.10 & 0.00 & 0.00 & 0.55 & 0.01 & 1.36 & 0.00 & 0.00 & 0.02 & 0.00 & 0.00 & 0.00 & 4.00 & 71 \\
\hline 14SAB-L004A01-spot1-1 & Orthopyroxene & 1.9 & 0.12 & 0.00 & & 0.50 & & 1.39 & & & & 0.00 & 0.00 & 0.00 & 99 & 73 \\
\hline 14SAB-L004A01-spot1-2 & Orthopyroxene & 1.94 & 0.11 & 0.00 & 0.00 & 0.51 & 0.01 & 1.40 & 0.00 & 0.00 & 0.02 & 0.00 & 0.00 & 0.00 & 4.00 & 73 \\
\hline 14SAB-L004A01-spot2-4 & Orthopyroxene & 1.99 & 0.04 & 0.00 & 0.00 & 0.52 & 0.01 & 1.43 & 0.00 & 0.00 & 0.01 & 0.00 & 0.00 & 0.00 & 3.99 & 73 \\
\hline 14SAB-L004A01-spot2-3 & Orthopyroxene & 1.95 & 0.11 & 0.00 & 0.00 & 0.50 & 0.01 & 1.40 & 0.00 & 0.00 & 0.02 & 0.00 & 0.00 & 0.00 & 3.99 & 74 \\
\hline 15SAB-L112A01-spot1-3 & Orthopyroxene & 1.92 & 0.13 & 0.00 & 0.00 & 0.50 & 0.01 & 1.43 & 0.00 & 0.00 & 0.02 & 0.00 & 0.00 & 0.00 & 4.01 & 74 \\
\hline 15SAB-L112A01-spot2-2 & Orthopyroxene & & 0.16 & 0.00 & & 0.48 & & 1.40 & & 00 & & 00 & 0.00 & 0.00 & 00 & 74 \\
\hline 14SAB-L007A02-spot1-4 & Orthopyroxene & 1.94 & 0.11 & 0.00 & 0.00 & 0.49 & 0.01 & 1.43 & 0.00 & 0.00 & 0.01 & 0.00 & 0.00 & 0.00 & 4.00 & 75 \\
\hline 14SAB-L007A02-spot2-2 & Orthopyroxene & 1.96 & 0.10 & 0.00 & 0.00 & 0.48 & 0.01 & 1.43 & 0.00 & 0.00 & 0.01 & 0.00 & 0.00 & 0.00 & 3.99 & 75 \\
\hline 14SAB-L007A02-spot2-3 & Orthopyroxene & 1.95 & 0.10 & 0.00 & 0.00 & 0.48 & 0.01 & 1.44 & 0.00 & 0.00 & 0.01 & 0.00 & 0.00 & 0.00 & 4.00 & 75 \\
\hline L012A02-spot2-2 & Orthopyroxene & 1.95 & 0.10 & 0.00 & 0.00 & 0.48 & 0.01 & 1.45 & 0.00 & 0.00 & 0.01 & 0.00 & 0.00 & 0.00 & 4.00 & 75 \\
\hline 14SAB-L007A02-spot1-3 & Orthopyroxene & 1.94 & 0.11 & 0.00 & 0.00 & 0.48 & 0.01 & 1.44 & 0.00 & 0.00 & 0.02 & 0.00 & 0.00 & 0.00 & 4.00 & 75 \\
\hline L012A02-spot2-1 & Orthopyroxene & 1.96 & 0.07 & 0.00 & 0.00 & 0.48 & 0.01 & 1.46 & 0.00 & 0.00 & 0.01 & 0.00 & 0.00 & 0.00 & 4.00 & 75 \\
\hline 15SAB-D196A01-spot3-5 & Orthopyroxene & 1.93 & 0.14 & 0.00 & 0.00 & 0.46 & 0.01 & 1.45 & 0.00 & 0.00 & 0.02 & 0.00 & 0.00 & 0.00 & 4.00 & 76 \\
\hline 15SAB-D196A01-spot1-1 & Orthopyroxene & 1.92 & 0.14 & 0.00 & 0.00 & 0.46 & 0.01 & 1.46 & 0.00 & 0.00 & 0.02 & 0.00 & 0.00 & 0.00 & 4.01 & 76 \\
\hline 14SAB-L001A01-spot1-2 & Orthopyroxene & 1.94 & 0.12 & 0.00 & 0.00 & 0.45 & 0.01 & 1.45 & 0.00 & 0.00 & 0.02 & 0.00 & 0.00 & 0.00 & 4.00 & 76 \\
\hline 14SAB-L001A01-spot1-3 & Orthopyroxene & 1.94 & 0.10 & 0.00 & 0.00 & 0.46 & 0.01 & 1.46 & 0.00 & 0.00 & 0.01 & 0.00 & 0.00 & 0.00 & 4.00 & 76 \\
\hline 14SAB-L001A01-spot2-1 & Orthopyroxene & 1.95 & 0.12 & 0.00 & 0.00 & 0.45 & 0.01 & 1.45 & 0.00 & 0.00 & 0.02 & 0.00 & 0.00 & 0.00 & 3.99 & 76 \\
\hline 14SAB-L009A01-area1-2 & Orthopyroxene & 1.94 & 0.13 & 0.00 & 0.00 & 0.44 & 0.01 & 1.45 & 0.00 & 0.00 & 0.02 & 0.00 & 0.00 & 0.00 & 3.99 & 77 \\
\hline 14SAB-L009A01-area1-1 & Orthopyroxene & 1.94 & 0.12 & 0.00 & 0.00 & 0.44 & 0.01 & 1.46 & 0.00 & 0.00 & 0.01 & 0.00 & 0.00 & 0.00 & 3.99 & 77 \\
\hline 14SAB-L009A01-area2-2 & Orthopyroxene & 1.94 & 0.12 & 0.00 & 0.00 & 0.44 & 0.01 & 1.47 & 0.00 & 0.00 & 0.01 & 0.00 & 0.00 & 0.00 & 4.00 & 77 \\
\hline 14SAB-L006B01-spot1-2 & Orthopyroxene & 1.95 & 0.11 & 0.00 & 0.00 & 0.44 & 0.01 & 1.46 & 0.00 & 0.00 & 0.02 & 0.00 & 0.00 & 0.00 & 3.99 & 77 \\
\hline 14SAB-L009A01-area2-3 & Orthopyroxene & 1.94 & 0.13 & 0.00 & 0.00 & 0.44 & 0.01 & 1.46 & 0.00 & 0.00 & 0.02 & 0.00 & 0.00 & 0.00 & 4.00 & 77 \\
\hline 14SAB-L009A01-area2-4 & Orthopyroxene & 1.93 & 0.12 & 0.00 & 0.00 & 0.43 & 0.01 & 1.48 & 0.00 & 0.00 & 0.02 & 0.00 & 0.00 & 0.00 & 4.00 & 77 \\
\hline L076-A02-spot1-3 & Orthopyroxene & 1.94 & 0.12 & 0.00 & 0.00 & 0.42 & 0.01 & 1.49 & 0.00 & 0.00 & 0.01 & 0.00 & 0.00 & 0.00 & 4.00 & 78 \\
\hline 15SAB-L076A01 area 2-3 & Orthopyroxene & 1.94 & 0.12 & 0.00 & 0.00 & 0.42 & 0.01 & 1.49 & 0.00 & 0.00 & 0.01 & 0.00 & 0.00 & 0.00 & 4.00 & 78 \\
\hline 15SAB-L076A01 area 2-4 & Orthopyroxene & 1.93 & 0.13 & 0.00 & 0.00 & 0.42 & 0.01 & 1.50 & 0.00 & 0.00 & 0.01 & 0.00 & 0.00 & 0.00 & 4.00 & 78 \\
\hline 14SAB-S130A01-spot2-5 & Orthopyroxene & 1.94 & 0.12 & 0.00 & 0.00 & 0.40 & 0.01 & 1.51 & 0.00 & 0.00 & 0.01 & 0.00 & 0.00 & 0.00 & 4.00 & 79 \\
\hline 14SAB-S130A01-spot2-6 & Orthopyroxene & 1.94 & 0.12 & 0.00 & 0.00 & 0.39 & 0.01 & 1.50 & 0.00 & 0.00 & 0.01 & 0.00 & 0.00 & 0.00 & 3.99 & 79 \\
\hline 14SAB-S130A01-spot2-4 & Orthopyroxene & 2.00 & 0.00 & 0.00 & 0.00 & 0.41 & 0.01 & 1.57 & 0.00 & 0.00 & 0.01 & 0.00 & 0.00 & 0.00 & 4.00 & 79 \\
\hline L014-A01-spot2-5 & Orthopyroxene & 1.94 & 0.12 & 0.00 & 0.00 & 0.39 & 0.01 & 1.53 & 0.00 & 0.00 & 0.01 & 0.00 & 0.00 & 0.00 & 4.00 & 79 \\
\hline L077-A01-spot2-1 & Orthopyroxene & 1.94 & 0.12 & 0.00 & 0.00 & 0.39 & 0.01 & 1.52 & 0.00 & 0.00 & 0.01 & 0.00 & 0.00 & 0.00 & 4.00 & 80 \\
\hline L077-A01-spot3-3 & Orthopyroxene & 1.94 & 0.13 & 0.00 & 0.00 & 0.38 & 0.01 & 1.52 & 0.00 & 0.00 & 0.01 & 0.00 & 0.00 & 0.00 & 3.99 & 80 \\
\hline L077-A01-spot3-2 & Orthopyroxene & 1.94 & 0.12 & 0.00 & 0.00 & 0.39 & 0.01 & 1.53 & 0.00 & 0.00 & 0.01 & 0.00 & 0.00 & 0.00 & 4.00 & 80 \\
\hline L014-A01-spot2-6 & Orthopyroxene & 1.95 & 0.10 & 0.00 & 0.00 & 0.39 & 0.01 & 1.54 & 0.00 & 0.00 & 0.01 & 0.00 & 0.00 & 0.00 & 4.00 & 80 \\
\hline L079-A01-spot1-3 & Orthopyroxene & 1.93 & 0.13 & 0.00 & 0.00 & 0.37 & 0.01 & 1.55 & 0.00 & 0.00 & 0.01 & 0.00 & 0.00 & 0.00 & 4.01 & 81 \\
\hline L079-A01-spot2-1 & Orthopyroxene & 1.93 & 0.13 & 0.00 & 0.00 & 0.37 & 0.01 & 1.55 & 0.00 & 0.00 & 0.01 & 0.00 & 0.00 & 0.00 & 4.01 & 81 \\
\hline 14SAB-L002A01-spot2-2 & Orthopyroxene & 1.96 & 0.07 & 0.00 & 0.00 & 0.37 & 0.01 & 1.56 & 0.00 & 0.00 & 0.02 & 0.00 & 0.00 & 0.00 & 4.00 & 81 \\
\hline 14SAB-L012A01-spot2-1 & Orthopyroxene & 1.93 & 0.13 & 0.00 & 0.00 & 0.36 & 0.01 & 1.57 & 0.00 & 0.00 & 0.01 & 0.00 & 0.00 & 0.00 & 4.00 & 81 \\
\hline
\end{tabular}


Amphibole - Electron Microprobe Data

\begin{tabular}{|c|c|c|c|c|c|c|c|c|c|c|c|c|c|c|c|c|c|}
\hline SAMPLE & lineral & $\mathrm{SiO} 2$ & Al2O3 & $\mathrm{TiO} 2$ & $\mathrm{Cr} 2 \mathrm{O} 3$ & $3 \mathrm{FeO}$ & $\mathrm{MnO}$ & $\mathrm{MgO}$ & $\mathrm{NiO}$ & $\mathrm{ZnO}$ & $\mathrm{CaO}$ & $\mathrm{Na} 2 \mathrm{O}$ & $\mathrm{K} 2 \mathrm{O}$ & $\mathrm{BaO}$ & $\mathrm{F}$ & $\mathrm{Cl}$ & \\
\hline 14SAB-L012A01-spot2-2 & mphibole & 7.08 & 12.14 & 0.25 & 0.10 & 7.21 & 0.14 & 17.48 & 0.03 & 0.00 & 11.79 & 1.44 & 0.00 & 0.00 & 0.00 & 0.00 & 7.66 \\
\hline SAB-L012A01-spot2-rep & mphibole & .06 & 2.20 & .23 & 07 & & 14 & 7.38 & 0.04 & 0.00 & 11.95 & 1.41 & & 0.00 & 0.00 & 00 & \\
\hline 12A01-circle2-4-hb & & & 14 & & & & & .12 & & & & 1.52 & 22 & & 0.00 & & \\
\hline 13A02-spot1-1-hb & nphibole & & .72 & 27 & 14 & & 12 & 5.32 & & 0.09 & 12.53 & 1.96 & .41 & 0.00 & 0.05 & & \\
\hline 15A01-spot2-3 & iphbole & 5.00 & .90 & 25 & 02 & $13.1 \mathrm{~s}$ & 24 & 3.29 & 0.00 & 0.00 & 19 & 1.56 & 0.34 & 0.01 & 0.01 & 0.02 & \\
\hline-1 & ole & & 0.91 & 18 & 02 & 13.4 & 0.20 & 13.14 & 00 & 0.00 & .12 & .65 & 0.30 & 0.00 & 0.11 & 0.02 & \\
\hline ot1-2 & ole & 5.90 & 93 & 56 & 22 & 11.5 & 0.27 & 14.37 & 00 & 0.00 & .43 & 1.06 & 0.82 & 0.00 & 0.00 & 0.00 & \\
\hline ot2-2 & sole & & 12 & 68 & 0.13 & 11.72 & 0.21 & 14.53 & 0.00 & 0.00 & .23 & 1.14 & 0.76 & 0.00 & 0.09 & 0.06 & 30 \\
\hline ot2-3 & bole & .05 & 16 & .55 & 0.16 & 11.8 & 0.26 & 4.15 & 0.01 & 0.00 & .38 & 1.02 & 0.81 & 0.00 & 0.00 & 0.00 & 6.37 \\
\hline-4 & bole & 5.70 & 65 & .47 & 0.12 & 7. & 0.14 & 6.38 & 0.00 & 0.00 & .41 & 1.27 & 0.41 & 0.00 & 0.03 & 0.04 & 86 \\
\hline $0 / 6$ & bole & 8.09 & .44 & 0.27 & .04 & 6.58 & 0.06 & 16.84 & 0.00 & 0.00 & .18 & 1.13 & 0.21 & 0.00 & 0.00 & 0.01 & 83 \\
\hline 076 & ibole & 7.62 & .46 & .31 & .05 & 6.65 & 0.09 & 16.62 & 0.00 & 0.00 & 2.17 & 1.13 & 0.20 & 0.00 & 0.01 & 0.01 & 7.33 \\
\hline 077 & bole & 8.86 & .27 & 0.22 & 0.07 & 6.25 & 0.11 & 17.39 & 0.00 & 0.00 & 1.48 & 1.03 & 0.05 & 0.00 & 0.01 & 0.00 & 75 \\
\hline 077 & nphibole & 8.57 & .62 & .20 & 0.08 & 5.97 & 0.11 & 17.40 & 0.00 & 0.00 & .64 & 1.12 & 0.06 & 0.00 & 0.00 & 0.00 & 6.77 \\
\hline 079 & nphibole & 8.76 & & .32 & 0.08 & 5.90 & 0.10 & 17.76 & 0.00 & 0.00 & 1 & 1.33 & 0.10 & 0.00 & 0.06 & 0.01 & 8.07 \\
\hline $0 / 5$ & oole & 8.14 & & J.31 & .11 & 5.8 & 0.09 & 17.90 & 0.00 & 0.00 & 1 & 1.21 & 0.10 & 0.00 & 0.05 & 0.00 & 16 \\
\hline 880 & & 9.96 & 98 & 0.41 & 31 & 9.66 & 19 & 15.95 & 0.00 & 0.00 & 1 & 1.05 & 0.09 & 0.00 & 0.06 & 0.02 & 23 \\
\hline 880 & & 1.57 & 38 & .4/ & 0.30 & $11.4 \mathrm{C}$ & 0.21 & 16.61 & 0.00 & 0.00 & 1 & 0.92 & 0.11 & 0.00 & 0.08 & 0.03 & 35 \\
\hline 080 & bole & 0.06 & 60 & 0.43 & 0.26 & 9.9 & 0.24 & 16.14 & 0.00 & 0.00 & 1 & 0.98 & 0.11 & 0.00 & 0.00 & 0.03 & 6.99 \\
\hline 880 & bole & 0.66 & 83 & & 0.19 & 9. & .21 & 6.13 & 0.00 & 0.00 & 1 & 0.95 & 0.10 & 0.00 & 0.07 & 0.02 & 71 \\
\hline 880 & ole & 1.09 & & & 0.18 & 10.37 & 23 & 16.02 & 0.00 & 0.00 & 1 & 1.00 & 0.09 & 0.00 & 0.06 & 0.02 & 75 \\
\hline D78 & & 7.64 & .82 & 33 & 0.25 & 5. & 11 & 17.34 & 0.00 & 0.00 & 1 & .32 & 0.22 & 0.00 & 0.02 & 0.02 & 58 \\
\hline $07 \varepsilon$ & & 3.28 & & & 0.24 & 5. & 10 & 1 & 0. & 0.00 & 1 & 1.23 & 0.23 & 0.00 & 0.00 & 0.01 & \\
\hline & & 3.23 & & & .15 & 7. & 10 & 14.92 & & 0.00 & & .64 & 0.35 & 0.00 & 0.11 & 0.0 & 76 \\
\hline & & 4.25 & & & .24 & & & 15.44 & & 0.00 & & .54 & 0.34 & 0.00 & 0.04 & 0.02 & 11 \\
\hline 012 & & 43.97 & .71 & 1.05 & 0.26 & 8. & & 14.47 & 0.00 & 0.00 & 1 & 2.41 & 0.53 & 0.00 & 0.07 & 0.02 & 06 \\
\hline & & 4 & & &.$/ 6$ & & & 7.73 & 0.00 & 0.00 & & 01 & 0.21 & 0.00 & 0.00 & 0.02 & \\
\hline & & 4 & & & 0.78 & 5. & & 17.46 & 0.00 & 0.00 & 1 & 0.95 & 0.16 & 0.00 & 0.00 & 0.00 & 7.19 \\
\hline & & 53.03 & & & & & & 1 & 0. & 0.00 & & 0.61 & 0.07 & 0.00 & 0.00 & 0.00 & 43 \\
\hline & & 45.48 & & & & 9. & & 15.40 & & 0.00 & & 1.80 & 0.97 & 0.00 & 0.00 & 0.02 & 6 \\
\hline & & & & & 0.33 & & & 15.2 & & 00 & & 1.76 & 0.9 & & 0.00 & 0.0 & 21 \\
\hline & & 4 & & & 0.01 & 21.7 & & 6.07 & & 00 & & 99 & 1.60 & 0.0 & 0.00 & 0.00 & 77 \\
\hline & & & & & 0.00 & 22.7 & & & & 0.00 & & 1.91 & 1.56 & 0.0 & 0.11 & 0.0 & \\
\hline & & & & & & & & 1 & & & & & & & 0.12 & & \\
\hline & & 55. & & & & & & 1 & & 0.00 & & 12 & 0.00 & & 0.00 & & \\
\hline & & & & & & & & & & & & & 1.3 & & & & \\
\hline & & & & & 01 & 12. & & & & & & & 1.3 & & 0 & & \\
\hline & & & & & & & & & & & & 26 & & & & & \\
\hline & & & & & & & & 1 & & & & 1.30 & 0 & & 0.00 & 0.0 & \\
\hline & & 46. & & & & & & 1 & & 0 & & 1.11 & 0.1 & & 0.0 & & \\
\hline & & & & & & & & & & & & & & & & & \\
\hline & & & & & & & & & & & & & 0.1 & 0. & $c$ & 0.02 & \\
\hline & & & & & & & & & & & & & 0 & & & & \\
\hline & & & & & & & & & & & & & .14 & & 02 & 0.6 & \\
\hline & & & & & & & & & & 0 & & 30 & 0.16 & & & 0.6 & \\
\hline & & & & & & & & & & 0.00 & & .27 & 0.16 & .0 & 05 & 0.00 & 49 \\
\hline & & & & & c & & 0.0 & .50 & 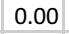 & 0.00 & .7 & 1.19 & 0.16 & 0.0 & .03 & 0.0 & \\
\hline & & & & & & & & & & & & & & & & & \\
\hline
\end{tabular}


Amphibole - Electron Microprobe Data

SAMPLE

15SAB-L076A01 area 1-2

15SAB-L076A01 area 2-5

14SAB-R010A01-spot1-4

14SAB-R010A01-spot2-1

14SAB-L007A02-spot1-5

14SAB-L007A02-spot1-1

14SAB-L016A01-spot1-1

14SAB-L016A01-spot2-3

14SAB-L003A01-spot1-1

14SAB-L003A01-spot2-3

14SAB-L008A02-spot1-1

14SAB-L008A02-spot1-2

14SAB-L008A02-spot2-3

14SAB-L057B02-spot1-1

14SAB-L057B02-spot2-4

15SAB-L119A01-spot1-5

15SAB-L119A01-spot1-4

15SAB-L119A01-spot2-1

14SAB-H080A01-spot1-5

14SAB-H080A01-spot1-6

14SAB-H080A01-spot1-7

14SAB-H080A01-spot1-7

15SAB-L077B01-area1- 1

15SAB-L077B01-area1- 2

15SAB-L077B01-area2-3

14SAB-L009A01-area1-3

14SAB-L009A01-area1-4

14SAB-L009A01-area2-1

14SAB-L004A01-spot1-5

14SAB-L004A01-spot1-6

14SAB-L004A01-spot2-1

14SAB-S130A01-spot1-4

14SAB-S130A01-spot2-1

14SAB-S130A01-spot2-2

14SAB-L001B01-spot1-5

14SAB-L001B01-spot2-1

14SAB-L003B01-spot1-5

14SAB-L003B01-spot2-1

15SAB-L056B01-spot1-4

15SAB-L056B01-spot3

14SAB-L001A01-spot1-1

14SAB-L001A01-spot2-2

15SAB-L112A01-spot1-4

15SAB-L112A01-spot2-1

15SAB-D196A01-spot2-4re

15SAB-D196A01-spot3-3

15SAB-M005A01-spot1-3

15SAB-M005A01-spot2-2

14SAB-L011A02-spot1-2

14SAB-L011A02-spot1-3

14SAB-L010C01-spot1-2

14SAB-L010C01-spot2-3

14SAB-L005A01-spot1-1

14SAB-L005A01-spot2-3

14SAB-L005A02-spot1-1

14SAB-L005A02-spot2-3

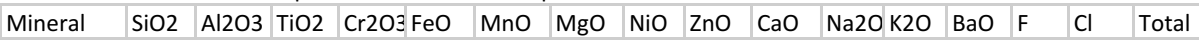

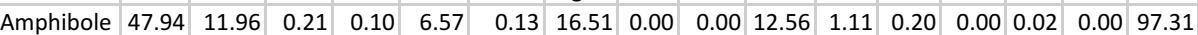

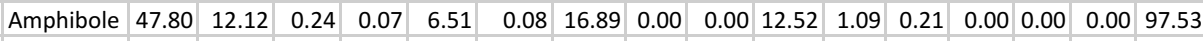

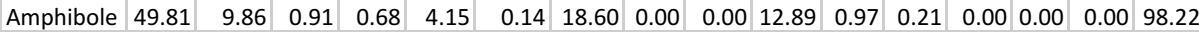

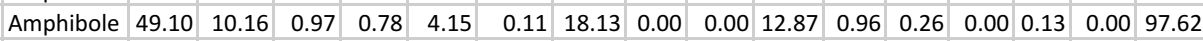
\begin{tabular}{|l|l|l|l|l|l|l|l|l|l|l|l|l|l|l|l|l} 
Amphibole & 44.86 & 13.56 & 1.17 & 0.33 & 7.88 & 0.10 & 15.31 & 0.00 & 0.00 & 12.06 & 1.69 & 0.49 & 0.00 & 0.04 & 0.00 & 97.50 \\
\hline
\end{tabular}

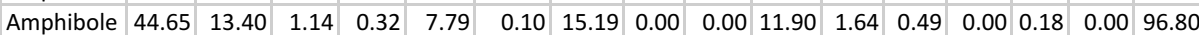
\begin{tabular}{|l|l|l|l|l|l|l|l|l|l|l|l|l|l|l|l|l} 
Amphibole & 47.09 & 9.21 & 0.51 & 0.24 & 10.94 & 0.23 & 14.52 & 0.00 & 0.00 & 11.53 & 1.17 & 0.65 & 0.00 & 0.07 & 0.00 & 96.17 \\
\hline
\end{tabular}

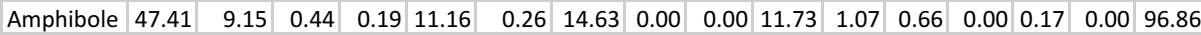
\begin{tabular}{|l|l|l|l|l|l|l|l|l|l|l|l|l|l|l|l|l|l|l|l|} 
Amphibole & 48.12 & 10.75 & 0.84 & 0.52 & 6.18 & 0.11 & 17.38 & 0.00 & 0.00 & 12.21 & 1.24 & 0.18 & 0.00 & 0.03 & 0.00 & 97.57 \\
\hline
\end{tabular}

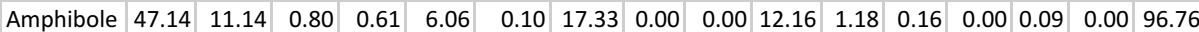

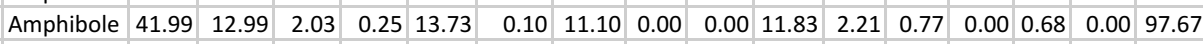

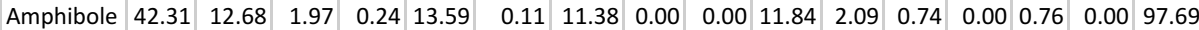

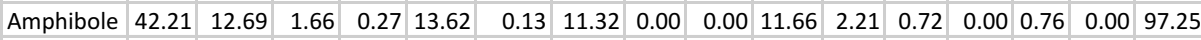

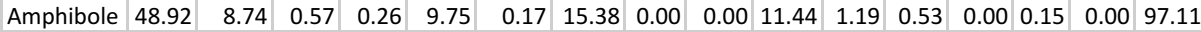

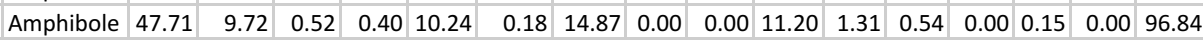

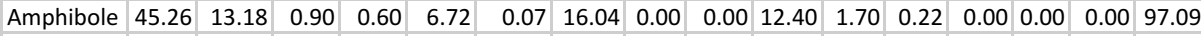

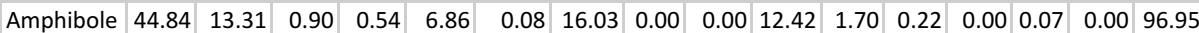

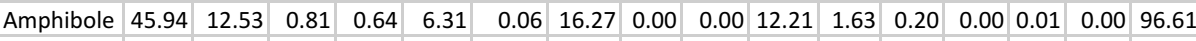
\begin{tabular}{|l|l|l|l|l|l|l|l|l|l|l|l|l|l|l|l|l|}
\hline Amphibole & 45.84 & 11.94 & 0.95 & 0.24 & 8.89 & 0.11 & 15.13 & 0.00 & 0.00 & 12.16 & 1.17 & 0.26 & 0.00 & 0.09 & 0.00 & 96.78 \\
\hline
\end{tabular} \begin{tabular}{|l|l|l|l|l|l|l|l|l|l|l|l|l|l|l|l|l|}
\hline Amphibole & 46.72 & 11.17 & 0.86 & 0.16 & 8.84 & 0.12 & 15.14 & 0.00 & 0.00 & 12.27 & 1.23 & 0.23 & 0.00 & 0.21 & 0.00 & 96.95 \\
\hline
\end{tabular} \begin{tabular}{|l|l|l|l|l|l|l|l|l|l|l|l|l|l|l|l|l|}
\hline Amphibole & 46.48 & 12.04 & 0.92 & 0.22 & 8.72 & 0.11 & 14.88 & 0.00 & 0.00 & 12.30 & 1.24 & 0.27 & 0.00 & 0.08 & 0.00 & 97.25 \\
\hline
\end{tabular}

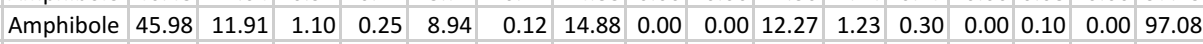

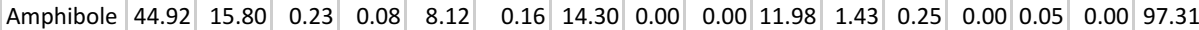

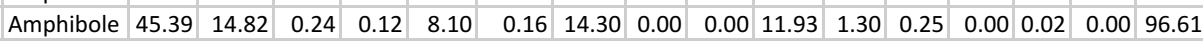
\begin{tabular}{|l|l|l|l|l|l|l|l|l|l|l|l|l|l|l|l|l} 
Amphibole & 46.80 & 12.34 & 0.38 & 0.19 & 8.66 & 0.12 & 14.72 & 0.00 & 0.00 & 12.25 & 1.10 & 0.17 & 0.00 & 0.05 & 0.00 & 96.77
\end{tabular}

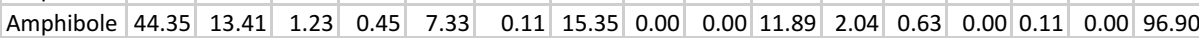
\begin{tabular}{|l|l|l|l|l|l|l|l|l|l|l|l|l|l|l|l|l|}
\hline Amphibole & 44.28 & 13.95 & 1.25 & 0.51 & 7.07 & 0.07 & 15.16 & 0.00 & 0.00 & 11.95 & 1.98 & 0.64 & 0.00 & 0.01 & 0.00 & 96.88 \\
\hline
\end{tabular} \begin{tabular}{|l|l|l|l|l|l|l|l|l|l|l|l|l|l|l|l|l|}
\hline Amphibole & 44.18 & 13.82 & 1.18 & 0.50 & 7.19 & 0.14 & 15.41 & 0.00 & 0.00 & 11.49 & 1.96 & 0.62 & 0.00 & 0.08 & 0.00 & 96.57 \\
\hline
\end{tabular}

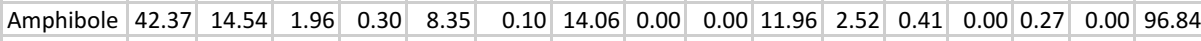

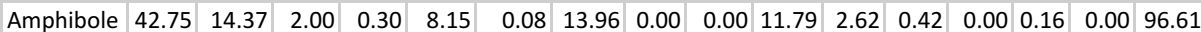

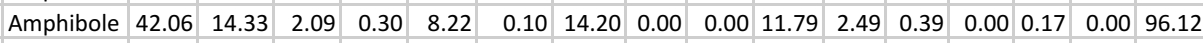

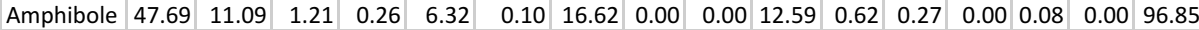

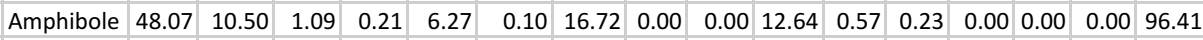

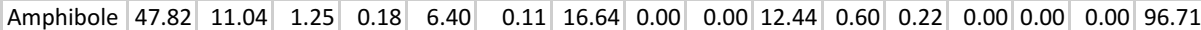
\begin{tabular}{|l|l|l|l|l|l|l|l|l|l|l|l|l|l|l|l|l|l|l|l|l|}
\hline Amphibole & 42.64 & 11.83 & 2.37 & 0.42 & 15.32 & 0.15 & 10.33 & 0.00 & 0.00 & 11.46 & 1.88 & 1.03 & 0.00 & 0.42 & 0.00 & 97.44 \\
\hline
\end{tabular}

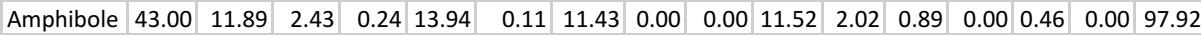
\begin{tabular}{|l|l|l|l|l|l|l|l|l|l|l|l|l|l|l|l|l|} 
Amphibole & 45.48 & 10.37 & 1.81 & 0.24 & 12.73 & 0.16 & 12.76 & 0.00 & 0.00 & 11.32 & 1.60 & 0.97 & 0.00 & 0.03 & 0.00 & 97.48 \\
\hline
\end{tabular}

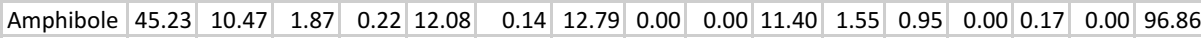
\begin{tabular}{|l|l|l|l|l|l|l|l|l|l|l|l|l|l|l|l|l|}
\hline Amphibole & 43.25 & 11.08 & 1.99 & 0.14 & 17.32 & 0.21 & 9.34 & 0.00 & 0.00 & 11.46 & 1.38 & 1.32 & 0.00 & 0.21 & 0.02 & 97.71 \\
\hline
\end{tabular}

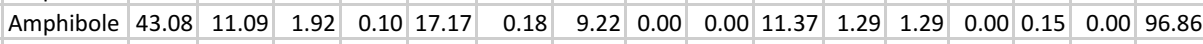
\begin{tabular}{|l|l|l|l|l|l|l|l|l|l|l|l|l|l|l|l|l}
\hline Amphibole & 48.74 & 9.80 & 0.98 & 0.39 & 6.40 & 0.07 & 16.57 & 0.00 & 0.00 & 12.61 & 0.69 & 0.07 & 0.00 & 0.00 & 0.00 & 96.31 \\
\hline
\end{tabular}

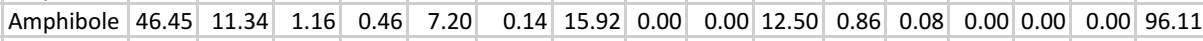
\begin{tabular}{|l|l|l|l|l|l|l|l|l|l|l|l|l|l|l|l|l} 
Amphibole & 41.86 & 15.43 & 0.23 & 0.06 & 9.23 & 0.08 & 14.47 & 0.00 & 0.00 & 11.97 & 2.85 & 0.35 & 0.00 & 0.31 & 0.00 & 96.83 \\
\hline
\end{tabular} \begin{tabular}{|l|l|l|l|l|l|l|l|l|l|l|l|l|l|l|l|l|}
\hline Amphibole & 43.35 & 14.73 & 0.07 & 0.02 & 8.40 & 0.12 & 15.20 & 0.00 & 0.00 & 11.97 & 2.80 & 0.27 & 0.00 & 0.35 & 0.00 & 97.26 \\
\hline
\end{tabular}

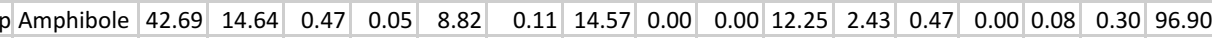

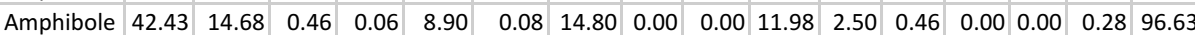

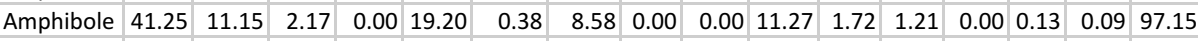
\begin{tabular}{|l|l|l|l|l|l|l|l|l|l|l|l|l|l|l|l|l|}
\hline Amphibole & 41.91 & 11.08 & 2.06 & 0.00 & 19.69 & 0.35 & 8.57 & 0.00 & 0.00 & 11.50 & 1.67 & 1.17 & 0.00 & 0.23 & 0.09 & 98.31 \\
\hline
\end{tabular}

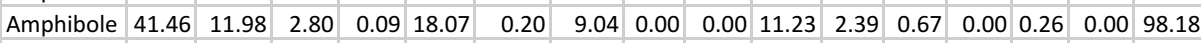

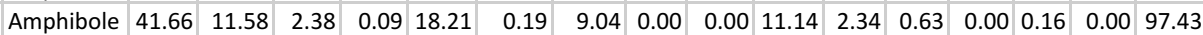
\begin{tabular}{|l|l|l|l|l|l|l|l|l|l|l|l|l|l|l|l|l|}
\hline Amphibole & 40.71 & 14.83 & 2.30 & 0.50 & 9.42 & 0.11 & 12.91 & 0.03 & 0.00 & 12.29 & 1.72 & 2.05 & 0.00 & 0.42 & 0.69 & 97.98 \\
\hline
\end{tabular} \begin{tabular}{|l|l|l|l|l|l|l|l|l|l|l|l|l|l|l|l|l|}
\hline Amphibole & 40.59 & 14.64 & 2.29 & 0.47 & 9.37 & 0.13 & 12.87 & 0.00 & 0.00 & 12.34 & 1.90 & 1.88 & 0.00 & 0.54 & 0.70 & 97.72 \\
\hline
\end{tabular}

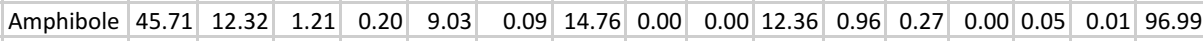
\begin{tabular}{|l|l|l|l|l|l|l|l|l|l|l|l|l|l|l|l|l}
\hline Amphibole & 44.53 & 13.05 & 1.41 & 0.22 & 8.93 & 0.08 & 14.36 & 0.00 & 0.00 & 12.55 & 0.95 & 0.30 & 0.00 & 0.00 & 0.00 & 96.38 \\
\hline
\end{tabular}

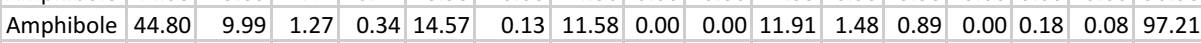

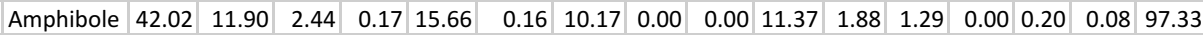




\begin{tabular}{|c|c|c|c|c|c|c|c|c|c|c|c|c|c|c|c|c|}
\hline \multicolumn{17}{|c|}{ Amphibole - Atoms Per Formula Unit } \\
\hline SAMPLE & Mineral & $\mathrm{Si}$ & Al & $\mathrm{Ti}$ & $\mathrm{Cr}$ & $\mathrm{Fe}$ & Mn & $\mathrm{Mg}$ & $\mathrm{Ni}$ & Zn & $\mathrm{Ca}$ & $\mathrm{Na}$ & $\mathrm{K}$ & $\mathrm{Ba}$ & $\sum$ cations & $\mathrm{Mg} /(\mathrm{Mg}+\mathrm{Fe})$ \\
\hline 14SAB-L012A01-spot2-2 & Amphibole & 6.67 & 2.03 & 0.03 & 0.01 & 0.85 & 0.02 & 3.69 & 0.00 & 0.00 & 1.79 & 0.39 & 0.00 & 0.00 & 15.48 & 0.81 \\
\hline 14SAB-L012A01-spot2-rep & Amphibole & 6.67 & 2.04 & 0.02 & 0.01 & 0.83 & 0.02 & 3.67 & 0.01 & 0.00 & 1.81 & 0.39 & 0.04 & 0.00 & 15.50 & 0.82 \\
\hline L012A01-circle2-4-hb & Amphibole & 6.65 & 2.05 & 0.03 & 0.01 & 0.84 & 0.01 & 3.65 & 0.00 & 0.00 & 1.81 & 0.42 & 0.04 & 0.00 & 15.52 & 0.81 \\
\hline L013A02-spot1-1-hb & Amphibole & 6.42 & 2.44 & 0.03 & 0.02 & 0.76 & 0.01 & 3.42 & 0.01 & 0.01 & 1.89 & 0.53 & 0.07 & 0.00 & 15.62 & 0.82 \\
\hline L015A01-spot2-3 & Amphbole & 6.64 & 1.90 & 0.14 & 0.00 & 1.63 & 0.03 & 2.92 & 0.00 & 0.00 & 1.77 & 70.45 & 0.06 & 0.00 & 15.53 & 0.64 \\
\hline L015A01-spot1-1 & Amphibole & 6.66 & 1.89 & 0.13 & 0.00 & 1.65 & 0.03 & 2.88 & 0.00 & 0.00 & 1.75 & 0.47 & 0.06 & 0.00 & 15.52 & 0.64 \\
\hline L017A02-spot1-2 & Amphibole & 6.92 & 1.55 & 0.06 & 0.03 & 1.43 & 0.03 & 3.16 & 0.00 & 0.00 & 1.81 & 0.30 & 0.15 & 0.00 & 15.45 & 0.69 \\
\hline L017A02-spot2-2 & Amphibole & 6.88 & 1.59 & 0.08 & 0.02 & 1.45 & 0.03 & 3.20 & 0.00 & 0.00 & 1.78 & 0.33 & 0.14 & 0.00 & 15.48 & 0.69 \\
\hline L017A02-spot2-3 & Amphibole & 6.93 & 1.59 & 0.06 & 0.02 & 1.46 & 0.03 & 3.11 & 0.00 & 0.00 & 1.80 & 0.29 & 0.15 & 0.00 & 15.43 & 0.68 \\
\hline L014-A01-spot2-4 & Amphibole & 6.57 & 2.14 & 0.05 & 0.01 & 0.87 & 0.02 & 3.51 & 0.00 & 0.00 & 1.91 & 0.35 & 0.08 & 0.00 & 15.52 & 0.80 \\
\hline L076-A02-spot1-1 & Amphibole & 6.76 & 2.06 & 0.03 & 0.00 & 0.77 & 0.01 & 3.53 & 0.00 & 0.00 & 1.83 & 0.31 & 0.04 & 0.00 & 15.35 & 0.82 \\
\hline L076-A02-spot1-2 & Amphibole & 6.74 & 2.08 & 0.03 & 0.01 & 0.79 & 0.01 & 3.51 & 0.00 & 0.00 & 1.85 & 0.31 & 0.04 & 0.00 & 15.36 & 0.82 \\
\hline L077-A01-spot3-1 & Amphibole & 6.91 & 1.88 & 0.02 & 0.01 & 0.74 & 0.01 & 3.67 & 0.00 & 0.00 & 1.74 & 0.28 & 0.01 & 0.00 & 15.27 & 0.83 \\
\hline L077-A01-spot3-2 & Amphibole & 6.87 & 1.94 & 0.02 & 0.01 & 0.71 & 0.01 & 3.67 & 0.00 & 0.00 & 1.76 & 0.31 & 0.01 & 0.00 & 15.30 & 0.84 \\
\hline L079-A01-spot1-2 & Amphibole & 6.82 & 1.95 & 0.03 & 0.01 & 0.69 & 0.01 & 3.70 & 0.00 & 0.00 & 1.77 & 0.36 & 0.02 & 0.00 & 15.36 & 0.84 \\
\hline L079-A01-spot2-2 & Amphibole & 6.80 & 1.93 & 0.03 & 0.01 & 0.69 & 0.01 & 3.77 & 0.00 & 0.00 & 1.79 & 0.33 & 0.02 & 0.00 & 15.37 & 0.85 \\
\hline L080-A02-spot1-1 & Amphibole & 7.16 & 1.35 & 0.04 & 0.04 & 1.16 & 0.02 & 3.41 & 0.00 & 0.00 & 1.77 & 0.29 & 0.02 & 0.00 & 15.26 & 0.75 \\
\hline L080-A02-spot1-2 & Amphibole & 7.25 & 1.22 & 0.05 & 0.03 & 1.34 & 0.03 & 3.48 & 0.00 & 0.00 & 1.55 & 0.25 & 0.02 & 0.00 & 15.21 & 0.72 \\
\hline L080-A02-spot1-3 & Amphibole & 7.19 & 1.29 & 0.05 & 0.03 & 1.20 & 0.03 & 3.46 & 0.00 & 0.00 & 1.72 & 0.27 & 0.02 & 0.00 & 15.25 & 0.74 \\
\hline L080-A02-spot2-3 & Amphibole & 7.21 & 1.31 & 0.04 & 0.02 & 1.17 & 0.02 & 3.42 & 0.00 & 0.00 & 1.73 & 0.26 & 0.02 & 0.00 & 15.22 & 0.74 \\
\hline L080-A02-spot2-4 & Amphibole & 7.27 & 1.27 & 0.04 & 0.02 & 1.23 & 0.03 & 3.40 & 0.00 & 0.00 & 1.64 & 0.28 & 0.02 & 0.00 & 15.19 & 0.73 \\
\hline L078A01-spot1-1 & Amphibole & 6.77 & 1.98 & 0.03 & 0.03 & 0.65 & 0.01 & 3.67 & 0.00 & 0.00 & 1.83 & 0.36 & 0.04 & 0.00 & 15.39 & 0.85 \\
\hline L078A01-spot1-2 & Amphibole & 6.82 & 1.93 & 0.04 & 0.03 & 0.63 & 0.01 & 3.68 & 0.00 & 0.00 & 1.82 & 0.34 & 0.04 & 0.00 & 15.35 & 0.85 \\
\hline L012A02-spot2-3 & Amphibole & 6.28 & 2.58 & 0.05 & 0.02 & 0.97 & 0.01 & 3.23 & 0.00 & 0.00 & 1.83 & 0.74 & 0.06 & 0.00 & 15.78 & 0.77 \\
\hline L012A02-spot2-4 & Amphibole & 6.38 & 2.42 & 0.05 & 0.03 & 0.91 & 0.01 & 3.32 & 0.00 & 0.00 & 1.84 & 0.71 & 0.06 & 0.00 & 15.73 & 0.79 \\
\hline L012A02-spot1-2 & Amphibole & 6.39 & 2.35 & 0.12 & 0.03 & 1.05 & 0.01 & 3.13 & 0.00 & 0.00 & 1.84 & 0.68 & 0.10 & 0.00 & 15.69 & 0.75 \\
\hline 14SAB-L002A01-spot1-3 & Amphibole & 6.88 & 1.63 & 0.08 & 0.08 & 0.69 & 0.01 & 3.76 & 0.00 & 0.00 & 1.90 & 0.28 & 0.04 & 0.00 & 15.35 & 0.85 \\
\hline 14SAB-L002A01-spot1-4 & Amphibole & 6.93 & 1.64 & 0.07 & 0.09 & 0.67 & 0.01 & 3.68 & 0.00 & 0.00 & 1.89 & 0.26 & 0.03 & 0.00 & 15.27 & 0.85 \\
\hline 14SAB-L002A01-spot2-1 & Amphibole & 7.40 & 0.98 & 0.04 & 0.03 & 0.59 & 0.01 & 4.06 & 0.00 & 0.00 & 1.85 & 0.17 & 0.01 & 0.00 & 15.14 & 0.87 \\
\hline 14SAB-L002A02-spot1-3 & Amphibole & 6.60 & 1.85 & 0.17 & 0.04 & 1.10 & 0.01 & 3.33 & 0.00 & 0.00 & 1.86 & 0.51 & 0.18 & 0.00 & 15.64 & 0.75 \\
\hline 14SAB-L002A02-spot2-1 & Amphibole & 6.53 & 1.90 & 0.17 & 0.04 & 1.18 & 0.02 & 3.32 & 0.00 & 0.00 & 1.85 & 0.50 & 0.18 & 0.00 & 15.68 & 0.74 \\
\hline 14SAB-L006A01-spot1-2 & Amphibole & 6.24 & 2.19 & 0.33 & 0.00 & 2.82 & 0.03 & 1.41 & 0.00 & 0.00 & 1.87 & 0.60 & 0.32 & 0.00 & 15.80 & 0.33 \\
\hline 14SAB-L006A01-spot2-4 & Amphibole & 6.21 & 2.19 & 0.33 & 0.00 & 2.87 & 0.03 & 1.42 & 0.00 & 0.00 & 1.86 & 0.58 & 0.31 & 0.00 & 15.80 & 0.33 \\
\hline 14SAB-L006B01-spot1-1 & Amphibole & 6.78 & 1.93 & 0.12 & 0.03 & 0.78 & 0.01 & 3.40 & 0.01 & 0.00 & 1.94 & 0.22 & 0.04 & 0.00 & 15.25 & 0.81 \\
\hline 14SAB-L006B01-spot2-4 & Amphibole & 7.67 & 0.66 & 0.04 & 0.01 & 0.57 & 0.01 & 4.05 & 0.00 & 0.00 & 1.92 & 0.03 & 0.00 & 0.00 & 14.97 & 0.88 \\
\hline 14SAB-L010A01-spot1-3 & Amphibole & 6.38 & 2.12 & 0.26 & 0.00 & 1.61 & 0.02 & 2.65 & 0.00 & 0.00 & 1.85 & 0.57 & 0.26 & 0.00 & 15.72 & 0.62 \\
\hline 14SAB-L010A01-spot2-5 & Amphibole & 6.41 & 2.08 & 0.22 & 0.00 & 1.61 & 0.02 & 2.70 & 0.00 & 0.00 & 1.88 & 0.55 & 0.26 & 0.00 & 15.73 & 0.63 \\
\hline 15SAB-L077B01- area 1-1 & Amphibole & 6.49 & 2.43 & 0.04 & 0.02 & 1.02 & 0.02 & 3.13 & 0.00 & 0.00 & 1.92 & 0.35 & 0.04 & 0.00 & 15.45 & 0.75 \\
\hline 15SAB-L077B01-area 1-2 & Amphibole & 6.45 & 2.54 & 0.03 & 0.02 & 1.00 & 0.02 & 3.05 & 0.00 & 0.00 & 1.92 & 0.36 & 0.05 & 0.00 & 15.44 & 0.75 \\
\hline 15SAB-L077B01-area2-2 & Amphibole & 6.68 & 2.14 & 0.04 & 0.02 & 1.05 & 0.02 & 3.16 & 0.00 & 0.00 & 1.92 & 0.31 & 0.04 & 0.00 & 15.37 & 0.75 \\
\hline 15SAB-L080A01-area1-1 & Amphibole & 7.14 & 1.33 & 0.09 & 0.01 & 1.16 & 0.03 & 3.38 & 0.00 & 0.00 & 1.80 & 0.28 & 0.02 & 0.00 & 15.25 & 0.74 \\
\hline 15SAB-L080A01-area1-2 & Amphibole & 7.14 & 1.31 & 0.10 & 0.02 & 1.18 & 0.03 & 3.39 & 0.00 & 0.00 & 1.78 & 0.30 & 0.02 & 0.00 & 15.26 & 0.74 \\
\hline 15SAB-L080A01-area2-2 & Amphibole & 7.18 & 1.31 & 0.08 & 0.01 & 1.16 & 0.03 & 3.38 & 0.00 & 0.00 & 1.78 & 0.28 & 0.02 & 0.00 & 15.23 & 0.74 \\
\hline 15SAB-L080A01-area2-3 & Amphibole & 7.19 & 1.30 & 0.08 & 0.01 & 1.11 & 0.02 & 3.43 & 0.00 & 0.00 & 1.78 & 0.25 & 0.03 & 0.00 & 15.20 & 0.76 \\
\hline 14SAB-H080B01-area1-1 & Amphibole & 6.74 & 1.85 & 0.09 & 0.07 & 0.67 & 0.01 & 3.67 & 0.00 & 0.00 & 1.91 & 0.36 & 0.03 & 0.00 & 15.40 & 0.84 \\
\hline 14SAB-H080B01 area 2-3 & Amphibole & 6.79 & 1.76 & 0.08 & 0.06 & 0.65 & 0.01 & 3.72 & 0.00 & 0.00 & 1.94 & 0.35 & 0.03 & 0.00 & 15.40 & 0.85 \\
\hline 14SAB-H080B01 area 2-4 & Amphibole & 6.77 & 1.80 & 0.08 & 0.07 & 0.66 & 0.01 & 3.70 & 0.00 & 0.00 & 1.94 & 0.33 & 0.03 & 0.00 & 15.39 & 0.85 \\
\hline 15SAB-L076A01 area 1-1 & Amphibole & 6.76 & 2.02 & 0.02 & 0.01 & 0.79 & 0.01 & 3.51 & 0.00 & 0.00 & 1.91 & 0.30 & 0.04 & 0.00 & 15.38 & 0.82 \\
\hline
\end{tabular}




\begin{tabular}{|c|c|c|c|c|c|c|c|c|c|c|c|c|c|c|c|c|}
\hline \multicolumn{17}{|c|}{ Amphibole - Atoms Per Formula Unit } \\
\hline SAMPLE & Mineral & $\mathrm{Si} \quad \mathrm{t}$ & Al & $\mathrm{Ti}$ & $\mathrm{Cr}$ & $\mathrm{Fe} \quad \mathrm{I}$ & $\mathrm{Mn}$ & Mg & $\mathrm{Ni}$ & $\mathrm{Zn}$ & $\mathrm{Ca}$ & $\mathrm{Na} \mathrm{r}$ & K & $\mathrm{Ba}$ & $\sum$ cations & $\mathrm{Mg} /(\mathrm{Mg}+\mathrm{Fe})$ \\
\hline 15SAB-L076A01 area 1-2 & Amphibole & 6.79 & 2.00 & 0.02 & 0.01 & 0.78 & 0.02 & 3.49 & 0.00 & 0.00 & 1.91 & 0.30 & 0.04 & 0.00 & 15.35 & 0.82 \\
\hline 15SAB-L076A01 area 2-5 & Amphibole & 6.75 & 2.02 & 0.03 & 0.01 & 0.77 & 0.01 & 3.56 & 0.00 & 0.00 & 1.90 & 0.30 & 0.04 & 0.00 & 15.37 & 0.82 \\
\hline 14SAB-R010A01-spot1-4 & Amphibole & 6.93 & 1.62 & 0.10 & 0.07 & 0.48 & 0.02 & 3.85 & 0.00 & 0.00 & 1.92 & 0.26 & 0.04 & 0.00 & 15.28 & 0.89 \\
\hline 14SAB-R010A01-spot2-1 & Amphibole & 6.88 & 1.68 & 0.10 & 0.09 & 0.49 & 0.01 & 3.79 & 0.00 & 0.00 & 1.93 & 0.26 & 0.05 & 0.00 & 15.28 & 0.89 \\
\hline 14SAB-L007A02-spot1-5 & Amphibole & 6.44 & 2.29 & 0.13 & 0.04 & 0.95 & 0.01 & 3.28 & 0.00 & 0.00 & 1.85 & 0.47 & 0.09 & 0.00 & 15.55 & 0.78 \\
\hline 14SAB-L007A02-spot1-1 & Amphibole & 6.46 & 2.28 & 0.12 & 0.04 & 0.94 & 0.01 & 3.28 & 0.00 & 0.00 & 1.84 & 0.46 & 0.09 & 0.00 & 15.53 & 0.78 \\
\hline 14SAB-L016A01-spot1-1 & Amphibole & 6.93 & 1.60 & 0.06 & 0.03 & 1.35 & 0.03 & 3.18 & 0.00 & 0.00 & 1.82 & 0.33 & 0.12 & 0.00 & 15.44 & 0.70 \\
\hline 14SAB-L016A01-spot2-3 & Amphibole & 6.93 & 1.58 & 0.05 & 0.02 & 1.37 & 0.03 & 3.19 & 0.00 & 0.00 & 1.84 & 0.30 & 0.12 & 0.00 & 15.43 & 0.70 \\
\hline 14SAB-L003A01-spot1-1 & Amphibole & 6.80 & 1.79 & 0.09 & 0.06 & 0.73 & 0.01 & 3.66 & 0.00 & 0.00 & 1.85 & 0.34 & 0.03 & 0.00 & 15.37 & 0.83 \\
\hline 14SAB-L003A01-spot2-3 & Amphibole & 6.73 & 1.87 & 0.09 & 0.07 & 0.72 & 0.01 & 3.69 & 0.00 & 0.00 & 1.86 & 0.33 & 0.03 & 0.00 & 15.39 & 0.84 \\
\hline 14SAB-L008A02-spot1-1 & Amphibole & 6.28 & 2.29 & 0.23 & 0.03 & 1.72 & 0.01 & 2.48 & 0.00 & 0.00 & 1.90 & 0.64 & 0.15 & 0.00 & 15.72 & 0.59 \\
\hline 14SAB-L008A02-spot1-2 & Amphibole & 6.32 & 2.23 & 0.22 & 0.03 & 1.70 & 0.01 & 2.54 & 0.00 & 0.00 & 1.90 & 0.60 & 0.14 & 0.00 & 15.70 & 0.60 \\
\hline 14SAB-L008A02-spot2-3 & Amphibole & 6.34 & 2.25 & 0.19 & 0.03 & 1.71 & 0.02 & 2.53 & 0.00 & 0.00 & 1.88 & 0.64 & 0.14 & 0.00 & 15.73 & 0.60 \\
\hline 14SAB-L057B02-spot1-1 & Amphibole & 7.06 & 1.49 & 0.06 & 0.03 & 1.18 & 0.02 & 3.31 & 0.00 & 0.00 & 1.77 & 0.33 & 0.10 & 0.00 & 15.34 & 0.74 \\
\hline 14SAB-L057B02-spot2-4 & Amphibole & 6.93 & 1.66 & 0.06 & 0.05 & 1.24 & 0.02 & 3.22 & 0.00 & 0.00 & 1.74 & 0.37 & 0.10 & 0.00 & 15.39 & 0.72 \\
\hline 15SAB-L119A01-spot1-5 & Amphibole & 6.48 & 2.23 & 0.10 & 0.07 & 0.80 & 0.01 & 3.43 & 0.00 & 0.00 & 1.90 & 0.47 & 0.04 & 0.00 & 15.53 & 0.81 \\
\hline 15SAB-L119A01-spot1-4 & Amphibole & 6.45 & 2.26 & 0.10 & 0.06 & 0.82 & 0.01 & 3.44 & 0.00 & 0.00 & 1.91 & 0.47 & 0.04 & 0.00 & 15.56 & 0.81 \\
\hline 15SAB-L119A01-spot2-1 & Amphibole & 6.59 & 2.12 & 0.09 & 0.07 & 0.76 & 0.01 & 3.48 & 0.00 & 0.00 & 1.88 & 0.45 & 0.04 & 0.00 & 15.47 & 0.82 \\
\hline 14SAB-H080A01-spot1-5 & Amphibole & 6.63 & 2.04 & 0.10 & 0.03 & 1.08 & 0.01 & 3.26 & 0.00 & 0.00 & 1.89 & 0.33 & 0.05 & 0.00 & 15.42 & 0.75 \\
\hline 14SAB-H080A01-spot1-6 & Amphibole & 6.75 & 1.90 & 0.09 & 0.02 & 1.07 & 0.02 & 3.26 & 0.00 & 0.00 & 1.90 & 0.35 & 0.04 & 0.00 & 15.39 & 0.75 \\
\hline 14SAB-H080A01-spot1-7 & Amphibole & 6.68 & 2.04 & 0.10 & 0.02 & 1.05 & 0.01 & 3.19 & 0.00 & 0.00 & 1.89 & 0.35 & 0.05 & 0.00 & 15.39 & 0.75 \\
\hline 14SAB-H080A01-spot1-7 & Amphibole & 6.64 & 2.03 & 0.12 & 0.03 & 1.08 & 0.02 & 3.20 & 0.00 & 0.00 & 1.90 & 0.34 & 0.05 & 0.00 & 15.41 & 0.75 \\
\hline 15SAB-L077B01-area1- 1 & Amphibole & 6.42 & 2.66 & 0.02 & 0.01 & 0.97 & 0.02 & 3.05 & 0.00 & 0.00 & 1.83 & 0.40 & 0.05 & 0.00 & 15.44 & 0.76 \\
\hline 15SAB-L077B01-area1- 2 & Amphibole & 6.53 & 2.51 & 0.03 & 0.01 & 0.97 & 0.02 & 3.07 & 0.00 & 0.00 & 1.84 & 0.36 & 0.05 & 0.00 & 15.39 & 0.76 \\
\hline 15SAB-L077B01-area2-3 & Amphibole & 6.74 & 2.09 & 0.04 & 0.02 & 1.04 & 0.01 & 3.16 & 0.00 & 0.00 & 1.89 & 0.31 & 0.03 & 0.00 & 15.34 & 0.75 \\
\hline 14SAB-L009A01-area1-3 & Amphibole & 6.41 & 2.29 & 0.13 & 0.05 & 0.89 & 0.01 & 3.31 & 0.00 & 0.00 & 1.84 & 0.57 & 0.12 & 0.00 & 15.63 & 0.79 \\
\hline 14SAB-L009A01-area1-4 & Amphibole & 6.39 & 2.37 & 0.14 & 0.06 & 0.85 & 0.01 & 3.26 & 0.00 & 0.00 & 1.85 & 0.55 & 0.12 & 0.00 & 15.60 & 0.79 \\
\hline 14SAB-L009A01-area2-1 & Amphibole & 6.40 & 2.36 & 0.13 & 0.06 & 0.87 & 0.02 & 3.32 & 0.00 & 0.00 & 1.78 & 0.55 & 0.12 & 0.00 & 15.60 & 0.79 \\
\hline 14SAB-L004A01-spot1-5 & Amphibole & 6.20 & 2.51 & 0.22 & 0.03 & 1.02 & 0.01 & 3.06 & 0.00 & 0.00 & 1.87 & 0.71 & 0.08 & 0.00 & 15.71 & 0.75 \\
\hline 14SAB-L004A01-spot1-6 & Amphibole & 6.25 & 2.47 & 0.22 & 0.03 & 1.00 & 0.01 & 3.04 & 0.00 & 0.00 & 1.85 & 0.74 & 0.08 & 0.00 & 15.69 & 0.75 \\
\hline 14SAB-L004A01-spot2-1 & Amphibole & 6.19 & 2.48 & 0.23 & 0.03 & 1.01 & 0.01 & 3.11 & 0.00 & 0.00 & 1.86 & 0.71 & 0.07 & 0.00 & 15.71 & 0.75 \\
\hline 14SAB-S130A01-spot1-4 & Amphibole & 6.79 & 1.86 & 0.13 & 0.03 & 0.75 & 0.01 & 3.53 & 0.00 & 0.00 & 1.92 & 0.17 & 0.05 & 0.00 & 15.24 & 0.82 \\
\hline 14SAB-S130A01-spot2-1 & Amphibole & 6.86 & 1.77 & 0.12 & 0.02 & 0.75 & 0.01 & 3.56 & 0.00 & 0.00 & 1.93 & 0.16 & 0.04 & 0.00 & 15.22 & 0.83 \\
\hline 14SAB-S130A01-spot2-2 & Amphibole & 6.81 & 1.85 & 0.13 & 0.02 & 0.76 & 0.01 & 3.53 & 0.00 & 0.00 & 1.90 & 0.17 & 0.04 & 0.00 & 15.23 & 0.82 \\
\hline 14SAB-L001B01-spot1-5 & Amphibole & 6.39 & 2.09 & 0.27 & 0.05 & 1.92 & 0.02 & 2.31 & 0.00 & 0.00 & 1.84 & 0.55 & 0.20 & 0.00 & 15.64 & 0.55 \\
\hline 14SAB-L001B01-spot2-1 & Amphibole & 6.40 & 2.08 & 0.27 & 0.03 & 1.73 & 0.01 & 2.53 & 0.00 & 0.00 & 1.84 & 0.58 & 0.17 & 0.00 & 15.65 & 0.59 \\
\hline 14SAB-L003B01-spot1-5 & Amphibole & 6.69 & 1.80 & 0.20 & 0.03 & 1.57 & 0.02 & 2.80 & 0.00 & 0.00 & 1.78 & 0.46 & 0.18 & 0.00 & 15.52 & 0.64 \\
\hline 14SAB-L003B01-spot2-1 & Amphibole & 6.68 & 1.82 & 0.21 & 0.03 & 1.49 & 0.02 & 2.82 & 0.00 & 0.00 & 1.80 & 0.45 & 0.18 & 0.00 & 15.50 & 0.65 \\
\hline 15SAB-L056B01-spot1-4 & Amphibole & 6.53 & 1.97 & 0.23 & 0.02 & 2.19 & 0.03 & 2.10 & 0.00 & 0.00 & 1.85 & 0.40 & 0.25 & 0.00 & 15.58 & 0.49 \\
\hline 15SAB-L056B01-spot3 & Amphibole & 6.55 & 1.99 & 0.22 & 0.01 & 2.18 & 0.02 & 2.09 & 0.00 & 0.00 & 1.85 & 0.38 & 0.25 & 0.00 & 15.55 & 0.49 \\
\hline 14SAB-L001A01-spot1-1 & Amphibole & 6.96 & 1.65 & 0.11 & 0.04 & 0.76 & 0.01 & 3.53 & 0.00 & 0.00 & 1.93 & 0.19 & 0.01 & 0.00 & 15.19 & 0.82 \\
\hline 14SAB-L001A01-spot2-2 & Amphibole & 6.70 & 1.93 & 0.13 & 0.05 & 0.87 & 0.02 & 3.43 & 0.00 & 0.00 & 1.93 & 0.24 & 0.01 & 0.00 & 15.31 & 0.80 \\
\hline 15SAB-L112A01-spot1-4 & Amphibole & 6.15 & 2.67 & 0.02 & 0.01 & 1.13 & 0.01 & 3.17 & 0.00 & 0.00 & 1.88 & 0.81 & 0.06 & 0.00 & 15.93 & 0.74 \\
\hline 15SAB-L112A01-spot2-1 & Amphibole & 6.30 & 2.52 & 0.01 & 0.00 & 1.02 & 0.01 & 3.29 & 0.00 & 0.00 & 1.86 & 0.79 & 0.05 & 0.00 & 15.85 & 0.76 \\
\hline 15SAB-D196A01-spot2-4rep & Amphibole & 6.25 & 2.53 & 0.05 & 0.01 & 1.08 & 0.01 & 3.18 & 0.00 & 0.00 & 1.92 & 0.69 & 0.09 & 0.00 & 15.82 & 0.75 \\
\hline 15SAB-D196A01-spot3-3 & Amphibole & 6.23 & 2.54 & 0.05 & 0.01 & 1.09 & 0.01 & 3.24 & 0.00 & 0.00 & 1.88 & 0.71 & 0.09 & 0.00 & 15.85 & 0.75 \\
\hline 15SAB-M005A01-spot1-3 & Amphibole & 6.36 & 2.03 & 0.25 & 0.00 & 2.48 & 0.05 & 1.97 & 0.00 & 0.00 & 1.86 & 0.52 & 0.24 & 0.00 & 15.75 & 0.44 \\
\hline 15SAB-M005A01-spot2-2 & Amphibole & 6.40 & 1.99 & 0.24 & 0.00 & 2.51 & 0.04 & 1.95 & 0.00 & 0.00 & 1.88 & 0.50 & 0.23 & 0.00 & 15.73 & 0.44 \\
\hline 14SAB-L011A02-spot1-2 & Amphibole & 6.27 & 2.14 & 0.32 & 0.01 & 2.29 & 0.03 & 2.04 & 0.00 & 0.00 & 1.82 & 0.70 & 0.13 & 0.00 & 15.75 & 0.47 \\
\hline 14SAB-L011A02-spot1-3 & Amphibole & 6.35 & 2.08 & 0.27 & 0.01 & 2.32 & 0.02 & 2.05 & 0.00 & 0.00 & 1.82 & 0.69 & 0.12 & 0.00 & 15.74 & 0.47 \\
\hline 14SAB-L010C01-spot1-2 & Amphibole & 6.04 & 2.59 & 0.26 & 0.06 & 1.17 & 0.01 & 2.85 & 0.00 & 0.00 & 1.95 & 0.50 & 0.39 & 0.00 & 15.82 & 0.71 \\
\hline 14SAB-L010C01-spot2-3 & Amphibole & 6.04 & 2.57 & 0.26 & 0.06 & 1.17 & 0.02 & 2.86 & 0.00 & 0.00 & 1.97 & 0.55 & 0.36 & 0.00 & 15.84 & 0.71 \\
\hline 14SAB-L005A01-spot1-1 & Amphibole & 6.60 & 2.10 & 0.13 & 0.02 & 1.09 & 0.01 & 3.18 & 0.00 & 0.00 & 1.91 & 0.27 & 0.05 & 0.00 & 15.37 & 0.74 \\
\hline 14SAB-L005A01-spot2-3 & Amphibole & 6.48 & 2.24 & 0.15 & 0.03 & 1.09 & 0.01 & 3.12 & 0.00 & 0.00 & 1.96 & 0.27 & 0.06 & 0.00 & 15.39 & 0.74 \\
\hline 14SAB-L005A02-spot1-1 & Amphibole & 6.70 & 1.76 & 0.14 & 0.04 & 1.82 & 0.02 & 2.58 & 0.00 & 0.00 & 1.91 & 0.43 & 0.17 & 0.00 & 15.56 & 0.59 \\
\hline 14SAB-L005A02-spot2-3 & Amphibole & 6.35 & 2.12 & 0.28 & 0.02 & 1.98 & 0.02 & 2.29 & 0.00 & 0.00 & 1.84 & 0.55 & 0.25 & 0.00 & 15.70 & 0.54 \\
\hline
\end{tabular}


Plagioclase - Electron Microprobe Data

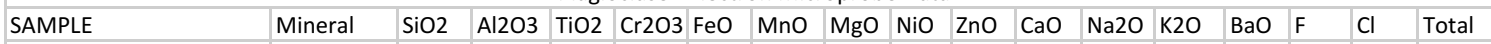

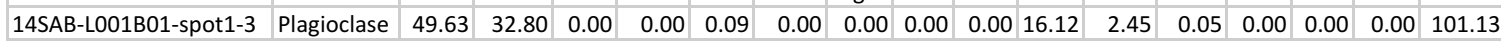
\begin{tabular}{|l|l|l|l|l|l|l|l|l|l|l|l|l|l|l|l|l|l|}
\hline 14SAB-L001B01-spot1-4 & Plagioclase & 49.14 & 32.82 & 0.00 & 0.00 & 0.09 & 0.00 & 0.00 & 0.00 & 0.00 & 16.49 & 2.25 & 0.03 & 0.00 & 0.00 & 0.00 & 100.82 \\
\hline
\end{tabular}

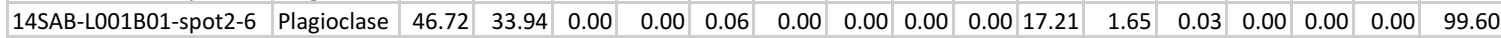
\begin{tabular}{|l|l|l|l|l|l|l|l|l|l|l|l|l|l|l|l|l|l|}
\hline 14SAB-L001B01-spot2-7 & Plagioclase & 46.62 & 34.05 & 0.00 & 0.00 & 0.11 & 0.00 & 0.00 & 0.00 & 0.00 & 17.46 & 1.51 & 0.01 & 0.00 & 0.00 & 0.00 & 99.76 \\
\hline
\end{tabular}

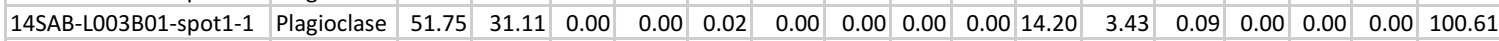

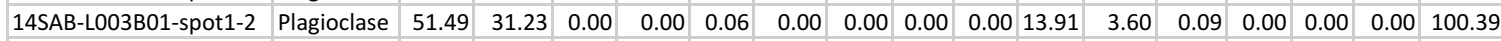

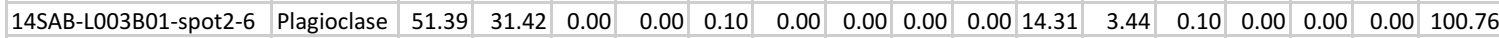

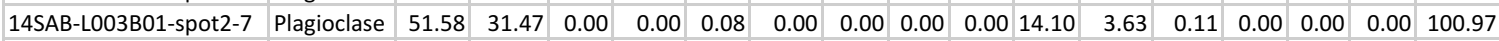

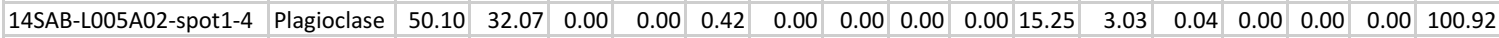

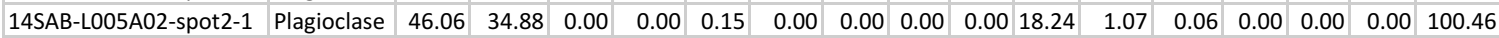

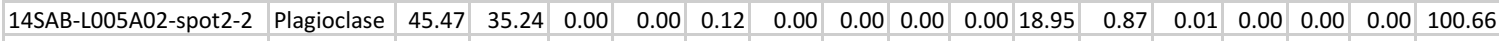

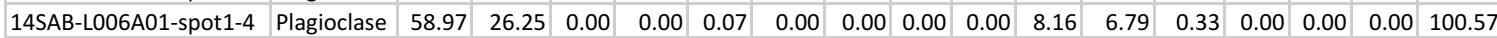

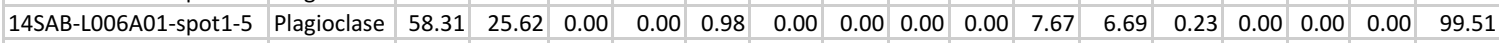
\begin{tabular}{|l|l|l|l|l|l|l|l|l|l|l|l|l|l|l|l|l|l|l|l|l|l|l|}
\hline 14SAB-L006A01-spot2-1 & Plagioclase & 58.84 & 26.39 & 0.00 & 0.00 & 0.08 & 0.00 & 0.00 & 0.00 & 0.00 & 8.04 & 6.99 & 0.27 & 0.00 & 0.00 & 0.00 & 100.60 \\
\hline
\end{tabular}

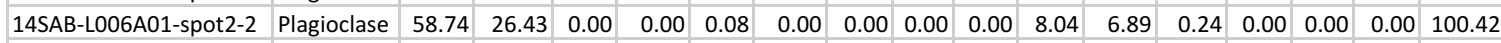

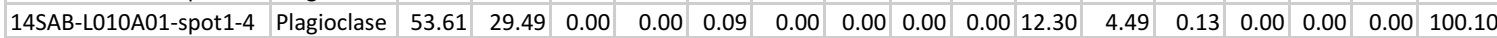

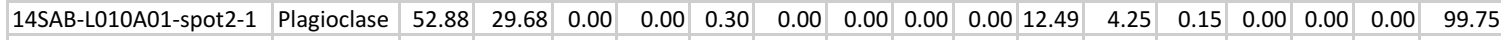

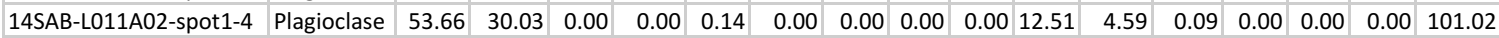

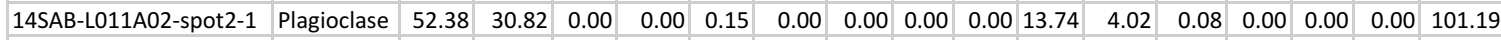

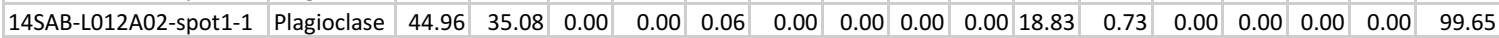

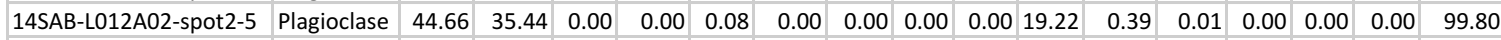

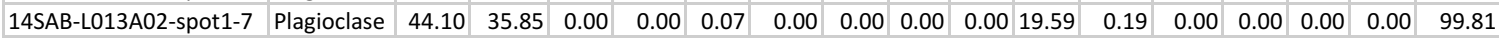

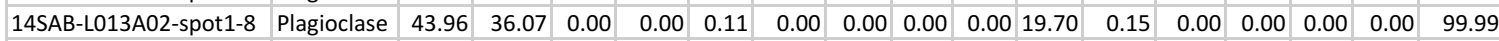

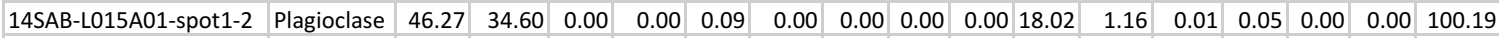

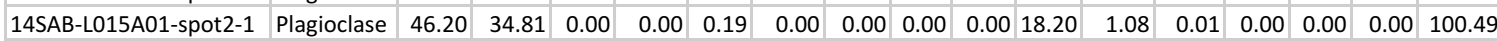

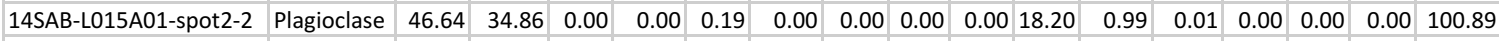

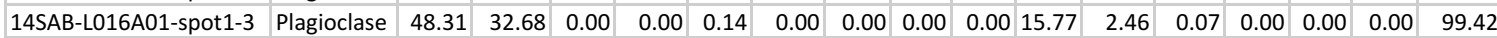

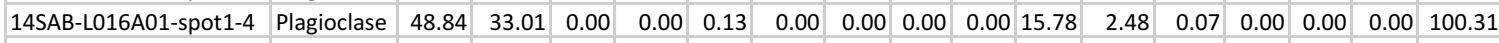
\begin{tabular}{|l|l|l|l|l|l|l|l|l|l|l|l|l|l|l|l|l|l|}
\hline 14SAB-L016A01-spot2-1 & Plagioclase & 49.06 & 33.36 & 0.00 & 0.00 & 0.16 & 0.00 & 0.00 & 0.00 & 0.00 & 16.02 & 2.41 & 0.06 & 0.00 & 0.00 & 0.00 & 101.07
\end{tabular}

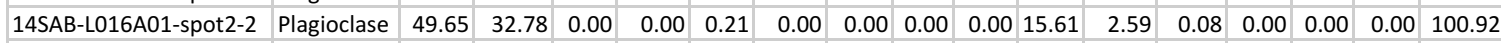

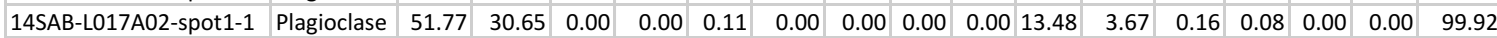

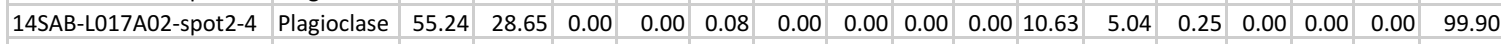

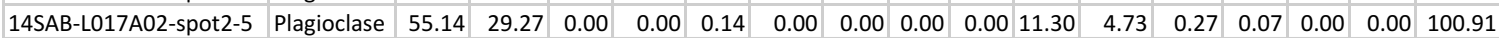

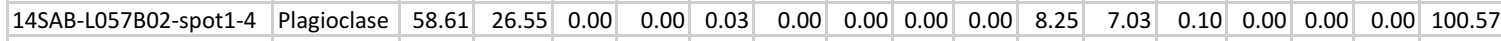

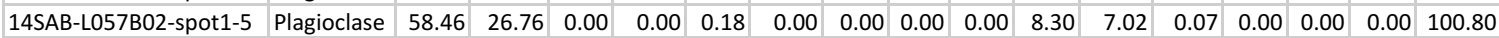

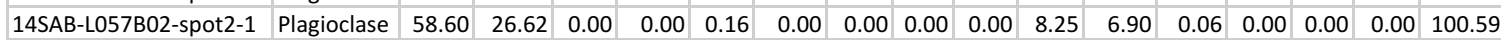

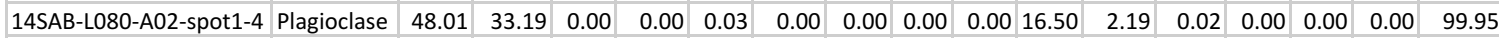

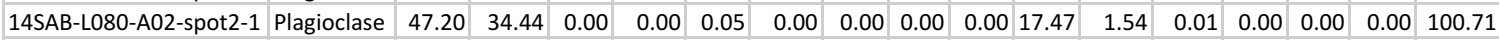

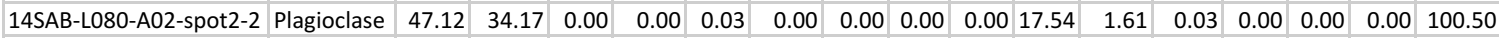

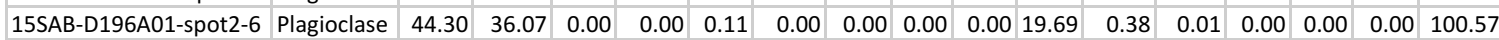

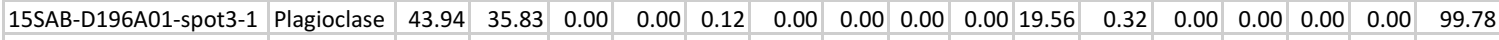

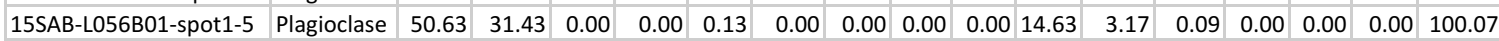
\begin{tabular}{|l|l|l|l|l|l|l|l|l|l|l|l|l|l|l|l|l|l|}
\hline 15SAB-L056B01-spot1-6 & Plagioclase & 54.43 & 28.82 & 0.00 & 0.00 & 0.05 & 0.00 & 0.00 & 0.00 & 0.00 & 11.58 & 4.86 & 0.17 & 0.00 & 0.00 & 0.00 & 99.91 \\
\hline
\end{tabular} \begin{tabular}{|l|l|l|l|l|l|l|l|l|l|l|l|l|l|l|l|l|l|}
\hline 15SAB-L056B01-spot2-1 & Plagioclase & 50.34 & 31.34 & 0.00 & 0.00 & 0.15 & 0.00 & 0.00 & 0.00 & 0.00 & 14.71 & 3.07 & 0.09 & 0.00 & 0.00 & 0.00 & 99.71 \\
\hline
\end{tabular}

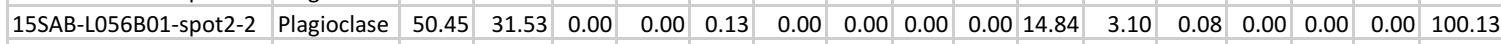

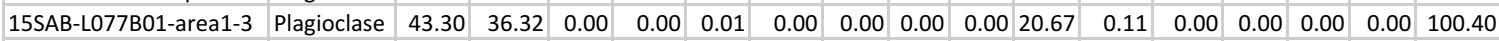

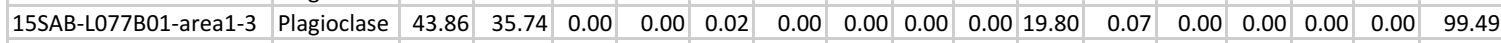

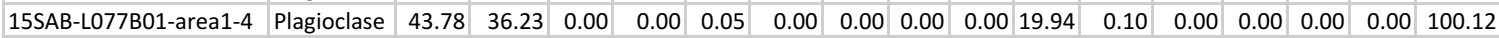

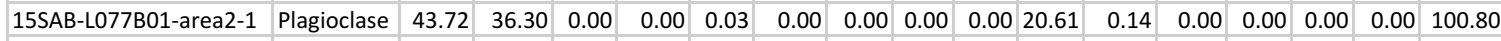

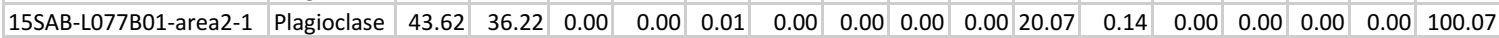

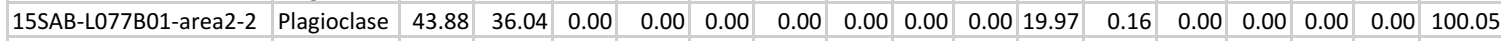

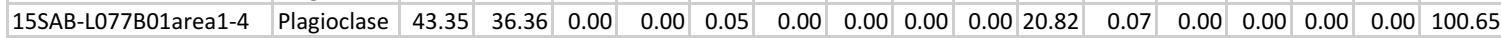

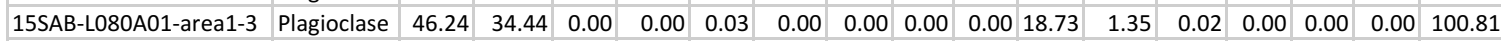

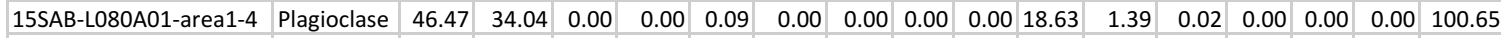
\begin{tabular}{|l|l|l|l|l|l|l|l|l|l|l|l|l|l|l|l|l|l|l|l|l|l|}
\hline 15SAB-L080A01-area2-1 & Plagioclase & 46.40 & 34.39 & 0.00 & 0.00 & 0.05 & 0.00 & 0.00 & 0.00 & 0.00 & 18.51 & 1.37 & 0.01 & 0.00 & 0.00 & 0.00 & 100.72 \\
\hline
\end{tabular} \begin{tabular}{|l|l|l|l|l|l|l|l|l|l|l|l|l|l|l|l|l|l|}
\hline 15SAB-L112A01-spot1-1 & Plagioclase & 44.71 & 35.01 & 0.00 & 0.00 & 0.06 & 0.00 & 0.00 & 0.00 & 0.00 & 19.02 & 0.67 & 0.01 & 0.00 & 0.00 & 0.00 & 99.48 \\
\hline
\end{tabular} \begin{tabular}{|l|l|l|l|l|l|l|l|l|l|l|l|l|l|l|l|l|l|}
\hline 15SAB-L112A01-spot1-2 & Plagioclase & 44.52 & 34.89 & 0.00 & 0.00 & 0.09 & 0.00 & 0.00 & 0.00 & 0.00 & 19.19 & 0.68 & 0.01 & 0.00 & 0.00 & 0.00 & 99.38 \\
\hline
\end{tabular}

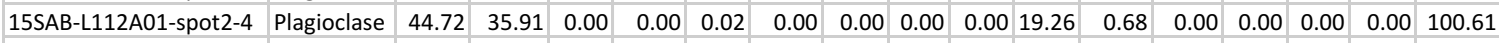
\begin{tabular}{|l|l|l|l|l|l|l|l|l|l|l|l|l|l|l|l|l|l|l|}
\hline 15SAB-M005A01-spot1-4 Plagioclase & 54.83 & 28.51 & 0.00 & 0.00 & 0.12 & 0.00 & 0.00 & 0.00 & 0.00 & 11.01 & 5.11 & 0.22 & 0.00 & 0.00 & 0.00 & 99.80 \\
\hline
\end{tabular}

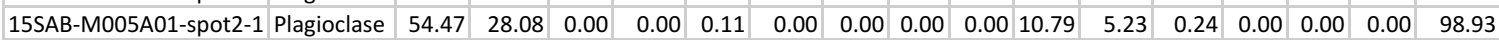


Plagioclase - Atoms Per Formula Unit

\begin{tabular}{|l|l|l|l|l|l|l|l|l|l|l|l|l|l|l|l|l}
\hline SAMPLE & Mineral & $\mathrm{Si}$ & $\mathrm{Al}$ & $\mathrm{Ti}$ & $\mathrm{Cr}$ & $\mathrm{Fe}$ & $\mathrm{Mn}$ & $\mathrm{Mg}$ & $\mathrm{Ni}$ & $\mathrm{Zn}$ & $\mathrm{Ca}$ & $\mathrm{Na}$ & $\mathrm{K}$ & $\mathrm{Ba}$ & $\sum$ cations An\%
\end{tabular}

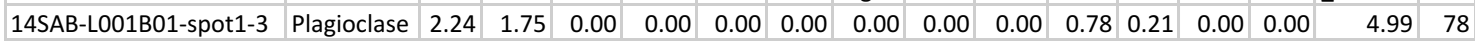

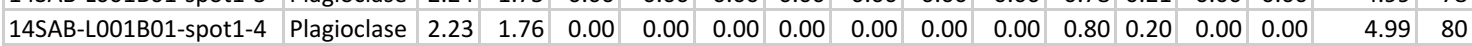

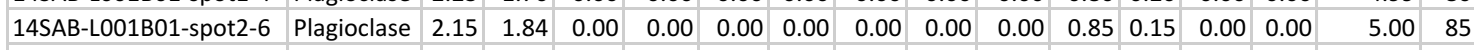

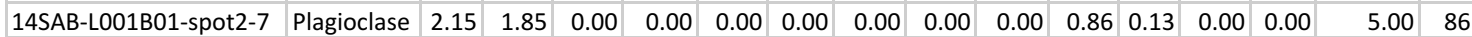

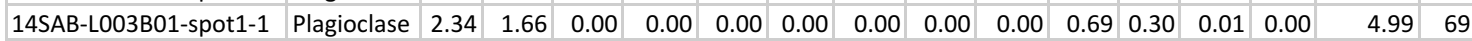

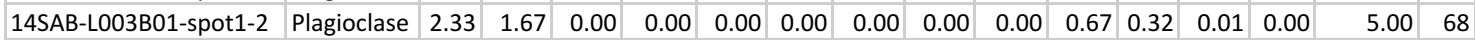

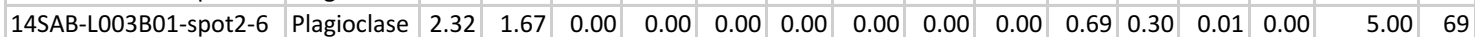

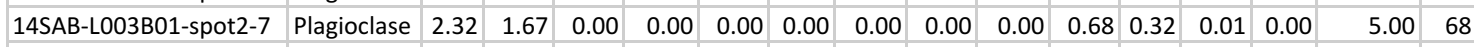

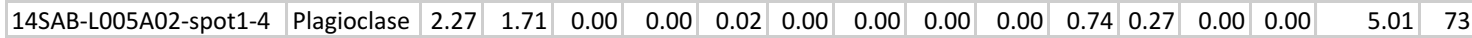

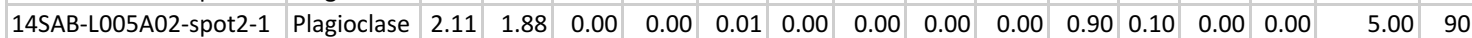

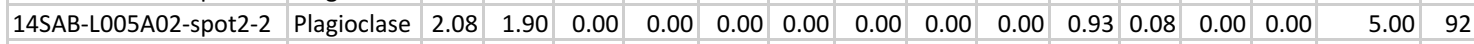

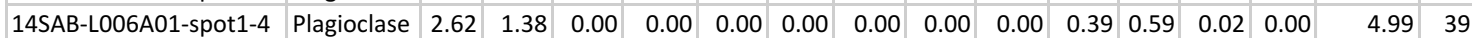

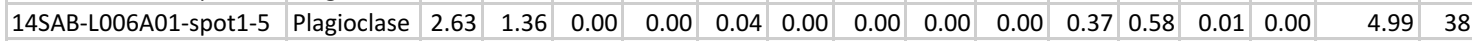

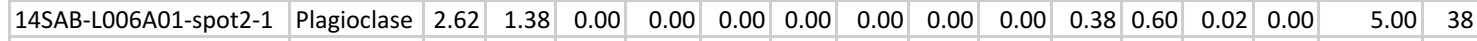

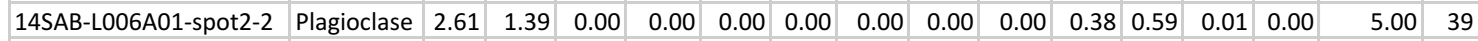

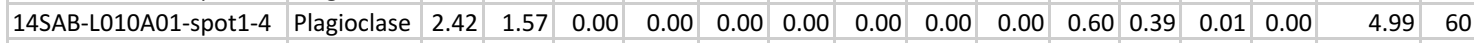

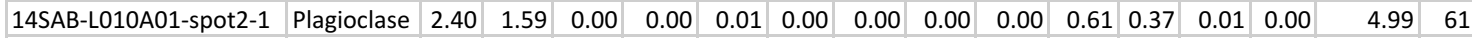

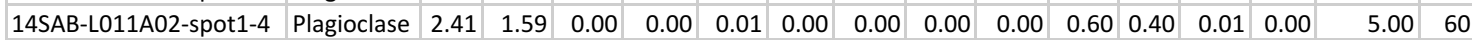

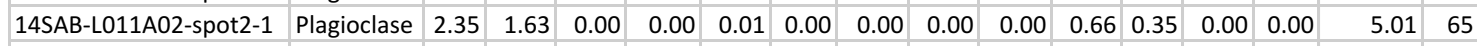

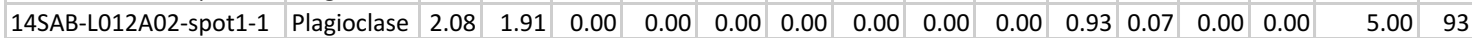

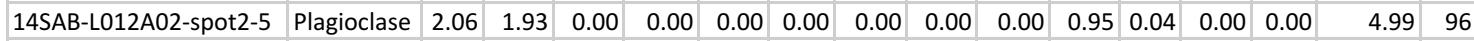

\begin{tabular}{|l|l|l|l|l|l|l|l|l|l|l|l|l|l|l|l|l|}
\hline 14SAB-L013A02-spot1-7 & Plagioclase & 2.04 & 1.96 & 0.00 & 0.00 & 0.00 & 0.00 & 0.00 & 0.00 & 0.00 & 0.97 & 0.02 & 0.00 & 0.00 & 4.99 & 98 \\
\hline
\end{tabular}

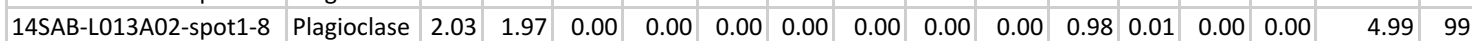

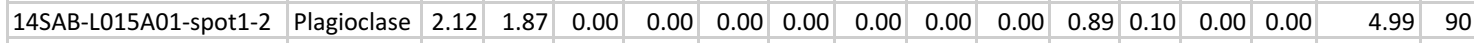

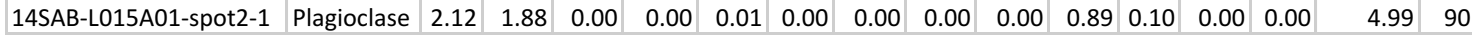

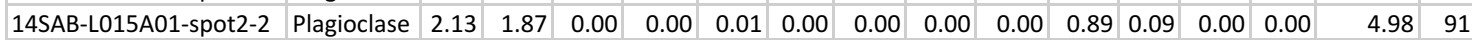

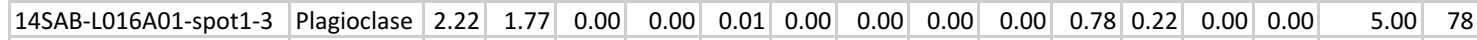

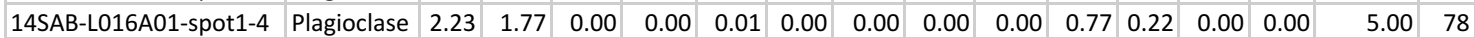

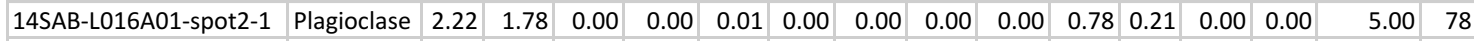

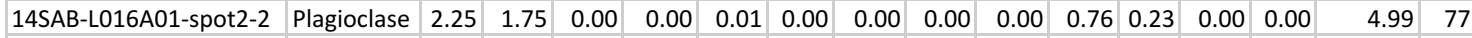

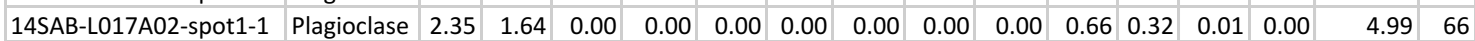

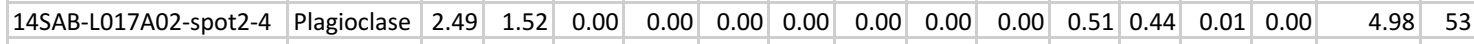

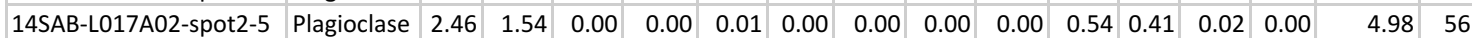

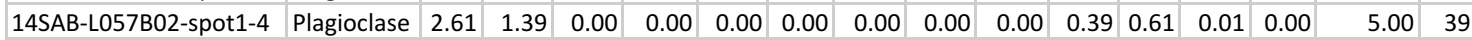

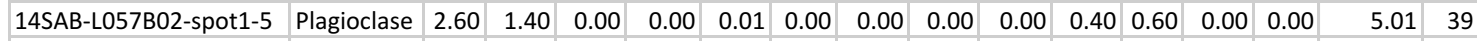

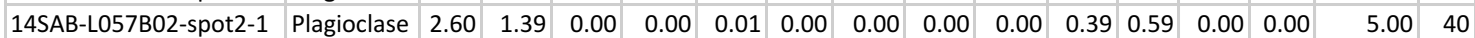

\begin{tabular}{|l|l|l|l|l|l|l|l|l|l|l|l|l|l|l|l|}
\hline 14SAB-L080-A02-spot1-4 Plagioclase & 2.20 & 1.79 & 0.00 & 0.00 & 0.00 & 0.00 & 0.00 & 0.00 & 0.00 & 0.81 & 0.19 & 0.00 & 0.00 & 5.00 & 81 \\
\hline
\end{tabular}

\begin{tabular}{|l|l|l|l|l|l|l|l|l|l|l|l|l|l|l|l|}
\hline 14SAB-L080-A02-spot2-1 Plagioclase & 2.15 & 1.85 & 0.00 & 0.00 & 0.00 & 0.00 & 0.00 & 0.00 & 0.00 & 0.85 & 0.14 & 0.00 & 0.00 & 4.99 & 86 \\
\hline
\end{tabular}

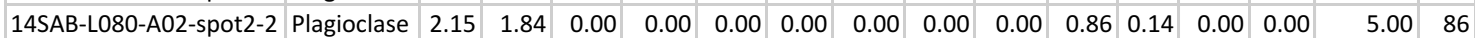

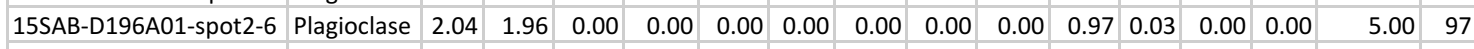

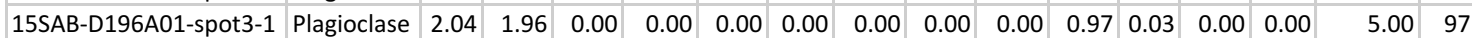

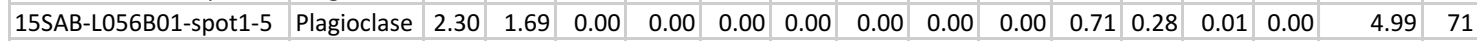

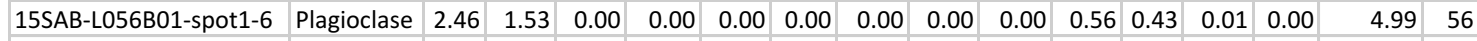

\begin{tabular}{|l|l|l|l|l|l|l|l|l|l|l|l|l|l|l|l|l|}
\hline 15SAB-L056B01-spot2-1 & Plagioclase & 2.30 & 1.69 & 0.00 & 0.00 & 0.01 & 0.00 & 0.00 & 0.00 & 0.00 & 0.72 & 0.27 & 0.01 & 0.00 & 4.99 & 72 \\
\hline
\end{tabular}

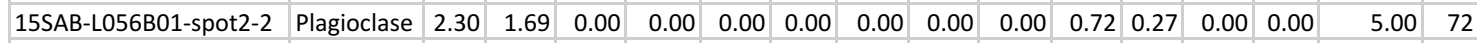

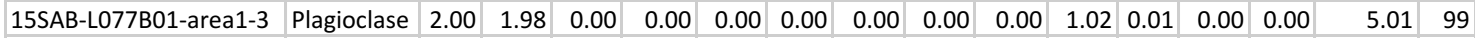

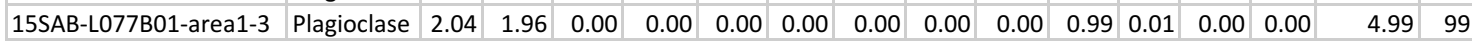

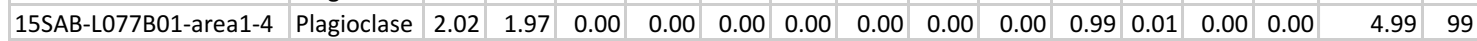

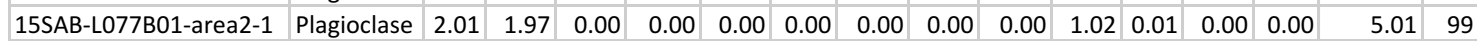

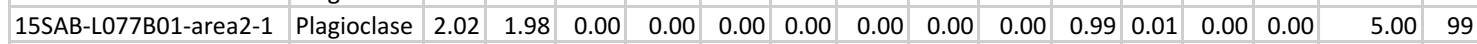

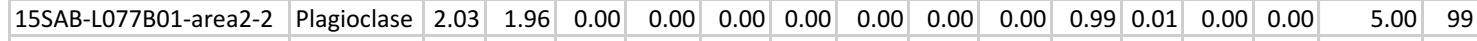

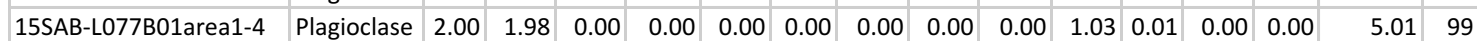

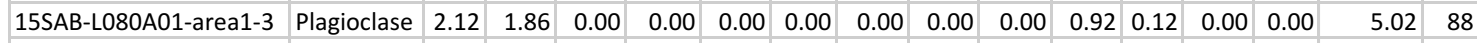

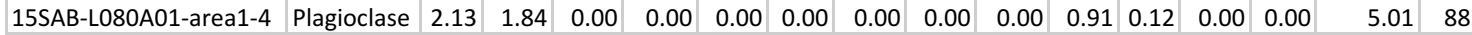

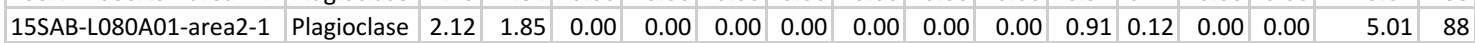

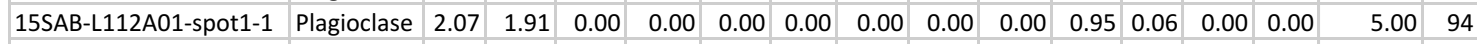

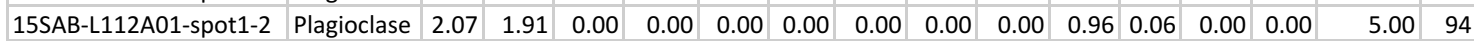

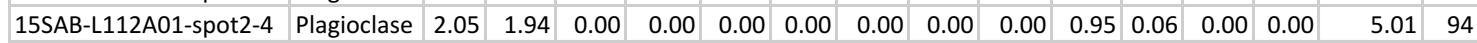

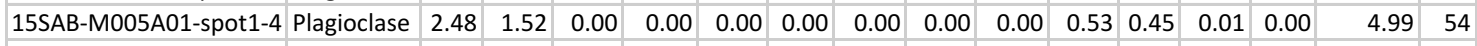

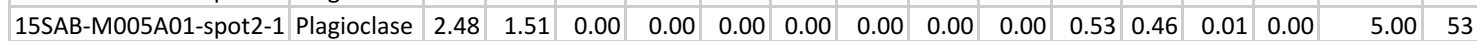


Spinel - Electron Microprobe Data

\begin{tabular}{|l|l|l|l|l|l|l|l|l|l|l|l|l|l|l|l|l|l|l}
\hline SAMPLE & Mineral & $\mathrm{SiO} 2$ & $\mathrm{Al} 2 \mathrm{O} 3$ & $\mathrm{TiO} 2$ & $\mathrm{Cr} 2 \mathrm{O} 3$ & $\mathrm{FeO}$ & $\mathrm{MnO}$ & $\mathrm{MgO}$ & $\mathrm{NiO}$ & $\mathrm{ZnO}$ & $\mathrm{CaO}$ & $\mathrm{Na} 2 \mathrm{O}$ & $\mathrm{K} 2 \mathrm{O}$ & $\mathrm{BaO}$ & $\mathrm{F}$ & $\mathrm{Cl}$ & $\mathrm{Total}$ \\
\hline
\end{tabular}

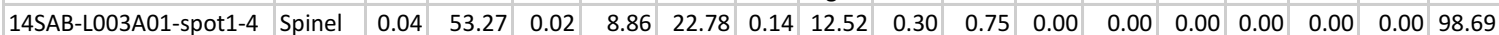

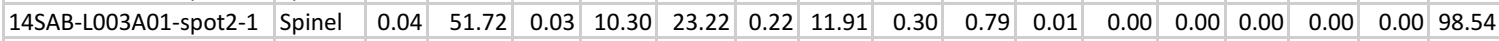

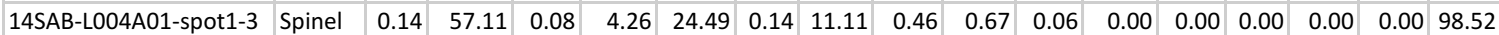

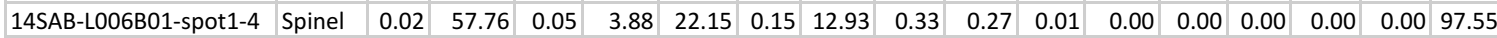

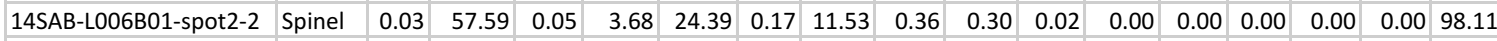

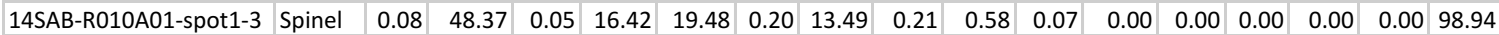
\begin{tabular}{|l|l|l|l|l|l|l|l|l|l|l|l|l|l|l|l|l|l|}
\hline 14SAB-S130A01-spot1-3 & Spinel & 0.01 & 58.54 & 0.03 & 3.59 & 21.15 & 0.14 & 14.37 & 0.31 & 0.11 & 0.00 & 0.00 & 0.00 & 0.00 & 0.00 & 0.00 & 98.25 \\
\hline
\end{tabular}

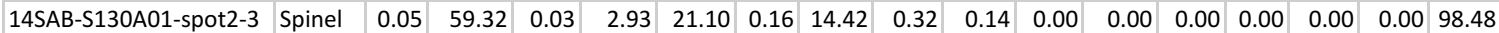
\begin{tabular}{|l|l|l|l|l|l|l|l|l|l|l|l|l|l|l|l|l|}
\hline 15SAB-D196A01-spot2-3 Spinel & 0.10 & 60.47 & 0.01 & 0.39 & 22.27 & 0.15 & 13.67 & 0.08 & 1.06 & 0.01 & 0.04 & 0.00 & 0.00 & 0.00 & 0.00 & 98.26 \\
\hline
\end{tabular}

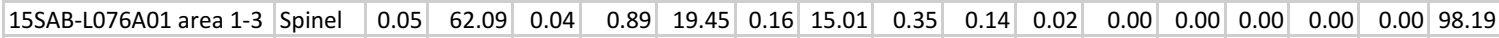

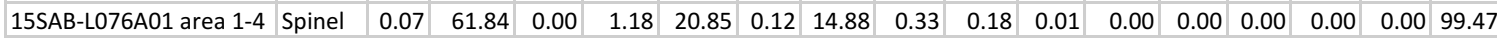

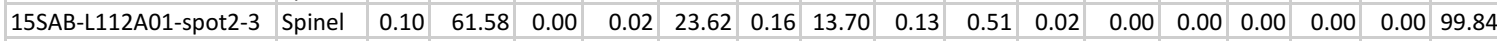

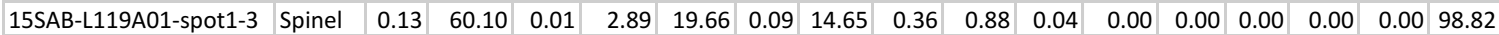

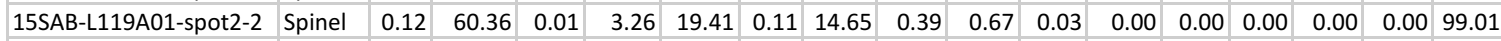
\begin{tabular}{|l|l|l|l|l|l|l|l|l|l|l|l|l|l|l|l|l|}
\hline 14SAB-L012A01-circle2-3 Spinel & 0.01 & 60.53 & 0.00 & 1.26 & 20.29 & 0.16 & 16.05 & 0.26 & 0.21 & 0.00 & 0.00 & 0.00 & 0.00 & 0.00 & 0.00 & 98.78 \\
\hline
\end{tabular} \begin{tabular}{|l|l|l|l|l|l|l|l|l|l|l|l|l|l|l|l|l|}
\hline 14SAB-L013A02-spot1-3 Spinel & 0.05 & 63.00 & 0.00 & 1.34 & 18.95 & 0.13 & 16.03 & 0.16 & 0.18 & 0.01 & 0.01 & 0.00 & 0.00 & 0.00 & 0.00 & 99.86 \\
\hline
\end{tabular}

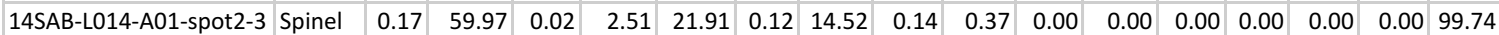

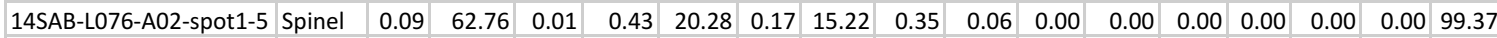
\begin{tabular}{|l|l|l|l|l|l|l|l|l|l|l|l|l|l|l|l|l|}
\hline 14SAB-L076-A02-spot2-1 Spinel & 0.00 & 62.67 & 0.03 & 0.63 & 19.85 & 0.12 & 15.38 & 0.37 & 0.14 & 0.00 & 0.00 & 0.00 & 0.00 & 0.00 & 0.00 & 99.20 \\
\hline
\end{tabular}

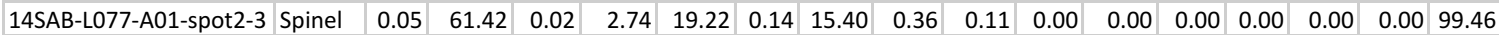
\begin{tabular}{|l|l|l|l|l|l|l|l|l|l|l|l|l|l|l|l|l|}
\hline 14SAB-L078A01-spot1-3 Spinel & 0.07 & 60.44 & 0.04 & 3.21 & 17.61 & 0.10 & 15.95 & 0.30 & 0.22 & 0.00 & 0.00 & 0.00 & 0.00 & 0.00 & 0.00 & 97.94 \\
\hline
\end{tabular}

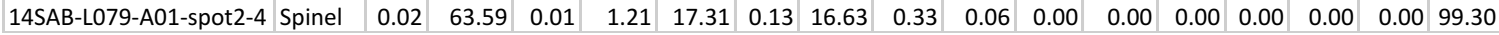

Spinel - Atoms Per Formula Unit

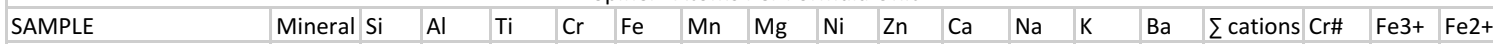
\begin{tabular}{|l|l|l|l|l|l|l|l|l|l|l|l|l|l|l|l|l|l|l|l|l|l|l|}
\hline 14SAB-L003A01-spot1-4 & Spinel & 0.00 & 1.75 & 0.00 & 0.20 & 0.53 & 0.00 & 0.52 & 0.01 & 0.02 & 0.00 & 0.00 & 0.00 & 0.00 & 3.03 & 0.10 & 0.07 & 0.46 \\
\hline
\end{tabular}

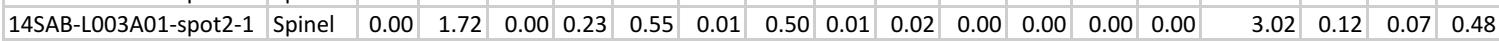

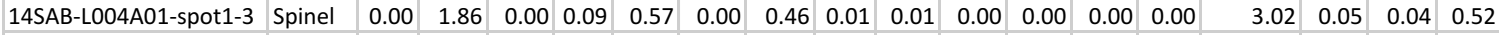
\begin{tabular}{|l|l|l|l|l|l|l|l|l|l|l|l|l|l|l|l|l|l|l|l|l|l|l|l|l|}
\hline 14SAB-L006B01-spot1-4 & Spinel & 0.00 & 1.87 & 0.00 & 0.08 & 0.51 & 0.00 & 0.53 & 0.01 & 0.01 & 0.00 & 0.00 & 0.00 & 0.00 & 3.02 & 0.04 & 0.05 & 0.46 \\
\hline
\end{tabular}

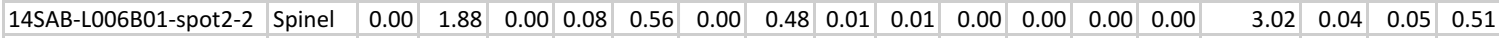

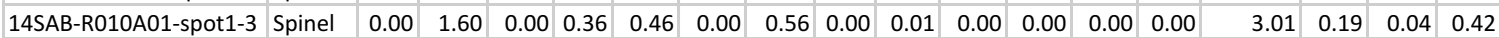
\begin{tabular}{|l|l|l|l|l|l|l|l|l|l|l|l|l|l|l|l|l|l|l|l|l|l|l|}
\hline 14SAB-S130A01-spot1-3 Spinel & 0.00 & 1.87 & 0.00 & 0.08 & 0.48 & 0.00 & 0.58 & 0.01 & 0.00 & 0.00 & 0.00 & 0.00 & 0.00 & 3.02 & 0.04 & 0.06 & 0.42 \\
\hline
\end{tabular} \begin{tabular}{|l|l|l|l|l|l|l|l|l|l|l|l|l|l|l|l|l|l|l|l|l|l|l|l|l|}
\hline 14SAB-S130A01-spot2-3 & Spinel & 0.00 & 1.89 & 0.00 & 0.06 & 0.48 & 0.00 & 0.58 & 0.01 & 0.00 & 0.00 & 0.00 & 0.00 & 0.00 & 3.02 & 0.03 & 0.06 & 0.42 \\
\hline
\end{tabular} \begin{tabular}{|l|l|l|l|l|l|l|l|l|l|l|l|l|l|l|l|l|l|l|l|l|l|l|l|l|}
\hline 15SAB-D196A01-spot2-3 Spinel & 0.00 & 1.93 & 0.00 & 0.01 & 0.50 & 0.00 & 0.55 & 0.00 & 0.02 & 0.00 & 0.00 & 0.00 & 0.00 & 3.03 & 0.00 & 0.07 & 0.43 \\
\hline
\end{tabular}

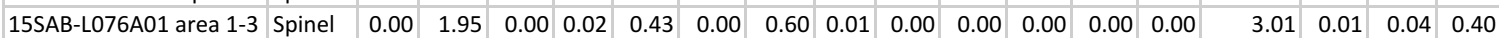
\begin{tabular}{|l|l|l|l|l|l|l|l|l|l|l|l|l|l|l|l|l|l|l|l|l|l|l|l|l|}
\hline 15SAB-L076A01 area 1-4 Spinel & 0.00 & 1.93 & 0.00 & 0.02 & 0.46 & 0.00 & 0.59 & 0.01 & 0.00 & 0.00 & 0.00 & 0.00 & 0.00 & 3.02 & 0.01 & 0.05 & 0.41 \\
\hline
\end{tabular} \begin{tabular}{|l|l|l|l|l|l|l|l|l|l|l|l|l|l|l|l|l|l|l|l|l|l|l|l|}
\hline 15SAB-L112A01-spot2-3 & Spinel & 0.00 & 1.94 & 0.00 & 0.00 & 0.53 & 0.00 & 0.55 & 0.00 & 0.01 & 0.00 & 0.00 & 0.00 & 0.00 & 3.03 & 0.00 & 0.08 & 0.45 \\
\hline
\end{tabular} \begin{tabular}{|l|l|l|l|l|l|l|l|l|l|l|l|l|l|l|l|l|l|l|l|l|l|l|l|l|}
\hline 15SAB-L119A01-spot1-3 & Spinel & 0.00 & 1.90 & 0.00 & 0.06 & 0.44 & 0.00 & 0.59 & 0.01 & 0.02 & 0.00 & 0.00 & 0.00 & 0.00 & 3.02 & 0.03 & 0.04 & 0.40 \\
\hline
\end{tabular}

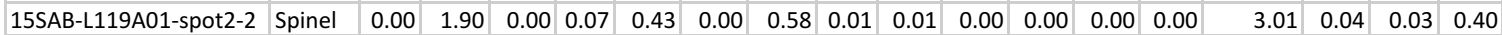

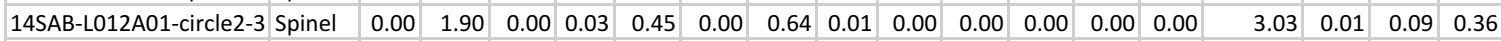

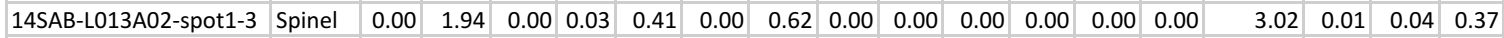
\begin{tabular}{|l|l|l|l|l|l|l|l|l|l|l|l|l|l|l|l|l|l|l|l|l|l|l|l|l|}
\hline 14SAB-L014-A01-spot2-3 Spinel & 0.00 & 1.89 & 0.00 & 0.05 & 0.49 & 0.00 & 0.58 & 0.00 & 0.01 & 0.00 & 0.00 & 0.00 & 0.00 & 3.03 & 0.03 & 0.07 & 0.42 \\
\hline
\end{tabular} \begin{tabular}{|l|l|l|l|l|l|l|l|l|l|l|l|l|l|l|l|l|l|l|l|l|l|l|l|}
\hline 14SAB-L076-A02-spot1-5 Spinel & 0.00 & 1.95 & 0.00 & 0.01 & 0.45 & 0.00 & 0.60 & 0.01 & 0.00 & 0.00 & 0.00 & 0.00 & 0.00 & 3.02 & 0.00 & 0.05 & 0.40 \\
\hline
\end{tabular}

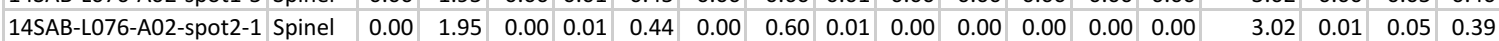
\begin{tabular}{|l|l|l|l|l|l|l|l|l|l|l|l|l|l|l|l|l|l|l|l|l|l|l|l|}
\hline 14SAB-L077-A01-spot2-3 Spinel & 0.00 & 1.91 & 0.00 & 0.06 & 0.42 & 0.00 & 0.61 & 0.01 & 0.00 & 0.00 & 0.00 & 0.00 & 0.00 & 3.01 & 0.03 & 0.04 & 0.39 \\
\hline
\end{tabular} \begin{tabular}{|l|l|l|l|l|l|l|l|l|l|l|l|l|l|l|l|l|l|l|l|l|l|l|l|l|}
\hline 14SAB-L078A01-spot1-3 & Spinel & 0.00 & 1.90 & 0.00 & 0.07 & 0.39 & 0.00 & 0.63 & 0.01 & 0.00 & 0.00 & 0.00 & 0.00 & 0.00 & 3.01 & 0.03 & 0.03 & 0.36 \\
\hline
\end{tabular} \begin{tabular}{|l|l|l|l|l|l|l|l|l|l|l|l|l|l|l|l|l|l|l|l|l|l|l|l|l|l|}
\hline 14SAB-L079-A01-spot2-4 Spinel & 0.00 & 1.95 & 0.00 & 0.02 & 0.38 & 0.00 & 0.65 & 0.01 & 0.00 & 0.00 & 0.00 & 0.00 & 0.00 & 3.01 & 0.01 & 0.03 & 0.35 \\
\hline
\end{tabular} 
Biotite - Electron Microprobe Data

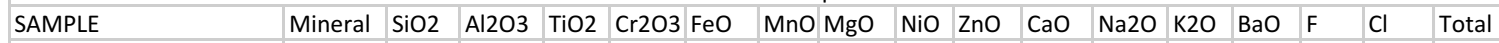

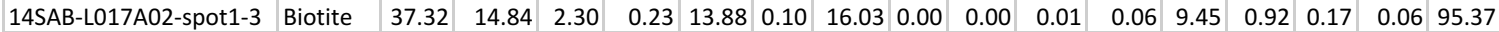

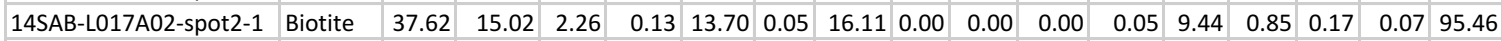

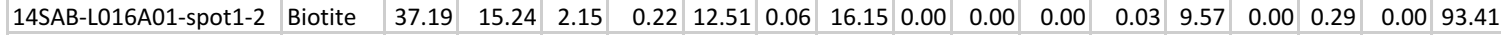

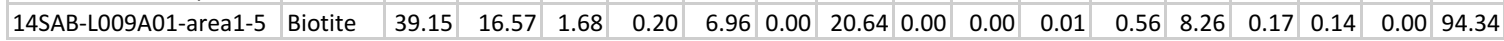

Biotite - Atoms Per Formula Unit

\begin{tabular}{|l|l|l|l|l|l|l|l|l|l|l|l|l|l|l|l|l|l|}
\hline SAMPLE & Mineral & $\mathrm{Si}$ & $\mathrm{Al}$ & $\mathrm{Ti}$ & $\mathrm{Cr}$ & $\mathrm{Fe}$ & $\mathrm{Mn}$ & $\mathrm{Mg}$ & $\mathrm{Ni}$ & $\mathrm{Zn}$ & $\mathrm{Ca}$ & $\mathrm{Na}$ & $\mathrm{K}$ & $\mathrm{Ba}$ & $\mathrm{\Sigma}$ cations & $\mathrm{Al3}+$ & $\mathrm{Al4}+$ \\
\hline 14SAB-L017A02-spot1-3 & Biotite & 6.12 & 2.87 & 0.28 & 0.03 & 1.90 & 0.01 & 3.92 & 0.00 & 0.00 & 0.00 & 0.02 & 1.98 & 0.06 & 17.14 & 0.99 & 1.88 \\
\hline 14SAB-L017A02-spot2-1 & Biotite & 6.15 & 2.89 & 0.28 & 0.02 & 1.87 & 0.01 & 3.92 & 0.00 & 0.00 & 0.00 & 0.02 & 1.97 & 0.05 & 17.11 & 1.04 & 1.85 \\
\hline 14SAB-L016A01-spot1-2 & Biotite & 6.13 & 2.96 & 0.27 & 0.03 & 1.72 & 0.01 & 3.97 & 0.00 & 0.00 & 0.00 & 0.01 & 2.01 & 0.00 & 17.12 & 1.09 & 1.87 \\
\hline 14SAB-L009A01-area1-5 & Biotite & 6.15 & 3.07 & 0.20 & 0.03 & 0.91 & 0.00 & 4.83 & 0.00 & 0.00 & 0.00 & 0.17 & 1.66 & 0.01 & 17.02 & 1.22 & 1.85 \\
\hline
\end{tabular}


Serpentine - Electron Mircoprobe Data

\begin{tabular}{|l|l|l|l|l|l|l|l|l|l|l|l|l|l|l|l|l|l|l|l|}
\hline SAMPLE & Mineral & SiO2 & Al2O3 & TiO2 & Cr2O3 & FeO & MnO & MgO & NiO & ZnO & CaO & Na2O & K2O & BaO & F & Cl & Total \\
\hline 14SAB-L013A02-spot1-4 & Serpentine & 42.60 & 0.13 & 0.01 & 0.01 & 17.92 & 0.49 & 25.92 & 0.04 & 0.00 & 0.24 & 0.00 & 0.00 & 0.00 & 0.00 & 0.00 & 87.37 \\
\hline 14SAB-L013A02-spot1-5 & Serpentine & 54.73 & 0.20 & 0.00 & 0.01 & 12.72 & 0.13 & 21.83 & 0.10 & 0.00 & 0.32 & 0.00 & 0.05 & 0.00 & 0.00 & 0.00 & 90.08 \\
\hline 14SAB-L014A01-spot1-1 & Serpentine & 37.04 & 1.42 & 0.04 & 0.01 & 14.11 & 0.22 & 30.16 & 0.01 & 0.00 & 0.11 & 0.02 & 0.00 & 0.00 & 0.00 & 0.40 & 83.53 \\
\hline 14SAB-L014A01-spot1-2 & Serpentine & 36.34 & 0.12 & 0.01 & 0.00 & 11.32 & 0.09 & 34.66 & 0.07 & 0.00 & 0.02 & 0.00 & 0.00 & 0.00 & 0.00 & 0.60 & 83.21 \\
\hline 14SAB-L076-A02-spot1-4 Serpentine & 41.72 & 0.02 & 0.00 & 0.00 & 22.18 & 0.25 & 19.91 & 0.00 & 0.00 & 0.12 & 0.00 & 0.01 & 0.00 & 0.00 & 0.14 & 84.34 \\
\hline 14SAB-L076-A02-spot2-3 Serpentine & 42.52 & 0.02 & 0.00 & 0.00 & 5.77 & 0.01 & 38.20 & 0.23 & 0.00 & 0.00 & 0.00 & 0.00 & 0.00 & 0.00 & 0.00 & 86.75 \\
\hline 14SAB-L076-A02-spot2-4 Serpentine & 48.88 & 0.02 & 0.04 & 0.02 & 20.05 & 0.13 & 18.17 & 0.25 & 0.00 & 0.13 & 0.00 & 0.11 & 0.00 & 0.00 & 0.00 & 87.80 \\
\hline
\end{tabular}


White Mica - Electron Microprobe Data

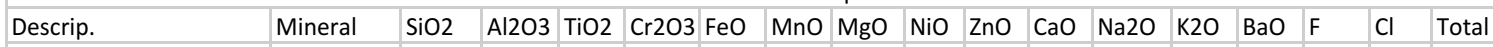
\begin{tabular}{|l|l|l|l|l|l|l|l|l|l|l|l|l|l|l|l|l|}
\hline 14SAB-L013A02-spot1-6 White mica & 45.70 & 37.00 & 0.02 & 0.00 & 0.13 & 0.29 & 0.13 & 0.01 & 0.00 & 0.37 & 0.29 & 9.61 & 0.55 & 0.03 & 0.00 & 94.13 \\
\hline
\end{tabular} 


\begin{tabular}{|c|c|c|c|c|c|c|c|c|c|c|c|c|c|}
\hline \multicolumn{14}{|c|}{ Sulphides - Electron Microprobe Data } \\
\hline SAMPLE & Mineral & $\mathrm{Fe}$ & S & $\mathrm{Cu}$ & $\mathrm{Ni}$ & Co & $\mathrm{Zn}$ & As & $\mathrm{Mn}$ & $\mathrm{Pb}$ & $\mathrm{Cd}$ & $\mathrm{Sb}$ & Total \\
\hline 15SAB-M005A01-spot1-1 & pyrrhotite & 59.24 & 39.00 & 0.00 & 0.07 & 0.17 & 0.00 & 0.01 & 0.00 & 0.00 & 0.00 & 0.00 & 98.50 \\
\hline 15SAB-M005A01-spot2-1 & pyrrhotite & 60.19 & 38.74 & 0.16 & 0.04 & 0.18 & 0.02 & 0.00 & 0.01 & 0.00 & 0.00 & 0.00 & 99.33 \\
\hline 14SUB-H029B2-spot1-1 & troilite (pyrrhotite) & 63.16 & 35.71 & 0.00 & 0.01 & 0.01 & 0.00 & 0.00 & 0.00 & 0.00 & 0.00 & 0.00 & 98.90 \\
\hline 14SUB-H029B2-spot1-4 & pyrrhotite & 62.07 & 35.95 & 0.00 & 0.04 & 0.00 & 0.00 & 0.00 & 0.03 & 0.00 & 0.00 & 0.00 & 98.09 \\
\hline 14SAB-L006A02-spot1-2 & pyrrhotite & 57.61 & 40.20 & 0.02 & 1.08 & 0.09 & 0.02 & 0.00 & 0.00 & 0.00 & 0.00 & 0.00 & 99.02 \\
\hline 14SAB-L007A01-spot1-1 & pyrrhotite & 58.85 & 38.77 & 0.00 & 0.37 & 0.03 & 0.02 & 0.01 & 0.01 & 0.00 & 0.00 & 0.00 & 98.05 \\
\hline 14SAB-L007A01-spot1-2 & pyrrhotite & 59.97 & 39.08 & 0.09 & 0.28 & 0.00 & 0.01 & 0.01 & 0.01 & 0.00 & 0.00 & 0.00 & 99.45 \\
\hline 14SAB-L011A01-spot1-1 & pyrrhotite & 57.69 & 40.04 & 0.02 & 0.94 & 0.08 & 0.01 & 0.00 & 0.00 & 0.00 & 0.00 & 0.00 & 98.77 \\
\hline 15SAB-L056B02-spot1-2 & pyrrhotite & 59.96 & 38.17 & 0.00 & 0.39 & 0.07 & 0.01 & 0.00 & 0.00 & 0.00 & 0.00 & 0.00 & 98.59 \\
\hline 15SAB-L076A02-spot3-3 & pyrrhotite & 59.06 & 39.28 & 0.01 & 0.18 & 0.01 & 0.02 & 0.00 & 0.00 & 0.00 & 0.00 & 0.00 & 98.57 \\
\hline 15SAB-L080A03-spot1-2 & pyrrhotite & 59.47 & 39.36 & 0.00 & 0.56 & 0.04 & 0.00 & 0.01 & 0.00 & 0.00 & 0.00 & 0.00 & 99.44 \\
\hline 15SAB-D196B01-spot1-1 & troilite (pyrrhotite) & 63.09 & 36.09 & 0.01 & 0.00 & 0.00 & 0.02 & 0.00 & 0.00 & 0.00 & 0.00 & 0.00 & 99.22 \\
\hline 15SAB-D196B01-spot1-5 & troilite (pyrrhotite) & 63.13 & 36.07 & 0.04 & 0.00 & 0.03 & 0.00 & 0.02 & 0.00 & 0.00 & 0.00 & 0.00 & 99.28 \\
\hline 15SAB-D196B01-spot1-7 & pyrrhotite & 59.85 & 33.47 & 0.04 & 0.50 & 0.06 & 0.03 & 0.00 & 0.02 & 0.00 & 0.00 & 0.00 & 93.96 \\
\hline 14SAB-L009A02-spot1-1 & pyrrhotite & 60.06 & 39.07 & 0.03 & 0.31 & 0.01 & 0.01 & 0.01 & 0.00 & 0.00 & 0.00 & 0.00 & 99.50 \\
\hline 14SAB-L009B02-spot1-1 & pyrrhotite & 59.96 & 39.22 & 0.00 & 0.32 & 0.05 & 0.01 & 0.00 & 0.01 & 0.00 & 0.00 & 0.00 & 99.57 \\
\hline 14SAB-L017A02-spot3-1 & pyrrhotite & 60.13 & 39.09 & 0.00 & 0.73 & 0.00 & 0.03 & 0.00 & 0.00 & 0.00 & 0.00 & 0.00 & 99.98 \\
\hline 14SAB-L017A02-spot3-5 & pyrrhotite & 59.26 & 38.92 & 0.00 & 1.23 & 0.01 & 0.00 & 0.00 & 0.00 & 0.00 & 0.00 & 0.00 & 99.41 \\
\hline 15SAB-M005A01-spot2-2 & chalcopyrite & 30.62 & 33.87 & 33.95 & 0.00 & 0.00 & 0.00 & 0.00 & 0.00 & 0.00 & 0.00 & 0.00 & 98.43 \\
\hline 14SAB-L003B01-spot3-2 & chalcopyrite & 30.34 & 33.67 & 34.28 & 0.02 & 0.01 & 0.01 & 0.00 & 0.00 & 0.00 & 0.00 & 0.00 & 98.33 \\
\hline 14SAB-L006A01-spot3-2 & chalcopyrite & 29.63 & 33.55 & 35.10 & 0.00 & 0.01 & 0.06 & 0.02 & 0.02 & 0.00 & 0.00 & 0.00 & 98.39 \\
\hline 14SAB-L006A02-spot1-1 & chalcopyrite & 29.57 & 34.39 & 34.98 & 0.01 & 0.00 & 0.03 & 0.00 & 0.01 & 0.00 & 0.00 & 0.00 & 98.99 \\
\hline 14SAB-L011A01-spot1-2 & chalcopyrite & 29.69 & 34.63 & 34.76 & 0.00 & 0.01 & 0.00 & 0.00 & 0.01 & 0.00 & 0.00 & 0.00 & 99.11 \\
\hline 14SAB-L015A02-spot 2-2 & chalcopyrite & 29.34 & 34.58 & 34.12 & 0.00 & 0.00 & 0.00 & 0.01 & 0.01 & 0.00 & 0.00 & 0.00 & 98.05 \\
\hline 15SAB-L078A02-spot1-4 & chalcopyrite (pure) & 30.13 & 33.69 & 33.95 & 0.27 & 0.01 & 0.02 & 0.00 & 0.02 & 0.00 & 0.00 & 0.00 & 98.10 \\
\hline 15SAB-L056B02-spot1-1 & chalcopyrite & 30.68 & 33.57 & 33.58 & 0.03 & 0.00 & 0.05 & 0.02 & 0.01 & 0.00 & 0.00 & 0.00 & 97.94 \\
\hline 15SAB-L076A02-spot3-2 & chalcopyrite & 29.91 & 34.14 & 35.37 & 0.01 & 0.01 & 0.00 & 0.00 & 0.01 & 0.00 & 0.00 & 0.00 & 99.46 \\
\hline 15SAB-D196B01-spot1-6 & chalcopyrite & 30.27 & 33.98 & 34.73 & 0.02 & 0.01 & 0.00 & 0.00 & 0.01 & 0.00 & 0.00 & 0.00 & 99.02 \\
\hline 14SAB-L009A02-spot1-2 & chalcopyrite & 30.72 & 33.99 & 34.96 & 0.03 & 0.00 & 0.00 & 0.00 & 0.00 & 0.00 & 0.00 & 0.00 & 99.70 \\
\hline 14SAB-L009B02-spot1-2 & chalcopyrite & 29.49 & 33.64 & 34.53 & 0.00 & 0.01 & 0.00 & 0.00 & 0.01 & 0.00 & 0.00 & 0.00 & 97.68 \\
\hline 14SAB-L017A02-spot3-3 & chalcopyrite & 30.39 & 33.95 & 35.43 & 0.01 & 0.00 & 0.05 & 0.00 & 0.01 & 0.00 & 0.00 & 0.00 & 99.84 \\
\hline 14SAB-L015A02-spot 1-2 & chalcopyrite & 29.98 & 34.78 & 33.93 & 0.00 & 0.00 & 0.00 & 0.00 & 0.00 & 0.00 & 0.00 & 0.00 & 98.69 \\
\hline 15SAB-L080A03-spot1-1 & chalcopyrite & 30.05 & 34.12 & 35.43 & 0.01 & 0.00 & 0.02 & 0.00 & 0.00 & 0.00 & 0.00 & 0.00 & 99.63 \\
\hline
\end{tabular}




\begin{tabular}{|c|c|c|c|c|c|c|c|c|c|c|c|c|c|}
\hline \multicolumn{14}{|c|}{ Sulphides - Electron Microprobe Data } \\
\hline SAMPLE & Mineral & $\mathrm{Fe}$ & $\mathrm{S}$ & $\mathrm{Cu}$ & $\mathrm{Ni}$ & Co & Zn & As & $\mathrm{Mn}$ & $\mathrm{Pb}$ & $\mathrm{Cd}$ & $\mathrm{Sb}$ & Total \\
\hline 14SUB-H029B2-spot1-2 & pentlandite & 40.37 & 31.52 & 0.04 & 26.12 & 0.60 & 0.01 & 0.03 & 0.01 & 0.00 & 0.00 & 0.00 & 98.69 \\
\hline 14SUB-H029B2-spot1-3 & pentlandite & 36.24 & 33.42 & 0.00 & 30.17 & 0.99 & 0.00 & 0.00 & 0.02 & 0.00 & 0.00 & 0.00 & 100.83 \\
\hline 14SUB-H029B2-spot1-5 & pentlandite & 33.10 & 32.65 & 0.00 & 32.82 & 0.71 & 0.00 & 0.00 & 0.02 & 0.00 & 0.00 & 0.00 & 99.30 \\
\hline 14SAB-L007A01-spot1-2 & pentlandite & 31.20 & 33.23 & 0.00 & 34.79 & 1.24 & 0.00 & 0.01 & 0.01 & 0.00 & 0.00 & 0.00 & 100.48 \\
\hline 14SAB-L007A01-spot1-2 & pentlandite & 30.81 & 33.19 & 0.00 & 34.83 & 1.17 & 0.05 & 0.00 & 0.00 & 0.00 & 0.00 & 0.00 & 100.05 \\
\hline 15SAB-L078A02-spot1-1 & pentlandite & 28.49 & 32.13 & 0.04 & 37.29 & 1.05 & 0.00 & 0.00 & 0.01 & 0.00 & 0.00 & 0.00 & 99.00 \\
\hline 15SAB-L078A02-spot1-3 & pentlandite & 29.24 & 32.26 & 0.17 & 36.02 & 1.15 & 0.00 & 0.00 & 0.02 & 0.00 & 0.00 & 0.00 & 98.87 \\
\hline 15SAB-L076A02-spot3-1 & pentlandite & 31.57 & 32.76 & 0.00 & 33.99 & 1.19 & 0.00 & 0.00 & 0.00 & 0.00 & 0.00 & 0.00 & 99.52 \\
\hline 15SAB-D196B01-spot1-2 & pentlandite & 28.07 & 32.68 & 0.00 & 25.69 & 12.34 & 0.00 & 0.00 & 0.00 & 0.00 & 0.00 & 0.00 & 98.78 \\
\hline 15SAB-D196B01-spot1-3 & pentlandite & 31.05 & 32.65 & 0.51 & 27.71 & 6.96 & 0.02 & 0.00 & 0.00 & 0.00 & 0.00 & 0.00 & 98.90 \\
\hline 15SAB-D196B01-spot1-4 & pentlandite & 29.70 & 32.60 & 0.23 & 26.66 & 9.49 & 0.00 & 0.00 & 0.00 & 0.00 & 0.00 & 0.00 & 98.68 \\
\hline 14SAB-L009A02-spot1-3 & pentlandite & 33.26 & 33.66 & 0.00 & 30.75 & 2.15 & 0.01 & 0.00 & 0.00 & 0.00 & 0.00 & 0.00 & 99.84 \\
\hline 14SAB-H006A01-spot1-1 & pyrite & 47.02 & 53.06 & 0.00 & 0.02 & 0.00 & 0.00 & 0.00 & 0.00 & 0.00 & 0.00 & 0.00 & 100.10 \\
\hline 14SAB-H006A01-spot1-2 & pyrite & 47.55 & 53.21 & 0.03 & 0.03 & 0.13 & 0.01 & 0.00 & 0.00 & 0.00 & 0.00 & 0.00 & 100.95 \\
\hline 14SAB-L003B01-spot3-1 & pyrite & 46.44 & 53.28 & 0.02 & 0.10 & 0.08 & 0.02 & 0.00 & 0.00 & 0.00 & 0.00 & 0.00 & 99.94 \\
\hline 14SAB-L006A01-spot3-1 & pyrite & 46.11 & 52.45 & 0.01 & 0.16 & 0.13 & 0.00 & 0.00 & 0.00 & 0.00 & 0.00 & 0.00 & 98.86 \\
\hline 14SAB-L015A02-spot 1-1 & pyrite & 45.28 & 53.77 & 0.01 & 0.01 & 1.12 & 0.00 & 0.00 & 0.00 & 0.00 & 0.00 & 0.00 & 100.19 \\
\hline 14SAB-L015A02-spot 2-1 & pyrite & 45.84 & 52.90 & 0.00 & 0.03 & 0.02 & 0.00 & 0.00 & 0.01 & 0.00 & 0.00 & 0.00 & 98.80 \\
\hline 14SAB-L017A02-spot3-2 & pyrite & 46.38 & 53.54 & 0.03 & 0.00 & 0.75 & 0.01 & 0.01 & 0.00 & 0.00 & 0.00 & 0.00 & 100.72 \\
\hline 14SAB-L017A02-spot3-3 & pyrite & 46.40 & 53.67 & 0.00 & 0.02 & 0.88 & 0.00 & 0.01 & 0.00 & 0.00 & 0.00 & 0.00 & 100.98 \\
\hline 14SAB-L015A02-spot 1-3 & pyrite & 45.67 & 53.74 & 0.00 & 0.02 & 0.77 & 0.01 & 0.00 & 0.00 & 0.00 & 0.00 & 0.00 & 100.21 \\
\hline
\end{tabular}




\section{Appendix E - Sm-Nd Isotopic Geochemical Data}




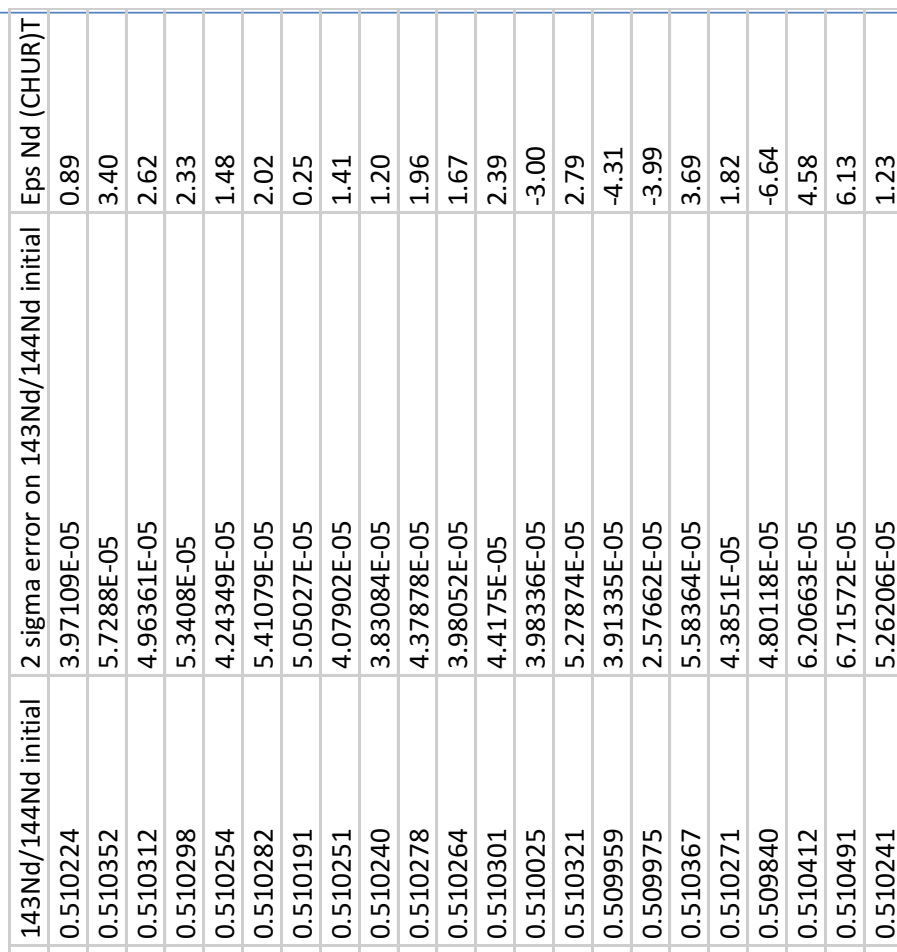

肎

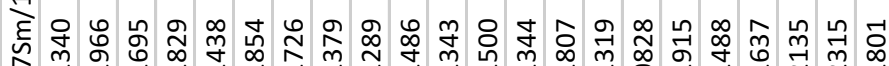

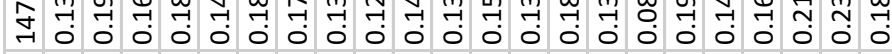

$\overline{\underline{a}}$

总

F

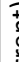

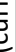

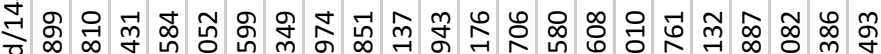

2

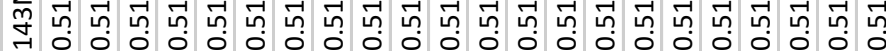

$\bar{\varepsilon}$

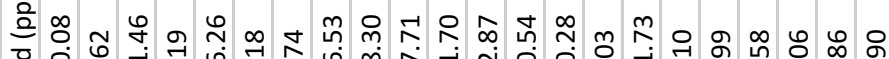

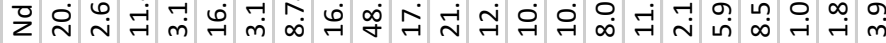

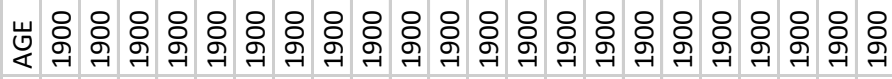

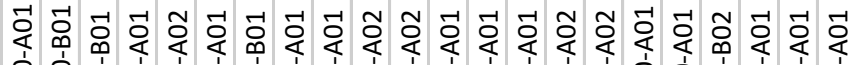

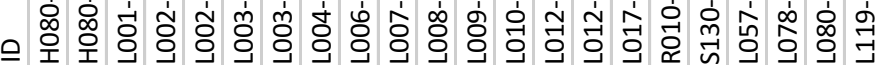

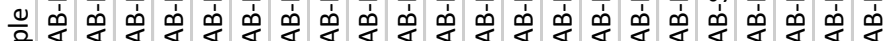

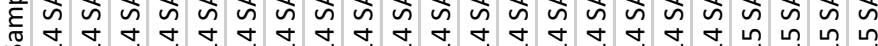

